http://dx.doi.org/10.18778/7969-465-5

\title{
EDUKACJA FINANSOWA \\ I INKLUZJA BANKOWA \\ W REALIZACJI KONCEPCJI \\ SILVER ECONOMY
}


酱 
Iwa Kuchciak, Marika Świeszczak Krzysztof Świeszczak, Monika Marcinkowska EDUKACJA FINANSOWA I INKLUZJA BANKOWA W REALIZACJI KONCEPCJI SILVER ECONOMY 
Iwa Kuchciak (1.2, 1.3 (współautorstwo), 3, 4, 5.1 (współautorstwo)), Marika Świeszczak (współautorstwo: 1.1, 1.4, 2.2, 5.1, 5.2), Krzysztof Świeszczak (współautorstwo: 1.1, 1.4, 2.2

5.1, 5.2), Monika Marcinkowska (Wstęp, 1.3 (współautorstwo), 2.1, Zakończenie)

- Uniwersytet Łódzki, Wydział Ekonomiczno-Socjologiczny, Katedra Bankowości 90-214 Łódź, ul. Rewolucji 1905 r. nr 39

\author{
RECENZENT \\ Matgorzata Iwanicz-Drozdowska \\ REDAKTOR WYDAWNICTWA UŁ \\ Bogustawa Kwiatkowska \\ PROJEKT OKŁADKI \\ Stämpfli Polska Sp. z o.o. \\ Zdjęcie na okładce: Cshutterstock.com
}

SKŁAD I $Ł A M A N I E$
AGENT PR

Publikacja powstała w efekcie realizacji projektu ,, Właczenie bankowe” jako kluczowy standard $w$ realizacji koncepcji silver economy w województwie tódzkim, finansowanego przez Bank Zachodni WBK w ramach Santander Universidades oraz ze środków na działalność statutową Katedry Bankowości Uniwersytetu Łódzkiego

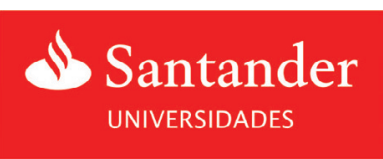

\title{
Bank Zachodni WBK \\ (1) Grupa Santander
}

Santander Universidades realizowany jest w Polsce przez Bank Zachodni WBK należący do Grupy Santander

(C) Copyright by Uniwersytet Łódzki, Łódź 2014

Wydane przez Wydawnictwo Uniwersytetu Łódzkiego

Wydanie I. W.06640.14.0.K

ISBN 978-83-7969-465-5

ISBN (ebook) 978-83-7969-774-8

Wydawnictwo Uniwersytetu Łódzkiego

90-131 Łódź, Lindleya 8

www.wydawnictwo.uni.lodz.pl

e-mail: ksiegarnia@uni.lodz.pl

tel. (42) 6655863 , faks (42) 66558 


\section{Spis treści}

Wstęp

Rozdzial I. Koncepcja „srebrnej gospodarki” i problemy wykluczenia ……........................... 11

1.1. „Srebrna gospodarka” na szczeblu krajowym i międzynarodowym _............................... 11

1.1.1. Silver economy w polityce społecznej i dokumentach Unii Europejskiej ....... $\quad 12$

1.1.2. Lokalna polityka na rzecz osób starszych ….....................................................

1.1.3. Trendy demograficzne w Polsce na tle krajów Unii Europejskiej ..................... 21

1.2. Wykluczenie społeczne jako problem społeczno-gospodarczy _..................................... 27

1.2.1. Identyfikacja pojęcia wykluczenia społecznego …….................................. 27

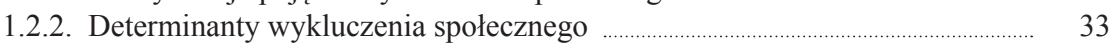

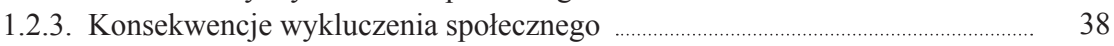

1.2.4. Skala wykluczenia społecznego osób w wieku 50+ na tle pozostałych

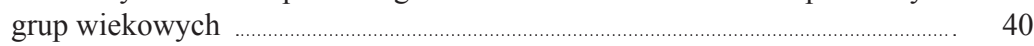

1.3. Wykluczenie bankowe jako obszar wykluczenia społecznego _........................................ 46

1.3.1. Wykluczenie finansowe a wykluczenie bankowe …….................................... 46

1.3.2. Determinanty wykluczenia bankowego ............................................. 55

1.3.3. Skala wykluczenia finansowego i bankowego osób w wieku 50+ .................. 61

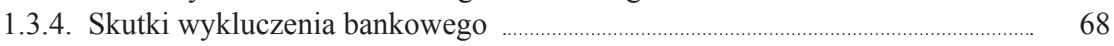

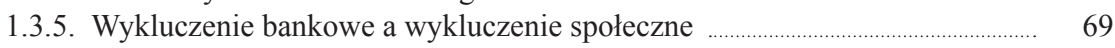

1.3.6. Zadłużenie i niewypłacalność gospodarstw domowych a wykluczenie finan-

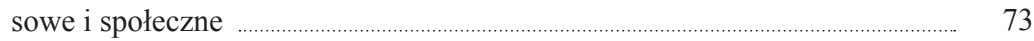

1.4. Kierunki interwencji na rzecz zwiększania aktywności społecznej osób starszych . 83

Rozdział II. Ocena dostępności i atrakcyjności usług bankowych dla osób w wieku 50+ ... $\quad 89$

2.1. Potrzeby i zachowania finansowe gospodarstw domowych …………….................. 89

2.1.1. Typologia i determinanty potrzeb i zachowań finansowych gospodarstw domowych ze szczególnym uwzględnieniem osób z segmentu 50+

2.1.2. Zarządzanie finansami gospodarstw domowych - zapotrzebowanie na pro-

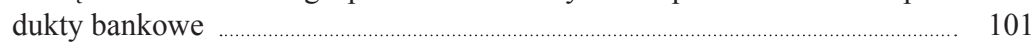

2.2. Ocena dostępności i atrakcyjności oferty bankowej dedykowanej dla segmentu 50+ 116

2.2.1. Dostępność podstawowych usług bankowych i ich zróżnicowanie ................ 116

2.2.2. Ocena atrakcyjności oferty rachunków oszczędnościowo-rozliczeniowych

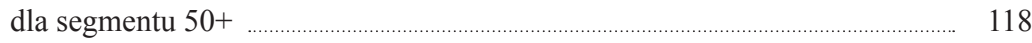

2.2.3. Ocena atrakcyjności oferty lokat bankowych dedykowanych seniorom ......... 127

2.2.4. Ocena atrakcyjności oferty kredytów dedykowanych seniorom …..................... 134

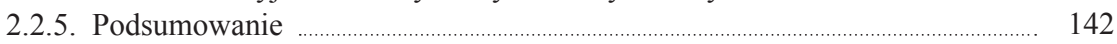


Rozdział III. Edukacja finansowa w podnoszeniu aktywności społecznej osób 50+

3.1. Definicyjne ujęcie edukacji finansowej

3.2. Ekonomiczne i społeczne korzyści edukacji finansowej

3.3. Specyfika badań nad poziomem świadomości finansowej ……............................ 166

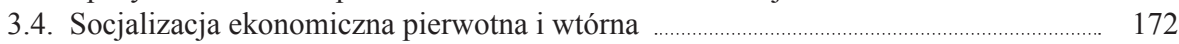

3.5. Edukacja finansowa w Polsce ……………................................................................................ 175

3.5.1. Problem edukacji finansowej w Polsce _............................................. 175

3.5.2. Stan świadomości finansowej w Polsce na tle krajów UE w świetle badań wtórnych

Rozdzial IV. Świadomość finansowa gospodarstw domowych w świetle badań pierwotnych

4.1. Tendencje demograficzne $w$ województwie łódzkim i ich konsekwencje w dziedzinie zaspokajania potrzeb osób $50+$

4.2. Metodyka badań w zakresie ekskluzji bankowej

4.3. Analiza struktury na podstawie przeprowadzonych badań pierwotnych ………......... 205

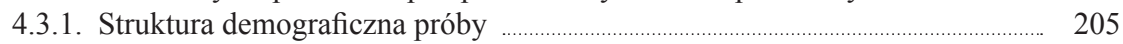

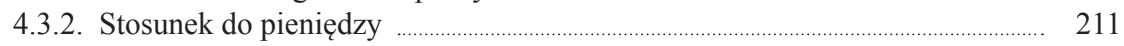

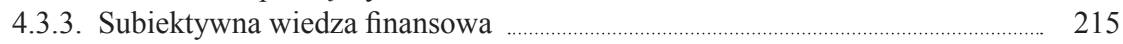

4.3.4. Zakres i częstotliwość korzystania z produktów bankowych _..................... 217

4.4. Identyfikacja zależności między poszczególnymi determinantami wykluczenia

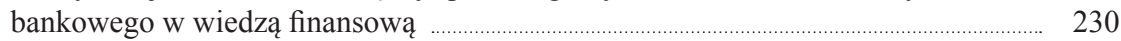

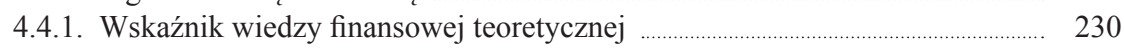

4.4.2. Wskaźnik wiedzy finansowej praktycznej …........................................... 235

4.4.3. Aktualne posiadanie produktów finansowych …............................................ 240

4.4.4. Posiadane produkty finansowe w ciągu 2 ostatnich lat ................................... 248

4.5. Wiedza finansowa teoretyczna a aktualne posiadanie produktów finansowych ......... 256

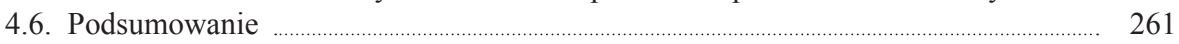

Rozdział V. Program wyrównywania szans w dostępie do wiedzy finansowej osób 50+

5.1. Rekomendacje dedykowane instytucjom bankowym w zakresie działań stymulujących ograniczanie zjawiska wykluczenia bankowego i podnoszenie świadomości finansowej

5.1.1. Przegląd i ocena działań prowadzonych przez instytucje sektora bankowego w Polsce na rzecz podnoszenia wiedzy finansowej ............................... 267

5.1.2. Przykłady dobrych praktyk podejmowanych przez banki za granicą .............. 284

5.1.3. Rekomendacje rozwiązań na rzecz osób w wieku 50+ na podstawie przykładów dobrych praktyk

5.2. Rekomendacje dla podmiotów działających na rzecz osób 50+ na poziomie lokalnym w obszarze kształtowania świadomości finansowej

5.2.1. Przegląd doświadczeń zagranicznych w obszarze edukacji i włączenia w sektor bankowy osób 50+

5.2.2. Zidentyfikowanie rozwiązań na rzecz osób w wieku 50+ jako przykładów dobrych praktyk

5.2.3. Rekomendacje rozwiązań na rzecz osób w wieku 50+ na podstawie przykładów dobrych praktyk 


\section{Wstęp}

Współcześnie coraz większą uwagę przykłada się do problemu starzejącego się społeczeństwa. Kwestia ta przekłada się na problemy ekonomiczne i społeczne gospodarek krajowych, toteż w ostatnich latach powstało wiele inicjatyw mających na celu ograniczenie negatywnych konsekwencji tego zjawiska i poprawę warunków życia seniorów. Inicjatywy te postrzegają starzenie się społeczeństw nie jako zagrożenie, lecz szansę dla rozwoju gospodarczego i wzrostu konkurencyjności państw. Powstają organizacje, stowarzyszenia i nieformalne inicjatywy, których celem jest poprawa jakości życia seniorów, m.in. poprzez promowanie rozwoju produktów i usług skierowanych do starszych konsumentów. Można już mówić o nowym segmencie - silver economy, czyli srebrnej gospodarce, zwanej też gospodarką senioralną ${ }^{1}$.

Gospodarka senioralna to szeroko pojęty system ekonomiczny ukierunkowany na wykorzystanie potencjału osób starszych i uwzględniający ich potrzeby $^{2}$. Działania w tym obszarze są podejmowane na szczeblu lokalnym, krajowym i międzynarodowym (np. poprzez inicjatywy Unii Europejskiej), ale także przez poszczególne podmioty gospodarcze lub organizacje branżowe i środowiskowe.

Jednym z kluczowych aspektów życia każdego człowieka i społeczeństwa jest sfera finansowa. We współczesnym świecie usługi finansowe są ważnym obszarem,

${ }^{1}$ Należy przy tym zaznaczyć, że bardzo zróżnicowane jest podejście do tego, kto określany jest mianem seniora. Wynika to $\mathrm{z}$ faktu, że dzięki postępowi medycyny oraz przemianom społecznym i kulturowym istotnie przesuwana jest granica wieku uznawanego za podeszły. Niegdyś jako osoby w podeszłym wieku traktowani byli ludzie po 50., a nawet 40. roku życia. Współcześni pięćdziesięcio-, sześćdziesięciolatkowie to z reguły osoby aktywne zawodowo, cieszące się dobrym zdrowiem, korzystające z życia. W tych segmentach jest jednak dostrzegalne bardzo duże zróżnicowanie sytuacji materialnej i społecznej oraz ogólnego radzenia sobie z życiem. Toteż - niezależnie od zmieniającego się postrzegania granicy „senioralności” i „starości” - koncepcja „srebrnej gospodarki” dotyczy zwykle osób po pięćdziesiątym roku życia (zdarzają się też inicjatywy adresowane do osób po 45. roku życia), a część zagadnień - w zależności od ich specyfiki - jest adresowana do osób po sześćdziesiątym (lub sześćdziesiątym piątym) roku życia. W ślad za tymi trendami niniejsza publikacja koncentruje się na najszerszym ujęciu segmentu silver, tj. osobach z segmentu 50+.

${ }_{2}$ M. Rudnicka, A. Surdej, Gospodarka senioralna. Nowy sektor gospodarki narodowej w Polsce, Centrum im. Adama Smitha, Warszawa 2013, s. 3. 
niezbędnym gdy idzie o zapewnienie seniorom dobrej jakości życia. Problematyka srebrnej gospodarki w tym aspekcie odnosi się do różnych produktów i usług finansowych oraz sposobów ich świadczenia, a dotyczy w szczególności³:

- sprostania (dodatkowym) potrzebom seniorów związanym z produktami i usługami specyficznymi dla ich wieku (a z których nabyciem lub otrzymaniem osoby te mogą mieć problem) w celu zapewnienia kontynuacji niezależnego życia i zachowania dobrego standardu życia (m.in. akcentuje się możliwość dalszego mieszkania w dotychczas posiadanych nieruchomościach),

- dostosowania form aktywów finansowych w celu zapewnienia wymaganej płynności finansowej i satysfakcjonującego poziomu życia po przejściu na emeryturę,

- finansowania nowych produktów i usług (w tym w szczególności usług mieszkaniowych i innych usług adresowanych do seniorów), uwzględniając specyficzne wymogi banków i innych pośredników finansowych, a także udostępnienia nowych opcji związanych z nieruchomościami (sprzedaż z leasingiem zwrotnym, odwrócona hipoteka itp.),

- zapewnienia doradztwa i pomocy w korzystaniu z produktów finansowych zarówno $\mathrm{w}$ odniesieniu do samej istoty i funkcjonowania tych produktów, jak również form i kanałów dostępu do nich oraz ich obsługi,

- nowych form współpracy między różnymi interesariuszami (dostawcami usług, bankami, inwestorami, władzą publiczną), tj. rozwoju klastrów gospodarki senioralnej w celu tworzenia innowacji w świadczeniu usług seniorom i ich finansowaniu (co przełoży się na tworzenie nowych miejsc pracy i wzrost ekonomiczny).

Kwestie te bezpośrednio wiążą się z szerokim zagadnieniem wykluczenia społecznego, w tym przede wszystkim wykluczenia finansowego. W szerszym kontekście należy też wspomnieć tu o zagadnieniu świadomości finansowej. Jej odpowiedni poziom postrzegany jest z jednej strony jako warunek inkluzji bankowej, ale z drugiej także jako czynnik sprzyjający zapewnianiu stabilności sektora finansowego.

Niniejsza praca poświęcona jest zagadnieniom wykluczenia bankowego i świadomości finansowej osób z segmentu silver, czyli po pięćdziesiątym roku życia. Jej celami są:

- analiza dostępności i atrakcyjności ofert polskich banków dedykowanych seniorom,

- zdiagnozowanie poziomu wiedzy finansowej mieszkańców województwa łódzkiego $\mathrm{w}$ wieku 50+ oraz zidentyfikowanie istnienia zależności między posiadaną wiedzą finansową a zakresem korzystania z produktów finansowych,

${ }^{3}$ Zagadnieniami tymi szerzej zajmuje się m.in. SEN@ER (wspólna inicjatywa regionów europejskich, Silver Economy Network of European Regions); patrz: www.silvereconomy-europe. org/network/sigs/finances/background_en.htm oraz Conference, Financial Services - Silver Economy in Europe, Office of the Representative of the German state of North Rhine-Westphalia, Belliardstraat, Brussels, 8-9 March, 2006. 
- opracowanie rekomendacji odnośnie do działań stymulujących ograniczanie zjawiska wykluczenia bankowego i podnoszenie świadomości finansowej seniorów.

Praca składa się z pięciu rozdziałów. W pierwszym przybliżono koncepcję „srebrnej gospodarki” (silver economy) i polityki społecznej dotyczącej osób po pięćdziesiątym roku życia. Dla zobrazowania istoty i skali problemu przedstawiono trendy demograficzne wskazujące wielkość i rosnące znaczenie tego segmentu. Omówiono tu także kluczowe kwestie dotyczące wykluczenia społecznego i jednego z jego obszarów: wykluczenia bankowego (w tym kontekście zaakcentowano zagadnienia odpowiedzialnego kredytowania, a także niewypłacalności osób fizycznych). Stanowi to tło dla prezentacji kierunków interwencji na rzecz zwiększania aktywności społecznej osób starszych.

$\mathrm{W}$ drugim rozdziale zarysowano kluczowe zagadnienia dotyczące zarządzania finansami osobistymi seniorów, przedstawiając zapotrzebowanie na produkty finansowe. Szczególną uwagę poświęcono analizie aktualnego stopnia korzystania przez seniorów z produktów finansowych (form lokowania oszczędności, źródeł kredytów), zwracając przy tym uwagę na cele oszczędzania i zaciągania zobowiązań. Zagadnienia te są punktem wyjścia do analiz ofert podstawowego rachunku (służącego głównie celom oszczędnościowo-rozliczeniowym), lokat oraz kredytów. W dalszej części rozdziału przeprowadzono ocenę dostępności i atrakcyjności ofert produktów bankowych dedykowanych dla klientów segmentu 50+. Analizie poddano RORy, lokaty terminowe i kredyty siedmiu banków komercyjnych.

Kolejny rozdział poświęcono zagadnieniu edukacji finansowej. Jest ona fundamentem dla podnoszenia aktywności społecznej osób starszych i czynnikiem sprzyjającym inkluzji bankowej. W rozdziale tym pochylono się w szczególności nad problemem świadomości finansowej w Polsce (na podstawie badań wtórnych) i edukacji finansowej. Zagadnienia te są podstawą do zaplanowania własnych badań empirycznych w tym obszarze.

Rozdział czwarty przedstawia wyniki własnych badań empirycznych dotyczących wiedzy finansowej oraz posiadania produktów bankowych. Analizę przeprowadzono wśród osób powyżej pięćdziesiątego roku życia, zamieszkałych na terenie województwa łódzkiego ${ }^{4}$. Badania te pozwoliły nie tylko na ocenę poziomu wiedzy finansowej i skali wykluczenia bankowego tego segmentu, ale także na zidentyfikowanie kluczowych zależności między poszczególnymi determinantami wykluczenia bankowego a wiedzą finansową respondentów.

$\mathrm{W}$ ostatnim rozdziale - opierając się na wnioskach z przeprowadzonych badań empirycznych wśród banków i społeczeństwa - sformułowano rekomendacje

${ }^{4}$ Badanie zostało przeprowadzone metodą indywidualnego wywiadu osobistego face to face w domu respondenta (technika PAPI) w okresie maj-czerwiec 2013 r., na reprezentatywnej próbie mieszkańców województwa łódzkiego w wieku 50+. Zastosowano wystandaryzowaną technikę badawczą w postaci wywiadu kwestionariuszowego. 
w zakresie działań stymulujących podnoszenie świadomości finansowej Polaków z segmentu 50+ i ograniczanie zjawiska wykluczenia finansowego wśród nich. Kluczowa grupa rekomendacji adresowana jest do samych banków, ale dodatkowo wskazano także sugestie dotyczące pożądanych działań instytucji rządowych, samorządowych i innych. Rekomendacje te w znacznej mierze powstały na podstawie analizy dobrych praktyk występujących w badanych obszarach.

Podniesiona w pracy tematyka wpisuje się w szerszy nurt badań prowadzonych przez pracowników Katedry Bankowości Uniwersytetu Łódzkiego. Autorzy pragną podziękować Bankowi Zachodniemu WBK SA, którego wsparcie finansowe - udzielone w ramach programu Santander Universidades - umożliwiło realizację badań empirycznych, których wyniki zaprezentowano w niniejszej monografii. Dziękujemy także Recenzentce, prof. Małgorzacie Iwanicz-Drozdowskiej, za cenne uwagi i wskazówki, które umożliwiły nam doskonalenie monografii. Oczywiście, wszelkie niedociągnięcia i braki obciążają autorów. 


\section{Rozdział I. Koncepcja „srebrnej gospodarki” i problemy wykluczenia}

\section{1. „Srebrna gospodarka” na szczeblu krajowym i międzynarodowym}

Obserwowane obecnie negatywne zjawiska demograficzne stają się przedmiotem zainteresowań wielu badaczy z różnorodnych dyscyplin naukowych oraz obszarów tematycznych. Jednym z większych zagrożeń, w obliczu których stają gospodarki na całym świecie, okazuje się proces starzenia się ludności analizowany zarówno na gruncie krajowym, jak i międzynarodowym, a niekiedy nawet globalnym. Permanentny wzrost udziału osób po 50. roku życia w populacji ogółem z jednej strony może być odbierany pozytywnie, świadczy bowiem o wzroście skuteczności medycyny, a tym samym o wydłużaniu życia ludzi, z drugiej zaś negatywnie, co jest wynikiem obaw o stan gospodarki w perspektywie najbliższych dekad, w związku z analizowanym zjawiskiem.

Konsekwencje procesu starzenia się ludności są nierozerwalnie związane z sytuacją gospodarczą państw, które już zmagają się z tym problemem (przykładem może być Japonia), bądź też w przyszłości, w perspektywie kilkunastu lub kilkudziesięciu lat będą zmuszone do przedsięwzięcia działań mających za cel niwelowanie skutków negatywnych zjawisk demograficznych. W tle dyskursu, jaki prowadzony jest już od dłuższego czasu również w skali globalnej, zrodziła się koncepcja „,srebrnej gospodarki" (silver economy), zwracająca uwagę na potrzebę wykorzystania wzrostu udziału osób starszych w populacji ogółem do ukierunkowania rozwoju państw w taki sposób, aby wspomniane zagrożenie stało się szansą. Zgodnie ze wskazaną ideą, dla osiągnięcia korzyści wynikających ze starzenia się społeczeństwa konieczne jest zauważenie, że za zmianą struktury wieku ludności podąża zmiana struktury potrzeb populacji oraz pobudzenie osób po 65. roku życia (tzw. aktywne starzenie się) do aktywności na różnych płaszczyznach, w tym zawodowej ${ }^{1}$.

${ }^{1}$ S. Golinowska, ,Srebrna gospodarka” i miejsce w niej sektora zdrowotnego. Koncepcja i regionalne przykłady zastosowania, „Zdrowie Publiczne i Zarządzanie” 2011, t. IX, nr 1, s. 76. 
W odpowiedzi na zmiany o charakterze społeczno-gospodarczym zachodzące w wielu państwach można zaobserwować tworzenie przedsiębiorstw, których produkty i usługi są dedykowane dla osób starszych ${ }^{2}$. Tym samym z jednej strony pojawiające się potrzeby osób starszych są lepiej zaspokajane, z drugiej zaś osoby starsze mają możliwość uczestnictwa w życiu społecznym, kulturalnym oraz gospodarczym w zakresie znacznie większym niż poprzednie pokolenia ${ }^{3}$. Oczywiste jest, że w związku z kreowaniem nowego rynku i nowych potrzeb pojawiają się nowe miejsca pracy, przyczyniające się zwłaszcza do wzrostu integracji starszej części populacji z pozostałymi grupami wiekowymi społeczeństwa.

\subsubsection{Silver economy w polityce społecznej i dokumentach Unii Europejskiej}

Starzenie się ludności należy do najczęściej obecnie analizowanych zjawisk demograficznych. Proces ten pociąga za sobą liczne reperkusje, determinujące w długim okresie m.in. tempo rozwoju wielu gospodarek oraz zmiany w życiu społeczno-gospodarczym.

Problem ten po raz pierwszy stał się przedmiotem społecznego dyskursu w latach 60-tych XX w., kiedy to Zgromadzenie Ogólne ONZ najpierw zleciło przygotowanie raportu na temat starzenia się społeczeństwa, a następnie w $1973 \mathrm{r}$. przyjęło rezolucję (3137/XXVIII) ${ }^{4}$ dotyczącą sytuacji osób starszych. Dokument ten zawierał szereg rekomendacji uwzględniających konieczność przedsięwzięcia przez państwa członkowskie Organizacji Narodów Zjednoczonych odpowiednich kroków na szczeblu krajowym, zmierzających przede wszystkim do zabezpieczenia finansowego wskazanej grupy społeczeństwa, zapewnienia integracji społecznej z przedstawicielami innych przedziałów wiekowych, a także zwiększenia ich partycypacji w życiu społeczno-gospodarczym.

Działania podejmowane przez Organizację Narodów Zjednoczonych, a w kolejnych latach również przez Międzynarodową Organizację Pracy (International Labour Organization - ILO), Światową Organizację Zdrowia (World Health Organization - WHO) oraz Organizację Narodów Zjednoczonych do spraw Wychowania, Nauki i Kultury (UNESCO), zaowocowały powstaniem licznych inicjatyw, wśród których wymienić można m.in.:

${ }^{2}$ T. Obi, J.-P. Auffret, N. Iwasaki, Aging Society and ICT: Global Silver Innovation, IOS Press, Amsterdam 2013, s. 215.

${ }^{3}$ R. Vos, J. A. Ocampo, A. L. Cortez (ed.), Ageing and Development, United Nations Publications, New York 2008, s. 58.

${ }^{4}$ Question of the elderly and the aged, Rezolucja Organizacji Narodów Zjednoczonych, A/RES/3137(XXVIII),www.un.org/en/ga/search/view_doc.asp?symbol=A/RES/3137\%28 XXVIII\%29\&Lang=E\&Area= RESOLUTION (stan na dzień 18.01.2014). 
- organizację Światowego Zgromadzenia w sprawie starzenia się (26 lipca - 6 sierpnia 1982 r., Wiedeń) ${ }^{5}$,

- uchwalenie Międzynarodowego Planu Działania w sprawie starzenia się $(1983 \text { r. })^{6}$,

- ustanowienie 1 października Międzynarodowym Dniem Seniora (1990 r.) ${ }^{7}$,

- uchwalenie Programu Działania podczas Światowego Szczytu Rozwoju Społecznego (Kopenhaga, 1995 r.) ${ }^{8}$,

- ustanowienie roku 1999 Międzynarodowym Rokiem Seniorów ${ }^{9}$.

Wymienione inicjatywy stały się inspiracją dla działań podejmowanych przez Unię Europejską. W 1999 r., a więc podczas Międzynarodowego Roku Seniorów, Komisja Europejska opublikowała komunikat, w ramach którego zwróciła uwagę na wieloaspektowy charakter wyzwania, jakim jest starzenie się społeczeństwa. W dokumencie tym zidentyfikowano następujące wymiary analizowanego zjawiska ${ }^{10}$ :

- pierwszy, odnoszący się do starzenia się siły roboczej - zaakcentowano konieczność zarządzania zasobami ludzkimi w kontekście wieku pracowników oraz kształcenia ustawicznego jako rozwiązania problemu relatywnie wczesnego wychodzenia z rynku pracy (odchodzenia na emeryturę),

- drugi, związany z coraz większym obciążeniem systemów emerytalnych oraz finansów publicznych, wynikający z rosnącej liczby emerytów oraz spadku liczby ludności w wieku produkcyjnym - zwrócono uwagę na fakt, że systemy emerytalne powinny być tworzone w taki sposób, aby cechowały się mniejszą wrażliwością na zmiany demograficzne,

- trzeci, odnoszący się do zapotrzebowania na opiekę zdrowotną oraz opiekę nad osobami starszymi - konsekwencją starzenia się społeczeństwa będzie zwiększony popyt na usługi medyczne, w związku z czym systemy opieki zdrowotnej powinny być rozwijane, m.in. poprzez wzrost wiedzy i świadomości pacjentów na temat profilaktyki, zdrowego trybu życia oraz sposobów zapobiegania nawet najprostszym wypadkom,

${ }^{5}$ L. A. Morgan, S. R. Kunkel, Aging, Society, and the Life Course, Fourth Edition, Springer Publishing Company, New York 2011, s. 266.

${ }^{6}$ Międzynarodowy Plan Dziatania w sprawie starzenia się, Organizacja Narodów Zjednoczonych, Nowy Jork 1983, www.un.org/es/globalissues/ageing/docs/vipaa.pdf (stan na dzień 18.01.2014).

7 J. C. Batra, Rights for the Aged, [w:] P. H. Parekh (ed.), Human Rights Year Book 2010, Universal Law Publishing, New Delhi 2010, s. 87.

${ }^{8}$ D. B. Rao, Programme of Action of the World Summit for Social Development, Discovery Publishing House, New Delhi 1998, s. 35-125.

${ }^{9}$ G. Andrews, M. J. Clark, The International Year of Older Persons: Putting Aging and Research Onto the Political Agenda, [w:] D. L. Infeld, Disciplinary Approaches to Aging: Sociology of Aging, Taylor \& Francis, New York 2002, s. 155.

${ }_{10}$ Towards a Europe for All Ages - Promoting Prosperity and Intergenerational Solidarity, COM(1999) 221 final, Commission of the European Communities, Brussels 1999, s. 4. 
- czwarty, związany z rosnącą różnorodnością zasobów i potrzeb osób starszych - zaakcentowano istotne ryzyko występowania wykluczenia społecznego oraz ubóstwa determinowanego wiekiem.

Warto zauważyć, że we wskazanym dokumencie pojawia się termin ,aktywnego starzenia", który na szczeblu unijnym oznacza pomaganie ludziom w pozostawaniu odpowiedzialnym za ich własne życie tak długo, jak jest to możliwe, uwzględniając ich wiek i możliwości, w celu przyczyniania się do rozwoju społecznego i gospodarczego ${ }^{11}$. Innymi słowy, chodzi o uwzględnianie w stylu życia faktu, że żyjemy dłużej, często wykazując się lepszym stanem zdrowia i wykorzystanie tego m.in. poprzez przyjęcie zdrowego stylu życia, przedłużenie okresu pracy zawodowej, odłożenie w czasie momentu przejścia na emeryturę oraz pozostawanie aktywnym po zakończeniu kariery zawodowej ${ }^{12}$.

Kolejnym dokumentem poruszającym problem starzenia się obywateli Unii Europejskiej jest Zielona Księga „Wobec zmian demograficznych: nowa solidarność między pokoleniami”. Komunikat Komisji Wspólnot Europejskich z 2005 r. wskazuje, że niezbędne dla neutralizacji negatywnych zjawisk demograficznych będzie „rozwinięcie nowego rodzaju solidarności międzypokoleniowej” ${ }^{3}$, której fundamenty stanowić będą:

- lepsza integracja młodego pokolenia - oparta głównie na przeciwdziałaniu dyskryminacji, podnoszeniu poziomu kształcenia oraz umożliwianiu zdobywania wiedzy w sposób zdalny i na odległość,

- całościowe podejście do cyklu aktywności zawodowej - zakładające wykorzystanie nowych technologii oraz tworzenie nowych, bardziej elastycznych organizacji pracy,

- nowe miejsca dla „seniorów” - uwzględniające relatywnie lepszy stan zdrowia przyszłych emerytów oraz ich większą mobilność,

- solidarność z osobami w podeszłym wieku - oparta m.in. na tworzeniu przez społeczność lokalną ośrodków opieki nad osobami w podeszłym wieku (powyżej 80. roku życia).

Z perspektywy udziału osób starszych w życiu społecznym i gospodarczym istotne znaczenie ma także Decyzja Rady z dnia 6 października 2006 r. w sprawie strategicznych wytycznych Wspólnoty dla spójności wraz z załącznikiem - Strategiczne wytyczne Wspólnoty dla spójności gospodarczej, społecznej i terytorialnej na lata 2007-2013. W dokumencie tym wskazano jednoznacznie konieczność promowania społeczeństwa integracyjnego poprzez wzrost dostępności dla osób starszych technologii informacyjnych i komuni-

${ }^{11} \mathrm{http} / /$ ec.europa.eu/social/main.jsp?catId=1062\&langId=en (stan na dzień 18.01.2014).

12 I. Hoskins, Focusing on opportunities: Active ageing, [w:] A Society for All Ages, United Nations. Economic Commission for Europe, United Nations Publications, Geneva 2008, s. 73.

13 Zielona Księga ,Wobec zmian demograficznych: nowa solidarność między pokoleniami”, $\operatorname{COM}(2005) 94$ końcowy, Komisja Wspólnot Europejskich, Bruksela 2005, s. 7. 
kacyjnych, co w konsekwencji powinno się przełożyć na pobudzenie wzrostu gospodarczego i zatrudnienia ${ }^{14}$.

Kolejnym dokumentem stanowiącym odpowiedź na problem starzenia się ludności w Unii Europejskiej jest „Demograficzna przyszłość Europy - przekształcić wyzwania w nowe możliwości”. Komisja Wspólnot Europejskich w 2006 r. opracowała strategię przeciwdziałania negatywnym zjawiskom demograficznym opartą na następujących fundamentach ${ }^{15}$ :

1. Europa sprzyjająca odnowie pokoleń - zakłada przedsięwzięcie odpowiednich kroków będących reakcją na spadek wskaźnika urodzeń, wśród których wymienić można np. niwelowanie niepewności towarzyszących wejściu młodych ludzi na rynek pracy oraz dążenie do poprawy ich warunków życia.

2. Europa doceniająca znaczenie zatrudnienia: więcej miejsc pracy i dłuższe aktywne życie o wysokiej jakości - oparta na wzroście elastyczności rynku pracy, promowaniu uczenia się przez całe życie oraz proaktywnej polityce rynku pracy i ochrony socjalnej.

3. Europa bardziej produktywna i konkurencyjna - zakłada wykorzystanie potencjału rynku wewnętrznego, implementację zasad konkurencji, a także nadanie priorytetowego znaczenia jakości ram prawnych, w szczególności w stosunku do sektora małych i średnich przedsiębiorstw.

4. Europa zorganizowana w taki sposób, aby przyjąć imigrantów i zapewnić im integrację - oparta na poszukiwaniu optymalnych rozwiązań w zakresie wewnętrznej mobilności obywateli Unii Europejskiej oraz zacieśnianiu partnerstwa z krajami trzecimi.

5. Europa posiadająca stabilne finanse publiczne: gwarancja odpowiedniej ochrony socjalnej i równości międzypokoleniowej - zakłada m.in. konieczność reformowania wybranych systemów emerytalnych w celu wydłużania wieku emerytalnego oraz aktywizacji zawodowej osób starszych, które swoje dochody ze świadczeń emerytalnych mogłyby powiększyć o wynagrodzenie uzyskiwane $\mathrm{z}$ pracy w niepełnym wymiarze godzin.

Sytuacja starszych obywateli Unii Europejskiej była również przedmiotem rozważań Komisji Wspólnot Europejskich w 2007 r. W Komunikacie Komisji do Parlamentu Europejskiego, Rady, Europejskiego Komitetu Ekonomiczno-Społecznego i Komitetu Regionów, zatytułowanym „Promowanie solidarności między pokoleniami”, zwrócono uwagę na jakość usług świadczonych na rzecz

${ }^{14}$ Decyzja Rady z dnia 6 października 2006 r. w sprawie strategicznych wytycznych Wspólnoty dla spójności wraz z załącznikiem - Strategiczne wytyczne Wspólnoty dla spójności gospodarczej, społecznej i terytorialnej na lata 2007-2013 (2006/702/WE), Bruksela 2006, s. 12, www.mir.gov.pl/aktualnosci/fundusze_europejskie_2007_2013/documents/f8d206ed005b4da 38290a5117005a7c0sww20072013 pl4.pdf (stan na dzień 18.01.2014).

${ }^{15}$ Demograficzna przyszłość Europy-przeksztatcić wyzwania wnowe możliwości, COM(2006) 571 wersja ostateczna, Komisja Wspólnot Europejskich, Bruksela 2006, s. 7-13, http://eur-lex.euro pa.eu/LexUriServ/ LexUriServ.do?uri=COM:2006:0571:FIN:PL:PDF (stan na dzień 18.01.2014). 
niesamodzielnych starszych osób oraz opieki, a także na możliwości podjęcia wspólnych inicjatyw (na płaszczyźnie państw członkowskich przy współpracy z organami Unii Europejskiej) poprawiających infrastrukturę we wskazanym obszarze $^{16}$.

W kolejnym dokumencie opracowanym przez Komisję Wspólnot Europejskich w 2009 r. zwrócono szczególną uwagę na gospodarcze oraz finansowe konsekwencje starzenia się społeczeństwa w kontekście obserwowanej recesji. Zawarte w Komunikacie Komisji do Parlamentu Europejskiego, Rady, Europejskiego Komitetu Ekonomiczno-Społecznego i Komitetu Regionów, zatytułowanym „Sprostanie wyzwaniom związanym ze skutkami starzenia się społeczeństwa w UE (Sprawozdanie na temat starzenia się społeczeństwa, 2009)", propozycje kierunków rozwoju Unii Europejskiej koncentrują się wokół takich obszarów, jak: odnowa demograficzna, tworzenie nowych miejsc pracy, wzrost wydajności oraz konkurencyjności Wspólnoty oraz problemy związane z imigrantami ${ }^{17}$.

Odniesienie do zjawiska starzenia się społeczeństwa można znaleźć również $\mathrm{w}$ „Strategii na rzecz inteligentnego i zrównoważonego rozwoju sprzyjającego włączeniu społecznemu (Europa 2020)”. W przytoczonym komunikacie Komisji Europejskiej z dnia 3.03.2010 r. można znaleźć jednoznaczne stwierdzenie, że jedyną szansą na rozwiązanie problemu wynikającego z negatywnych zjawisk demograficznych jest pełne wykorzystanie potencjału siły roboczej Unii Europejskiej, a co za tym idzie - aktywizacja zawodowa osób starszych ${ }^{18}$.

Jednym z priorytetów związanych z problemem starzenia się ludności, wynikającym ze strategii „Europa 2020” jest „Europejskie partnerstwo na rzecz innowacji sprzyjającej aktywnemu starzeniu się w dobrym zdrowiu". Celem działań podejmowanych $w$ ramach wskazanej inicjatywy jest wydłużenie życia obywateli Unii Europejskiej o 2 lata do roku 2020, natomiast sam projekt jest realizowany we współpracy podmiotów publicznych z prywatnymi. Analizowana inicjatywa koncentruje się wokół następujących zagadnień, stanowiących jednocześnie filary działania ${ }^{19}$ :

16 Promowanie solidarności między pokoleniami, Komisja Wspólnot Europejskich, KOM (2007) 244 wersja ostateczna, Bruksela 2007, s. 7.

${ }^{17}$ Sprostanie wyzwaniom zwiazanym ze skutkami starzenia się społeczeństwa w UE (Sprawozdanie na temat starzenia się społeczeństwa, 2009), KOM(2009) 180 wersja ostateczna, Komisja Wspólnot Europejskich, Bruksela 2009, s. 3-11, http://eur-lex.europa.eu/LexUriServ/LexUriServ. do?uri =COM:2009:0180:FIN:PL:PDF (stan na dzień 18.01.2014).

18 Strategia na rzecz inteligentnego i zrównoważonego rozwoju sprzyjającego włączeniu spoŁecznemu (Europa 2020), KOM(2010) 2020 wersja ostateczna, Komisja Wspólnot Europejskich, Bruksela 2010, s. 20, http://ec.europa.eu/eu2020/pdf/1_PL_ACT_part1_v1.pdf (stan na dzień 18.01.2014).

${ }^{19}$ Komisja Europejska, Działania w ramach Strategicznego planu realizacji Europejskiego partnerstwa na rzecz innowacji sprzyjającej aktywnemu starzeniu się $w$ dobrym zdrowiu, $\operatorname{COM}(2012) 83$ final, Bruksela 2012, s. 5, http://eur-lex.europa.eu/LexUriServ/LexUriServ.do?uri= COM:2012:0083:FIN:PL:PDF (stan na dzień 18.01.2014). 
- profilaktyka, badania przesiewowe i wczesna diagnoza,

- opieka i leczenie,

- starzenie się i niezależne życie.

Wspomniane filary oraz przypisane im obszary działań priorytetowych i konkretne działania realizowane $\mathrm{w}$ ramach „Europejskiego partnerstwa na rzecz innowacji sprzyjającej aktywnemu starzeniu się w dobrym zdrowiu" przedstawia tablica 1.

Tablica 1. Filary oraz przypisane im obszary działań priorytetowych i konkretne działania realizowane w ramach „Europejskiego partnerstwa na rzecz innowacji sprzyjającej aktywnemu starzeniu się w dobrym zdrowiu"

\begin{tabular}{|c|c|c|}
\hline Filar & Obszar działań priorytetowych & Konkretne działania \\
\hline \multirow[t]{3}{*}{$\begin{array}{l}\text { Profilaktyka, } \\
\text { badania } \\
\text { przesiewowe } \\
\text { i wczesna } \\
\text { diagnoza }\end{array}$} & $\begin{array}{l}\text { Kompetencje zdrowotne, zwiększanie } \\
\text { roli pacjentów, etyka i programy w za- } \\
\text { kresie przestrzegania zaleceń terapeu- } \\
\text { tycznych, wykorzystujące innowacyjne } \\
\text { narzędzia i usługi }\end{array}$ & $\begin{array}{l}\text { Określanie innowacyjnych rozwiązań } \\
\text { dla zapewnienia lepszego przestrzegania } \\
\text { zaleceń terapeutycznych na poziomie re- } \\
\text { gionalnym }\end{array}$ \\
\hline & $\begin{array}{l}\text { Zindywidualizowane zarządzanie zdro- } \\
\text { wotne }\end{array}$ & $\begin{array}{l}\text { Poszukiwanie innowacyjnych rozwią- } \\
\text { zań w zakresie lepszego zarządzania } \\
\text { własnym zdrowiem i zapobiegania } \\
\text { upadkom starszych ludzi }\end{array}$ \\
\hline & $\begin{array}{l}\text { Profilaktyka pogorszenia sprawności za- } \\
\text { równo fizycznej, jak i umysłowej u osób } \\
\text { starszych }\end{array}$ & $\begin{array}{l}\text { Działania profilaktyczne zapobiegają- } \\
\text { ce utracie sił fizycznych i pogorszeniu } \\
\text { sprawności }\end{array}$ \\
\hline $\begin{array}{l}\text { Opi } \\
\text { i lec }\end{array}$ & $\begin{array}{l}\text { Zwiększanie potencjału i możliwość } \\
\text { powielania dobrze działających zinte- } \\
\text { growanych systemów opieki opierają- } \\
\text { cych się na innowacyjnych narzędziach } \\
\text { i usługach }\end{array}$ & $\begin{array}{l}\text { Promowanie zintegrowanych modeli } \\
\text { opieki w odniesieniu do chorób przewle- } \\
\text { kłych, w tym stosowanie zdalnego mo- } \\
\text { nitorowania na poziomie regionalnym }\end{array}$ \\
\hline $\begin{array}{l}\text { Aktywne } \\
\text { starzenie się } \\
\text { i niezależne } \\
\text { życie }\end{array}$ & $\begin{array}{l}\text { Wydłużanie aktywnego i niezależnego } \\
\text { życia za pośrednictwem otwartych i zin- } \\
\text { dywidualizowanych rozwiązań }\end{array}$ & $\begin{array}{l}\text { Opracowywanie w oparciu o technolo- } \\
\text { gie informacyjno-komunikacyjne roz- } \\
\text { wiązań umożliwiających osobom star- } \\
\text { szym dłuższą niezależność, aktywność, } \\
\text { mobilność }\end{array}$ \\
\hline $\begin{array}{l}\text { Kwestie } \\
\text { horyzontalne }\end{array}$ & $\begin{array}{l}\text { Tematyczne forum wymiany: Innowacje } \\
\text { w zakresie budynków, miast i środowisk } \\
\text { przyjaznych osobom starszym }\end{array}$ & $\begin{array}{l}\text { Promowanie innowacji w zakresie bu- } \\
\text { dynków, miast i środowisk przyjaznych } \\
\text { i dostępnych osobom starszym }\end{array}$ \\
\hline
\end{tabular}

Źródło: Komisja Europejska, Działania w ramach Strategicznego planu realizacji Europejskiego partnerstwa na rzecz innowacji sprzyjajacej aktywnemu starzeniu się w dobrym zdrowiu, $\operatorname{COM}(2012) 83$ final, Bruksela 2012, s. 5; http://eurlex.europa.eu/LexUriServ/LexUriServ.do?uri=COM:2012:0083:FIN:PL:PDF (stan na dzień 18.01.2014).

Znaczenie problemu starzenia się przede wszystkim dla długoterminowego rozwoju gospodarczego i jego nagłośnienie wpłynęły na decyzję Parlamentu Europejskiego i Rady z dnia 14 września 2011 r. o ustanowieniu Europejskiego 
Roku Aktywności Osób Starszych i Solidarności Międzypokoleniowej w 2012 r. Poprzez wskazaną inicjatywę realizowano między innymi następujące cele ${ }^{20}$ :

- podniesienie ogólnej świadomości na temat wartości aktywności osób starszych,

- zaakcentowanie wkładu wnoszonego przez osoby starsze zarówno do społeczeństwa, jak i gospodarki,

- propagowanie aktywności osób starszych,

- przedsięwzięcie działań umożliwiających prowadzenie niezależnego życia przez osoby starsze.

Oprócz powyższych, istotnym celem było również kreowanie płaszczyzny niezbędnej do wymiany poglądów, obserwacji oraz dobrych praktyk pomiędzy państwami członkowskimi oraz zainteresowanymi podmiotami i jednostkami życia społeczno-gospodarczego. Działania podejmowane przez Unię Europejską mają głównie charakter informacyjny i stanowią kierunkowskaz dla inicjatyw podejmowanych przez poszczególne kraje członkowskie Wspólnoty.

\subsubsection{Lokalna polityka na rzecz osób starszych}

Konsekwencją wzrostu zainteresowania problemami osób starszych, w tym zagadnieniem aktywnego starzenia się, jest m.in. uwzględnianie wskazanego obszaru życia społeczno-gospodarczego w dokumentach strategicznych, określających priorytety działań podejmowanych w Polsce, przy wykorzystaniu środków unijnych. Należą do nich:

1. Strategia Rozwoju Kraju 2007-2015,

2. Strategia Polityki Społecznej na lata 2007-2013,

3. Strategia Wspierania Rozwoju Społeczeństwa Obywatelskiego na lata 2009-2015.

Pierwszym z wymienionych strategicznych dokumentów jest Strategia Rozwoju Kraju 2007-2015 identyfikująca cele i priorytety związane z rozwojem Polski, a także określająca warunki niezbędne dla ich realizacji. W dokumencie zaakcentowane zostały m.in. następujące postulaty:

- podniesienia poziomu życia obywateli w szczególności poprzez zwiększenie dostępności do usług zdrowotnych, opiekuńczych i socjalnych ${ }^{21}$,

- zwiększenia dostępności i rozwoju oferty programowej placówek edukacyjnych, jak i kreowania trwałych mechanizmów aktualizacji kwalifikacji zawodowych w miejscu pracy, zwłaszcza dla pracowników starszych ${ }^{22}$,

${ }^{20}$ Decyzja Parlamentu Europejskiego i Rady nr 940/2011/UE z dnia 14 września 2011 r. w sprawie Europejskiego Roku Aktywności Osób Starszych i Solidarności Międzypokoleniowej (2012), Dziennik Urzędowy Unii Europejskiej (23.9.2011), L246, s. 8.

${ }^{21}$ Ministerstwo Rozwoju Regionalnego, Strategia Rozwoju Kraju 2007-2015, Warszawa 2006, s. 38, www.mir.gov.pl/rozwoj_regionalny/Polityka_rozwoju/SRK/Documents/SRK_2007_2015.pdf (stan na dzień 19.01.2014).

${ }^{22}$ Ibidem, s. 45. 
- promowania wielopłaszczyznowej integracji społecznej, zwłaszcza w zakresie funkcji opiekuńczych ${ }^{23}$.

Kolejnym dokumentem jest przyjęta przez Radę Ministrów w dniu 13 września 2005 r. Strategia Polityki Społecznej na lata 2007-2013, uzupełniająca plany i projekcje zawarte w Narodowym Planie Rozwoju na lata 2007-2013. Wyznaczone w Strategii kierunki polityki społecznej są zbieżne z niwelowaniem negatywnych zjawisk demograficznych i są skoncentrowane m.in. wokół następujących priorytetów:

- Priorytetu 2. - Wdrożenia aktywnej polityki społecznej, zwłaszcza w zakresie wspierania aktywności zawodowej i edukacyjnej poprzez system pomocy społecznej oraz ograniczenia zachęt do dezaktywizacji zawodowejej,

- Priorytetu 3. - Kompleksowej rehabilitacji i aktywizacji osób niepełnosprawnych, w szczególności dzięki usprawnieniu systemu rehabilitacji na rzecz utrzymania możliwości aktywności zawodowej25,

- Priorytetu 4. - Tworzenia warunków sprzyjających integracji w starzejącym się społeczeństwie, w szczególności poprzez rozwijanie systemu opieki pielęgnacyjnej $\mathrm{w}$ celu zbudowania środowiskowego modelu integracji ludzi starszych i wymagających pomocy, aktywizacji i integracji lokalnej osób w wieku poprodukcyjnym, wykorzystania potencjału osób starszych w środowisku lokalnym oraz zapewnienia odpowiednich świadczeń emerytalnych na starośćc ${ }^{26}$.

Ostatnim z wymienionych dokumentów jest Strategia Wspierania Rozwoju Społeczeństwa Obywatelskiego na lata 2009-2015 koncentrująca się wokół zagadnień związanych z procesem rozwoju społeczeństwa obywatelskiego w Polsce. Ograniczanie skutków obserwowanych negatywnych zjawisk demograficznych odbywa się m.in. poprzez realizację działań w ramach następujących priorytetów:

- Priorytetu 1. - Aktywni, świadomi obywatele, aktywne wspólnoty lokalne - zwłaszcza poprzez realizację działań z zakresu edukacji obywatelskiej oraz aktywizację obywateli w sprawach publicznych ${ }^{27}$,

- Priorytetu 3. - Rozwój organizacji pozarządowych na rzecz integracji społecznej - w szczególności dzięki realizacji działań z obszaru zapobiegania powstawaniu ryzyka wykluczenia społecznego poprzez wzmacnianie roli i funkcji rodziny i wspólnoty lokalnej oraz aktywizację osób zagrożonych wykluczeniem społecznym, a także przedsięwzięć związanych z zapewnianiem tworzenia i funkcjonowania mechanizmów kompleksowego wsparcia integracji społecznej ${ }^{28}$.

${ }^{23}$ Ibidem, s. 49.

${ }^{24}$ Ministerstwo Polityki Społecznej, Strategia Polityki Społecznej na lata 2007-2013, Warszawa 2005, s. 29-31, www.mpips.gov.pl/userfiles/File/nowe/strategiaps.pdf (stan na dzień 19.01.2013).

25 Ibidem, s. 33.

${ }^{26}$ Ibidem, s. 34-35.

27 Strategia Wspierania Rozwoju Społeczeństwa Obywatelskiego na lata 2009-2015, Załącznik do uchwały nr 240/2008 Rady Ministrów z dnia 4 listopada 2008 r., s. 41-44, www.mpips.gov. pl/userfiles/ File/pozytek/ SWRSO\%202009-2015.pdf (stan na dzień 19.01.2014).

${ }^{28}$ Ibidem, s. 48-49. 
Cechą wspólną wszystkich przytoczonych dokumentów jest diagnoza problemów społecznych uwzględniająca proces starzenia się społeczeństwa jako istotne wyzwanie, przed którym stanie Polska w najbliższych latach. Odpowiedzią na negatywne zjawiska demograficzne, obserwowane w skali zarówno Unii Europejskiej, jak i kraju, był „Rządowy Program na rzecz Aktywności Społecznej Osób Starszych na lata 2012-2013" stanowiący Załącznik do uchwały nr 137 Rady Ministrów z dnia 24 sierpnia 2012 r. Zarówno w przypadku wspomnianej inicjatywy, jak i jej kontynuacji, tj. „Rządowego Programu na rzecz Aktywności Społecznej Osób Starszych na lata 2014-2020”, celem głównym przedsięwzięć jest poprawa jakości i poziomu życia osób starszych, identyfikowanych jako osoby powyżej 60 . roku życia, dla godnego starzenia się poprzez aktywność społeczną. Innymi słowy, intencją działań podejmowanych na szczeblu rządowym było włączenie społeczno-gospodarcze osób 50+ oraz wykorzystanie ich potencjału w życiu publicznym.

Wskazanemu celowi głównemu obu inicjatyw towarzyszyły cele szczegółowe ${ }^{29}$ :

1. Zwiększenie różnorodności i poprawa jakości oferty edukacyjnej dla osób starszych - związany przede wszystkim z kreowaniem warunków niezbędnych dla tworzenia oraz rozwijania oferty edukacyjno-kulturalnej.

2. Tworzenie warunków dla integracji wewnątrz i międzypokoleniowej osób starszych przy wykorzystaniu istniejącej infrastruktury społecznej - wynikający z potrzeby uświadamiania społeczeństwu zmian zachodzących wraz z wiekiem, m.in. o charakterze zdrowotnym oraz społecznym.

3. Rozwój zróżnicowanych form aktywności społecznej, w tym upowszechnianie wolontariatu, partycypacji w procesach decyzyjnych, w życiu społecznym, w tym udział osób starszych w kształtowaniu polityki publicznej - wynikający m.in. z konieczności promowania określonych postaw w społeczeństwie.

4. Zwiększenie dostępności, podniesienie jakości usług społecznych oraz wspieranie działań na rzecz samopomocy i samoorganizacji wspierania osób starszych zarówno niezależnych, poprzez tworzenie dedykowanych dla nich usług w obszarze sportu turystyki i kultury, jak i o ograniczonej samodzielności, dzięki kreowaniu systemów wsparcia.

Zarówno Rządowy Program na rzecz Aktywności Społecznej Osób Starszych na lata 2012-2013, jak i Rządowy Program na rzecz Aktywności Społecznej Osób Starszych na lata 2014-2020 stanowią wsparcie dla lokalnych instytucji i organizacji pozarządowych, których działalność w wielu przypadkach, najczęściej z powodu

${ }^{29}$ Rządowy Program na rzecz Aktywności Społecznej Osób Starszych na lata 2012-2013, Załącznik do uchwały nr 137 Rady Ministrów z dnia 24 sierpnia 2012 r., Warszawa 2012, s. 1921, www.mpips.gov.pl/gfx/ mpips/userfiles/_public/1_NOWA\%20STRONA/Aktualnosci/seniorzy/Rzadowy\%20Program\%20ASOS_2012-2013.pdf (stan na dzień 19.01.2014) oraz Rządowy Program na rzecz Aktywności Społecznej Osób Starszych na lata 2014-2020, projekt z dnia 29 sierpnia 2013 r., Warszawa 2013, s. 8-10, www.mpips.gov.pl/download /gfx/mpips/pl/defaultopisy/8266/1/1/ASOS\%202014-2020\%20projekt\%20z\%20dnia\%2029\%20sierpnia\% 202013\%20 r.,pdf (stan na dzień 29.01.2014). 
braku wystarczających środków finansowych, nie koncentruje się wokół problemów wynikających ze zjawiska starzenia się społeczeństwa. Analizowane inicjatywy zakładają silną współpracę międzysektorową (szczególnie na płaszczyźnie podmiotów kierujących ofertę do różnych grup społecznych i wiekowych oraz jednostek samorządu terytorialnego), dzięki czemu istnieje wysokie prawdopodobieństwo wzrostu efektywności przedsięwzięć realizowanych na poziomie lokalnym.

\subsubsection{Trendy demograficzne w Polsce na tle krajów Unii Europejskiej}

Negatywne zjawiska demograficzne widoczne są zarówno w Polsce, jak i Unii Europejskiej. Różnica sprowadza się w większości państw jedynie do skali poszczególnych zjawisk, a tym samym skali zagrożenia dla życia społeczno-gospodarczego wynikającego z postępującego procesu starzenia się społeczeństwa. Potencjalny wpływ negatywnych zjawisk demograficznych na sytuację wszystkich członków Wspólnoty ma tym większe znaczenie (zarówno ogólnospołeczne, jak i ogólnogospodarcze), że dotyczy blisko 506 mln osób w skali całej UE.

Jak wynika z danych Eurostatu, populacja Polski w 2013 r. wyniosła nieco ponad 38,5 mln osób i stanowiła 7,62\% łącznej populacji 28 krajów członkowskich Unii Europejskiej. Prognozę udziału liczby obywateli Polski w populacji Wspólnoty w latach 2015-2060 przedstawia rysunek 1.

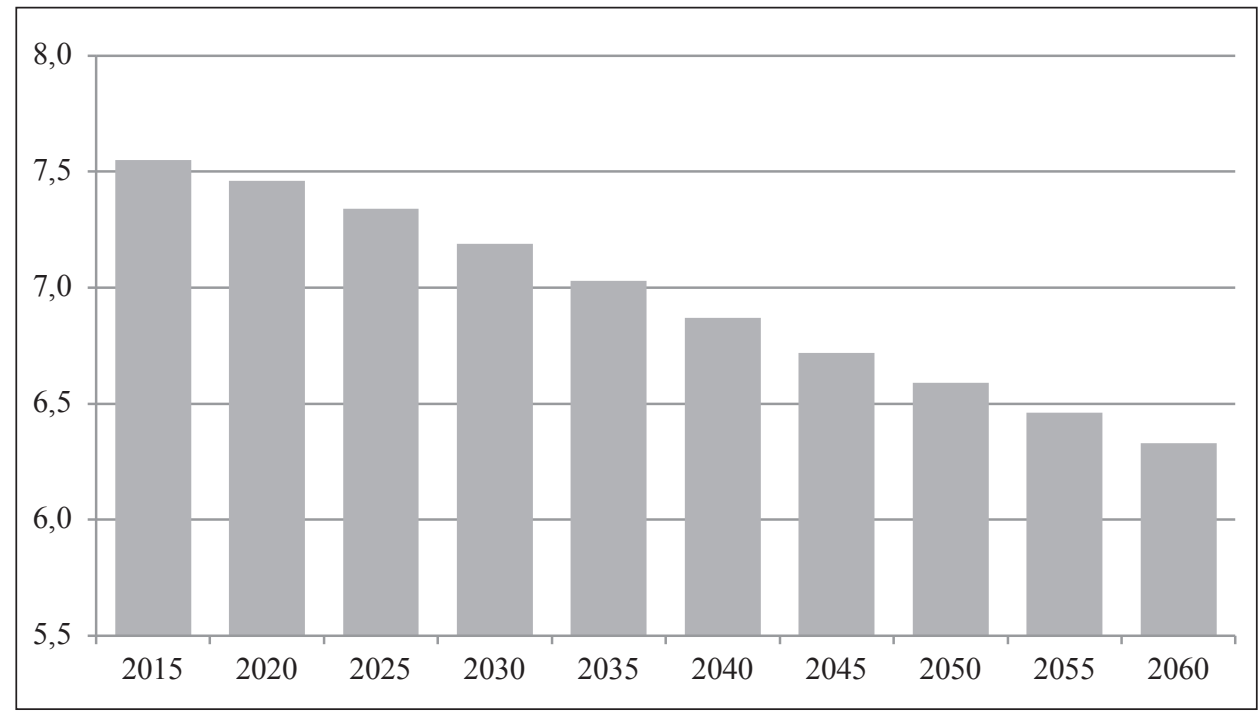

Rysunek 1. Prognoza udziału procentowego obywateli Polski w populacji Unii Europejskiej w latach 2015-2060 (w \%)

Źródło: opracowanie własne na podstawie danych Eurostatu 
Według prognoz Eurostatu liczba obywateli Polski do 2060 r. zmniejszy się o ponad $14 \% \mathrm{w}$ porównaniu ze stanem obecnym. Warto przy tym zauważyć, że jest to jedynie wynik analiz zmian w przemianach płodności i umieralności, co oznacza, że nie został uwzględniony w analizie wpływ poakcesyjnego odpływu ludności z Polski. Sytuacja wydaje się niezwykle niepokojąca, zwłaszcza biorąc pod uwagę starzenie się społeczeństwa. Analizowana miara przyjmuje bardziej niekorzystne wartości jedynie w przypadku Bułgarii (27\%), Łotwy (26\%), Litwy (20\%), Rumunii (19\%) oraz Niemiec (19\%).

Obywatele Unii Europejskiej żyją coraz dłużej, czego jedną z konsekwencji jest wyższa wartość mediany wieku w poszczególnych państwach członkowskich. Wartości mediany wieku w 27 krajach UE (ze względu na brak danych w zestawieniu nie uwzględniono Chorwacji) w 2012 r. w porównaniu z 1992 r. przedstawia rysunek 2 .

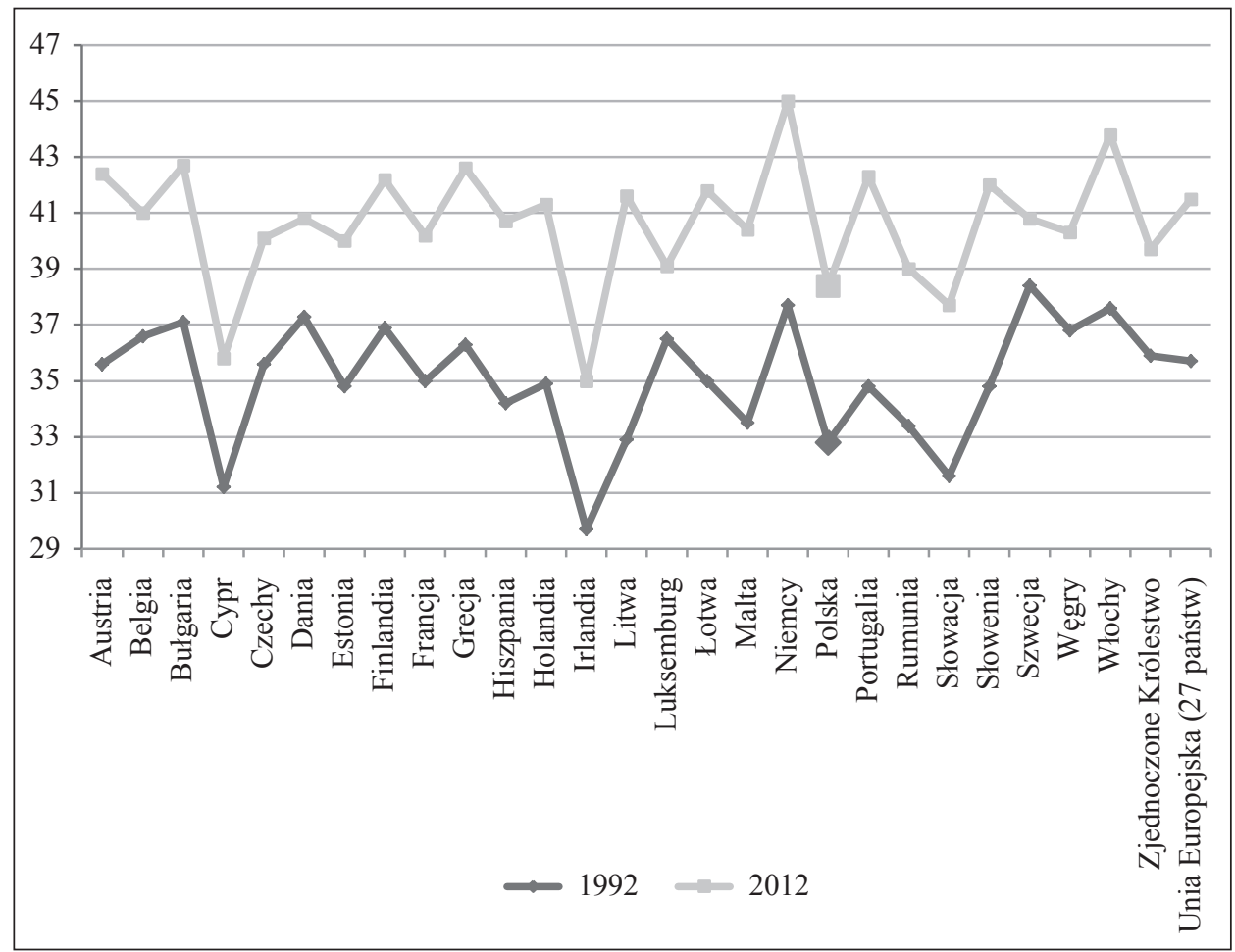

Rysunek 2. Porównanie wartości mediany wieku w 27 krajach UE w 1992 r. i 2012 r.

Źródło: jak przy rys. 1

Połowa populacji Unii Europejskiej ma nie więcej niż 41,5 lat, przy czym najwyższą wartość mediany odnotowano w Niemczech (wartość wskaźnika na poziomie 45 lat), natomiast najniższą w Irlandii, gdzie połowa obywateli ma co 
najwyżej 35 lat. Zgodnie z prognozą Eurostatu w 2060 r. mediana wieku obywateli Wspólnoty będzie kształtować się na poziomie 47,6 lat, tym samym wartość analizowanego wskaźnika będzie wyższa o blisko 15 lat w porównaniu z 1960 r. ${ }^{30}$

Kolejną miarą pozwalającą określić sytuację demograficzną w poszczególnych państwach członkowskich Unii Europejskiej jest wskaźnik przeciętnego oczekiwanego trwania życia dla nowo narodzonego człowieka. Wartości analizowanego miernika dla 28 państw Wspólnoty dla roku 2003 oraz 2011 przedstawia rysunek 3 .

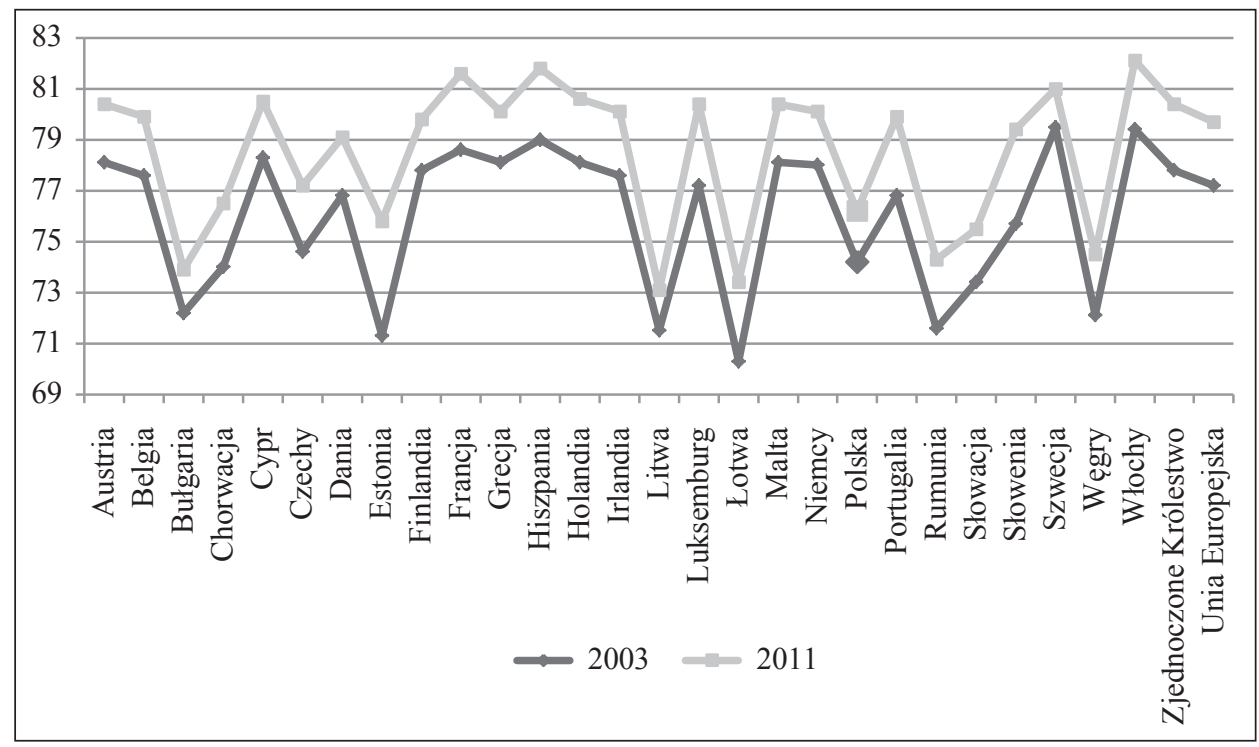

Rysunek 3. Porównanie wartości wskaźnika przeciętnego trwania życia nowo narodzonego człowieka w Unii Europejskiej dla 2003 r. i 2011 r.

Źródło: jak przy rys. 1

Obywatel Unii Europejskiej urodzony w 2003 r. będzie żyć przeciętnie 77,2 lat, natomiast osoby urodzone w 2011 r. będą żyć dłużej o około 2,5 roku (w przypadku Polski wskaźnik przeciętnego trwania życia wzrośnie o 2 lata). Należy przy tym podkreślić, że $\mathrm{w}$ analizowanym okresie tendencja ta utrzymywała się we wszystkich krajach Unii Europejskiej.

Jedną z konsekwencji starzenia się społeczeństwa jest również wzrost udziału osób powyżej 50. roku życia w populacji ogółem. Prognozowaną relację w analizowanym zakresie w skali Unii Europejskiej (27 krajach należących do Wspólnoty, bez Chorwacji) oraz poszczególnych państwach członkowskich w wybranych latach $(2020,2040,2060)$ przedstawia rysunek 4.

${ }^{30}$ Active ageing and solidarity between generations. A statistical portrait of the European Union 2012, Eurostat, Luksemburg 2011, s. 17. 


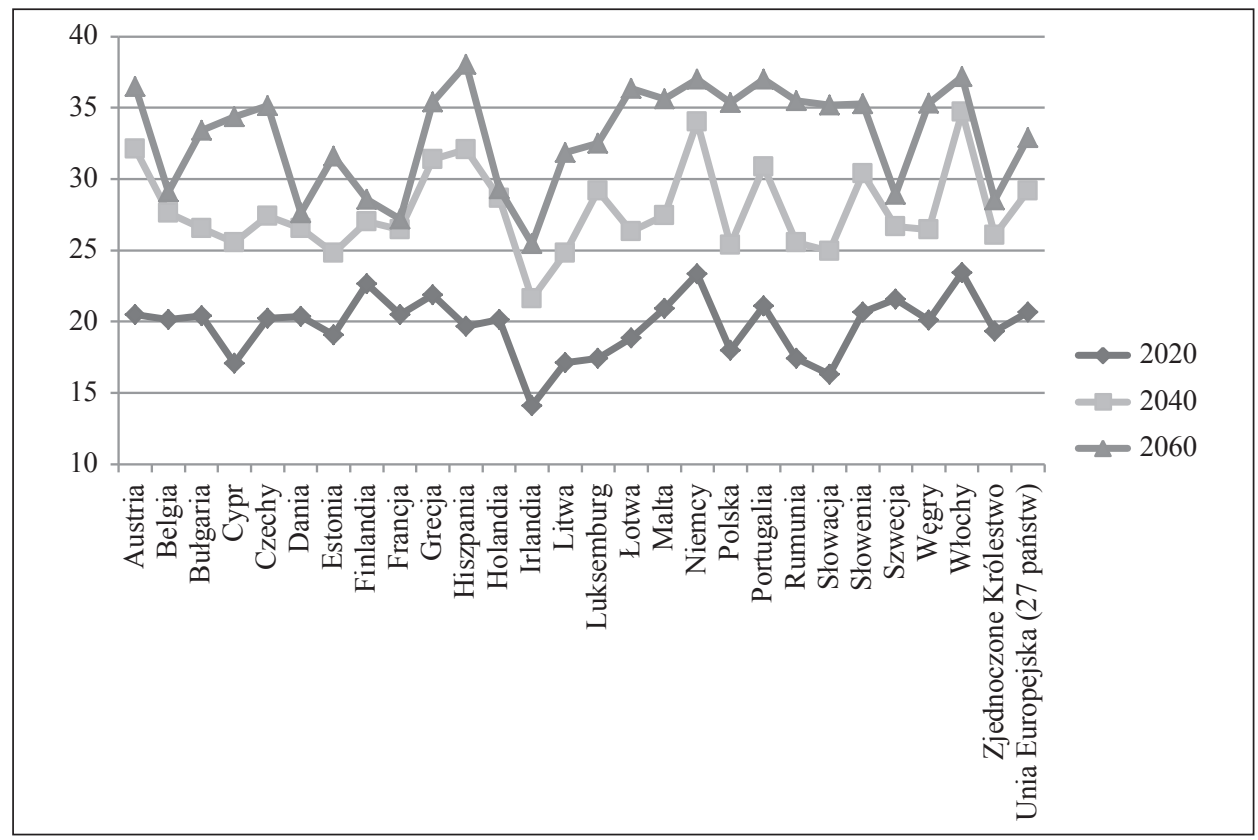

Rysunek 4. Prognozowany udział procentowy społeczeństwa powyżej 50. roku życia w populacji ogółem Unii Europejskiej oraz państw członkowskich w wybranych latach $(2020,2040,2060)$ (w \%)

Źródło: jak przy rys. 1

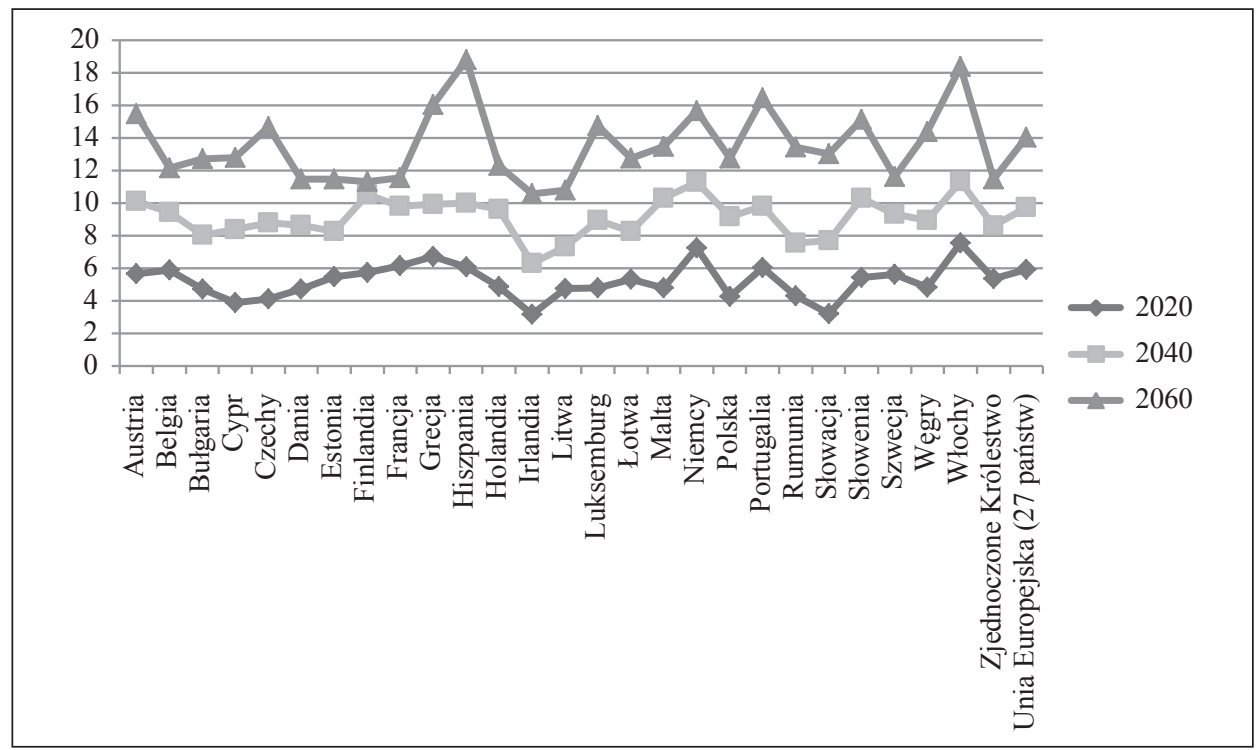

Rysunek 5. Prognozowany udział procentowy społeczeństwa powyżej 80. roku życia w populacji ogółem Unii Europejskiej oraz państw członkowskich w latach 2020, 2040, 2060 (w \%)

Źródło: jak przy rys. 1 
W okresie najbliższych 50 lat prognozowany jest permanentny wzrost udziału procentowego społeczeństwa w wieku powyżej 50. roku życia w populacji ogółem. Dotyczy to zarówno Unii Europejskiej (udział analizowanej grupy w $2020 \mathrm{r}$. wyniesie $20,65 \%$, natomiast w 2060 r. 32,88\%), jak i wszystkich państw członkowskich, w tym również Polski, gdzie wartość miary w 2020 r. wyniesie 17,98\%, natomiast 2060 r. 35,36\%).

Starzenie się społeczeństwa jest także widoczne we wzroście udziału osób powyżej 80. roku życia w populacji ogółem. Prognozowaną relację w analizowanym zakresie w skali Unii Europejskiej (27 krajach należących do Wspólnoty, bez Chorwacji) oraz poszczególnych państwach członkowskich w wybranych latach $(2020,2040,2060)$ przedstawia rysunek 5 .

Podobnie jak w przypadku osób powyżej 50. roku życia, udział grupy obywateli powyżej 80. roku życia w populacji ogółem w okresie najbliższych 50 lat będzie cechować się permanentnym wzrostem. Dotyczy to zarówno Unii Europejskiej (udział analizowanej grupy w 2020 r. wyniesie 5,91\%, natomiast w $2060 \mathrm{r}$. 14,03\%), jak i wszystkich państw członkowskich, w tym również Polski, gdzie wartość miary w 2020 r. wyniesie 4,27\%, natomiast w 2060 r. 12,74\%.

Niezwykle istotnym wskaźnikiem obrazującym sytuację demograficzną państw jest współczynnik obciążenia ekonomicznego osobami powyżej 65. roku życia (patrz rysunek 6). Wskazany miernik określa stosunek liczby osób w wieku poprodukcyjnym przypadającej na 100 osób w wieku produkcyjnym.

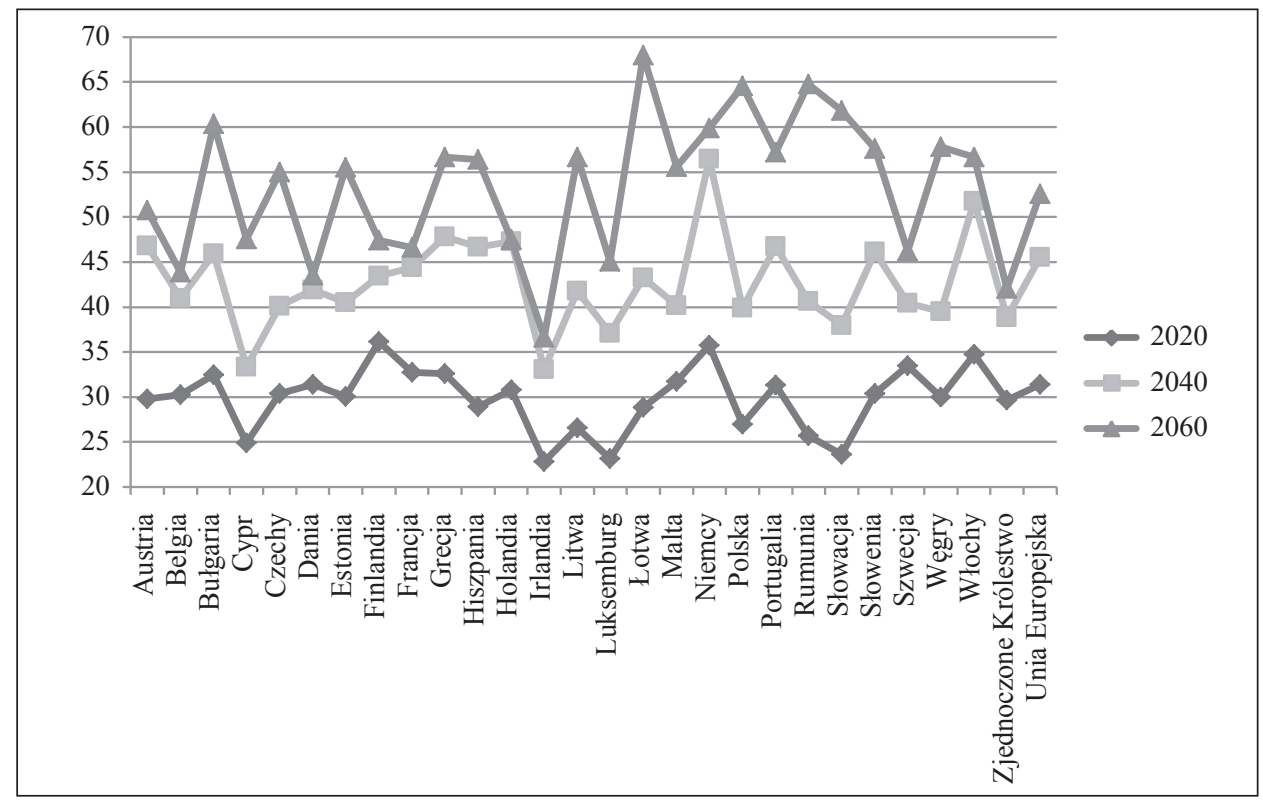

Rysunek 6. Współczynnik obciążenia ekonomicznego osobami powyżej 65. roku życia w Unii Europejskiej i państwach członkowskich w latach 2020, 2040, 2060 (w \%)

Źródło: jak przy rys. 1 
Wartości współczynnika obciążenia ekonomicznego osobami powyżej 65. roku życia zarówno w Unii Europejskiej, jak i we wszystkich państwach członkowskich na przestrzeni najbliższych 50 lat będą systematycznie wzrastać. Liczba osób w wieku poprodukcyjnym przypadająca na 100 osób w wieku produkcyjnym w UE wzrośnie w 2060 r. do ponad 52 (dla porównania w 2020 r. wyniesie nieco ponad 31 osób), natomiast w Polsce, zgodnie z prognozami Eurostatu, w 2060 r. wskaźnik będzie na poziomie blisko 65 osób, w 2020 r. miara przyjmie wartość 27 osób. Należy zauważyć, że prognozowane poziomy współczynnika obciążenia ekonomicznego w Polsce w perspektywie najbliższych 50 lat należą do najwyższych w Unii Europejskiej (jedynie Rumunia oraz Łotwa cechować się będą wyższymi wartościami analizowanego wskaźnika).

Dopełnieniem obrazu sytuacji demograficznej Polski na tle państw członkowskich Unii Europejskiej jest analiza indeksu aktywnego starzenia (Active Ageing Index), obrazującego możliwości aktywnego starzenia się w zdrowiu. Analizowany wskaźnik obejmuje 22 mierniki charakteryzujące różnorodne aspekty starzenia się podzielone na cztery obszary ${ }^{31}$ :

1) zatrudnienie, obejmujące wskaźniki zatrudnienia w poszczególnych przedziałach wiekowych, np. 55-59, 60-64, 65-69 itd.;

2) aktywność społeczna, zawierająca w sobie takie sfery, jak: wolontariat, opiekę nad wnukami oraz zaangażowanie polityczne itd.;

3) niezależne, zdrowe i bezpieczne życie, mierzone poprzez analizę m.in. dostępności do opieki medycznej, stopnia zagrożenia ubóstwem oraz stopnia aktywności fizycznej;

4) zdolności i przygotowanie otoczenia do wykorzystania potencjału starzejącego się społeczeństwa obejmujące np. skalę korzystania z Internetu, dalsze oczekiwane trwanie życia w zdrowiu oraz więzi społeczne.

Na podstawie analizy indeksu aktywnego starzenia dokonanej w ramach 22 zidentyfikowanych wskaźników, przydzielonych do 4 obszarów, sporządzono ranking państw członkowskich Unii Europejskiej (uwzględniający 27 państw, bez Chorwacji). Zestawienia krajów należących do Wspólnoty oraz uzyskane punkty w ramach oceny analizowanego indeksu przedstawia rysunek 7.

Spośród wszystkich państw członkowskich Unii Europejskiej (w zestawieniu nie uwzględniono Chorwacji) Polska zajęła ostatnie miejsce (uzyskując 27,3 pkt na 100 pkt możliwych do uzyskania), charakteryzując się bardzo niskimi wartościami analizowanych wskaźników. Zajęta pozycja w rankingu, będąca odzwierciedleniem oceny podstawowych aspektów starzenia się polskiego społeczeństwa w kontekście m.in. ich partycypacji w życiu społecznym, kulturalnym oraz gospodarczym, jednoznacznie wskazuje na istotny problem Polski, związany z negatywnymi zjawiskami demograficznymi.

${ }^{31}$ A. Zaidi i in.., Active Ageing Index 2012. Concept, Methodology and Final Results, European Centre Vienna, Vienna 2013, s. 8. 


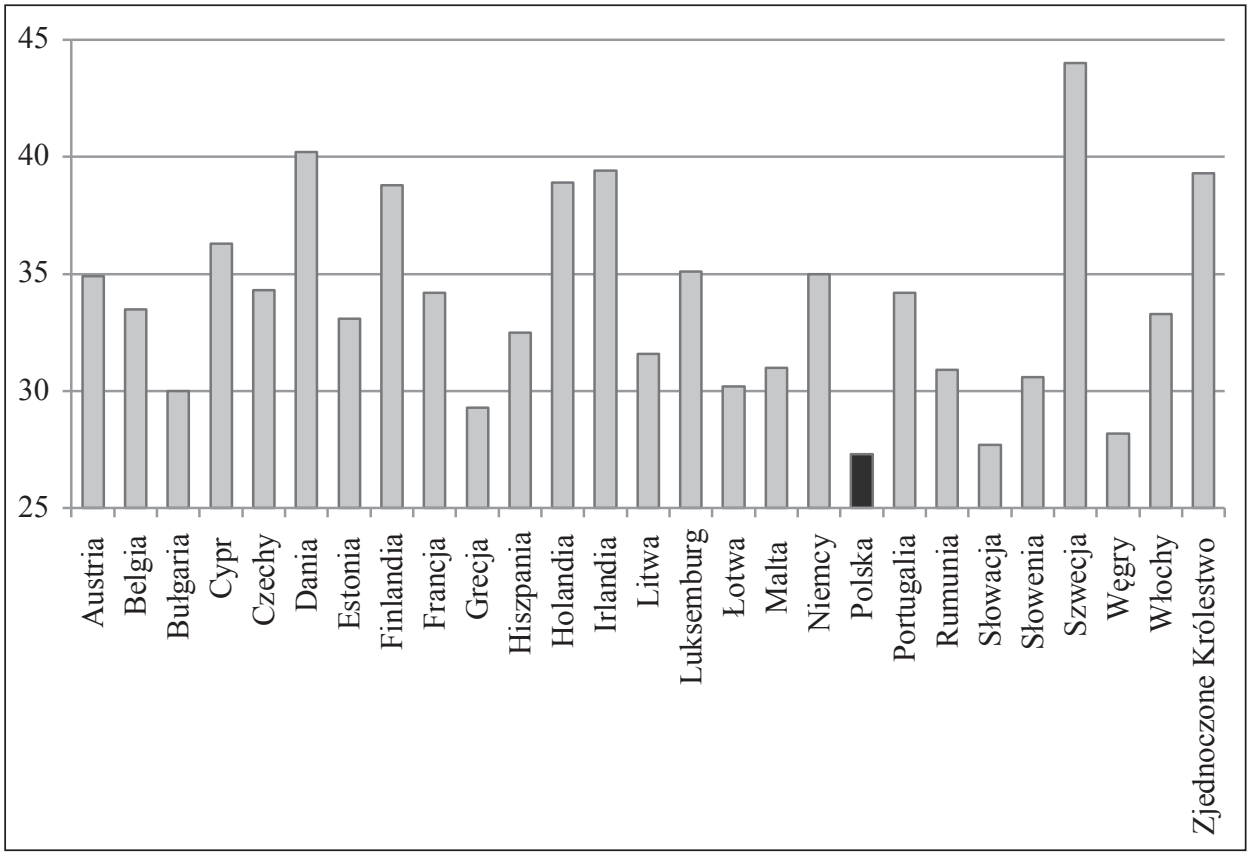

Rysunek 7. Indeks aktywnego starzenia dla państw członkowskich Unii Europejskiej

Źródło: opracowanie własne na podstawie: A. Zaidi i in., Active Ageing Index 2012.

Concept, Methodology and Final Results, European Centre Vienna, Vienna 2013, s. 20

\subsection{Wykluczenie społeczne jako problem społeczno-gospodarczy}

\subsubsection{Identyfikacja pojęcia wykluczenia społecznego}

Przedstawione wcześniej prognozy demograficzne jednoznacznie wskazują na postępujący proces starzenia się społeczeństwa polegający na wzroście liczby osób w starszym wieku i ich udziału w ogólnej liczbie ludności przy jednoczesnym spadku liczby i udziału dzieci i młodzieży w ogólnej liczbie ludności. Obserwowane zmiany demograficzne są poważnym wyzwaniem dla polityki społecznej i gospodarczej UE i państw członkowskich.

Główne problemy, jakie zidentyfikowano, to zagrożenie wydolności finansowej systemów emerytalnych oraz rosnące wydatki na opiekę medyczną i usługi socjalne adresowane do osób starszych przy przewidywanych zmniejszających się 
zasobach pracy. Ich rozwiązanie lub przynajmniej złagodzenie wymaga prowadzenia skutecznej polityki zmierzającej do aktywizacji osób starszych i zaspokojenia ich potrzeb oraz integrację z lokalną społecznością. Tym samym kluczowym wyzwaniem stała się konieczność prowadzenia polityki „włączenia” osób starszych do społeczeństwa.

Wykluczenie społeczne postrzegane jest jako proces, podczas którego niektórzy członkowie danego społeczeństwa spychani są na jego margines z powodu braku posiadania podstawowych umiejętności funkcjonowania w społeczeństwie i kompetencji edukacyjnych. W szerszym ujęciu wykluczenie społeczne rozumiane jest jako brak lub ograniczenie możliwości uczestnictwa, wpływania i korzystania z podstawowych instytucji publicznych i rynków, które powinny być dostępne dla wszystkich, a w szczególności dla osób o niskich dochodach ${ }^{32}$. Początek dzisiejszej, w sensie terminologicznym, koncepcji wykluczenia społecznego wywodzi się z publikacji Rene Lenoira z 1974 r. Les exclus. Wprowadziła ona nowa kategorię pojęciową, koncentrując się na mieszkańcach Francji nieuczestniczących w życiu społecznym ani ekonomicznym ${ }^{33}$.

W Polsce sformułowanie „wykluczenie społeczne” rozpowszechniło się w dokumentach publicznych i w literaturze dopiero na początku XXI w. Wcześniej podobne zjawiska określano w Polsce pojęciem marginalizacji ${ }^{34}$ lub marginalnością ${ }^{35}$. Uznawane za najbardziej potoczne określenie „margines społeczny” zdefiniowano w Słowniku Języka Polskiego PWN, uznając, że jest to „nieliczna i mało znacząca warstwa społeczna, składająca się z jednostek prowadzących pasożytniczy tryb życia, wykolejonych, naruszających przepisy prawa i normy współżycia społecznego"36.

Popularyzacja sformułowania wykluczenie społeczne bądź jego antonimu włączanie/włączenie społeczne miała związek z przystąpieniem Polski do struktur Unii Europejskiej. W polityce Unii Europejskiej na zjawisko wykluczenia społecznego zwrócono uwagę w połowie lat 70. XX w., gdy uchwalono pierwszy

${ }^{32}$ Szerzej: Eurostat, Combating poverty and social exclusion. A statistical portrait of the European Union, 2010, http://epp.eurostat.ec.europa.eu/cache/ITY_OFFPUB/KS-EP-09-001/EN/KSEP-09-001-EN.PDF (stan na dzień 29.01.2014).

33 Zjawisko wykluczenia albo wykluczania rozumianego jako proces ma swoje korzenie już w starożytności, odnosiło się także do najniższych kast w Indiach, niewolnictwa i wygnania. W Europie popularne było rozróżnienie na osoby określane mianem insiders, których status pozwalał na realizację w pełni ich praw oraz outsiders, pozbawione pełni praw ze względu na niski status społeczny. Te pierwsze formy wykluczenia przekształciły się następnie w różne formy rasizmu, fundamentalizmu, separowania, stratyfikacji społecznej, stygmatyzacji. Szerzej na temat powstania i ewolucji pojęcia wykluczenia społecznego: P. Broda-Wysocki, Wykluczenie i inkluzja społeczna. Paradygmaty i próby definicji, IPIS, Warszawa 2012, s. 25.

${ }^{34}$ T. Kowalak, hasło: marginalizacja społeczna, [w:] B. Rysz-Kowalczyk (red.), Leksykon polityki społecznej, ASPRA-JR, Warszawa 2001.

${ }^{35}$ K. W. Frieske, hasło: marginalność społeczna, [w:] Encyklopedia socjologii, t. 2, Oficyna Naukowa, Warszawa 1999.

36 Stownik języka polskiego, t. 2, PWN, Warszawa 1992, s. 108. 
Program Działań Społecznych, natomiast szczególnie obszernie ujęto ją w strategii lizbońskiej, gdzie podkreślono, że podstawowym elementem europejskiego modelu społecznego jest spójność społeczna, a za jeden z podstawowych priorytetów w tym zakresie należy przyjąć zapobieganie ryzyku wykluczenia, głównie poprzez pomoc najbardziej narażonym na ubóstwo i wykluczenie grupom społecznym (szczególnie osobom w wieku 50+) oraz regionom, mobilizując do tego działania wszystkie właściwe instytucje rządowe, samorządowe i biznes ${ }^{37}$. Ideę ochrony przed ubóstwem i marginalizacją społeczną skonkretyzowano w Zrewidowanej Europejskiej Karcie Społecznej, której art. 30 zobowiązuje państwa członkowskie do podejmowania działań w ramach ogólnego i skoordynowanego podejścia, dla popierania rzeczywistego dostępu osób oraz ich rodzin znajdujących się lub zagrożonych znalezieniem się w sytuacji marginalizacji społecznej lub ubóstwa, zwłaszcza do zatrudnienia, mieszkań, szkolenia, kształcenia, kultury, pomocy społecznej i medycznej oraz dokonywania, na ile to konieczne, przeglądu tych działań w celu ich dostosowywania do istniejącej sytuacji ${ }^{38}$.

Ze względu na zidentyfikowaną skalę zagrożenia wykluczeniem społecznym na poziomie 84 mln mieszkańców Europy, Unia Europejska ogłosiła rok $2010 \mathrm{Eu}-$ ropejskim Rokiem Walki z Ubóstwem i Wykluczeniem Społecznym. Głównymi celami było zwiększenie świadomości opinii publicznej na temat ubóstwa i wykluczenia społecznego oraz zwiększenie zaangażowania politycznego Unii Europejskiej i państw członkowskich w walkę z tymi problemami. Zasadą przewodnią roku 2010 było zwrócenie uwagi na problemy i obawy ludzi, którzy zmagają się z problemem ubóstwa i wykluczenia społecznego, oraz zainspirowanie wszystkich obywateli Europy oraz partnerów społecznych, aby zaangażowali się w walkę z tym poważnym problemem ${ }^{39}$. Szacunki Eurostatu jednoznacznie wskazywały, że najsilniej zagrożonymi ubóstwem są dwie grupy wiekowe: dzieci i młodzież oraz osoby powyżej 65 . roku życia.

W 2010 r. opracowana została nowa strategia gospodarcza „Europa 2020” - zastępująca Strategię Lizbońską - stymulująca rozwój inteligentnego i zrównoważonego systemu gospodarczego UE, sprzyjającego włączeniu społecznemu. Jednym z kluczowych celów strategii „Europa 2020” jest zmniejszenie ubóstwa i poprawa integracji społecznej poprzez zapewnienie szerokiego udziału w korzyściach ze wzrostu oraz możliwości odgrywania aktywnej roli w społeczeństwie przez osoby pozostające obecnie na marginesie ${ }^{40}$.

${ }^{37}$ Szerzej: Presidency conclusion, Main Conclusions of the Lisbon Summit by the Portuguese Presidency of the EU, Lisbon 2000.

${ }^{38}$ European charter (reviesed), European Treaty Series - No. 163, Strasbourg, 3.V.1996, rozdział 30 .

${ }^{39}$ European Year For Combating Poverty and Social Exclusion, http://ec.europa.eu/employment_social/2010 againstpoverty/?langid=pl (stan na dzień 10.01.2014).

${ }^{40}$ Szerzej: Komisja Europejska, Europa 2020. Strategia na rzecz inteligentnego i zrównoważonego rozwoju sprzyjającego włączeniu Społecznemu, Bruksela 2010. 
Wyrazem dostosowania Polski do regulacji na szczeblu UE było powołanie Zespołu Zadaniowego ds. Reintegracji Społecznej w celu zdiagnozowania sytuacji i stanu badań zjawiska wykluczenia społecznego oraz opracowania Narodowej Strategii Integracji Społecznej dla Polski (NSIS) ${ }^{41}$. NSIS wprowadziła definicje wykluczenia społecznego, uznając je za brak lub ograniczenie możliwości uczestnictwa, wpływania i korzystania z podstawowych instytucji publicznych i rynków, które powinny być dostępne dla wszystkich, a w szczególności dla osób ubogich ${ }^{42}$.

Zbliżone ujęcie definicyjne znalazło swoje miejsce $\mathrm{w}$ dalszych pracach rządu m.in. w trakcie przygotowywania projektu dokumentu strategicznego Narodowy Plan Rozwoju 2007-2013 (NPR), który został przyjęty przez Radę Ministrów we wrześniu 2005 r. Według NPR pojęcie integracji społecznej - jako jeden z sześciu celów strategicznych - zdefiniowano jako „stan sprawiedliwej, wolnej od nierówności struktury społecznej, którego osiągnięcie jest możliwe poprzez działania wspólnotowe oparte na zasadach dialogu wzajemności i równorzędności, a w rezultacie prowadzące do celu, jakim jest funkcjonowanie społeczeństwa w warunkach demokratycznego ładu społecznego, wyznaczonego współuczestnictwem, rządami prawa i poszanowaniem różnorodności kulturowej, w którym obowiązują i są realizowane podstawowe prawa człowieka i obywatela oraz skutecznie wspomagane są jednostki i grupy w realizacji ich życiowych celów"43. W Strategii Rozwoju Kraju 2007-2015, przyjętej w listopadzie 2006 r., integracja społeczna ujęta została jako jedno z działań w ramach czwartego priorytetu $\mathrm{Bu}$ dowa zintegrowanej wspólnoty spolecznej i jej bezpieczeństwa. Problem integracji społecznej potraktowany został tym samym jako element polityki społecznej w wymiarze aktywizacyjnym ${ }^{44}$.

Zgodnie z systematyzacją definicji wykluczenia społecznego należy wskazać na ${ }^{45}$ :

- definicje analityczne - wskazujące na charakteryzowane cechy zjawiska, wymiary, mechanizmy i przejawy, reprezentujące albo podejście partycypacyjne (akcentujące ograniczenie lub brak uczestnictwa w życiu ekonomicznym, politycznym, społecznym) albo dystrybucyjne (koncentrujące się na ograniczeniu lub braku dostępu do ważnych społecznie zasobów i usług);

${ }^{41}$ W grudniu 2001 r. i w lutym 2002 r. Komisja Europejska zaproponowała krajom kandydującym mechanizm włączenia ich w realizację celów Agendy Społecznej 2000. Współpraca w dziedzinie budowania programu integracji społecznej opierała się o deklarację wspólnych działań zwaną Wspólnym Memorandum o Integracji Społecznej (Joint Memorandum on Social Inclusion lub Joint Inclusion Memorandum - JIM) przyjętym przez Komisję UE i dany kraj kandydujący. NSIS została przyjęta w $2004 \mathrm{r}$.

${ }^{42}$ Narodowa Strategia Integracji Społecznej dla Polski, s. 22, www.funduszestrukturalne.gov. $\mathrm{pl} /$ informator/npr2/dokumenty $\% 20$ strategiczne/Narodowa\%20Strategia\%20Integracji\%20Spolecznej.pdf (stan na dzień 15.01.2014).

${ }^{43}$ Narodowy Plan Rozwoju 2007-2013, s. 32, www.funduszestrukturalne.gov.pl/informator/ npr2/npr.htm (stan na dzień 15.01.2014).

${ }^{44}$ Ministerstwo Rozwoju Regionalnego, Strategia Rozwoju Kraju, listopad 2006, s. 61.

45 J. Grotowska-Leder (red.), Ekskluzja i inkluzja społeczna. Diagnoza - uwarunkowania kierunki działań, Wydawnictwo Edukacyjne Akapit, Toruń 2005, s. 64-67. 
- definicje robocze - operacjonalizujące kategorię na użytek prowadzonych badań i koncentrujące się albo na specyficznych problemach i kategoriach społecznych lub na braku partycypacji i jego pomiarze;

- definicje oficjalne - znajdujące się w dokumentach funkcjonujących w sferze polityki społecznej.

Przegląd definicji marginalności i wykluczenia społecznego ${ }^{46}$ daje podstawę do wyróżnienia czterech nurtów koncepcyjnych ${ }^{47}$ :

1. Problem z uczestnictwem/partycypacją w życiu społecznym lub zbiorowym.

2. Problem z prawami społecznymi i socjalnymi (odmowa, niekorzystanie, problemy z realizacją).

3. Problem z dostępem (ograniczony, utrudniony) do zasobów, dóbr publicznych, instytucji i systemów społecznych.

4. Relatywna i wielowymiarowa deprywacja.

W ramach każdego z czterech nurtów określania wykluczenia społecznego możliwe jest przytoczenie przykładów definicji. Zestawienie nurtów badawczych wraz z ujęciem definicyjnym ujmuje tablica 2.

Tablica 2. Koncepcje wykluczenia społecznego

\begin{tabular}{|c|c|c|}
\hline $\begin{array}{l}\text { Nurty w definiowaniu } \\
\text { wykluczenia } \\
\text { społecznego }\end{array}$ & Autor & Przykładowe definicje \\
\hline 1 & 2 & 3 \\
\hline \multirow[t]{3}{*}{$\begin{array}{l}\text { Problem } \\
\text { z uczestnictwem }\end{array}$} & $\begin{array}{l}\text { C. Gore, } \\
\text { J. B. Figueiredo } \\
(2003)\end{array}$ & $\begin{array}{l}\text { Wykluczenie społeczne to niezdolność do uczestnictwa } \\
\text { w uznawanych za ważne aspektach życia społecznego } \\
\text { - gospodarczych, politycznych i kulturowych. Skrajne } \\
\text { wykluczenie społeczne występuje, gdy niezdolności } \\
\text { do uczestnictwa w tych trzech wymiarach życia spo- } \\
\text { łecznego mają bardziej charakter wzajemnych wzmoc- } \\
\text { nień niż równoważenia się. }\end{array}$ \\
\hline & $\begin{array}{l}\text { G. Germani } \\
(1980)\end{array}$ & $\begin{array}{l}\text { Marginalność to brak uczestnictwa jednostek i grup } \\
\text { społecznych w tych sferach życia, w których uzasadnio- } \\
\text { ne jest - stosownie do określonych kryteriów - oczeki- } \\
\text { wanie, że jednostki te i grupy będą w nich uczestniczyły. }\end{array}$ \\
\hline & $\begin{array}{l}\text { T. Burchardt, } \\
\text { J. Le Grand, } \\
\text { D. Piachaud } \\
(1999)\end{array}$ & $\begin{array}{l}\text { Jednostka jest społecznie wykluczona, jeżeli jest ona } \\
\text { pod względem geograficznym mieszkańcem tego społe- } \\
\text { czeństwa, ale 1) z powodów będących poza jej kontrolą } \\
\text { nie może uczestniczyć w normalnych aktywnościach } \\
\text { obywateli w tym społeczeństwie i } 2 \text { ) chciałaby ona } \\
\text { w nich uczestniczyć. }\end{array}$ \\
\hline
\end{tabular}

${ }^{46}$ Por. P. Broda-Wysocki, Wykluczenie i inkluzja spoteczna.

${ }^{47}$ R. Szarfenberg, Marginalizacja i wykluczenie społeczne - panorama językowo-teoretyczna, s. 10, http://rszarf.ips.uw.edu.pl/pdf/miws_panorama.pdf (stan na dzień 15.01.2014). 
Tablica 2 (cd.)

\begin{tabular}{|c|c|c|}
\hline 1 & 2 & 3 \\
\hline \multirow[t]{3}{*}{$\begin{array}{l}\text { Problem z prawami } \\
\text { społecznymi i socjal- } \\
\text { nymi }\end{array}$} & $\begin{array}{l}\text { G. Room } \\
(1991)\end{array}$ & $\begin{array}{l}\text { Definiujemy wykluczenie społeczne przede wszyst- } \\
\text { kim w związku z prawami społecznymi. Badamy, jakie } \\
\text { prawa społeczne mają obywatele w kontekście zatrud- } \\
\text { nienia, mieszkania, ochrony zdrowia; jak skutecznie } \\
\text { krajowe polityki umożliwiają obywatelom zabezpiecze- } \\
\text { nie tych praw; jakie są przeszkody wykluczające ludzi } \\
\text { z tych praw. }\end{array}$ \\
\hline & \begin{tabular}{|l|} 
C. Gore, \\
J. B. Figueiredo \\
$(2003)$
\end{tabular} & $\begin{array}{l}\text { Wykluczenie społeczne to odmowa podstawowych } \\
\text { praw socjalnych, zapewniających obywatelom pozy- } \\
\text { tywną wolność do uczestnictwa w życiu społecznym } \\
\text { i ekonomicznym i przez to nadających znaczenie ich } \\
\text { podstawowym wolnościom negatywnym. }\end{array}$ \\
\hline & \begin{tabular}{|l|} 
C. Gore, \\
J. B. Figueiredo \\
$(2003)$
\end{tabular} & $\begin{array}{l}\text { Wykluczenie społeczne to proces erozji uznania i sza- } \\
\text { cunku dla prawobywatelskich, od których zależą środki } \\
\text { do życia i jego poziom. Związane jest to z konflikta- } \\
\text { mi i negocjacjami społecznymi, w których atakuje się } \\
\text { i broni określonych uprawnień. }\end{array}$ \\
\hline \multirow[t]{3}{*}{$\begin{array}{l}\text { Problem z dostępem } \\
\text { (ograniczony, utrud- } \\
\text { niony) do zasobów, } \\
\text { dóbr publicznych, } \\
\text { instytucji i systemów } \\
\text { społecznych }\end{array}$} & \begin{tabular}{|l|} 
C. Gore, \\
J. B. Figueiredo \\
$(2003)$
\end{tabular} & $\begin{array}{l}\text { Wykluczenie społeczne to zarówno stan, jak i proces. } \\
\text { Jako stan jest równoznaczne z relatywną deprywacją, } \\
\text { jako proces odnosi się do społecznie kształtowanych } \\
\text { struktur i procesów, które utrudniają części populacji } \\
\text { dostęp do zasobów gospodarczych, do dóbr społecz- } \\
\text { nych, i do instytucji określających ich los. }\end{array}$ \\
\hline & $\begin{array}{l}\text { K. W. Frieske, } \\
\text { P. Poławski } \\
(1996)\end{array}$ & $\begin{array}{l}\text { Problem społecznej marginalności mimo swojej histo- } \\
\text { rycznej zmienności - jest to przede wszystkim kwestia } \\
\text { utraty podstaw społecznego zakorzenienia jednostek, } \\
\text { sposobów ich włączania się w życie zbiorowe i korzy- } \\
\text { stania ze związanych z tym uprawnień; a zatem kwestia } \\
\text { dostępu do - uznawanych za ważne - instytucji społecz- } \\
\text { nych. W społeczeństwach przemysłowych to kwestia } \\
\text { dostępu do rynku pracy i do rynku konsumpcji, a także } \\
\text { dostępu do przywilejów związanych ze statusem oby- } \\
\text { watela. }\end{array}$ \\
\hline & $\begin{array}{l}\text { R. Szarfenberg } \\
(2004)\end{array}$ & $\begin{array}{l}\text { Wykluczenie społeczne to dynamiczny i wielowymiaro- } \\
\text { wy proces pełnego odcięcia lub częściowego ogranicza- } \\
\text { nia dostępu do różnych społecznych, gospodarczych, } \\
\text { kulturowych i politycznych systemów, które pomagają } \\
\text { jednostce w integracji ze społeczeństwem. }\end{array}$ \\
\hline $\begin{array}{l}\text { Relatywna i wielowy- } \\
\text { miarowa deprywacja }\end{array}$ & $\begin{array}{l}\text { P. Alcock, } \\
\text { A. Erskine, } \\
\text { M. May (2002) }\end{array}$ & $\begin{array}{l}\text { Wykluczenie społeczne oznacza więcej aspektów de- } \\
\text { prywacji (niż niskie zasoby i dochody), które przeszka- } \\
\text { dzają ludziom w uczestnictwie w społecznych aktywno- } \\
\text { ściach lub w korzystaniu z publicznych lub prywatnych } \\
\text { usług. }\end{array}$ \\
\hline
\end{tabular}




\begin{tabular}{|l|l|l|}
\hline \multicolumn{1}{|c|}{1} & \multicolumn{1}{|c|}{2} & \multicolumn{1}{|c|}{3} \\
\hline $\begin{array}{l}\text { Relatywna i wielowy- } \\
\text { miarowa deprywacja }\end{array}$ & $\begin{array}{l}\text { C. Gore, } \\
\text { J. B. Figueiredo } \\
\text { (2003) }\end{array}$ & $\begin{array}{l}\text { Wykluczenie społeczne to zarówno obiektywna, jak } \\
\text { i subiektywna cecha ludzkiego życia. W sensie obiek- } \\
\text { tywnym charakteryzuje się materialną deprywacją i na- } \\
\text { ruszaniem praw socjalnych (włączając w to prawa za- } \\
\text { trudnionych i bezrobotnych). Jako uczucie subiektywne } \\
\text { cechuje się poczuciem społecznej niższości lub utratą } \\
\text { wcześniejszego statusu społecznego. }\end{array}$ \\
\cline { 2 - 4 } & & $\begin{array}{l}\text { Proces będący wynikiem akumulacji i współoddziały- } \\
\text { wania między różnymi czynnikami ryzyka o charakte- } \\
\text { rze społecznym i środowiskowym, który sprawia, że lu- } \\
\text { dzie są bardziej narażeni na (i dotknięci) ubóstwo. Jest } \\
\text { to więc proces ubożenia. }\end{array}$ \\
\hline
\end{tabular}

${ }^{a}$ G. Quaranta za: E. Mastropietro, Rapid Appraisal Method of Social Exclusion and Poverty (RAMSEP Project): Handbook, European Commission, lipiec 2000.

Źródło: opracowanie własne na podstawie: R. Szarfenberg, Marginalizacja i wykluczenie spoteczne - panorama językowo-teoretyczna, s. 9-10, http://rszarf.ips.uw.edu.pl/pdf/miws_panorama. pdf (stan na dzień 15.01.2014).

Przedstawione wyżej definicje wykluczenia społecznego potwierdzają wielowymiarowość i złożoność tego zjawiska. Z punktu widzenia istnienia związku między wykluczeniem społecznym a wykluczeniem z systemu finansowego szczególnie ważna jest koncepcja traktująca wykluczenie jako problem z uczestnictwem oraz problem z dostępem do zasobów, dóbr, instytucji.

\subsubsection{Determinanty wykluczenia społecznego}

W powszechnym użyciu pojęcie wykluczenia społecznego bardzo często rozpatrywane jest jako synonim ubóstwa ${ }^{48}$. Jest to zbyt upraszczająca interpretacja, gdyż bieda jest kategorią jednowymiarową, a wykluczenie społeczne kategorią złożoną, odwołującą się nie tylko do kategorii ubóstwa, ale także do procesów deprywacji i braku uczestnictwa w życiu społecznym. Ubóstwo nie jest ani warunkiem koniecznym, ani wystarczającym występowania wykluczenia społecznego. Faktem jest natomiast, że zjawiska te występują często razem i występują między nimi związki przyczynowo-skutkowe ${ }^{49}$.

${ }^{48}$ Słowo ubóstwo (poverty) wywodzi się z biedy (poor).

${ }^{49}$ Wykluczenie społeczne rozpatrywane jest także w kontekście wymagań finansowych. W tym wymiarze, wykluczenie społeczne postrzegane jest przez pryzmat trudności w płaceniu raty kredytu hipotecznego na czas, braku zdolności do spłacania pożyczek, braku możliwości oszczędzania pieniędzy oraz niemożności opłacenia nagłych wydatków. J. Grotowska-Leder (red.), Ekskluzja i inkluzja społeczna. Diagnoza - uwarunkowania - kierunki działań, Wydawnictwo Edukacyjne Akapit, Toruń 2005, s. 64-67. 
W podobny sposób postrzegane jest bezrobocie, zwłaszcza długotrwałe, które jest w stanie wykluczyć z życia społecznego i gospodarczego osobę długotrwale bezrobotną oraz jej bliskich. Praca bowiem postrzegana jest przede wszystkim w wymiarze finansowym jako źródło dochodów umożliwiające sfinansowanie potrzeb życiowych, ale także podkreślenia wymaga jej rola w wyznaczaniu miejsca w tym społeczeństwie.

Często podkreślaną w literaturze przedmiotu determinantą wykluczenia są czynniki regionalne - na obszarach miejskich będące efektem recesji starych regionów przemysłowych i kryzysu na rynku pracy, zaś na obszarach wiejskich będące efektem upadku Państwowych Gospodarstw Rolnych oraz gospodarczego nieprzystosowania rolnictwa indywidualnego do warunków wolnorynkowych. W Polsce, opracowania dotyczące wykluczenia społecznego wskazują, że największe ryzyko wykluczenia społecznego dotyczy dzieci z rodzin wielodzietnych, osób długotrwale bezrobotnych, z niskim wykształceniem, osób w podeszłym wieku, a także osób niepełnosprawnych.

Wykluczenie społeczne skorelowane jest $\mathrm{z}$ aktywnością ekonomiczną członków gospodarstwa domowego oraz ich statusem na rynku pracy, co z kolei uzależnione jest chociażby od wieku osób tworzących gospodarstwo domowe. Tym samym, ważnym aspektem wykluczenia społecznego jest kwestia aktywności osób 50+ na rynku pracy. Instytucje zajmujące się analizami rynku pracy i problemem bezrobocia opracowują odrębne analizy przeprowadzane dla grupy wiekowej $50+$ ze względu na odmienne szanse i zagrożenia jej towarzyszące ${ }^{50}$. Zgodnie z profilem aktywności zawodowej według wieku, liczba lat wskazywana jest jako kluczowa bariera utrudniająca podjęcie pracy przez połowę bezrobotnych, którzy przekroczyli 50 lat ${ }^{51}$. Ponadto, w Polsce wskaźniki aktywności zawodowej osób starszych są niskie w porównaniu z innymi krajami europejskimi, a decydującą rolę wciąż odgrywa wczesne odchodzenie z rynku pracy na emeryturę i jej substytuty (renty, świadczenia i zasiłki przedemerytalne itp.).

W literaturze wskazuje się, że w Polsce mamy do czynienia zarówno z dyskryminacją, jak i autodyskryminacją osób w dojrzałym wieku na rynku pracy. Prawdopodobnie najważniejszym czynnikiem wykluczającym osoby starsze z rynku pracy jest brak akceptacji społecznej dla pracujących seniorów, w szczególności kobiet. Przy czym niechęć ta może być podyktowana przynajmniej kilkoma czynnikami ${ }^{52}$ :

- obawą młodych przed konkurencją na rynku pracy i „blokowaniem” miejsc pracy przez ludzi starszych;

${ }^{50}$ I. E. Kotowska (red.), Rynek pracy i wykluczenie społeczne w kontekście percepcji Polaków. Diagnoza społeczna 2013. Raport tematyczny, MPiPS, Warszawa 2014, s. 17.

${ }^{51}$ S. Czarnik, K. Turek, Aktywność zawodowa Polaków. Praca zawodowa, wykształcenie, kompetencje, Polska Agencja Rozwoju Przedsiębiorczości, Warszawa 2012, s. 7.

${ }^{52}$ Szerzej: Szukalski P. (red.), Przygotowanie do starości. Polacy wobec starzenia się, Instytut Spraw Publicznych, Warszawa 2009. 
- tradycyjnym postrzeganiem starości i ludzi starych, jako nieaktywnych zawodowo, w

- szczególności wizerunkiem babci zajmującej się domem i wnukami;

- postrzeganiem starszych pracowników jako lojalnych i dyspozycyjnych, ale znacznie mniej kreatywnych i dynamicznych, niepotrafiących się adaptować do nowych sytuacji oraz gorzej wykwalifikowanych; obawami samych seniorów przed dyskryminacją, czy też niechęcią do pracy zarobkowej ze względu na zły stan zdrowia i chęć odpoczynku.

Wyrazem troski o aktywność zawodową osób w wieku 50+ było opracowanie i wdrożenie w 2008 r. rządowego programu „Solidarność pokoleń” zawierającego pakiet działań rządowych zmierzających do zwiększenia zatrudnienia osób powyżej 50. roku życia w Polsce. Celem Programu „Solidarność pokoleń” jest osiągnięcie w perspektywie do 2020 r. wskaźnika zatrudnienia osób w wieku 55-64 lata na poziomie 50\%. Przyjęty wówczas Program zakładał potrzebę skoordynowanych działań, wpływających z jednej strony na zwiększenie popytu na pracę osób 50+ oraz z drugiej strony oddziałujących na stronę podażową, poprzez tworzenie zachęt do wydłużania aktywności zawodowej oraz działania na rzecz kapitału ludzkiego w tej populacji. W latach 2008-2013 zrealizowano szereg zaplanowanych działań, w tym ${ }^{53}$ :

- obniżono koszty pracy dla osób powyżej 50. roku życia poprzez obniżenie składek na Fundusz Pracy i Fundusz Gwarantowanych Świadczeń Pracowniczych oraz kosztów wynagrodzeń za czas choroby ponoszonych przez pracodawców;

- wprowadzono emerytury pomostowe i bardzo istotnie ograniczono możliwości korzystania z wcześniejszych emerytur;

- podjęto decyzję o stopniowym podnoszeniu od 2013 r. ustawowego wieku emerytalnego kobiet i mężczyzn - do 67 roku życia dla obu płci (w przypadku mężczyzn będzie on osiągnięty w 2020 r., a w przypadku kobiet w 2040 r. $)^{54}$.

W najbliższym okresie na skutek procesów demograficznych liczba osób w wieku 60/65 lat w polskim społeczeństwie zwiększy się, tym samym problem aktywności na rynku pracy stanie się jeszcze wyraźniej widoczny. Niezbędne są już działania na rzecz zmiany wizerunku osób dojrzałych i ich stylów życia, co wymaga przeobrażeń mentalnych całego polskiego społeczeństwa oraz wielowymiarowych działań we wszystkich fazach życia, w ramach pewnego przygotowania do wkroczenia w bardziej dojrzały etap życia.

Istotnym czynnikiem jest również charakterystyczny dla większości jednostek czy grup społecznych zagrożonych procesami wykluczenia społecznego

${ }^{53}$ Program Solidarność pokoleń. Działania dla zwiększenia aktywności zawodowej osób w wieku 50+, Warszawa, październik 2013 r., www.mpips.gov.pl/download/gfx/.../Program50_30.10.2013ost1.pdf, s. 5-6 (stan na dzień 15.01.2014).

${ }^{54}$ Szczególnie wydłużenie wieku emerytalnego wymaga podejmowania działań wspierających, zwłaszcza osoby po 60. roku życia, w utrzymywaniu aktywności zawodowej i uzyskiwaniu środków z pracy zawodowej, a tym samym przeciwdziałanie wykluczeniu społecznemu ze względu na brak dochodów. 
syndrom wyuczonej bezradności, korespondującej z bezradnością autentyczną spowodowaną niekorzystnymi indywidualnymi czynnikami: kalectwem, śmiercią jedynego żywiciela rodziny, ciężką chorobą, więzieniem itd.

Wskazane powyżej grupy osób podatnych i zagrożonych wykluczeniem społecznym wyodrębnione zostały ze względu na jedno dominujące kryterium. W rzeczywistości charakterystyczne jest współwystępowanie kilku cech, np. osoby bezdomne są często uzależnione, chorują psychicznie i mają inne stałe problemy zdrowotne. $Z$ tego powodu w podejściu niektórych krajów do identyfikacji grup zagrożonych wykluczeniem społecznym stosuje się miary agregatowe, np. indeksy ${ }^{55}$.

Zgodnie z opracowaniami UE najbardziej zagrożone ubóstwem lub wykluczeniem są dzieci, osoby starsze, samotne kobiety, samotni rodzice, osoby słabo wykwalifikowane, bezrobotni, osoby w wieku produkcyjnym nieaktywne zawodowo, w tym niepełnosprawne, osoby zamieszkujące obszary wiejskie i migranci. W niektórych statystykach krajowych jako na grupę narażoną na duże ryzyko wykluczenia społecznego wskazuje się na mniejszości narodowe ${ }^{56}$.

Inną klasyfikację przyczyn wykluczenia społecznego wymienia R. Szarfenberg, zgodnie z nią należy wskazać na ${ }^{57}$ :

- mające źródło w samych wykluczonych lub ich bliskich - spowodowane różnymi deficytami, brakami, np.: brakiem wykształcenia, niepełnosprawnością, chorobą;

- leżące w innych, którzy nie są wykluczeni - poprzez wykluczanie innych podnoszą w ten sposób swoją pozycję i nie muszą dzielić się dobrobytem, np. miejscem pracy;

- wynikające z konstrukcji ,społecznego domu"58 - jest on za ciasny dla niektórych grup, np. brak pokoi dla osób innego wyznania, narodowości, płci, orientacji seksualnej;

- bezosobowe procesy (np. gospodarcze) powodujące, że dla niektórych osób brakuje miejsca, możliwości partycypacji w życiu społecznym.

Determinanty wykluczenia społecznego rozważane są także w wymiarze czynników biologicznych, społecznych, losowych, zdrowotnych, kompetencyjnych i ekonomicznych. Na podstawie weryfikacji przyczyn jeden z podziałów różnicuje wykluczenie społeczne na ${ }^{59}$ :

${ }^{55}$ Indeks może obejmować albo domenę, albo demograficzną grupę ludności i przy nadaniu wag miarom jednostkowym daje syntetyczny obraz deprywacji w danej dziedzinie czy w danej grupie populacyjnej.

56 Szerzej: European Commission, Social Protection and Social Inclusion in Europe - Key facts and figures, Brussels, 16 October 2008. Por. European Commission, Eurobarometer survey on poverty and social exclusion, Brussels 2009.

${ }^{57}$ Szerzej: R. Szarfenberg, Ubóstwo i wykluczenie społeczne w Polsce pomiar, wyjaśnianie, strategie przeciwdziałania, www.feswar.org.pl/fes2009/pdf_doc/debaty6.pdf (stan na dzień 10.01.2014).

58 Jest to konstrukcja opisująca społeczeństwo jako dom podzielony na piętra (stanowią one warstwy społeczne), a na każdym z nich są pokoje (odpowiadające poszczególnym stylom życia).

${ }^{59}$ Szerzej: R. Szarfenberg, C. Żołędowski, M. Thesiss (red.),Ubóstwo i wykluczenie społeczne, perspektywa poznawcza (red.), Dom Wydawniczy Elipsa, Warszawa 2010. 
- strukturalne - wynika z miejsca zamieszkania oraz dochodu poniżej granicy ubóstwa;

- fizyczne - nawiązuje do wieku, niepełnosprawności, poziomu wykształcenia rodziców ${ }^{60}$;

- normatywne - związane jest z konfliktami z prawem, patologicznymi zjawiskami, brakiem odpowiedniej legislacji w stosunku do migrantów, opieki penitencjarnej.

Determinanty wykluczenia społecznego rozpatrywanego w kontekście ubóstwa rozważane są także w ramach Diagnozy Społecznej. Wyniki prezentuje tablica 3.

Tablica 3. Determinanty ubóstwa w Diagnozie Społecznej

\begin{tabular}{|l|l|}
\hline \multicolumn{1}{|c|}{ Czynnik } & \multicolumn{1}{c|}{ Odniesienie w Diagnozie Społecznej } \\
\hline $\begin{array}{l}\text { Źródło utrzymania } \\
\text { głowy gospodarstwa } \\
\text { domowego }\end{array}$ & $\begin{array}{l}\text { Grupami gospodarstw domowych o największym ryzyku ubóstwa są gospo- } \\
\text { darstwa utrzymujących się z niezarobkowych źródeł innych niż emerytura } \\
\text { lub renta oraz gospodarstwa domowe rencistów. }\end{array}$ \\
\hline $\begin{array}{l}\text { Liczba osób } \\
\text { w rodzinie }\end{array}$ & $\begin{array}{l}\text { Najwyższy poziom ryzyka ubóstwa występuje w gospodarstwach 1-osobo- } \\
\text { wych. Ryzyko rośnie wraz ze zwiększeniem się liczby osób w gospodar- } \\
\text { stwie, poza gospodarstwami 2-osobowymi. }\end{array}$ \\
\hline $\begin{array}{l}\text { Klasa miejscowości } \\
\text { zamieszkania }\end{array}$ & $\begin{array}{l}\text { W 2013 r. wszystkie oszacowania parametrów modelu stojących przy } \\
\text { zmiennych reprezentujących klasy miejscowości zamieszkania nie są istot- } \\
\text { ne. W poprzednich analizach gospodarstwa domowe zamieszkujące klasy } \\
\text { miejscowości inne niż największe miasta charakteryzowały się ryzykiem } \\
\text { ubóstwa wyższym. }\end{array}$ \\
\hline $\begin{array}{l}\text { Wykształcenie } \\
\text { głowy gospodarstwa } \\
\text { domowego }\end{array}$ & $\begin{array}{l}\text { Wyraźnie najniższe ryzyko wejścia w sferę ubóstwa mają gospodarstwa } \\
\text { domowe, których głowa ma wykształcenie wyższe. Im niższy poziom wy- } \\
\text { kształcenia głowy gospodarstwa, tym w zasadzie większe ryzyko ubóstwa. }\end{array}$ \\
\hline $\begin{array}{l}\text { Wiek głowy gospo- } \\
\text { darstwa domowego }\end{array}$ & $\begin{array}{l}\text { Tylko ryzyko ubóstwa dla tej grupy gospodarstw z głową w wieku 35-39 lat } \\
\text { jest istotnie niższe niż dla grupy gospodarstw stanowiącej punkt odniesienia } \\
\text { (z głową w wieku powyżej 60 lat). }\end{array}$ \\
\hline $\begin{array}{l}\text { Bezrobotni w go- } \\
\text { spodarstwie domo- } \\
\text { wym }\end{array}$ & $\begin{array}{l}\text { Zidentyfikowano znacząco większe ryzyko wpadnięcia w sferę ubóstwa } \\
\text { gospodarstw z osobami bezrobotnymi niż gospodarstw domowych bez bez- } \\
\text { robotnych. }\end{array}$ \\
\hline $\begin{array}{l}\text { Niepełnosprawni } \\
\text { w gospodarstwie } \\
\text { domowym }\end{array}$ & $\begin{array}{l}\text { Występowanie osób niepełnosprawnych istotnie zwiększa ryzyko ubóstwa } \\
\text { gospodarstw domowych. }\end{array}$ \\
\hline
\end{tabular}

Źródło: opracowanie własne na podstawie: J. Czapiński, T. Panek (red.), Diagnoza społeczna 2013, Rada Monitoringu Społecznego, Warszawa 2013, s. 355-366.

${ }^{60}$ Wyniki analizy czynnikowej (ładunki czynnikowe) wybranych kryteriów wykluczenia z rotacją varimax w latach 2011-2013 zawarte w Diagnozie Społecznej wskazują w ramach wykluczenia fizycznego na najwyższą istotność wieku 50+. 
Wiele determinant ubóstwa jest silnie skorelowanych, co oznacza, że przenoszą one te same informacje dotyczące ryzyka ubóstwa. Programy ukierunkowane na zwalczanie wykluczenia, aby były skuteczne, muszą uwzględniać problem kumulacji cech determinujących wykluczenie ${ }^{61}$.

W czterech pierwszych rundach badania Diagnozy Społecznej, w 2000, 2003, 2005 i w 2007 r., 10 barier w uczestniczeniu w pełni w głównym nurcie życia społecznego (podeszły wiek, samotność, ubóstwo, mieszkanie na wsi, niskie wykształcenie, uzależnienie od alkoholu lub narkotyków, konflikt z prawem, poczucie dyskryminacji, niepełnosprawność i bezrobocie) układało się konsekwentnie w trzy kryteria wykluczenia społecznego (wykluczenia fizycznego, strukturalnego i normatywnego). W ostatnich trzech edycjach obraz struktury czynnikowej uległ pewnej zmianie, wyodrębniło się jeszcze czwarte kryterium, z którym najsilniej związane jest bezrobocie i ubóstwo - wykluczenie materialne wynikające $\mathrm{z}$ braku stałych dochodów z pracy.

\subsubsection{Konsekwencje wykluczenia społecznego}

Definicje prezentujące zjawisko wykluczenia społecznego nawiązywały do sytuacji znacznie utrudniających lub nawet uniemożliwiających wypełnianie ról społecznych, korzystanie z zasobów publicznych i godne zabezpieczenie własnej egzystencji poprzez rynek i zgodnie z obowiązującymi zasadami. Z tego względu najbardziej charakterystyczne skutki wykluczenia społecznego obejmują niewypełnienie ról społecznych, niekorzystanie z zasobów publicznych, niezabezpieczanie własnej egzystencji w godny sposób, prowadzące w dłuższej perspektywie do izolacji społecznej, ubożenia i ubóstwa oraz utraty poczucia godności (upokorzenia). Tym samym wykluczenie społeczne rozumiane jako sytuacje uniemożliwiające ma za skutek izolację społeczną, upokorzenie, ubóstwo i/lub przestępczość. Proces prowadzący do tych skutków będzie wolniejszy u jednostek z większym potencjałem osobowym, rodzinnym i materialnym, a szybszy tam, gdzie te zasoby są mniejsze. Cechą charakterystyczną jest także pogłębianie się nierówności społecznych będących wynikiem wykluczenia na skutek powiększania się wartości i zakresu zasobów, z których korzystają włączeni w system.

Konsekwencje wykluczenia społecznego podsumowuje tablica 4.

Wykluczenie społeczne generuje negatywne konsekwencje o charakterze indywidulanym i w stosunku do całego społeczeństwa. Stwarza ono bezpośrednie zagrożenia dla ładu i porządku społecznego. Wiąże się ono z polaryzacją i zróżnicowaniem społecznym. Zróżnicowanie to ma często swoje podstawy w nierów-

${ }^{61}$ Indeks obejmuje albo domenę, albo demograficzną grupę ludności i przy nadaniu wag miarom jednostkowym daje syntetyczny obraz deprywacji w danej dziedzinie czy w danej grupie populacyjnej. 
nym podziale dóbr pomiędzy poszczególne grupy, nierówności szans lub dyskryminacyjnym charakterze instytucji społecznych. Może też być przejawem indywidualnych stylów zachowań czy różnic jednostkowych w radzeniu sobie z trudnymi sytuacjami życiowymi. Sprzyja populistycznym i skrajnym siłom politycznym, destabilizując porządek demokratyczny.

Tablica 4. Skutki wykluczenia społecznego

\begin{tabular}{|c|c|}
\hline Skala konsekwencji & Specyfikacja \\
\hline \multirow{10}{*}{$\begin{array}{l}\text { Skutki o charakterze } \\
\text { indywidulanym }\end{array}$} & samotność \\
\hline & deprywacja potrzeb \\
\hline & bezradność \\
\hline & osłabienie więzi rodzinnych \\
\hline & rozpad rodziny \\
\hline & stygmatyzacja \\
\hline & izolacja \\
\hline & osłabienie mechanizmu samokontroli \\
\hline & marginalizacja \\
\hline & utrata poczucia tożsamości i celu w życiu \\
\hline \multirow[t]{4}{*}{ Skutki dla społeczeństwa } & osłabienie więzi społecznych \\
\hline & ograniczenia demokracji lub jej zagrożenie \\
\hline & polaryzacja społeczeństwa i ekstremalne nierówności \\
\hline & pojawienie się podklasy oraz „gett” \\
\hline
\end{tabular}

Źródło: opracowanie na podstawie: Narodowa Strategia Integracji Spolecznej dla Polski, www.funduszestrukturalne. gov.pl/informator/npr2/dokumenty\%20strategiczne/Narodowa\%20Stra tegia\%20Integracji\%20Spolecznej.pdf (stan na dzień 15.01.2014), s. 22; P. Broda-Wysocki, Wykluczenie i inkluzja społeczna. Paradygmaty i próby definicji, IPISS, Warszawa 2012, s. 246-247.

Wykluczenie osób starszych w wymiarze społecznym najsilniej przejawia się w osłabieniu ich społecznych kontaktów. Liczne badania dowodzą bardzo niskiego poziomu zaangażowania seniorów w życie społeczności lokalnych (ok. 8\%). Ograniczenie społecznych kontaktów przekłada się nie tylko na zmniejszenie aktywności obywatelskiej, ale także aktywności na rynku pra$\mathrm{cy}^{62}$. Wyraźnie widoczne jest wykluczenie osób starszych z obszaru komunikacji społecznej poprzez sporadyczną obecność w przekazach informacyjnych i w publicystyce, zwykle obciążoną stereotypami (osób chorych, ubogich, potrzebujących opieki) ${ }^{63}$. Zwiększenie szans na włączenie społeczne gospodarstw

${ }^{62}$ P. Broda-Wysocki, Wykluczenie i inkluzja społeczna, s. 88.

${ }^{63}$ R. Szarfenberg, C. Żołędowski, M. Thesiss (red.), Ubóstwo i wykluczenie społeczne..., s. 234 . 
domowych, szczególnie gospodarstw domowych emerytów, wymaga nie tylko dążenia samych wykluczonych do włączenia się w życie społeczne, ale przede wszystkim zmiany stereotypowego myślenia pozostałych obywateli na temat znaczenia, jakie dojrzałe osoby mogą i powinny pełnić w życiu społecznym i gospodarczym kraju. Jest to niezbędne dla powodzenia realizacji koncepcji silver economy.

\subsubsection{Skala wykluczenia społecznego osób w wieku 50+ na tle pozostałych grup wiekowych}

Wykluczenie społeczne jest zjawiskiem na tyle złożonym, że zwykle w literaturze poszukuje się czynnika głównego, który byłby dominującą przyczyną tego zjawiska i stara się go zmierzyć. Od lat 70. XX w. opracowywane są i modyfikowane wskaźniki służące określeniu poziomu wykluczenia społecznego. Najbardziej znanymi wskaźnikami są publikowane regularnie przez UNDP Human Development Report oraz wskazane w raporcie Atkinsa, które stanowiły podstawę do opracowania 18 wskaźników zaakceptowanych na szczycie europejskim $^{64}$.

Reprezentatywnym, cyklicznym badaniem, przeprowadzanym na skalę międzynarodową jest sondaż Eurobarometr, który łączy ubóstwo i wykluczenie społeczne. Zgodnie z jego wynikami, w 2004 r. 16\% obywateli UE 15 żyło poniżej progu ubóstwa, który wynosi $60 \%$ średnich dochodów w każdym kraju. Natomiast w badaniach Eurobarometru z lutego 2007 r. aż około $25 \%$ obywateli UE przyznało, że dotyczy ich ryzyko popadnięcia w ubóstwo, a $62 \%$ było zdania, że sytuacja taka może zdarzyć się komukolwiek, na każdym etapie życia ${ }^{65}$. Podobnie negatywne rezultaty dotyczące zagrożenia ubóstwem uzyskano w badaniu Eurobarometru 2009. Zgodnie z nim, prawie 80 milionów Europejczyków, czyli 16\% unijnej populacji, żyło poniżej granicy ubóstwa. Jest to zjawisko mocno odczuwalne, gdyż prawie trzy czwarte respondentów (73\%) uważa, że ubóstwo w ich kraju jest zjawiskiem powszechnym i ponad $80 \%$ respondentów przyznało, że zjawisko ubóstwa nasiliło się w kolejnych latach.

Wyniki sondażu wykazały, że Europejczycy rozumieją ubóstwo na różne sposoby. Zdaniem prawie jednej czwartej (24\%) respondentów ludzie uznawani są za ubogich, jeśli posiadane przez nich środki są tak ograniczone, że uniemożliwiają im pełne uczestnictwo w życiu swojej społeczności. Kolejne 22\% re-

${ }^{64}$ Szerzej: European Commission, Report on indicators in the field of poverty and social exclusion, 2001.

${ }^{65}$ European Commission, Special Eurobarometer 273, European Social Reality, 2007, s. 23. 
spondentów definiowało ubóstwo jako niemożność nabycia podstawowych dóbr niezbędnych do życia, podczas gdy dla $21 \%$ respondentów ubóstwo oznaczało konieczność korzystania z pomocy organizacji charytatywnych lub pobierania zasiłków socjalnych. Najmniejszy odsetek (18\%) respondentów uważał, że ludzie są ubodzy, jeśli ich środki dostępne na miesięczne utrzymanie są poniżej poziomu wyznaczonego przez linię ubóstwa ${ }^{66}$.

Problematyka dochodów jest przedmiotem Europejskiego badania warunków życia ludności (EU-SILC), który umożliwia dostarczenie porównywalnych dla krajów Unii Europejskiej danych dotyczących różnych aspektów poziomu życia, w tym dochodów, ubóstwa i społecznego wykluczenia ${ }^{67}$. W wymiarze finansowym kwestie wykluczenia społecznego są także rozpatrywane poprzez prezentację wskaźnika Giniego. Wraz ze wzrostem wartości wskaźnika, rośnie stopień koncentracji dochodów, a tym samym występują większe nierówności osiąganych dochodów. Od 2005 r. wartość współczynnika Giniego w Polsce umiarkowanie spada, przybliżając się do średniej dla UE. Ostatnie, dostępne dane z 2012 r. wskazują, że współczynnik Giniego wyniósł 30,9 i był nieznacznie wyższy od wartości dla całej UE równej $30,6^{68}$.

Badanie EU-SILC jest również ważnym źródłem danych do monitorowania realizacji celów europejskiej Strategii „Europa 2020,” która zastąpiła po kryzysie finansowym Strategię Lizbońską. Przyjęcie Strategii „Europa 2020” spowodowało, że w sferze ubóstwa i wykluczenia zaczęto przyjmować trzy kluczowe wskaźniki Strategii „Europa 2020”:

- wskaźnik zagrożenia ubóstwem jako procent osób, których dochód ekwiwalentny do dyspozycji jest niższy od granicy ubóstwa ustalonej na poziomie $60 \%$ krajowej mediany ekwiwalentnych rocznych dochodów do dyspozycji,

- wskaźnik pogłębionej deprywacji materialnej (według metodologii Eurostatu), opierający się na wymuszonym sytuacją finansową niezaspokojeniu kilku potrzeb z szerszej ich listy (co najmniej dowolnych 4 z 9),

- wskaźnik intensywności zatrudnienia w gospodarstwie domowym. W tym przypadku granicą jest próg zatrudnienia dorosłych członków gospodarstwa

${ }^{66}$ Szerzej: European Commission, Special Eurobarometer 279 - Poverty and exclusion, 2009.

${ }^{67}$ Organizacja i metodologia badania EU-SILC (European Union Statistics on Income and Living Conditions) regulowana jest rozporządzeniem Parlamentu Europejskiego i Rady nr 1177/2003 z 16 czerwca 2003 r. (ze zmianami zawartymi w rozporządzeniu nr 1553/2005) dotyczącym statystyki dochodów i warunków życia ludności (EU-SILC) oraz korespondującymi z tym aktem prawnym rozporządzeniami Komisji Europejskiej. Badanie EU-SILC zostało wdrożone przez GUS w 2005 r.

${ }^{68}$ GUS, Europejskie badanie dochodów $i$ warunków życia (EU-SILC) w 2012 r., 23.12.2013, www.stat.gov.pl/cps/rde/xbcr/gus/WZ_badanie_dochodow_warunkow_zycia_EU-SILC2012.pdf (stan na dzień 10.01.2014). 
wynoszący $20 \%$ ich potencjalnego, pełnego rocznego czasu pracy z roku poprzedzającego badanie.

Wartości tych trzech kluczowych wskaźników przedstawia rysunek 8.

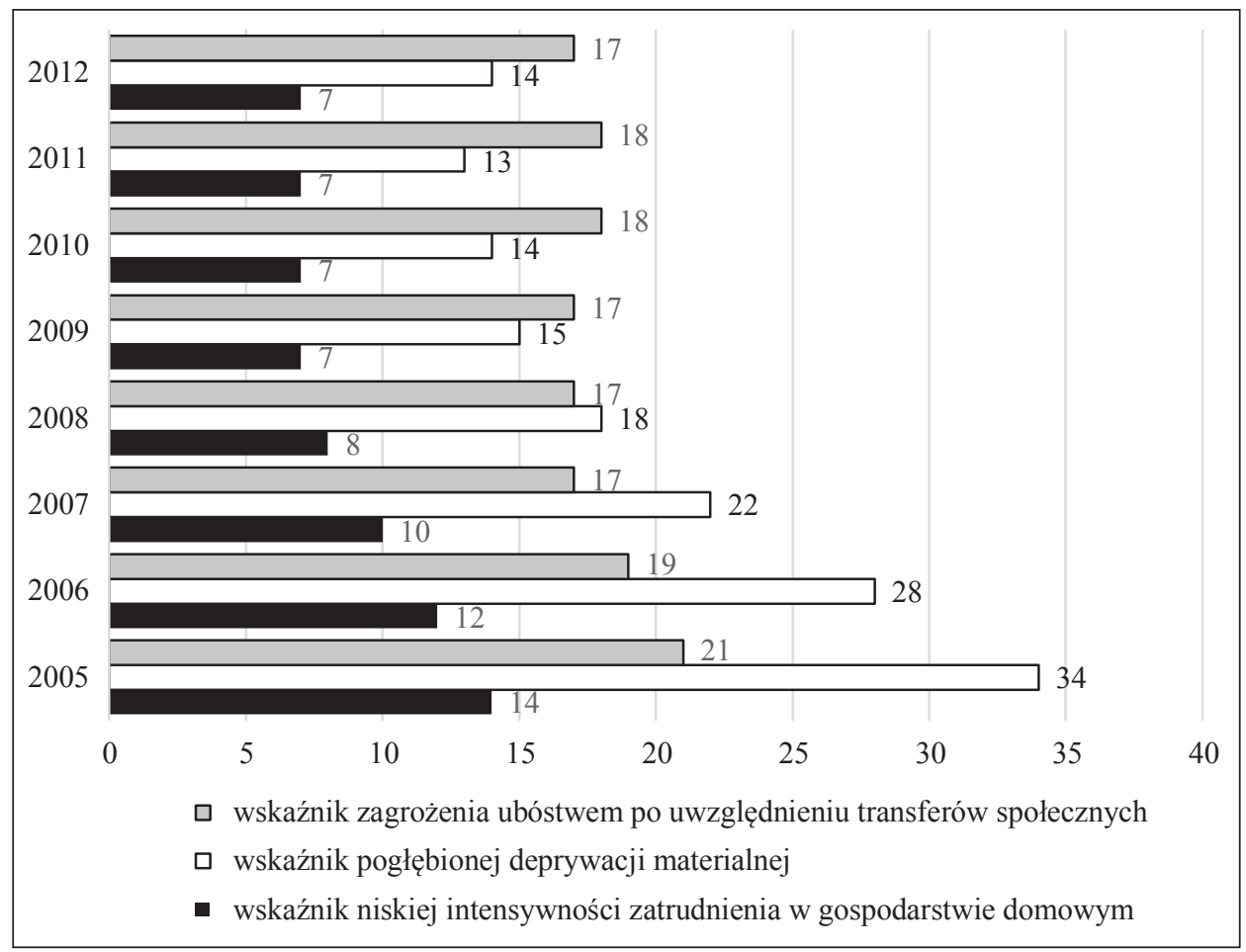

Rysunek 8.Wskaźniki wykluczenia społecznego w Polsce w latach 2005-2012 (w \%)

Źródło: opracowanie własne na podstawie GUS

Ostatnie opublikowane przez GUS dane wskazują na korzystny trend w przypadku wskaźnika pogłębionej deprywacji materialnej, który systematycznie malał w latach 2005-2011, ale odnotował wzrost w 2012 r. w stosunku do roku 2011. Do roku 2008 obniżaniu ulegały także dwa pozostałe wskaźniki, jednak po tym roku oba wskaźniki zaczęły wzrastać do roku 2011. W roku 2012 symbolicznemu obniżeniu uległ wskaźnik niskiej intensywności pracy oraz wskaźnik zagrożenia ubóstwem po uwzględnieniu transferów społecznych.

Kompleksowe ujęcie trzech wymienionych wskaźników umożliwiło opracowanie wskaźnika wykluczenia społecznego ogółem. Jest on interpretowany jako odsetek osób, które są zagrożone ubóstwem i/lub pogłębioną deprywacją materialną, i/ lub żyją w gospodarstwach domowych o bardzo niskiej intensywności pracy tzn. takich, w których osoby dorosłe (w wieku 18-59 lat) w minionym roku przepracowały mniej niż 20\% ich całkowitego potencjału pracy. Wysokość w Polsce wskaźnika wykluczenia społecznego ogółem na tle krajów UE przedstawia rysunek 9. 


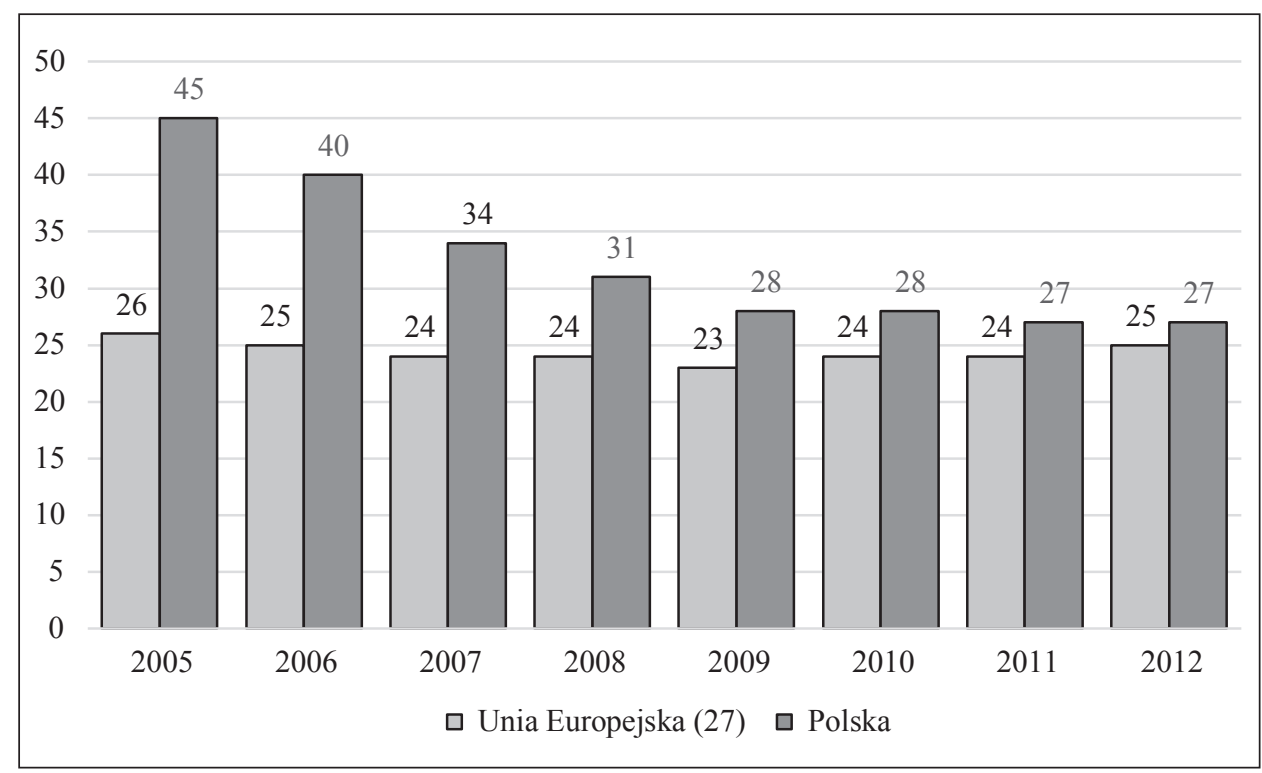

Rysunek 9. Wskaźnik wykluczenia społecznego ogółem w Polsce na tle UE w latach 2005-2012 (w \%)

\section{Źródło: jak przy rys. 8}

Polska wśród krajów UE 27 należy do państw o wyższym niż średni wskaźniku zagrożenia ubóstwem lub wykluczeniem społecznym (26,7\% populacji w Polsce wobec $24,8 \%$ dla UE 27). Jednak w Polsce notuje się stopniowy spadek wartości tego wskaźnika. W okresie od 2005 r. jego wartość zmniejszyła się o 18,6 pkt. proc. W latach 2005-2008 widoczny był systematyczny spadek udziału osób wykluczonych społecznie, ale dynamika tego spadku w kolejnych latach wyhamowała.

Osobno wskazywaną grupą dla wskaźnika wykluczenia społecznego ogółem są emeryci. Na rysunku 10 zawarte zostało porównanie tej grupy do ogółu społeczeństwa.

We wszystkich kategoriach wskaźników służących pomiarowi wykluczenia społecznego widoczna jest niekorzystna wartość towarzysząca grupie emerytów. Najbardziej widoczny negatywny trend odnotowany został w przypadku wskaźnika niskiej intensywności zatrudnienia, ale jest to związane ze specyfiką tej grupy społecznej. Natomiast bardziej niepokojąco przedstawiały się dysproporcje we wskaźniku wykluczenia społecznego ogółem, który dla emerytów był wyższy o 4,1 pkt. proc. Nawiązując do raportu z badania dochodów i warunków życia ludności w Polsce, gospodarstwa domowe emerytów są grupą społeczno-ekonomiczną o niższych przeciętnych rocznych dochodach do dyspozycji netto na 1 osobę w gospodarstwach domowych niż w przypadku gospodarstw domowych pracowników lub pracujących na własny rachunek. 
Deklarują też oni częściej niż pozostałe kategorie gospodarstw domowych brak możliwości pokrycia z własnych środków nieoczekiwanych wydatków w kwocie 950 zł oraz częściej występujące niż przeciętnie trudności w zaspokajaniu potrzeb $^{69}$.

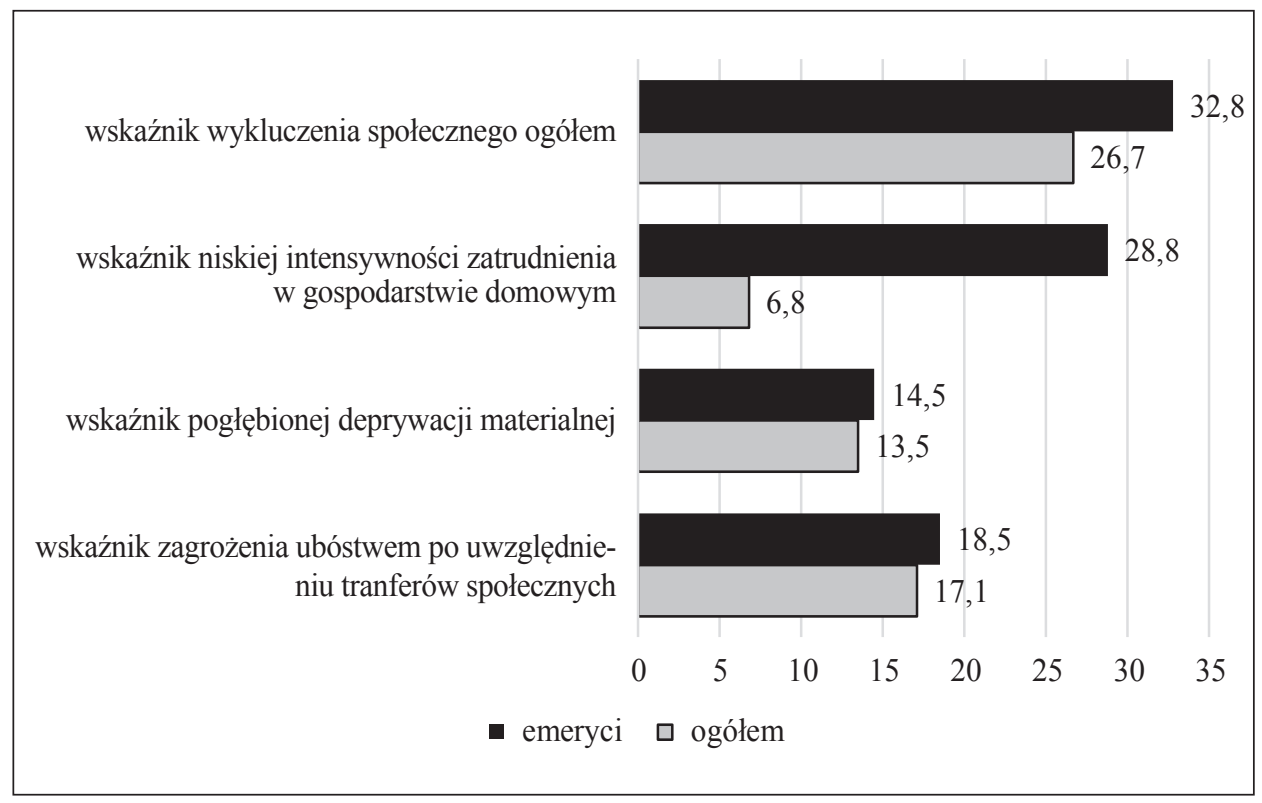

Rysunek 10. Wskaźniki wykluczenia społecznego emerytów (w \%)

Źródlo: jak przy rys. 8

Na szczeblu międzynarodowym przeprowadzone zostały także badania dotyczące ubóstwa i wykluczenia starszych obywateli $\mathrm{UE}^{70}$. Badania przeprowadzono dwuetapowo. Na pierwszym etapie w próbie 18 państw członkowskich przeprowadzono szereg zogniskowanych wywiadów grupowych $\mathrm{z}$ osobami $\mathrm{w}$ wieku 60 lat i więcej, które doświadczają ubóstwa i wykluczenia społecznego ${ }^{71}$. Wyniki pierwszej części badania wykluczenia społecznego osób starszych przedstawia tablica 5.

${ }^{69}$ GUS, Dochody $i$ warunki życia ludności Polski (raport z badania EU-SILC 2012), Warszawa 2014, http://stat.gov.pl/obszary-tematyczne/warunki-zycia/dochody-wydatki-i-warunki-zycia-ludnosci/dochody-i-warunki-zycia-ludnosci-polski-raport-z-badania-eu-silc-2012,6,5.html, s. 14-18 (stan na dzień 20.07.2014).

${ }^{70}$ TNS Qual+, Ubóstwo i wykluczenie starszych obywateli UE. Sprawozdanie zbiorcze - styczeń 2011 r., Eurobarometr 2011, s. 6-7.

${ }^{71}$ Jeden wywiad grupowy, który trwał około 90 minut, został przeprowadzony w każdym kraju z 8-12 uczestnikami żyjącymi poniżej progu ubóstwa w kraju, w którym mieszkają. 
Tablica 5. Wykluczenie społeczne a życie poniżej progu ubóstwa

\begin{tabular}{|c|c|c|c|c|c|c|}
\hline \multirow[b]{2}{*}{ Państwo } & \multicolumn{2}{|c|}{ Płeć } & \multirow[b]{2}{*}{$\begin{array}{c}\text { Zakres } \\
\text { wiekowy } \\
\text { uczestników }\end{array}$} & \multirow[b]{2}{*}{$\begin{array}{l}\text { Poniżej } \\
\text { progu } \\
\text { ubóstwa }\end{array}$} & \multirow[b]{2}{*}{$\begin{array}{c}\text { Wykluczenie } \\
\text { społeczne }\end{array}$} & \multirow[b]{2}{*}{$\begin{array}{c}\text { Miejsce przeprowadzenia } \\
\text { zogniskowanego wywiadu } \\
\text { grupowego }\end{array}$} \\
\hline & $\frac{\overrightarrow{0}}{\frac{0}{0}}$ & 㺼 & & & & \\
\hline Belgia & 4 & 4 & $60-73$ & wszyscy & $8 \mathrm{z} 8$ & Bruksela \\
\hline Czechy & 4 & 4 & $60-65$ & wszyscy & $4 \mathrm{z} 8$ & Praga \\
\hline Dania & 5 & 6 & $64-81$ & wszyscy & $10 \mathrm{z} 11$ & Kopenhaga \\
\hline Francja & 3 & 6 & $60-75$ & wszyscy & $9 \mathrm{z} 9$ & Paryż \\
\hline Niemcy & 4 & 6 & $60-75$ & wszyscy & $10 \mathrm{z} 10$ & Monachium \\
\hline Grecja & 4 & 4 & $60-10$ & wszyscy & $4 \mathrm{z} 8$ & Ateny \\
\hline Węgry & 4 & 4 & $60-65$ & wszyscy & $6 \mathrm{z} 8$ & Budapeszt \\
\hline Irlandia & 3 & 5 & $63-71$ & wszyscy & $4 \mathrm{z} 8$ & Dublin \\
\hline Włochy & 5 & 4 & $63-70$ & wszyscy & $9 \mathrm{z} 9$ & Mediolan \\
\hline Łotwa & 3 & 7 & 59-78 & wszyscy & $8 \mathrm{z} 10$ & Ryga \\
\hline Malta & 6 & 4 & $60-82$ & wszyscy & $9 \mathrm{z} 10$ & St. Julians \\
\hline Polska & 4 & 4 & $60-69$ & wszyscy & $6 \mathrm{z} 8$ & Warszawa \\
\hline Portugalia & 3 & 5 & $63-74$ & wszyscy & $8 \mathrm{z} 8$ & Lizbona \\
\hline Rumunia & 3 & 6 & $60-86$ & wszyscy & $8 \mathrm{z} 9$ & Bukareszt \\
\hline Słowacja & 3 & 5 & $61-78$ & wszyscy & $8 \mathrm{z} 8$ & Bratysława \\
\hline Hiszpania & 5 & 4 & $60-72$ & wszyscy & $6 \mathrm{z} 9$ & Madryt \\
\hline Szwecja & 3 & 7 & $62-74$ & wszyscy & $8 \mathrm{z} 10$ & Göteborg \\
\hline $\begin{array}{l}\text { Wielka } \\
\text { Brytania }\end{array}$ & 1 & 8 & $62-69$ & wszyscy & 8 z 9 & Londyn \\
\hline
\end{tabular}

Źródło: TNS Qual+, Ubóstwo i wykluczenie starszych obywateli UE. Sprawozdanie zbiorcze - styczeń 2011 r., Eurobarometr 2011, s. 14.

Następnym etapem badań było zaproszenie wybranych uczestników zogniskowanych wywiadów grupowych do Brukseli w styczniu 2011 r., aby wzięli udział w drugiej dyskusji w celu sformułowania materiału stanowiącego wkład w agorę ${ }^{72}$. Dyskusja toczyła się wokół czterech kluczowych zagadnień ${ }^{73}$ :

1. Sposób postrzegania mediów i społeczeństwa oraz osobiste doświadczenia respondentów - wśród respondentów dominował pogląd, że nie ma dostatecznego zaangażowania w kwestie ubóstwa i wykluczenia społecznego. W mediach kwestie ubóstwa i wykluczenia społecznego są przedstawiane w sposób wyolbrzymiony lub nieścisły, a ponadto brak jest empatii, działania i zainteresowania ze strony społeczeństwa.

${ }^{72}$ Z Polski wybrane zostały 2 osoby.

${ }^{73}$ Szerzej: TNS Qual+, Ubóstwo i wykluczenie starszych obywateli UE. Sprawozdanie zbiorcze-styczeń 2011 r., Eurobarometr 2011. 
2. Zrozumienie kwestii ubóstwa $i$ wykluczenia społecznego wśród decydentów - decydenci i twórcy polityki, zarówno na szczeblu lokalnym, krajowym, jak i europejskim, wprawdzie są świadomi kwestii wykluczenia, ale w dużej mierze nie rozumieją problemów ubóstwa i wykluczenia społecznego.

3. Polityki UE dotyczace walki z ubóstwem - wiedza i oczekiwania-zasadniczo respondenci nie posiadali znacznej wiedzy o politykach UE dotyczących walki z ubóstwem, podali szereg pomysłów dotyczących działań, które UE powinna podjąć w celu walki z ubóstwem. Dwoma najczęściej wymienianymi pomysłami było rozwiązanie problemu bezrobocia i poprawa warunków życia i sąsiedztwa.

4. Kwestie szczególowe - Internet, warunki życia i zatrudnienie - około jednej trzeciej respondentów miało dostęp do Internetu, większość respondentów wyrażała obawy w związku ze złymi warunkami życia lub złymi warunkami panującymi w sąsiedztwie, respondenci oczekiwali wprowadzenia środków służących do walki z dyskryminacją ze względu na wiek w miejscu pracy oraz zwiększenia zaangażowania urzędów pracy w znajdowanie odpowiednich miejsc pracy dla starszych pracowników.

Podsumowując, osoby starsze okazały się być grupą ludności, która:

- czuje się ignorowana przez pozostałą część społeczeństwa,

- uważa, że realia jej życia nie są przedstawiane w głównych mediach,

- jest przekonana, że twórcy polityki nie rozumieją, jak wygląda życie osób zmuszonych radzić sobie z ubóstwem i wykluczeniem społecznym.

Głównymi problemami są materialne, codzienne aspekty ubóstwa - koszty utrzymania, zatrudnienie, emerytury, opieka zdrowotna. Mniej namacalne aspekty są również istotne - wpływ wykluczenia społecznego na poczucie własnej wartości oraz pragnienie poczucia, że jest się słuchanym i cenionym w społeczeństwie. Poczucie niewidzialności i wykluczenia często zwiększa stygmatyzacja ubóstwa i uczucie wstydu lub skrępowania wśród wielu respondentów.

\subsection{Wykluczenie bankowe jako obszar wykluczenia społecznego}

\subsubsection{Wykluczenie finansowe a wykluczenie bankowe}

Początkowo wykluczenie finansowe rozpatrywane było w kontekście geograficznych utrudnień w dostępie do usług finansowych. Interpretacja pojęcia wykluczenia finansowego uległa zmianie w połowie lat 90-tych XX w. Wówczas termin ten zaczęto wykorzystywać w szerszym zakresie, w celu określenia osób, które mają ograniczony dostęp do głównego nurtu usług finansowych już bez koncentrowania się na fizycznych lub geograficznych barierach ${ }^{74}$.

${ }^{74}$ Por. M. Marcinkowska, Kapitat relacyjny banku, t. 2, Relacje banku z kluczowymi interesariuszami, Wydawnictwo UŁ, Łódź 2013, s. 140-141. 
W definicjach wykluczenia finansowego bardzo często autorzy koncentrują się na utrudnieniach w korzystaniu $\mathrm{z}$ usług finansowych osób o niskich dochodach, znajdujących się w niekorzystnej sytuacji społecznej. Zgodnie z jedną z najbardziej popularnych definicji ,wykluczenie finansowe to procesy, które służą ograniczeniu dostępu do systemu finansowego określonym grupom społecznym. Dotyka ono najczęściej grupy o ograniczonych dochodach"75. Zbliżoną interpretację odnaleźć można w definicji traktującej wykluczenie finansowe jako ,niezdolność (rozumiana jako brak możliwości) do dostępu do systemu finansowego niektórych grup społecznych"76.

W podobny sposób problem wykluczenia rozumiany jest przez L. Anderloni, która interpretuje je jako „trudności, jakich doświadczają osoby o niskich dochodach i znajdujące się w niekorzystnej sytuacji społecznej (socially disadvantaged) w korzystaniu z usług finansowych, które są im potrzebne - np. posiadanie konta i możliwości dokonywania rozliczeń bezgotówkowych, dostęp do kredytu o „rozsądnym” poziomie oprocentowania czy też budowanie nawet niewielkich oszczędności, z uwzględnieniem niestabilnej sytuacji zawodowej"77.

Z kolei G. Gloukoviezoff podkreślił, że kwestia dostępu do usług finansowych stanowi jedynie część problemu wykluczenia finansowego. Jego zdaniem największym wyzwaniem jest edukacja społeczeństwa dotyczącą właściwego korzystania z usług finansowych ${ }^{78}$.

Warto także wskazać definicję, na którą powołuje się Komisja Europejska w raporcie Financial Services Provision and Prevention of Financial Exclusion. Zgodnie z nią wykluczenie finansowe jest to „proces, w którym obywatele doświadczają problemów $\mathrm{w}$ dostępie do i/lub korzystaniu z produktów i usług finansowych na głównym rynku (mainstream market), które są odpowiednie do ich potrzeb i umożliwiają im prowadzenie normalnego życia w społeczeństwie"79.

${ }^{75}$ Autorzy tej definicji zwracają uwagę, iż pewne grupy osób generują zbyt wysoki poziom ryzyka dla instytucji finansowych, przez co one decydują się unikać ich jako klientów. A. Leyshon, N. Thrift, Geographies of financial exclusion: financial abandonment in Britain and the United States, Transactions of the Institute of British Geographers, New Series No.20, 1995, http://www.jstor. org $/$ discover $/ 10.2307 / 622654$ ?uid $=3739256 \&$ uid $2 \&$ uid $=4 \&$ sid $=21104514833753$, s. 312 (stan na dzień 20.07.2014).

${ }^{76}$ Szerzej: S. Carbo, E. P. Gardener, P. Molyneux, Financial Exclusion, Palgrave MacMillan, London 2005.

${ }^{77}$ L. Anderloni, Access to Bank Account and Payment Services, [w:] L. Anderloni, M. D. Braga, E. M. Carluccio (ed.), New Frontiers in Banking Services. Emerging Needs and Tailored Products for Untapped Markets, Springer - Verlag, Berlin-Heidelberg 2007, http://books.google.pl/ books?id=UCH1yc3p314C\&pg= PA28\&lpg=PA28\&dq=Anderloni, +socially+disadvantage \& source=bl\&ots=pwfwxMNq60\&sig=V_I2V0QWNO36 7QgnFX145_mQ_fI\&hl=pl\&sa=X\& ei=JBbOU6DPO4SCzAOa6YKICQ\&ved $=0$ CDwQ6AEwBA\# $\mathrm{v}=$ onepage $\& \mathrm{q}=$ Anderloni $\% 2 \mathrm{C} \% 20$ social$1 \mathrm{y} \% 20$ disadvantage $\& \mathrm{f}=$ false, s. 7 (stan na dzień 20.07.2014).

${ }^{78}$ G. Gloukoviezoff, The Caisse d'Epargne and housholds' financial exclusion: Which actions should be taken and what are the prospects?, Access to Finance Conference, World Savings Banks Institute - The World Bank, Bruxelles 2004, http://www.spanish.microfinancegateway.org/ files/21774_exclusion.pdf, s. 2 (stan na dzień 20.07.2014).

${ }^{79}$ European Commission, Financial Services Provision and Prevention of Financial Exclusion, VC/2006/0183, March 2008. 
W ramach węższego podejścia do definiowania zjawiska wykluczenia finansowego większy nacisk kładziony jest na specyficzne usługi i brak dostępu do nich. Często określa się je mianem podstawowych lub uniwersalnych (essential services). Są to usługi finansowe, które nie mają wpływu na budżet gospodarstwa domowego, ale jednocześnie stanowią ważny element $\mathrm{w}$ życiu jednostki dla jej przetrwania, bezpieczeństwa oraz dla uczestnictwa w życiu społecznym i ekonomicznym ${ }^{80}$.

Na gruncie podstawowych usług finansowych powstała definicja wykluczenia finansowego interpretująca je jako „niezdolność do korzystania z niezbędnych usług finansowych w odpowiedniej formie, która może być wynikiem problemów $\mathrm{z}$ dostępem do usług finansowych, warunkami, ceną, marketingiem lub efektem samowykluczenia wynikającego z negatywnych doświadczeń lub przekonań" ${ }^{81}$. $\mathrm{Na}$ podstawie wskazanych barier w korzystaniu z usług finansowych można zidentyfikować różne aspekty wykluczenia finansowego. Są to ${ }^{82}$ :

- wykluczenie ze względu na dostępność geograficzną (geographical access);

- wykluczenie ze względu na dostępność (access exclusion) - występujące w przypadku, gdy ograniczenia w dostępie wynikają z procesu oceny ryzyka;

- wykluczenie ze względu na warunki (condition exclusion) - mające miejsce w sytuacji, kiedy oferta produktowa nie jest właściwie dopasowana do potrzeb danej grupy osób;

- wykluczenie cenowe (price exclusion) - związane z istnieniem zbyt wysokich cen, które są barierą w uzyskaniu dostępu do usług finansowych;

- wykluczenie marketingowe (marketing exclusion) - istniejące w sytuacji, kiedy dana grupa osób zostaje wykluczona zgodnie z przyjętą polityką marketingową instytucji finansowej;

- samowykluczenie (self-exclusion) - przyczyny występowania tego rodzaju wykluczenia leżą w przekonaniu grupy osób o braku potrzeby korzystania z usług bankowych ze względu na oczekiwane rozczarowanie po skorzystaniu z tych usług. Niekiedy jest to wynikiem odmówienia dostępu do usług finansowych w przeszłości lub przekonaniem, że instytucje finansowe nie akceptują niektórych grup osób, np. ze względu na ich miejsce zamieszkania.

$\mathrm{Na}$ gruncie wskazanych wyżej definicji wykluczenia finansowego można skonstruować własną interpretację tego pojęcia. W opinii autorów wykluczenie finansowe powinno być rozpatrywane dwojako, z jednej strony jako dobrowolne niekorzystanie z produktów finansowych, zaś z drugiej jako wykluczenie

${ }^{80}$ Por. I. Kuchciak, Nadmierne zadtużanie się gospodarstw domowych - przyczyna i skutek wykluczenia finansowego, „Bezpieczny Bank” 2013, nr 2-3 (51-52), s. 142-146.

${ }^{81}$ S. P. Sinclair, Financial Exclusion: an introductory survey, Heriot Watt University Centre for Research into Socially Inclusive Services (CRSIS), Edinburgh 2001, s. 14.

${ }^{82}$ Szerzej: E. Kempson, C. Whyley, Kept Out or Opted Out? Understanding and Combating Financial Exclusion, Bristol: Policy Press, 1999, http://www.pfrc.bris.ac.uk/Reports/Kept_out_ opted_out.pdf (stan na dzień 20.07.2014). 
będące efektem braku możliwości korzystania z produktów finansowych oferowanych przez podmioty rynku finansowego działające na nim zgodnie z przepisami prawa.

Publikacje na temat wykluczenia finansowego często podkreślają fakt, że osoby społecznie wykluczone albo nie posiadają dostępu do usług finansowych, albo dostęp ten jest niewystarczający, albo też niewłaściwy ${ }^{83}$. Często trudności $w$ dostępie do usług finansowych traktowane są jako konsekwencje wystąpienia trudności w użytkowaniu (brak komputera, brak Internetu), szczególnie widoczne w przypadku rozwiązań bazujących na nowoczesnych technologiach (np. bankowość mobilna). Wykluczenie cyfrowe jest charakterystyczne dla gospodarstw domowych emerytów i zamiast być stymulatorem włączenia w system bankowy, okazuje się być trudną do pokonania barierą ${ }^{84}$.

Wzrost znaczenia technologii informacyjno-komunikacyjnych w różnych sferach życia wynika z przenoszenia się coraz większej liczby działań i aktywności do Internetu (dbania o relacje społeczne z osobami, które wyjechały zagranicę lub z obszaru finansowego - funkcjonowanie banków internetowych). Ponadto Internet staje się coraz ważniejszym kanałem dostępu do informacji i wiedzy ze względu na prędkość zamieszczania w nim aktualności. Wreszcie Internet to przede wszystkim przestrzeń gospodarcza służąca do wymiany handlowej, wykonywania pracy, jej oferowania i poszukiwania.

Brak wiedzy lub niedostateczna wiedza finansowa postrzegana jest również jako bariera we włączeniu w system finansowy. Istnieje bowiem powiązanie pomiędzy wykluczeniem cyfrowym i finansowym i faktem jest, że bez znajomości technologii informacyjno-komunikacyjnych trudno o pełne korzystanie z usług finansowych.

Należy również wskazać, że instytucje finansowe niekiedy same odmawiają dostępu wybranej grupie klientów w przypadku, gdy przewidują, że wystąpią trudności w ich wykorzystaniu lub gdy oceniają, iż osoby te są zbyt ubogie, by przynosić korzyści finansowe instytucji finansowej. Najczęściej odmowa

${ }^{83} \mathrm{Na}$ podstawie przeprowadzonego na 359 osobach zamieszkujących greckie wyspy badania skontrastowano poglądy osób, które nigdy nie doświadczyły włączenia finansowego z osobami, które zamieszkiwały w przeszłości inne obszary i miały szansę korzystania z usług finansowych. W efekcie okazało się, iż niezależnie od przynależności do grupy wyrażane było niezadowolenie z dostawców usług finansowych, szczególnie silnie wyrażane przez drugą grupę ankietowanych. G. G. Panigyrakis, P. K. Theodoridis, C. A. Veloutsou, All customers are not treated equally: Financial exclusion in isolated Greek islands, "Journal of Financial Services Marketing" 2002, No.7, s. 54-66.

${ }^{84}$ Wykluczenie cyfrowe jest także barierą dla wykorzystania potencjału e-administracji (jak szacuje PwC elektroniczne rozliczanie tylko podatku PIT przyniosłoby oszczędności rzędu 140 milionów złotych rocznie) oraz rozwoju zakupów w sieci (powołując się na PwC średnie oszczędności na zakupach w sieci to około 15 procent w porównaniu do tradycyjnej formy zakupów). Szerzej: PwC, Raport e-commerce 2011. Aktualne wyzwania dla handlu detalicznego, czyli jak skutecznie wprowadzić elektroniczny kanat sprzedaży w tradycyjnym sklepie?, listopad 2011. 
występuje w przypadku produktów o charakterze pożyczkowo-kredytowym. W przypadku dostępu do kredytów identyfikowane są następujące poziomy wykluczenia ${ }^{85}$ :

- wyłączenie kredytowe,

- niewłaściwa oferta kredytowa oferowana przez alternatywnych kredytodawców,

- niewłaściwa oferta kredytowa oferowana przez główny rynek finansowy,

- właściwa oferta kredytowa oferowana przez alternatywnych kredytodawców,

- właściwa oferta kredytowa oferowana przez główny rynek finansowy.

$\mathrm{Z}$ tego względu wykluczenie kredytowe dotyka dwóch podstawowych grup osób ${ }^{86}$ :

- osób nieposiadających historii kredytowej lub posiadających złą historię kredytową,

- osób o niskich dochodach.

W obszarze wykluczenia kredytowego warto rozgraniczyć produkty pożyczkowo-kredytowe na cele konsumpcyjne (zakup dóbr trwałego użytku, remont domu lub mieszkania) i kredyty hipoteczne. Należy podkreślić, że dostępność pierwszych z nich jest znacznie większa i na remont domu lub mieszkania relatywnie najczęściej wykorzystywały kredyty gospodarstwa domowe pracowników oraz emerytów (odpowiednio prawie 33 proc. i prawie 30 proc. gospodarstw korzystających z kredytów). Zwykle w odniesieniu do niewielkich kredytów gotówkowych większą barierą niż wiek jest niski dochód potencjalnego kredytobiorcy.

Problem zbyt wysokiego wieku występuje natomiast w przypadku kredytów hipotecznych. W większości polityk kredytowych banków istnieją zapisy w procedurach kredytowych stanowiące, że kredyt musi zostać spłacony przed ukończeniem określonego wieku kredytobiorcy. Zazwyczaj jest to 65-70 lat. Tym samym znacznie skraca się okres kredytowania i podnosi wysokość raty, uniemożliwiając praktycznie zaciągniecie tego zobowiązania.

Należy jednocześnie podkreślić, że zapotrzebowanie na kredyty hipoteczne jest charakterystyczne dla grupy wiekowej 25-35 lat. Gospodarstwa domowe emerytów najczęściej posiadają już nieruchomości i dla nich bardziej atrakcyjnym rozwiązaniem, zwiększającym miesięczne dochody do dyspozycji, mogłaby być odwrócona hipoteka. Oczywiście pod warunkiem jej ostatecznego usankcjonowania w polskich przepisach prawnych oraz z uwzględnieniem indywidualnej sytuacji rodzinnej i materialnej każdego gospodarstwa domowego.

${ }^{85}$ European Commission, Financial Services Provision and Prevention of Financial Exclusion, VC/2006/0183, March 2008, s. 15. Por. N. Byrne, O. McCarthy, M. Ward, Meeting the Credit Needs of Low-Income Groups: Credit Unions-V-Moneylenders, Working paper 05/05, Dublin: Combat Poverty Agency, 2005.

${ }^{86}$ E. Kempson, C. Whyley, J. Caskey, S. Collard, In or Out? Financial Exclusion: a literature and research review, FSA, UK, 2000, s. 42. 
Wreszcie, w przypadku dostępu do produktów oszczędnościowych nieco inaczej określa się problem wykluczenia. Nie jest on determinowany brakiem dostępu lub niekorzystaniem, ale możliwościami oszczędzania, jakie ma dana osoba w określonym momencie (zwykle mierzonymi posiadanym dochodem) i skłonnością do oszczędzania zmieniającą się wraz z wiekiem. Kwestia wieku jako czynnika determinującego zachowania oszczędnościowe szczególnie nabiera na znaczeniu w obliczu zidentyfikowanych wcześniej trendów demograficznych ${ }^{87}$. Hipoteza cyklu życia zakłada negatywną stopę oszczędności w okresie młodości, następnie wzrost oszczędności wraz z wiekiem oraz jej dodatni poziom w okresie produkcyjnym. Szczyt oszczędności zgromadzonych w celu zaspokojenia potrzeb w okresie starszym przypada na wiek 60-65 lat ${ }^{88}$. Tym samym teoretycznie dopiero w późniejszym okresie życia pojawia się potrzeba akumulacji oszczędności w celu zabezpieczenia przyszłości dorastających dzieci oraz własnej w okresie emerytury, zaś w ostatniej fazie cyklu życia zwiększa się znaczenie motywu przezornościowego (związanego ze zwiększonym ryzykiem konieczności poniesienia kosztów leczenia) i pojawia się aprobata dla ograniczania konsumpcji bieżącej.

Istotną kwestią skorelowaną ze skłonnością do oszczędzania jest rosnąca wraz z wiekiem awersja do ryzyka. Badania potwierdzają, że najwyższą aktywność inwestycyjną zaobserwowano wśród osób między 40. a 60. rokiem życia. Wśród emerytów odnotowano wyższy niż przeciętny odsetek gospodarstw korzystających z bezpiecznych form oszczędzania: lokat bankowych w złotych i obligacji skarbowych, przy niższym niż przeciętnie udziale inwestycji w zakup akcji, jednostek uczestnictwa w funduszu inwestycyjnym, lokat w nieruchomości. Jest to związane ze skłonnością do ponoszenia ryzyka w tej grupie wiekowej ${ }^{89}$.

Interesującym elementem uzupełniającym kwestie wykluczenia w obszarze produktów oszczędnościowych jest przedstawiona w Diagnozie Społecznej analiza wpływu wieku głowy gospodarstwa domowego na szanse posiadania oszczędności przez gospodarstwa domowe. Mianowicie, wskazuje ona, że największe prawdopodobieństwo posiadania oszczędności występuje w grupie gospodarstw domowych, w których głowa jest w wieku 65 i więcej lat ${ }^{90}$. Zatem potencjalnie gospodarstwa domowe emerytów, posiadając nawet niewielkie oszczędności, powinny być zainteresowane bezpiecznym ich ulokowaniem, a banki powinny

${ }^{87}$ Szerzej: P. Anioła, Z. Gołaś, Zastosowanie wielowymiarowych metod statystycznych $w$ typologii strategii oszczędnościowych gospodarstw domowych w Polsce, „Materiały i Studia”, Zeszyt nr 282, Warszawa 2012.

${ }^{88}$ Hipoteza ta była wielokrotnie pozytywnie weryfikowana, ale wykazywała też niezgodną z modelem cyklu życia zależność między wiekiem a stopą oszczędzania.

${ }^{89}$ G. Rytelewska, A. Kłopocka, Wpływ czynników demograficznych na poziom i strukturę oszczędności gospodarstw domowych w Polsce, „Bank i Kredyt” 2010, 41 (1), s. 57-80. Por. M. Iwanicz-Drozdowska (red.), Polski rynek finansowy wobec zmian społeczno-demograficznych, Instytut Badań nad Gospodarką Rynkową, Gdańsk 2009, s. 56.

90 J. Czapiński, T. Panek (red.), Diagnoza społeczna 2013, Rada Monitoringu Społecznego, Warszawa 2013, s. 72. 
posiadać w swojej ofercie produkty oszczędnościowe dopasowane do potrzeb i możliwości tej grupy wiekowej, co wpłynęłoby na włączenie jej w system bankowy ${ }^{11}$.

Włączenie finansowe obejmuje zagwarantowanie dostępu do szeregu usług finansowych, obejmujących zarówno oszczędności, pożyczki, ubezpieczenia, płatności, jak i doradztwo świadczone przez profesjonalne instytucje finansowe. Jednocześnie włączenie finansowe jest możliwe, gdy aktywności podejmowane przez społeczeństwo w celu nawiązania kontaktu z instytucjami finansowymi będą poparte przeświadczeniem o korzyściach z tego płynących. Można je sprowadzić do trzech kluczowych obszarów ${ }^{92}$ :

- otwarcie rachunku bankowego i zrozumienie, w jaki sposób można go używać, ułatwia zarządzanie finansami;

- posiadanie dostępu do kredytów i wybór produktu najlepiej dostosowanego do oczekiwań;

- korzystanie z produktów oszczędnościowych pozwala na zbalansowanie wydatków codziennych i zapewnienie długoterminowego zabezpieczenia.

Poza wskazanymi powyżej trzema obszarami, istotnym aspektem wykluczenia jest kwestia ubezpieczenia. Posiadanie ubezpieczenia na życie traktowane jest jako popularna forma oszczędzania w grupie osób powyżej 50. roku życia, którą zainteresowanie zwiększa się wraz ze zbliżającym się wiekiem emerytalnym.

Na gruncie wykluczenia finansowego pojawiły się nawet określenia oznaczające różne jego poziomy. Skrajnymi są dwa przypadki. Pierwszy z nich oznacza osoby, które w sposób aktywny i konsekwentny korzystają z szerokiego wachlarza usług i produktów finansowych. Są one określane mianem super włączonych finansowo (superincluded). Na przeciwległym krańcu znajdują się osoby zupełnie wykluczone finansowo, które odmawiają korzystania nawet $\mathrm{z}$ najbardziej podstawowych produktów. Między nimi z kolei można wskazać na grupy osób korzystające z pewnych pakietów usług bankowych, np. tylko depozytów, albo wypłat pieniężnych. Osoby te zwykle posiadają ograniczony dostęp do usług bankowych i nie mogą w pełni elastycznie korzystać z oferty instytucji finansowych ${ }^{93}$.

Natomiast ze względu na fakt, że w systemie finansowym banki pełnią kluczową rolę, uwaga w monografii skoncentrowana będzie głównie na wykluczeniu bankowym. Dostęp do usług bankowych jest postrzegany jako uniwersalna potrzeba występująca w większości rozwiniętych społeczeństw. Brak dostępu do usług

${ }^{91}$ W IV kwartale 2013 r. stopa oszczędzania, stanowiąca relację oszczędności brutto gospodarstw domowych do ich dochodów do dyspozycji, wyniosła $11,6 \%$, wobec $9,7 \% \mathrm{w}$ poprzednim kwartale, a w ujęciu rocznym spadła o 6 punktów procentowych. Szerzej: G. Mierzejewska, F. Premik, Sytuacja finansowa sektora gospodarstw domowych w IV kw. 2013 r., Nr 02/14 (czerwiec 2014 r.), Instytut Ekonomiczny NBP, Warszawa 2014.

${ }^{92}$ S. Regan, W. Paxton, Beyond bank accounts: full financial inclusion, Citizens Advice Bureau/IPPR, 2003, s. 6.

${ }_{93}$ V. Leeladhar, Taking Banking Services to the Common Man - Financial Inclusion, "Reserve Bank of India Bulletin”, January 2006, s. 73-74. 
bankowych szczególnie negatywnie wpływa na proces włączenia społecznego stanowiącego priorytet w działaniach Unii Europejskiej. Wynika to z faktu, że:

- usługi bankowe są najbardziej popularne;

- posiadanie rachunku bankowego warunkuje dostęp do pozostałych usług bankowych, bez których osoby narażone są na nadmiernie wysokie opłaty generujące ryzyko pogłębiania ubóstwa;

- coraz trudniejsze i droższe jest dokonywanie płatności jedynie w formie gotówkowej;

- brak dostępu do usług bankowych generuje konieczność realizowania czasochłonnych procedur.

Posiadanie rachunku bankowego pozwala na ${ }^{94}$ :

- otrzymywanie regularnych (w formie elektronicznej) płatności, takich jak wynagrodzenia, emerytury lub środki z pomocy społecznej;

- zamianę czeków i voucherów na gotówkę;

- przechowywanie pieniędzy w bezpieczny sposób do momentu ich wypłaty;

- płacenie za produkty i usługi w innej formie niż gotówka;

- płacenie rachunków w sposób elektroniczny;

- realizację przekazów.

Rozważając włączenie w system bankowy, autorzy będą się koncentrowali na głównym rynku, czyli przede wszystkim na bankach komercyjnych, które dominują w polskim sektorze bankowym, z uwzględnieniem banków spółdzielczych. Wprawdzie od 27 października 2012 r. spółdzielcze kasy oszczędnościowo -kredytowe (SKOKi) znajdują się pod nadzorem Komisji Nadzoru Finansowego $(\mathrm{KNF})^{95}$, a tym samym przestały w pewnym stopniu spełniać definicję instytucji parabankowej (lub alternatywnego rynku bankowego) i mogłyby pełnić aktywną rolę we włączaniu w system bankowy szczególnie osób o niskich dochodach ${ }^{96}$, jednak ze względu na ich marginalną rolę w sektorze bankowym nie będą one analizowane ${ }^{97}$.

Podobnie, w przypadku platform pożyczek społecznościowych (social lending) oferujących zawieranie transakcji pożyczek bezpośrednio między potrzebującymi gotówki a inwestorami, bez pośrednictwa banków. Instytucje te nadal należą do kategorii shadow banking, gdyż chociaż świadczą usługi podobne do bankowych, to nie obowiązują ich przepisy prawa bankowego i nie są nadzorowane przez KNF. W literaturze przedmiotu wskazuje się, że instytucje parabankowe, w tym szczególnie o charakterze social lending i crowdfunding, pozwalają

${ }^{94}$ European Commission, Financial Services Provision and Prevention of Financial Exclusion, VC/2006/0183, March 2008, s. 11-12.

95 Ustawa z dnia 5 listopada 2009 r. o spółdzielczych kasach oszczędnościowo-kredytowych, Dz. U. z 2012 r. poz. 855, 1166; z 2013 r. poz. 613, 1036, 1289.

${ }^{96}$ M. Iwanicz-Drozdowska, Wykluczenie finansowe - poważny problem spoleczny, „Management and Business Administration. Central Europe" 2008, Vol. 16, No.1, s. 11.

${ }^{97}$ Aktywa SKOKów stanowią mniej niż 1\% aktywów instytucji finansowych w Polsce. 
w pewnym stopniu ograniczyć zjawisko wykluczenia finansowego, ale generują one szereg poważnych ryzyk dla klientów. Wprawdzie równoległy system bankowy tworzy dodatkowe źródła kapitału i usług finansowych dla szerokiej grupy konsumentów, ale jednocześnie generuje potencjalne ryzyko dla całego systemu.

Często z usług tych instytucji korzystają osoby, które uzyskały negatywną decyzję kredytową w banku ze względu na niewystarczającą zdolność kredytową bądź negatywną historię spłat wcześniej zaciągniętych długów. Z jednej strony korzystanie $\mathrm{z}$ ich usług stanowi szansę dla pożyczkobiorców na pozyskanie kapitału i sfinansowanie planowanych wydatków konsumpcyjnych lub inwestycyjnych, zaś z drugiej oferują pożyczkodawcom możliwość uzyskania wyższego oprocentowania lokat niż w banku. Inną ważną kwestią jest zwiększenie świadomości i aktywności ekonomicznej społeczeństwa. W szczególności w Polsce, gdzie odsetek osób korzystających z usług finansowych jest bardzo niski, zakres korzystania z usług bankowych przez osoby w wieku 50+ jest wąski, a ich przeciętna wiedza ekonomiczna ograniczona, tego rodzaju inicjatywy społeczne mogą mieć bardzo pozytywny wymiar ${ }^{98}$.

Jednocześnie należy pamiętać, że korzystanie z usług takich instytucji generuje poważne ryzyka. Należy zwrócić uwagę na ryzyko operacyjne, dla minimalizacji którego konieczne jest zapewnienie bezpieczeństwa danych wprowadzanych do serwisu i bezpieczeństwa przeprowadzanych transakcji, ryzyko kredytowe, które z kolei wymaga dywersyfikacji portfela ${ }^{99}$.

Poza wspomnianymi, pożyczki społecznościowe generują zagrożenia związane $\mathrm{z}$ brakiem regulacji prawnych chroniących interesy stron transakcji (poza prawem cywilnym), nieświadomością pełnych kosztów takiego zobowiązania, niebezpieczeństwem wpadnięcia w spiralę zadłużenia i groźbą pogłębienia ubóstwa gospodarstw domowych ${ }^{100}$. W przypadku gospodarstw domowych emerytów, ze względu na niską wiedzę finansową nie jest zalecane korzystanie z usług instytucji pożyczkowych. W przypadku gospodarstw domowych $50+$ przed skorzystaniem z platformy pożyczek społecznościowych warto dokładnie sprawdzić wiarygodność platformy i dokonać porównania oferty.

W literaturze pojęcie niedostatecznego korzystania z usług bankowych (finansowych) określa się jako niewystarczająco ubankowionych (underbanked) lub niekiedy marginalnie ubankowionych (marginally banked). Natomiast osoby, które w ogóle nie korzystają z produktów bankowych nazywane

${ }_{98}$ M. Marcinkowska, Pożyczki P2P-zagrożenie dla banków?, [w:] L. Dziawgo (red.), Wspótczesne finanse. Stan i perspektywy rozwoju bankowości, Wydawnictwo Naukowe UMK, Toruń 2008, s. 418-420.

${ }_{99}$ M. Marcinkowska, Społecznościowe parabanki - czyli o tym jak Internet eliminuje pośredników finansowych, [w:] E. Ostrowska, J. Ossowski (red.), Rynki finansowe. Mikrofinanse, Biblioteka Kwartalnika Naukowego „Pieniądze i Więź”, Sopot 2009, s. 298-303.

100 Por. M. Solarz, The importance of shadow banking sector entities for population affected by credit exclusion, "Copernican Journal of Finance \& Accounting" 2013, Vol. 2, Issue 2, s. 193-198. 
są nieubankowionymi (unbanked) ${ }^{101}$. Zwykle termin nieubankowieni odnosi się do osób, które nie mają rachunku bankowego i żadnego kontaktu z sektorem bankowym ${ }^{102}$.

Osoby marginalnie ubankowione identyfikowane są nieco bardziej zróżnicowanie. W literaturze przedmiotu można znaleźć interpretację, że są to osoby posiadające ograniczony dostęp do usług bankowych (np. kredyty) lub korzystające sporadycznie (np. raz w miesiącu dokonujące wypłaty wszystkich środków $\mathrm{z}$ rachunku). Inną interpretacją określającą osobę marginalnie ubankowioną jest podejście, że to grupa osób, które posiadają rachunek bankowy, ale korzystają także $\mathrm{z}$ innych usług finansowych oferowanych np. przez takie instytucje, jak realizatorzy czeków, podmioty udzielające szybkich pożyczek czy też instytucje leasingowe $\mathrm{e}^{103}$.

W opinii autorów prawidłowym jest stopniowanie poziomów włączenia w system bankowy, a przynajmniej podział na osoby włączone na poziomie podstawowym i zaawansowanym. Za osobę ubankowioną nie można uznać osoby, która jedynie posiada rachunek bankowy. Liczne badania dotyczące włączenia w system bankowy koncertują się tylko na kwestii posiadania rachunku bankowego. Bardziej miarodajnym jest określenie minimalnej liczby transakcji dokonywanych miesięcznie na rachunku na poziomie minimum 2 (w celu uniknięcia traktowania naliczenia opłaty za rachunek jako transakcji). Taki poziom można byłoby uznać za podstawowy. Natomiast zaawansowane włączenie w system bankowy powinno wymagać realizacji warunków włączenia podstawowego oraz korzystania z minimum jednego dodatkowego produktu: dokonywanie płatności kartą, posiadanie produktu pożyczkowo-kredytowego, posiadanie produktu oszczędnościowego czy też korzystanie z aplikacji mobilnej.

\subsubsection{Determinanty wykluczenia bankowego}

Czynniki determinujące poziom wykluczenia finansowego różnią się w poszczególnych krajach w zależności od rozwoju ekonomicznego i społecznego danego obszaru. Z tego względu determinanty, które kształtują skalę wykluczenia finansowego w jednym kraju, niekoniecznie pokrywać się będą w przypadku innego. W przypadku państw rozwijających się argumentuje się, że system finansowy nie zaspokaja wszystkich potrzeb. Często system bankowy i rynek kapitałowy są skoncentrowane na realizacji potrzeb osób o wyższych dochodach czy

\footnotetext{
${ }^{101}$ M. Barr, Banking the poor, "Yale Journal on Regulation" 2004, Vol. 21, s. 130.

102 Zamiast określenia banku w literaturze występuje także pojęcie instytucji depozytowej (depository institution).

103 Szerzej: FDIC, National Survey of Unbanked and Underbanked Households, December 2009. Por. European Commission, Consumers' views on switching service providers. Analytical Report, Flash Eurobarometer 243 - The Gallup Organization, January 2009, s. 31.
} 
też dużych podmiotów gospodarczych. Z tego względu pozostałe gospodarstwa domowe i przedsiębiorstwa cierpią z powodu utrudnień w dostępie do usług finansowych, hamujących ich wzrost i dobrobyt.

Głównymi czynnikami powodującymi problem wykluczenia finansowego są ${ }^{104}$ :

- poziom i zróżnicowanie dochodów;

- zmiany na rynku pracy, w tym niepewność zatrudnienia, a tym samym wysokości dochodów;

- zmiany demograficzne związane ze starzeniem się ludności i zmianą modelu rodziny.

Jak wskazuje badanie postaw Polaków powyżej 60. roku życia wobec obrotu bezgotówkowego, osoby powyżej 65. roku życia, które są posiadaczami rachunku bankowego, nadal preferują osobisty kontakt z bankiem. Deklarują one, że udają się osobiście do oddziału banku, aby wybrać pieniądze z kasy. Wynik ten wyraźnie pokazuje, że u osób starszych, które przełamały już bariery wobec banków i przekonały się do posiadania konta, cały czas duże opory budzi korzystanie z bankomatu i wolą one bezpośredni kontakt z osobą z banku. Co więcej, wśród osób z grupy wiekowej 55-59 38\% korzysta z bankowości internetowej; wśród osób powyżej 75. roku życia z bankowości internetowej korzysta zaledwie $3 \%$. W grupie 55-latków aż 32\% przynajmniej od czasu do czasu płaci rachunki drogą elektroniczną, natomiast w grupie $75+$ zaledwie 3\%. Wynik ten pokazuje, że właśnie płacenie rachunków przez Internet jest zachowaniem bezgotówkowym obarczonym największymi barierami. Interesujące jest to, że barierą przed płaceniem rachunków drogą elektroniczną przez osoby starsze jest nie tylko brak wiary we własne umiejętności i małe poczucie bezpieczeństwa (lęk, że ktoś może ukraść pieniądze, można zrobić błąd lub przelew nie dotrze do adresata), ale również przekonanie, że jest to droga forma płatności ${ }^{105}$.

Wykorzystując liczne badania przeprowadzane na skalę krajową i międzynarodową, można wskazać na pewne cechy poszczególnych osób lub całych gospodarstw domowych, które zwiększają prawdopodobieństwo wystąpienia wykluczenia finansowego. Początkowo badania jednoznacznie wskazywały na związek między wysokością dochodów a wykluczeniem finansowym. Osoby lub gospodarstwa o niskich dochodach częściej były wykluczone finansowo niż te o wyższych dochodach.

Przykładem mogą być wyniki badań przeprowadzonych w Wielkiej Brytanii $^{106}$. Relację między dochodem a ubankowieniem przedstawia rysunek 11.

${ }^{104}$ Financial Services Authority, In or Out? A Literature and Research Review, "Consumer Research", July 2000, No. 3, s. 11-15.

105 Badanie postaw Polaków powyżej 60. roku życia wobec obrotu bezgotówkowego, Warszawa, kwiecień 2012, http://www.nbp.pl/systemplatniczy/obrot_bezgotowkowy/raport_60_plus.pdf, s. 43 (stan na dzień 22.07.2014).

106 Badanie przeprowadzone zostało przez BMRB Social Research na zlecenie Financial Inclusion Taskforce na próbie 2007 respondentów w okresie listopad 2005 - styczeń 2006. Na potrzeby 


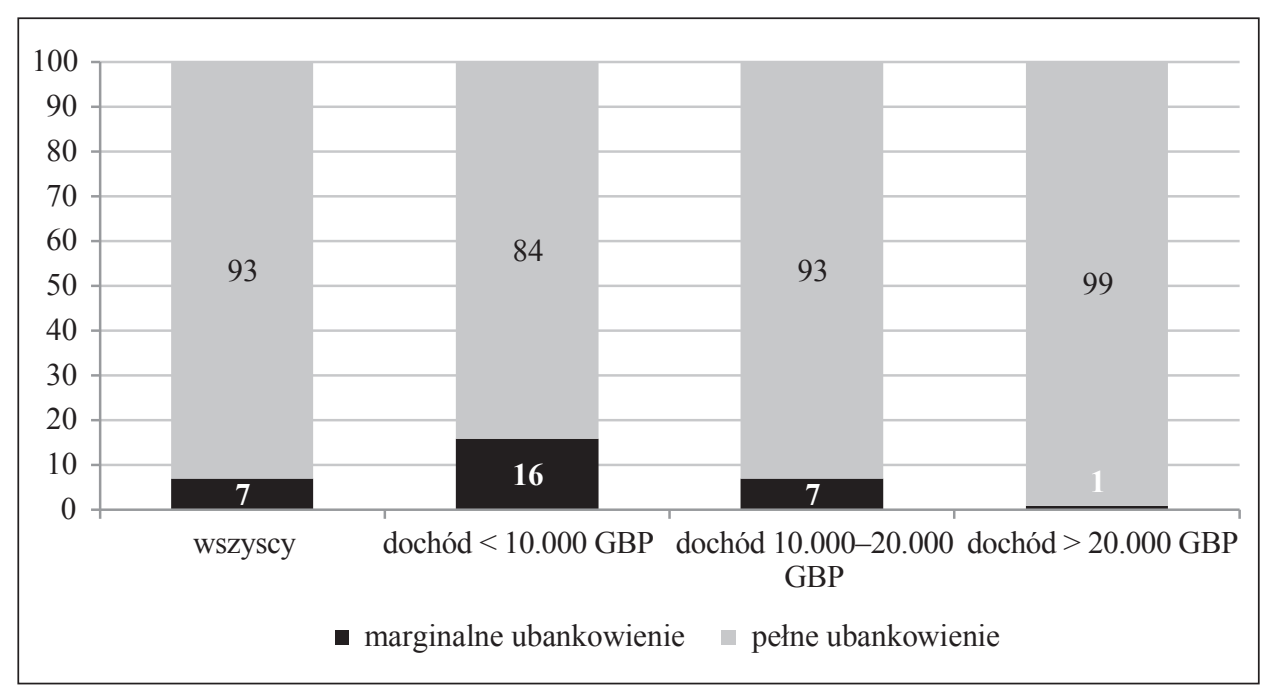

Rysunek 11. Status osoby marginalnie ubankowionej lub w pełni ubankowionej w zależności od dochodu (w \%)

Źródło: opracowanie własne na podstawie: Access to Financial Services by Those on the Margins of Banking. Final Report, Financial Inclusion Taskforce, November 2006, s. 12

Wyniki badania kwestionariuszowego potwierdzają przyjęte wcześniej założenia. Wraz ze wzrostem dochodów zwiększało się pełne ubankowienie, a zmniejszało ubankowienie marginalne. Podobnie, elementem wzmacniającym ubankowienie było zatrudnienie (w porównaniu do bycia osobą bezrobotną lub na emeryturze) oraz posiadanie nieruchomości.

Zbliżone rezultaty zostały osiągnięte podczas badania realizowanego na skalę UE. Jego wyniki przedstawia rysunek 12.

We wszystkich krajach wraz ze wzrostem dochodu zmniejszeniu ulegał udział osób wykluczonych finansowo. Podobnie wyraźne różnice wystąpiły w przypadku krajów zaliczonych do UE 10, gdzie aż 55\% respondentów dysponujących najniższymi dochodami pozostawała wykluczona, a już tylko 14\% spośród osób o najwyższych dochodach pozostawało w grupie wykluczonych, jak i w przypadku krajów UE 15, gdzie wskaźnik zmalał z 9\% do 2\%.

Wyniki te można odnieść do rezultatów uzyskanych w tym samym badaniu na skalę kraju. Posiadanie rachunku bankowego zostało zadeklarowane przez 58,7\% respondentów, których dochody nie przekroczyły 1000 PLN. 76,9\%

badania przyjęto dwie kategorie osób: marginalnie ubankowione (przynajmniej jedna z osób w gospodarstwie domowym posiada rachunek bankowy, ale go nie wykorzystuje do codziennego zarządzania płatnościami) oraz ubankowione w sposób pełny (przynajmniej jedna osoba w gospodarstwie domowym w sposób pełny korzysta z rachunku bankowego). Financial Inclusion Taskforce, Access to Financial Services by those on the Margins of Banking. Final Report, November 2006, s. 1-5. 
badanych, których dochód kształtował się w przedziale od 1000 do 2000 PLN było posiadaczami rachunku bankowego i wskaźnik ten wzrósł do $92,5 \% \mathrm{w}$ przypadku osób dysponujących dochodem powyżej 2001 PLN ${ }^{107}$.

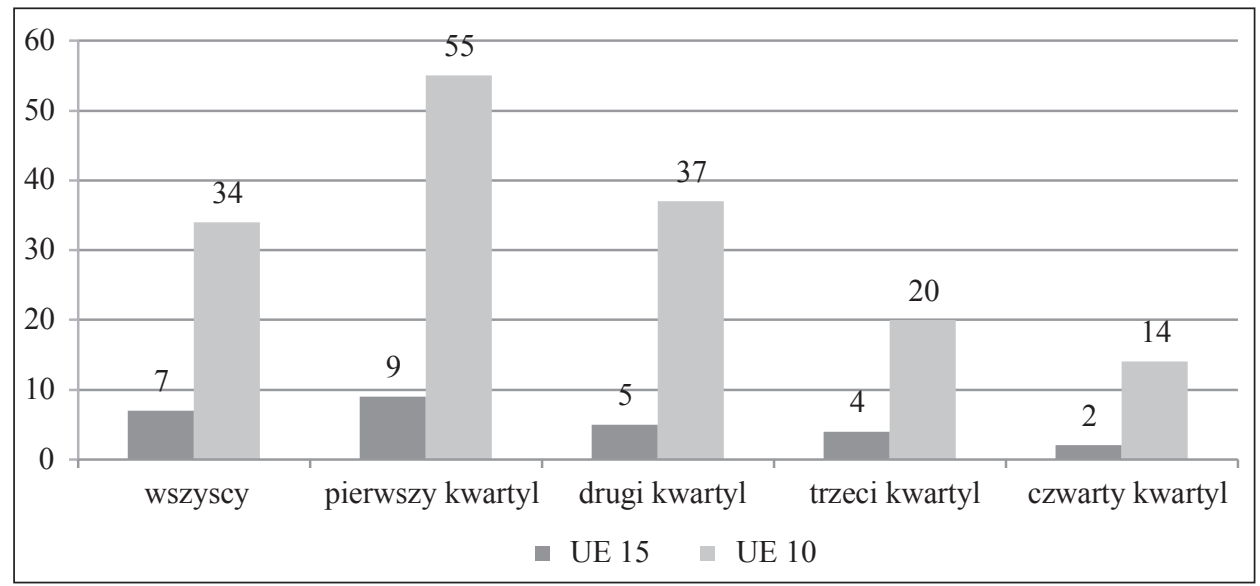

Rysunek 12. Poziom wykluczenia finansowego a dochód (w \%)

Źrodło: opracowanie własne na podstawie: European Commission, Financial services provision and the prevention of financial exclusion, March 2008, s. 32-33

W badaniu przeprowadzonym w 2010 r. na zlecenie NBP przez Dom Badawczy Maison niskie dochody były drugim najczęściej wskazywanym powodem braku rachunku bankowego ${ }^{108}$. W przypadku tego badania wskazane zostało jednak, że brak rachunku bankowego jest charakterystyczny dla osób o rzeczywiście niskich dochodach (renciści, osoby bezrobotne), natomiast w dużej mierze postrzeganie sytuacji finansowej jest subiektywnym przekonaniem i w przypadku osób o średnich dochodach nie należy przeceniać tej determinanty ${ }^{109}$.

Wykluczenie finansowe częściowo jest spowodowane niską wiedzą ekonomiczną i finansową. Niezbędne jest zatem prowadzenie szerokiej edukacji finansowej, rozumianej jako podejmowanie szeroko zakrojonych działań, mających upowszechniać wiedzę oraz wykształcać pozytywne nawyki wśród obywateli, prowadzące do podejmowania właściwych decyzji w zakresie zarządzania ich osobistymi finansami oraz efektywnego dysponowania przez nich środkami finansowymi, zgodnie z obecnymi i przyszłymi potrzebami ${ }^{110}$. Uważa się,

${ }^{107}$ P. Błędowski, M. Iwanicz-Drozdowska, Financial Services Provision and Prevention of Financial Exclusion in Poland, Fininc, Warsaw, September 2007, s. 6-7.

${ }^{108}$ D. Maison, Analiza barier dotyczacych korzystania z rachunku bankowego, NBP, Warszawa, wrzesień 2010, s. 28.

109 D. Maison, Polak wświecie finansów, Wydawnictwo Naukowe PWN, Warszawa 2013, s. 79.

110 Szerzej: M. Iwanicz-Drozdowska (red.), Edukacja i świadomość finansowa. Doświadczenia i perspektywy, Oficyna Wydawnicza SGH, Warszawa 2011. Por. OECD, Improving Financial Literacy. Analysis of Issues and Policies, OECD Publishing, Paris 2005. 
że niski poziom edukacji finansowej przyczynił się do kryzysu finansowego ${ }^{111}$. Klienci, którzy nie rozumieją zasad ekonomii i nie potrafią odpowiedzialnie zarządzać finansami osobistymi, nieumiejętnie, a czasem beztrosko korzystają z produktów bankowych, nie potrafią ocenić ryzyka, jakie wiąże się z kontraktami finansowymi i dokonują nieefektywnych wyborów. Niebezpieczne jest zarówno nadmiernie optymistyczne lokowanie przez nich środków w instrumenty obarczone wysokim ryzykiem, jak i nierozważne zaciąganie kredytów bez wnikliwej analizy możliwości sprostania w przyszłości obowiązkom ich spłaty wraz z odsetkami ${ }^{112}$.

Jedno z badań prowadzonych nad determinantami wykluczenia finansowego poza uwzględnianiem kwestii dochodów rozpatruje także inne czynniki jako predestynujące do pozostawania wykluczonym finansowo. Kompleksowe zestawienie przyczyn wykluczenia finansowego dokonane zostało na zlecenie Komisji Europejskiej. Jego wyniki ilustruje tablica 6.

Tablica 6. Główne przyczyny wykluczenia finansowego w wybranych krajach UE*

\begin{tabular}{|c|c|c|}
\hline & Glówne przyczyny & $\begin{array}{l}\text { Liczba krajów uczestniczących } \\
\text { w badaniu, w których dana } \\
\text { przyczyna wykluczenia finansowego } \\
\text { zostala wskazana/zidentyfikowana }\end{array}$ \\
\hline 1 & 2 & 3 \\
\hline \multirow{12}{*}{$\begin{array}{l}\text { Czynniki } \\
\text { społeczne }\end{array}$} & Zmiany demograficzne/luka technologiczna & $10 / 14$ \\
\hline & Zmiany na rynku pracy & $8 / 14$ \\
\hline & Nierówność w poziomie wynagrodzenia & $8 / 14$ \\
\hline & $\begin{array}{l}\text { Liberalizacja rynku, brak uwagi poświęco- } \\
\text { nej segmentom marginalnym }\end{array}$ & $6 / 14$ \\
\hline & Pomoc społeczna/socjalna & $5 / 14$ \\
\hline & Zmiany demograficzne/nadmierne zadłużenie & $4 / 14$ \\
\hline & $\begin{array}{l}\text { Liberalizacja rynku, zanikanie instytucji de- } \\
\text { dykowanych populacji o niskich dochodach }\end{array}$ & $5 / 14$ \\
\hline & Przeciwdziałanie praniu brudnych pieniędzy & $3 / 14$ \\
\hline & Polityka fiskalna & $3 / 14$ \\
\hline & Zmiany demograficzne/młodzież & $2 / 14$ \\
\hline & $\begin{array}{l}\text { Zmiany demograficzne/migracje i mniej- } \\
\text { szości narodowe }\end{array}$ & $2 / 14$ \\
\hline & Brak gotówki & $1 / 14$ \\
\hline
\end{tabular}

${ }^{111}$ European Commission Internal Market and Services DG, Review of the Initiatives of the European Commission in the Area of Financial Education, Staff Working Document of the Internal Market and Services DG, Brussels, March 2011, http://ec.europa.eu/internal_market/finservices-retail/docs/capability/evaluation_financial_education_en.pdf, s. 1 (stan na dzién 20.12.2013).

112 Szerzej: M. Marcinkowska, Kapitał relacyjny banku. 
Tablica $6(\mathrm{~cd}$.

\begin{tabular}{|c|c|c|}
\hline 1 & 2 & 3 \\
\hline \multirow[t]{8}{*}{$\begin{array}{l}\text { Czynniki } \\
\text { podażowe }\end{array}$} & $\begin{array}{l}\text { Zarządzanie ryzykiem/ocena zdolności kre- } \\
\text { dytowej }\end{array}$ & $8 / 14$ \\
\hline & Marketing & $8 / 14$ \\
\hline & Dostęp geograficzny & $7 / 14$ \\
\hline & Struktura produktu (warunki) & $7 / 14$ \\
\hline & Kanały dystrybucji & $7 / 14$ \\
\hline & Złożoność wyboru & $7 / 14$ \\
\hline & Cena & $4 / 14$ \\
\hline & Typ produktu & $1 / 14$ \\
\hline \multirow{9}{*}{$\begin{array}{l}\text { Czynniki } \\
\text { popytowe }\end{array}$} & Świadomość na temat kosztów & $8 / 14$ \\
\hline & Niska samoocena (nie dla biednych) & $8 / 14$ \\
\hline & Obawa przed utratą płynności finansowej & $7 / 14$ \\
\hline & Nieufność wobec dostawców usług & $7 / 14$ \\
\hline & $\begin{array}{l}\text { Preferencje wobec alternatywnych dostaw- } \\
\text { ców usług finansowych, czynniki kulturowe }\end{array}$ & $4 / 14$ \\
\hline & Religia & $4 / 14$ \\
\hline & Niechęć do korzystania z usług finansowych & $4 / 14$ \\
\hline & Złe doświadczenia & $1 / 14$ \\
\hline & Obawy przed zajęciem majątku & $1 / 14$ \\
\hline
\end{tabular}

* W ramach 14 krajów analizie zostały poddane: Austria, Belgia, Bułgaria, Francja, Niemcy, Irlandia, Włochy, Litwa, Norwegia, Polska, Słowacja, Hiszpania, Holandia, Wielka Brytania.

Źródło: European Commission, Financial Services Provision and Prevention of Financial Exclusion Study, Brussels 2008, s. 45.

Wprawdzie przyczyny wykluczenia finansowego były różnorodne i dodatkowo były odmienne w poszczególnych krajach, można wskazać na pewną generalną prawidłowość, że na ogół czynniki o charakterze społecznym były najczęściej wskazywane jako determinanta wykluczenia finansowego.

Spośród czynników o charakterze społecznym największa liczba krajów wskazywała na zmiany demograficzne/lukę technologiczną jako najczęściej występującą przyczynę wykluczenia finansowego. Na drugim miejscu znalazły się zmiany na rynku pracy oraz nierówność w poziomie wynagrodzenia. Zarządzanie ryzykiem/ocena zdolności kredytowej oraz marketing wskazane zostały jako najbardziej popularne determinanty o charakterze podażowym, zaś świadomość na temat kosztów oraz niska samoocena (nie dla biednych) o charakterze popytowym. 


\subsubsection{Skala wykluczenia finansowego i bankowego osób w wieku 50+}

Rozmiary zjawiska wykluczenia finansowego są już od kilku lat przedmiotem badań prowadzonych na szczeblu krajowym i międzynarodowym. W Polsce, już w połowie lat dziewięćdziesiątych prowadzone były pierwsze statystyki pokazujące skalę wykluczenia bankowego ${ }^{113}$. Powtarzającym się we wszystkich badaniach aspektem jest podstawowy poziom braku ubankowienia rozumiany jako brak rachunku bankowego ${ }^{114}$. Zgodnie z danymi, w latach dziewięćdziesiątych jedynie $30 \%$ osób zadeklarowało ten podstawowy poziom ubankowienia ${ }^{115}$, podczas gdy ostatnie dostępne wyniki badań wskazują na 78\% ${ }^{116}$.

Poziom ubankowienia w Polsce, jakkolwiek systematycznie rośnie w ostatnich latach, wciąż jest niższy od średniej obserwowanej w Unii Europejskiej. Porównanie skali posiadania rachunku bankowego w Polsce i w pozostałych krajach UE wśród osób starszych przedstawia rysunek 13.

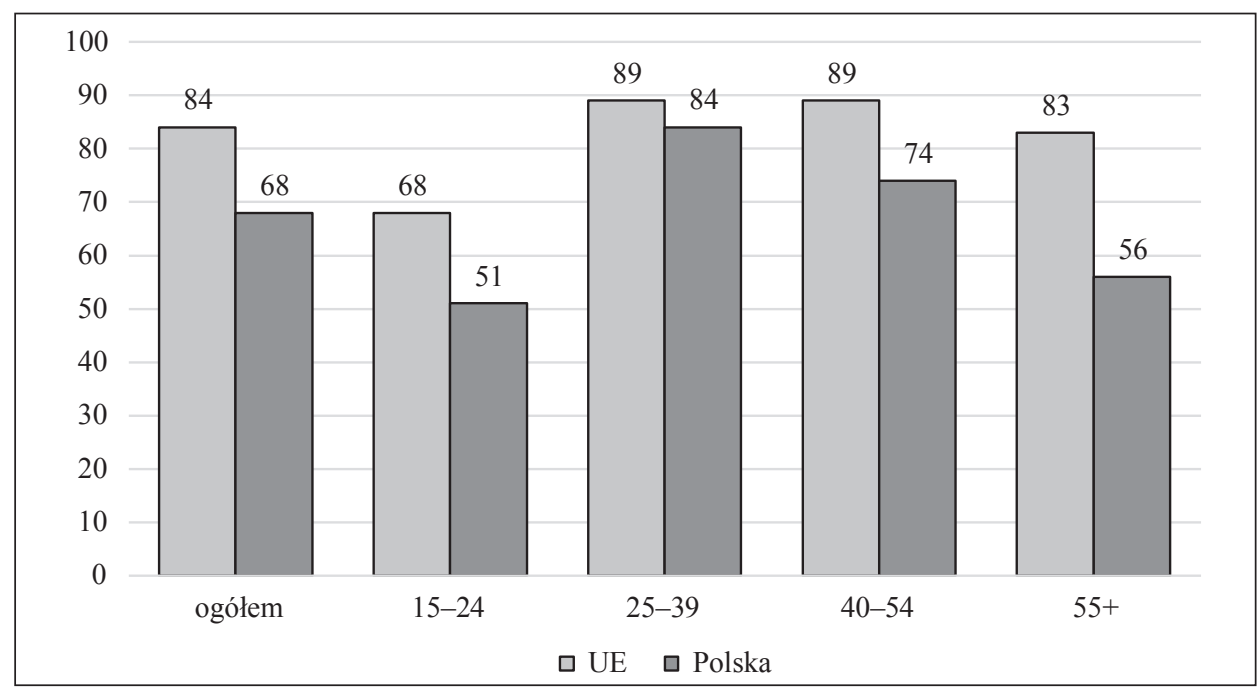

Rysunek 13. Odsetek osób posiadających rachunek w banku w poszczególnych grupach wiekowych (w \%)

Źródło: opracowanie własne na podstawie: European Commission, Special Eurobarometer 373, Retail financial services, 2012

113 Por. I. Kuchciak, Problematyka nadmiernego zadlużania w kontekście wykluczenia finansowego, „Prace Naukowe Uniwersytetu Ekonomicznego we Wrocławiu” 2013, nr 306, s. 213-224.

${ }_{114}$ Przyznać należy, że samo posiadanie rachunku bankowego nie musi oznaczać korzystania $\mathrm{z}$ niego. $\mathrm{Z}$ tego względu $\mathrm{w}$ raportach pojawiają się dane liczbowe ilustrujące liczbę rachunków bankowych oraz liczbę dokonywanych na nich transakcji.

${ }_{115}$ M. Iwanicz-Drozdowska, A. K. Nowak, A. Lewandowski, Preferencje polskich gospodarstw domowych $w$ zakresie korzystania z ustug finansowych. Wyniki badania ankietowego, „Bank i Kredyt”, październik 2008, s. 37.

${ }^{116}$ European Commission, Special Eurobarometer 373, Retail financial services, 2012, s. 14. 
Warto odnotować, że spośród osób ubankowionych seniorzy stanowią najmniej liczną grupę osób zaraz po młodzieży w wieku 15-24 lata. Trend ten widoczny jest zarówno w Polsce, jak i w pozostałych krajach UE. Niepokojąco przedstawiają się dysproporcje widoczne w grupie osób 55+: podczas gdy w UE średnio $83 \%$ osób w wieku powyżej 55 lat posiada rachunek bankowy, w Polsce dotyczyło to jedynie $56 \%$ osób ${ }^{117}$.

Poziom ubankowienia może być oceniany w bardziej zaawansowany (i przystający do rzeczywistości) sposób, aniżeli tylko poprzez fakt posiadania rachunku bankowego. Większą wiedzę na temat tego zjawiska daje przyjrzenie się sposobom i częstotliwości korzystania $\mathrm{z}$ tego rachunku, a także skali posiadania innych produktów bankowych (finansowych). Zjawisko to można przeanalizować na podstawie przynależności do poszczególnych poziomów zaawansowania bezgotówkowego (patrz rysunek 14):

- poziom I oznacza korzystanie wyłącznie z rachunku bankowego,

- poziom II obejmuje rachunek bankowy i kartę płatniczą,

- poziom III dotyczy usług z poziomu II oraz dostępu do nich przy wykorzystaniu bankowości elektronicznej,

- poziom IV obejmuje usługi z poziomu III i płacenie rachunków przez Internet.

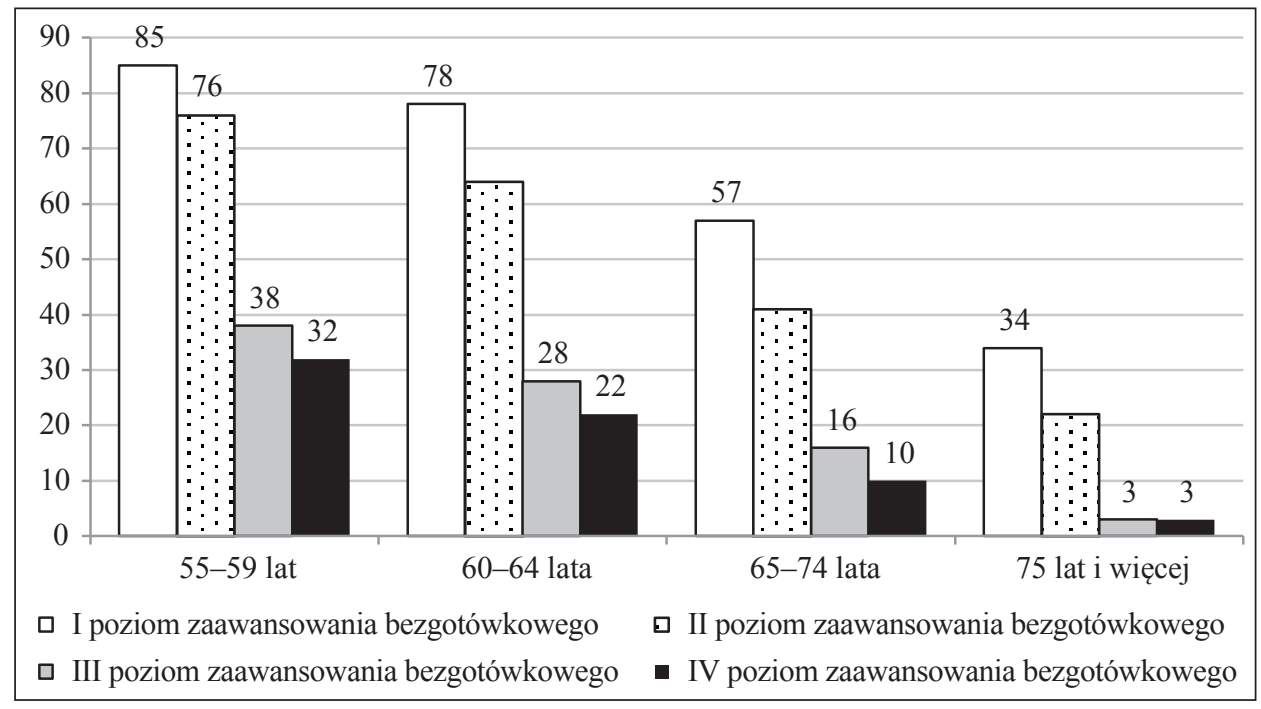

Rysunek 14. Poziomy zaawansowania bezgotówkowego w poszczególnych grupach wiekowych (w \%)

Źródło: opracowanie własne na podstawie: D. Maison, Postawy i zachowania finansowe osób powyżej 55. roku życia z uwzględnieniem płatności bezgotówkowych, NBP, Warszawa 2012

117 Por. I. D. Czechowska, Ograniczenia $w$ dostepie do ustug bankowych $60+w$ perspektywie zrównoważonych finansów, „Zeszyty Prac Naukowych Uniwersytetu Ekonomicznego we Wrocławiu" 2013, nr 311. 
Najwyższy poziom ubankowienia reprezentowały osoby w wieku 55-59 lat i systematycznie malał on wraz z wiekiem. Ponadto, najstarsze osoby relatywnie rzadko korzystają z usług banków, przy czym koncentrują się niemal wyłącznie na podstawowych i stosunkowo prostych w obsłudze produktach.

Zbliżonych wyników dotyczących włączenia w system bankowy dostarczyło badanie postaw Polaków powyżej 60. roku życia wobec obrotu bezgotówkowego. W grupie wiekowej 55-59 lat 85\% respondentów posiadało konto w banku. Odsetek ten spadał wraz z wiekiem tak, że wśród osób mających ponad 75 lat więcej respondentów nie miało konta (66\%) niż miało (34\%). Zdecydowana większość osób, które nie posiadały w trakcie badania konta, nie miała go też w przeszłości $^{118}$. Wynik ten pokazuje, że rezygnacja z posiadania konta jest zjawiskiem sporadycznym i zwykle związana jest z przejściem na emeryturę i obniżeniem dochodów.

Wraz z wiekiem maleje korzystanie z usług bankowych w postaci lokat i kredytów. W przypadku osób powyżej 75. roku życia proporcjonalnie wzrastała liczba osób korzystających z pożyczek w kasie oszczędnościowej lub firmie pożyczkowej w porównaniu z korzystaniem z pożyczek bankowych. Jednocześnie wraz z wiekiem rosła liczba osób zadłużonych na małe kwoty (kredyty/pożyczki konsumpcyjne) w porównaniu do osób zadłużonych na wysokie kwoty (np. kredyty hipoteczne).

Posiadanie oszczędności zadeklarowało $35 \%$ ankietowanych ${ }^{119}$. Osoby posiadające oszczędności przechowywały je przede wszystkim w banku na koncie bieżącym (49\% posiadających oszczędności) oraz na koncie oszczędnościowym lub lokacie terminowej ( $41 \%$ posiadających oszczędności). Równocześnie $18 \%$ posiadających oszczędności trzymało je w domu i tendencja ta zwiększała się wraz z wiekiem. Inwestowanie oszczędności w dobra trwałe lub zaawansowane instrumenty finansowe było sporadyczne w tej grupie wiekowej. Wśród osób do 60. roku życia więcej osób posiadało duże oszczędności (powyżej 5000 zł), natomiast wśród najstarszych (75+) dominowały oszczędności do $1000 \mathrm{z}^{120}$.

\footnotetext{
118 Wśród respondentów w wieku powyżej 75 lat zaledwie 12\% osób miało wcześniej konto.

119 Większość osób powyżej 55. roku życia nie posiadało wyraźnego celu oszczędzania i oszczędzało przede wszystkim na „czarną godzinę”. Na drugim miejscu znalazło się oszczędzanie na dzieci i wnuki (im młodsza osoba, tym częściej oszczędza na ten cel); na trzecim miejscu zaś oszczędzanie na wypadek choroby (bardziej charakterystyczne dla osób w wieku 65 lat i starszych niż dla osób w wieku 55-64 lata). Dla porównania w 2013 r. mniejszy odsetek Polaków oszczędzał z myślą o emeryturze (9\% vs 13\% w 2012 r.). Częściej były to osoby w wieku 26-60 lat, z wykształceniem wyższym, o wyższym poziomie dochodów w gospodarstwie domowym. TNS Polska, Postawy Polaków wobec oszczędzania, raport Fundacji Kronenberga przy Citi Handlowy, październik 2013, s. 41.

${ }^{120}$ Badanie postaw Polaków powyżej 60. roku życia wobec obrotu bezgotówkowego, Raport przygotowany dla NBP, Dom Badawczy Maison, Warszawa, kwiecień 2012, s. 22-44.
} 
Poza wspomnianymi produktami bankowymi analizowana była także popularność kart płatniczo-bankomatowych i kredytowych. Karty płatnicze posiadało $51 \%$ Polaków powyżej 55. roku życia, natomiast zaledwie $8 \%$ posiadało karty kredytowe. Równocześnie posiadanie obu rodzajów kart wyraźnie malało wraz z wiekiem. Wśród osób w wieku 55-59 lat zdecydowana większość (90\%) posiadaczy kont posiadała również kartę płatniczą, podczas gdy w grupie $75+$ zaledwie $34 \%$ posiadaczy kont posiadało również kartę. Wynika z tego, że wraz z wiekiem bariery przed posiadaniem (i używaniem) karty stają się wyraźnie silniejsze niż bariery związane z posiadaniem konta ${ }^{121}$.

W zależności od wieku odnotowano także różne wykorzystanie kart. Aż 93\% posiadaczy kart deklarowało wykorzystywanie jej tylko do pobierania pieniędzy i zdecydowanie rzadziej do płacenia za zakupy. Wśród osób poniżej 60. roku życia $78 \%$ posiadaczy kart często wyciąga przy ich pomocy pieniądze z bankomatu, ale już wśród osób powyżej 75 . lat zaledwie $49 \%$. Po raz kolejny potwierdza to tezę o barierach technologicznych w korzystaniu z produktów i usług bankowych przez osoby najstarsze. Poza barierami technicznymi czynnikiem ograniczającym popularność płatności realizowanych przy użyciu karty dla osób w wieku $60+$ okazały się być problemy z kontrolą nad wydatkami oraz obawa o bezpieczeństwo dokonywanej transakcji.

Spośród badanych 35\% zadeklarowało posiadanie dostępu do bankowości elektronicznej, a 25\% korzystanie z niej, przy czym w grupie wiekowej powyżej 75. roku życia z bankowości internetowej korzystało zaledwie $3 \%$. Zwykle korzystanie z bankowości elektronicznej miało wymiar pasywny, czyli sprowadzało się do sprawdzania stanu konta. Najmniej popularne okazało się być płacenie rachunków przez Internet. Jedynie 17\% deklarowało korzystanie $\mathrm{z}$ tej formy płatności przynajmniej od czasu do czasu, przy czym w grupie wiekowej 75+ wskaźnik ten wyniósł zaledwie 3\%. Głównymi podawanymi barierami był brak wiary we własne umiejętności, obawa przed popełnieniem błędu lub o bezpieczeństwo transakcji, a także przekonanie, że jest to droga forma płatności ${ }^{122}$.

Wskazane bariery świadczą o niskiej wiedzy finansowej badanych i o potrzebie edukowania nawet na temat sposobów korzystania z pozoru nieskomplikowanych produktów i usług bankowych. Pozwoliłoby to zwiększyć popularność usług bankowych w segmencie 50+.

W skali UE popularność usług finansowych wśród osób starszych również pozostaje na niskim poziomie. Porównanie zakresu korzystania z produktów finansowych osób starszych na tle średnich wyników dla wszystkich respondentów przedstawia rysunek 15 .

\footnotetext{
121 Ibidem, s. 65.

122 Ibidem, s. 76.
} 


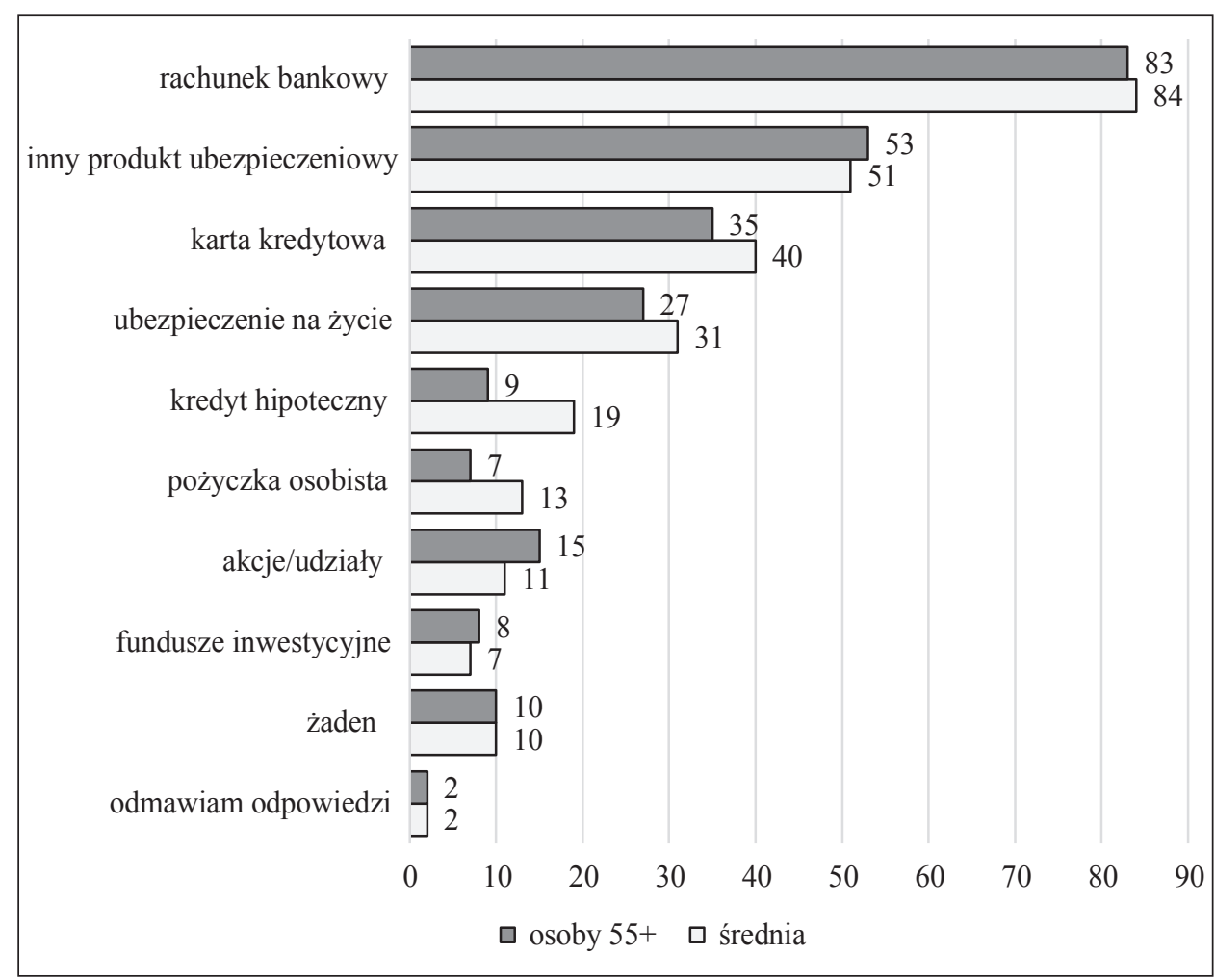

Rysunek 15. Porównanie zakresu korzystania z produktów finansowych w krajach UE wśród osób 55+ (w \%)

Źródło: jak przy rys. 13

Najbardziej wyraźnie zarysowują się dysproporcje w zakresie korzystania z produktów kredytowych przez osoby starsze na tle całego społeczeństwa. Są one szczególnie wyraźne w przypadku kredytów hipotecznych, z których korzysta jedynie 9\% osób w wieku 55+ (jest to efektem korelacji wieku i preferencji w zakresie korzystania z produktów bankowych). Z kart kredytowych korzysta $35 \%$ osób $55+$, podczas gdy średnia europejska wynosi $40 \%$, z pożyczki osobistej $7 \%$ osób w wieku 55+ (13\% średnia UE), zaś ubezpieczenie na życie posiada $27 \%$ osób w wieku 55+ i 31\% wszystkich obywateli UE. Osoby powyżej 55. roku życia przejawiały wyższą aktywność w przypadku posiadania akcji i udziałów, gdzie korzystało z nich $15 \%$ osób w wieku 55+, co jest efektem rosnącej wraz z wiekiem awersji do ryzyka. Korzystanie z pozostałych produktów finansowych było na zbliżonym poziomie we wszystkich grupach wiekowych.

Podobne dysproporcje były widoczne w przypadku produktów finansowych zakupionych w ciągu ostatnich 5 lat. Odpowiednie zestawienie przedstawia rysunek 16. 


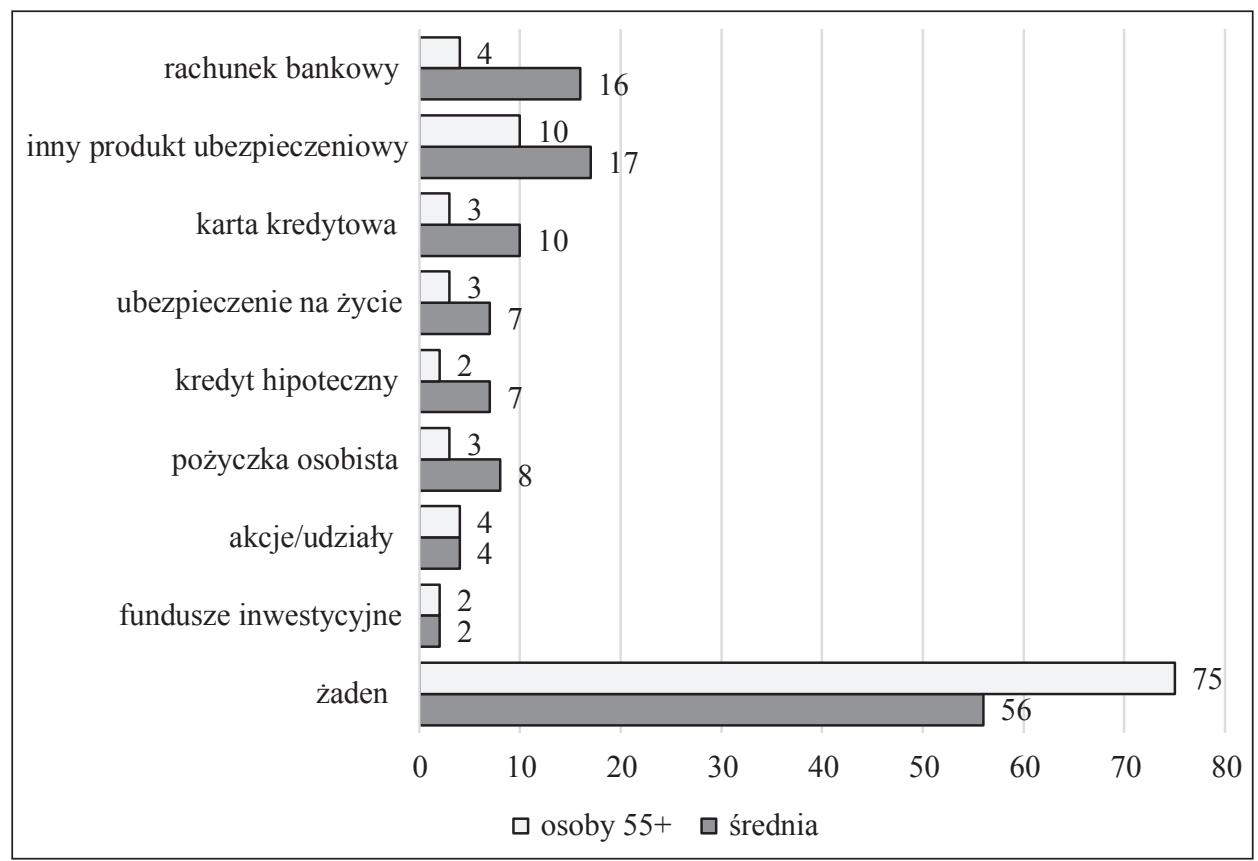

Rysunek 16. Porównanie zakresu nabywanych produktów finansowych w krajach UE wśród osób 55+ w ciągu ostatnich 5 lat (w \%)

Źródlo: jak przy rys. 13

Podobnie jak w przypadku analizy korzystania z produktów finansowych, widoczne są wyraźne dysproporcje między osobami 55+ a średnią UE. Aż 75\% osób $\mathrm{w}$ wieku 55+ nie nabyło żadnego produktu finansowego w ciągu 5 lat, aż $16 \%$ nie otworzyło rachunku bankowego, a 17\% nie nabyło innego produktu ubezpieczeniowego. Biorąc pod uwagę wcześniejszą analizę dotyczą posiadania produktów finansowych, różnic tych nie można tłumaczyć faktem pełnego ubankowienia osób starszych.

Zaprezentowana skala wykluczenia finansowego i bankowego sprawia, że wykluczenie należy postrzegać jako zjawisko silnie odczuwalne w Polsce. Podobnie niekorzystny obraz występował w przypadku wykluczenia społecznego, kiedy to z porównania ze średnią unijną wynikało, że poziom wykluczenia społecznego i ubóstwa w Polsce przewyższają średnią. Konsekwencje wykluczenia zostaną omówione w dalszej części rozdziału.

Warto przeanalizować powody, dla których osoby z poszczególnych grup wiekowych pozostają nieubankowione. Wykluczeni finansowo pytani o powody braku dostępu do rachunku bankowego najczęściej odpowiadają, że go nie chcą, nie potrzebują (patrz rysunek 17). Co istotne, odpowiedź taka pada w Polsce częściej niż średnio w UE (66\% wobec 56\%). Seniorzy częściej niż inne grupy wiekowe 
podają tę argumentację (choć w Polsce odsetek ten znów jest znacznie wyższy niż w UE: $80 \%$ wobec $65 \%$ ). W grupie $55+$ najniższy jest natomiast odsetek osób deklarujących, że używają rachunku innej osoby (3\% wobec 5\% średnio we wszystkich grupach wiekowych). Rzadziej niż w grupie 40-54 lat wskazywano jako powód odmowy otwarcia rachunku złą historię kredytową (1\% wobec 3\%). Co istotne, w analizowanej grupie wiekowej nie wskazywano innych powodów odmowy założenia rachunku (brak regularnego dochodu, brak wymaganych dokumentów, brak wskazania powodów), ale relatywnie spora grupa osób ( $4 \%$ wobec średniej 2\%) wskazywała inne przyczyny nieposiadania rachunku.

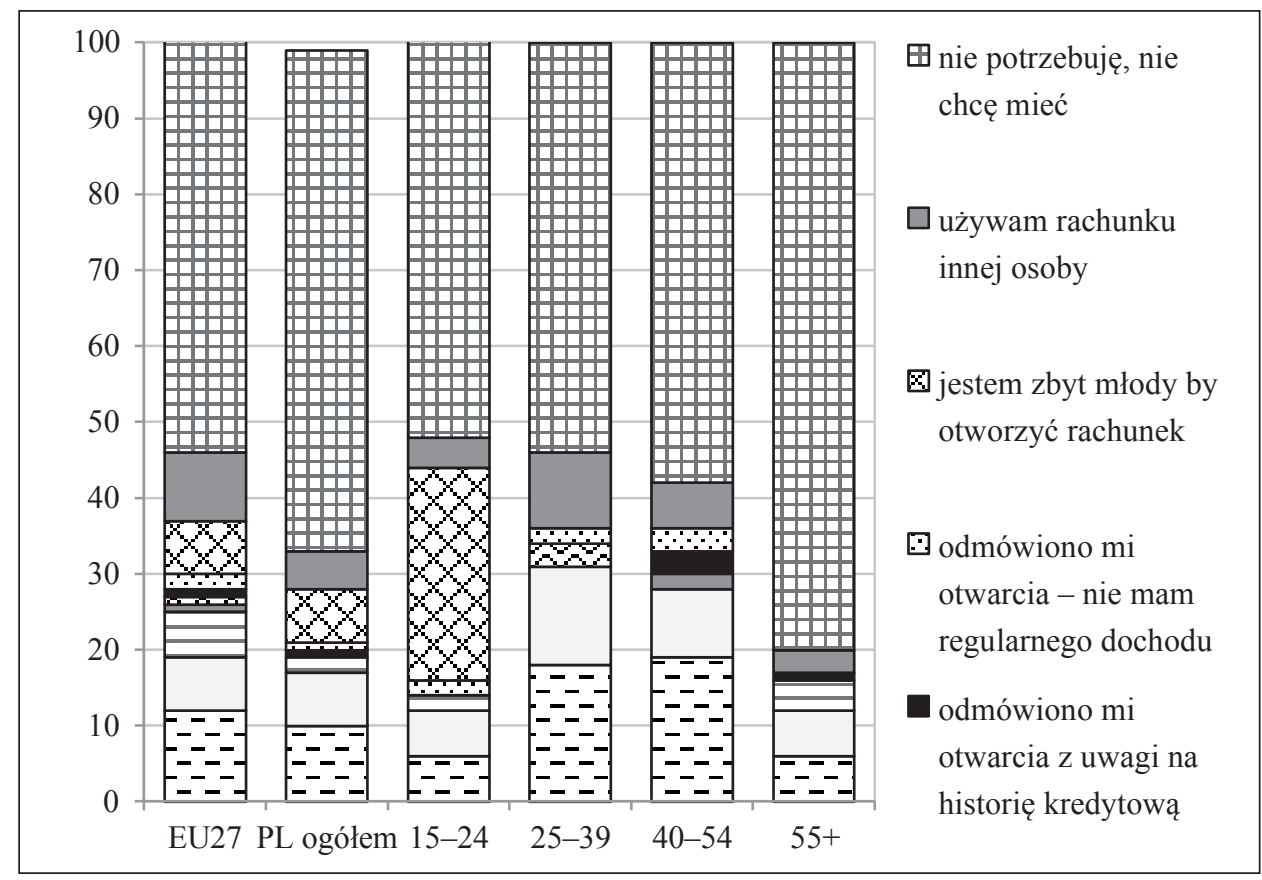

Rysunek 17. Powody nieposiadania rachunku w banku w poszczególnych grupach wiekowych (w \%)

Źródło: M. Ziemba, K. Świeszczak, M. Marcinkowska, Wykluczenie finansowe osób 50+ w kontekście dostępności oferty bankowej, „Finanse”, nr 1(7)/2014 (na podstawie: European Commission, Special Eurobarometer 373, Retail financial services, 2012)

W dokładnym badaniu służącym poznaniu zwyczajów płatniczych Polaków uwzględniono szerszy wachlarz odpowiedzi, co pozwala bliżej poznać specyfikę segmentu „silver” 123 . Przykładowo, seniorzy znacznie rzadziej wskazują, że nie mają oszczędności i regularnych dochodów, natomiast częściej odnoszą się do kwestii opłacalności rachunku (odpowiadając, że mają zbyt niskie dochody,

${ }^{123}$ T. Koźliński, Zwyczaje płatnicze Polaków, NBP, Departament Systemu Płatniczego, Warszawa, maj 2013. 
by posiadać konto lub wprost wskazując na to, że konto jest zbyt drogie w stosunku do korzyści, zbyt nisko oprocentowane, banki pobierają zbyt duże prowizje). Częściej niż w innych grupach wiekowych pada także odpowiedź „,wolę trzymać pieniądze w gotówce"124. Uwagę bankowców winno też przykuć wyjaśnienie: ,posiadanie i obsługa konta bankowego jest zbyt skomplikowane, za trudne dla mnie", znacznie częściej deklarowane przez przedstawicieli segmentu 55+ niż młodszych grup wiekowych.

\subsubsection{Skutki wykluczenia bankowego}

Wykluczenie finansowe generuje wysokie koszty zarówno dla osób wykluczonych, jak i ich otoczenia i całej gospodarki. Z punktu widzenia kosztów ponoszonych w sposób indywidualny można zaliczyć ${ }^{125}$ :

- wyższe opłaty za realizację podstawowych transakcji finansowych i kredytowych - brak dostępu do rachunku bankowego oznacza, że niektóre z transakcji finansowych, takie jak transfery pieniężne i realizacja czeków, są droższe;

- brak dostępu do niektórych produktów lub usług - szereg usług oferowanych przy wykorzystaniu telefonów komórkowych wymaga posiadania rachunku bankowego dla realizacji płatności;

- niebezpieczeństwo związane z przechowywaniem pieniędzy w domu - posiadanie tylko gotówki generuje wyższe ryzyko jej utraty lub kradzieży;

- pewne ograniczenia przy zatrudnieniu - wielu pracodawców wymaga podania numeru rachunku bankowego w celu wypłaty wynagrodzenia.

Dla szerszej społeczności wykluczenie finansowe powoduje dalsze koszty ${ }^{126}$ :

- szerzenie się ubóstwa, szczególnie wśród dzieci;

- dostępu do systemu zasiłków, który ma na celu zapewnienie minimalnego standardu życia;

- wystąpienia wykluczenia społecznego ${ }^{127}$.

Wykluczenie bankowe polegające na braku rachunku bankowego generuje konieczność ponoszenia opłat masowych w formie gotówkowej, która jest droższa od płatności bezgotówkowych. Utrudnia proces regulowania wynagrodzenia przez pracodawcę i sprzyja rozwojowi szarej strefy. W ślad za niższym niż

124 Tę kwestię (preferowanie pieniądza gotówkowego, przyzwyczajenie do trzymania gotówki w domu) bardzo często podnoszą bankowcy pytani o powody niższej - w porównaniu z mieszkańcami innych krajów UE - skłonności Polaków do współpracy z bankami. Najczęściej jednak wskazują na brak nawyków, wykształconej potrzeby oszczędzania ZBP, TNS Pentor, „Monitor Bankowy", 11/2011.

${ }^{125}$ HM Treasury, Promoting financial inclusion, December 2004, s. 10-11.

126 Ibidem.

${ }^{127} \mathrm{~W}$ literaturze wskazuje się, że wykluczenie społeczne może być w jednym przypadku jedną z przyczyn, a w innym jednym ze skutków wykluczenia bankowego. 
średnia europejska poziomem rozwoju obrotu bezgotówkowego w Polsce idzie wyższy poziom szarej strefy. Wprawdzie dokładne rozmiary szarej strefy są trudne do oszacowania, ale zgodnie z dostępnymi szacunkami. Wynosiły one około 3,2 biliona EUR w Europie w 2011 r. ${ }^{128}$ Zwiększenie popularności korzystania z rachunków bankowych pozwoliłoby także ograniczyć koszty związane z wypłacaniem zasiłków oraz rent i emerytur w formie gotówkowej.

Ważną kwestią jest także dostęp do produktów kredytowych. Trudności w dostępie do uzyskania finansowania są przyczyną ubóstwa i przyczyniają się do szerszego problemu, jakim jest wykluczenie społeczne.

Nadmierne zadłużenie jest pochodną trudności w dostępie do kredytów lub utrudnień we właściwym ich użytkowaniu. Z drugiej zaś strony, nadmierne zadłużenie prowadzi do ograniczenia możliwości pozyskiwania finansowania na głównym rynku finansowym. Osoby nadmiernie zadłużone napotykają takie same trudności w korzystaniu z usług finansowych jak osoby całkowicie nieubankowione lub ubankowione marginalnie. Utrudnienia te wymuszają korzystanie z oferty alternatywnych pożyczkodawców na warunkach mniej korzystnych dla kredytobiorcy, co prowadzi do zjawiska wykluczenia finansowego i pogłębienia niewypłacalności.

Społeczeństwo potrzebuje właściwego dostępu do szerokiego wachlarza produktów i usług finansowych, zarówno rachunku bankowego, jak i lokowania oszczędności, zaciągania kredytów czy też ubezpieczeń. Pozwala to lepiej radzić sobie w przypadku wystąpienia wahań w wysokości osiąganych dochodów, zarządzać wydatkami i planować przyszłość. Ponadto, społeczeństwo potrzebuje szansy i zdolności do użytkowania produktów i usług finansowych oraz umiejętności podejmowania decyzji, które będą najbardziej dopasowane do indywidualnych potrzeb, przez co pozwolą one na korzystanie w pełni ze swoich praw obywatelskich i wypełnianie obowiązków domowych i zawodowych.

\subsubsection{Wykluczenie bankowe a wykluczenie społeczne}

W literaturze przedmiotu istnieją opracowania, w których podkreślany jest związek między wykluczeniem finansowym a wykluczeniem społecznym. W publikacjach Leyshona i Thrifta można spotkać się z koncepcją obywatelstwa finansowego (financial citizenship). Koncepcja ta zwróciła uwagę na znaczenie systemu finansowego w życiu codziennym obywateli i gospodarstw domowych

${ }^{128}$ Trudności w pomiarze szarej strefy wynikają nie tylko z jej cech charakterystycznych, takich jak nieoficjalny charakter prowadzenia działalności gospodarczej, trudności w obserwowaniu zjawisk i procesów składających się na tę gospodarkę oraz uchwycenia rozmiarów i efektów działalności nieoficjalnej, ale także z rozbieżności definicyjnych. F. Schneider, Shadow Economies and Corruption All Over the World: New Estimates for 145 Countries, "Economics", July 2007, 2007-9, s. 4-5. 
w celu umożliwienia im brania aktywnego udziału w życiu gospodarczym i akumulowaniu bogactwa ${ }^{129}$.

Aspekt ten podkreślony został silniej przez kolejnych autorów. Zdaniem Kempson i Whyley wykluczenie finansowe jest procesem, który przyczynia się do rozwoju wykluczenia społecznego na poziomie indywidualnym, jak i zbiorowym. W przypadku gdy całe społeczności mają ograniczony dostęp do produktów finansowych, proces staje się samonapędzającym i stanowi istotny przyczynek do wykluczenia społecznego ${ }^{130}$. Ideę efektów społecznych towarzyszących trudnościom w dostępie do usług finansowych rozwijał Sinclair, udowadniając, że włączenie finansowe prowadzić może do generowania wkładu ekonomicznego dla całej społeczności ${ }^{131}$.

W każdym kraju rozmiary i forma wykluczenia finansowego i społecznego zależą od różnych czynników, jak np. od systemu zabezpieczeń społecznych, sytuacji na rynku pracy, funkcjonowania systemu sprawiedliwości i nieformalnych sieci wsparcia. Cechą wspólną natomiast pozostaje podobieństwo cech społeczno-demograficznych i psychologicznych charakteryzujących osoby wykluczone finansowo, bankowo i społecznie ${ }^{132}$.

W tablicy 7 został przedstawiony katalog cech stymulujących proces wykluczenia finansowego i społecznego. Uwzględnia on czynniki zarówno o charakterze społeczno-demograficznym, jak i psychologicznym.

Tablica 7. Cechy predestynujące do wykluczenia finansowego i społecznego

\begin{tabular}{|c|c|}
\hline \multicolumn{2}{|r|}{ Cechy społeczno-demograficzne } \\
\hline Wiek & osoba do 25. roku życia, osoba powyżej 50. roku życia \\
\hline Płeć & kobieta \\
\hline Wykształcenie & podstawowe lub średnie \\
\hline Status społeczny & $\begin{array}{l}\text { osoba samotna, samotnie wychowująca dzieci, wywodząca się ze śro- } \\
\text { dowiska patologicznego }\end{array}$ \\
\hline Dochód & $\begin{array}{l}\text { poniżej } 60 \% \text { mediany dochodu ekwiwalentnego, brak systematyczne- } \\
\text { go dochodu, niskie transfery społeczne }\end{array}$ \\
\hline Miejsce zamieszkania & $\begin{array}{l}\text { wieś, bezdomność, przebywanie w miejscach odosobnionych (areszt, } \\
\text { zakład opieki społecznej, szpital psychiatryczny) }\end{array}$ \\
\hline Religia, rasa, narodowość & przynależność do mniejszości narodowych \\
\hline Sytuacja zawodowa & pozostawanie długotrwale bezrobotnym, niskie kwalifikacje \\
\hline Inne & niepełnosprawność, przewlekła choroba, uzależnienie od używek \\
\hline
\end{tabular}

129 Szerzej: A. Leyshon, N. Thrift, Geographies of financial exclusion: financial abandonment in Britain and the United States, Transactions of the Institute of British Geographers, "New Series" 1995, Vol. 20, No. 3, s. 312-341.

${ }^{130}$ Szerzej: E. Kempson, C. Whyley, Kept out or opted out? Understanding and combating financial exclusion, The Policy Press, Bristol 1999.

131 S. P. Sinclair, Financial Exclusion: an introductory survey, Edinburgh: Heriot Watt University/Centre for Research into Socially Inclusive Services (CRSIS), 2001, s. 14.

${ }_{132}$ M. Sarma, Index of Financial Inclusion, Indian Council for Research on International Economic Relations, Working Paper No. 215, 2008. 
Tablica 7 (cd.)

\begin{tabular}{|l|}
\multicolumn{1}{c|}{ Cechy psychologiczne } \\
\hline - bezradność w życiu, \\
- brak skłonności do oszczędzania, \\
- brak umiejętności zarządzania budżetem domowym, \\
- skłonność do przemocy, zachowań przestępczych, \\
- brak umiejętności w przystosowaniu do życia młodzieży opuszczającej placówki opiekuńczo- \\
-wychowawcze lub osób opuszczających zakłady karne. \\
\hline
\end{tabular}

Źródło: opracowanie własne.

Wymienione w tablicy cechy stanowią wspólne dla wykluczenia finansowego i społecznego determinanty generujące zwiększone prawdopodobieństwo wystąpienia obu form wykluczenia jednocześnie. Nie wyczerpują one katalogu cech predestynujących osobno do wykluczenia finansowego i osobno społecznego. Szczególnie wiele wspólnych cech występuje w ramach kryteriów społeczno-demograficznych. Są one widoczne w przypadku wieku, płci, wykształcenia, statusu społecznego, osiagganego dochodu, miejsca zamieszkania oraz sytuacji zawodowej. Ich charakter można określić jako finansowy, gdyż każda z cech generuje w pierwszej kolejności niższy status materialny, który w konsekwencji prowadzi do wykluczenia. Ze względu na tak szeroki wspólny zakres cech społeczno-demograficznych można wyciągnąć wniosek o współwystępowaniu obu zjawisk.

Dodatkowo warto zauważyć, że zjawiskiem pośredniczącym w obu tych typach wykluczenia może być wykluczenie cyfrowe ${ }^{133}$. Jest to o tyle istotna obserwacja, że współczesny rynek usług finansowych w znacznym stopniu zdeterminowany jest technologią. Korzystanie z produktów finansowych z jednej strony stało się prostsze, bardziej dostępne i wygodne dzięki zastosowaniu technologii cyfrowej, jednak z drugiej strony, brak możliwości lub umiejętności korzystania z technologii informatycznych może powodować trudność (lub nawet brak możliwości) korzystania z usług pośredników finansowych, przyczyniając się do wykluczenia z tego rynku. Z trzeciej jednak strony, umiejętne wykorzystanie nowoczesnych technologii (np. telefonii mobilnej) przez banki może być ważnym narzędziem umożliwiającym inkluzję finansową ${ }^{134}$. Traktowanie nowoczesnych technologii jako stymulatora procesów włączenia w system bankowy musi być skorelowane z edukacją na temat sposobów korzystania z oferowanych przez nią możliwości oraz kwestii bezpieczeństwa realizowanych transakcji. Szczególnie widoczna jest taka potrzeba wśród gospodarstw domowych najbardziej zaawansowanych wiekowo.

${ }^{133}$ M. Maciejasz-Świątkiewicz, Wykluczenie finansowe i narzędzia jego ograniczania, Wydawnictwo Uniwersytetu Opolskiego, Opole 2013, s. 26.

${ }^{134}$ Inspirację niesie przykład niemal powszechnego wykorzystywania mobilnych płatności w Kenii (M-pesa); szerzej: N. Geach, The Digital Devine, Financial Exclusion and Mobile Phone Technology: Two Problems, One Solution?, "Journal of International Trade Law and Policy” 2007, Vol. 6, Issue 1, s. 21-29. 
Z punktu widzenia analizy współzależności i współwystępowania wykluczenia finansowego i społecznego ważnym jest podkreślenie wspólnych konsekwencji, jakie pozostawanie wykluczonym generuje. Zostaną one przeanalizowane pod kątem skutków obciążających poszczególne osoby dotknięte wykluczeniem, jak i w skali makroekonomicznej, z punktu widzenia gospodarki jako całości. Przedstawia je tablica 8.

Tablica 8. Skutki o charakterze indywidualnym i makroekonomicznym wykluczenia finansowego i społecznego

\begin{tabular}{|c|c|}
\hline Skala konsekwencji & Specyfikacja \\
\hline \multirow{6}{*}{$\begin{array}{l}\text { Skutki o charakterze } \\
\text { indywidualnym } \\
\text { - osobiste }\end{array}$} & zjawisko izolacji społecznej \\
\hline & obniżone poczucie własnej wartości \\
\hline & spadek możliwości zatrudnienia \\
\hline & wzrost postaw biernych lub agresywnych \\
\hline & niewypełnienie ról społecznych \\
\hline & niekorzystanie z zasobów publicznych \\
\hline \multirow{4}{*}{$\begin{array}{l}\text { Skutki o charakterze } \\
\text { indywidualnym } \\
\text { - finansowe }\end{array}$} & pogłębiające się trudności w utrzymaniu się, dalsze ubożenie \\
\hline & $\begin{array}{l}\text { zaciąganie przez osoby o niskich dochodach kredytów na rynku niefor- } \\
\text { malnym, na gorszych warunkach niż na głównym rynku finansowym }\end{array}$ \\
\hline & $\begin{array}{l}\text { utrudnienia w zarządzaniu budżetem domowym w przypadku wystąpie- } \\
\text { nia nagłych trudności finansowych }\end{array}$ \\
\hline & trudności w zaspokajaniu potrzeb konsumpcyjnych \\
\hline \multirow{4}{*}{$\begin{array}{l}\text { Skutki o charakterze } \\
\text { makroekonomicznym }\end{array}$} & zwiększenie transferów społecznych \\
\hline & zwiększenie długu publicznego \\
\hline & spadek PKB \\
\hline & wzrost bezrobocia \\
\hline
\end{tabular}

Źródło: opracowanie własne.

Wykluczenie społeczne i finansowe generuje wspólne konsekwencje w obszarze mikro- i makroekonomicznym. Mają one wymiar jednoznacznie negatywny. W skali indywidualnej można wskazać na skutki o charakterze osobistym i finansowym. Te o charakterze osobistym koncentrują się wokół pozycji społecznej, zaś te w wymiarze finansowym podkreślają dysproporcję w dochodach osób wykluczonych i problem dalszego ubożenia. Natomiast konsekwencje makroekonomiczne znajdują swoje odzwierciedlenie głównie w zwiększeniu transferów społecznych wywołanych koniecznością wyrównywania dysproporcji w dochodach gospodarstw domowych.

Podsumowując, wykluczenie społeczne traktowane jest jako brak lub ograniczenie możliwości pełnego uczestnictwa, wpływania i korzystania z podstawowych instytucji publicznych i rynków, które powinny być dostępne dla wszyst- 
kich, a w szczególności dla osób ubogich, podczas gdy wykluczenie finansowe (w szczególności bankowe) jest pojęciem węższym, koncertującym się albo na braku dostępu do rynku usług finansowych, albo na celowym niekorzystaniu z produktów bankowych.

\subsubsection{Zadłużenie i niewypłacalność gospodarstw domowych a wykluczenie finansowe i społeczne ${ }^{135}$}

Zadłużanie się gospodarstw domowych jest naturalnym procesem determinowanym niewystarczającym poziomem posiadanych dochodów w odniesieniu do oczekiwanego poziomu konsumpcji i inwestycji. Powstawanie zadłużenia będące efektem zaciągania zobowiązań przez gospodarstwa domowe jest traktowane jako naturalny etap jego rozwoju. Kredyty i pożyczki umożliwiają poprawę jakości życia i zapewniają lepszy dostęp do niezbędnych dóbr i usług, które w przeciwnym razie byłyby nie do osiągnięcia, lub stałyby się dostępne dopiero po długim czasie. Jeśli jednak pojawiają się poważne problemy zawodowe, miesięczna kwota długu przekracza tzw. rozsądną część miesięcznych zarobków, ilość zaciągniętych kredytów jest zbyt wysoka, a posiadane oszczędności nie są w stanie zrekompensować nagłej sytuacji utraty dochodów - mogą one doprowadzić do sytuacji nadmiernego zadłużenia ${ }^{136}$.

Zjawisko nadmiernego zadłużenia (ang. overindebtedness) występuje, kiedy to dłużnik nie jest w stanie spłacić wszystkich swoich długów w perspektywie długoterminowej lub gdy istnieje poważne ryzyko, że tak się może stać ${ }^{137}$. Osoby uznawane są za nadmiernie zadłużone, w przypadku gdy ich dochody netto nie wystarczają na pokrycie bieżących kosztów utrzymania i spłatę zadłużenia w wymaganym terminie ${ }^{138}$.

Pojęcie nadmiernego zadłużenia jest bardzo różnie definiowane w poszczególnych krajach. W Austrii, Belgii i Luksemburgu gospodarstwa domowe są postrzegane jako nadmiernie zadłużone, jeśli po odjęciu kosztów życia pozostała kwota środków pieniężnych nie wystarcza na pokrycie wszystkich zobowiązań płatniczych. We Francji za osobę nadmiernie zadłużoną uważa się dłużnika, który

${ }^{135} \mathrm{~W}$ punkcie wykorzystano fragmenty publikacji I. Kuchciak, Nadmierne zadtużanie się gospodarstw domowych..., s. 135-157.

136 Opinia Europejskiego Komitetu Ekonomiczno-Spolecznego w sprawie: Kredyty a wykluczenie społeczne w społeczeństwie dobrobytu, 2008/C 44/19, Dz. Urz. UE C44/74, s. 3.

${ }_{137}$ Według wzorcowej definicji nadmierne zadłużenie oznacza obiektywną niezdolność do zapłaty, a dokładniej sytuację, w której po odliczeniu od dochodu wydatków na życie pozostała kwota nie wystarcza na spłatę długów, gdy nadejdzie termin ich spłaty.

${ }_{138}$ S. Stamp, A policy framework for addressing over-indebtedness, Combat Poverty Agency, Dublin 2009, s. 7. 
pomimo dobrej woli nie jest $\mathrm{w}$ stanie spłacać zobowiązań zgodnie $\mathrm{z}$ warunkami przyjętymi w umowach. W Niemczech w definicji nadmiernego zadłużenia znajduje się odniesienie nie tylko do trudności w obsłudze zadłużenia, ale także do obniżenia standardu życia. W niektórych krajach należących do UE: Litwa, Bułgaria, Włochy, Hiszpania czy Grecja nie ma żadnej oficjalnie obowiązującej definicji nadmiernego zadłużenia ${ }^{139}$. W polskim ustawodawstwie można znaleźć odniesienie do zjawiska niewypłacalności zamiast nadmiernego zadłużenia. Dłużnika uważa się za niewypłacalnego, jeżeli nie wykonuje swoich wymagalnych zobowiązań pieniężnych ${ }^{140}$.

Nadmierne zadłużenie mierzone jest w różny sposób. Pomiar może odbywać się na podstawie administracyjnych źródeł danych, np. w formie orzeczeń sądowych, częściej jednak brane są pod uwagę dane wskazujące na zaległości w płatnościach. Jedną z największych trudności w ocenie zakresu nadmiernego zadłużenia w Europie jest brak wiarygodnych danych statystycznych lub brak możliwości porównania istniejących danych ze względu na różne metodologie, pojęcia i okresy pomiarów ${ }^{141}$.

Zadłużenie polskich gospodarstw domowych z tytułu zaciągniętych kredytów i pożyczek systematycznie wzrasta. Dane publikowane przez NBP wskazują, że zadłużenie gospodarstw domowych w odniesieniu do PKB pozostaje wprawdzie na niższym poziomie niż $\mathrm{w}$ innych krajach UE (ok. 30\%), jednak tempo przyrostu zadłużenia jest wyższe ${ }^{142}$. Strukturę zadłużenia gospodarstw domowych przedstawia rysunek 18 .

W latach 2005-2011 podobna liczba badanych gospodarstw domowych deklarowała zadłużenie. W 2011 r. ponad 39\% badanych gospodarstw domowych potwierdziło korzystanie z pożyczek i kredytów. Na podobnym poziomie utrzymało się zadłużenie sięgające wysokości miesięcznych dochodów oraz dochodów z przedziału od 3 do 6 i 6 do 12 miesięcy. Najbardziej niepokojącym zjawiskiem jest przyrost liczby gospodarstw domowych, których zadłużenie wynosiło powyżej ich rocznych dochodów. W okresie 6 lat to niekorzystne i niebezpieczne w skutkach zjawisko podwoiło się.

139 European Commission, Towards a common operational definition of over-indebtedness, European Commission, February 2007, s. 34-36.

${ }^{140}$ Ustawa z dnia 28 lutego 2003 r. Prawo upadłościowe i naprawcze, Dz. U. nr 60, poz. 535 ze zm., art. 11.

${ }^{141}$ Instrumentem mającym na celu dostarczenie aktualnych i porównywalnych na poziomie krajów członkowskich danych dotyczących dochodów, ubóstwa, wykluczenia społecznego i warunków życia jest Europejskie badanie dochodów i warunków życia (European Union Statistics on Income and Living Conditions - EU-SILC). Organizacja i metodologia badania EU-SILC regulowana jest rozporządzeniem Parlamentu Europejskiego i Rady nr 1177/2003 z 16 czerwca 2003 r. (ze zmianami zawartymi w rozporządzeniu nr 1553/2005) dotyczącym statystyki dochodów i warunków życia ludności (EU-SILC) oraz korespondującymi z tym aktem prawnym rozporządzeniami Komisji Europejskiej.

${ }^{142}$ A. Lilico, Household Indebtness in the EU, European Parliament, 2010, s. 30. 


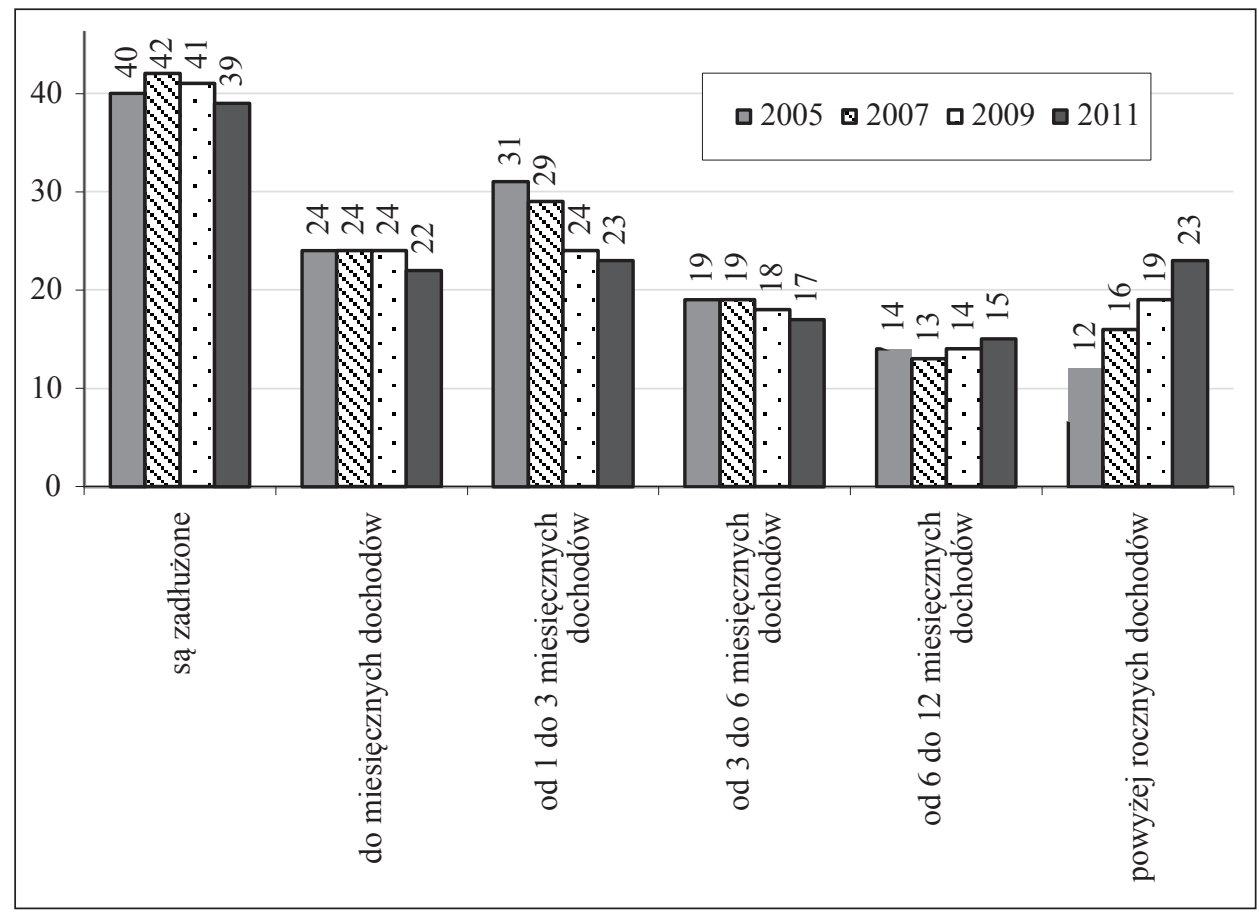

Rysunek 18. Zmiany skali zadłużenia gospodarstw domowych (w \%)

Źródło: J. Czapiński, T. Panek (red.), Diagnoza społeczna. Warunki i jakość życia Polaków. Raport, Rada Monitoringu Społecznego, Warszawa 2012, s. 82

Z punktu widzenia związku między zadłużeniem a wykluczeniem finansowym ważnym jest określenie źródeł zasilania gospodarstw domowych. W $2011 \mathrm{r}$. $90 \%$ badanych gospodarstw domowych zadłużało się w bankach, w 2012 r. było to $88 \%{ }^{143}$. W latach $2005-2011$ malało znaczenie innych instytucji oraz osób prywatnych jako podmiotów udzielających finansowania.

Przedstawione wyżej dane nakreślają skalę problemu zadłużenia gospodarstw domowych. Trudno jednak na tej podstawie określić znaczenie wzrostu zadłużenia dla sytuacji ekonomiczno-finansowej gospodarstw domowych, na którą w dużej mierze mają wpływ płatności związane z obsługą zaciągniętych zobowiązań. Niemożność spłaty zobowiązań w wyznaczonym terminie, a nie sam poziom zadłużenia gospodarstwa domowego, przyczynia się bowiem w głównej mierze do pogorszenia jego sytuacji finansowej, która może doprowadzić do niewypłacalności ${ }^{144}$.

${ }^{143}$ Prawie 37\% badanych gospodarstw domowych deklarowało w lutym/marcu 2013 r. korzystanie z pożyczek i kredytów. J. Czapiński, T. Panek (red.), Diagnoza społeczna. Warunki i jakość życia Polaków. Raport, Rada Monitoringu Społecznego, Warszawa 2012, s. 62.

${ }^{144}$ Szerzej: A. B. Atkinson, E. Marlier, Income and living conditions in Europe, Eurostat, European Union, 2010. 
Łączna kwota zaległych płatności klientów podwyższonego ryzyka w województwie łódzkim, odnotowanych w Rejestrze Dłużników prowadzonym przez BIG InfoMonitor oraz w Biurze Informacji Kredytowej, na koniec grudnia $2013 \mathrm{r}$. wyniosła 2,38 mld złotych ${ }^{145}$. Odniesienie wielkości łącznych zaległych płatności w województwie łódzkim na tle ogólnopolskich przedstawia rysunek 19.

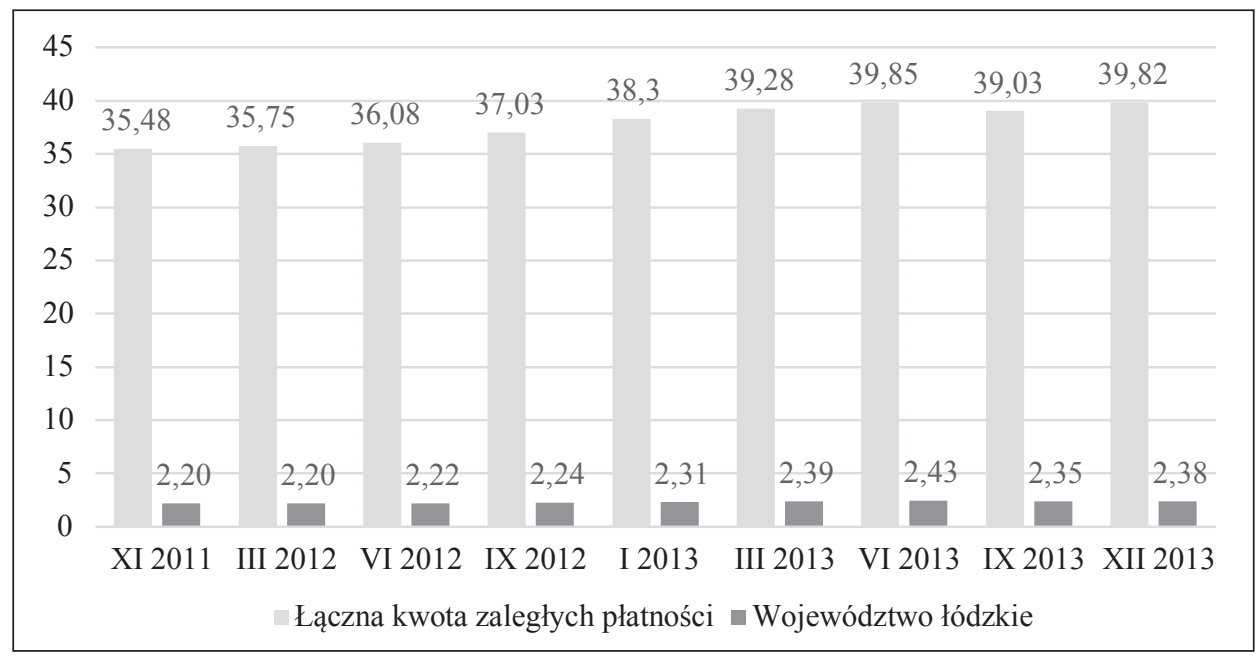

Rysunek 19. Kwota zaległych płatności w województwie łódzkim na tle łącznej kwoty zaległych płatności (w mld zł)

Źródło: BIG InfoMonitor, Ogólnopolski raport o klientach wysokiego i podwyższonego ryzyka w obrocie gospodarczym, Polskie regiony, styczeń 2014, s. 25

Kwota zadłużenia mieszkańców województwa łódzkiego powiększyła się od listopada 2011 r. o 180 mln złotych (8,1\%). Na koniec grudnia 2013 r. łączna kwota niespłaconych zobowiązań mieszkańców tego regionu była siódmą najwyższą co do wielkości w Polsce. Wysokość średniego zaległego zobowiązania dla mieszkańców województwa łódzkiego na tle średniej ogólnopolskiej przedstawia rysunek 20.

Średnie zaległe zobowiązanie dla mieszkańców województwa łódzkiego na koniec grudnia 2013 r. wyniosło 14430 złotych. Zatem w niespełna rok zadłużenie wzrosło zaledwie o 16 złotych, czyli o $1 \%$. W porównaniu do średniej dla całej Polski, trend przez cały miniony rok był zbliżony, uwzględniając wzrost na początku i spadek na koniec roku. Ponadto od końca 2012 r. przybyło blisko 3,7 tys. niesolidnych dłużników, czyli w niespełna rok ich liczba wzrosła o ponad $2 \%$.

145 Zobowiązania te wynikają m.in. z niezapłaconych rachunków za energię elektryczną, gaz, usługi telekomunikacyjne, czynsz za mieszkanie, z tytułu alimentów, pożyczek, a także z niespłacanych kredytów hipotecznych i konsumpcyjnych. 


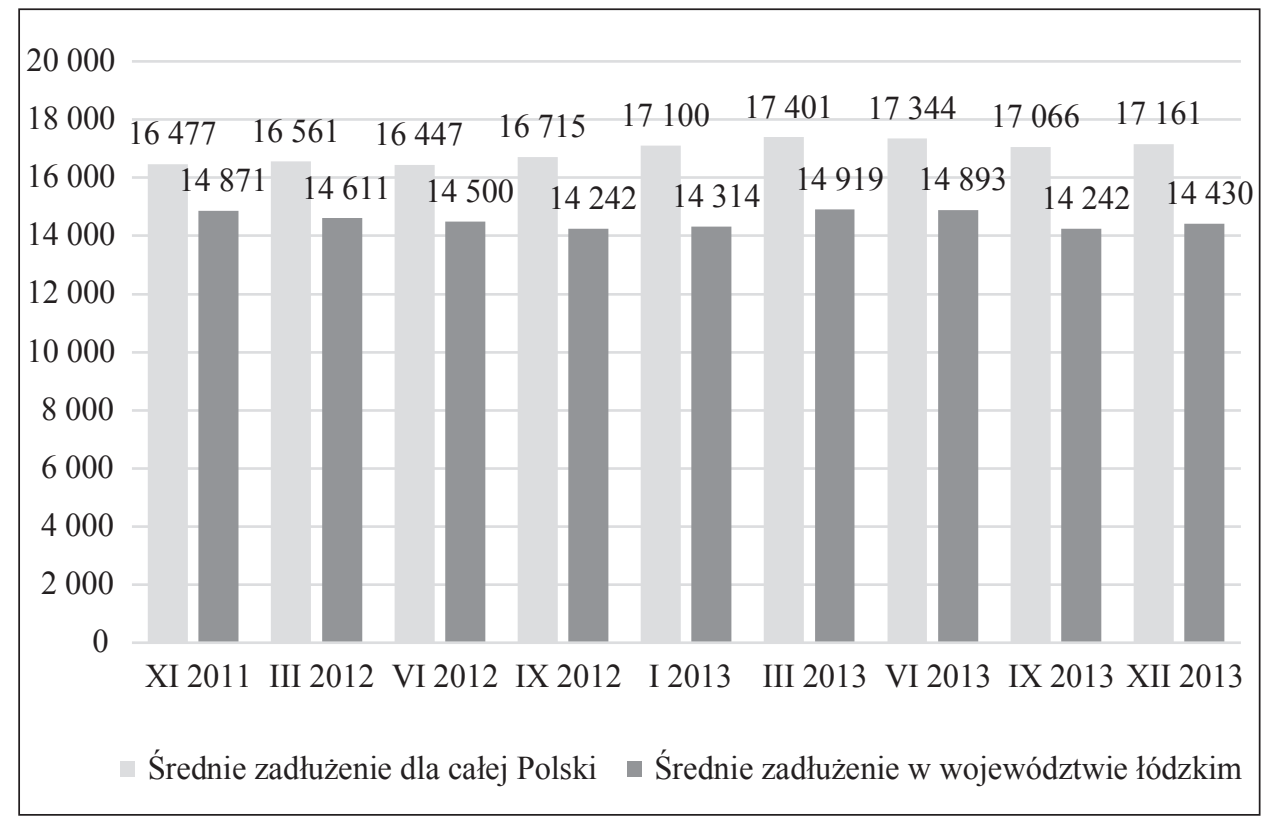

Rysunek 20. Średnie zadłużenie w województwie łódzkim na tle łącznej kwoty zaległych płatności (w zł)

Źródło: jak przy rys. 19, s. 27

Podsumowując, sytuacja w obszarze zadłużenia i zaległych płatności w województwie łódzkim była w analizowanych latach stabilna, a pozycja województwa łódzkiego w kontekście nadmiernego zadłużania się na tle pozostałych województw ukształtowała się na średnim poziomie.

Koncepcja wykluczenia finansowego i nadmiernego zadłużenia jest często analizowana osobno, ale istnieje kilka obszarów wspólnych dla tych dwóch zjawisk. Pierwszym z nich jest rozpatrywany w literaturze związek między konsekwencjami wykluczenia finansowego i nadmiernego zadłużenia a statusem społeczno-ekonomicznym.

Na gruncie badania relacji między wykluczeniem a nadmiernym zadłużeniem analizowane są cechy osób dotkniętych tymi problemami. Pozwala to na identyfikację przyczyn obu zjawisk ${ }^{146}$. Zestawienie cech społeczno-demograficznych charakteryzujących osoby wykluczone finansowo i nadmiernie zadłużone oraz sytuacji, które zwiększają prawdopodobieństwa wystąpienia obu zjawisk ilustruje tablica 9.

146 M. Sarma, Index of Financial Inclusion, Indian Council for Research on International Economic Relations, Working Paper No. 215, June 2008, s. 3. Szerzej: S. Carbó, E. P. M. Gardener, P. Molyneux, Financial exclusion, Palgrave MacMillan, 2005. 
Tablica 9. Cechy predestynujące oraz determinanty wykluczenia i nadmiernego zadłużenia

\begin{tabular}{|c|c|c|}
\hline \multicolumn{2}{|c|}{$\begin{array}{c}\text { Cechy predestynujące do wykluczenia } \\
\text { i nadmiernego zadłużenia }\end{array}$} & $\begin{array}{l}\text { Determinanty wykluczenia } \\
\text { i nadmiernego zadłużenia }\end{array}$ \\
\hline \multicolumn{2}{|c|}{ społeczno-demograficzne: } & spoleczno-demograficzne: \\
\hline wiek & powyżej 50. roku życia & starzenie się społeczeństwa \\
\hline płeć & mężczyzna & ubożenie społeczeństwa \\
\hline wykształcenie & podstawowe lub średnie & podniesienie poziomu życia \\
\hline status społeczny & $\begin{array}{l}\text { osoby samotne, samotnie } \\
\text { wychowujące dzieci }\end{array}$ & ekonomiczne: \\
\hline dochód & $\begin{array}{l}\text { poniżej } 60 \% \text { mediany } \\
\text { dochodu ekwiwalentnego }\end{array}$ & bezrobocie i pogorszenie się warunków pracy \\
\hline $\begin{array}{l}\text { religia, rasa, } \\
\text { narodowość }\end{array}$ & $\begin{array}{l}\text { przynależność } \\
\text { do mniejszości } \\
\text { narodowych }\end{array}$ & $\begin{array}{l}\text { zmiany w strukturze gospodarstwa domowego, } \\
\text { jak np. rozwód, śmierć współmałżonka, niepla- } \\
\text { nowane narodziny }\end{array}$ \\
\hline sytuacja zawodowa & $\begin{array}{l}\text { pozostawanie długotrwa- } \\
\text { le bezrobotnym }\end{array}$ & $\begin{array}{l}\text { niepowodzenie samodzielnej działalności go- } \\
\text { spodarczej lub bankructwo małych przedsię- } \\
\text { biorstw rodzinnych }\end{array}$ \\
\hline \multirow[t]{2}{*}{ inne } & \multirow[t]{2}{*}{$\begin{array}{l}\text { niepełnosprawność, } \\
\text { uzależnienie od używek }\end{array}$} & $\begin{array}{l}\text { celowe ukrywanie przez klienta informacji } \\
\text { umożliwiających instytucjom finansowym osza- } \\
\text { cowanie jego wypłacalności }\end{array}$ \\
\hline & & nieumiejętne zarządzanie budżetem domowym \\
\hline \multicolumn{2}{|l|}{ psychologiczne: } & $\begin{array}{l}\text { nadmierne korzystanie z kart kredytowych, kre- } \\
\text { dytów odnawialnych i innych wysoko oprocen- } \\
\text { towanych form kredytów osobistych }\end{array}$ \\
\hline \multicolumn{2}{|c|}{ brak skłonności do oszczędzania } & $\begin{array}{l}\text { zaciąganie kredytów używanych do spłacania } \\
\text { innych kredytów }\end{array}$ \\
\hline \multicolumn{2}{|c|}{ nadmierna skłonność do ryzyka } & $\begin{array}{l}\text { zaciąganie przez osoby o niskich dochodach, } \\
\text { kredytów na rynku nieformalnym, z lichwiar- } \\
\text { skimi odsetkami }\end{array}$ \\
\hline \multirow{2}{*}{\multicolumn{2}{|c|}{ skłonność do nadmiernych zakupów }} & $\begin{array}{l}\text { wzrost stóp procentowych, zmiany kursów wa- } \\
\text { lutowych }\end{array}$ \\
\hline & & spowolnienie gospodarcze \\
\hline
\end{tabular}

Źródło: opracowanie własne na podstawie: European Commission, Special Eurobarometer 279 - Poverty and exclusion, 2009; Opinia Europejskiego Komitetu Ekonomiczno-Społecznego w sprawie: Kredyty a wykluczenie społeczne w społeczeństwie dobrobytu, 2008/C 44/19, Dz. Urz. UE C44/74, pkt. 3.2.

Przedstawione $\mathrm{w}$ tablicy cechy predestynujące oraz determinanty wykluczenia i nadmiernego zadłużenia pozwalają wnioskować, że są one zarówno przyczyną, jak i skutkiem ubóstwa i wykluczenia społecznego. Ilustrację zależności zachodzących między wykluczeniem a nadmiernym zadłużeniem ilustruje rysunek 21 . 


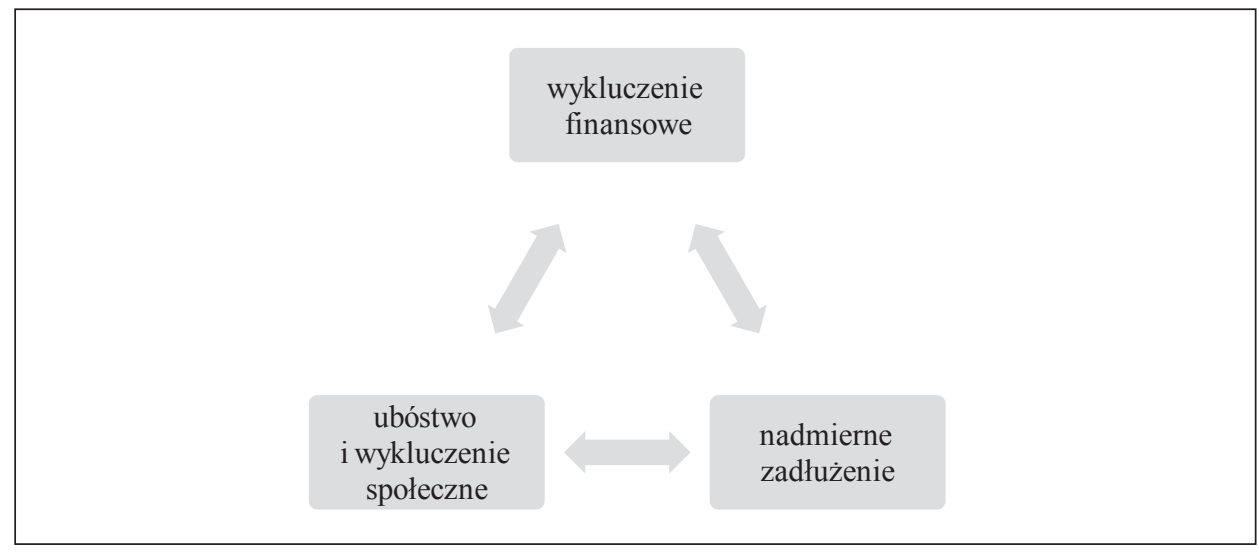

Rysunek 21. Współzależności między wykluczeniem a nadmiernym zadłużeniem

Źródło: opracowanie własne na podstawie: G. Glukoviezoff, From Financial Exclusion to Overindebtedness: The Paradox of Difficulties for People on Low Income?, [w:] L. Anderloni,

M. D. Braga, E. Carluccio, New frontiers in banking services. Emerging needs and tailored products for untapped markets, Springer Verlag, Berlin 2006, s. 5-10

Trudności w dostępie do kredytów, na jakie napotykają gospodarstwa domowe, pojawiające się szczególnie w przypadku wystąpienia trudnych sytuacji życiowych (jak np. choroba, wypadek, niepełnosprawność) prowadzą do poszukiwania droższych form finansowania, chociażby w instytucjach parabankowych. W dłuższej perspektywie zadłużanie się poza sektorem bankowym generuje wysokie koszty obsługi takiego zadłużenia, drastyczne zmniejszenie środków pozostających do dyspozycji i w efekcie ubożenie gospodarstw domowych. Z drugiej strony należy wskazać, że nieposkromiony apetyt gospodarstw domowych na kredyty również może prowadzić do powstania pętli zadłużenia, a w konsekwencji do ubóstwa.

Drugi nurt badań nad związkiem między wykluczeniem a nadmiernym zadłużeniem koncentruje się wokół weryfikacji hipotezy, że nadmierne zadłużenie prowadzi do wykluczenia będącego efektem trudności w dostępie do produktów kredytowych. Trudności w dostępie wynikają z czynników leżących po stronie popytu, za który odpowiedzialne są gospodarstwa domowe, oraz podaży, rozumianej jako gotowość banków do udzielenia kredytu ${ }^{147}$.

Instytucje finansowe odmawiają dostępu wybranej grupie klientów w przypadku, gdy przewidują, że wystąpią trudności w ich wykorzystaniu lub gdy oceniają, iż osoby te są zbyt ubogie, by przynosić korzyści finansowe instytucji finansowej. Takie działania mogą polegać np. na odmowie otwarcia rachunku bankowego z limitem kredytowym osobom, w przypadku których zidentyfikowane zostało ryzyko wystąpienia przekredytowania lub niemożności spłacenia

${ }^{147}$ Por. M. Marcinkowska, Kapitat relacyjny banku, s. 140-143. 
zadłużenia ze względu na nieregularne dochody. Z drugiej strony, niekiedy sami klienci odmawiają korzystania $\mathrm{z}$ takich usług bankowych, w przypadku których mają podejrzenia, że ich sytuacja finansowa może spowodować trudności w regulowaniu zaciągniętych zobowiązań. Tym samym trudności w użytkowaniu sprowadzają się do dwóch sytuacji. Po pierwsze, kiedy osoby nie korzystają z usług finansowych, do których mają zagwarantowany dostęp ze względu na brak pewności lub świadomości ryzyka. Po drugie osoby korzystające z usług finansowych napotykają na negatywne konsekwencje z tego względu, iż usługi finansowe nie są dostosowane do ich potrzeb lub korzystają z nich w sposób niewłaściwy ${ }^{148}$.

Doświadczenia niektórych krajów (Francji, Belgii) wskazują, że możliwość zaciągnięcia drobnych kredytów na dogodnych warunkach może przeciwdziałać popadnięciu w nadmierne zadłużenie wywołane koniecznością korzystania z droższej oferty instytucji parabankowych lub pozwala na sfinansowanie aktywów, które są wykorzystywane w pracy lub ułatwiają mobilność niezbędną niekiedy do utrzymania pracy.

Zgodnie z wynikami badań prowadzonych w Irlandii nadmierne zadłużenie może stwarzać problemy w dostępie lub utrzymaniu pracy, co może prowadzić do deprywacji materialnej, a w dalszej perspektywie wykluczenia ${ }^{149}$. Natomiast, powołując się na badania prowadzone we Francji, negatywna historia kredytowa utrudnia lub całkowicie uniemożliwia uzyskanie dostępu do kredytów lub innych dóbr i usług niż bankowe, co z kolei skutkuje wykluczeniem finansowym i społecznym ${ }^{150}$.

$\mathrm{Z}$ drugiej strony istnieje pewien związek między wykluczeniem a nadmiernym zadłużeniem wskazujący, że przyczyną nadmiernego zadłużenia jest wykluczenie bankowe. W Polsce zaciągnięcie kredytu bankowego wymaga posiadania rachunku bankowego, podobnie jak w większości krajów europejskich. Zatem osoby wykluczone bankowo nie mają fizycznej możliwości skorzystania z produktów kredytowych oferowanych przez banki komercyjne lub spółdzielcze. Alternatywą dla nich mogą być produkty oferowane przez SKOKi, jednak biorąc pod uwagę niski ich udział w rynku (w 2014 r.: aktywa: 18905 mln, kredyty: $10464 \mathrm{mln}$, depozyty: $17585 \mathrm{mln}$ ) nie są one w stanie zapełnić luki popytowej ${ }^{151}$.

148 Wykluczenie finansowe postrzegane bywa jako proces, który łączy trudności w dostępie z trudnościami w użytkowaniu usług. Na początku tego procesu osoby mają dostęp do usług finansowych, lecz wykorzystują go w sposób niewłaściwy. Powoduje to wystąpienie trudności w użytkowaniu. Na końcu osoby zostają pozbawione dostępu do usług finansowych i pozostają wówczas faktycznie wykluczone. G. Glukoviezoff, Understanding and combating financial exclusion and over indebtedness in Ireland: a European perspective. What could Ireland learn from Belgium, France and the United Kingdom?, Studies in Public Policy, October 2011, s. 4. Por. P. Jones, T. Barnes, Would You Credit It?: People Telling Stories About Credit, The Co-operative Bank in association with Liverpool JMU and Citizen Advice Bureau, 2005, s. 10-15.

149 C. Corr, Financial Exclusion in Ireland: An exploratory study and policy review, Combat Poverty Agency, Dublin 2006, s. 177-178.

${ }^{150}$ G. Gloukoviezoff, The link between financial exclusion and over-indebtedness, Working paper, http://gloukoviezoff.files.wordpress.com/2009/01/wp-link-fe-oi.pdf (stan na dzień 28.03.2013).

${ }^{151}$ Raport o sytuacji systemu SKOK w I kwartale 2014 r., Departament Bankowości Spółdzielczej i Spółdzielczych Kas Oszczędnościowo-Kredytowych, Warszawa, czerwiec 2014, s. 3. 
Powołując się na wyniki najnowszego opracowania dotyczącego psychologicznych uwarunkowań zachowań finansowych Polaków, należy wskazać, że brak rachunku bankowego jest charakterystyczny dla osób starszych, niepełnosprawnych, posiadających niższe wykształcenie i niższe dochody ${ }^{152}$. Tym samym brak dostępu do rachunku bankowego jest charakterystyczny dla osób ubogich lub zagrożonych deprywacją materialną. Wprawdzie brak rachunku nie prowadzi bezpośrednio do nadmiernego zadłużenia, ale może przyczynić się do niego. Może bowiem generować dodatkowe wydatki obciążające domowy budżet takie jak koszty opłat za rachunki opłacane w formie gotówkowej. To z kolei pogarsza kondycję finansową gospodarstwa domowego. Może nawet się zdarzyć, że bank podejmie decyzję o zamknięciu rachunku bankowego osoby nadmiernie zadłużonej, a takie działania utrudniają spłatę posiadanych wierzytelności ${ }^{153}$.

Ważnym nurtem rozważań nad związkiem przyczynowo-skutkowym wykluczenia i nadmiernego zadłużenia jest analiza wpływu występowania trudności w korzystaniu z produktów bankowych na występowanie niewypłacalności ${ }^{154}$. W odniesieniu do kredytów trudności występujące w przypadku gdy kredytobiorca korzysta z kredytu w sposób nieodpowiedni lub nie ma dostępu do odpowiedniego kredytu, mogą spowodować negatywne skutki społeczno-ekonomiczne.

Dostęp do kredytu na dogodnych warunkach może być bowiem użytecznym narzędziem, pozwalającym przezwyciężyć chwilowe trudności finansowe. Osoby pozbawione możliwości zaciągnięcia kredytu na dogodnych warunkach sięgają po droższe i mniej elastyczne źródła finansowania oferowane przez alternatywnych dostawców.

Jedną z kluczowych przyczyn popadania w nadmierne zadłużenie wskazanych wcześniej było gwałtowne pogorszenie się sytuacji życiowej. Nadmierne zadłużenie będące efektem niekorzystnej i nieoczekiwanej zmiany w życiu jest wynikiem trudności w korzystaniu z produktów kredytowych powstałych na skutek ${ }^{155}$ :

- podjęcia błędnej decyzji przez kredytobiorcę posiadającego niski poziom możliwości finansowych lub niski poziom zaufania do kredytodawców;

- braku możliwości dostosowania terminów i warunków zaciągniętych kredytów do zmienionych warunków życiowych kredytobiorcy.

${ }^{152}$ D. Maison, Polak w świecie finansów, Wydawnictwo Naukowe PWN, Warszawa 2013, s. 73-86. Podobne wyniki uzyskane zostały w badaniach prowadzonych w innych krajach.

${ }^{153}$ Eurofinas AISBL, Eurofinas response to the European Commission's consultation on European households'over-indebtedness, February 2013, s. 9.

${ }^{154}$ Wyniki badań na temat zadłużenia i niewypłacalności gospodarstw domowych przedstawiają m.in. prace: B. Świecka (red.), Bankructwa gospodarstw domowych. Perspektywa ekonomiczna i społeczna, Difin, Warszawa 2008 oraz B. Świecka, Niewypłacalność gospodarstw domowych. Przyczyny - skutki-przeciwdziałanie, Difin, Warszawa 2009.

155 European Commission, Financial services provision and prevention of financial exclusion, VC/2006/0183, March 2008, s. 52. 
Trudności w korzystaniu z kredytów mogą powodować trudności w dostępie do kolejnych kredytów. Brak historii kredytowej obniża ocenę scoringową potencjalnego kredytobiorcy, a niekiedy nawet uniemożliwia zaciągnięcie kredytu gotówkowego bez konieczności dłuższej weryfikacji przez analityka kredytowego.

Na bazie badań przeprowadzonych na francuskim społeczeństwie w obszarze występowania trudności w dostępie i użytkowaniu produktów bankowych udowodniony został ich związek z utrudnieniami w uczestnictwie w życiu społecznym prowadzący w dalszej perspektywie do wykluczenia społecznego. Analizy te stały się przyczynkiem do zredefiniowania pojęcia wykluczenia finansowego jako procesu, podczas którego ludzie napotykają trudności w dostępie lub użytkowaniu usług finansowych, które uniemożliwiają im dalsze prowadzenie normalnego życia w społeczeństwie, do którego należą ${ }^{156}$. Rozważania te stanowią podstawę do sformułowania hipotezy, że nadmierne zadłużenie się jest jedną z najbardziej widocznych konsekwencji wykluczenia finansowego.

Promowane jest zatem odpowiedzialne kredytowanie przez banki (responsible lending), ale także odpowiedzialne zadłużanie się przez klientów (responsible borrowing $)^{157}$. W szerszym ujęciu mówi się także o uczciwym kredytowaniu (fair lending), związanym między innymi z zakazem dyskryminowania potencjalnych klientów ${ }^{158}$. Odpowiedzialne udzielanie kredytów jest obowiązkiem banku wobec jego klientów, ale należy tu wskazać na szerszy kontekst tej odpowiedzialności - wobec społeczeństwa ${ }^{159}$.

${ }^{156}$ G. Glukoviezoff, From Financial Exclusion to Overindebtedness: The Paradox of Diffculties for People on Low Income?, [w:] L. Anderloni, M. D. Braga, E. Carluccio, New frontiers in banking services. Emerging needs and tailored products for untapped markets, Springer Verlag, Berlin 2006, s. 6.

157 European Commission Internal Market and Services DG, Public consultation on Responsible Lending and Borrowing in the EU, Brussels, June 2009.

${ }^{158}$ Comptroller of the Currency, Administrator of National Banks, Fair Lending. Comptroller's Handbook, January 2010.

159 Podstawowym argumentem przemawiającym za tą tezą jest fakt, że nadmierne zadłużanie się konsumentów zwykle oznacza ,życie ponad stan” - na koszt społeczeństwa. Do tego samego w istocie sprowadza się upadłość konsumencka. W. Szpringer, Kredyt konsumencki i upadłość konsumencka na rynku ustug finansowych UE, Dom Wydawniczy ABC, Warszawa 2005, s. 48. Dodatkowo można wskazać, że pogorszenie jakości portfela kredytowego (lub podportfela dotyczącego określonej grupy klientów bądź produktów) na którymś etapie może spowodować ograniczenie dalszego rozwoju akcji kredytowej (w całości lub niektórych segmentach) lub podniesienie cen kredytów w celu sfinansowania wyższego ryzyka kredytowego. Dodatkowo, w przypadku istnienia na danym rynku prawnych ograniczeń cen kredytów (tzw. regulacji antylichwiarskich) mogą zdarzać się przypadki, że bank będzie przerzucał na innych klientów koszty ryzyka kredytowego klientów o gorszej wiarygodności kredytowej; klienci charakteryzujący się lepszymi ocenami będą zatem subsydiować klientów o najgorszych ocenach. Konsekwencje w postaci ograniczonego dostępu do kredytów lub wyższych ich kosztów obciążają zatem społeczeństwo. M. Marcinkowska, Kapitat relacyjny banku, s. 311. 


\subsection{Kierunki interwencji na rzecz zwiększania aktywności społecznej osób starszych}

Aktywne starzenie się jest definiowane jako ,proces tworzenia optymalnych możliwości w zakresie zdrowia, uczestnictwa i bezpieczeństwa w celu zwiększenia jakości życia ludzi w okresie starości"160. Zjawisko to należy rozważać w trzech wymiarach: zatrudnienie, udział w życiu społecznym i samodzielne życie. W tym drugim wymiarze należy mówić o aktywności społecznej rozumianej jako ,zwiększanie szans oraz poprawa warunków dla osób starszych do wnoszenia wkładu w życie społeczne w roli wolontariuszy lub osób sprawujących opiekę nad członkami rodziny i do uczestniczenia w życiu społeczeństwa, co ma pozwolić uniknąć izolacji społecznej, a także wielu związanych z nią problemów i zagrożeń"161. Działania podejmowane w tym obszarze można podzielić na dwa rodzaje ${ }^{162}$ :

- działania dostosowawcze - reagowanie na już zaistniałe zmiany demograficzne w taki sposób, aby wdrażane inicjatywy jak najlepiej odpowiadały potrzebom społeczeństwa,

- działania aktywne - opóźnianie i spowalnianie wycofywania się seniorów z życia społecznego.

W celu zwiększania aktywności społecznej osób starszych podejmuje się oba rodzaje działań. Należy przy tym wskazać, że aktywność społeczna związana jest z pełnieniem funkcji wykraczających poza funkcje jednostki w rodzinie i poza funkcje zawodowe. Szansą dla seniorów na zachowanie aktywności jest wcześniejsze planowanie życia na emeryturze, wsparcie ze strony bliskich i rozwój programów służących zaangażowaniu do takich aktywności, które mają dla starszych osób duże znaczenie i są przez nich uznawane za sensowne.

Działania na rzecz osób starszych powinny promować ${ }^{163}$ :

- aktywne zaangażowanie w życie społeczności lokalnych,

- działalność woluntarystyczną,

- zdrowy tryb życia, zapewniający dłuższy czas niezależności życiowej seniorów,

- integrację międzypokoleniową,

- aktywne uczestnictwo w sferze usług społecznych, rozumiane jako działania osób starszych na rzecz innych osób starszych.

160 Active ageing and solidarity between generations.

$161 \mathrm{http} / /$ europa.eu/ey2012/ey2012main.jsp?langId=pl\&catId=971 (stan na dzień 24.01.2014).

162 W. Zgliczyński, Aktywność społeczna osób starszych w Polsce $w$ ramach wolontariatu i uniwersytetów trzeciego wieku, „Studia BAS” 2012, nr 2 (30), s. 130-131.

${ }^{163}$ Ministerstwo Pracy i Polityki Społecznej, Krajowy Plan Działania na rzecz Europejskiego Roku Aktywności Osób Starszych i Solidarności Międzypokoleniowej 2012 w Polsce, Warszawa 2012, s. 10. 
Inicjatywy zwiększające aktywność społeczną mogą mieć formę formalną (przynależność do różnego rodzaju organizacji) oraz nieformalną (spontaniczne działanie). Przykładem tej pierwszej jest wolontariat uznawany za dobry sposób przezwyciężenia przez osoby starsze odosobnienia i przyniesienia pozytywnych efektów dla zdrowia fizycznego i psychicznego, a także poprawy samopoczu$\mathrm{cia}^{164}$. Niemniej należy wskazać, że ta forma zwiększania aktywności społecznej jest mało popularna wśród seniorów ${ }^{165}$ i raczej nie jest ona priorytetowym kierunkiem działania dla instytucji rządowych i samorządowych ${ }^{166}$. Działania administracji rządowej opierają się przede wszystkim na organizowaniu konkursów na finansowanie projektów (przykładem może być nadzorowany przez Ministerstwo Pracy i Polityki Społecznej program operacyjny „Fundusz Inicjatyw Obywatelskich Działanie 1.1 Aktywizacja seniorów, integracja międzypokoleniowa”, mający na celu rozwijanie form uczestnictwa seniorów, wzmacniających ich podmiotowość społeczną w środowisku lokalnym, rozwój solidarności międzypokoleniowej, integrację seniorów i młodych poprzez wykorzystywanie różnych potencjałów tych dwóch grup społecznych) ${ }^{167}$.

Na poziomie samorządowym, jak wskazują badania przeprowadzone przez Instytut Spraw Publicznych (ISP), działania podnoszące aktywność seniorów są w niewielkim stopniu podejmowane. Wśród inicjatyw wspierających wolontariat seniorów można wymienić np. projekt „Poznański Wolontariat 50+” (PW 50+) realizowany przez Centrum Inicjatyw Senioralnych (CIS), polegający na poznaniu $\mathrm{i}$ angażowaniu seniorów w dopasowane do ich potrzeb inicjatywy ${ }^{168}$.

Jedną z funkcjonujących obecnie form inkluzji seniorów w procesy decyzyjne w jednostkach samorządu terytorialnego są tzw. rady seniorów, które pełnią rolę ciał opiniodawczo-doradczych i reprezentacji interesów tej grupy społecznej wobec władz samorządowych. Inicjatywa ta ma charakter spontanicznej „oddolnej” aktywności mieszkańców lub lokalnych władz. Należy przy tym wskazać, że w wielu gminach rady seniorów napotykają na opór władz samorządowych, które odmawiają ich powoływania, wskazując na brak bezpośredniej podstawy prawnej ${ }^{169}$.

Organizacje pozarządowe w życiu seniorów nie tylko świadczą takie usługi, jak usługi bytowe, pielęgnacyjne, wspierające i edukacyjne, ale też prowadzą działania mające na celu zwiększenie integracji społecznej, zawodowej i samo-

${ }^{164}$ F. Tang, E. Choi, N. Morrow-Howell, Organizational Support and Volunteering Benefits for Older Adults, „The Gerontologist” 2010, Vol. 50, No. 5, s. 603-612.

165 Szerzej: Aktywność społeczna w organizacjach obywatelskich, CBOS, Warszawa 2012.

166 Szerzej: J. Przewłocka, Ukryty potencjat? Sektor pozarzadowy w starzejacej się Polsce, [w:] M. Racław (red.), Publiczna troska, prywatna opieka, Instytut Spraw Publicznych, Warszawa 2011.

167 Program Operacyjny Fundusz Inicjatyw Obywatelskich na lata 2009-2013, Fundusz Inicjatyw Obywatelskich, Warszawa 2008.

168 www.centrumis.pl/poznanski-wolontariat-o-projekcie.html (stan na dzień 24.01.2014).

169 www.isp.org.pl/aktualnosci,1,1287.html (stan na dzień 24.01.2014). 
rozwoju osób starszych ${ }^{170}$. Niemniej należy wskazać, że rola sektora pozarządowego nie jest doceniana przez władze i same organizacje ${ }^{171}$. Jednym z przykładów ich działalności jest sieć centrów wolontariatu, które zajmują się m.in. pośrednictwem ofert pomiędzy organizacjami a osobami chcącymi zostać wolontariuszami oraz przygotowywaniem obydwu tych grup do współpracy ${ }^{172}$.

Inną formą działalności na rzecz zwiększania aktywności społecznej osób starszych są Uniwersytety Trzeciego Wieku. W Polsce powstają trzy typy tej instytucji:

- działające w strukturach bądź pod patronatem wyższej uczelni, kierowane najczęściej przez pełnomocnika rektora danej uczelni;

- powołane przez stowarzyszenia prowadzące działalność popularnonaukową;

- inne, działające przy domach kultury, bibliotekach, domach dziennego pobytu, ośrodkach pomocy społecznej itp.

Uniwersytety Trzeciego Wieku zajmują się upowszechnianiem inicjatyw edukacyjnych, aktywizacją (intelektualną, psychiczną, społeczną i fizyczną) seniorów, poszerzaniem ich wiedzy i umiejętności, uproszczeniem kontaktów z instytucjami, takimi jak służba zdrowia, ośrodki kultury, ośrodki rehabilitacyjne i inne, włączaniem w aktywność na rzecz środowiska oraz podtrzymywaniem więzi społecznych i komunikacji międzyludzkiej ${ }^{173}$.

Wśród inicjatyw integracyjnych, czyli działań o charakterze naukowo-szkoleniowym, towarzyskim i charytatywnym, oprócz Uniwersytetów Trzeciego Wieku należy wymienić kluby senioralne, koła gospodyń, towarzyskie spotkania w restauracjach i kawiarniach oraz grupy samopomocowe. Spotkania seniorów mogą odbywać się w domach kultury, remizach, domach osób prywatnych lub miejscach publicznych. Tego typu zrzeszenia mają zachęcić osoby starsze do aktywności społecznej, przy czym należy wskazać, że działalność tych instytucji obejmuje nie tylko fizyczne spotkania seniorów (zachętą do tego mogą być kupony uprawniające do zakupu kawy, herbaty, wstępu na imprezy okolicznościowe dystrybuowane po symbolicznej cenie, np. w ramach inicjatywy Kawiarenka dla Seniora ${ }^{174}$, przyznanie certyfikatów „Miejsca przyjaznego Seniorom” ${ }^{175}$, organizowanie imprez cyklicznych, np. targów Aktywni $50+{ }^{176}$ ), ale również wsparcie i edukację (m.in. programy organizowane przez Miejskie Ośrodki

${ }^{170}$ Szerzej: P. Sobiesiak, Aktywni 60+? Wolontariat osób starszych w Polsce, ISP, „Analizy i Opinie" 2011, nr 117.

${ }^{171}$ Szerzej: M. Dutkiewicz, P. Sobiesiak-Penszko, Starość w trzecim sektorze-aktywnie czy opiekuńczo?, „Trzeci Sektor” 2011, nr 25.

$172 \mathrm{http}: / /$ wolontariat.org.pl/ (stan na dzień 25.01.2014).

173 www.utw.pl/index.php?id=10 (stan na dzień 25.01.2014).

174 www.mops.czestochowa.um.gov.pl/formy-pomocy/pomoc-osobom-starszym-i-niepelnosprawnym /kawiarenka-dla-seniora/ (stan na dzień 25.01.2014).

175 www.centrumis.pl/miejsce-przyjazne-seniorom3.html (stan na dzień 25.01.2014).

176 www.centrumis.pl/rekrutacja-do-piatej-edycji-targow-aktywni-501.html (stan na dzień 25.01.2014). 
Pomocy Społecznej, np. Aktywizowanie Społeczności Lokalnej ${ }^{177}$ ), w tym także za pośrednictwem portali internetowych i społecznościowych (np. Klub Senio$\mathrm{ra}^{178}$ ). Należy przy tym wskazać, że część z tych programów bazuje na usługach świadczonych przez samych seniorów (np. Bank Czasu Seniora ${ }^{179}$ ).

Portale internetowe i społecznościowe, prowadzone przez różne instytucje, działające na rzecz osób starszych pełnią także ważną funkcję edukacyjną w zakresie możliwości aktywnych sposobów spędzania wolnego czasu, zdrowego trybu życia, działalności woluntarystycznej, obsługi sprzętów telekomunikacyjnych itp. Na stronach internetowych tych organizacji seniorzy mogą pobrać broszury informacyjne lub obejrzeć filmy multimedialne ${ }^{180}$. Tego typu działalność jest szczególnie istotna w pierwszej fazie włączania społecznego osób starszych, gdyż materiały pozwalają zaznajomić się tym osobom z przekazywanymi informacjami w domu $\mathrm{w}$ dowolnym momencie.

Na uwagę zasługują także programy zwiększające mobilność osób starszych (np. „Mobilność seniorów bez granic”181), których celem jest przełamanie izolacji osób starszych oraz przekazanie obrazu godnego starzenia się, zachowania radości życia, niezależności oraz aktywności.

W aktywizacji społecznej osób starszych należy podkreślić znaczenie środków pozyskanych w ramach Programu Operacyjnego Kapitał Ludzki, w którym przewidziano liczne formy wsparcia dla osób po 50. roku życia. Obejmują one usługi o charakterze aktywizacyjnym, edukacyjnym i społeczno-integracyjnym. Do końca I półrocza 2013 r. udział w projektach rozpoczęło blisko 321 tys. osób po 50. roku życia. Najwięcej uzyskało wsparcie dotyczące integracji społecznej $-68,5$ tys. oraz wsparcie na rynku pracy $-50,8$ tys. osób ${ }^{182}$.

Podsumowując prowadzone rozważania oraz odnosząc się do priorytetowych działań wyszczególnionych w Rządowym Programie na rzecz Aktywności Społecznej Osób Starszych (patrz podrozdział 1.1.2), można określić następujące kierunki interwencji na rzecz zwiększania aktywności społecznej osób starszych: edukacja, zwiększanie integracji wewnątrz- i międzypokoleniowej, włączenie społeczne osób starszych, świadczenie usług społecznych na rzecz osób starszych. Przykładowe działania w tych obszarach zestawia tablica 10.

\footnotetext{
177 www.mops.czestochowa.um.gov.pl/category/projekty-i-programy/aktywizowanie-spolecznosci-lokalnej/ (stan na dzień 25.01.2014).

178 www.klub.senior.pl/ (stan na dzień 25.01.2014).

179 www.mops.czestochowa.um.gov.pl/category/projekty-i-programy/bank-czasu-seniora/ (stan na dzień 25.01.2014).

${ }^{180}$ Przykładem może być: http://centrumis.pl/spoty-reklamowe-seniorze-masz-wyb\%C3\%B3r. html (stan na dzień 25.01.2014).

181 A. Krawczy-Balon, Starość jest barwna - działania wzmacniajace politykę senioralna, Ministerstwo Pracy i Polityki Społecznej, Warszawa 2013, s. 4.

182 www.efs.gov.pl/2014_2020/strony/fe_dla_osob_50_plus_171213.aspx (stan na dzień 25.01.2014).
} 
Tablica 10. Kierunki interwencji na rzecz zwiększania aktywności społecznej osób starszych

\begin{tabular}{|l|l|}
\hline Kierunek interwencji & \multicolumn{1}{c|}{ Przykładowe działania } \\
\hline Edukacja & - edukacja z różnych dziedzin, programy edukacyjne i warsztaty o starze- \\
& niu, osobach starszych i aktywnym starzeniu (w tym także prowadzone \\
& poprzez portale internetowe i społecznościowe), \\
- & zajęcia przygotowujące do usług wolontariackich, \\
- & kształcenie opiekunów, \\
- & promowanie wolontariatu kompetencji, \\
- & promocja oferty edukacyjnej wśród osób starszych.
\end{tabular}

Źródło: opracowanie własne na podstawie: Rządowy Program na rzecz Aktywności Społecznej Osób Starszych na lata 2014-2020, Ministerstwo Pracy i Polityki Społecznej, Warszawa 2013, s. 22-24.

Podjęte działania mają zwiększyć aktywność osób starszych i umożliwić im stanie się aktywnymi uczestnikami życia społeczności lokalnych ${ }^{183}$. Co istotne, proponowane kierunki interwencji mają wpływ nie tylko na społeczne włączenie seniorów, ale także finansowe. Większość podmiotów zaangażowanych w zwiększanie aktywności społecznej tych osób ma świadomość powiązania pomiędzy obydwoma zjawiskami i dlatego też w poszczególnych działaniach dołącza komponent o charakterze finansowym (np. inicjatywy edukacyjne poszerzane są o szkolenia z zakresu podnoszenia wiedzy finansowej).

${ }^{183}$ Rzadowy Program na rzecz Aktywności Spolecznej Osób Starszych na lata 2014-2020, Ministerstwo Pracy i Polityki Społecznej, Warszawa 2013, s. 22-24. 



\section{Rozdział II. Ocena dostępności i atrakcyjności usług bankowych dla osób w wieku 50+}

\subsection{Potrzeby i zachowania finansowe gospodarstw domowych}

\subsubsection{Typologia i determinanty potrzeb i zachowań finansowych gospodarstw domowych ze szczególnym uwzględnieniem osób z segmentu $50+$}

Zachowania ekonomiczne gospodarstw domowych wiążą się z gospodarowaniem majątkiem i budżetem domowym i oznaczają sposoby pozyskiwania i wykorzystania finansowych i niefinansowych składników majątkowych ${ }^{1}$. Ludzie podejmują określone zachowania finansowe w celu zaspokojenia potrzeb finansowych, tj.: przechowywania i zabezpieczania środków pieniężnych, kontroli nad nimi, dostępu do nich oraz realizacji przyszłych celów poprzez oszczędzanie, inwestowanie, zaciąganie kredytów, ubezpieczanie się ${ }^{2}$. Wiąże się to zatem z korzystaniem z usług oferowanych przez różne instytucje finansowe (w szczególności banki).

Można wskazać pięć podstawowych potrzeb finansowych, które mogą być zaspokajane przez banki ${ }^{3}$ :

- potrzeba dostępu do gotówki - ludzie odczuwają potrzebę stałego dostępu do gotówki, zatem banki oferują produkty i usługi umożliwiające zaspokojenie tej potrzeby (wypłaty w placówkach bankowych, karty płatnicze, karty bankomatowe, czeki);

${ }^{1}$ C. Bywalec, Ekonomika i finanse gospodarstw domowych, Wydawnictwo Naukowe PWN, Warszawa 2009, s. 105.

${ }^{2}$ D. Fatuła, Zachowania polskich gospodarstw domowych na rynku finansowym, Wydawnictwo Uniwersytetu Ekonomicznego w Krakowie, Kraków 2010, s. 34.

${ }^{3}$ D. A. Yorke, The Definition of Market Segments for Banking Services, "European Journal of Marketing" 1982, s. Vol. 16, Issue 3, s. 14-22. 
- potrzeba bezpieczeństwa środków - istnieje konieczność zapewnienia fizycznego bezpieczeństwa gotówki (ochrona przed utratą pieniędzy), a także zabezpieczenia przed obniżeniem wartości posiadanych zasobów; depozyty pozwalają zaspokoić obie potrzeby (w szczególności dotyczy to oprocentowanych lokat);

- potrzeba transferu środków - potrzeba realizacji transakcji, przesyłania środków na odległość bez konieczności posługiwania się gotówką; rozwój technologiczny umożliwił znaczne skrócenie czasu realizacji transakcji bezgotówkowych (obecnie możliwe jest wykonywanie operacji w czasie rzeczywistym);

- potrzeba odroczenia płatności - z uwagi na chęć odroczenia płatności w czasie (opóźnienia płatności), klienci zaciągają w banku kredyty, pożyczki, dokonują płatności kartami kredytowymi;

- potrzeba doradztwa finansowego - jako że produkty i rynki finansowe stają się coraz bardziej skomplikowane, klienci potrzebują rzetelnej i uczciwej informacji i porady w celu dokonania optymalnego wyboru.

Aby zaistniało zachowanie konsumenta na rynku, konieczne są:

- motywacja do zaangażowania się w określone zachowanie - może być związana z wrodzoną ciekawością (potrzebą poznania), wewnętrznymi zainteresowaniami, stosunkiem osobistym lub zewnętrznymi bodźcami (działaniami promocyjnymi firm, informacją nieformalną, radami znajomych itp.);

- zdolności umożliwiające zaangażowanie się w to zachowanie - są związane $\mathrm{z}$ intelektualnymi predyspozycjami konsumenta (inteligencją) oraz posiadaną wiedzą, umiejętnościami, doświadczeniem rynkowym, a także posiadanymi zasobami finansowymi (i ewentualnie innymi);

- postrzegane możliwości, które sprzyjają zaangażowaniu się w to zachowanie - związane są z przychylnością (lub jej brakiem) otoczenia, w którym zachowanie ma mieć miejsce (zróżnicowanie oferty rynkowej, dostępność firm oferujących dane produkty i usługi, dostępność produktu lub usługi).

Wszystkie z wymienionych czynników są niezbędne dla wystąpienia określonych zachowań konsumentów.

Do kluczowych determinant kształtujących zachowania ekonomiczne gospodarstw domowych należą: biologiczne i ekologiczne, ekonomiczne, demograficzne i społeczne, kulturowe ${ }^{5}$. Podsumowuje je tablica 11.

Można wyodrębnić kilka poziomów zachowań finansowych, tworzących określoną hierarchię. Generalnie ludzie angażują się w pewne rodzaje zachowań dopiero po realizacji działań na niższych poziomach, choć w indywidualnych przypadkach mogą one występować równolegle lub w innej kolejności, zależnie

${ }^{4}$ S. Smyczek, Modele zachowań konsumentów na rynku ustug finansowych, Wydawnictwo Akademii Ekonomicznej w Katowicach, Katowice 2007, s. 90-92.

${ }^{5}$ C. Bywalec, Ekonomika i finanse..., s. 105 i nast. 
od osobistych motywów. Niektóre zachowania mają charakter podstawowy i dotyczą wszystkich osób, część natomiast ma charakter wyższego rzędu i nie jest podejmowana przez wszystkich ${ }^{6}$.

Tablica 11. Determinanty zachowań ekonomicznych gospodarstw domowych

\begin{tabular}{|c|c|}
\hline Determinanty & Znaczenie \\
\hline $\begin{array}{l}\text { Biologiczne } \\
\text { i ekologiczne }\end{array}$ & $\begin{array}{l}\text { - właściwości anatomiczne i fizjologiczne człowieka (wiek, wzrost, waga, stan } \\
\text { zdrowia, sprawność fizyczna, struktura psychiczna) wpływają na potencjał } \\
\text { fizyczny i intelektualny człowieka, a w konsekwencji na wielkość i rodzaj } \\
\text { nakładów pracy, potrzeby żywieniowe, potrzeby osłony (odzieżowe i miesz- } \\
\text { kaniowe), potrzeby rekreacji (odpoczynku, relaksu) itp. } \\
\text { - środowisko przyrodnicze, w którym człowiek żyje (klimat, ukształtowanie te- } \\
\text { renu, pogoda, krajobraz itd.) wpływa na odmienność stylów życia człowieka, } \\
\text { sposoby odżywiania się, ubierania, mieszkania, pracy i odpoczynku }\end{array}$ \\
\hline Ekono & $\begin{array}{l}\text { - rodzaj i stopień aktywności gospodarczej członków gospodarstwa domowego } \\
\text { - zasoby majątkowe gospodarstwa i dostęp do dóbr publicznych } \\
\text { - dochody bieżące gospodarstwa i sposoby ich pozyskiwania } \\
\text { - poziom i relacje dóbr nabywanych przez gospodarstwo } \\
\text { - podaż dóbr nabywanych przez gospodarstwo i sposoby ich dystrybucji }\end{array}$ \\
\hline $\begin{array}{l}\text { Demograficzne } \\
\text { i społeczne }\end{array}$ & $\begin{array}{l}\text { - skład gospodarstwa domowego (liczba członków, płeć, wiek itd.) } \\
\text { - faza rozwojowa gospodarstwa domowego } \\
\text { - aktywność i pozycja zawodowa członków gospodarstwa domowego } \\
\text { - poziom i rodzaj wykształcenia członków gospodarstwa domowego } \\
\text { - aspiracje zawodowe, kulturowe i społeczne członków gospodarstwa domowego } \\
\text { - więzi członków gospodarstwa domowego z otoczeniem }\end{array}$ \\
\hline Kultı & $\begin{array}{l}\text { - przyzwyczajenia, obyczaje, zwyczaje, tradycje, nawyki, konwencje, stereoty- } \\
\text { py (narodowe, lokalne, rodzinne) } \\
\text { - systemy wartości } \\
\text { - oddziaływanie wzorców konsumpcji } \\
\text { - czas wolny (zasoby, sposoby spędzania) } \\
\text { - edukacja ekonomiczna w zakresie: } \\
\text { - potrzeb oraz środków i skutków ich zaspokojenia } \\
\text { - pracy i pozyskiwania dóbr materialnych i środków finansowych } \\
\text { - racjonalnego gospodarowania środkami finansowymi (oszczędzanie, ocena } \\
\text { ryzyka finansowego, zarządzanie ryzykiem) } \\
\text { - zachowania się konsumentów na rynku } \\
\text { - zachowania się człowieka w gospodarstwie domowym (obchodzenie się z na- } \\
\text { bytymi dobrami) }\end{array}$ \\
\hline
\end{tabular}

Źródło: opracowanie własne na podstawie: C. Bywalec, Ekonomika i finanse gospodarstw domowych, Wydawnictwo Naukowe PWN, Warszawa 2009, s. 105 i nast.

${ }^{6}$ M. Krasucka, M. Maciejasz-Świątkiewicz, J. Pieczonka, R. Poskart, Produkty i ustugi finansowe dla gospodarstw domowych $w$ Polsce, Wydawnictwo Uniwersytetu Opolskiego, Opole 2011, s. 21. 
Dokonując klasyfikacji i hierarchizacji zachowań finansowych, można odwołać się do motywów oszczędzania. Wśród wielu koncepcji warto wskazać przede wszystkim tę autorstwa Keynesa. Wyróżnił on motywy: ostrożności, przezorności, wyrachowania (spekulacyjny), zwiększenia dobrobytu, niezależności, przedsiębiorczości, dumy, skąpstwa ${ }^{7}$ (patrz tablica 12).

Tablica 12. Motywy oszczędzania według J. M. Keynesa

\begin{tabular}{|l|l|}
\hline \multicolumn{1}{|c|}{ Motyw } & \multicolumn{1}{|c|}{ Znaczenie } \\
\hline Ostrożności & $\begin{array}{l}\text { Tworzenie rezerw na wypadek wystąpienia nieprzewidzianych } \\
\text { wydatków (np. choroba, bezrobocie). Oszczędności stanowią } \\
\text { środek zabezpieczenia }\end{array}$ \\
\hline Przezorności & $\begin{array}{l}\text { Gromadzenie rezerw na dalszy okres życia, kiedy stosunek } \\
\text { między dochodem a potrzebami może być odmienny od stanu } \\
\text { teraźniejszego (zabezpieczenia na okres starości) lub sfinanso- } \\
\text { wanie przyszłych potrzeb (np. edukacja dzieci) }\end{array}$ \\
\hline Wyrachowania/spekulacyjny & $\begin{array}{l}\text { Wykorzystanie wyższej stopy procentowej w celu pomnożenia } \\
\text { kapitału }\end{array}$ \\
\hline Poprawy/zwiększenia dobrobytu & Chęć zapewnienia sobie wyższej stopy życiowej w przyszłości \\
\hline Niezależności & $\begin{array}{l}\text { Zapewnienie sobie możliwości realizacji swoich zamierzeń, } \\
\text { poczucie niezależności i swobody }\end{array}$ \\
\hline Przedsiębiorczości & $\begin{array}{l}\text { Możliwość zgromadzenia kapitału na prowadzenie działalności } \\
\text { gospodarczej }\end{array}$ \\
\hline Dumy/spadku & $\begin{array}{l}\text { Potrzeba pozostawienia po sobie spadku w postaci majątku } \\
\text { (np. ze względu na chęć zabezpieczenia dzieci) }\end{array}$ \\
\hline Skąpstwa & $\begin{array}{l}\text { Ograniczenie bieżących wydatków jako wyraz niechęci do wy- } \\
\text { dawania pieniędzy }\end{array}$ \\
\hline
\end{tabular}

Źródło: J. Harasim (red.), Oszczędzanie i inwestowanie w teorii i praktyce, Polskie Towarzystwo Ekonomiczne Oddział w Katowicach, Katowice 2010, s. 38.

Wielu innych autorów wymienia jeszcze inne motywy $^{8}$, w tym np. zapewnienie płynności gospodarstwa domowego, przekonanie o konieczności oszczędzania, chęć przesunięcia konsumpcji w czasie, konieczność liczenia tylko na siebie, uzyskiwanie stabilnych dochodów z oszczędności. Najbardziej spopularyzowanym hierarchicznym modelem motywów zarządzania finansami osobistymi jest model Lindqvista9 : najbardziej podstawowym motywem jest zarządzanie

${ }^{7}$ J. M. Keynes, Ogólna teoria zatrudnienia, procentu i pieniądza, Wydawnictwo Naukowe PWN, Warszawa 2003, s. 82.

${ }^{8}$ Ich przegląd przedstawia m.in. S. Białowąs, Zachowania oszczędnościowe w polskich gospodarstwach domowych. Postawy, determinanty, model, Wydawnictwo Uniwersytetu Ekonomicznego w Poznaniu, Poznań 2013, s. 39 i nast.

9 A. Lindqvist, A note on determinants of household saving behavior, "Journal of Economic Psychology" 1981, Vol. 1, Issue 1, s. 39-57. 
gotówką (płynnością), następnie gromadzenie oszczędności buforowych (zabezpieczenie wydatków związanych z nieprzewidzianymi zdarzeniami) oraz oszczędzanie na konkretny cel, zaś na samym szczycie motywów jest chęć zarządzania majątkiem (pomnażania go).

Uwzględniając powyższe rozważania, można wskazać ogólną hierarchię tych zachowań, w kontekście ich motywów (rysunek 22). Najbardziej podstawowym zachowaniem jest zarządzanie budżetem i gotówką, wynikające z motywów płynnościowych i transakcyjnych.

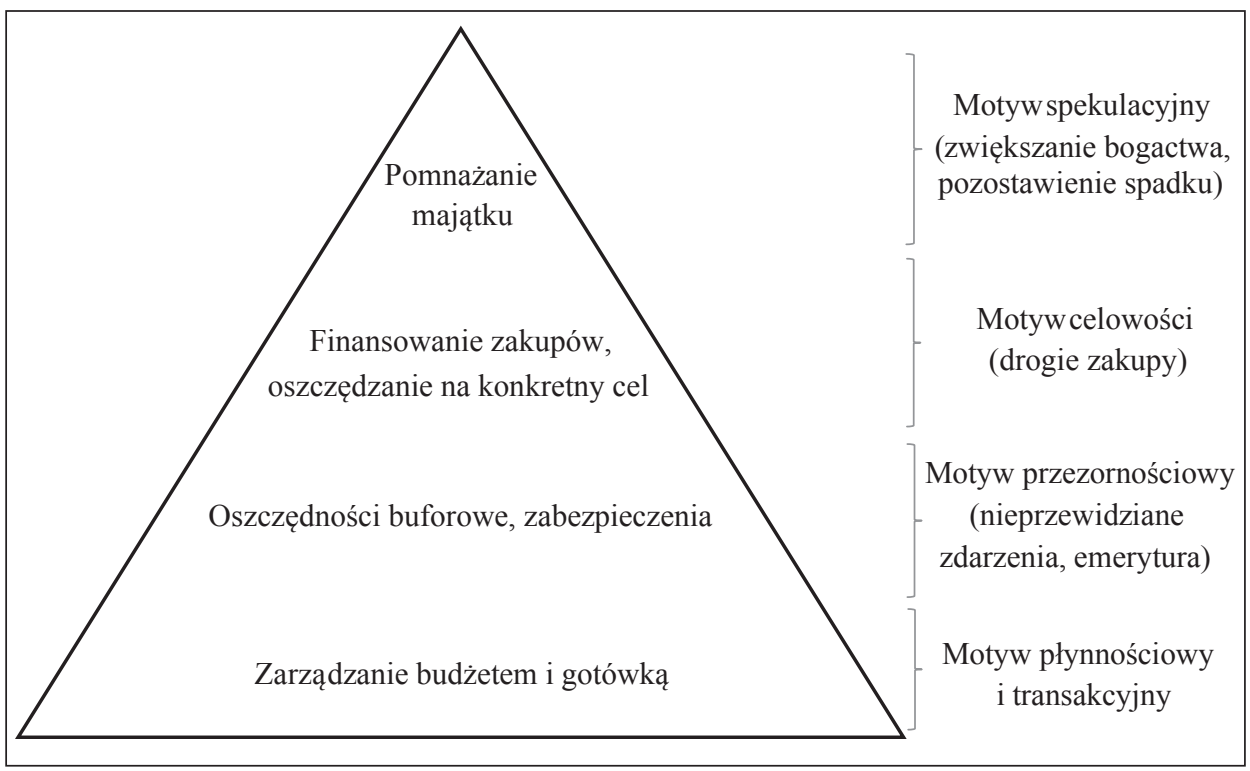

Rysunek 22. Hierarchia zachowań finansowych i ich motywy

Źródło: opracowanie własne na podstawie: A. Lindqvist, A note on determinants of household saving behavior, "Journal of Economic Psychology" 1981, Vol. 1, Issue 1, s. 39-57; M. Krasucka, M. Maciejasz-Świątkiewicz, J. Pieczonka, R. Poskart, Produkty i ustugi finansowe dla gospodarstw domowych w Polsce, Wydawnictwo Uniwersytetu Opolskiego, Opole 2011, s. 22 oraz S. Białowąs, Zachowania oszczędnościowe w polskich gospodarstwach domowych. Postawy, determinanty, model, Wydawnictwo Uniwersytetu Ekonomicznego w Poznaniu, Poznań 2013, s. 50

Poszczególne motywy odgrywają inne znaczenie na różnych etapach życia człowieka. Badania empiryczne ${ }^{10}$ potwierdzają, że chęć zachowania płynności finansowej - jak wspomniano - ma charakter podstawowy i jest ona dominującym motywem we wszystkich okresach życia. Motyw przezornościowy (chęć zapewnienia środków na nieprzewidziane zdarzenia) jest drugi w hierarchii i znaczenie tego motywu nie zmienia się istotnie w czasie (relatywnie mniejsze znaczenie ma

${ }^{10}$ S. Białowąs, Zachowania oszczędnościowe..., s. 51 i nast. 
on wśród osób najmłodszych, jednak później utrzymuje się na względnie stałym poziomie). Inny aspekt przezorności - chęć zabezpieczenia emerytury - początkowo ma niewielkie znaczenie, ale rośnie w czasie - wśród osób powyżej 40. roku życia stanowi trzeci co do znaczenia motyw (a jego istotność nieznacznie rośnie wraz ze zbliżaniem się okresu emerytalnego). Motyw celowości ma najmniejsze znaczenie w ostatnich etapach życia, a dość silne - w początkowych (gdy istnieje silniejsza potrzeba sfinansowania wielu drogich zakupów). Znaczenie motywu spekulacyjnego (w rozumieniu chęci pomnożenia majątku, zwiększenia bogactwa) spada z wiekiem; początkowo motyw ten jest bardzo istotny (tuż po motywie płynnościowym i przezornościowym), by w ostatnich latach mocno tracić na znaczeniu. Odwrotną natomiast prawidłowość obserwuje się w przypadku motywu spekulacyjnego, rozumianego jako chęć pozostawienia spadku - do ok. 40. roku życia ten aspekt ma najmniejsze znaczenie, najwyższe notowania ma zaś u osób najstarszych (wyprzedzając chęć pomnożenia majątku i finansowania drogich zakupów). Podsumowanie znaczenia poszczególnych motywów oszczędzania wśród osób w różnym wieku przedstawia rysunek 23.

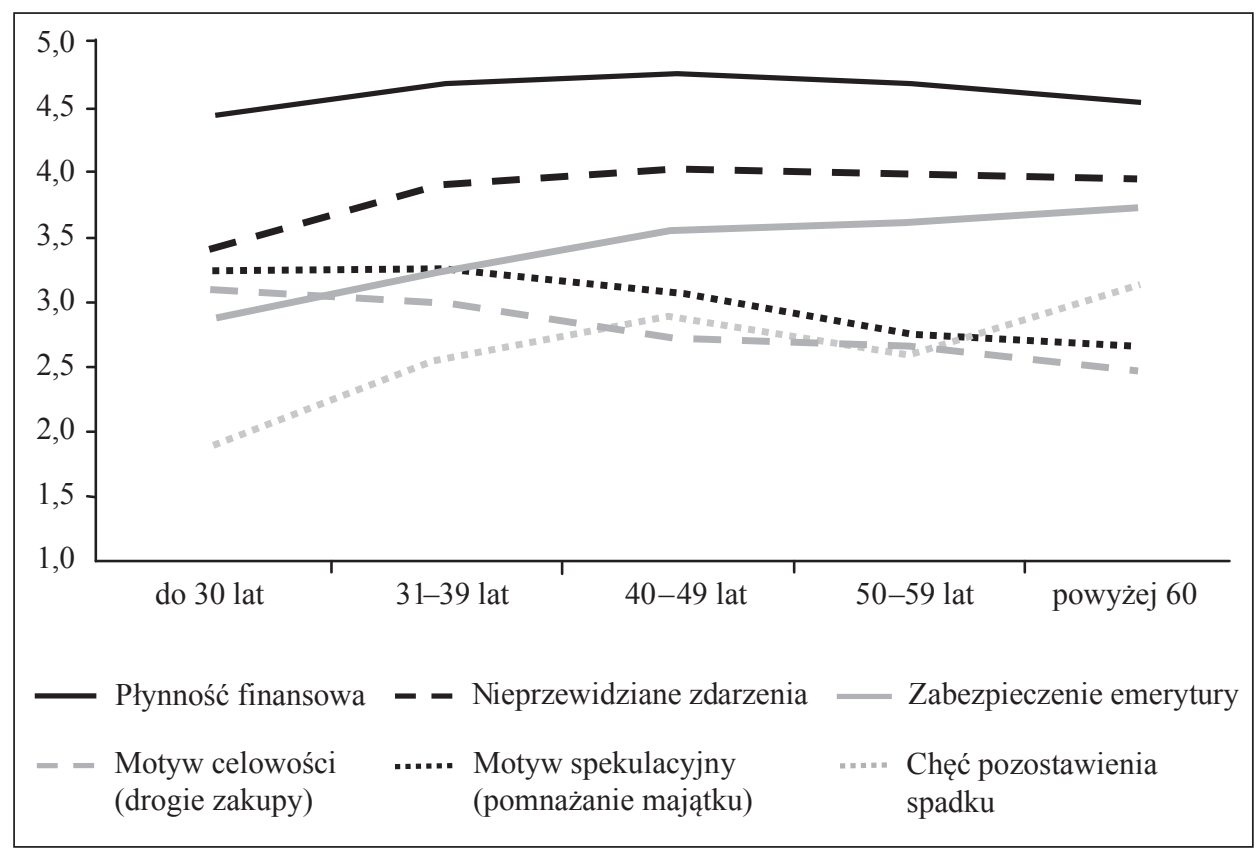

Rysunek 23. Motywy oszczędzania a wiek

Źródło: opracowanie własne na podstawie: S. Białowąs, Zachowania oszczędnościowe..., s. 52

Warto też zauważyć, że wiek jest jednym z kluczowych czynników (obok m.in. wykształcenia, poziomu wiedzy finansowej, dochodów, poziomu awersji do ryzyka), który wpływa na skłonność do oszczędzania. W teorii skłonność 
do konsumpcji maleje wraz z dochodami, a skłonność do oszczędzania - odwrotnie $^{11}$. Zważywszy na zależność między wiekiem a dochodami, a także na ścieżki konsumpcji (zależne od fazy cyklu życia gospodarstw domowego) ${ }^{12}$, można dowieść kształtowania się skłonności do oszczędzania i konsumpcji w zależności od wieku. Badania empiryczne wskazują, że skłonność do oszczędzania jest najniższa u osób najmłodszych i rośnie do ok. 70. roku życia, by następnie znów się zmniejszać13 (patrz rysunek 24).

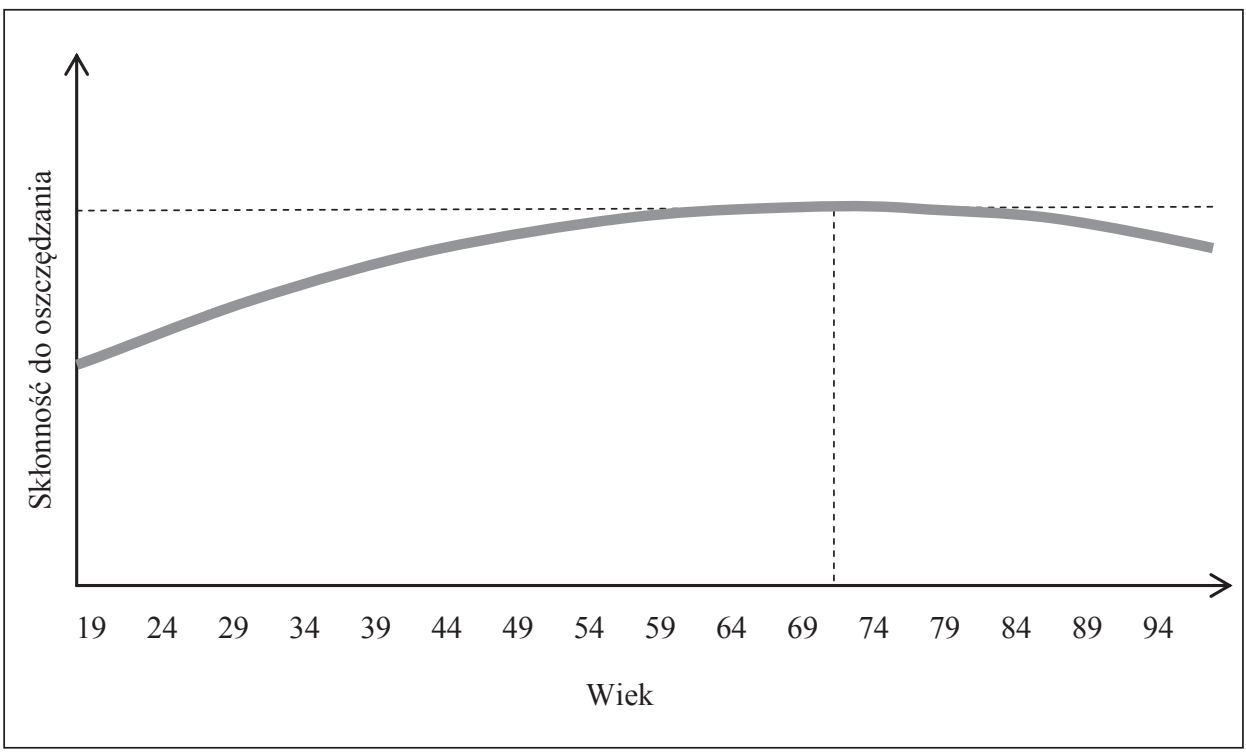

Rysunek 24. Zależność między skłonnością do oszczędzania a wiekiem

Źródło: opracowanie własne na podstawie: E. Beckmann, M. Hake, J. Urvova, Determinants of Households' Savings in Central, Eastern and Southeastern Europe, "Focus on European Economic Integration", Q3/13, s. 8-29

Na kształtowanie się poziomu konsumpcji wpływają dodatkowo transfery międzypokoleniowe: we wczesnych latach - transfery otrzymywane od rodziców, w późnych latach - transfery przekazywane do dzieci. Poziom i skala tych transferów zależą w znacznej mierze od zamożności rodziców (i dzieci) oraz wzorców kulturowych (tradycji solidarności międzypokoleniowej lub samodzielności).

11 J. M. Keynes, Ogólna teoria zatrudnienia..., s. 28.

${ }^{12}$ Można tu przywołać hipotezę cyklu życia Modiglianiego i Ando. A. Ando, F. Modigliani, The "Life Cycle" Hypothesis of Saving: Aggregate Implications and Tests, "The American Economic Review" 1963, Vol. 53, No. 1, Part 1, s. 55-84.

${ }^{13}$ E. Beckmann, M. Hake, J. Urvova, Determinants of Households' Savings in Central, Eastern and Southeastern Europe, "Focus on European Economic Integration", Q3/13, s. 8-29. 
Wymienione determinanty są ogólnymi charakterystykami wyznaczającymi różnice $\mathrm{w}$ zachowaniach finansowych ludzi. Dodatkowo istotne znaczenie mają indywidualne czynniki psychograficzne. Na podstawie analizy podejścia do zakupów, wydawania pieniędzy, kontroli rachunków, kosztów, cen itp., można wyznaczyć trzy wymiary zarządzania pieniędzmi (domowym budżetem) ${ }^{14}$ :

- zaciskanie pasa - postawa polegająca na ograniczaniu wszelkich wydatków (kupowanie tanich rzeczy, poszukiwanie promocji i przecen, wybieranie tańszych zamienników),

- gospodarność - wiąże się z racjonalnym planowaniem wydatków i rozważnym zarządzaniem domowym budżetem (dobre planowanie, świadomość wydatków, płacenie rachunków w terminie, wygospodarowanie oszczędności),

- łatwość wydawania pieniędzy - oznacza czerpanie przyjemności z zakupów, bawienie się nimi, może przejawiać się w skłonności do rozrzutności.

Rysunek 25 podsumowuje kluczowe zależności między tymi stylami a głównymi zmiennymi demograficznymi. Postawa zaciskania pasa jest najsilniejsza wśród osób o niższym wykształceniu, mniejszej wiedzy ekonomicznej i niższych dochodach. Wysoka gospodarność cechuje osoby z wyższym wykształceniem i większą wiedzą ekonomiczną. Gospodarność jest dość niska wśród najmłodszych osób, a w kolejnych stadiach życia utrzymuje się na zbliżonym poziomie. Łatwość wydawania pieniędzy cechuje przede wszystkim osoby młode (później znacząco zmniejsza się z wiekiem), osoby o wyższym wykształceniu i wyższych dochodach, równocześnie lepiej oceniających stan swojej wiedzy ekonomicznej.

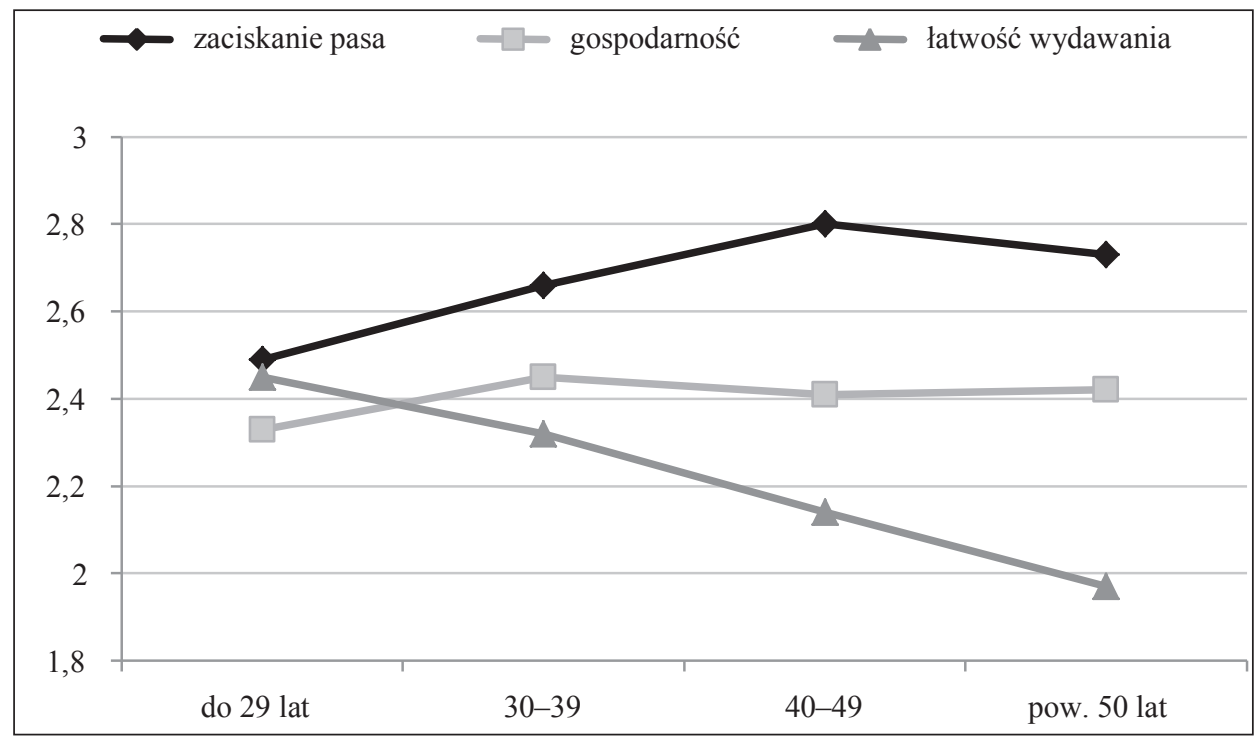

${ }^{14}$ D. Maison, Polak w świecie finansów, Wydawnictwo Naukowe PWN, Warszawa 2013, s. $61 \mathrm{i}$ nast. 

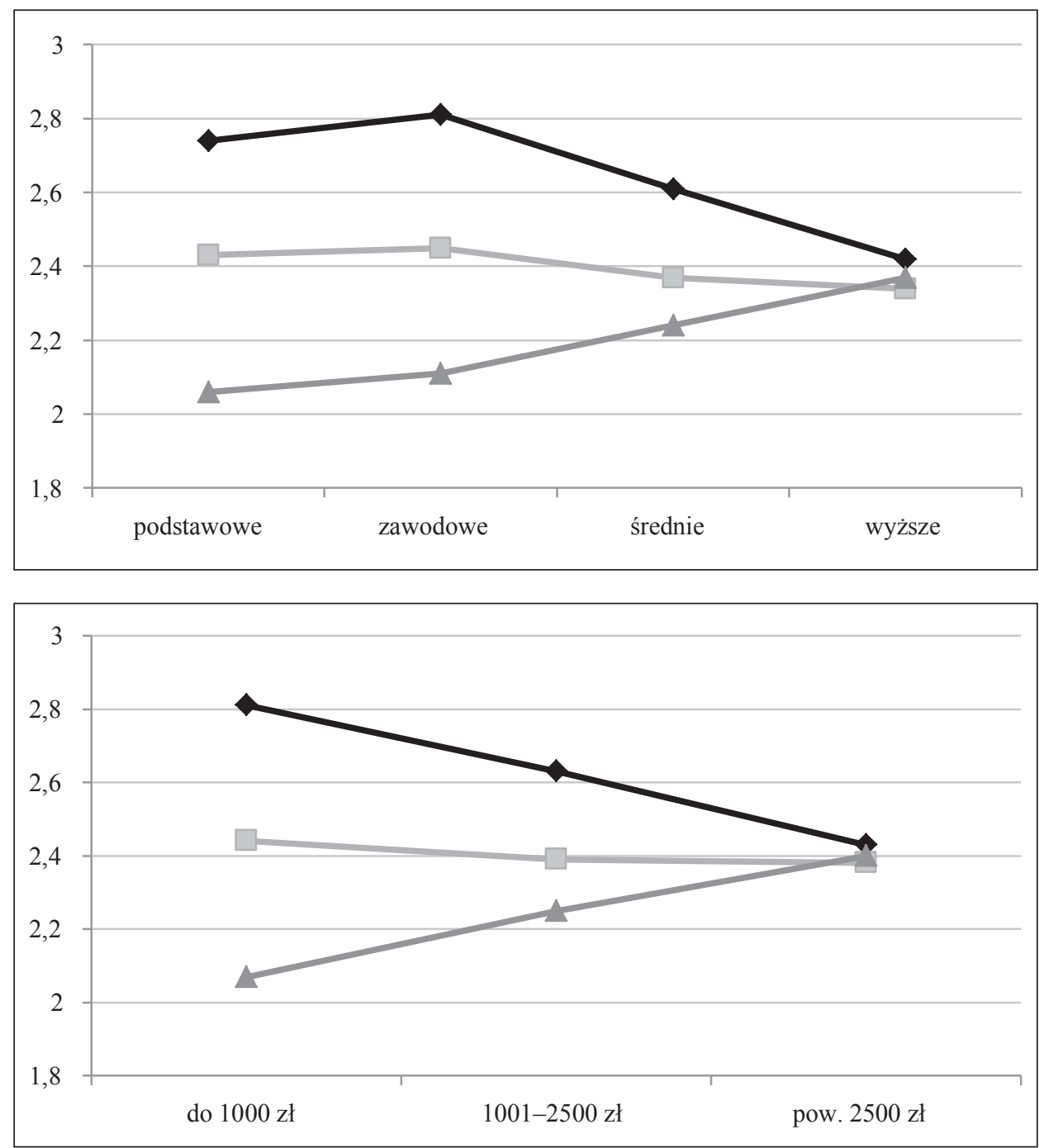

Rysunek 25. Style wydawania pieniędzy a zmienne demograficzne

Źródło: opracowanie własne na podstawie: D. Maison, Polak w świecie finansów, Wydawnictwo Naukowe PWN, Warszawa 2013, s. 63

Wymienione determinanty i motywacje mają wpływ na kształtowanie indywidualnych postaw i zachowań gospodarstw domowych w sferze zarządzania finansami i określają zapotrzebowanie na konkretne produkty finansowe (w tym w szczególności bankowe). Warto przy tym podkreślić, że zachowania finansowe charakteryzują się różnym poziomem racjonalności. W zależności m.in. od emocji, wiedzy finansowej, umiejętności analizowania informacji, ale także 
uwarunkowań osobistych i społecznych, decyzje finansowe (podjęcie określonych zachowań, dokonywanie określonych decyzji i wyboru produktów finansowych) mogą mieć bardziej lub mniej racjonalny charakter (patrz tablica 13) ${ }^{15}$.

Tablica 13. Zachowania finansowe - podział ze względu na racjonalność podejmowanych decyzji

\begin{tabular}{|c|c|c|c|c|}
\hline & $\begin{array}{c}\text { Zachowania } \\
\text { racjonalne }\end{array}$ & $\begin{array}{c}\text { Zachowania } \\
\text { nawykowe }\end{array}$ & $\begin{array}{l}\text { Zachowania } \\
\text { impulsywne }\end{array}$ & $\begin{array}{c}\text { Zachowania } \\
\text { uwarunkowane } \\
\text { względami } \\
\text { społecznymi }\end{array}$ \\
\hline $\begin{array}{l}\text { Stopień } \\
\text { planowania }\end{array}$ & Planowane & $\begin{array}{l}\text { Planowane } \\
\text { lub nieplanowane }\end{array}$ & Nieplanowane & Planowane \\
\hline $\begin{array}{l}\text { Stopień } \\
\text { przetwarzania } \\
\text { informacji }\end{array}$ & $\begin{array}{l}\text { Duże zapotrzebo- } \\
\text { wanie na infor- } \\
\text { macje }\end{array}$ & $\begin{array}{l}\text { Niski, automa- } \\
\text { tyzm działania }\end{array}$ & $\begin{array}{l}\text { Niski, działanie } \\
\text { spontaniczne, } \\
\text { szybkie }\end{array}$ & $\begin{array}{l}\text { Niski, działania } \\
\text { pod wpływem } \\
\text { poglądów, opinii } \\
\text { i systemów war- } \\
\text { tości innych osób } \\
\text { lub instytucji }\end{array}$ \\
\hline $\begin{array}{l}\text { Zaangażowanie } \\
\text { emocjonalne }\end{array}$ & Małe & Małe & Duże & Średnie \\
\hline $\begin{array}{l}\text { Zaangażowanie } \\
\text { procesów } \\
\text { poznawczych }\end{array}$ & Duże & Małe & Małe & Małe \\
\hline Przykłady & $\begin{array}{l}\text { Wybór kredytu } \\
\text { poparty dokład- } \\
\text { nym poszukiwa- } \\
\text { niem najlepszej } \\
\text { oferty }\end{array}$ & $\begin{array}{l}\text { Wybór kredytu } \\
\text { w banku, w któ- } \\
\text { rym od lat prowa- } \\
\text { dzony jest ROR }\end{array}$ & $\begin{array}{l}\text { Wybór kredytów } \\
\text { podczas zakupów } \\
\text { lub pod wpływem } \\
\text { reklamy }\end{array}$ & $\begin{array}{l}\text { Wybór kredytu } \\
\text { w banku, o którym } \\
\text { otoczenie mówi, } \\
\text { że jest jedynym } \\
\text { uczciwym ban- } \\
\text { kiem na rynku }\end{array}$ \\
\hline
\end{tabular}

Źródło: E. Bogacka-Kisiel (red.), Finanse osobiste. Zachowania - produkty - strategie, Wydawnictwo Naukowe PWN, Warszawa 2012, s. 41.

Wśród kluczowych czynników wpływających na zachowania ekonomiczne należy wymienić także czynniki związane z indywidualnymi nadziejami (pragnieniami) i obawami konsumentów. Można tu wskazać czynniki ogólne, typowe (w różnym stopniu) dla wszystkich grup gospodarstw domowych, jak i czynniki specyficzne dla określonych środowisk. Wśród powszechnie obserwowanych pragnień finansowych można wskazać m.in. nadzieję wyższych dochodów, posiadania domu, dobrego samochodu itp. Obawy finansowe wiążą się natomiast z ryzykiem utraty pracy, brakiem wystarczających środków

15 Szerzej na temat racjonalności podmiotów ekonomicznych patrz także T. Tyszka (red.), Psychologia ekonomiczna, Gdańskie Towarzystwo Ekonomiczne, Gdańsk 2004, s. 39 i nast. oraz o zachowaniach konsumenckich - ibidem, s. 427 i nast. 
na pokrycie bieżących wydatków, kosztami opieki zdrowotnej w przypadku wystąpienia problemów; gospodarstwa domowe odczuwają także niepokój związany z ogólnym stanem gospodarki (który przełoży się na kondycję finansową i możliwości zarobkowania gospodarstw) ${ }^{16}$. Tablica 14 podsumowuje nadzieje i obawy finansowe gospodarstw domowych, wyodrębniając dodatkowo specyficzne wskazania ze strony osób nieubankowionych i niedostatecznie ubankowionych.

Tablica 14. Nadzieje i obawy finansowe konsumentów

\begin{tabular}{|l|l|l|}
\hline \multicolumn{1}{|c|}{ Respondenci } & \multicolumn{1}{|c|}{ Nadzieje, pragnienia } & \multicolumn{1}{c|}{ Obawy } \\
\hline Ogółem & - Posiadanie domu & - Utrata pracy \\
& - Dobry samochód & - Brak wystarczających kwot pie- \\
niędzy & - Brak możliwości opłacenia rachun- \\
& & ków \\
& & - Problemy zdrowotne/koszty opieki \\
& & zdrowotnej \\
& & - Stan gospodarki \\
\hline Nieubankowieni & - Oszczędzanie na przyszłość & - Problemy zdrowotne/koszty opieki \\
$($ unbanked $)$ & - Finansowanie edukacji dzieci & zdrowotnej \\
& - Lepsze zarządzanie budżetem & - Jak oszczędzać pieniądze i nie \\
& - Brak konieczności życia od wypłaty & roztrwonić ich \\
& do wypłaty & - Upadłość konsumencka \\
& & - Długi \\
\hline $\begin{array}{l}\text { Niedostatecznie } \\
\text { ubankowieni } \\
(\text { underbanked })\end{array}$ & - Plany oszczędnościowe & - Brak środków na edukację dzieci \\
& - Srodki na niespodziewane wydatki & - Problemy zdrowotne/koszty opieki \\
& - Pieniądze na emeryturę & zdrowotnej \\
& - Spłacenie długów & - Brak oszczędności; brak oszczęd- \\
& & ności na emeryturę \\
& & - Niespodziewane duże wydatki \\
& & - Spirala zadłużenia \\
& & - Licytacja majątku za długi \\
\hline
\end{tabular}

Źródło: opracowanie własne na podstawie: Federal Reserve Bank of Kansas City, A Study of the Unbanked \& Underbanked Consumer in the Tenth Federal Reserve District, May 2010, www. kansascityfed.org/publicat/research/ community/Unbanked.Report.pdf, s. 4.

Uwzględniając powyższe czynniki subiektywne i emocjonalne, tym większe znaczenie ma tu kwestia po pierwsze edukacji finansowej konsumentów, prostej, zrozumiałej konstrukcji produktów finansowych, ale także etycznych reklam tych produktów i uczciwego postępowania pracowników instytucji finansowych, które

${ }^{16}$ Federal Reserve Bank of Kansas City, A Study of the Unbanked \& Underbanked Consumer in the Tenth Federal Reserve District, May 2010, www.kansascityfed.org/publicat/research/community/Unbanked. Report.pdf, s. 4. 
ułatwią kształtowanie kompetencji finansowych konsumentów. To właśnie ów ostatni aspekt jawi się jako podstawowy obowiązek i odpowiedzialność zarówno samego banku, jak i poszczególnych pracowników ${ }^{17}$.

Kompetencje finansowe, niezbędne dla skutecznego zarządzania finansami gospodarstwa domowego i podejmowania optymalnych decyzji finansowych, wymagają jednak nie tylko wiedzy, ale także umiejętności jej praktycznego wykorzystania, wykreowania odpowiedzialnych postaw finansowych i podejmowania określonych zachowań ekonomicznych (patrz rysunek 26).

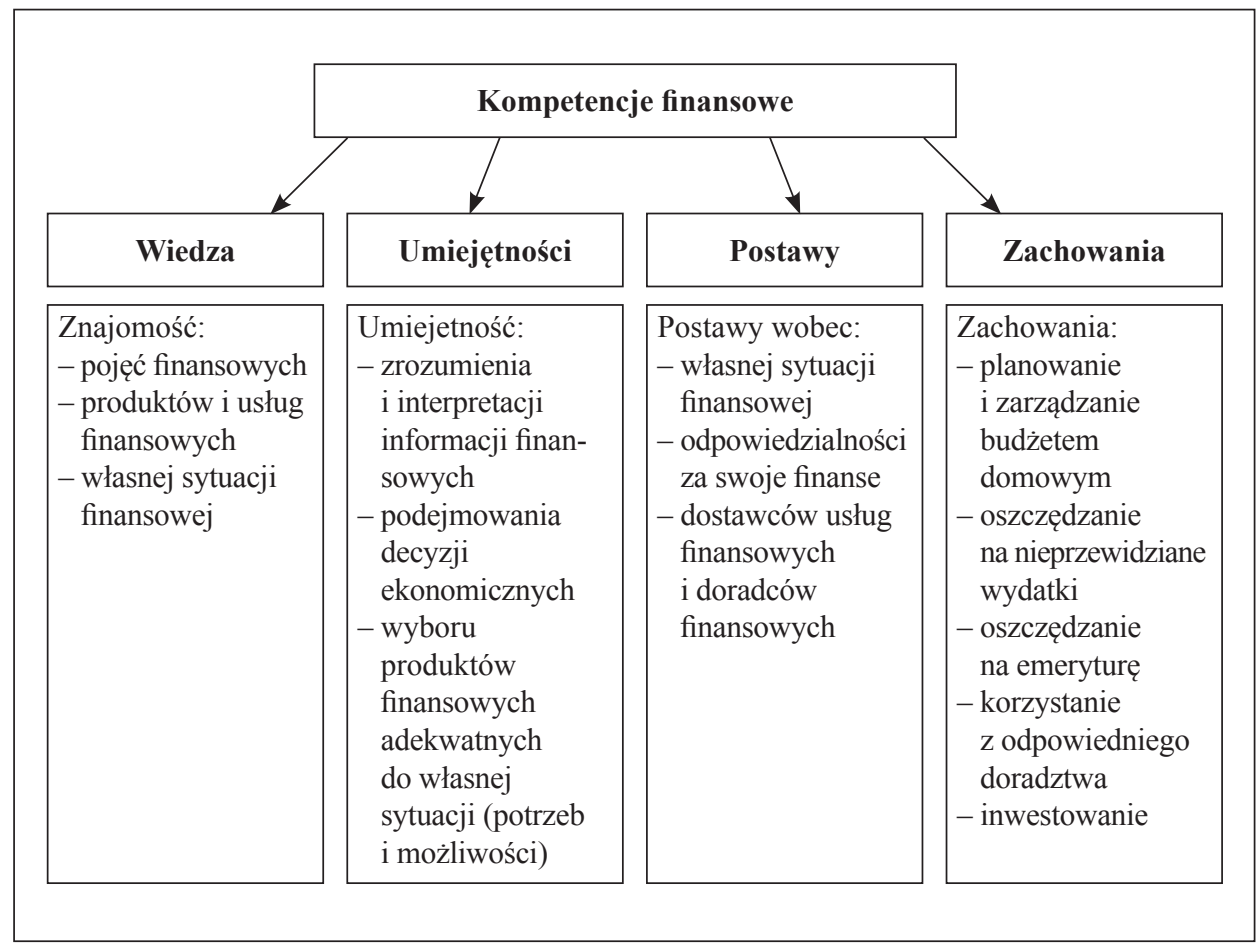

Rysunek 26. Kompetencje finansowe

Źródło: opracowanie własne na podstawie: Citi Foundation, CSR Europe, Enterprise 2020, Money Advice Service, Financial Capability for Europe's Youth and Pre-retirees. Improving the Provision of Financial Education and Advice, July 2012 oraz K. Kaczmar, Kompetencje finansowe Polaków w gospodarce rynkowej, „Infos”, 7 marca 2013, nr 5(142)

${ }^{17}$ Warto podkreślić, że zasady etyki bankowej obejmują zarówno dobre praktyki adresowane do banków (zasady dobrych praktyk bankowych), jak i ich pracowników (kodeks etyki pracownika banku). Porównaj np.: Związek Banków Polskich, Kodeks Etyki Bankowej (Zasady dobrej praktyki bankowej), Warszawa, kwiecień 2013. 


\subsubsection{Zarządzanie finansami gospodarstw domowych - zapotrzebowanie na produkty bankowe}

Kluczowymi kategoriami w zarządzaniu finansami gospodarstw domowych są:

- elementy zasobowe: aktywa i kapitały gospodarstwa oraz

- elementy przepływowe: dochody i wydatki gospodarstwa.

Aktywami (majątkiem) gospodarstwa domowego jest zasób dóbr materialnych, niematerialnych i finansowych stanowiący własność (wspólną lub indywidualną) członków gospodarstwa domowego. Majątek może służyć celom konsumpcyjnym lub do działalności wytwórczej. Może on być wyrażony w jednostkach naturalnych (sztukach, metrach, kilogramach) oraz pieniężnych ${ }^{18}$. Podobnie jak w przypadku jednostek gospodarczych, wśród aktywów gospodarstwa domowego można wyróżnić środki trwałe (np. nieruchomości, samochody, urządzenia), wartości niematerialne i prawne (np. prawa autorskie, licencje, know-how), należności (np. z tytułu udzielonych pożyczek), inwestycje (np. akcje, obligacje, dzieła sztuki). Podobnie, przez analogię, można wskazać podział kapitałów na własne i obce. Kapitały własne mogą zostać określone jako zasoby pozyskane przez członków gospodarstwa domowego w rezultacie bieżącej działalności gospodarczej, równowartość zasobów pozyskanych w drodze spadków, darowizn, zasoby otrzymywane jako wynagrodzenie za pracę, transfery socjalne (np. emerytury, renty, stypendia), zyski kapitałowe (np. odsetki, dywidendy) oraz inne dochody ${ }^{19}$. Kapitały obce są natomiast zobowiązaniami zaciąganymi przez gospodarstwo domowe na krótki lub długi termin.

W zarządzaniu finansami gospodarstw domowych podstawowe znaczenie ma budżet gospodarstwa, czyli przychody i rozchody (pieniężne i niepieniężne) w danym okresie ${ }^{20}$. Jego elementy składowe przedstawia rysunek 27.

Zarządzanie finansami gospodarstw obejmuje proces planowania wydatków konsumpcyjnych, inwestycji i pozyskiwania środków (finansowania) w celu optymalizacji sytuacji finansowej gospodarstwa. Planowanie finansowe dotyczy trzech aktywności o charakterze długoterminowym: inwestowania, pozyskiwania kapitału (finansowania) i zabezpieczenia kapitału oraz jednej aktywności o charakterze krótkoterminowym: zarządzania płynnością gospodarstwa domowego ${ }^{21}$.

${ }^{18}$ C. Bywalec, Ekonomika i finanse..., s. 34 i nast.

19 Ibidem, s. 39.

${ }^{20}$ Por.: GUS, Budzety gospodarstw domowych w 2012 r., Warszawa 2013, s. 17.

${ }^{21}$ K. Jajuga, Bank a gospodarstwo domowe - znaczenie edukacji i doradztwa, [w:] S. Flejterski, A. Gospodarowicz (red.), Banki w spolecznej gospodarce rynkowej w świetle doświadczeń z kryzysu i stanu rozwoju rynku finansowego, Związek Banków Polskich, Warszawa 2014, s. 245-253. 


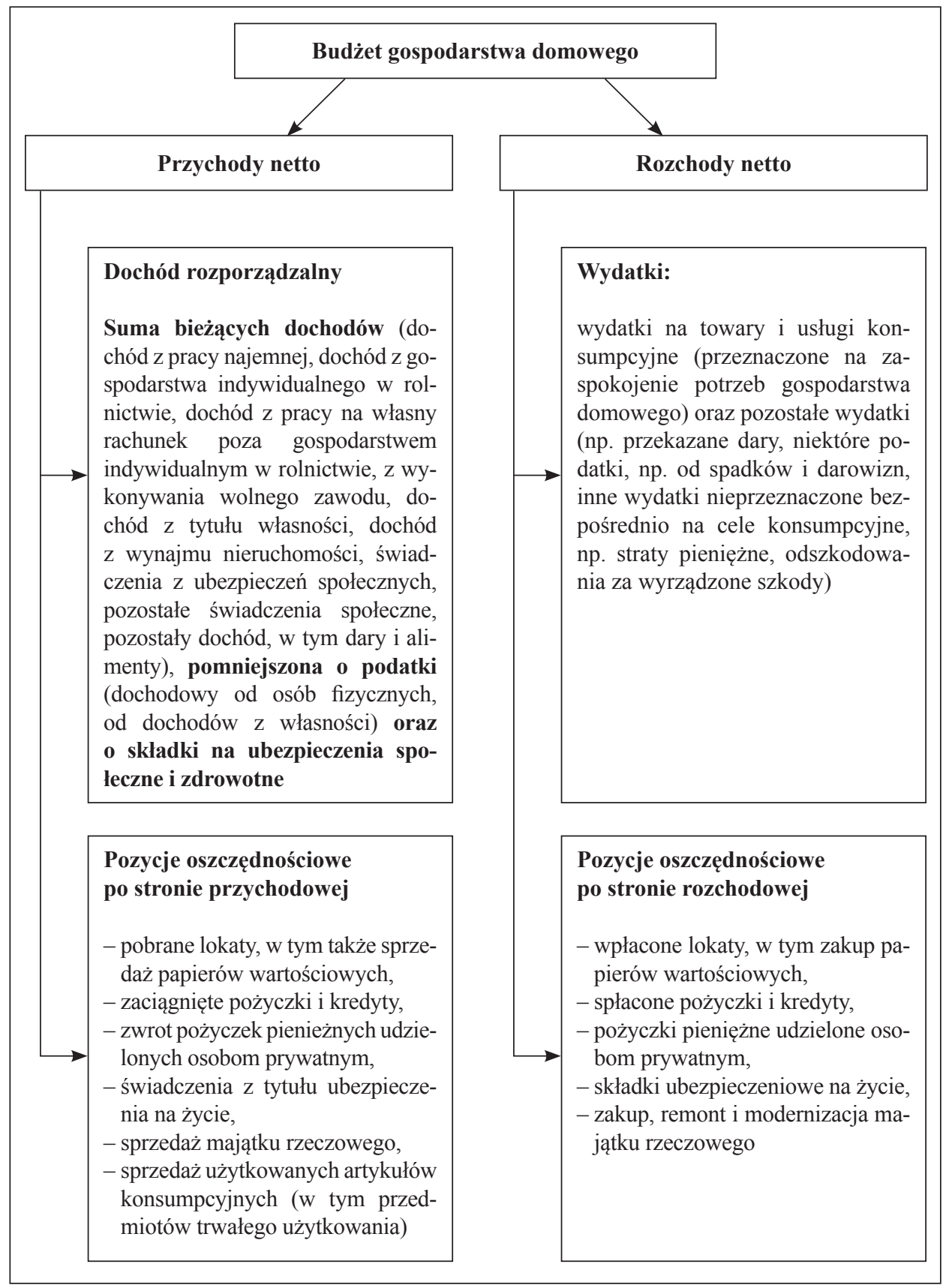

Rysunek 27. Budżet gospodarstwa domowego

Źródło: opracowanie własne na podstawie: GUS, Budżety gospodarstw domowych w 2012 r, Warszawa 2013, s. 17 i nast. 
Można wskazać podstawowe zależności dotyczące przepływów gotówkowych dokonywanych przez gospodarstwa domowe. Dochody przeznaczane są na konsumpcję. W przypadku, gdy bieżące dochody są wyższe od potrzeb konsumpcyjnych, nadwyżka przeznaczana jest na oszczędności i inwestycje. Jeśli natomiast potrzeby konsumpcyjne są wyższe od dochodów, gospodarstwo może zaciągnąć zobowiązanie w celu ich realizacji. Zobowiązania mogą być także zaciągane w celu zakupu inwestycji (np. nieruchomości, papierów wartościowych itd.). Na spłatę tych zobowiązań gospodarstwo będzie musiało wyasygnować część dochodów, względnie na spłatę może zostać przeznaczona część oszczędności lub inwestycji, lub zaciągnięte kolejne zobowiązanie. Przepływy pieniężne mogą także wystąpić w obrębie posiadanych przez gospodarstwo oszczędności i inwestycji (reinwestycja zysków, zmiana struktury instrumentów finansowych). Procesy te podsumowuje schematycznie rysunek 28.

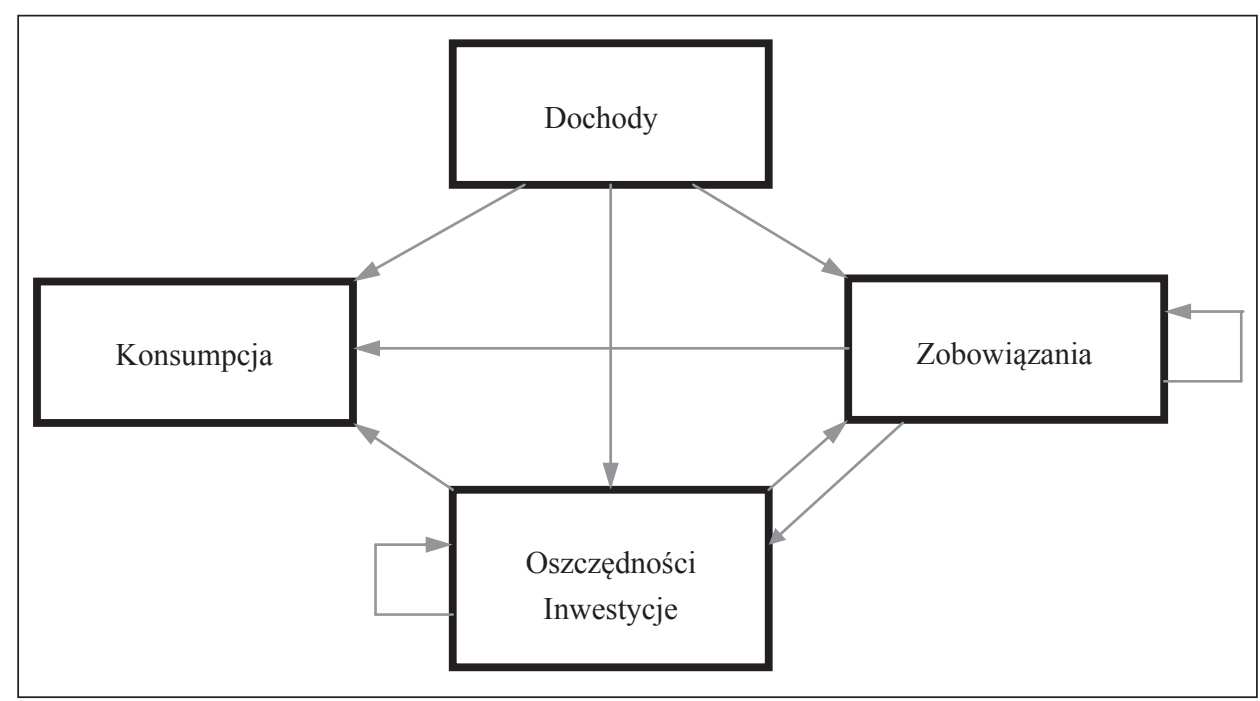

Rysunek 28. Schemat przepływów gotówkowych w gospodarstwie domowym

Źródło: opracowanie własne na podstawie: D. Fatuła, Zachowania polskich gospodarstw domowych na rynku finansowym, Wydawnictwo Uniwersytetu Ekonomicznego w Krakowie, Kraków 2010, s. 46

Na poziom zobowiązań oraz oszczędności i inwestycji wpływa wielkość dochodów, a także potrzeby konsumpcyjne (te mogą być nieograniczone). Konieczność i pilność realizacji potrzeb konsumpcyjnych ma w pewnym zakresie charakter obiektywny (wiąże się z zaspokojeniem podstawowych potrzeb), częściowo zaś zależy od subiektywnych cech konsumenta. W zależności od sposobu finansowania, można więc wyróżnić konsumpcję: proporcjonalną (finansowaną z bieżących dochodów), przyspieszoną (finansowaną kredytem) i odłożoną w czasie (wydatki są realizowane w późniejszym okresie z wykorzystaniem środków zakumulowanych w okresach wcześniejszych) ${ }^{22}$.

${ }^{22}$ E. Wójcik, Konkurencja na rynku oszczędności w Polsce, CeDeWu, Warszawa 2014, s. 52. 
Zarządzanie budżetem domowym wymaga przede wszystkim zarządzania płynnością, planowania dochodów i wydatków, gospodarowania przepływami gotówkowymi. W zależności od poziomu dochodów i potrzeb konsumpcyjnych i inwestycyjnych oraz indywidualnej skłonności do oszczędności i skłonności do konsumpcji, zaspokajanie potrzeb finansowych gospodarstw domowych może być dokonywane $\mathrm{z}$ wykorzystaniem różnych produktów finansowych. W poprzednim punkcie zasygnalizowano, że motywy zachowań finansowych są zależne m.in. od wieku konsumentów. Jest to ściśle związane z cyklicznością potrzeb finansowych i ich specyfiką w poszczególnych stadiach życia człowieka.

Jak już wspomniano, realizacja potrzeb finansowych, podejmowanie zachowań ekonomicznych wiążą się z korzystaniem z produktów oferowanych przez instytucje finansowe. W modelowej sytuacji (rysunek 29) oszczędności rosną w wieku młodzieńczym - przede wszystkim za sprawą osób trzecich (zwykle rodziców lub innych członków rodziny), które wyposażają nieletnich w lokaty posagowe, fundusze powiernicze, a także przekazują środki, które mogą być deponowane np. jako oszczędności w SKO lub na rachunkach bankowych oferowanych osobom niepełnoletnim. W kolejnych latach poziom oszczędności i inwestycji generalnie rośnie i jest uwarunkowany m.in. poziomem zarobków i decyzjami finansowymi podejmowanymi na kolejnych etapach życia, a dotyczącymi np. zakupu nieruchomości, finansowania potrzeb gospodarstwa domowego, finansowania własnego rozwoju zawodowego i edukacji dzieci, realizacji pasji życiowych. Po zakończeniu pracy zawodowej poziom oszczędności zwykle maleje, gdyż bieżące dochody są wydawane, a dodatkowo konsumowane są środki zgromadzone wcześniej, z przeznaczeniem właśnie na życie na emeryturze.

Zapotrzebowanie na kredyty kształtuje się nieco odmiennie w zależności od poziomu dochodów oraz indywidualnych cech związanych ze skłonnością do oszczędzania i potrzebami konsumpcyjnymi. Kredyty (i inne zobowiązania) umożliwiają szybszy dostęp do dóbr i usług, poprawę standardu życia. W odróżnieniu od oszczędności, kredyty mogą być zaciągane jedynie przez osoby pełnoletnie. Początkowo są to zwykle kredyty na edukację (kredyty studenckie), samochód, urządzenie mieszkania, wyjazdy na wakacje i ogólną konsumpcję. Następnie kluczowy w życiu wydatek - zakup lub wybudowanie nieruchomości - dokonuje się na ogół na kredyt, który jest spłacany przez kilkanaście lub kilkadziesiąt lat. Okresowo mogą być także zaciągane kolejne zobowiązania, związane $\mathrm{z}$ wyposażeniem i remontem mieszkania, finansowaniem kształcenia dzieci (niekiedy także zakupem nieruchomości dla dzieci), a także finansowaniem wyjazdów wakacyjnych, ogólnej konsumpcji i zakupu kolejnych dóbr trwałego użytku. W ostatnich fazach życia kredyty zwykle dotyczą już jedynie ogólnej konsumpcji, czasem także wakacji, a niekiedy także zaspokojenia potrzeb rodziny (potomków).

Warto też wspomnieć o relatywnie nowym produkcie finansowym, jakim jest odwrócony kredyt hipoteczny (reverse mortgage). Jest to specyficzny kredyt, w przypadku którego właściciel nieruchomości, bez względu na fakt posiadania zdolności kredytowej, przenosi własność na rzecz kredytodawcy, a ten zo- 
bowiązuje się do wypłaty określonych świadczeń na jego rzecz przez określony czas lub dożywotnio. Co przy tym istotne, jakkolwiek hipoteka jest ustanowiona na rzecz kredytodawcy, to kredytobiorca zachowuje prawo do nieruchomości. W istocie zatem produkt ów polega na tym, że klient sprzedaje bankowi (lub innej instytucji finansowej) swą nieruchomość, a podmiot ten wypłaca mu następnie rentę (w zależności od umowy: dożywotnio lub przez określony czas) ${ }^{23}$.

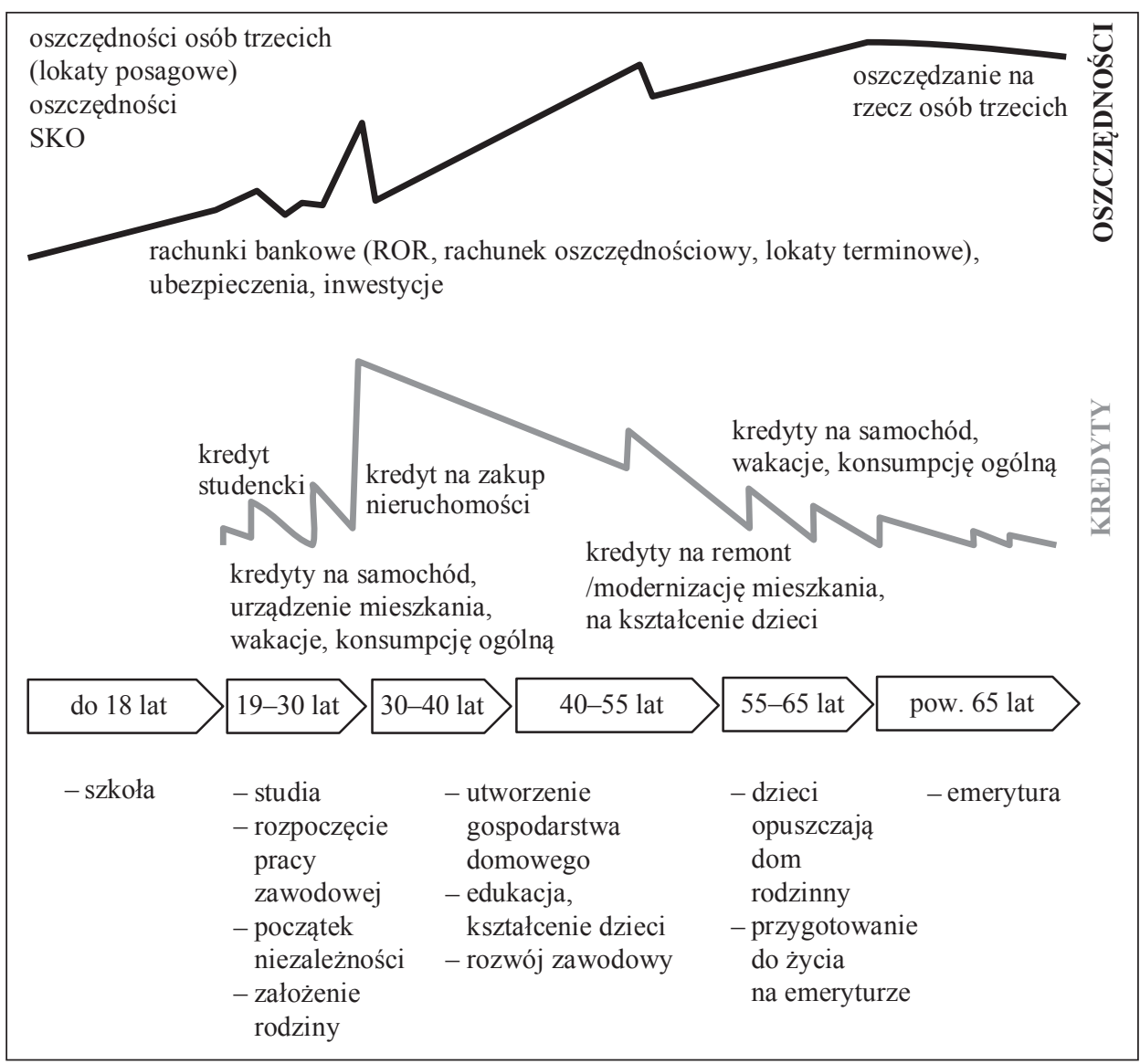

Rysunek 29. Fazy życia i potrzeby finansowe (korzystanie z produktów bankowych)

Źródlo: opracowanie własne na podstawie: U. C. Swoboda, Bankowość detaliczna, CeDeWu, Warszawa 2004, s. 123

${ }^{23}$ Szerzej na temat odwróconej hipoteki: I. Kuchciak, Odwrócona hipoteka jako odpowiedź sektora bankowego na trendy demograficzne, „Annales UMCS” 2010, Sectio H, t. XLIV, z. 2., s. 297-310; M. Zaleska (red.), Współczesna bankowość, Difin, Warszawa 2007, s. 210. W Polsce produkt ten jeszcze nie jest spopularyzowany, m.in. z powodu długo trwających prac legislacyjnych. Obszar ten będzie regulowany dwiema ustawami, dedykowanymi dwóm modelom tego produktu: modelowi kredytowemu (Ustawa z dnia 23 października 2014 r. o odwróconym kredycie hipotecznym, Dz. U. 2014, poz. 1585) oraz modelowi sprzedażowemu (rencie dożywotniej - Ustawa o dożywotnim świadczeniu pieniężnym). 
Jak zaznaczono, korzystanie z produktów oszczędnościowych i kredytowych może przebiegać równolegle bądź rozłącznie. W rozdziale pierwszym przedstawiono dane dotyczące skali korzystania z produktów finansowych przez Polaków w różnym wieku (obrazując tym samym skalę wykluczenia finansowego). Obecnie przyjrzymy się poszczególnym obszarom (oszczędnościom i kredytom $)^{24}$.

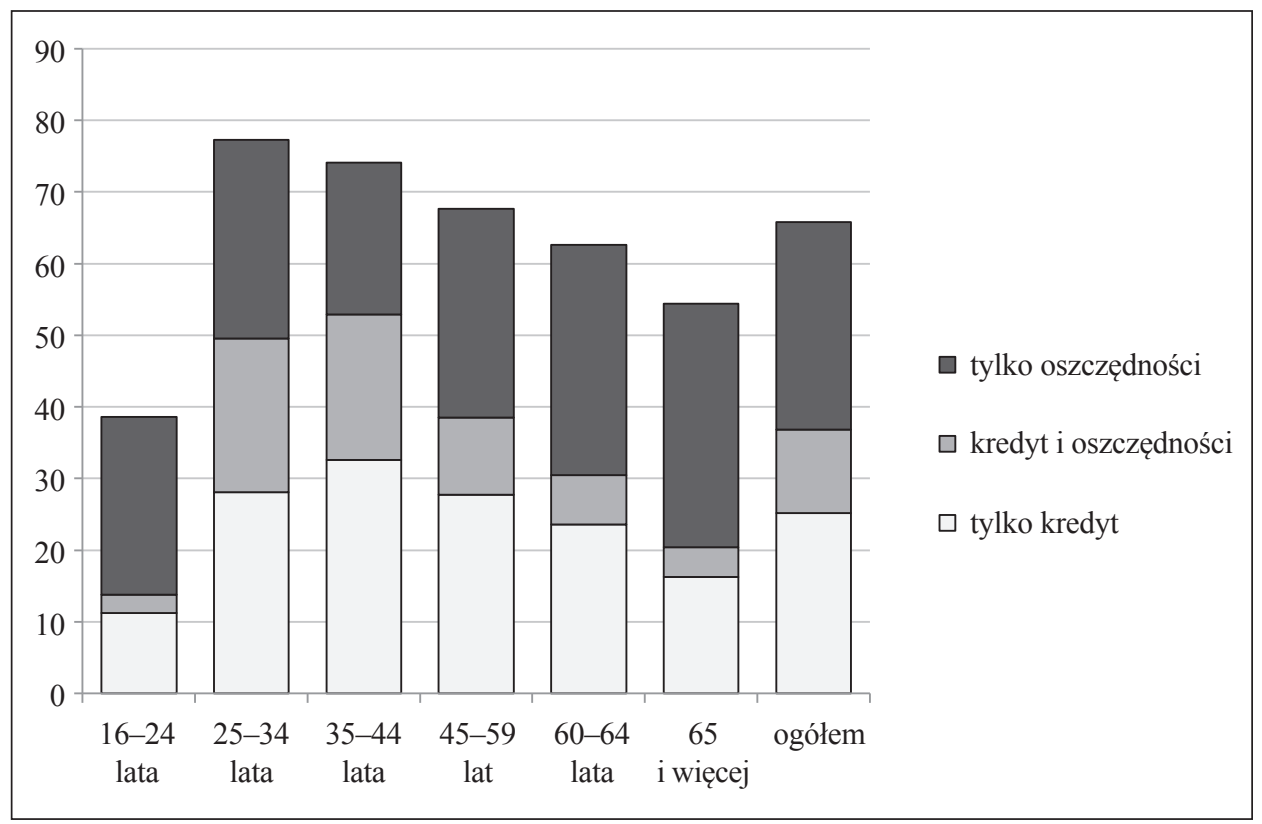

Rysunek 30. Gospodarstwa domowe aktywnie uczestniczące w rynku finansowym według wieku głowy gospodarstwa domowego oraz typu aktywności w 2013 r. (w \%)

Źródło: opracowanie własne na podstawie: I. E. Kotowska (red.), Diagnoza społeczna 2013. Rynek pracy $i$ wykluczenie społeczne w kontekście percepcji Polaków, Ministerstwo Pracy i Polityki Społecznej, Centrum Rozwoju Zasobów Ludzkich, Warszawa 2014, s. 148-149

Rysunek 30 obrazuje zakres aktywnego uczestnictwa gospodarstw domowych w rynku finansowym, w zależności od wieku głowy rodziny. Odsetek gospodarstw korzystających z produktów finansowych jest najniższy w najmłodszej grupie wiekowej (do 24 lat), najwyższy w następnej (do 34 lat), a w kolejnych maleje. W gronie gospodarstw, w których głowa rodziny ma co najmniej 45 lat odsetek podmiotów posiadających tylko lokaty (oszczędności)

${ }^{24}$ I. E. Kotowska (red.), Diagnoza społeczna 2013. Rynek pracy $i$ wykluczenie społeczne w kontekście percepcji Polaków, Ministerstwo Pracy i Polityki Społecznej, Centrum Rozwoju Zasobów Ludzkich, Warszawa 2014, s. 148 i nast. 
jest wyższy od średniej i rośnie w kolejnych grupach wiekowych, by osiągnąć najwyższy odsetek w grupie osób powyżej 65 lat. Równocześnie w tych samych grupach obserwuje się malejący odsetek gospodarstw mających tylko kredyt oraz mających zarówno kredyt, jak i oszczędności (w obydwu przypadkach najniższy odsetek obserwuje się wśród najmłodszych gospodarstw). W najstarszej grupie wiekowej gospodarstw mających wyłącznie kredyt jest dwukrotnie mniej niż gospodarstw posiadających w bankach wyłącznie oszczędności. Dostrzegalna jest też polaryzacja aktywności finansowej wraz z wiekiem: o ile w przedziale wiekowym 25-34 lata odsetek podmiotów posiadających wyłącznie oszczędności, oszczędności i kredyt oraz wyłącznie kredyt był dość zbliżony, o tyle w ostatnim przedziale (powyżej 65 lat) gospodarstwa posiadające zarówno kredyt, jak i oszczędności stanowiły znikomą część, a dominowały podmioty z oszczędnościami. Do trzeciego przedziału wiekowego (35-44 lata) udział gospodarstw z kredytami rósł, a w następnych spadał. Był to także ostatni przedział wiekowy, w którym istotny był odsetek gospodarstw posiadających zarówno oszczędności, jak i kredyt - w kolejnych grupach odsetek takich podmiotów malał. Podsumowując, można zauważyć, że z wiekiem maleje odsetek gospodarstw korzystających z produktów bankowych i zmienia się struktura aktywności finansowej na korzyść produktów lokacyjnych.

Przyglądając się bliżej formom lokowania oszczędności gospodarstw domowych, także można zauważyć pewne prawidłowości w zależności od wieku (rysunek 31). W przypadku osób po 60. roku życia odsetek środków ulokowanych w złotowych depozytach bankowych jest najwyższy (i rośnie wraz z wiekiem). Wiąże się to z prostotą, łatwą dostępnością i wysokim bezpieczeństwem tego instrumentu. Większa od przeciętnej jest także część oszczędności utrzymywanych w gotówce (co ciekawe jednak, w przypadku najmłodszych badanych - 25-34 lat jest ona wyższa niż u osób z przedziału 60-64 lat) ${ }^{25}$. Relatywnie wysoki udział oszczędności utrzymywanych $\mathrm{w}$ tej formie jest efektem dużego przywiązania do gotówki (niskiej skłonności do dokonywania transakcji bezgotówkowych), łatwości i powszechności korzystania z niej (dokonywania transakcji) oraz łatwości dysponowania nią (możliwości natychmiastowego dokonania transakcji). W strukturze oszczędności gospodarstw domowych dość znaczący jest udział funduszy inwestycyjnych (choć oczywiście jest to zależne przede wszystkim od koniunktury giełdowej oraz od poziomu stóp procentowych), przy czym jest on najwyższy u osób w wieku 45-59 lat, a w kolejnych grupach wiekowych maleje - najniższy jest u osób powyżej 65. roku życia. W ostatniej grupie wiekowej najwyższy ze wszystkich grup jest jednak udział papierów wartościowych notowanych na giełdzie (choć jest to ogółem mało znacząca pozycja). Wśród

${ }^{25}$ Warto przy tym zauważyć, że odsetek gospodarstw domowych (ogółem) deklarujących posiadanie oszczędności w formie gotówki jest bardzo wysoki (45\%), jednak są to zwykle niewielkie kwoty, jak na to wskazuje udział tej formy oszczędności (ogółem 13,5\%). 
najstarszych grup (pow. 60 lat) mniejszą popularnością cieszy się lokowanie środków w nieruchomości i polisy ubezpieczeniowe.

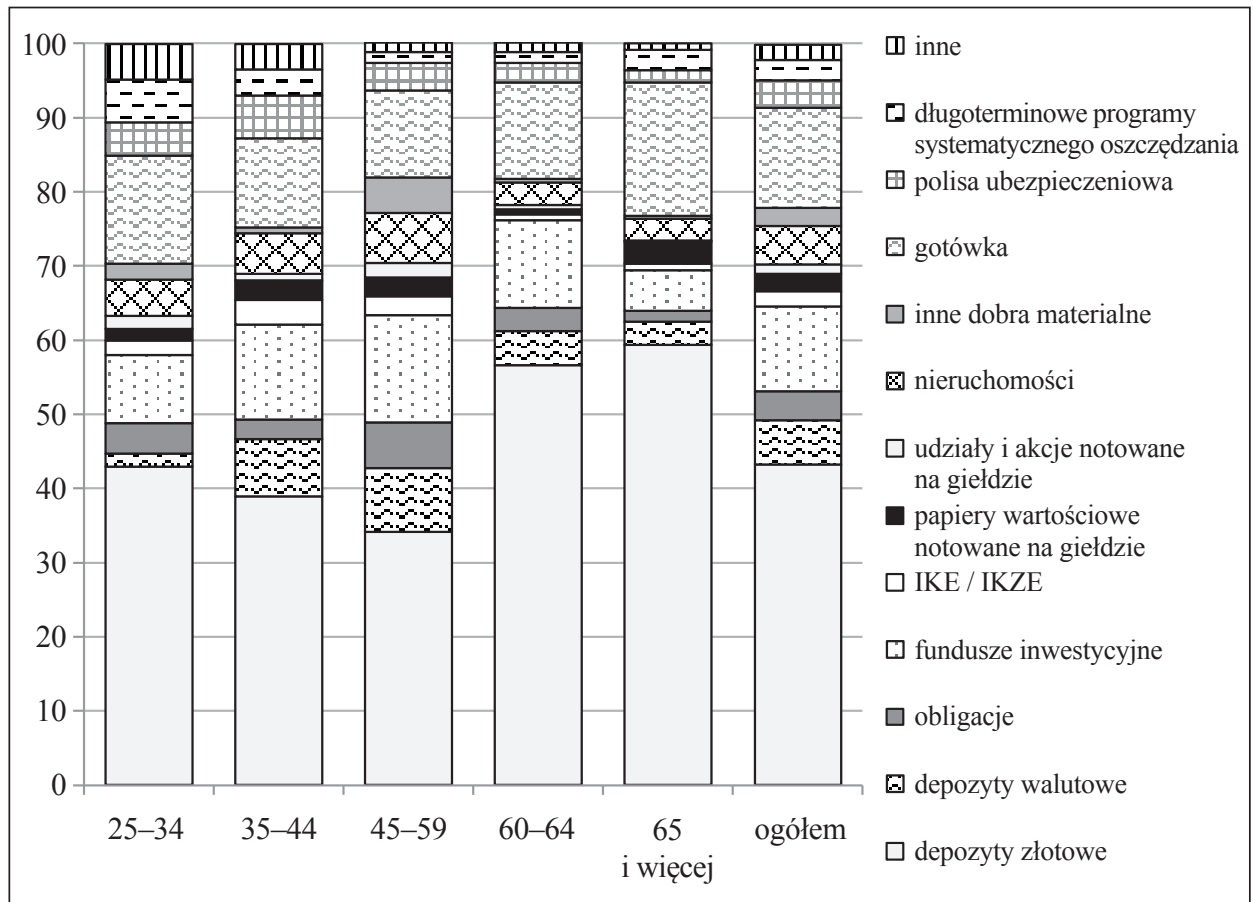

Rysunek 31. Struktura form oszczędzania w gospodarstwach domowych według wieku w 2013 r. (w \%)

Źródło: jak przy rys. 30, s. 161

Warto uzupełnić tę analizę spojrzeniem na motywy oszczędzania (patrz rysunek 32). W gospodarstwach domowych składających się z najstarszych osób dominuje motyw przezornościowy - zabezpieczenie na starość. Przesłanka ta jest najsilniejsza w grupie wiekowej 60-64 lata, a więc w okresie ostatnich lat aktywności zawodowej (co jest sytuacją dość niepokojącą, gdyż ten cel oszczędzania winien mieć charakter długoterminowy i powinien być podejmowany znacznie wcześniej) i nieco słabnie w wieku emerytalnym; jak należało się spodziewać, jest ona najniższa w najmłodszych gospodarstwach. Drugi co do znaczenia cel oszczędzania także wiąże się z motywem przezornościowym, a dotyczy rezerwy na sytuacje losowe. Co ciekawe, taki cel oszczędzania jest wyższy od średniej u najmłodszych osób, by maleć w kolejnych grupach wiekowych, a następnie istotnie rosnąć (największe znaczenie ma w grupie 60-64 lata, a w kolejnej nieznacznie maleje). Innym celem związanym z motywem przezornościowym jest chęć zabezpieczenia przyszłości dzieci; znaczenie tego celu jest najwyższe w grupie wiekowej 35-44 lata, a w kolejnych grupach maleje, by w ostatnim przedziale nieznacznie wzro- 
snąć. Wśród celów oszczędzania najstarszych gospodarstw domowych można zauważyć wyższy od średniego udział oszczędności przeznaczanych na leczenie i rehabilitację (łącznie ponad 15\% udział w grupie powyżej 65 lat i nieco ponad 10\% w grupie 60-64 lata, przy średniej ogółem wynoszącej 6,5\%). Co oczywiste, z wiekiem istotnie maleje znaczenie oszczędzania na zakup nieruchomości (największy udział - ponad $20 \%$ - ma ów cel w najmłodszej grupie gospodarstw i stopniowo maleje w kolejnych grupach wiekowych). Podobne tendencje (acz przy znacznie niższych udziałach procentowych) można zaobserwować w przypadku oszczędzania na zakup dóbr trwałego użytku. Znacznie wolniej natomiast maleje znaczenie oszczędzania na wypoczynek (w najmłodszej grupie wiekowej oszczędności na ten cel mają udział ponad 7\%, a w najstarszej - nieco powyżej 5\%).

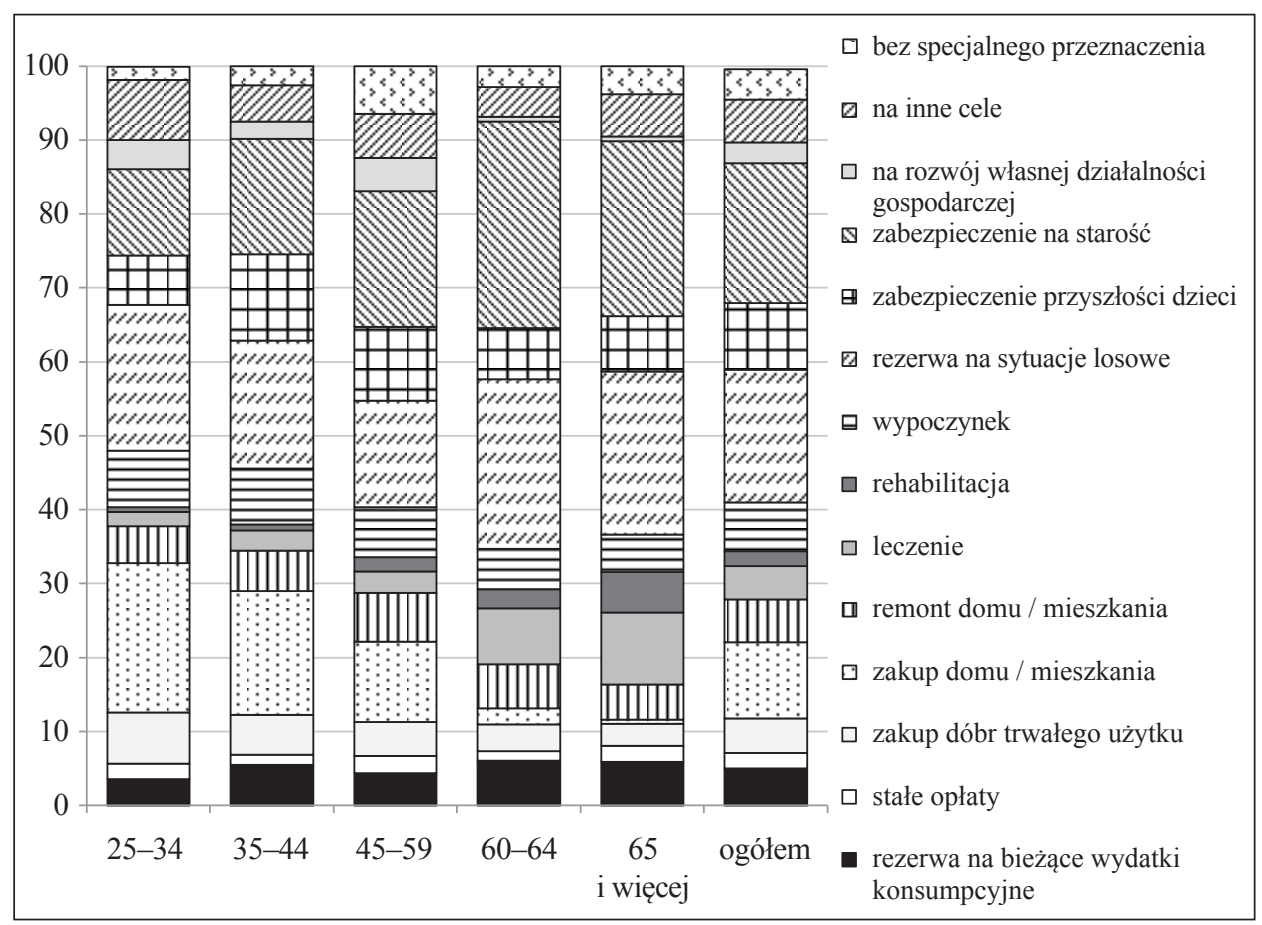

Rysunek 32. Struktura celów oszczędzania w gospodarstwach domowych według wieku w 2013 r. (w \%)

Źródlo: jak przy rys. 30, s. 164

Ciekawe jest porównanie celów oszczędzania z celami zobowiązań zaciąganych przez gospodarstwa domowe (rysunek 33). Dominującym celem posiadanych kredytów i pożyczek jest zakup nieruchomości, przy czym cel ów ma największy udział w strukturze zobowiązań najmłodszych gospodarstw, a w gospodarstwach starszych ma ponad dwukrotnie niższy udział (najniższy w grupie 
60-64 lat). W kolejnych grupach wiekowych rośnie natomiast udział zobowiązań przeznaczonych na zakup dóbr trwałego użytku (najwyższy udział ma w najstarszych gospodarstwach, powyżej 18\%), a także kredytów na remont domu lub mieszkania (najwyższy udział zobowiązań notuje grupa wiekowa 60-64 lata - 19\%). Znacznie wyższy niż w innych grupach wiekowych jest u seniorów udział zobowiązań zaciąganych na leczenie. Niepokojący jest relatywnie wysoki (łącznie) udział zobowiązań zaciąganych na bieżące wydatki konsumpcyjne, stałe opłaty i spłatę wcześniejszych długów w najstarszych gospodarstwach. W grupach gospodarstw powyżej 45. roku życia notuje się też rosnący (choć ogółem niewielki) udział zobowiązań związanych z kształceniem dzieci i zabezpieczeniem ich przyszłości.

Patrząc natomiast na strukturę spłat zobowiązań, gospodarstwa najstarsze najwięcej środków przeznaczają na spłatę kredytów na zakup dóbr trwałego użytku oraz remont domu lub mieszkania, a w dalszej kolejności na bieżące wydatki konsumpcyjne, zakup nieruchomości oraz leczenie.

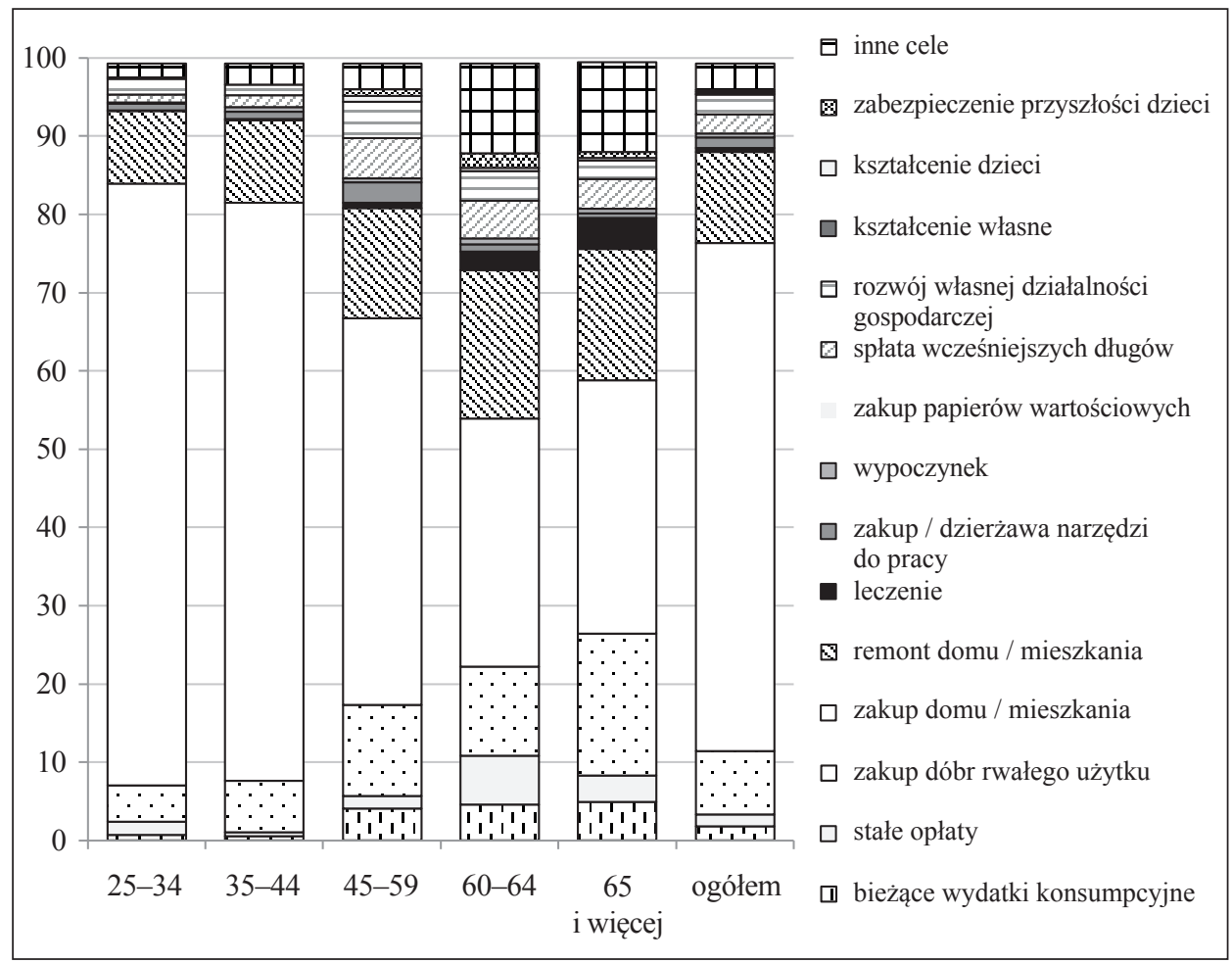

Rysunek 33. Struktura zobowiązań gospodarstw domowych według celu zobowiązań i wieku głowy gospodarstwa w 2013 r. (w \%)

Źródło: jak przy rys. 30, s. 168 
W cytowanym badaniu nie wyszczególniono zjawiska, które nasila się w ostatnich latach - pożyczania przez seniorów dla swoich potomków (którzy np. nie mają zdolności kredytowej). W tym kontekście emeryci jawią się jako bezpieczni kredytobiorcy: mają stałe dochody (emerytury, renty), których ryzyko utraty jest bardzo niskie, a przy tym są wypłacane terminowo i które - w przypadku ewentualnego niespłacenia kredytów - są łatwym celem windykacji.

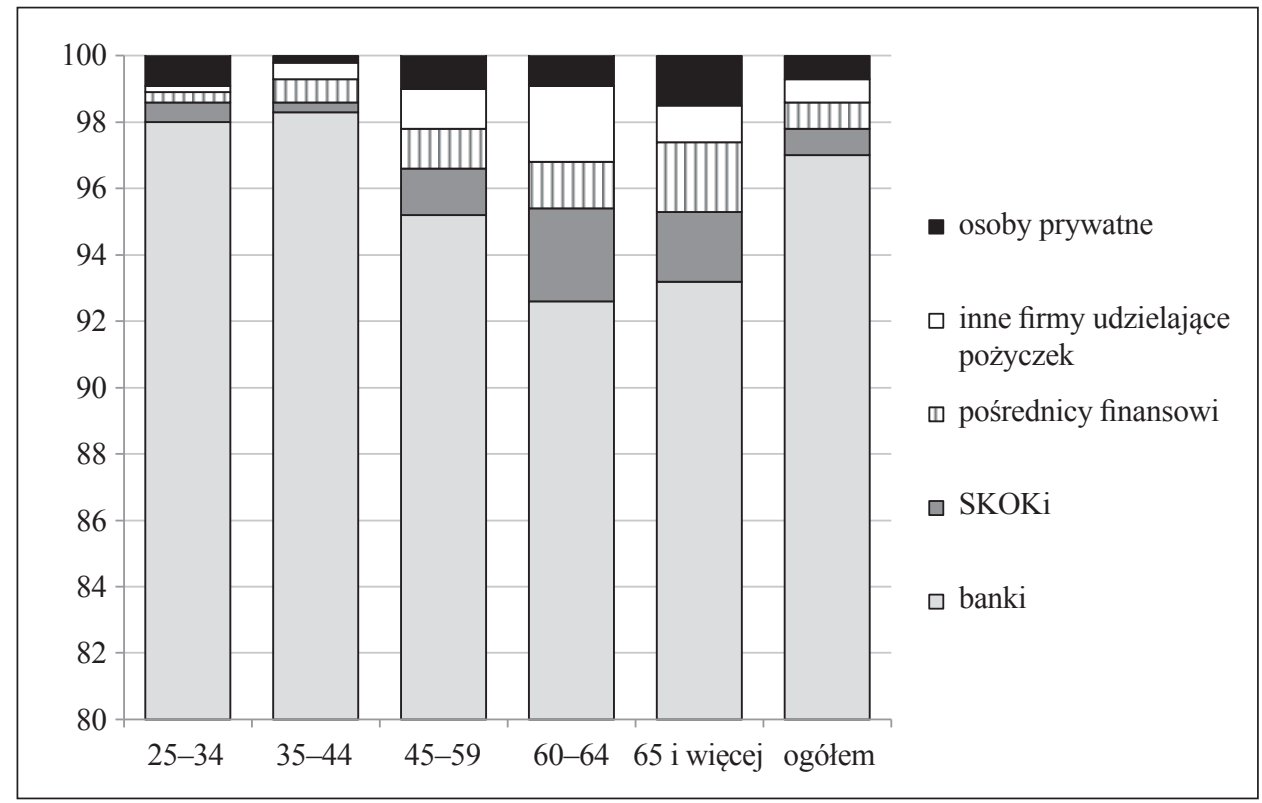

Rysunek 34. Struktura zobowiązań gospodarstw domowych ze względu na źródło pochodzenia zobowiązania, według wieku (w 2013 r.) (w \%)

Źródło: jak przy rys. 30, s. 166

Zobowiązania są zaciągane przede wszystkim w bankach, jednak można zauważyć, że w przypadku seniorów to źródło ma najmniejszy udział. Wśród gospodarstw najstarszych osób notujemy wyższy od średniego udział pożyczek zaciąganych w SKOKach, u pośredników finansowych i innych firm udzielających pożyczek oraz u osób prywatnych (rysunek 34). Może być to dowodem na istnienie wykluczenia bankowego osób starszych w tym obszarze wynikającego z braku możliwości zaciągnięcia kredytu w banku bądź ich decyzji (podjętej świadomie, na podstawie analizy ofert lub w wyniku niedostatecznej wiedzy finansowej). Ogółem jednak skala zobowiązań zaciąganych w instytucjach innych niż banki jest niska (najwyższa w grupie wiekowej 60-64 lata - 6,5\% ogółu zobowiązań i grupie powyżej 65 lat $-5,3 \%$ ). Udział spłat zobowiązań w tych instytucjach jest natomiast wyższy (najwyższa w grupie wiekowej 60-64 lata - 13,7\% ogółu spłat zobowiązań i grupie powyżej 65 lat - 15,8\%), co można tłumaczyć tym, 
że - w przeciwieństwie do kredytów bankowych - są to z reguly zobowiązania krótkoterminowe. Można zatem podsumować, że skala zadłużenia osób starszych w podmiotach niebankowych - jakkolwiek jest wyższa niż w młodszych grupach wiekowych - nie jest zbyt wysoka i nie można mówić o wysokich obciążeniach z tytułu tego zadłużenia.

Podsumowując, można powiedzieć, że aktywność osób starszych w zakresie korzystania z produktów finansowych jest niższa niż osób młodszych, odmienne są także cele zarówno oszczędzania, jak i kredytowania. Osoby starsze chętniej lokują środki w płynnych, bezpiecznych instrumentach (lokatach bankowych), jednak wysoki jest udział gotówki. Wśród celów oszczędzania u osób starszych dominują motywy przezornościowe, znacznie większe niż u młodszych osób jest znaczenie oszczędzania na cele zdrowotne (leczenie i rehabilitacja). Osoby starsze korzystające z kredytów i pożyczek zaciągają je głównie w celu zakupu dóbr trwałych, remontu mieszkania. Niepokojący jest relatywnie wysoki udział w tej grupie zobowiązań zaciąganych na finansowanie bieżących wydatków (w tym stałych opłat) i leczenia, oznacza to bowiem, że bieżące dochody i ewentualne oszczędności nie wystarczają na pokrycie podstawowych potrzeb.

Przeprowadzona przez autorów Diagnozy społecznej segmentacja gospodarstw domowych ze względu na decyzje dotyczące oszczędzania i zaciąganie zobowiązań ${ }^{26}$ potwierdza, że dominująca część osób starszych należy do grupy gospodarstw o niskim lub średnim poziomie oszczędności, które utrzymywane są głównie w formie gotówki, a oszczędności w innych formach występują marginalnie. Seniorzy stanowią znaczą część osób nieposiadających zobowiązań kredytowych, jednak niestety mają też dość znaczący udział w trzech segmentach osób zadłużonych:

- zaciągających pożyczki na dość niskie kwoty, przede wszystkim w podmiotach niebankowych, z przeznaczeniem głównie na finansowanie zakupu dóbr trwałych;

- zaciągających kredyty na dość niskie kwoty, głównie w bankach, przede wszystkim z chęci zaspokojenia własnych potrzeb konsumpcyjnych lub pokrycia stałych opłat;

- zaciągających dość niewielkie pożyczki głównie w SKOKach i firmach pożyczkowych, celem sfinansowania konsumpcji, stałych opłat, zakupu dóbr trwałych i remontu mieszkania.

Wnioski z tego badania podkreślają potrzebę większej popularyzacji oferty bankowej wśród osób starszych i zapewnienia im dostępu do prostych produktów bankowych we wszystkich obszarach:

- transakcyjnym: rachunku oszczędnościowo-rozliczeniowego, kart płatniczych;

${ }^{26}$ I. E. Kotowska (red.), Diagnoza społeczna 2013. Rynek pracy i wykluczenie..., s. 170 i nast. 
- oszczędnościowym: lokaty terminowe, rachunki oszczędnościowe;

- dłużnym: kredyty i pożyczki bankowe.

Banki powinny zatem zmodyfikować swoje strategie marketingowe i uwzględnić w nich specyficzne potrzeby starszych klientów. Należy mieć przy tym świadomość, że kryterium wiekowe nie może być wyłącznym kryterium segmentacji także i w tej grupie klientów i potencjalnych klientów (choć - jak dowiodły także prezentowane w pracy wyniki badań empirycznych - wiele różnic jest dostrzegalnych właśnie wśród podgrup wiekowych osób 50+). Bez wątpienia należy uwzględnić także inne kryteria demograficzne i społeczno-ekonomiczne (w tym płeć, status rodzinny i zawodowy, wykształcenie, poziom dochodów i wielkość majątku). Segmentacja musi jednak uwzględnić także aspekty psychograficzne i behawioralne. Osoby w wieku powyżej 50 lat są bowiem grupą bardzo zróżnicowaną. Po pierwsze, należy tu wyodrębnić osoby w dojrzałym wieku, aktywne zawodowo (często czynnie uczestniczące w życiu społecznym i kulturalnym), a także osoby starsze, które już przeszły na emeryturę.

Przemiany społeczne, kulturowe, technologiczne powodują przy tym, że można wyodrębnić grupę seniorów będących osobami nowoczesnymi, lepiej przygotowanymi do życia i radzenia sobie ze sferą ekonomiczną (patrz tablica 15). Wciąż jednak znaczna część to seniorzy tradycyjni - i to właśnie ta grupa jest w większym stopniu narażona na ekskluzję finansową.

Tablica 15. Różnice między tradycyjnymi i nowoczesnymi seniorami

\begin{tabular}{|l|l|l|}
\hline \multicolumn{1}{|c|}{ Aspekt } & \multicolumn{1}{|c|}{ Tradycyjni seniorzy } & \multicolumn{1}{|c|}{ Nowocześni seniorzy } \\
\hline \multicolumn{1}{|c|}{2} & \multicolumn{1}{|c|}{3} \\
\hline $\begin{array}{l}\text { Postrzeganie } \\
\text { osób starszych }\end{array}$ & $\begin{array}{l}\text { Postrzegają wszystkie osoby starsze } \\
\text { jako bardzo podobne pod względem } \\
\text { wyglądu }\end{array}$ & $\begin{array}{l}\text { Postrzegają siebie samych jako od- } \\
\text { miennych pod względem wyglądu } \\
\text { w porównaniu z innymi osobami } \\
\text { w tym samym wieku }\end{array}$ \\
\hline $\begin{array}{l}\text { Postrzeganie } \\
\text { starości }\end{array}$ & Starość jest cechą fizyczną & Starość jest stanem umysłu \\
\hline $\begin{array}{l}\text { Postrzeganie } \\
\text { swojego wieku }\end{array}$ & $\begin{array}{l}\text { Postrzegają się dokładnie tak, jak } \\
\text { wskazuje na to ich metryka }\end{array}$ & $\begin{array}{l}\text { Postrzegają się jako młodsi niż wyni- } \\
\text { kałoby z ich metryki }\end{array}$ \\
\hline $\begin{array}{l}\text { Zależność } \\
\text { zachowania } \\
\text { od wieku }\end{array}$ & $\begin{array}{l}\text { Uważają, że każdy powinien zachowy- } \\
\text { wać się stosownie do swojego wieku }\end{array}$ & $\begin{array}{l}\text { Czują się, myślą i działają tak, jakby } \\
\text { byli młodsi }\end{array}$ \\
\hline $\begin{array}{l}\text { Wpływ } \\
\text { na swój los }\end{array}$ & $\begin{array}{l}\text { Mają poczucie, że są „marionetkami” } \\
\text { (ich los zależy od innych) i jest to } \\
\text { dla nich naturalne }\end{array}$ & $\begin{array}{l}\text { Mają poczucie, że są ,panami swego } \\
\text { losu” - samodzielnie kierują swoim } \\
\text { życiem }\end{array}$ \\
\hline $\begin{array}{l}\text { Decyzje } \\
\text { zakupowe }\end{array}$ & $\begin{array}{l}\text { Są niezbyt pewni siebie przy podej- } \\
\text { mowaniu decyzji zakupowych }\end{array}$ & $\begin{array}{l}\text { Są pewni siebie przy podejmowaniu } \\
\text { decyzji zakupowych }\end{array}$ \\
\hline $\begin{array}{l}\text { Kompetencje } \\
\text { konsumenckie }\end{array}$ & $\begin{array}{l}\text { Mają słabo rozwinięte podstawowe } \\
\text { kompetencje konsumenckie }\end{array}$ & $\begin{array}{l}\text { Są doświadczonymi, mądrymi i czuj- } \\
\text { nymi konsumentami }\end{array}$ \\
\hline
\end{tabular}


Tablica 15 (cd.)

\begin{tabular}{|l|l|l|}
\hline \multicolumn{1}{|c|}{1} & \multicolumn{1}{|c|}{2} & \multicolumn{1}{c|}{3} \\
\hline $\begin{array}{l}\text { Stosunek } \\
\text { do nowych } \\
\text { technologii }\end{array}$ & $\begin{array}{l}\text { Cechuje ich awersja do nowości tech- } \\
\text { nologicznych }\end{array}$ & $\begin{array}{l}\text { Selektywnie otwarci na nowości tech- } \\
\text { nologiczne }\end{array}$ \\
\hline $\begin{array}{l}\text { Stosunek } \\
\text { do nowości }\end{array}$ & $\begin{array}{l}\text { Poszukują stabilności oraz rutyny gwa- } \\
\text { rantującej poczucie bezpieczeństwa }\end{array}$ & $\begin{array}{l}\text { Poszukują nowych doświadczeń i wy- } \\
\text { zwań }\end{array}$ \\
\hline $\begin{array}{l}\text { Satysfakcja } \\
\text { życiowa }\end{array}$ & Niska satysfakcja z życia & Wysoka satysfakcja z życia \\
\hline $\begin{array}{l}\text { Ocena } \\
\text { bezpieczeństwa } \\
\text { finansowego }\end{array}$ & $\begin{array}{l}\text { Mają obawy o swoje bezpieczeństwo } \\
\text { finansowe }\end{array}$ & $\begin{array}{l}\text { Czują się względnie dobrze zabezpie- } \\
\text { czeni finansowo }\end{array}$ \\
\hline
\end{tabular}

Źródło: opracowanie własne na podstawie: J. K. Solarz, Nowi wykluczeni. Ryzyko finansowe codzienności, Społeczna Akademia Nauk, Łódź-Warszawa 2012, s. 86-87.

Wnikliwa analiza potrzeb i oczekiwań różnych grup seniorów winna być podstawą dla skonstruowania oferty bankowej dostosowanej do specyfiki tych osób. W szczególności banki powinny zapewnić srebrnej gospodarce:

- podstawowy rachunek bankowy (ROR), zapewniający możliwość wykonywania kluczowych operacji: polecenia przelewu, transakcji płatniczych przy użyciu karty płatniczej, polecenia zapłaty ${ }^{27}$;

27 Warto tu wspomnieć o cennej inicjatywie Unii Europejskiej, nakazującą państwom członkowskim ułatwienie konsumentom nieposiadającym rachunku bankowego dostępu do zwykłego rachunku płatniczego. Przyjęta w kwietniu 2014 r. dyrektywa wymaga, aby co najmniej jeden dostawca usług płatniczych na terytorium państwa członkowskiego oferował konsumentom podstawowy rachunek płatniczy, przy czym rachunek ten nie może być oferowany wyłącznie z zastosowaniem narzędzi bankowości internetowej, a dostęp do niego nie może być uzależniony od wykupienia dodatkowych usług i konsument nie może otrzymywać oferty kredytu w rachunku bieżącym w połączeniu z posiadanym podstawowym rachunkiem płatniczym. W ramach podstawowego rachunku płatniczego winny być zapewnione następujące usługi płatnicze: usługi umożliwiające wszelkie działania niezbędne do otwarcia, prowadzenia i zamknięcia rachunku płatniczego, usługi umożliwiające wpłatę środków pieniężnych na rachunek płatniczy, usługi umożliwiające wypłatę gotówki z rachunku płatniczego w obrębie Unii, dokonywanie następujących transakcji płatniczych w obrębie Unii: poleceń zapłaty, transakcji płatniczych przy użyciu karty płatniczej, w tym płatności online, poleceń przelewu. Usługi te mają być oferowane nieodpłatnie lub za adekwatną opłatą. Dostawcy usług płatniczych mają udostępniać konsumentom informacje na temat szczególnych cech oferowanych podstawowych rachunków płatniczych, wiążących się z nimi opłat oraz warunków korzystania z takich rachunków. Państwa członkowskie muszą także zapewnić funkcjonowanie co najmniej jednej porównywarki cenowej rachunków bankowych (patrz: Wniosek Dyrektywa Parlamentu Europejskiego i Rady w sprawie porównywalności opłat za prowadzenie rachunku płatniczego, przenoszenia rachunku płatniczego oraz dostępu do podstawowego rachunku płatniczego, COM/2013/0266 final - 2013/0139 (COD), Bruksela, 8.05.2013). Zdaniem Komisji Europejskiej spełnienie tych wymogów przyczyni się do ograniczenia wykluczenia finansowego, do umożliwienia obywatelom szerszego uczestniczenia w życiu społecznym i gospodarczym. 
- atrakcyjne formy lokowania oszczędności i inwestowania, uwzględniające dostosowane do potrzeb seniorów horyzonty czasowe produktów i profil ryzyka adekwatny do możliwości klientów;

- dostępność kredytów umożliwiających spełnienie potrzeb finansowych, przy uwzględnieniu wymogów odpowiedzialnego kredytowania, zabezpieczenie przed nadmiernym zadłużeniem się klientów;

- dodatkowe usługi umożliwiające osiąganie przez seniorów dodatkowych korzyści z relacji z bankami (m.in. ubezpieczenia, usługi concierge, dostęp do opieki zdrowotnej, kultury i rozrywki, zniżki na określone produkty);

- dostęp do przejrzystych, zrozumiałych, pełnych informacji na temat swej oferty oraz profesjonalne doradztwo w wyborze i korzystaniu z produktów finansowych;

- edukację i pomoc w korzystaniu z nowoczesnych kanałów dystrybucji (bankomaty, bankowość internetowa, bankowość mobilna).

Świadczenie usług na rzecz osób starszych i nieubankowionych z reguły postrzegane jest jako działalność deficytowa. Toteż działania na rzecz inkluzji społecznej i finansowej, podnoszenie świadomości ekonomicznej i wspieranie przedsiębiorczości społecznej są dziś postrzegane jako obszary właściwe tzw. bankom alternatywnym (etycznym, społecznym, zrównoważonym, solidarnym) ${ }^{28}$. Bankowość społeczna, rozumiana jako wywieranie pozytywnego wpływu na ludzi, środowisko i kulturę poprzez środki właściwe bankom, tj. rachunki oszczędnościowe, kredyty, inwestycje i inne produkty i usługi ${ }^{29}$, jest wciąż jednym z niszowych zagadnień bankowości.

Trzeba jednak podkreślić, że od każdego banku należy oczekiwać odpowiedzialności - w tym bowiem wymiarze można postrzegać opisywane w niniejszej monografii działania. W kontekście omawianych tu zagadnień oznacza to m.in. zapewnienie przez banki przejrzystości dotyczącej konstrukcji produktów i warunków umów, uczciwej, jednoznacznej reklamy i innych przekazów informacyjnych, przedkładania podstawowych interesów klientów ponad własne ${ }^{30}$.

${ }^{28}$ FEBEA, What really differentiates ethical banks from traditional banks?, April 2012, www. ethicalbankingeurope.com/sites/default/files/Definition\%20Ethical\%20Bank.pdf (stan na dzień 10.09.2012); F. de Clerk, Ethical banking, [w:] V. Vandemeulebrouke, K. Beck, K. Käufer, Networking Social Finance, Brussels 2010, s. 16-32, www.social-banking.org/fileadmin/isb/Artikel und_Studien/Networking_Social_Finance_Beck_Kaeufer_Vandemeulebrouke.pdf (stan na dzień 10.09.2012); R. Benedikter, Social Banking and Social Finance. Answers to the Economic Crisis, Springer, New York 2011.

${ }^{29}$ O. Weber, S. Remer (red.), Social Banks and the Future of Sustainable Finance, Routledge, London-New York 2011, s. 2.

${ }^{30}$ M. Marcinkowska, Kapitat relacyjny banku, t. 2, Relacje banku z kluczowymi interesariuszami, Wydawnictwo Uniwersytetu Łódzkiego, Łódź 2013, s. 312. 


\subsection{Ocena dostępności i atrakcyjności oferty bankowej dedykowanej dla segmentu $50+$}

\subsubsection{Dostępność podstawowych usług bankowych i ich zróżnicowanie}

Postępujący proces starzenia się społeczeństwa z jednej strony kreuje nowe, z drugiej zaś, uwydatnia już istniejące potrzeby starszych osób. W odpowiedzi na obserwowane zapotrzebowanie, coraz więcej przedsiębiorstw $\mathrm{z}$ różnych sektorów gospodarki dostrzega pojawiającą się szansę na zdobycie części tworzącego się wciąż rynku, a tym samym zauważa niszę, która pozostaje niezagospodarowana.

Konsekwencją negatywnych zjawisk demograficznych z punktu widzenia gospodarki jest tworzenie się segmentu rynku odpowiedzialnego za zaspokajanie potrzeb osób starszych, co z kolei niejednokrotnie jest równoznaczne z opracowywaniem nowych, niekiedy innowacyjnych produktów i usług. Prowadzi to w efekcie do jeszcze większej dywersyfikacji oferty produktowej oferowanej klientom przez podmioty gospodarcze należące do różnych branż.

Podobnie jest w przypadku rynku finansowego, a zwłaszcza sektora bankowego, który coraz częściej dostrzega konieczność dostosowania parametrów produktów i usług do specyfiki potrzeb osób starszych. W ramach prowadzonej segmentacji klientów banki wyróżniają wiele różnorodnych grup klientów indywidualnych, przy czym relatywnie od niedawna zmieniają podejście do problemu starzenia się społeczeństwa, tym samym wprowadzając zmiany w ofercie. Dotychczas osoby starsze najczęściej korzystały z produktów i usług bankowych na zasadach standardowych, co oznacza, że nie występowała żadna preferencyjność względem tej grupy. Takie podejście wciąż obowiązuje w wielu bankach, gdzie zarówno osoby młode, w średnim wieku, jak i w podeszłym wieku korzystają z takich samych produktów i usług bankowych. Standaryzacja oferty bez względu na wiek klienta, zwłaszcza w przypadku banków, często nie pozwala w pełni zaspokoić ich potrzeb, dlatego też tak istotne jest uwzględnianie specyfiki wszystkich klientów, przeprowadzanie procesu segmentacji, a w dalszym etapie proponowanie spersonalizowanych, ewentualnie dedykowanych dla wybranych grup rozwiązań.

Warto również zauważyć, że w przypadku banków, których oferta nie koncentruje się wokół specyficznych potrzeb osób starszych, niekiedy występują ograniczenia wiekowe w dostępie do produktów i usług bankowych. Fakt ten może komplikować sytuację klientów w podeszłym wieku, którzy, chcąc skorzystać z oferty banku, muszą wziąć pod uwagę zarówno standardową ofertę, jak i występujące w niej ograniczenia i limity. W przypadku wybranych produktów i usług można spotkać sytuację, że ich sprzedaż jest możliwa jedynie w przypad- 
ku, gdy klient nie ukończył określonego roku życia. Po jego ukończeniu osoba w podeszłym wieku z jednej strony nie może skorzystać ze standardowej oferty, z drugiej zaś, często nie oferuje się jej alternatywnego produktu lub usługi, która mogłaby zaspokoić określone potrzeby (szczególnie w przypadku kredytów, kiedy to wiek kredytobiorcy ma znaczenie przy ocenie zdolności kredytowej). W takim przypadku może nastąpić wykluczenie bankowe osoby, która dotychczas wykluczoną nie była.

Biorąc pod uwagę aktualną ofertę produktową banków można zauważyć, że coraz częściej instytucje te wyróżniają wśród swoich klientów osoby starsze, oferując dedykowane dla nich produkty i usługi. Niejednokrotnie są one powiązane z dodatkowymi korzyściami, bonusami, dzięki którym osoby starsze mają ułatwiony dostęp do opieki zdrowotnej, kultury czy też posiadają zniżki przy płatnościach za wybrane produkty, np. leki.

Uwzględniając negatywne zjawiska demograficzne, w tym postępujący proces starzenia się społeczeństwa, można zakładać, że oferta banków w przyszłości będzie coraz częściej uwzględniać potrzeby osób starszych. Jest to szczególnie istotne w kontekście obserwowanego wzrostu wskaźnika przeciętnego trwania życia, który sprawia, że osoby w podeszłym wieku są zainteresowane różnorodnymi produktami i usługami finansowymi (np. nie tylko oszczędnościowymi, ale również kredytowymi), co wynika z aktywizacji wskazanej grupy społeczeństwa na różnych płaszczyznach.

Porównania atrakcyjności oferty bankowej dedykowanej dla segmentu 50+ dokonano w oparciu o przeprowadzone wśród grupy dziesięciu seniorów (osoby powyżej 50. roku życia, zamieszkałe na terytorium województwa łódzkiego, które zgodziły się na uczestnictwo w badaniu) indywidualne wywiady pogłębione o wysokim stopniu standaryzacji, które pozwoliły wyróżnić kryteria i parametry oceny produktów oraz przypisać im odpowiednie znaczenie (wagi), wyliczone jako liczba odpowiedzi respondentów w stosunku do ogółu respondentów wyrażona procentowo. W oparciu o tak przyjętą metodologię porównano oferty w zakresie lokat terminowych, rachunków oszczędnościowo-rozliczeniowych oraz kredytów w siedmiu bankach komercyjnych ${ }^{31}$, które w swojej ofercie posiadały produkty dedykowane dla seniorów chociaż $\mathrm{w}$ jednej z trzech wymienionych kategorii (rachunki oszczędnościowo-rozliczeniowe, lokaty, kredyty) oraz dokonano oceny ich atrakcyjności z punktu widzenia osoby powyżej 50. roku życia zgodnie z trójstopniową skalą, gdzie 1 oznacza najmniej atrakcyjną ofertę, 2 - średnio atrakcyjną ofertę, a 3 - najbardziej atrakcyjną ofertę. $\mathrm{W}$ badanym okresie tylko te banki komercyjne posiadały ofertę dedykowaną dla seniorów.

${ }^{31}$ Pekao SA, Bank Pocztowy SA, Bank Zachodni WBK SA, PKO Bank Polski SA, Deutsche Bank SA, Getin Noble Bank SA, Bank Gospodarki Żywnościowej SA. 


\subsubsection{Ocena atrakcyjności oferty rachunków oszczędnościowo- -rozliczeniowych dla segmentu $50+$}

W celu przeprowadzenia oceny atrakcyjności oferty rachunków oszczędnościowo-rozliczeniowych przyjęto następujące kryteria:

- dostępność,

- cena,

- dodatkowe usługi.

Każdemu z tych kryteriów przypisano wagę $e^{32}$. Kryterium dostępności oceniono jako istotne dla oceny w $40 \%$, kryterium ceny w $55 \%$, a kryterium dodatkowych usług w $5 \%$.

W ramach kryterium: dostępność przy analizie były brane pod uwagę następujące parametry:

- wiek klienta powyżej 50. roku życia (istotność: $5 \%)^{33}$,

- możliwość założenia rachunku w oddziale banku (istotność: 15\%),

- dostęp do bankomatów (istotność: 5\%),

- dostęp do placówek banku (istotność: $15 \%$ ).

Z kolei dla kryterium: cena przyjęto następujące parametry:

- wysokość oprocentowania (istotność: 2\%),

- wysokość opłaty za prowadzenie rachunku bankowego (istotność: 25\%),

- wysokość opłaty za wydanie karty do rachunku bankowego (istotność: 5\%),

- wysokość opłaty miesięcznej za użytkowanie karty (istotność: 10\%),

- wysokość opłaty za przelew złożony w oddziale banku (istotność: 10\%),

- wysokość opłaty za przelew elektroniczny (istotność: $1 \%$ ),

- wysokość opłaty za wypłatę z obcego bankomatu (istotność: 2\%).

Ostatnim kryterium branym pod uwagę przy ocenie atrakcyjności rachunków bankowych były dodatkowe usługi, dla których zidentyfikowano następujące parametry:

- ubezpieczenie Medical Assistance (istotność: 4\%),

- zniżki u partnerów (istotność: 4\%),

- dodatkowe ubezpieczenia (istotność: $1 \%$ ).

Rachunki bankowe dedykowane seniorom można znaleźć w ofercie siedmiu banków: Pekao SA, Bank Pocztowy SA, Bank Zachodni WBK SA, PKO Bank Polski SA, Deutsche Bank SA, Getin Noble Bank SA, Bank Gospodarki Żyw-

${ }^{32}$ Wagi dla poszczególnych kryteriów i parametrów ustalono jako średnią arytmetyczną odpowiedzi respondentów w kwestionariuszach indywidualnych wywiadów pogłębionych. Pytania w kwestionariuszu miały charakter kafeterii, przy czym obok wariantów odpowiedzi sformułowanych na podstawie literatury przedmiotu, respondenci mogli zaproponować własne kryteria i parametry.

${ }^{33}$ Problem ograniczenia wieku w kontekście ograniczeń korzystania z oferty banków przez seniorów podejmuje m.in. I. D. Czechowska, Ograniczenia $w$ dostępie do ustug bankowych 60+ w perspektywie zrównoważonych finansów, „Zeszyty Prac Naukowych Uniwersytetu Ekonomicznego we Wrocławiu" 2013, nr 311, s. 6. 
nościowej SA. Oferta tych produktów dla klientów $50+$ była oceniana w ramach poszczególnych kryteriów i parametrów oraz otrzymywała odpowiednią ocenę punktową, zgodnie ze schematem: 1 - oferta rachunku mało atrakcyjna, 2 - oferta rachunku przeciętnie atrakcyjna, 3 - oferta rachunku bardzo atrakcyjna.

W przypadku kryterium TAK/NIE zastosowano ocenę punktową 1 lub 3, przy czym 1 oznacza ofertę mało atrakcyjną, a 3 - bardzo atrakcyjną.

Oferta rachunków bankowych tylko niektórych banków jest dedykowana dla osób powyżej 50. roku życia, z tym że niektóre banki podwyższają tę granicę do 60. roku życia (Bank Gospodarki Żywnościowej SA, Bank Pocztowy SA i PKO Bank Polski SA). Oprócz Banku Gospodarki Żywnościowej SA, który w ramach parametru: dostęp do placówek banku wypada słabiej, instytucje finansowe wypadają w porównaniu tak samo.

Poszczególne banki oceniono zgodnie z informacjami dostępnymi na ich stronach internetowych, przy czym parametry: dostęp do placówek banku i dostęp do bankomatów oceniono na podstawie map gęstości występowania placówek i bankomatów.

Tablica 16. Oferta rachunków bankowych dedykowanych dla seniorów z punktu widzenia kryterium: dostępność

\begin{tabular}{|l|c|c|c|c|}
\hline \multicolumn{1}{|c|}{ Bank } & $\begin{array}{c}\text { Wiek klienta } \\
\text { powyżej } \\
\text { 50. roku życia }\end{array}$ & $\begin{array}{c}\text { Możliwość } \\
\text { zalożenia } \\
\text { rachunku } \\
\text { w oddziale } \\
\text { banku }\end{array}$ & $\begin{array}{c}\text { Dostęp } \\
\text { do bankomatów }\end{array}$ & $\begin{array}{c}\text { Dostęp } \\
\text { do placówek } \\
\text { banku }\end{array}$ \\
\hline $\begin{array}{l}\text { Bank Gospodarki } \\
\text { Żywnościowej SA }\end{array}$ & $\begin{array}{c}\text { TAK (powyżej } \\
60 . \text { roku życia) }\end{array}$ & TAK & DUŻY & MAEY \\
\hline Bank Pocztowy SA & $\begin{array}{l}\text { TAK (powyżej } \\
60 . \text { roku życia) }\end{array}$ & TAK & DUŻY & DUŻY \\
\hline Bank Pekao SA & TAK & TAK & DUŻY & DUŻY \\
\hline $\begin{array}{l}\text { Bank Zachodni } \\
\text { WBK SA }\end{array}$ & TAK & TAK & DUŻY & DUŻY \\
\hline Deutsche Bank SA & TAK & TAK & DUŻY & DUŻY \\
\hline $\begin{array}{l}\text { Getin Noble } \\
\text { Bank SA }\end{array}$ & $\begin{array}{l}\text { TAK (powyżej } \\
55 . \text { roku życia) }\end{array}$ & TAK & DUŻY & DUŻY \\
\hline $\begin{array}{l}\text { PKO Bank } \\
\text { Polski SA }\end{array}$ & $\begin{array}{l}\text { TAK (powyżej } \\
60 . \text { roku życia) }\end{array}$ & TAK & DUŻY & DUŻY \\
\hline
\end{tabular}

Źródlo: opracowanie własne na podstawie stron internetowych poszczególnych banków.

W przypadku kryterium ceny, oferty rachunków poszczególnych banków różnią się znacznie między sobą. 


\begin{tabular}{|c|c|c|c|c|c|}
\hline 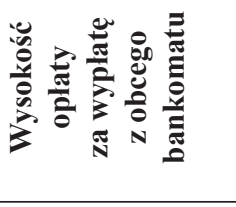 & 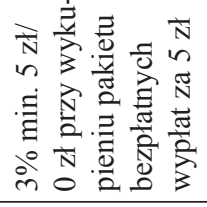 & $\begin{array}{l}\bar{N} \\
i n\end{array}$ & 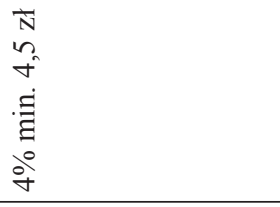 & $\begin{array}{l}\bar{N} \\
0\end{array}$ & $\begin{array}{l}\mathbf{N} \\
0\end{array}$ \\
\hline 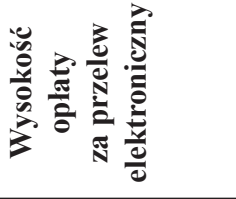 & $\begin{array}{l}\bar{N} \\
0\end{array}$ & $\begin{array}{l}\bar{N} \\
0\end{array}$ & $\begin{array}{l}\bar{N} \\
0\end{array}$ & $\begin{array}{l}\bar{N} \\
0 \\
n \\
0\end{array}$ & $\begin{array}{l}\bar{N} \\
0\end{array}$ \\
\hline 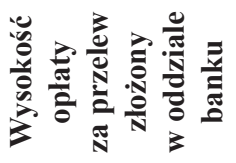 & $\begin{array}{l}\bar{N} \\
0\end{array}$ & $\begin{array}{l}\bar{N} \\
0\end{array}$ & $\begin{array}{l}\bar{N} \\
\stackrel{\alpha}{ } \\
\dot{f}\end{array}$ & $\begin{array}{l}\bar{N} \\
N\end{array}$ & $\begin{array}{l}\bar{N} \\
0\end{array}$ \\
\hline 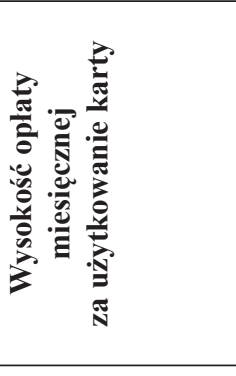 & 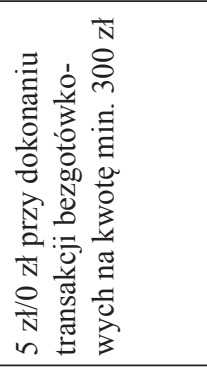 & 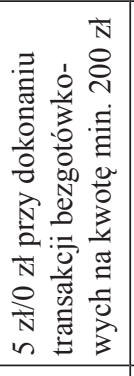 & 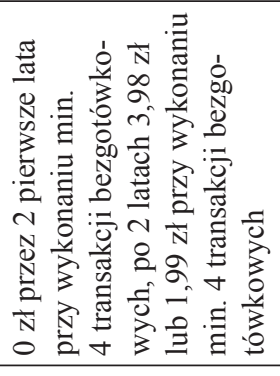 & 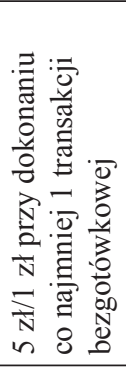 & 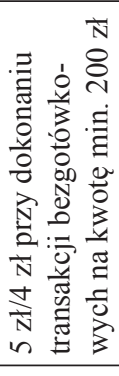 \\
\hline 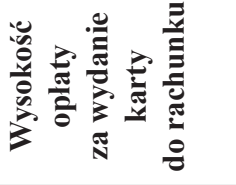 & $\begin{array}{l}\bar{N} \\
0\end{array}$ & $\begin{array}{l}\bar{N} \\
0\end{array}$ & $\begin{array}{l}\bar{N} \\
0\end{array}$ & $\begin{array}{l}\bar{N} \\
0\end{array}$ & $\begin{array}{l}\bar{N} \\
0\end{array}$ \\
\hline 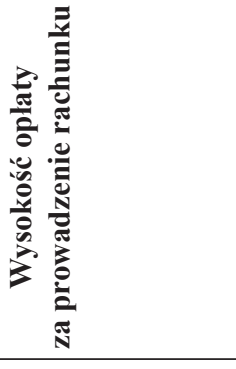 & 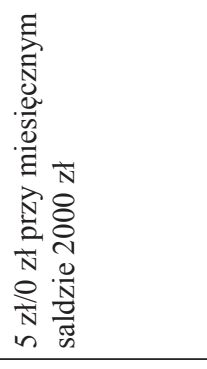 & 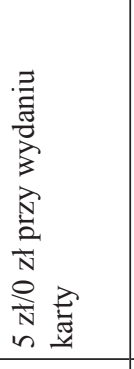 & 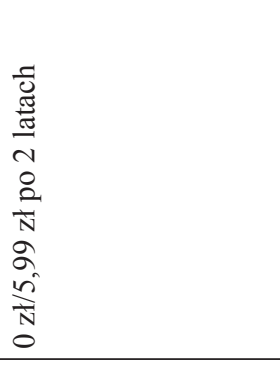 & 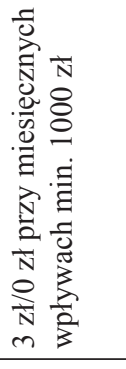 & $\begin{array}{l}\bar{N} \\
m\end{array}$ \\
\hline 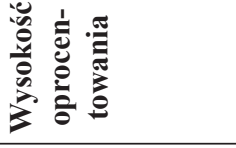 & ठे & ठे & ठें & ठें & $\stackrel{\circ}{-}$ \\
\hline बै & 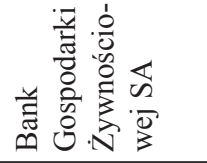 & 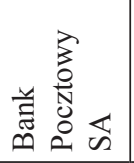 & 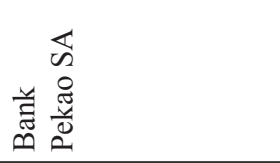 & 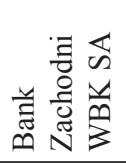 & 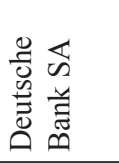 \\
\hline
\end{tabular}




\begin{tabular}{|c|c|}
\hline $\begin{array}{c}\bar{N} \\
n \\
\dot{\Xi} \\
\dot{\Xi} \\
\text { 品 } \\
\text { in } \\
\text { m }\end{array}$ & $\begin{array}{l}\bar{N} \\
0\end{array}$ \\
\hline $\begin{array}{l}\mathbf{N} \\
0\end{array}$ & $\begin{array}{l}\bar{N} \\
0\end{array}$ \\
\hline $\begin{array}{l}\bar{N} \\
\stackrel{2}{ } \\
\hat{n}\end{array}$ & $\begin{array}{l}\bar{N} \\
n\end{array}$ \\
\hline 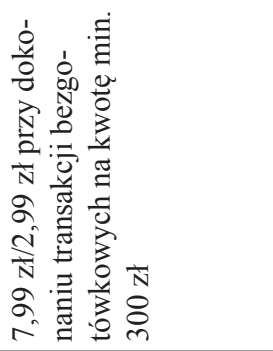 & 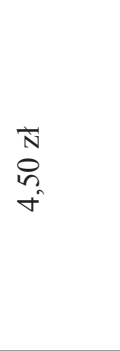 \\
\hline 太े & $\begin{array}{l}\bar{N} \\
0\end{array}$ \\
\hline 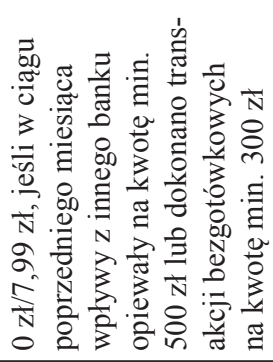 & 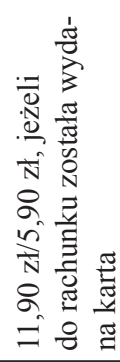 \\
\hline ஃ̊ & $\frac{0}{0}$ \\
\hline 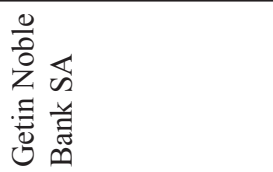 & 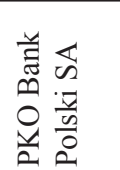 \\
\hline
\end{tabular}

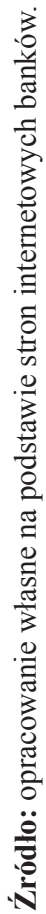


Co istotne, każda $\mathrm{z}$ wymienionych instytucji finansowych oferuje seniorom dodatkowe usługi, z tym że ich zakres różni się między sobą (choć głównie koncentruje się na ubezpieczeniu medycznym).

Tablica 18. Oferta rachunków oszczędnościowo-rozliczeniowych dedykowanych dla seniorów z punktu widzenia kryterium: dodatkowe usługi

\begin{tabular}{|l|c|c|c|}
\hline \multicolumn{1}{|c|}{ Bank } & $\begin{array}{c}\text { Ubezpieczenie } \\
\text { Medical Assistance }\end{array}$ & Zniżki u partnerów & $\begin{array}{c}\text { Dodatkowe } \\
\text { ubezpieczenie }\end{array}$ \\
\hline $\begin{array}{l}\text { Bank Gospodarki } \\
\text { Żywnościowej SA }\end{array}$ & NIE & TAK & NIE \\
\hline Bank Pocztowy SA & NIE & TAK & NIE \\
\hline Bank Pekao SA & TAK & NIE & TAK \\
\hline $\begin{array}{l}\text { Bank Zachodni } \\
\text { WBK SA }\end{array}$ & TAK & TAK & TAK \\
\hline $\begin{array}{l}\text { Deutsche } \\
\text { Bank SA }\end{array}$ & TAK & NIE & NIE \\
\hline $\begin{array}{l}\text { Getin Noble } \\
\text { Bank SA }\end{array}$ & NIE & TAK & TAK \\
\hline $\begin{array}{l}\text { PKO Bank } \\
\text { Polski SA }\end{array}$ & TAK & NIE & \\
\hline
\end{tabular}

Źródło: opracowanie własne na podstawie stron internetowych banków. Kolejne tablice zawierają oceny punktowe ofert rachunków banków w ramach poszczególnych kryteriów.

Tablica 19. Ocena punktowa ofert rachunków oszczędnościowo-rozliczeniowych dedykowanych dla seniorów z punktu widzenia kryterium: dostępność

\begin{tabular}{|l|c|c|c|c|}
\hline \multicolumn{1}{|c|}{ Bank } & $\begin{array}{c}\text { Wiek klienta } \\
\text { powyżej } \\
\text { 50. roku życia }\end{array}$ & $\begin{array}{c}\text { Możliwość } \\
\text { założenia rachunku } \\
\text { w oddziale banku }\end{array}$ & $\begin{array}{c}\text { Dostęp } \\
\text { do bankoma- } \\
\text { tów }\end{array}$ & $\begin{array}{c}\text { Dostęp } \\
\text { do placówek } \\
\text { banku }\end{array}$ \\
\hline $\begin{array}{l}\text { Bank Gospodarki } \\
\text { Żywnościowej SA }\end{array}$ & 1 & 3 & 3 & 1 \\
\hline Bank Pocztowy SA & 1 & 3 & 3 & 3 \\
\hline Bank Pekao SA & 3 & 3 & 3 & 3 \\
\hline $\begin{array}{l}\text { Bank Zachodni } \\
\text { WBK SA }\end{array}$ & 3 & 3 & 3 & 3 \\
\hline Deutsche Bank SA & 3 & 3 & 3 & 3 \\
\hline $\begin{array}{l}\text { Getin Noble } \\
\text { Bank SA }\end{array}$ & 2 & 3 & 3 & 3 \\
\hline $\begin{array}{l}\text { PKO Bank } \\
\text { Polski SA }\end{array}$ & 1 & 3 & 3 & 3 \\
\hline
\end{tabular}

Źródło: opracowanie własne. 


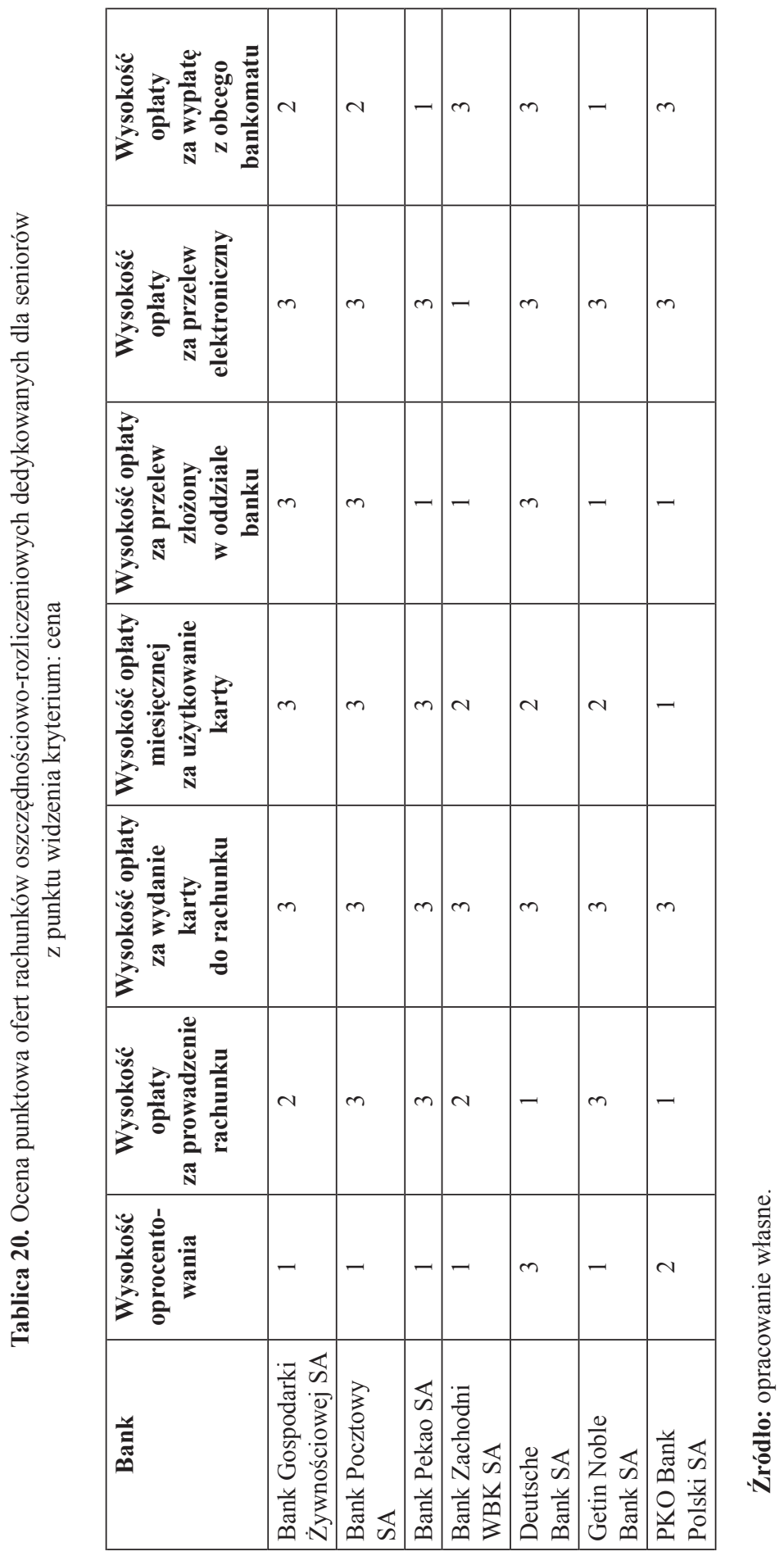


Tablica 21. Ocena punktowa ofert rachunków oszczędnościowo-rozliczeniowych dedykowanych dla seniorów z punktu widzenia kryterium: dodatkowe usługi

\begin{tabular}{|l|c|c|c|}
\hline \multicolumn{1}{|c|}{ Bank } & $\begin{array}{c}\text { Ubezpieczenie } \\
\text { Medical } \\
\text { Assistance }\end{array}$ & $\begin{array}{c}\text { Zniżki } \\
\text { u partnerów }\end{array}$ & $\begin{array}{c}\text { Dodatkowe } \\
\text { ubezpieczenie }\end{array}$ \\
\hline $\begin{array}{l}\text { Bank } \\
\text { Gospodarki } \\
\text { Żywnościowej SA }\end{array}$ & 1 & 3 & 1 \\
\hline $\begin{array}{l}\text { Bank Pocztowy } \\
\text { SA }\end{array}$ & 1 & 3 & 3 \\
\hline Bank Pekao SA & 3 & 1 & 1 \\
\hline $\begin{array}{l}\text { Bank Zachodni } \\
\text { WBK SA }\end{array}$ & 3 & 3 & 3 \\
\hline $\begin{array}{l}\text { Deutsche } \\
\text { Bank SA }\end{array}$ & 3 & 1 & 1 \\
\hline $\begin{array}{l}\text { Getin Noble } \\
\text { Bank SA }\end{array}$ & 1 & 3 & 3 \\
\hline $\begin{array}{l}\text { PKO Bank } \\
\text { Polski SA }\end{array}$ & 3 & 1 & 1 \\
\hline
\end{tabular}

Źródło: opracowanie własne.

Ocena ofert rachunków bankowych w oparciu o przyjętą metodologię wypada najkorzystniej w przypadku Banku Pocztowego SA, Banku Pekao SA i Getin Noble Banku SA. Z kolei PKO Bank Polski SA wypada w zestawieniu najsłabiej. W ramach kryterium: dostępność najkorzystniej wypada Bank Pekao SA, Bank Zachodni WBK SA oraz Deutsche Bank SA, zaś najgorzej Bank Gospodarki Żywnościowej SA. Oceniając ofertę w ramach kryterium: cena, można zauważyć, że najwięcej punktów otrzymał Bank Pocztowy SA, Bank Pekao SA i Bank Gospodarki Żywnościowej SA, a najmniej PKO Bank Polski SA. Z kolei z punktu widzenia kryterium: dodatkowe usługi wyróżnił się pozytywnie Bank Zachodni WBK SA, zaś negatywnie Bank Gospodarki Żywnościowej SA, Bank Pocztowy SA oraz Getin Noble Bank SA. 


\begin{tabular}{|c|c|c|c|c|c|c|c|c|c|c|c|c|c|}
\hline 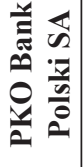 & $\infty$ & & $\stackrel{2}{0}$ & $\mathfrak{n}_{0}^{n}$ & $\frac{n}{0}$ & $\stackrel{n}{f}$ & $\Rightarrow$ & & $O_{0}^{+}$ & $\stackrel{n}{1}$ & $\frac{n}{0}$ & $\overrightarrow{0}$ & $\overrightarrow{0}$ \\
\hline 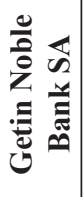 & 1 & & $\overrightarrow{0}$ & 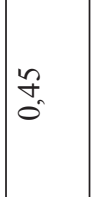 & $\frac{n}{0}$ & $\stackrel{n}{n}$ & $\stackrel{n}{=}$ & & $\delta_{0}$ & $\frac{n}{0}$ & $\frac{n}{0}$ & ్. & $\overrightarrow{0}$ \\
\hline 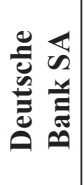 & 0 & & $\frac{n}{0}$ & $\underset{\sigma}{n}$ & $\frac{n}{0}$ & $\stackrel{n}{n}$ & $\cong$ & & ¿ & $\tilde{n}$ & $\frac{n}{0}$ & $\tilde{o}$ & ? \\
\hline 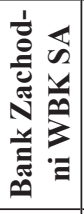 & in & 总 & $\frac{n}{0}$ & 年 & $\frac{n}{0}$ & 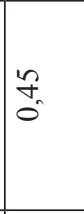 & 그 & $\pi$ & Oे & $n$ & $\frac{n}{0}$ & $\tilde{\sigma}$ & $\overrightarrow{0}$ \\
\hline 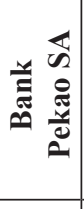 & $\nabla$ & 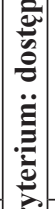 & $\frac{n}{0}$ & fr & $\frac{n}{0}$ & $\stackrel{n}{2}$ & $\cong$ & 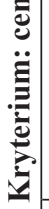 & $\tilde{O}_{0}$ & $\frac{n}{0}$ & $\frac{n}{0}$ & $\hat{0}$ & $\overrightarrow{0}$ \\
\hline 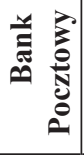 & $m$ & & $\stackrel{n}{0}$ & In & $\frac{n}{0}$ & $\mathfrak{n}_{0}^{n}$ & $=$ & & $\tilde{\sigma}_{0}$ & $\frac{n}{0}$ & $\frac{n}{0}$ & $\overbrace{0}^{2}$ & $\tilde{n}^{2}$ \\
\hline 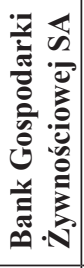 & $N$ & & $\stackrel{n}{0}$ & fo & $\frac{n}{0}$ & $\frac{n}{0}$ & $\stackrel{\infty}{0}$ & & Õ & n & $\frac{n}{0}$ & $\hat{0}$ & ? \\
\hline & - & & 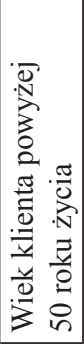 & 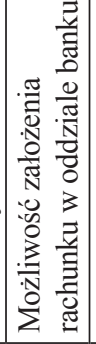 & 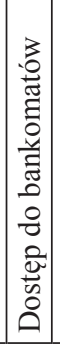 & 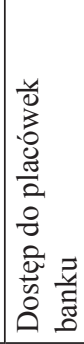 & 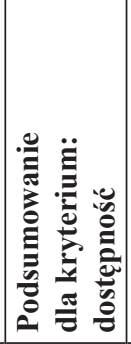 & & 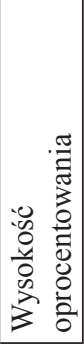 & 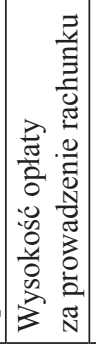 & 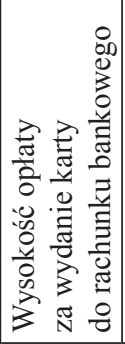 & 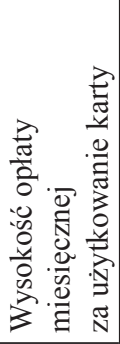 & 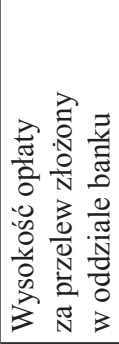 \\
\hline
\end{tabular}




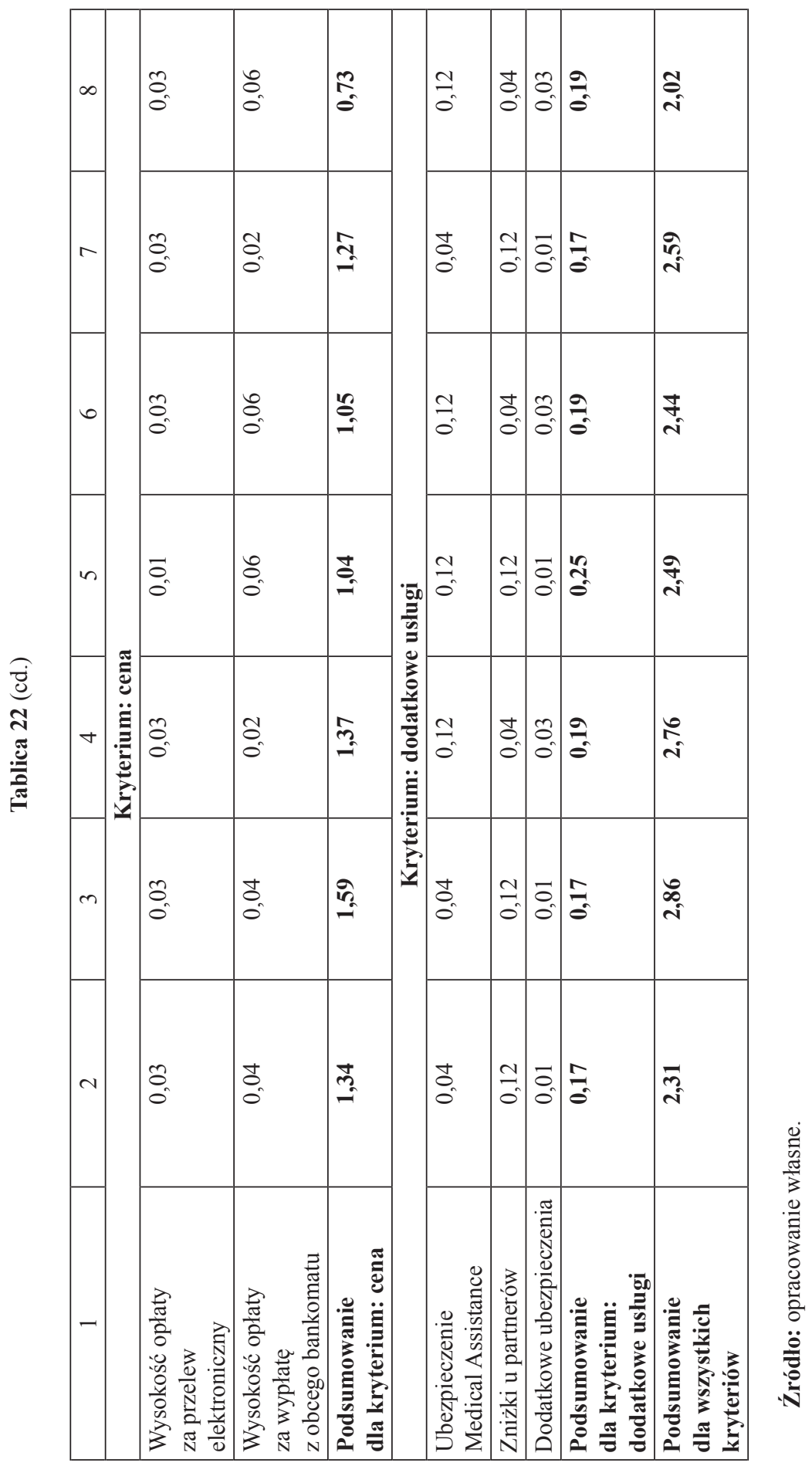




\subsubsection{Ocena atrakcyjności oferty lokat bankowych dedykowanych seniorom}

W celu przeprowadzenia oceny atrakcyjności oferty lokat bankowych (depozytów terminowych) zidentyfikowano następujące kryteria:

- dostępność,

- cena,

- elastyczność warunków.

Każdemu z wyodrębnionych kryteriów przypisano poziom istotności ${ }^{34}$ : dostępność $20 \%$, cena $70 \%$, elastyczność depozytów $10 \%$.

W ramach kryterium: dostępność przy analizie były brane pod uwagę następujące parametry:

- warunek minimalnego zainwestowanego kapitału (istotność: 10\%),

- warunek maksymalnego zainwestowanego kapitału (istotność: 3\%),

- możliwość założenia lokaty w oddziale banku (istotność: 5\%),

- konieczność posiadania rachunku w banku (istotność: 2\%).

Z kolei dla kryterium: cena przyjęto następujące parametry:

- wysokość oprocentowania (istotność: $60 \%$ ),

- wypłata odsetek na koniec okresu umowy (istotność: 3\%),

- kapitalizacja odsetek (istotność: 1\%),

- wyższe oprocentowanie dla nowych klientów (istotność: 5\%),

- dodatkowe opłaty za wykonanie czynności bankowych związanych z depozytami (istotność: $1 \%$ ).

Ostatnim kryterium branym pod uwagę przy ocenie atrakcyjności lokat bankowych była elastyczność warunków, dla której zidentyfikowano następujące parametry:

- możliwość zerwania lokaty przed czasem (istotność: 5\%),

- możliwość odnowienia lokaty na tych samych warunkach (istotność: 5\%).

W ofercie banków nie występują lokaty dedykowane wyłącznie dla seniorów. Osoby starsze muszą dokonywać wyborów spośród standardowej oferty depozytów terminowych. Ze względu na krótkoterminowe preferencje społeczeństwa w zakresie oszczędzania ${ }^{35}$ analizie poddano ofertę lokat trzymiesięcznych. Aby zapewnić porównywalność wyników analizę przeprowadzono wśród tych banków, które oferowały rachunki oszczędnościowo-rozliczeniowe dla seniorów.

Oferta tych lokat bankowych była oceniana w ramach poszczególnych kryteriów i parametrów oraz otrzymywała odpowiednią ocenę punktową, zgodnie z poniższym schematem:

${ }^{34}$ Wagi dla poszczególnych kryteriów i parametrów ustalono jako średnią arytmetyczną odpowiedzi respondentów w kwestionariuszach indywidualnych wywiadów pogłębionych. Pytania w kwestionariuszu miały charakter kafeterii, przy czym obok wariantów odpowiedzi sformułowanych na podstawie literatury przedmiotu respondenci mogli zaproponować własne kryteria i parametry.

${ }^{35} \mathrm{~K}$. Kontek, Bariery rozwoju polskiego systemu funduszy emerytalnych, „Studia Ekonomiczne" 2010, nr 3, s. 244. 
- 1 - oferta lokaty mało atrakcyjna,

- 2 - oferta lokaty przeciętnie atrakcyjna,

- 3 - oferta lokaty bardzo atrakcyjna.

W przypadku kryterium TAK/NIE zastosowano ocenę punktową 1 lub 3, przy czym 1 oznacza ofertę mało atrakcyjną, a 3 - bardzo atrakcyjną.

Tablica 23. Oferta lokat bankowych dedykowanych dla seniorów z punktu widzenia kryterium: dostępność

\begin{tabular}{|c|c|c|c|c|}
\hline Bank & $\begin{array}{c}\text { Warunek } \\
\text { minimalnego } \\
\text { zainwestowanego } \\
\text { kapitału }\end{array}$ & $\begin{array}{c}\text { Warunek } \\
\text { maksymalnego } \\
\text { zainwestowanego } \\
\text { kapitału }\end{array}$ & $\begin{array}{c}\text { Możliwość } \\
\text { założenia } \\
\text { lokaty } \\
\text { w oddziale } \\
\text { banku }\end{array}$ & $\begin{array}{c}\text { Konieczność } \\
\text { posiadania } \\
\text { innego produktu } \\
\text { w banku }\end{array}$ \\
\hline $\begin{array}{l}\text { Bank Gospodarki } \\
\text { Żywnościowej SA }\end{array}$ & $\begin{array}{c}\text { TAK } \\
(1000 \mathrm{zl})\end{array}$ & NIE & TAK & $\begin{array}{c}\text { TAK (konto } \\
\text { oszczędnościowe } \\
\text { Eskalacja) }\end{array}$ \\
\hline \begin{tabular}{|l|} 
Bank \\
Pocztowy SA
\end{tabular} & $\begin{array}{c}\text { TAK } \\
(500 \mathrm{zl})\end{array}$ & NIE & TAK & $\begin{array}{l}\text { TAK (rachunek } \\
\text { bankowy) }\end{array}$ \\
\hline $\begin{array}{l}\text { Bank } \\
\text { Pekao SA }\end{array}$ & $\begin{array}{c}\text { TAK } \\
(500 \mathrm{zl})\end{array}$ & NIE & TAK & NIE \\
\hline $\begin{array}{l}\text { Bank Zachodni } \\
\text { WBK SA }\end{array}$ & $\begin{array}{c}\text { TAK } \\
(1000 \mathrm{zl})\end{array}$ & NIE & TAK & NIE \\
\hline $\begin{array}{l}\text { Deutsche } \\
\text { Bank SA }\end{array}$ & $\begin{array}{c}\text { TAK } \\
(2000 \mathrm{zl})\end{array}$ & NIE & TAK & NIE \\
\hline \begin{tabular}{|l|} 
Getin Noble \\
Bank SA
\end{tabular} & $\begin{array}{c}\text { TAK } \\
(500 \mathrm{zl})\end{array}$ & NIE & TAK & NIE \\
\hline $\begin{array}{l}\text { PKO Bank } \\
\text { Polski SA }\end{array}$ & $\begin{array}{c}\text { TAK } \\
(1000 \mathrm{zl})\end{array}$ & NIE & TAK & $\begin{array}{l}\text { TAK (rachunek } \\
\text { bankowy) }\end{array}$ \\
\hline
\end{tabular}

Źródło: opracowanie własne na podstawie stron internetowych banków.

Każdy z analizowanych banków przy ofercie lokaty dodawał warunek minimalnego kapitału, przy czym najwyższy był on w Deutsche Bank SA. Wszystkie instytucje finansowe rezygnowały $\mathrm{z}$ warunku maksymalnego zainwestowanego kapitału oraz stwarzały możliwość założenia lokaty w oddziale banku. Bank Gospodarki Żywnościowej SA, Bank Pocztowy SA oraz PKO Bank Polski SA przy założeniu lokaty wymagały także posiadania innego produktu bankowego.

Najwyższe oprocentowanie lokat trzymiesięcznych jest w przypadku oferty Banku Pocztowego SA oraz Getin Noble Banku SA. Oprócz Banku Gospodarki Żywnościowej SA, wypłata odsetek z lokat następuje na koniec okresu umowy. Tylko w Banku Zachodnim WBK SA odsetki były kapitalizowane. Dwa banki (Deutsche Bank SA i Getin Noble Bank SA) oferowały klientom specjalne warunki (podwyższone oprocentowanie po spełnieniu określonego warunku). Zakładając lokaty, klienci wszystkich analizowanych banków nie ponoszą dodatkowych kosztów. 


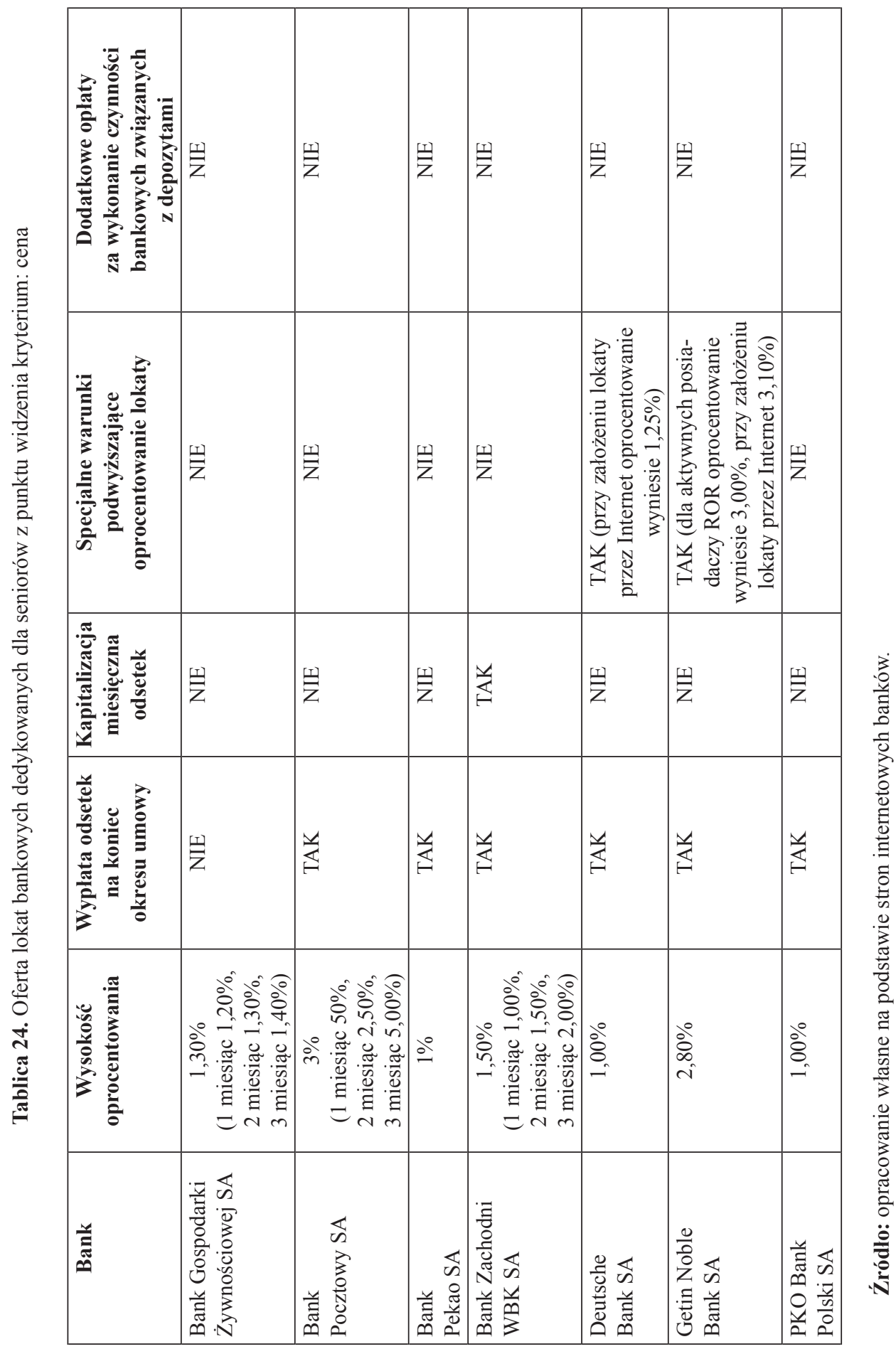


Tablica 25. Oferta lokat bankowych dedykowanych dla seniorów z punktu widzenia kryterium: elastyczność warunków

\begin{tabular}{|l|c|c|}
\hline \multicolumn{1}{|c|}{ Bank } & $\begin{array}{c}\text { Możliwość zerwania lokaty } \\
\text { przed czasem bez utraty odsetek }\end{array}$ & $\begin{array}{c}\text { Możliwość odnowienia lokaty } \\
\text { na tych samych warunkach }\end{array}$ \\
\hline $\begin{array}{l}\text { Bank Gospodarki } \\
\text { Żywnościowej SA }\end{array}$ & TAK & NIE \\
\hline Bank Pocztowy SA & TAK & NIE \\
\hline Bank Pekao SA & NIE & TAK \\
\hline $\begin{array}{l}\text { Bank Zachodni } \\
\text { WBK SA }\end{array}$ & TAK & TAK \\
\hline Deutsche Bank SA & TAK & TAK \\
\hline Getin Noble Bank SA & NIE & TAK \\
\hline PKO Bank Polski SA & NIE & TAK \\
\hline
\end{tabular}

Źródło: opracowanie własne na podstawie stron internetowych banków.

Tylko Bank Zachodni WBK SA i Deutsche Bank SA oferują klientom możliwość zerwania lokaty przed czasem bez utraty odsetek oraz możliwość odnowienia lokaty na tych samych warunkach. Kolejne tablice zawierają oceny punktowe ofert depozytów trzymiesięcznych w ramach poszczególnych kryteriów.

Tablica 26. Ocena punktowa ofert lokat bankowych dedykowanych dla seniorów z punktu widzenia kryterium: dostępność

\begin{tabular}{|l|c|c|c|c|}
\hline \multicolumn{1}{|c|}{ Bank } & $\begin{array}{c}\text { Warunek } \\
\text { minimalnego } \\
\text { zainwestowanego } \\
\text { kapitału }\end{array}$ & $\begin{array}{c}\text { Warunek } \\
\text { maksymalnego } \\
\text { zainwestowanego } \\
\text { kapitalu }\end{array}$ & $\begin{array}{c}\text { Możliwość } \\
\text { zalożenia lokaty } \\
\text { w oddziale } \\
\text { banku }\end{array}$ & $\begin{array}{c}\text { Konieczność } \\
\text { posiadania } \\
\text { innego produktu } \\
\text { w banku }\end{array}$ \\
\hline $\begin{array}{l}\text { Bank Gospodarki } \\
\text { Żywnościowej SA }\end{array}$ & 2 & 3 & 3 & 1 \\
\hline $\begin{array}{l}\text { Bank } \\
\text { Pocztowy SA }\end{array}$ & 3 & 3 & 3 & 1 \\
\hline $\begin{array}{l}\text { Bank } \\
\text { Pekao SA }\end{array}$ & 3 & 3 & 3 & 3 \\
\hline $\begin{array}{l}\text { Bank Zachodni } \\
\text { WBK SA }\end{array}$ & 2 & 3 & 3 & 3 \\
\hline $\begin{array}{l}\text { Deutsche } \\
\text { Bank SA }\end{array}$ & 1 & 3 & 3 & 3 \\
\hline $\begin{array}{l}\text { Getin Noble } \\
\text { Bank SA }\end{array}$ & 3 & 3 & 3 & 3 \\
\hline $\begin{array}{l}\text { PKO Bank } \\
\text { Polski SA }\end{array}$ & 2 & 3 & 3 & 1 \\
\hline
\end{tabular}

Źródło: opracowanie własne. 

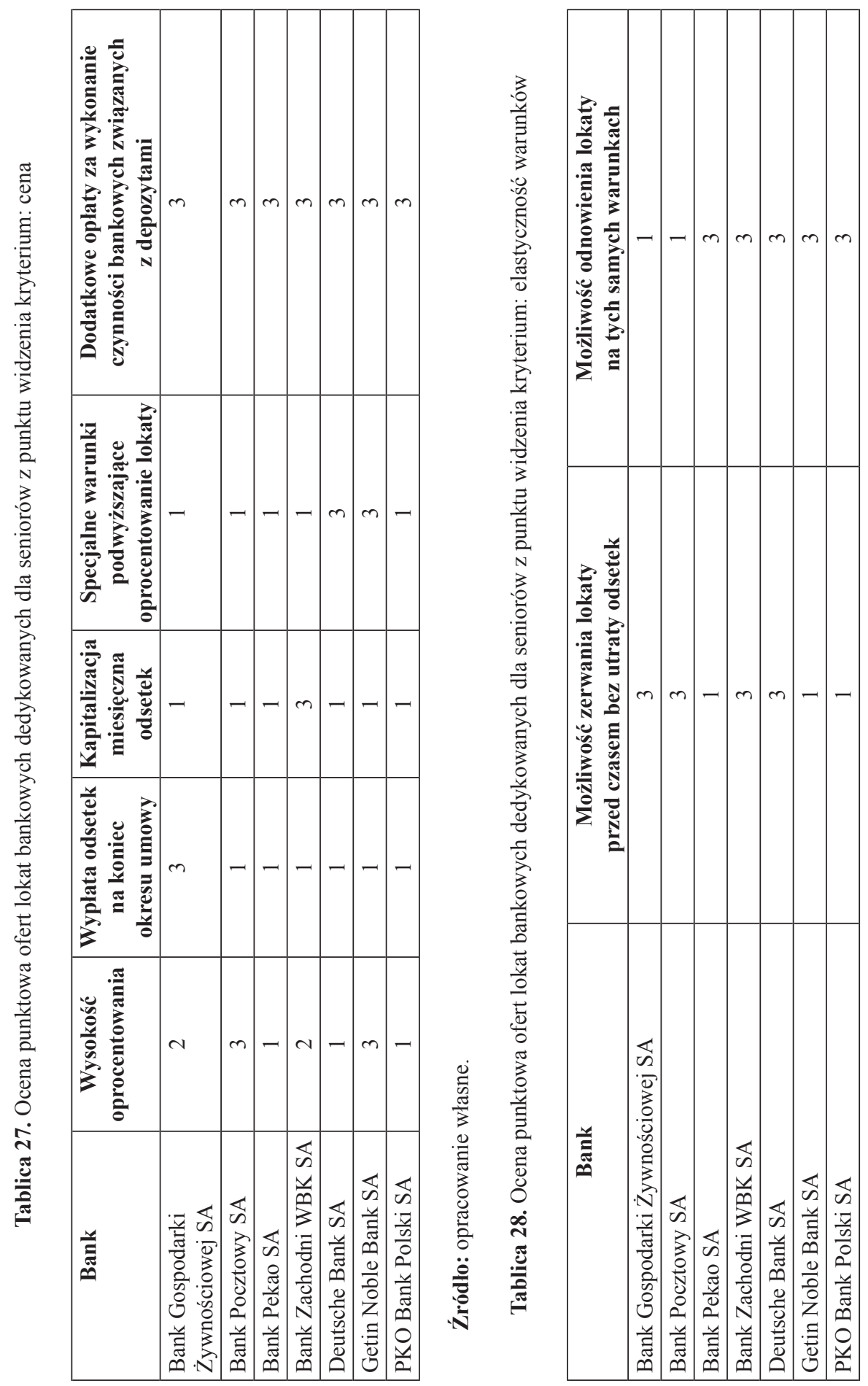

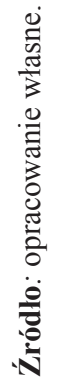




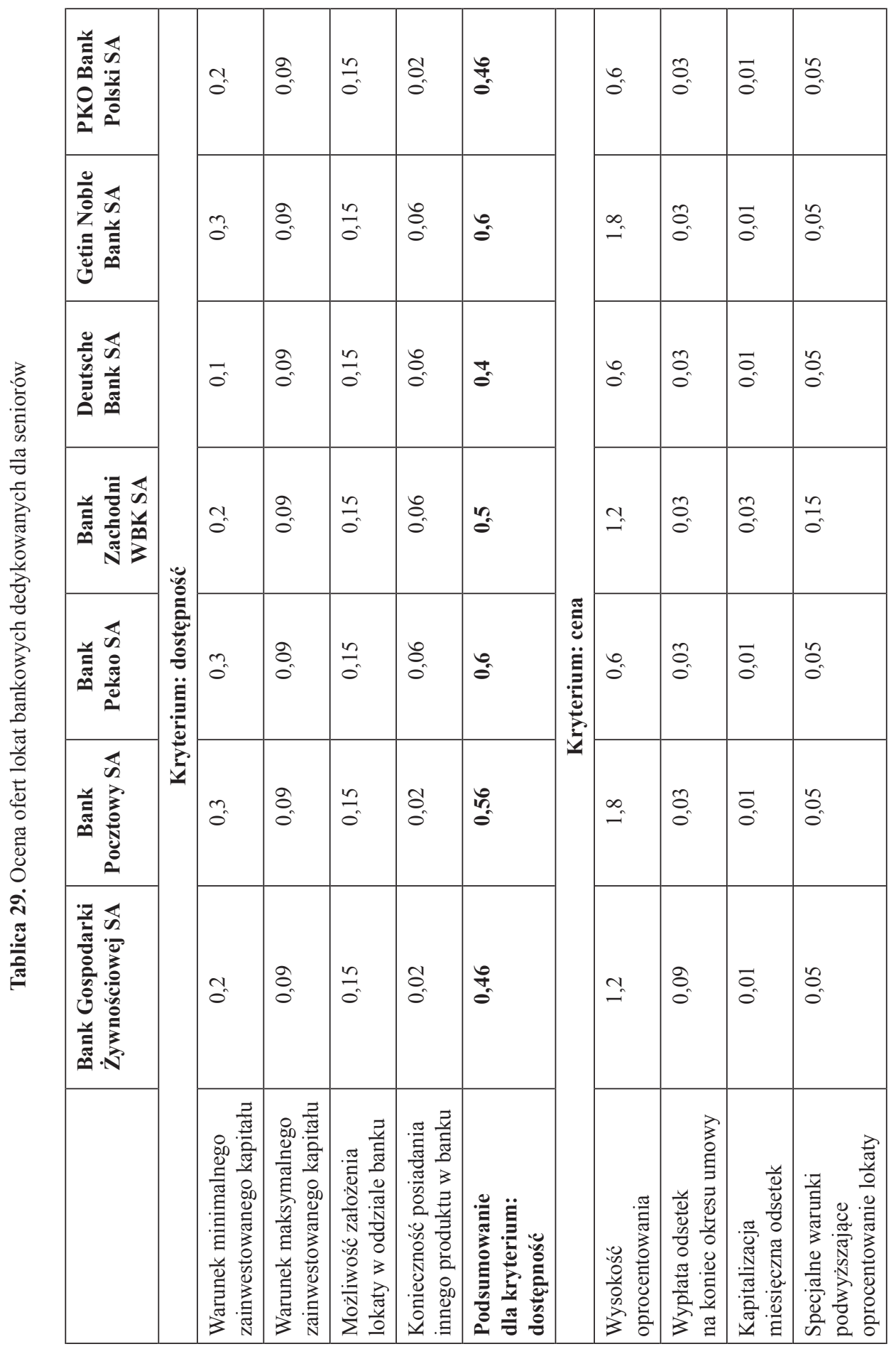




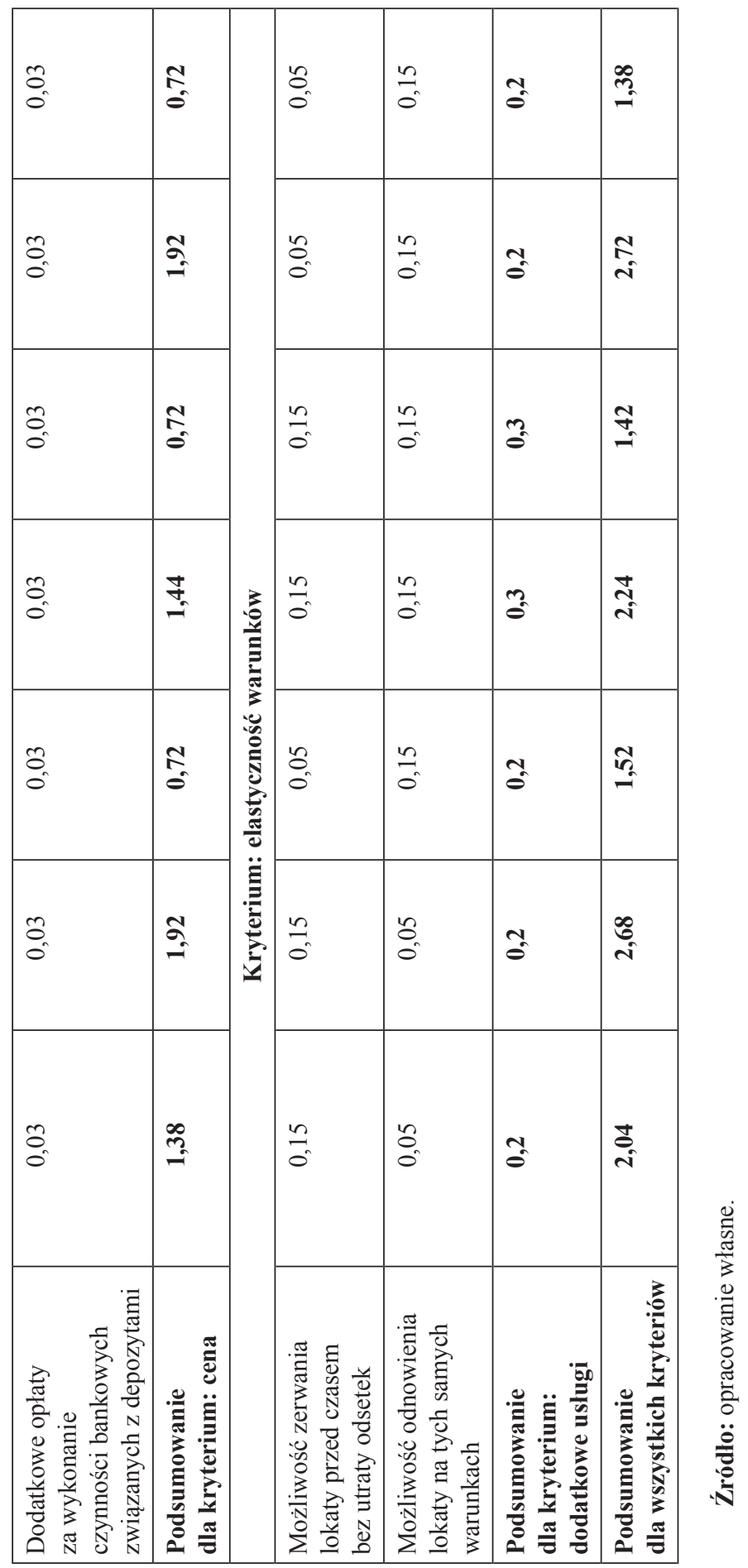


Ocena lokat trzymiesięcznych w oparciu o przyjętą metodologię wypada najkorzystniej w przypadku Getin Noble Banku SA, Banku Pocztowego SA oraz Banku Zachodniego WBK SA. Z kolei PKO Bank Polski SA i Deutsche Bank SA wypadają w zestawieniu najsłabiej. W ramach kryterium: dostępność najkorzystniej wypada Getin Noble Bank SA, Bank Pekao SA i Bank Pocztowy SA, zaś najgorzej Deutsche Bank SA. Oceniając ofertę w ramach kryterium: cena, można zauważyć, że najwięcej punktów otrzymał Bank Pocztowy SA i Getin Noble Bank SA, a najmniej Bank Pekao SA, PKO Bank Polski SA i Deutsche Bank SA. Z kolei z punktu widzenia kryterium: elastyczność depozytów wyróżnił się pozytywnie Bank Zachodni WBK SA i Deutsche Bank SA.

\subsubsection{Ocena atrakcyjności oferty kredytów dedykowanych seniorom}

W celu przeprowadzenia oceny atrakcyjności oferty produktów kredytowych (kredyty gotówkowe) zidentyfikowano następujące kryteria:

- dostępność,

- cena,

- wygoda oraz uproszczone procedury.

Każdemu z wyodrębnionych kryteriów przypisano poziom istotności: dostępność $30 \%$, cena $60 \%$, wygoda oraz uproszczone procedury $10 \%{ }^{36}$.

W ramach kryterium: dostępność przy analizie były brane pod uwagę następujące parametry:

- maksymalny wiek kredytobiorcy (istotność: 15\%),

- maksymalny okres kredytowania (istotność: 5\%),

- maksymalna kwota kredytu (istotność: $10 \%$ ).

Z kolei dla kryterium: cena przyjęto następujące parametry:

- oprocentowanie (istotność: 40\%),

- rodzaj rat (istotność: 3\%),

- prowizja za udzielenie kredytu (istotność: 9\%),

- prowizja za wcześniejszą spłatę kredytu (istotność: $1 \%$ ),

- prowizja za podwyższenie kwoty kredytu (istotność: $1 \%$ ),

- ubezpieczenie (istotność: 6\%).

Ostatnim kryterium branym pod uwagę przy ocenie atrakcyjności produktów kredytowych była wygoda oraz uproszczone procedury, dla której zidentyfikowano następujące parametry:

${ }^{36}$ Wagi dla poszczególnych kryteriów i parametrów ustalono jako średnią arytmetyczną odpowiedzi respondentów w kwestionariuszach indywidualnych wywiadów pogłębionych. Pytania $\mathrm{w}$ kwestionariuszu miały charakter kafeterii, przy czym obok wariantów odpowiedzi sformułowanych na podstawie literatury przedmiotu, respondenci mogli zaproponować własne kryteria i parametry. 
- uproszczone procedury, rozumiane jako formalności niezbędne w procesie oceny zdolności kredytowej (np. dostarczenie odcinka renty lub emerytury, dowodu osobistego itp.), oceniane przez respondentów jako niesprawiające problemów (istotność: 4\%);

- szybka decyzja kredytowa, rozumiana jako krótki czas podjęcia decyzji o udzieleniu kredytu (istotność: 4\%);

- konieczność posiadania rachunku w banku (istotność: 2\%).

Oprócz Getin Noble Banku SA, który dla seniorów stworzył specjalną ofertę kredytową, pozostałe banki nie posiadają kredytów skierowanych do osób powyżej 50. roku życia. W dalszej analizie wzięto pod uwagę oprócz Getin Noble Banku SA wszystkie banki, które posiadały rachunki bankowe dla osób starszych.

Oferta kredytów była oceniana w ramach poszczególnych kryteriów i parametrów oraz otrzymywała odpowiednią ocenę punktową, zgodnie z poniższym schematem:

- 1 - oferta kredytu mało atrakcyjna,

- 2 - oferta kredytu przeciętnie atrakcyjna,

- 3 - oferta kredytu bardzo atrakcyjna.

W przypadku kryterium TAK/NIE zastosowano ocenę punktową 1 lub 3, przy czym 1 oznacza ofertę mało atrakcyjną, a 3 bardzo atrakcyjną.

Podstawowym warunkiem udzielenia kredytu jest posiadanie przez kredytobiorcę zdolności kredytowej. Jednakże niektóre banki wstrzymują się od udzielenia kredytu osobom powyżej określonej granicy wieku (przykładowo w Euro Banku SA jest to 79 lat, a w PKO Banku Polskim SA 70 lat).

Tablica 30. Oferta kredytów dedykowanych dla seniorów z punktu widzenia kryterium: dostępność

\begin{tabular}{|l|c|c|c|}
\hline \multicolumn{1}{|c|}{ Bank } & $\begin{array}{c}\text { Maksymalny wiek } \\
\text { kredytobiorcy }\end{array}$ & $\begin{array}{c}\text { Maksymalny okres } \\
\text { kredytowania }\end{array}$ & $\begin{array}{c}\text { Maksymalna kwota } \\
\text { kredytu (w zl) }\end{array}$ \\
\hline $\begin{array}{l}\text { Bank Gospodarki } \\
\text { Żywnościowej SA }\end{array}$ & 75 lat & 96 miesięcy & 150000 \\
\hline Bank Pocztowy SA & brak ograniczeń & 120 miesięcy & 100000 \\
\hline Bank Pekao SA & 75 lat & 84 miesiące & 100000 \\
\hline $\begin{array}{l}\text { Bank Zachodni } \\
\text { WBK SA }\end{array}$ & brak ograniczeń & 72 miesiące & 120000 \\
\hline $\begin{array}{l}\text { Deutsche } \\
\text { Bank SA }\end{array}$ & 72 lata & 84 miesiące & 150000 \\
\hline $\begin{array}{l}\text { Getin Noble } \\
\text { Bank SA }\end{array}$ & 75 lat & 84 miesiące & 150000 \\
\hline PKO Bank Polski SA & 70 lat & 96 miesięcy & 150000 \\
\hline
\end{tabular}

Źródło: opracowanie własne na podstawie stron internetowych banków. 


\begin{tabular}{|c|c|c|c|c|c|c|}
\hline 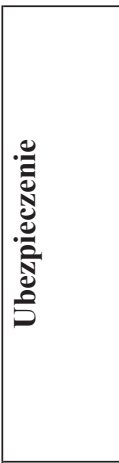 & 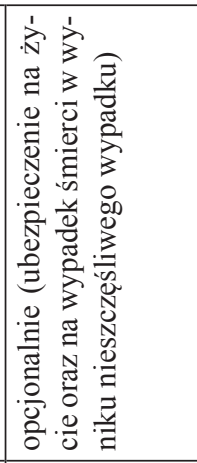 & 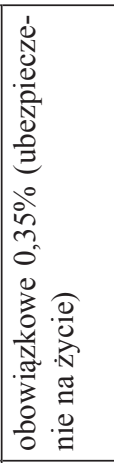 & 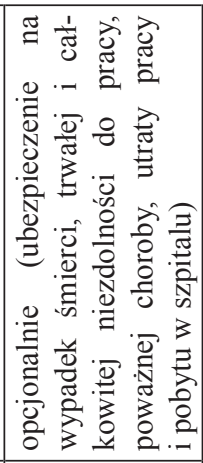 & 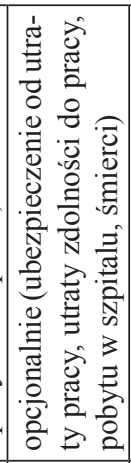 & 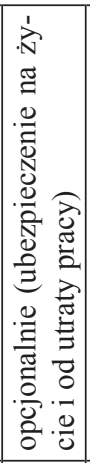 & 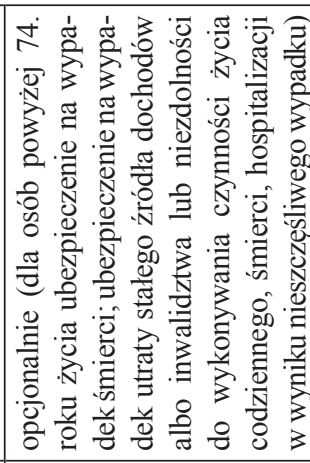 \\
\hline 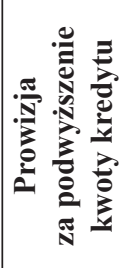 & 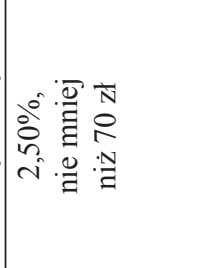 & 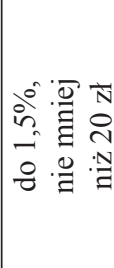 & $\begin{array}{l}\bar{N} \\
\sim \\
\sim\end{array}$ & $\begin{array}{l}\bar{N} \\
0\end{array}$ & 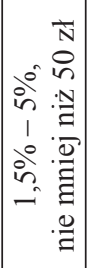 & 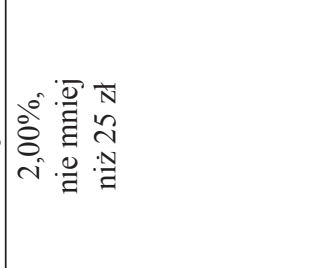 \\
\hline 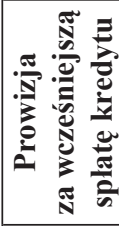 & & $\bar{N}$ & 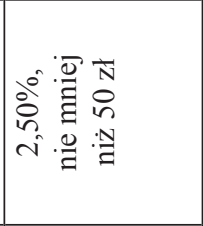 & $\begin{array}{l}\bar{N} \\
0\end{array}$ & $\varrho^{0}$ & 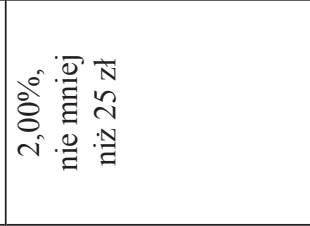 \\
\hline 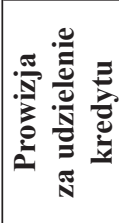 & 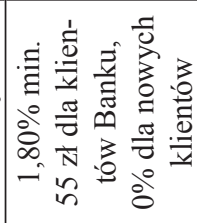 & 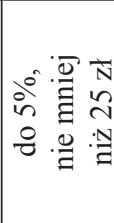 & ले & 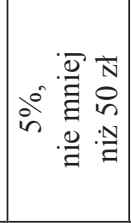 & in & 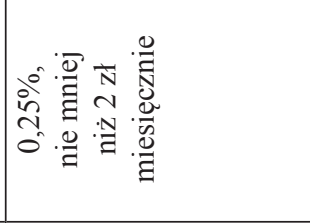 \\
\hline 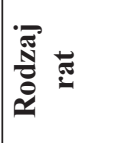 & 苛 & 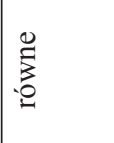 & 造 & 菅 & 章 & 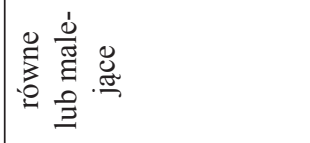 \\
\hline 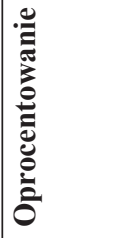 & $\begin{array}{c}80 \\
0 \\
1 \\
8\end{array}$ & $\begin{array}{l}\dot{0} \\
\stackrel{0}{1} \\
1 \\
\stackrel{0}{\circ} \\
2 \\
\text { ले }\end{array}$ & $\begin{array}{l}80 \\
i n \\
n \\
n \\
\overline{0} \\
8\end{array}$ & 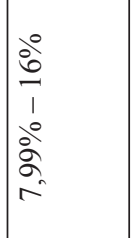 & $\begin{array}{l}\frac{0}{2} \\
\frac{\partial}{2} \\
\frac{0}{0}\end{array}$ & $\begin{array}{l}80 \\
8 \\
\infty \\
0 \\
0\end{array}$ \\
\hline 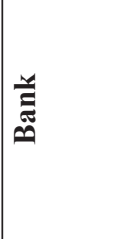 & 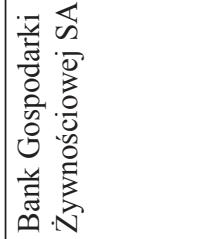 & 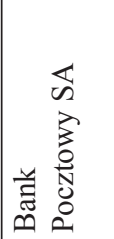 & 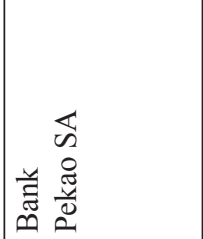 & 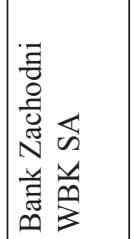 & 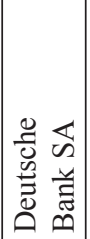 & 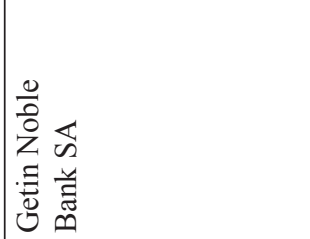 \\
\hline
\end{tabular}



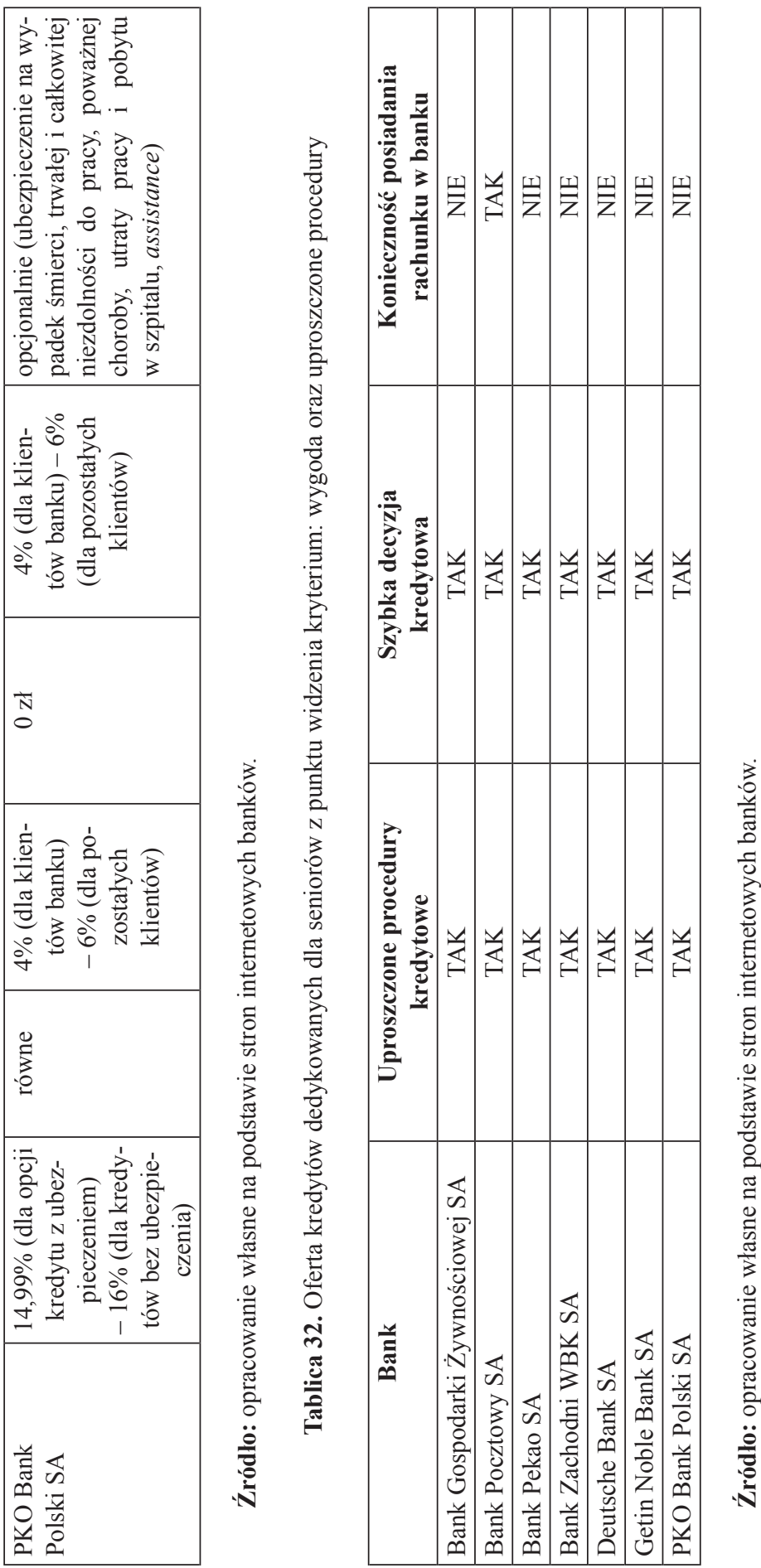
Oferty kredytów w poszczególnych bankach znacznie różnią się między sobą w ramach zidentyfikowanych parametrów (przykładowo maksymalny okres kredytowania waha się od 72 miesięcy w Banku Zachodnim WBK SA do 120 miesięcy w Banku Pocztowym SA, a maksymalna kwota kredytu od 100000 zł w Banku Pocztowym SA i Banku Pekao SA do 150000 zł w Banku Gospodarki Żywnościowej SA, Deutsche Banku PBC SA, Getin Noble Banku SA i PKO Banku Polskim SA.

W przypadku kryterium ceny, oferty kredytów w poszczególnych bankach różnią się znacznie między sobą. Najniższe oprocentowanie kredytów oferuje Bank Zachodni WBK SA i Deutsche Bank SA. Oprócz Getin Noble Banku SA, który oferuje możliwość wyboru rat kapitałowych równych lub malejących, wszystkie banki przyjęły wariant rat równych. Wyłącznie Bank Pocztowy SA wymaga obowiązkowego ubezpieczenia kredytu.

W ramach kryterium: wygoda oraz uproszczone procedury oprócz Banku Pekao SA, który jako warunek konieczny udzielenia kredytu wymagał posiadania rachunku bankowego, wszystkie banki posiadały takie same warunki przyznania kredytu z perspektywy parametrów: uproszczone procedury kredytowe, szybka decyzja kredytowa i konieczność posiadania rachunku w banku.

Kolejne tablice zawierają oceny punktowe ofert rachunków banków w ramach poszczególnych kryteriów.

Tablica 33. Ocena punktowa ofert kredytów dedykowanych dla seniorów z punktu widzenia kryterium: dostępność

\begin{tabular}{|l|c|c|c|}
\hline \multicolumn{1}{|c|}{ Bank } & $\begin{array}{c}\text { Maksymalny wiek } \\
\text { kredytobiorcy }\end{array}$ & $\begin{array}{c}\text { Maksymalny okres } \\
\text { kredytowania }\end{array}$ & $\begin{array}{c}\text { Maksymalna kwota } \\
\text { kredytu }\end{array}$ \\
\hline $\begin{array}{l}\text { Bank Gospodarki } \\
\text { Żywnościowej SA }\end{array}$ & 2 & 3 & 3 \\
\hline $\begin{array}{l}\text { Bank } \\
\text { Pocztowy SA }\end{array}$ & 3 & 3 & 1 \\
\hline $\begin{array}{l}\text { Bank } \\
\text { Pekao SA }\end{array}$ & 2 & 2 & 2 \\
\hline $\begin{array}{l}\text { Bank Zachodni } \\
\text { WBK SA }\end{array}$ & 3 & 1 & 3 \\
\hline $\begin{array}{l}\text { Deutsche } \\
\text { Bank SA }\end{array}$ & 1 & 2 & 3 \\
\hline $\begin{array}{l}\text { Getin Noble } \\
\text { Bank SA }\end{array}$ & 2 & 2 & 3 \\
\hline $\begin{array}{l}\text { PKO Bank } \\
\text { Polski SA }\end{array}$ & 1 & 3 & 1 \\
\hline
\end{tabular}

Źródło: opracowanie własne. 

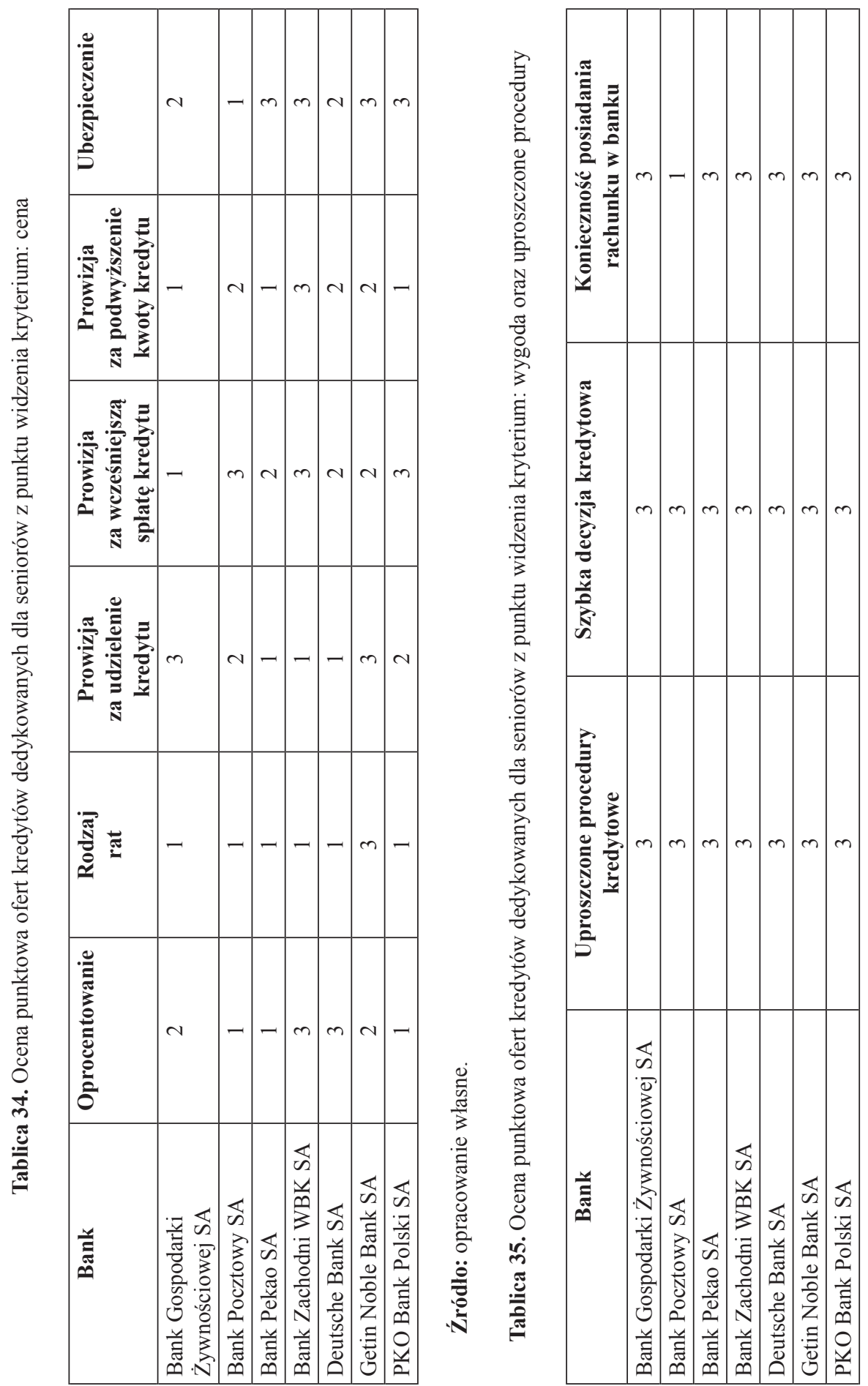

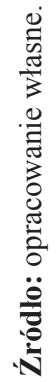




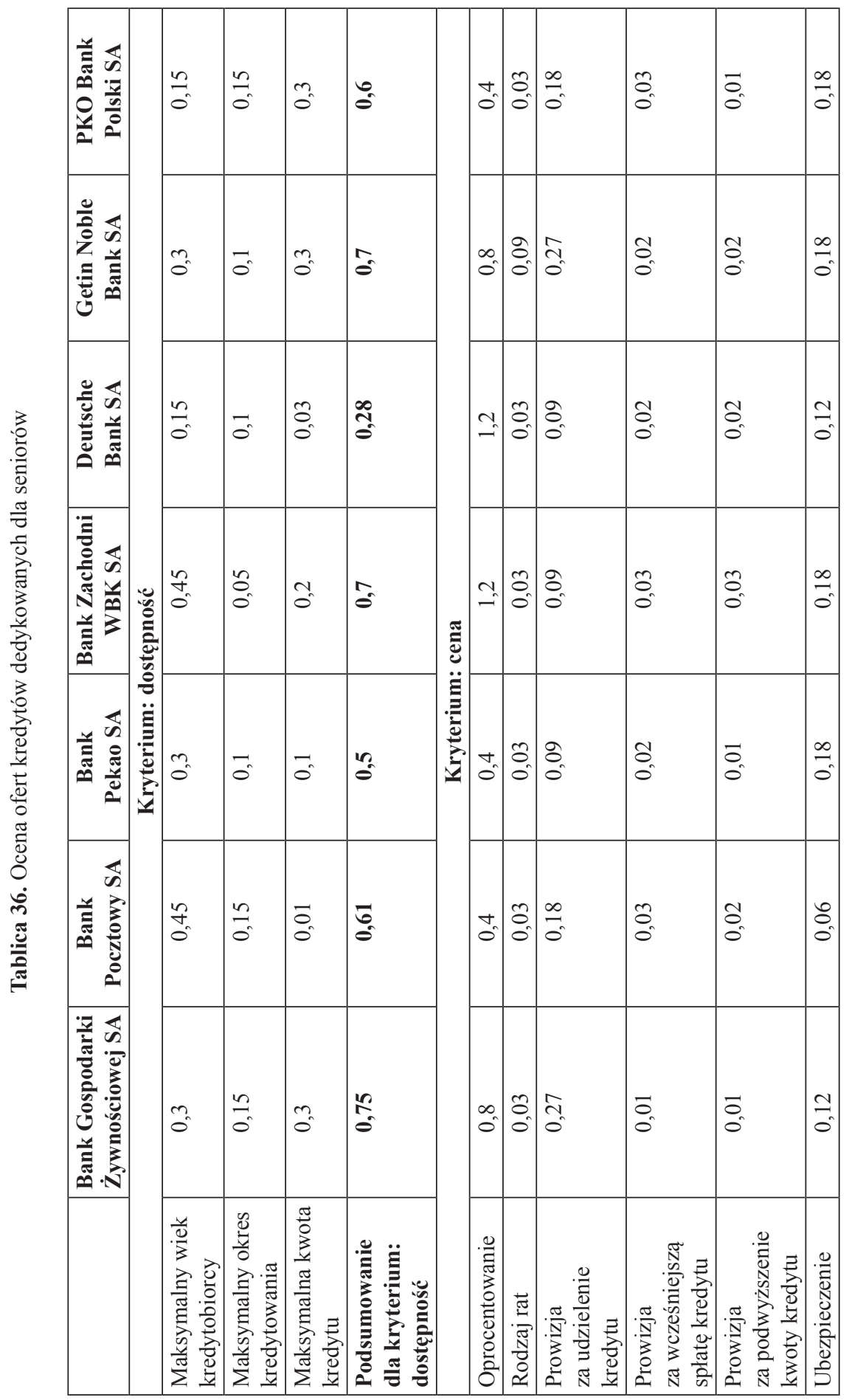




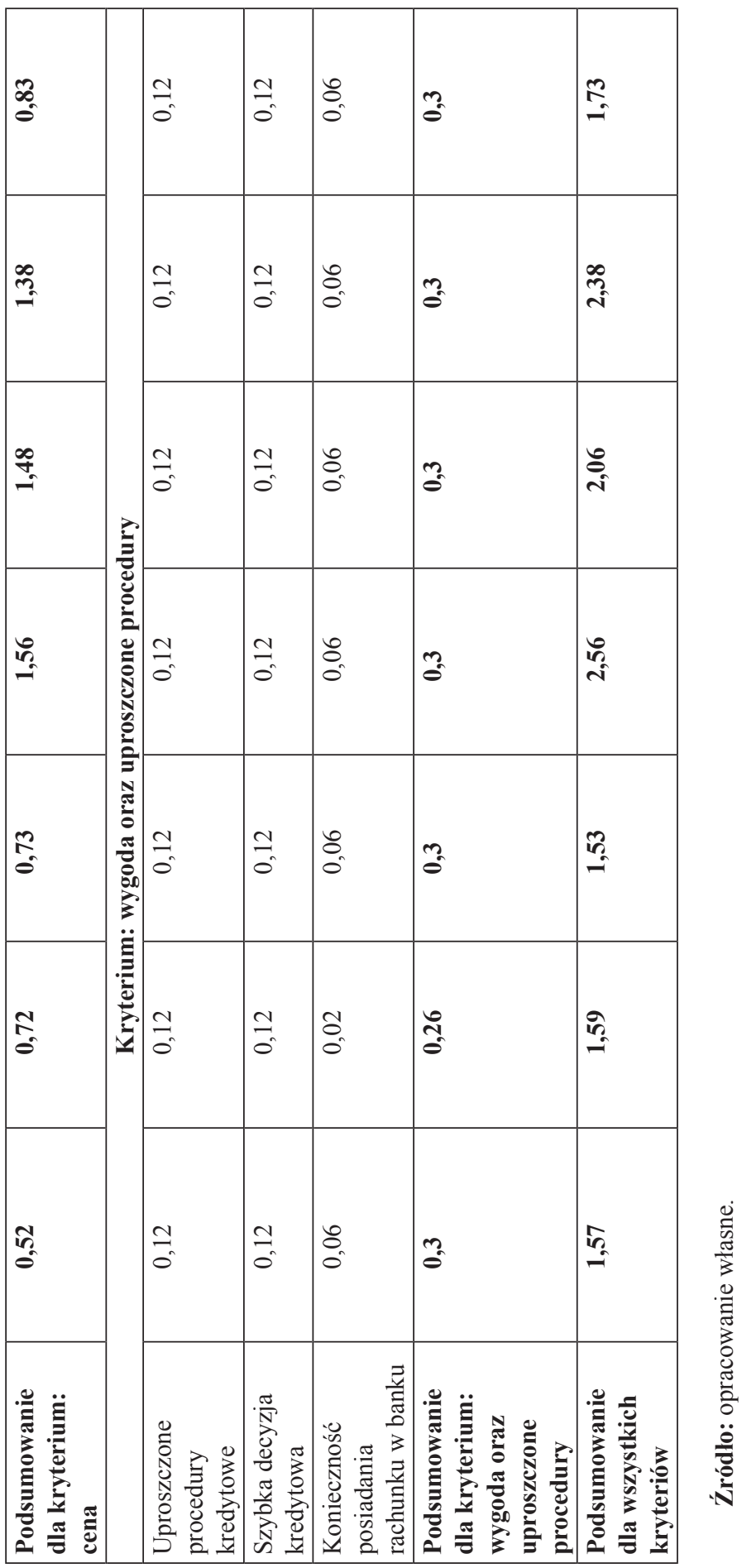


Ocena ofert kredytów w oparciu o przyjętą metodologię wypada najkorzystniej w przypadku Banku Zachodniego WBK SA, Getin Noble Banku SA i Deutsche Banku SA. Z kolei Bank Pekao SA, Bank Gospodarki Żywnościowej SA i Bank Pocztowy SA wypadają w zestawieniu najsłabiej. W ramach kryterium: dostępność najkorzystniej wypada Bank Gospodarki Żywnościowej SA, Bank Zachodni WBK SA i Getin Noble Bank SA, zaś najgorzej Deutsche Bank SA. Oceniając ofertę w ramach kryterium: cena, można zauważyć, że najwięcej punktów otrzymał Bank Zachodni WBK SA, Deutsche Bank SA i Getin Noble Bank SA, a najmniej Bank Gospodarki Żywnościowej SA. Z kolei z punktu widzenia kryterium: wygoda oraz uproszczone procedury oprócz Banku Pocztowego SA, który otrzymał niższą ocenę, wszystkie banki uzyskały tyle samo punktów.

\subsubsection{Podsumowanie}

Podstawowym wnioskiem z przeprowadzonej analizy jest niewystarczająca oferta banków dla osób powyżej 50. roku życia. Instytucje finansowe w małym stopniu dostrzegają konieczność tworzenia oddzielnej oferty dla seniorów, których potrzeby są niejednokrotnie różne od pozostałej części społeczeństwa. Zaledwie siedem banków wychodzi naprzeciw tym potrzebom, co jest zdecydowanie niezadawalającym rezultatem.

Tablica 37. Ocena oferty banków w zakresie rachunków bankowych, lokat i kredytów

\begin{tabular}{|l|c|c|c|c|}
\hline \multicolumn{1}{|c|}{ Bank } & $\begin{array}{c}\text { Ocena oferty } \\
\text { w zakresie rachunków } \\
\text { oszczędnościowo- } \\
\text {-rozliczeniowych }\end{array}$ & $\begin{array}{c}\text { Ocena oferty } \\
\text { w zakresie } \\
\text { lokat } \\
\text { bankowych }\end{array}$ & $\begin{array}{c}\text { Ocena oferty } \\
\text { w zakresie } \\
\text { kredytów }\end{array}$ & $\begin{array}{c}\text { Lączna } \\
\text { ocena oferty }\end{array}$ \\
\hline $\begin{array}{l}\text { Bank Gospodarki } \\
\text { Żywnościowej SA }\end{array}$ & 2,31 & 2,04 & 1,57 & 5,92 \\
\hline Bank Pocztowy SA & 2,86 & 2,68 & 1,59 & 7,13 \\
\hline Bank Pekao SA & 2,76 & 1,52 & 1,53 & 5,81 \\
\hline $\begin{array}{l}\text { Bank Zachodni } \\
\text { WBK SA }\end{array}$ & 2,49 & 2,24 & 2,56 & 7,29 \\
\hline Deutsche Bank SA & 2,44 & 1,42 & 2,06 & 5,92 \\
\hline Getin Noble Bank SA & 2,59 & 2,72 & 2,38 & 7,69 \\
\hline PKO Bank Polski SA & 2,02 & 1,38 & 1,73 & 5,13 \\
\hline
\end{tabular}

Źródlo: opracowanie własne.

Należy przy tym wskazać, że banki, których produkty były wykorzystane w analizie, także nie mają kompletnej oferty dla seniorów (najkorzystniej pod tym względem wypadł Getin Noble Bank SA, który osobom starszym dedykował 
rachunek bankowy i kredyt). Oceniając ofertę poszczególnych banków z punktu widzenia przeprowadzonej analizy rachunków bankowych, lokat i kredytów (rysunek 35 i 36), można zauważyć, że najkorzystniej wypadła ona w przypadku Getin Noble Banku SA, Banku Zachodniego WBK SA oraz Banku Pocztowego SA

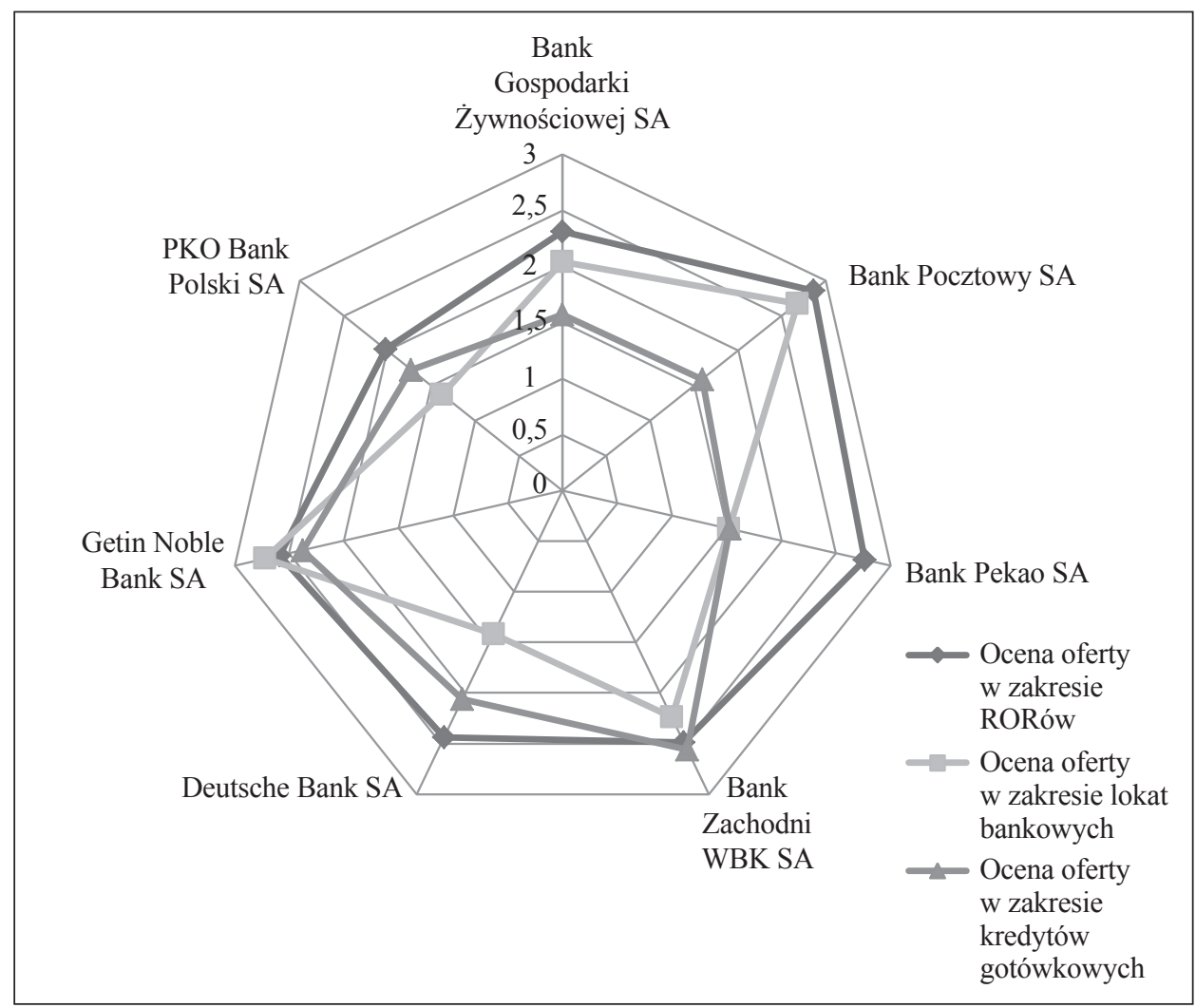

Rysunek 35. Ocena ofert banków w zakresie rachunków bankowych, lokat i kredytów gotówkowych

Źródło: opracowanie własne

Należy przy tym wskazać, że oferta analizowanych banków komercyjnych dedykowana seniorom niejednokrotnie jest mniej atrakcyjna niż ta, którą oferują pozostałym grupom klientów, a szczególnie korzystającym z bankowości elektronicznej, a nie tradycyjnej (tak jest w przypadku Pekao SA, PKO BP SA, Getin Noble Bank SA, Banku Zachodniego WBK SA, Deutsche Bank SA i Banku Gospodarki Żywnościowej SA). Wyjątkiem jest Bank Pocztowy SA, który oferuje seniorom rachunek bankowy, który w przeciwieństwie do standardowej oferty zwalnia ich z opłat za czynności najbardziej atrakcyjne z ich punktu widzenia, np. ustanowienie dyspozycji na wypadek śmierci, dostarczenie gotówki 
na wskazany adres do kwoty 300 zł na podstawie zlecenia wypłaty itd. To, co wyróżnia ofertę rachunków dla osób powyżej 50. roku życia, to przede wszystkim usługi dodatkowe - zniżki w aptekach i u partnerów banków, ubezpieczenie Medical Assistance itd., niedostępne w standardowej ofercie instytucji. W przypadku kredytu gotówkowego przygotowanego dla seniorów przez Getin Noble Bank SA cechą odróżniającą od standardowej oferty jest ściśle określony przy badaniu zdolności kredytowej wymóg minimalnego dochodu (550 zł), skorelowany z przeciętną wysokością emerytur i rent. Można zatem mówić o uproszczeniu procedur kredytowych dla osób powyżej 50. roku życia przez Getin Noble Bank SA.

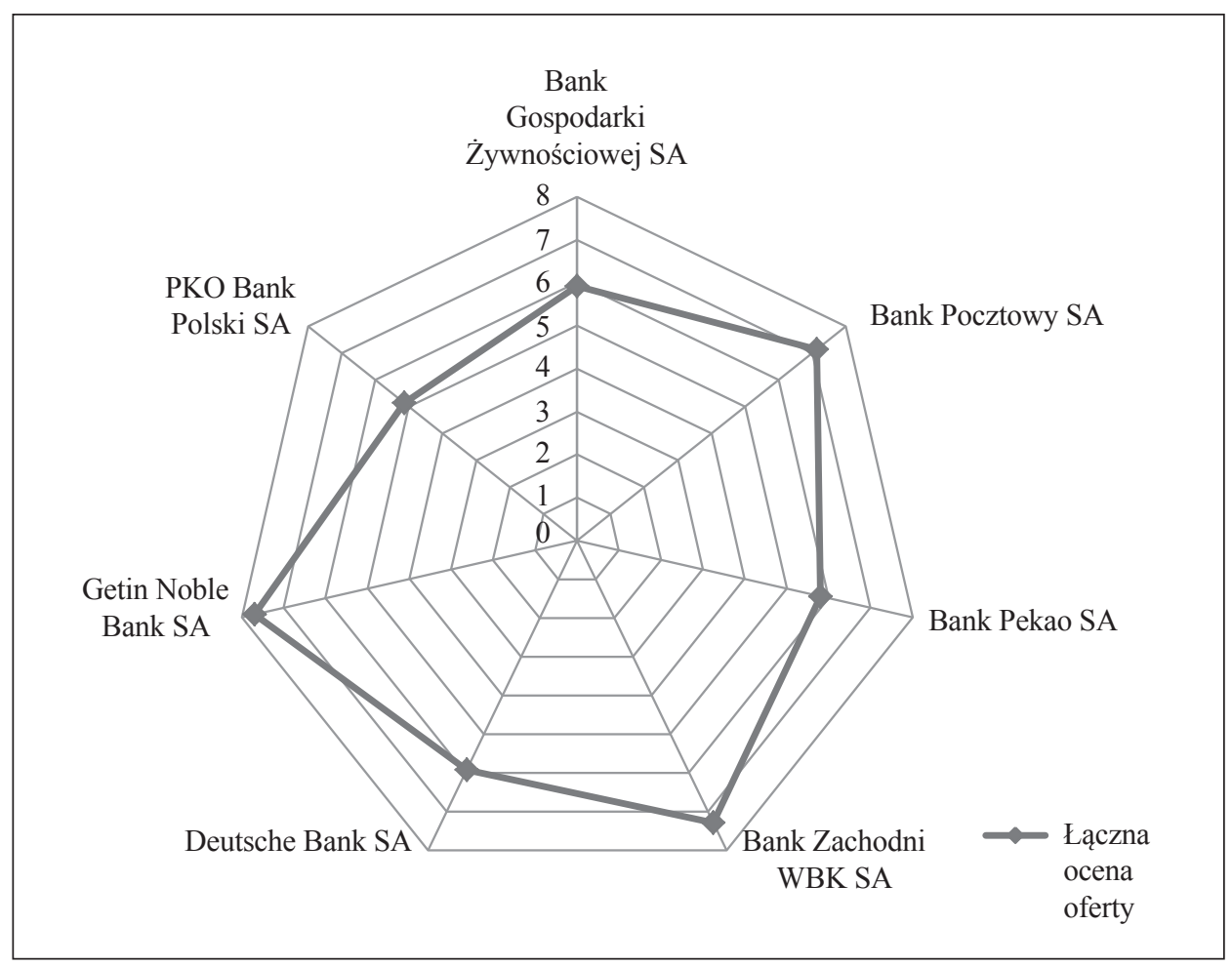

Rysunek 36. Łączna ocena oferty banków w zakresie rachunków bankowych, lokat i kredytów gotówkowych

Źródło: opracowanie własne

Co istotne, analizie poddano wyłącznie ofertę banków komercyjnych, działających na terenie całej Polski. Należy jednak zaznaczyć, że seniorzy mają do dyspozycji także produkty bankowe dostępne w bankach spółdzielczych. Mają one $\mathrm{z}$ reguły w ofercie rachunki oszczędnościowo-rozliczeniowe bezpłatne lub wyma- 
gające ponoszenia niskich opłat ${ }^{37}$, ponadto ze względu na swą specyfikę działania (bliski kontakt z klientem z uwagi na lokalny zakres funkcjonowania tych instytucji) mają większą szansę na dotarcie do seniorów.

${ }^{37} \mathrm{~W}$ wielu przypadkach otwarcie i prowadzenie kont w bankach spółdzielczych jest bezpłatne, podobnie zresztą jak i usługa zleceń stałych i wydanie karty do rachunku, zwykle jedyna opłata dotyczy zleceń wykonania przelewu, składanych w oddziale banku; przykładem może być oferta rachunku dla seniorów Banku Spółdzielczego w Ostrowcu Świętokrzyskim - http://www.bs.ostrowiec.pl/konto-dla-seniorow (stan na dzień 1.08.2014), Banku Spółdzielczego w Oleśnicy - https:// www.bsolesnica.pl/page/57/pol-konto-senior.html (stan na dzień 1.08.2014), Banku Spółdzielczego w Dobrzeniu Wielkim - http://www.bsdobrzen.pl/index.php? c=texts\&text=156\&itemid=12 (stan na dzień 1.08.2014) czy też Powiślańskiego Banku Spółdzielczego - http://www.powislanski.pl/ oferta/ror-senior.html (stan na dzień 1.08.2014). 



\section{Rozdział III. Edukacja finansowa w podnoszeniu aktywności społecznej osób 50+}

\subsection{Definicyjne ujęcie edukacji finansowej}

Znaczenie edukacji w życiu człowieka wzrosło wraz z przyspieszeniem procesów globalizacyjnych i modernizacyjnych. Szybki rozwój technologiczny sprawia, że aktywne uczestnictwo w życiu społecznym wymaga nie tylko nabycia odpowiednich umiejętności w szkole, ale również nieustannego podnoszenia swoich kompetencji w dalszych etapach życia, tj. uczenia się przez całe życie (lifelong learning - LLL). Znajduje to odzwierciedlenie na rynku pracy, na którym wzrasta popyt na wykwalifikowanych pracowników, kosztem zapotrzebowania na pracę osób o niskich kompetencjach.

Problematyka ciągłej aktualizacji posiadanej wiedzy i umiejętności oraz uczenia się przez całe życie jest szczególnie ważna w realizacji koncepcji silver economy, która to ma bazować na potencjale osób w wieku 50+. Niestety, już od lat Polska charakteryzuje się jednym z najniższych wskaźników partycypacji w uczeniu się przez całe życie w Europie, co oznacza, że niewiele osób po skończeniu 25. roku życia decyduje się uzupełniać i/lub nabywać nowe kompetencje, a aktywne uczestnictwo w życiu społecznym i gospodarczym właśnie tego wymaga. Tymczasem z danych Eurostat wynika również, że w Polsce uczestnictwo osób dorosłych w kształceniu i szkoleniu jest silnie uzależnione od ich wieku, poziomu wykształcenia i formy edukacji (edukacji formalnej lub pozaformalnej). Pomiędzy najmłodszymi osobami dorosłymi (grupa wieku 18-24 lata) i najstarszymi (50+ i $60+$ ) oraz najniżej i najwyżej wykształconymi istnieje w Polsce wybijająca się na tle UE różnica. Nakłada się na to duża różnica w uczestnictwie w edukacji formalnej i pozaformalnej. Uczestnictwo osób dorosłych w kategorii wiekowej 55-74 lata zarówno w edukacji formalnej, jak i pozaformalnej wyraźnie odstaje od średniej w UE (Polska 0,7, a UE 28 i UE $27-4,6)^{1}$. Zatem wyzwaniem w Polsce

${ }^{1}$ Eurostat, Participation rate in education and training (last 4 weeks) by sex and age, http://apps so.eurostat.ec.europa.eu/nui/submitViewTableAction.do;jsessionid=9ea7d07e30d6ea8a172d36824 b218af0e848ec863fbe.e34MbxeSahmMa40LbNiMbxaNa38Pe0 (stan na dzień 22.07.2014). 
znacznie bardziej widocznym niż w większości krajów UE jest edukacja (kształcenie i szkolenie) osób starszych, nisko wykształconych i, co pozostaje z tym w ścisłym związku, nieaktywnych ekonomicznie i społecznie. Dotyczy to różnych grup osób dorosłych pozostających w niekorzystnej sytuacji, w tym zagrożonych ubóstwem, chorych, samotnych, niepełnosprawnych, o ograniczonej sprawności itp.

Przykłady dobrej praktyki w zakresie edukacji dorosłych w obszarze UE wskazują, że skuteczna oferta edukacyjna, kierowana zwłaszcza do osób pozostających w niekorzystnej sytuacji, nie może być powieleniem tradycyjnej edukacji typu szkolnego. Interesującą alternatywą są Uniwersytety Trzeciego Wieku, których głównym celem jest właśnie edukacja osób starszych. Niezależnie od profilu UTW warto zajęcia na nim wzbogacić o elementy wiedzy finansowej, która staje się coraz bardziej ważnym wymogiem dla pełnego funkcjonowania w nowoczesnym społeczeństwie, a biorąc pod uwagę trendy w organizacji pracy, demografii i specyfikę kanałów dystrybucji produktów i usług, można wnioskować, że będzie ona jeszcze ważniejsza w nadchodzących latach.

Ten obszar edukacji, którym jest edukacja finansowa, uznawany jest współcześnie za kluczowy warunek rozwoju finansowego². Kreowanie świadomości finansowej jest związane z włączeniem finansowym i ochroną konsumentów korzystających z rynku finansowego.

Należy wskazać na różne znaczenia edukacji finansowej. Można ją rozpatrywać w szerokim ujęciu jako wpływ warunków ekonomicznych na decyzje finansowe podejmowane przez gospodarstwa domowe lub w wąskim, odnoszącym się bezpośrednio do podstaw zarządzania finansami: planowania wpływów i wydatków, oszczędzania, inwestowania i ubezpieczania się. Na edukację finansową można także patrzeć jako na zestaw umiejętności dotyczących podejmowania decyzji i finansów możliwych do zdobycia w procesie edukacyjnym. Łącząc wspomniane aspekty, edukacja finansowa jest procesem polegającym na pozyskaniu wiedzy na temat zarządzania posiadanym majątkiem, rozumieniu pojęć z dziedziny zarządzania posiadanymi składnikami majątku w formie aktywów trwałych i środków pieniężnych, a wreszcie pozyskaniu umiejętności wykorzystania posiadanej wiedzy w celu podejmowania i oceny decyzji finansowych ${ }^{3}$.

Edukacja finansowa może zostać zdefiniowana jako ,proces, w ramach którego konsumenci/inwestorzy poprawiają swoje zrozumienie produktów finansowych, pojęć i ryzyka i poprzez uzyskane informacje, instrukcje i/lub rady rozwijają umiejętność i pewność bycia bardziej świadomym ryzyka finansowego oraz możliwości podejmowania bardziej świadomych wyborów, aby wiedzieć, gdzie

${ }^{2}$ M. Penczar (red.), Rola edukacji finansowej w ograniczaniu wykluczenia finansowego, Instytut Badań nad Gospodarką Finansową, Gdańsk 2014, s. 5.

3 J. M. Hogarth, Financial Education and Economic Development, Paper prepared for Improving Financial Literacy International Conference hosted by the Russian G8 Presidency in Cooperation with the OECD, 29-30 November 2006, s. 4, www.oecd.org/finance/financialeduca tion/37742200.pdf (stan na dzień 30.12.2013). 
można szukać pomocy i jakie efektywne działania można podejmować, aby poprawić sytuację finansową"4. Można ją traktować jako zdolność do korzystania z wiedzy i umiejętności w celu skutecznego zarządzania środkami finansowymi, zapewniającego dobrobyt finansowy 5 .

Edukacja finansowa stanowi uzupełnienie środków legislacyjnych służących zapewnieniu konsumentom właściwych informacji i właściwego doradztwa, a także odpowiedniej ich ochrony. Interpretowana jest także jako zdolność do formułowania osądów i podejmowania efektywnych decyzji dotyczących wykorzystywania środków pieniężnych i zarządzania nimi ${ }^{6}$.

Zgodnie $\mathrm{z}$ definicją grupy działającej w ramach OECD ds. edukacji finansowej - International Network on Financial Education (INFE) - „,edukacja finansowa stanowi połączenie świadomości, wiedzy, umiejętności, postaw i zachowań niezbędnych w celu podejmowania decyzji finansowych i prowadzących do osiągnięcia indywidualnego finansowego dobrobytu"7. Z kolei, na potrzeby prac OECD nad problematyką narodowych strategii edukacji przyjęta została definicja edukacji finansowej, zgodnie z którą jest to „proces wspierania w sposób przystępny, we właściwym miejscu i czasie dostępu do produktów i usług oraz poszerzanie ich wykorzystania przez segmenty społeczeństwa poprzez implementację już istniejących i innowacyjnych metod kształtowania świadomości finansowej i edukacji z perspektywą promowania finansowego dobrobytu na równi z włączeniem ekonomicznym i społecznym"s.

Komisja Europejska zdefiniowała edukację finansową jako „zdolność konsumentów i właścicieli małych przedsiębiorstw do zrozumienia produktów finansowych w celu podejmowania świadomych decyzji finansowych" ${ }^{\text {. W }}$ ramach edukacji finansowej wyróżniane są trzy podstawowe kierunki ${ }^{10}$ :

- wiedza finansowa i zrozumienie przez klienta różnych form wykorzystania pieniądza i jego funkcji (np. gotówki, czeków, kredytów, pożyczek);

- umiejętności finansowe i kompetencje bazujące na posiadanej wiedzy, mające wpływ na wydatkowanie środków i oszczędzanie;

${ }^{4}$ OECD, Recommendation on Principles and Good Practices for Financial Education and Awareness, Recommendation of the Council, lipiec 2005 r., s. 4.

${ }_{5}^{5}$ Executive Order 13530, President's Advisory Council on Financial Capability, January 29, 2010, s. 1.

${ }^{6}$ Australian Securities and Investments Commission, National financial literacy strategy, March 2011, s. 12.

7 OECD/INFE, Measuring Financial Literacy: Questionnaire and Guidance Notes for Conducting an Internationally Comparable Survey of Financial Literacy, 2011, s. 3.

${ }^{8}$ A. Grifoni, F. A. Messy, Current Status of National Strategies for Financial Education. A comparative analysis and relevant practices, OECD Working Papers on Finance, Insurance and Private Pensions No. 16, OECD Publishing, 2012, s. 11.

${ }^{9}$ M. Habschick, B. Seidl, J. Evers, Survey of financial literacy schemes in the EU 27, VT Markt/2006/26H - Final Report, Hamburg, November 2007, s. 8.

${ }^{10}$ European Parliamentary Financial Services, Briefing paper compendium on financial services issue 2008-2009, 2009, s. 24. 
- odpowiedzialność rozumiana jako świadomość posiadana przez klientów, że podejmowane przez nich decyzje finansowe wywierają wpływ na inne osoby, np. członków rodziny.

Edukacja finansowa umożliwia rozwój świadomości finansowej w społeczeństwie i wykształcenie pozytywnych nawyków potrzebnych do rozsądnego zarządzania środkami finansowymi, przy uwzględnieniu celów ekonomicznych w bliższej lub dalszej perspektywie czasowej. Pogłębienie wiedzy finansowej pozwala na rozpoznanie szans i zagrożeń, które są związane z typowymi oraz nowymi produktami finansowymi, przez co obywatele podejmują bardziej świadome decyzje finansowe, które wpływają na nich samych oraz członków rodziny. Jest to istotne dla każdego obywatela, niezależnie od jego cech społeczno-demograficznych.

Posiadanie świadomości finansowej rozumiane jest jako kultura ekonomiczna, czyli zespół poglądów i zachowań związanych z gospodarowaniem własnymi zasobami nabytymi na skutek własnych życiowych doświadczeń, wychowania oraz wpływu środowiska społecznego. Generalnie edukacja finansowa zwiększa świadomość finansową w kilku kluczowych obszarach:

- ułatwia odpowiednie zarządzanie dochodami,

- wpływa na rozwój kultury oszczędzania,

- kształtuje nawyki inwestycyjne,

- wskazuje na znaczenie planowania finansowego,

- umożliwia dokonywanie porównania oferty produktów finansowych w celu dokonania wyboru najbardziej dostosowanego do indywidualnych potrzeb.

Edukacja finansowa może być postrzegana w 3 wymiarach ${ }^{11}$ :

- jako wiedza finansowa i zrozumienie produktów i mechanizmów finansowych pozwalająca klientom rozróżniać produkty finansowe i z nich korzystać;

- jako umiejętności i kompetencje bazujące na wiedzy, dzięki którym konsumenci mają wpływ na sposób lokowania środków lub pozyskiwania finansowania;

- jako odpowiedzialność polegająca na rozumieniu przez klientów podejmowanych decyzji finansowych i ich wpływu na otoczenie.

W związku z rozszerzaniem oferty oraz wzrostem stopnia skomplikowania usług finansowych na skutek innowacji i globalizacji, posiadanie wiedzy z zakresu finansów staje się dla obywateli coraz ważniejsze. W ostatnich latach możliwy jest do zaobserwowania dynamiczny rozwój usług finansowych. Odbywa się on poprzez wdrażanie licznych innowacyjnych rozwiązań, w dużej mierze opartych na nowych rozwiązaniach informatyczno-komunikacyjnych, jak również będących wynikiem postępującej globalizacji. Co więcej, postęp techniczny, rozwój elektronicznych kanałów dostaw oraz integracja rynków finansowych poszerzyły nie tylko wachlarz oferowanych produktów i usług finansowych, ale także moż-

${ }^{11}$ EPFSF, Briefing Financial Education and Financial Capability, European Parliamentary Financial Services, 14 March 2008, s. 2. 
liwości dostępu do nich. Biorąc jednak pod uwagę wysoki poziom wykluczenia cyfrowego odnotowywany w przypadku gospodarstw domowych $50+$, a szczególnie w grupie emerytów, to właśnie rozwój technologii okazuje się być barierą często nie do pokonania. Oczywiście, biorąc pod uwagę trendy demograficzne i fakt, że w wiek dojrzały zaczną za kilkanaście lat wchodzić osoby z pokolenia X, Y, a za kilkadziesiąt $Z$, które są bardziej zaznajomione z nowoczesnymi technologiami, elektroniczne kanały dystrybucji przestaną być postrzegane jako bariera, a będą zwykłym udogodnieniem w korzystaniu z produktów i usług bankowych. Zanim to jednak nastąpi, konieczne jest - poza dostarczeniem możliwości elektronicznego kontaktu z bankiem - wyposażenie obecnych i potencjalnych klientów w wiedzę umożliwiającą im bezpieczne korzystanie z nich. Oferowanie narzędzi powinno łączyć się z edukowaniem na temat możliwości ich wykorzystania.

Aktualnie, w ślad za idącym postępem w zakresie różnorodności produktów i usług oraz kanałów ich dystrybucji nie idzie w parze wprost proporcjonalne zainteresowanie nimi. Powodami takiej sytuacji jest chociażby powszechnie panujące przekonanie, że niektóre produkty finansowe są zbyt skomplikowane lub brak umiejętności skorzystania $\mathrm{z}$ nich. Niekiedy nawet stosunkowo proste produkty finansowe i rozwiązania technologiczne (jak karta płatnicza, bankomat) mogą się wydawać dość skomplikowane przeciętnemu obywatelowi, posiadającemu niewielką wiedzę z zakresu finansów, albo nieposiadającemu jej w ogóle ${ }^{12}$. Wynika to z nierównego poziomu wiedzy finansowej, a skalę problemu oddają wyniki cyklicznie prowadzonych przez różne organizacje krajowe i międzynarodowe badań na temat poziomu świadomości finansowej społeczeństwa. Główne determinanty wzrostu istotności edukacji finansowej przedstawia tablica 38.

Tablica 38. Główne determinanty edukacji finansowej

\begin{tabular}{|l|l|}
\hline \multicolumn{1}{|c|}{ Zlożoność indywidulanych potrzeb } & \multicolumn{1}{c|}{ Zlożoność produktów finansowych } \\
\hline - Rosnąca niestabilność życia zawodowego & - Nowe kanały dystrybucji \\
- Ograniczenia zabezpieczeń społecznych & - Deregulacja rynków finansowych \\
- Wzrost indywidulanej odpowiedzialności & - Szerszy wachlarz produktów finansowych i dy- \\
- Wzrost dobrobytu & namiki powstawania nowych produktów i usług \\
- Wzrost nadmiernego zadłużenia & - Większa ilość informacji \\
- Wzrost oczekiwań wobec jakości życia & \\
- Zwiększenie samozatrudnienia & \\
\hline
\end{tabular}

Źródło: opracowanie na podstawie: M. Habschick, B. Seidl, J. Evers, Survey of financial literacy schemes in the EU27, VT Markt/2006/26H - Final Report, Hamburg, November 2007, s. 5.

${ }^{12}$ Osoby powyżej 60. roku życia nie są dobrze obeznane z nowoczesną technologią - zaledwie $16 \%$ korzysta z komputera (za to niemal wszyscy, którzy umieją obsłużyć komputer, używają także Internetu). „Internetowi” seniorzy są aktywni - korzystają z możliwości sieci kilka razy w tygodniu. Badanie postaw Polaków powyżej 60. roku życia wobec obrotu bezgotówkowego, Warszawa, kwiecień 2012, http://www. nbp.pl/systemplatniczy/obrot_bezgotowkowy/raport_60_plus.pdf (stan na dzień 22.07.2014), s. 17. 
Znaczenie edukacji finansowej wynika z dążenia do sprostania złożoności indywidualnych potrzeb oraz złożoności produktów finansowych. Ze względu na zidentyfikowaną potrzebę edukacji finansowej stała się ona przedmiotem zainteresowania organizacji międzynarodowych. Problematyka edukacji ekonomicznej jest poruszana na szczeblu Unii Europejskiej oraz w ramach działań Organizacji Współpracy Gospodarczej i Rozwoju (OECD), European Banking Federation (EBF), World Council of Credit Unions (WOCCU), European Association for the Education of Adults (EAEA). Komisja UE i OECD opublikowaty wytyczne oraz rekomendacje dotyczące kształtowania strategii edukacyjnych.

W 2005 r. OECD zarekomendowała promowanie budowania świadomości finansowej opartej na rzetelnych informacjach i wskazówkach poprzez efektywną realizację skoordynowanych programów edukacyjnych. Narodowa strategia edukacji finansowej zdefiniowana została jako ,skoordynowane podejście na szczeblu krajowym do kwestii edukacji finansowej, która składa się z dostosowanych ram lub programu"13.

W opinii OECD programy edukacyjne powinny koncentrować się na kwestiach priorytetowych dla danego kraju z uwzględnieniem ram regulacyjnych i administracyjnych dotyczących wspierania wzrostu gospodarczego, budowania zaufania i stabilności systemów finansowych, regulowania zasad funkcjonowania instytucji finansowych oraz systemu ochrony konsumentów. Jednoznacznie podkreślona została konieczność zaangażowania instytucji finansowych w proces edukacji finansowej nie tylko w proces dostarczania informacji finansowych, ale przede wszystkim promowania świadomości finansowej wśród klientów z uwzględnieniem różnorodności ich potrzeb i sytuacji, w jakiej się znajdują. OECD rekomendowało dobre praktyki, jakie powinny być wykorzystywane w procesie edukacji finansowej. Ich zestawienie przedstawia tablica 39.

Wprawdzie za edukację finansową konsumentów odpowiedzialny jest w szczególności rząd oraz instytucje finansowe, jednak bezsprzecznie inicjatywa ta powinna być wspierana na szczeblu międzynarodowym. Ważną rolę we wspieraniu wymiany poglądów na szczeblu paneuropejskim na temat edukacji finansowej, kształcenia konsumentów i najlepszych praktyk oraz realizacji wspólnych projektów pełni OECD oraz Komisja Europejska.

Zainteresowanie OECD problematyką edukacji finansowej sięga 2003 r., kiedy to rozpoczęto realizację pierwszego międzynarodowego programu edukacji finansowej. Składał się on z trzech części. Pierwsza z nich miała charakter analityczny i polegała na analizie badań przeprowadzanych w krajach OECD, dotyczących edukacji finansowej z uwzględnieniem zmian ekonomicznych i demograficznych, które wpływają na wzrost znaczenia świadomości finansowej, i wylistowaniem rekomendacji mających na celu podniesienie poziomu wiedzy finansowej ${ }^{14}$.

13 A. Laboul, National strategies for financial education, Columbia-OECD-World Bank, Conference on Financial Education Cartagena, 31 October 2012, s. 11.

${ }^{14}$ Efektem była publikacja: OECD, Improving Financial Literacy: Analysis of issues and policies, OECD Publishing, Paris 2005. 
Tablica 39. Dobre praktyki w zakresie edukacji finansowej

\begin{tabular}{|c|c|}
\hline 1 & 2 \\
\hline Typ działania & Zalecenia \\
\hline \multirow[t]{6}{*}{$\begin{array}{l}\text { Działania } \\
\text { publiczne mające } \\
\text { na celu edukację } \\
\text { finansową }\end{array}$} & $\begin{array}{l}\text { Krajowe kampanie edukacyjne powinny zachęcać do podniesienia świado- } \\
\text { mości w zakresie poprawienia zrozumienia ryzyka finansowego i sposobów } \\
\text { ochrony przed nim poprzez proces oszczędzania, ubezpieczeń i edukacji fi- } \\
\text { nansowej. }\end{array}$ \\
\hline & $\begin{array}{l}\text { Edukacja finansowa powinna rozpoczynać się w szkołach, aby ludzie byli } \\
\text { edukowani w tym zakresie jak najszybciej. }\end{array}$ \\
\hline & $\begin{array}{l}\text { Należy rozważyć wdrożenie edukacji finansowej jako części programów po- } \\
\text { mocy społecznej państwa. }\end{array}$ \\
\hline & $\begin{array}{l}\text { Właściwe wyspecjalizowane instytucje odpowiedzialne za promowanie i ko- } \\
\text { ordynowanie edukacji finansowej, funkcjonujące na szczeblu krajowym i re- } \\
\text { gionalnym, powinny być promowane podobnie jak i publiczne oraz prywatne } \\
\text { inicjatywy lokalne. }\end{array}$ \\
\hline & $\begin{array}{l}\text { Powinny być promowane narodowe kampanie informacyjne, specyficzne } \\
\text { strony internetowe, darmowe serwisy informacyjne i serwisy ostrzegające } \\
\text { o kwestiach związanych z wysokim ryzykiem (np. defraudacja) dla konsu- } \\
\text { mentów korzystających z usług finansowych. }\end{array}$ \\
\hline & $\begin{array}{l}\text { Powinna być promowana międzynarodowa współpraca w dziedzinie edu- } \\
\text { kacji finansowej, łącznie z wykorzystaniem OECD jako międzynarodowe- } \\
\text { go forum wymiany informacji na temat najnowszych doświadczeń krajów } \\
\text { członkowskich w dziedzinie edukacji finansowej. }\end{array}$ \\
\hline \multirow[t]{5}{*}{$\begin{array}{l}\text { Rola instytucji } \\
\text { finansowych } \\
\text { w edukacji } \\
\text { finansowej }\end{array}$} & $\begin{array}{l}\text { Powinny zostać określone wymagania dotyczące zakresu informacji (w tym } \\
\text { wskazania miejsca znalezienia informacji oraz dostępności porównywalnych } \\
\text { i obiektywnych informacji na temat ryzyka i zwrotu z różnych rodzajów pro- } \\
\text { duktów), jakie instytucje finansowe dostarczają klientom. }\end{array}$ \\
\hline & $\begin{array}{l}\text { Edukacja finansowa powinna być wyraźnie oddzielona od przekazu komer- } \\
\text { cyjnego. Jeżeli informacje dotyczą długoterminowych zobowiązań lub usług } \\
\text { finansowych z potencjalnie znaczącymi konsekwencjami finansowymi, in- } \\
\text { stytucje finansowe powinny sprawdzić, czy zostały one przeczytane i są zro- } \\
\text { zumiałe. }\end{array}$ \\
\hline & $\begin{array}{l}\text { Instytucje finansowe powinny być zachęcane do dostarczania informacji } \\
\text { na kilku różnych poziomach w celu jak najlepszego zaspokojenia potrzeb } \\
\text { klientów. Mały druk lub niezrozumiała dokumentacja nie powinny być sto- } \\
\text { sowane. }\end{array}$ \\
\hline & $\begin{array}{l}\text { Edukacja finansowa prowadzona przez instytucje finansowe powinna pod- } \\
\text { legać regularnej ocenie w celu zapewnienia, że odpowiada ona potrzebom } \\
\text { klientów. Może to zostać osiągnięte dzięki współpracy z niezależnymi do- } \\
\text { radcami finansowymi. }\end{array}$ \\
\hline & $\begin{array}{l}\text { Instytucje finansowe powinny być zachęcane do szkolenia personelu i opra- } \\
\text { cowania kodeksu postępowania dotyczącego inwestowania i zaciągania zo- } \\
\text { bowiązań niezwiązanych z oferowaniem żadnych produktów finansowych. }\end{array}$ \\
\hline
\end{tabular}


Tablica 39 (cd.)

\begin{tabular}{|l|l|}
\hline \multicolumn{1}{|c|}{1} & \multicolumn{1}{|c|}{2} \\
\hline $\begin{array}{l}\text { Edukacja } \\
\text { finansowa } \\
\text { w zakresie } \\
\text { oszczędzania } \\
\text { na emeryturę }\end{array}$ & $\begin{array}{l}\text { Dla osób indywidualnych korzystających z osobistych planów emerytalnych } \\
\text { powinno być zapewnione dostarczenie właściwych informacji finansowych } \\
\text { umożliwiających zarządzanie ich przyszłymi oszczędnościami emerytalny- } \\
\text { mi. }\end{array}$ \\
\cline { 2 - 2 } $\begin{array}{l}\text { W przypadku systemów pracowniczych powinna być promowana edukacja } \\
\text { finansowa pracowników w zakresie opłacanych składek oraz przyszłych ko- } \\
\text { rzyści. }\end{array}$ \\
\hline $\begin{array}{l}\text { Programy edukacji } \\
\text { finansowej }\end{array}$ & $\begin{array}{l}\text { Powinny być promowane programy edukacji finansowej, które pomagają } \\
\text { poznać plusy, minusy oraz ryzyko towarzyszące poszczególnym produktom } \\
\text { i usługom finansowym. }\end{array}$ \\
\cline { 2 - 2 } & $\begin{array}{l}\text { Należy promować rozwój metodologii oceny istniejących systemów edu- } \\
\text { kacji finansowej oraz rozważyć oficjalne uznanie programów spełniających } \\
\text { odpowiednie kryteria. }\end{array}$ \\
\cline { 2 - 2 } & $\begin{array}{l}\text { Powinny być promowane programy edukacji finansowej dostosowane do po- } \\
\text { trzeb poszczególnych grup społecznych. }\end{array}$ \\
\cline { 2 - 3 } & $\begin{array}{l}\text { W celu osiągnięcia efektu skali powinny być wykorzystywane wszystkie do- } \\
\text { stępne media w rozpowszechnianiu edukacji finansowej. }\end{array}$ \\
\cline { 2 - 2 } & $\begin{array}{l}\text { Powinny być promowane różnorodne programy dostosowane do zindywidu- } \\
\text { alizowanych potrzeb w formie seminariów i spersonalizowanego doradztwa. }\end{array}$ \\
\cline { 2 - 3 } $\begin{array}{l}\text { Powinna być wspierana edukacja i rozwój kompetencji u wykładowców } \\
\text { przekazujących wiedzę finansową poprzez zapewnienie dostępu do odpo- } \\
\text { wiednich informacji i narzędzi. }\end{array}$ \\
\hline
\end{tabular}

Źródło: opracowanie na podstawie: OECD, Recommendation on Principles and Good Practices for Financial Education and Awareness, Recommendation of the Council, lipiec 2005 r., s. 4-7.

Drugi cel programu powiązany był z pierwszym i dotyczył rozwoju międzynarodowych wytycznych i dobrych praktyk w zakresie edukacji finansowej. Zawierały one sugestie w następujących obszarach ${ }^{15}$ :

- zwiększania świadomości finansowej społeczeństwa przez działania podejmowane na szczeblu rządowym,

- dostarczania obiektywnych informacji na temat produktów finansowych przez instytucje finansowe, sowych,

- wskazywania roli pracodawców w zakresie dostarczania informacji finan-

- edukacji w zakresie produktów oszczędnościowych i ubezpieczeniowych ${ }^{16}$,

${ }_{15}$ Taking Financial Literacy to the Next Level: Important Challenges and Promising Solutions, OECD-US Treasury International Conference on Financial Education, Washington, DC, USA, May 7-8, 2008, s. 9-10.

16 Szerzej: OECD, Good Practices for Enhanced Risk Awareness and Education on Insurance issues, 2008; OECD, Good Practices for Financial Education relating to Private Pensions, 2008. 
- podniesienia wiedzy finansowej na temat kredytów w świetle coraz częściej występujących problemów z nadmiernym zadłużaniem się ${ }^{17}$.

Ostatnim komponentem pierwszego programu edukacji finansowej realizowanego przez OECD była promocja międzynarodowej współpracy w obszarze podnoszenia świadomości finansowej. Forum międzynarodowe zostało wskazane jako odpowiednie do wymiany doświadczeń narodowych.

Ważnym krokiem było powołanie międzynarodowej grupy ds. edukacji finansowej - International Network on Financial Education (INFE). Nadrzędnym jej celem jest stworzenie międzynarodowej płaszczyzny służącej promowaniu działań na rzecz edukacji finansowej, która jest rozumiana zarówno jako edukacja, jak i świadomość, a odnosi się do produktów/usług finansowych oraz związanego z nimi ryzyka. Do celów grupy należy także identyfikacja wartościowych i skutecznych narzędzi, programów i inicjatyw w zakresie edukacji finansowej, a także jej promocja poprzez publikacje oraz współpracę z innymi międzynarodowymi organizacjami, instytucjami i forami.

W latach 2011-2012 działania OECD koncentrowały się wokół promowania programów edukacji finansowej i pomiaru ich efektywności ${ }^{18}$, jak również problemu budowania narodowej strategii edukacji finansowej ${ }^{19}$. Zostały także opracowane wytyczne dotyczące edukacji finansowej prowadzonej w szko$\operatorname{lach}^{20}$.

W przypadku Komisji Europejskiej prace nad kreowaniem świadomości finansowej przebiegały równie intensywnie. W komunikacie Komisji Europejskiej „Jednolity rynek Europy XXI wieku” podkreślono, że edukacja finansowa ma podstawowe znaczenie dla zapewnienia, by jednolity rynek mógł przynieść bezpośrednie korzyści obywatelom Europy poprzez umożliwienie im podejmowania świadomych decyzji dotyczących nabywania usług finansowych i zrozumienia podstaw prywatnych finansów ${ }^{21}$. Na wagę edukacji finansowej wskazano także w: Białej księdze ${ }^{22}$, Zielonej księdze w sprawie detalicznych usług finansowych 2009.

${ }_{17}$ Szerzej: OECD, Good Practices on Financial Education and Awareness relating to Credit,

${ }^{18}$ Szerzej: OECD/INFE, High-level Principles on the Evaluation of Financial Education Programmes and dedicated Guides on Evaluation, June 2011; OECD/INFE, Measuring Financial Literacy: Questionnaire and Guidance Notes for Conducting an Internationally Comparable Survey of Financial Literacy, 2011.

19 A. Grifoni, F. Messy, Current Status of National Strategies for Financial Education: A Comparative Analysis and Relevant Practices, OECD Working Paperson Finance, Insurance and Private Pensions, No. 16, OECD Publishing, 2012.

${ }^{20}$ Szerzej: OECD, Guidelines for Financial Education in Schools, 2012.

${ }^{21}$ Komisja Wspólnot Europejskich, Komunikat Komisji dla Parlamentu Europejskiego, Rady Europejskiego Komitetu Ekonomiczno-Społecznego i Komitetów Regionów - Jednolity rynek Europy XXI wieku, Bruksela 2007.

${ }^{22}$ Komisja Wspólnot Europejskich, Biała księga. Polityka $w$ dziedzinie usług finansowych na lata 2005-2010, Bruksela 2005. 
na jednolitym rynku ${ }^{23}$, konkluzjach Rady ECOFIN z dnia 8 maja 2007 r. $^{24}$, rezolucji Parlamentu Europejskiego w sprawie polityki w dziedzinie usług finansowych $^{25}$ oraz komunikacie Edukacja finansowa ${ }^{26}$.

Wyrazem zaangażowania Komisji Europejskiej w sprawę edukacji finansowej było powołanie w 2008 r. grupy ekspertów w dziedzinie edukacji finansowej. Do zadań tej grupy zaliczono ${ }^{27}$ :

- wymianę informacji o najlepszych praktykach w zakresie edukacji finansowej i promowanie tych praktyk,

- udzielanie Komisji porad na temat sposobu wdrażania zasad zapewniania wysokiej klasy programów edukacji finansowej, przewidzianych w komunikacie Komisji Edukacja finansowa,

- wspieranie Komisji w identyfikacji jakichkolwiek prawnych, regulacyjnych, administracyjnych i innych przeszkód, utrudniających zapewniane programów edukacji finansowej,

- doradzanie Komisji odnośnie do sposobów uporania się z tymi przeszkodami,

- wkład w przygotowanie szeregu inicjatyw przedstawionych w komunikacie w sprawie edukacji finansowej oraz ocena tych zaplanowanych inicjatyw w okresie do $2010 \mathrm{r}$.

Niestety aktywność tej grupy zakończyła się po kilku spotkaniach, podczas których miała głównie miejsce wymiana poglądów i padły propozycje dalszych działań w zakresie edukacji finansowej. Dostępne są materiały informacyjne jedynie z 5 spotkań tej grupy ${ }^{28}$.

Na poziomie europejskim zainicjowanych zostało kilka inicjatyw z dziedziny znajomości finansów w kontekście prac nad ochroną konsumentów i zwalczaniem wykluczenia społecznego ${ }^{29}$. W obszarze detalicznych usług finanso-

${ }^{23}$ Komisja Wspólnot Europejskich, Zielona księga w sprawie detalicznych ustug finansowych na jednolitym rynku, Bruksela 2007.

${ }^{24}$ Konkluzje Rady ECOFIN z dnia 8 maja 2007, 9171/07 (Presse 97).

${ }_{25}$ Rezolucja Parlamentu Europejskiego $w$ sprawie polityki $w$ dziedzinie ustug finansowych, P6 TA-PROV(2007)0338/A6-0248/2007.

${ }^{26}$ Komisja Wspólnot Europejskich, Komunikat Komisji. Edukacja finansowa, $\operatorname{KOM(2007)~}$ 808, Bruksela 2007.

${ }^{27}$ Komisja Wspólnot Europejskich, Decyzja Komisji z dnia 30 kwietnia 2008 r. powotująca grupę ekspertów w dziedzinie edukacji finansowej, 2008/365/WE.

${ }^{28}$ M. Iwanicz-Drozdowska, Działania na rzecz poprawy poziomu edukacji finansowej $w$ Unii Europejskiej podczas globalnego kryzysu finansowego, „Zarządzanie i Finanse, Journal of Management and Finance" 2013, nr 2/1, s. 191.

${ }^{29}$ Np. w latach 2005-2006 Komisja Europejska sfinansowała rozwój programu DOLCETA, internetowego narzędzia szkoleniowego przeznaczonego do wykorzystania przez dostawców usług edukacyjnych dla dorosłych. W 2006 r. Komisja Europejska sfinansowała badanie inicjatyw edukacji finansowej w UE w celu rozwinięcia i wymiany modeli najlepszych praktyk oraz nowych strategii poprawy dostępu do usług finansowych dla osób dotkniętych ubóstwem i wykluczeniem społecznym - zwłaszcza w odniesieniu do osób zadłużonych, które zostało przeprowadzone przez konsorcjum agencji zarządzania zadłużeniem. Komisja Wspólnot Europejskich, Zielona księga w sprawie detalicznych ustug finansowych na jednolitym rynku, Bruksela 2007, s. 18. 
wych $^{30}$ Komisja Europejska zarekomendowała jako jedną z dróg integracji detalicznych usług finansowych umożliwienie konsumentom podejmowania właściwych decyzji, które są odpowiednie w ich sytuacji finansowej. Pod tym względem istotnych jest kilka czynników, w tym znajomość finansów, przejrzyste, odpowiednie i terminowo przekazywane informacje, wysokiej jakości doradztwo i równe warunki konkurencji produktów postrzeganych jako mające podobne cechy. Konsumenci dysponujący większą wiedzą mogą być bardziej pewni siebie, wybierając optymalne oferty, zaspokajające ich potrzeby bez względu na lokalizację dostawcy usług finansowych.

Wreszcie opracowane zostały wytyczne w celu gromadzenia i promowania najlepszych praktyk oraz wskazywania nowych innowacyjnych podejść w dziedzinie edukacji finansowej. Komisja Europejska opracowała zbiór zasad, który miał na celu pomóc organom publicznym, podmiotom świadczącym usługi finansowe, organizacjom konsumentów, pracodawcom oraz pozostałym podmiotom zaangażowanym $\mathrm{w}$ proces tworzenia strategii edukacji finansowej. Zbiór tych zasad obejmował następujące wytyczne ${ }^{31}$ :

- Zasada nr 1: Edukacja finansowa powinna być aktywnie wspierana i powinna być dostępna w sposób ciągły na wszystkich etapach życia.

- Zasada nr 2: Programy edukacji finansowej powinny być starannie przystosowane do szczególnych potrzeb osób, które z nich korzystają. Osiągnięcie tego celu wymaga przeprowadzenia uprzednich badań w zakresie obecnego stanu wiedzy obywateli, tak by zidentyfikować te kwestie, w przypadku których niedostatki wiedzy są największe. Dostęp do programów powinien być łatwy.

- Zasada nr 3: Konsumenci powinni możliwie wcześnie zdobyć wiedzę na tematy ekonomiczne i finansowe. Właściwe organy krajowe powinny rozważyć włączenie wiedzy z tego zakresu do programów kształcenia jako przedmiotu obowiązkowego ${ }^{32}$.

- Zasada nr 4: Programy edukacji finansowej powinny obejmować ogólne narzędzia uświadamiające uczestnikom konieczność poszerzenia swojej wiedzy na tematy finansowe oraz zwiększenia umiejętności oceny ryzyka.

${ }^{30}$ Detaliczne usługi finansowe rozumiane są przez Komisję Europejską jako usługi, takie jak rachunki bieżące, kredyty konsumpcyjne, produkty hipoteczne, oszczędnościowe, emerytalne, inwestycyjne i ubezpieczeniowe, udostępniane konsumentom detalicznym, w tym inwestorom indywidualnym.

${ }^{31}$ Wskazówki te są zgodne z opublikowanymi w 2005 r. przez OECD Principles and Good Practices for Financial Education and Awareness (Zasadami i dobrymi praktykami edukacji finansowej), które zostały zatwierdzone przez wszystkie państwa członkowskie OECD, w tym również przez szereg państw członkowskich UE. Komisja Wspólnot Europejskich, Komunikat Komisji. Edukacja finansowa, $\mathrm{KOM}(2007)$ 808, Bruksela 2007, s. 9-11.

${ }^{32}$ Szerzej: Zalecenie parlamentu Europejskiego i Rady z dnia 18 grudnia 2006 r. w sprawie kompetencji kluczowych w procesie uczenia się przez całe życie, 2006/962/WE. 
- Zasada nr 5: Wiedza z zakresu finansów przekazywana przez podmioty oferujące usługi finansowe powinna być udostępniana w sposób uczciwy, przejrzysty i bezstronny. Należy zadbać o to, by interesy konsumentów były zawsze przestrzegane.

- Zasada nr 6: Osoby bezpośrednio realizujące program edukacji finansowej powinny otrzymać wystarczające środki oraz właściwe przeszkolenie, tak aby potrafiły przeprowadzić szkolenie skutecznie i z wiarą we własne umiejętności.

- Zasada nr 7: Należy wspierać koordynację na szczeblu krajowym wśród zainteresowanych stron, tak aby osiągnąć jasny podział zadań, ułatwić wymianę doświadczeń oraz wykorzystywać dostępne zasoby w sposób racjonalny i odpowiednio do priorytetów. Należy również usprawnić współpracę międzynarodową między podmiotami oferującymi programy edukacji finansowej, tak aby ułatwić wymianę najlepszych praktyk.

- Zasada nr 8: Podmioty oferujące programy edukacji finansowej powinny okresowo poddawać ocenie, a w razie konieczności aktualizować realizowane programy, tak aby zawsze odpowiadały one najlepszym stosowanym rozwiązaniom.

Poza sformułowaniem zasad tworzenia strategii edukacji finansowej Komisja Europejska sformułowała katalog inicjatyw, które objęła wsparciem merytorycznym $^{33}$ :

- stworzenie sieci podmiotów z praktycznym doświadczeniem w dziedzinie edukacji finansowej w celu wymiany doświadczeń i wspierania najlepszych praktyk w dziedzinie edukacji finansowej poprzez ustanowienie grupy ekspertów z dziedziny edukacji finansowej złożonej z przedstawicieli: organów państw członkowskich (w tym ekspertów w dziedzinie oświaty), podmiotów oferujących usługi finansowe, organizacji konsumentów i innych grup ${ }^{34}$;

- udzielenie pomocy finansowej dla państw członkowskich i podmiotów prywatnych na organizację krajowych/regionalnych konferencji poświęconych edukacji finansowej oraz promowanie idei powołania krajowych platform na rzecz edukacji finansowej, rozpowszechniających najlepsze praktyki na szczeblu lokalnym oraz wspierające istniejące inicjatywy;

- udostępnienie internetowej bazy danych na temat realizowanych programów edukacji finansowej oraz badań naukowych $\mathrm{z}$ tej dziedziny przeprowadzanych w UE zawierającej informacje o zasięgu geograficznym projektów, ich przedmiocie, grupie docelowej, a także szczegółowe informacje na temat podmiotu realizującego program;

${ }^{33}$ Komisja Wspólnot Europejskich, Komunikat Komisji. Edukacja finansowa, KOM(2007) 808, Bruksela 2007, s. 12-13.

${ }^{34}$ Komisja Wspólnot Europejskich, Decyzja Komisji z dnia 30 kwietnia 2008 r. powołująca grupę ekspertów w dziedzinie edukacji finansowej (2008/365/WE). 
- opracowanie modułu edukacyjnego z zakresu edukacji finansowej przy pomocy pedagogów i ekspertów finansowych przeznaczonego dla nauczycieli „Dolceta" ułatwiającym przybliżenie zagadnień finansowych i zachęcenie ich do dobrowolnego włączenia do ogólnych programów nauczania ${ }^{35}$.

Na problematykę kształtowania edukacji finansowej wpływ wywarł bardzo silnie kryzys finansowy. Komisja Europejska podniosła w związku z tym następujące kwestie ${ }^{36}$ :

- moment nauczania - kryzys finansowy stworzył możliwość szerokiego dotarcia z programami edukacji finansowej dzięki zwiększonemu zainteresowaniu zagadnieniami finansowymi w społeczeństwie, szczególnie wśród osób, które zostały dotknięte negatywnymi konsekwencjami kryzysu;

- podstawowa edukacja finansowa - rodzaje problemów napotykanych przez europejskich konsumentów wykazały, że potrzebują oni edukacji finansowej na poziome bardzo podstawowych umiejętności i wiedzy. Głównym zadaniem edukacji finansowej powinno być nauczenie podstawowych pojęć ekonomicznych, takich jak planowanie budżetu domowego, planowanie oszczędności, długoterminowe planowanie finansowe, poszukiwanie informacji w wiarygodnych źródłach;

- kryzys zaufania - w niektórych krajach był on jednym z głównych problemów związanych z kryzysem finansowym. Ze względu na osłabienie rynków finansowych i pogorszenie perspektyw ekonomicznych konsumenci potrzebują niezależnych źródeł informacji i porad, na których mogliby polegać;

- rola mediów - w wyniku kryzysu finansowego odnotowane było zwiększone zainteresowanie informacjami finansowymi publikowanymi w środkach masowego przekazu. W ślad za nim warto włączyć media w działania kształtujące świadomość finansową obywateli.

W świetle tak intensywnych działań podejmowanych przez UE w ostatnich latach wiele państw podjęło działania w kierunku opracowania i implementacji narodowych strategii edukacji ${ }^{37}$. Celem narodowych strategii edukacji jest określenie i dokonanie hierarchizacji podstawowych celów edukacji finansowej przy jednoczesnym wskazaniu możliwości ich realizacji. W strategiach ustalane są standardy kształcenia w obszarze edukacji finansowej, poszczególnym instytucjom przypisywane są konkretne zadania w zakresie kształtowania świadomości finansowej społeczeństwa. Ważnym elementem strategii jest wreszcie program wyrównywania szans w dostępie do wiedzy fachowej osób wykluczonych finansowo.

${ }^{35}$ Moduł 2: Usługi finansowe - zawiera sekcje: Budżet domowy; Kredyt konsumencki; Kredyt hipoteczny; Rachunek bieżący; Płatności gotówkowe; Inwestycje.

${ }^{36}$ European Commission, The financial crisis and financial education. Report, Brussels 2009, s. 8.

${ }^{37}$ Szerzej: European Commission, National Strategies for Financial Education. Report, Brussels 2008 . 
Powołując się na wyniki badania przeprowadzonego w 2012 r. przez OECD/ INFE 15 krajów już wdrożyło narodowe strategie edukacji finansowej. Należą do nich: Australia (2011), Brazylia (2010), Czechy (2010), Ghana (2009), Indie (2006/2010), Irlandia (2009) ${ }^{38}$, Japonia (2005), Malezja (2003), Holandia (2008), Nowa Zelandia (2008, 2010), Portugalia (2011), Słowenia (2011), Hiszpania (2008), Wielka Brytania (2003), USA (2006, 2011). Ponadto 21 państw zadeklarowało rozpoczęcie prac nad opracowaniem narodowej strategii edukacji finansowej: Kanada, Kolumbia, Estonia, Indonezja, Kenia, Łotwa, Liban, Malawi, Meksyk, Peru, Rumunia, Serbia, Afryka Płd., Szwecja, Tanzania, Turcja, Uganda, Rosja, Tajlandia, Zambia. W tej grupie znalazła się też Polska ${ }^{39}$.

Ze względu na fakt, że każde z państw promuje własne rozwiązania w zakresie tworzenia strategii edukacyjnych nie można wskazać na istnienie jednolitego modelu edukacji ekonomicznej. Zestawienie podstawowych celów poszczególnych strategii wdrożonych w 15 krajach zawiera tablica 40.

Tablica 40. Przegląd kluczowych celów narodowych strategii edukacji finansowej

\begin{tabular}{|l|l|}
\hline Państwo & \multicolumn{1}{|c|}{ Kluczowe cele strategii edukacji finansowej } \\
\hline 1 & \multicolumn{1}{|c|}{2} \\
\hline Australia & $\begin{array}{l}\text { Celem strategii jest zmiana zachowania, która pomaga konsumentom i inwestorom } \\
\text { osiągnąc lepsze wyniki finansowe i ostatecznie poprawić dobrobyt finansowy. } \\
\text { Rozwijając pewność siebie, wiedzę i umiejętności do zarządzania produktami i usłu- } \\
\text { gami finansowymi, obywatele będą bardziej zdolni do przezwyciężenia lub uniknię- } \\
\text { cia wykluczenia finansowego. }\end{array}$ \\
\hline Brazylia & $\begin{array}{l}\text { Celem strategii jest wspieranie i promowanie kultury edukacji finansowej w kraju. } \\
\text { Wyższy poziom świadomości finansowej obywateli w zakresie decyzji dotyczących } \\
\text { zarządzania zasobami przyczynia się do poprawy efektywności i kondycji rynków } \\
\text { finansowych. }\end{array}$ \\
\hline Czechy & $\begin{array}{l}\text { Celami strategii było kreowanie odpowiedzialnego zachowania na rynku finanso- } \\
\text { wym, przeciwdziałanie nadmiernemu zadłużania się oraz uświadomienie konieczno- } \\
\text { ści oszczędzania na emeryturę. }\end{array}$ \\
\hline Ghana & $\begin{array}{l}\text { Celami strategii jest kreowanie świadomości i edukowanie konsumentów w zakresie } \\
\text { dostępu do usług finansowych, uświadamianie praw i obowiązków klientom usług } \\
\text { finansowych, transformacja pozyskanej wiedzy na pozytywne zachowania finansowe. }\end{array}$ \\
\hline Indie & $\begin{array}{l}\text { Krajowa strategia ma na celu stworzenie finansowo świadomego obywatela dzięki } \\
\text { przeprowadzeniu na szeroką skalę kampanii edukacyjnej, aby pomóc obywatelom } \\
\text { zarządzać pieniędzmi tak, aby byli w stanie skuteczniej osiągać finansowy dobro- } \\
\text { byt dzięki dostępowi do odpowiednich produktów i usług finansowych oferowanych } \\
\text { za pośrednictwem podmiotów nadzorowanych. }\end{array}$ \\
\hline
\end{tabular}

${ }^{38} \mathrm{~W}$ przypadku Irlandii rekomendacje opierają się o zalecenia grupy sterującej i nie są typową strategią narodową.

39 A. Grifoni, F. Messy, Current Status of National Strategies for Financial Education: A Comparative Analysis and Relevant Practices, OECD Working Paperson Finance, Insurance and Private Pensions 2012, No. 16, s. 12. 


\begin{tabular}{|c|c|}
\hline 1 & 2 \\
\hline Irlandia & Celem strategii jest poprawa poziomu świadomości finansowej obywateli Irlandii. \\
\hline Japonia & $\begin{array}{l}\text { Celem strategii jest wspieranie udziału w rynku finansowym inwestorów, którzy sta- } \\
\text { nowią podstawę działania rynków pieniężnych i kapitałowych oraz poprawa świado- } \\
\text { mości finansowej obywateli. }\end{array}$ \\
\hline Malezja & $\begin{array}{l}\text { Strategia ma na celu rozwój kanałów dystrybucji informacji na temat produktów fi- } \\
\text { nansowych oraz promocję programów kształcących w zakresie zarządzania środkami } \\
\text { pieniężnymi realizowanych przy współpracy Ministerstwa Finansów z innymi orga- } \\
\text { nizacjami. }\end{array}$ \\
\hline Holandia & $\begin{array}{l}\text { Strategia obejmuje programy i projekty mające na celu poprawę wiedzy finansowej } \\
\text { i umiejętności konsumentów, a także stymulowanie aktywnej postawy, tak by kon- } \\
\text { sumenci mogli dokonywać świadomych wyborów finansowych i stać się finansowo } \\
\text { kompetentnymi. }\end{array}$ \\
\hline $\begin{array}{l}\text { Nowa } \\
\text { Zelandia }\end{array}$ & $\begin{array}{l}\text { Strategia określa kierunki dla poprawy świadomości finansowej w Nowej Zelandii. } \\
\text { Oferuje szereg rozwiązań mających na celu poprawę edukacji finansowej koncen- } \\
\text { trujących się wokół poprawy jakości edukacji finansowej, rozszerzenia tej edukacji, } \\
\text { udostępniania rozwiązań i dzielenia się doświadczeniami. }\end{array}$ \\
\hline Portugalia & $\begin{array}{l}\text { Strategia ma na celu przyczynić się do podniesienia poziomu wiedzy ekonomicznej } \\
\text { obywateli i promowania adekwatnego zachowania finansowego za pośrednictwem } \\
\text { zintegrowanego planu działania i zsynchronizowanych działan zainteresowanych } \\
\text { stron, przyczyniając się do zwiększenia dobrobytu obywateli i stabilności finansowej } \\
\text { systemu. }\end{array}$ \\
\hline Słowenia & $\begin{array}{l}\text { Strategia ma na celu poprawę edukacji finansowej obywateli w sposób systematyczny } \\
\text { i skoordynowany. Strategia identyfikuje problem i proponuje rozwiązania umożliwia- } \\
\text { jące obywatelom pozyskanie najważniejszych informacji na temat produktów usług } \\
\text { finansowych gwarantujące lepszą zdolność do podejmowania decyzji finansowych } \\
\text { w sposób ostrożny i odpowiedzialny. }\end{array}$ \\
\hline Hiszpania & $\begin{array}{l}\text { Celem strategii jest poprawa edukacji finansowej społeczeństwa umożliwiająca obec- } \\
\text { ność na rynku finansowym, osiągana za pomocą połączenia systemu edukacji i polityki. }\end{array}$ \\
\hline $\begin{array}{l}\text { Wielka } \\
\text { Brytania }\end{array}$ & $\begin{array}{l}\text { Strategia ma na celu wspieranie zrozumienia mechanizmów działania systemu finan- } \\
\text { sowego, a jednym ze strategicznych celów jest zapewnienie sprawiedliwego trakto- } \\
\text { wania klientów na rynku finansowym. }\end{array}$ \\
\hline USA & $\begin{array}{l}\text { Celem strategii jest podnoszenie poziomu świadomości i poprawianie dostępu do sku- } \\
\text { tecznej edukacji finansowej, określenie i zintegrowanie podstawowych kompetencji } \\
\text { finansowych, poprawa infrastruktury finansowej edukacji oraz określenie i prowadze- } \\
\text { nie skutecznych działań w obszarze edukacji finansowej. }\end{array}$ \\
\hline
\end{tabular}

Źródło: opracowanie własne na podstawie: Ministry of Finance, National Strategy for financial education, Czech Republic 2010, s. 14-15; www.mfcr.cz/cps/rde/xbcr/mfcr/EN_CZECH_NA TIONAL_STRATEGY_FOR_FINANCIAL_EDUCATION_2010.pdf; www.vidaedinheiro.gov.br/ Enef/Default.aspx;financialliteracy.org.nz/national-strategy; www.cnmv.es/DocPortal/Publicaciones/ PlanEducacion/PlanEducacion_een;www.mymoney.gov/sites/default/files/downloads/National StrategyBook_12310.pdf; www.fsa.gov.uk/pubs/other/fincap_delivering.pdf; www.pensionsboard. ie/en/News_Press/Improving_Financial_Capability_a_multi-stakeholder_approach.pdf; www.wijzering eldzaken.nl/; www.mf.gov.si/fileadmin/mf.gov.si/pageuploads/sporocila/oecd/NPFI_EN.pdf; www.oecd. org/finance/financialeducation/44919982.pdf; www.mfw4a. org/fileadmin/data_storage/documents/ other-internal-documents/Ghana_gyabaah.pdf (stan na dzień 30.12.2013). 
Wprawdzie widoczne jest zróżnicowanie poszczególnych strategii narodowych, jednak można wskazać na pewne ich podobieństwa. Zwykle obejmują one podstawowe pojęcia ekonomiczno-finansowe, takie jak: budżet, inwestycje, konta bankowe, inflacja, oszczędzanie, emerytura, kredyty, oprocentowanie. Cechą wspólną tych strategii jest wskazywanie na kompleksową diagnozę wiedzy ekonomicznej w różnych grupach społecznych, której celem jest dostosowanie istniejących programów edukacyjnych do rzeczywistych potrzeb, jako na kluczowy element warunkujący skuteczność strategii.

\subsection{Ekonomiczne i społeczne korzyści edukacji finansowej}

Efektywność wszystkich programów mających na celu podniesienie wiedzy finansowej obywateli $\mathrm{w}$ znacznym stopniu uzależniona jest od świadomości korzyści płynących z aktywnego uczestnictwa w rynku finansowym oraz świadomości ryzyka towarzyszącego niedostatecznej wiedzy finansowej. Ryzyka te odnoszą się zarówno do osób indywidualnych, jak i całej gospodarki. Ich zestawienie przedstawia rysunek 37 .

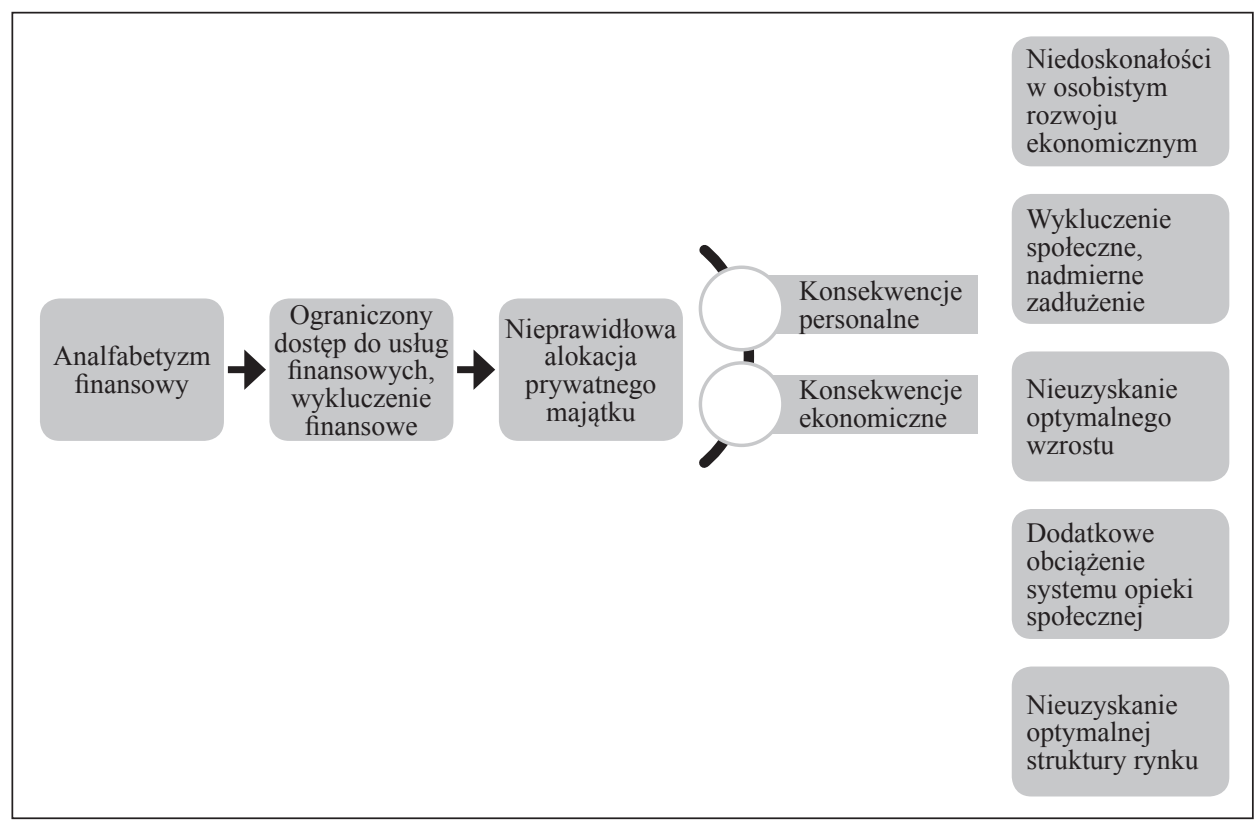

Rysunek 37. Ryzyka wynikające z braku wiedzy finansowej

Źródlo: opracowanie własne na podstawie: M. Habschick, B. Seidl, J. Evers, Survey of financial literacy schemes in the EU27, VT Markt/2006/26H - Final Report, Hamburg, November 2007, s. 7 
Nieprawidłowa alokacja majątku prywatnego skutkuje możliwością wystąpienia negatywnych efektów zarówno w sferze osobowej, jak i ekonomicznej. Może ona powodować regres społeczny i idący w ślad za nim wzrost wydatków publicznych w postaci opieki społecznej i opieki zdrowotnej. Tym samym problem edukacji finansowej powinien być rozpatrywany przez pryzmat korzyści wynikających z większej świadomości finansowej obywateli.

Cennym jest, że osoby w wieku 50+ są świadome pewnych korzyści, jakie niesie ze sobą edukacja finansowa. Jak wynika z badania „Stan wiedzy i świadomości ekonomicznej Polaków" realizowanego w październiku - listopadzie 2012 r. przez firmę Quality Watch na zamówienie NBP, podstawowa wiedza z zakresu ekonomii, finansów i gospodarki jest przydatna, gdyż pozwala ${ }^{40}$ :

- łatwiej uniknąć pułapek kredytowych,

- poprawić warunki życia,

- zwiększyć poczucie bezpieczeństwa finansowego.

W innych grupach wiekowych (poniżej 55 lat) wyżej cenione było osiąganie lepszych wyników w inwestowaniu i oszczędzaniu oraz znalezienie lepszej pracy. Osoby powyżej 50. roku życia nadają wysoką rangę bezpieczeństwu (ważne jest dla nich posiadanie środków do życia, a także bezpieczne dokonywanie transakcji).

Zdaniem Komisji Europejskiej edukacja finansowa przynosi korzyści osobom indywidualnym (na przykład pozwalając im uwzględniać w aspektach finansowych nieoczekiwane sytuacje), społeczeństwu (poprzez zmniejszenie ryzyka wykluczenia finansowego i zachęcanie konsumentów do uczestniczenia w zabezpieczeniach społecznych i do oszczędzania) oraz gospodarce jako całości (poprzez promowanie rozsądnych zachowań i zapewnienie płynności na rynkach finansowych). Zasygnalizowane korzyści zostaną przeanalizowane pod kątem konsekwencji płynących dla poszczególnych osób i ich gospodarstw domowych oraz w skali makroekonomicznej, z punktu widzenia gospodarki jako całości. Odpowiednie zestawienie przedstawia tablica 41.

Podnoszenie poziomu świadomości finansowej generuje konsekwencje w obszarze mikro- i makroekonomicznym. Mają one wymiar jednoznacznie pozytywny. W skali indywidualnej można wskazać na skutki o charakterze osobistym i finansowym. Te o charakterze osobistym koncentrują się wokół polepszenia pozycji społecznej, zaś te $\mathrm{w}$ wymiarze finansowym podkreślają rolę edukacji finansowej w umiejętnym korzystaniu z produktów finansowych i podejmowaniu świadomych decyzji w odniesieniu do usług finansowych. Wykluczenie finansowe wpływa bezpośrednio lub pośrednio na sposób, w jaki gospodarstwa domowe pozyskują i wykorzystują środki finansowe, co może mieć przełożenie na konsekwencje społeczne. Natomiast konsekwencje makroekonomiczne znajdują swoje odzwierciedlenie głównie w ograniczeniu niekorzystnego zjawiska, jakim jest

${ }^{40}$ Edukacja ekonomiczna seniorów, NBP, Krynica 5 września 2013 r., www.forumtrzeciego wieku.pl/index. php?...edukacja-ekonomiczna-seniorow (stan na dzień 22.07.2014), s. 4. 
wykluczenie finansowe i nadmierne zadłużenie, oraz ograniczaniu działań zmierzających do wyrównywania dysproporcji w dochodach gospodarstw domowych, chociażby poprzez wypłaty zasiłków społecznych.

Tablica 41. Korzyści o charakterze indywidualnym i makroekonomicznym podnoszenia świadomości finansowej

\begin{tabular}{|c|c|}
\hline Skala konsekwencji & Specyfikacja \\
\hline \multirow{6}{*}{$\begin{array}{l}\text { Skutki o charakterze } \\
\text { indywidualnym } \\
\text { - osobiste }\end{array}$} & poczucie włączenia społecznego \\
\hline & zwiększenie pewności siebie i poczucia własnej wartości \\
\hline & $\begin{array}{l}\text { bardziej świadomie prowadzenie konsumpcyjnego stylu życia i planowa- } \\
\text { nie go }\end{array}$ \\
\hline & $\begin{array}{l}\text { mniejsza skłonność do nieprawidłowego kształtowania zobowiązań oraz } \\
\text { struktury aktywów gospodarstw domowych }\end{array}$ \\
\hline & zwiększenie mobilności \\
\hline & zwiększenie możliwości zatrudnienia \\
\hline \multirow{6}{*}{$\begin{array}{l}\text { Skutki o charakterze } \\
\text { indywidualnym } \\
\text { - finansowe }\end{array}$} & wykorzystywanie budżetu domowego do planowania finansowego \\
\hline & zrozumienie wartości pieniądza i zwiększenie bezpieczeństwa finansowego \\
\hline & $\begin{array}{l}\text { bardziej świadome zarządzanie finansami osobistymi oparte na planowa- } \\
\text { niu długoterminowym zamiast krótkoterminowego }\end{array}$ \\
\hline & $\begin{array}{l}\text { lepsze radzenie sobie w przypadku wystąpienia nagłych trudności finan- } \\
\text { sowych poprzez dostęp do produktów kredytowych na głównym rynku } \\
\text { finansowym zamiast na rynku nieformalnym }\end{array}$ \\
\hline & racjonalne zaspokajanie potrzeb konsumpcyjnych \\
\hline & uniknięcie oszustw dokonywanych przez parabanki \\
\hline \multirow{5}{*}{$\begin{array}{l}\text { Skutki o charakterze } \\
\text { makroekonomicznym }\end{array}$} & ograniczenie zjawiska wykluczenia finansowego \\
\hline & ograniczenie zjawiska nadmiernego zadłużenia \\
\hline & zmniejszenie transferów społecznych \\
\hline & zwiększenie stabilności systemów finansowych, w szczególności bankowych \\
\hline & $\begin{array}{l}\text { ograniczenie stosowania przez władzę publiczną środków nadzwyczaj- } \\
\text { nych mających na celu ratowanie poszkodowanych obywateli }\end{array}$ \\
\hline
\end{tabular}

Źródło: opracowanie własne na podstawie: European Commission, Financial Education, Communication from the Commission, COM/2007/0808, 2007.

W obszarze korzyści, jakie świadomość finansowa niesie osobom indywidualnym, wskazać należy na jej znaczenie, chociażby w zrozumieniu wartości pieniądza, poznaniu zasad gospodarowania dostępnymi środkami i inwestowania ich nadwyżek, prowadzeniu samodzielnego życia, unikaniu oszustw związanych z płatnościami. Edukacja finansowa powinna oczywiście stanowić uzupełnienie odpowiedniej ochrony konsumenta na rynku finansowym oraz odpowiedzialnego postępowania podmiotów świadczących usługi finansowe ${ }^{41}$.

${ }^{41}$ B. D. Bernheim, D. M. Garrett, D. M. Maki, Education and Saving: The Long-term Effects of High School Financial Curriculum Mandates, "Journal of Public Economics" 2001, Vol. 80, Issue 3, s. 435-465. 
Jak wskazują wyniki badań, posiadana wiedza finansowa wpływa na decyzje dotyczące planowania wpływów i kontrolowania wydatków ${ }^{42}$. W przypadku respondentów o niższych dochodach dowiedzione zostało większe prawdopodobieństwo zaciągania kredytów na mniej korzystnych warunkach i niższa skłonność do refinansowania $i \mathrm{ch}^{43}$, spłacania jedynie minimalnego salda na karcie kredytowej, nadmiernego zadłużania $\operatorname{się}^{44}$. Opracowania wskazują na związek między posiadaną wiedzą finansową a podejmowaniem decyzji na temat oszczędzania na emeryturę ${ }^{45}$. Osoby o mniejszej świadomości finansowej mniej chętnie inwestują środki na giełdzie ${ }^{46}$.

Wiedza finansowa wywiera jednak również wpływ daleko poza sferą indywidualną i przynosi także korzyści dla całego społeczeństwa, przyczyniając się do rozwiązania problemów wykluczenia finansowego czy nawet szerzej społecznego. Edukacja finansowa może przyczynić się do poprawy stabilności systemu finansowego, gdyż ułatwia ona konsumentom wybór właściwych produktów i usług, prowadzi do zmniejszenia liczby przypadków niewywiązywania się ze zobowiązań finansowych oraz do zwiększenia dywersyfikacji, a tym samym bezpieczeństwa produktów oszczędnościowych i inwestycyjnych.

Konsument wyposażony w wiedzę ma świadomość możliwości, jakie daje rynek finansowy. W oczywisty sposób przekłada się to na zwiększony popyt na bardziej skomplikowane i innowacyjne instrumenty finansowe. Wpływa też na zwiększenie zaufania $w$ stosunku do elektronicznych kanałów dystrybucji,

${ }^{42}$ V. G. Perry, M. D. Morris, Who Is in control? The Role of Self-Perception, Knowledge, and Income in Explaining Consumer Financial Behavior, "Journal of Consumer Affairs" 2005, Vol. 39, No. 2, s. 299-313.

${ }^{43}$ D. Moore, Survey of Financial Literacy in Washington State: Knowledge, Behavior, Attitudes, and Experiences, Pullman, Washington: Washington State University Social and Economic Sciences Research Center, Technical Report, 2003, s. 8-9.

${ }^{44}$ Szerzej: K. Gerardi, L. Goette, S. Meier, Financial Literacy and Subprime Mortgage Delinquency: Evidence from a Survey Matched to Administrative Data, Federal Reserve Bank of Atlanta Working Paper Series No. 2010-10, 2010. Por. A. Lusardi, P. Tufano, Debt Literacy, Financial Experience and Overindebtedness, Working Paper NBER, 2008. Por. V. Stango, J. Zinman, Debit. Debit or Credit: How People Choose to Pay, Research Monograph, Filene Institute, 2008. Por. J. Campbell, Household Finance, "Journal of Finance" 2006, Vol. 61, No. 4, s.1553-1604.

${ }^{45}$ A. Lusardi, Preparing for Retirement: The Importance of Planning Costs, National Tax Association Proceedings 2002, s. 148-154. Por. A. Lusardi, O. S. Mitchell, Financial literacy and planning: Implications for retirement well-being, 2006, www.mrrc.isr.umich.edu/publica tions/conference/pdf/Lusardi-Mitchell\%20UM05-09A0805C.pdf (stan na dzień 20.11.2013). Por. B. D. Bernheim, Financial illiteracy, education, and retirement saving, [w:] O. Mitchell, S. Schieber (red.), Living with Defined Contribution Pensions, University of Pennsylvania Press, Philadelphia, PA, 1998, s. 38-68.

${ }^{46}$ M. Rooij, A. Lusardi, R. Alessie, Financial Literacy and Stock Market Participation, NBER Working Paper 13565, 2007, s. 2. Por. J. Yoong, Financial Illiteracy and Stock Market Participation, Mimeo, Stanford University, 2007. Por. D. Christelis, T. Jappelli, M. Padula, Cognitive abilities and portfolio choice, "European Economic Review” 2007, Vol. 54, Issue 1, s. 18-38. 
pozwalających na znaczne obniżenie kosztu obsługi. Dobrze poinformowany i wyedukowany konsument umie uwzględnić w swoich kalkulacjach ryzyko towarzyszące inwestycji, dzięki czemu wyższy poziom świadomości finansowej społeczeństwa oznacza zatem mniejsze prawdopodobieństwo, że w sytuacji niekorzystnych warunków na rynku wystąpi zniechęcenie do zawierania transakcji, a tym samym nagłe zmniejszenie popytu na usługi oferowane przez instytucje finansowe.

Konieczność podnoszenia poziomu wiedzy z zakresu finansów wynika nie tylko z potrzeby uchronienia klientów przed dotkliwymi konsekwencjami błędnych decyzji inwestycyjnych, ale także wzbudzenia zaufania do instytucji finansowych. Można je zbudować na zrozumieniu konstrukcji instrumentów finansowych i poznaniu mechanizmów funkcjonowania rynków. Edukacja ekonomiczna nie powinna być postrzegana jako jedyny środek zmniejszający asymetrię informacji pomiędzy dostawcami usług finansowych a ich klientami, ale raczej jako czynnik komplementarny w stosunku do regulacji zapewniających właściwy poziom ochrony klientów i odpowiedzialne zachowanie instytucji finansowych.

Zasygnalizowane $\mathrm{w}$ rozdziale korzyści płynące $\mathrm{z}$ posiadania wiedzy finansowej i jej pogłębiania czy też uaktualniania są uniwersalne, nie zostały skorelowane z wiekiem osób celowo. Wprawdzie, powołując się na cytowane wcześniej teorie dotyczące zachowań i preferencji finansowych konsumentów zmieniających się wraz z wiekiem na poszczególnych etapach życia, następuje koncentracja na różnych typach produktów finansowych, to biorąc pod uwagę różnorodność segmentu 50+ w odniesieniu do ich sytuacji życiowej i zawodowej, niemożliwym jest wyabstrahowanie spośród całego katalogu korzyści generowanych tylko tej grupie wiekowej.

\subsection{Specyfika badań nad poziomem świadomości finansowej}

Do 2000 r. rzadko podejmowano badania empiryczne w obszarze edukacji finansowej. Pewne informacje gromadzone były w USA i Wielkiej Brytanii ${ }^{47}$. Dopiero w 2005 r. przeprowadzone zostało pierwsze międzynarodowe badanie przez OECD, którego celem była identyfikacja poziomu wiedzy finansowej.

${ }^{47}$ Od początku lat dziewięćdziesiątych przeprowadzane były badania przez Consumer Federation of America and American Express, które raportowały niski poziom świadomości finansowej wśród uczniów gimnazjum, studentów oraz osób dorosłych. Szerzej: CFA, U.S. consumer knowledge: The results of a nationwide test, Washington 1990; CFA, High school student consumer knowledge: A nationwide test, Washington 1991, CFA, College student consumer knowledge: The results of a nationwide test, Washington 1993. 
Zgodnie z jego wynikami aż 8 na 10 osób niepoprawnie zidentyfikowało pojęcie stopy procentowej i innych kosztów kredytu, 5 z 10 osób przyznało, że nie rozumie produktów finansowych takich jak kredyt hipoteczny, a 2 na 10 osób nie było w stanie poprawnie odpowiedzieć na pytanie dotyczące inflacji i oprocentowania lokaty ${ }^{48}$.

W kolejnych latach w coraz większej liczbie państw zaczęły być prowadzone badania poświęcone weryfikacji poziomu edukacji finansowej obywateli. Poniżej (tablica 42) przedstawiono syntetycznie kierunki tych badań.

Tablica 42. Specyfika badań dotyczących poziomu świadomości finansowej

\begin{tabular}{|c|c|}
\hline Zakres badania świadomości finansowej & Uszczegółowienie \\
\hline 1 & 2 \\
\hline Posiadanie budżetu domowego & Świadome zarządzanie wpływami i wydatkami \\
\hline \multirow[t]{3}{*}{$\begin{array}{l}\text { Znajomość poszczególnych } \\
\text { produktów finansowych }\end{array}$} & $\begin{array}{l}\text { Klasyczne produkty bankowe (rachunek bieżący, ra- } \\
\text { chunek oszczędnościowy, kredyty, depozyty i lokaty } \\
\text { terminowe) }\end{array}$ \\
\hline & Produkty finansowe \\
\hline & $\begin{array}{l}\text { Identyfikacja obszarów wymagających najbardziej } \\
\text { intensywnej edukacji }\end{array}$ \\
\hline \multirow{2}{*}{$\begin{array}{l}\text { Identyfikacja cech demograficznych } \\
\text { warunkujących poziom wiedzy finansowej }\end{array}$} & Cechy demograficzne \\
\hline & Cechy psychologiczne \\
\hline \multirow[t]{3}{*}{$\begin{array}{l}\text { Wpływ kryzysu finansowego } \\
\text { na podejmowane decyzje finansowe }\end{array}$} & $\begin{array}{l}\text { Zmiany w zachowaniu gospodarstw domowych wy- } \\
\text { wołane kryzysem finansowym }\end{array}$ \\
\hline & $\begin{array}{l}\text { Wzrost zainteresowania wiedzą finansową po kryzy- } \\
\text { sie finansowym społeczeństwa }\end{array}$ \\
\hline & $\begin{array}{l}\text { Zwiększona liczba programów z obszaru edukacji } \\
\text { finansowej po kryzysie finansowym }\end{array}$ \\
\hline $\begin{array}{l}\text { Badanie związku między wykluczeniem } \\
\text { finansowym a wiedzą finansową }\end{array}$ & $\begin{array}{l}\text { Identyfikacja istnienia zależności między posiadaną } \\
\text { wiedzą finansową a zakresem i częstotliwością ko- } \\
\text { rzystania z poszczególnych produktów finansowych }\end{array}$ \\
\hline \multirow[t]{2}{*}{$\begin{array}{l}\text { Badanie związku między nadmiernym } \\
\text { zadłużeniem a wiedzą finansową } \\
\text { (idea responsible lending) }\end{array}$} & $\begin{array}{l}\text { Identyfikacja istnienia zależności pomiędzy nad- } \\
\text { miernym zadłużaniem się gospodarstw domowych } \\
\text { a posiadaną wiedzą finansową }\end{array}$ \\
\hline & Badanie zwyczajów płatniczych \\
\hline $\begin{array}{l}\text { Bezpieczeństwo poszczególnych } \\
\text { produktów finansowych }\end{array}$ & Znajomość pojęcia ryzyka \\
\hline $\begin{array}{l}\text { Konsekwencje braku } \\
\text { wiedzy finansowej }\end{array}$ & $\begin{array}{l}\text { Skutki niedostatecznego poziomu edukacji finanso- } \\
\text { wej w skali mikro- i makroekonomicznej }\end{array}$ \\
\hline
\end{tabular}

${ }^{48}$ Szerzej: OECD, Improving Financial Literacy, Analysis of Issues and Policies, OECD Publishing, Paris 2005. 
Tablica 42 (cd.)

\begin{tabular}{|c|c|}
\hline 1 & 2 \\
\hline \multirow[t]{3}{*}{ Źródła wiedzy finansowej } & $\begin{array}{l}\text { Identyfikacja typów inicjatyw mających na celu sze- } \\
\text { rzenie wiedzy finansowej }\end{array}$ \\
\hline & Identyfikacja źródeł przekazu wiedzy finansowej \\
\hline & $\begin{array}{l}\text { Wskazywanie instytucji odpowiedzialnych za kształ- } \\
\text { towanie świadomości finansowej w społeczeństwie } \\
\text { i stosunek poszczególnych instytucji do szerzenia } \\
\text { wiedzy finansowej }\end{array}$ \\
\hline \multirow{2}{*}{$\begin{array}{l}\text { Zróżnicowanie poziomu } \\
\text { wiedzy finansowej }\end{array}$} & Badania na szczeblu krajowym \\
\hline & Badania na szczeblu międzynarodowym \\
\hline
\end{tabular}

Źródło: opracowanie własne na podstawie: ANZ, Adult financial literacy in Australia, Full Report of the results from the 2011, ANZ Survey, December 2011, s. 2-3; A. Aizcorbe, A. Kennickell, K. B. Moore, Recent changes in U.S. family finances: evidence from the 1998 and 2001 Survey of Consumer Finances, "Federal Reserve Bulletin", January 2003, s. 1-32; R. Alessie, S. Hochguertel, A. van Soest, Household portfolios in the Netherlands, [w:] L. Guiso, M. Haliassos, T. Jappelli (red.), Household Portfolios, Cambridge, MA: MIT Press, 2002, s. 25-30; M. A. Hilgert, J. M. Hogarth, Household Financial Management: The Connection between Knowledge and Behavior, "Federal Reserve Bulletin", July 2003, s. 310-315; National Foundation for Credit Counseling, Financial Literacy Survey Exposes Significant Gaps In Grasp Of Personal Finance Skills, April 2012, www.nfcc.org/newsroom/newsreleases/SIGNIFICANT_GAPS.cfm (stan na dzień 30.12.2013).

Charakterystyczną cechą jest duża różnorodność prowadzonych badań weryfikujących poziom edukacji finansowej. Przejawia się ona przede wszystkim zróżnicowaniem zakresów prowadzonych badań i analiz, począwszy od diagnozy poziomu wiedzy finansowej w danym kraju, poprzez wskazanie przyczyn i skutków istniejącego poziomu wiedzy finansowej, a skończywszy na sformułowaniu rekomendacji mających na celu poprawienie świadomości finansowej. Przedmiotem większości tego rodzaju programów są podstawowe aspekty obchodzenia się z pieniędzmi, takie jak korzystanie z konta bankowego, a następnie umiejętności związane $\mathrm{z}$ właściwym budżetowaniem, w tym zarządzanie kredytami i zadłużeniem. Zagadnienia inwestowania, oszczędzania i emerytur, ubezpieczeń oraz zarządzania ryzykiem są poruszane dużo rzadziej, co wskazuje, że tym kwestiom należy być może poświęcić więcej uwagi w przyszłości. Bardzo często prowadzone badania mają charakter wieloaspektowy i łączą wybrane spośród wskazanych powyżej obszarów ${ }^{49}$.

49 Szerzej: European Commission, Financial Education, 2007. Por. M. Iwanicz-Drozdowska, Działania na rzecz poprawy poziomu edukacji finansowej w Unii Europejskiej podczas globalnego kryzysu finansowego, „Zarządzanie i Finanse, Journal of Management and Finance” 2013, nr 2/1, s. $187-189$. 
Analiza raportów będących wynikiem prowadzonych badań nad poziomem świadomości finansowej pozwoliła na opracowanie pewnego zestawu cech społeczno-demograficznych i psychologicznych osób dotkniętych brakiem wiedzy finansowej lub jej niedostatecznym poziomem. Wyniki przedstawia tablica 37.

Tablica 43. Determinanty różnicujące poziom wiedzy finansowej w społeczeństwie

\begin{tabular}{|l|l|}
\hline \multicolumn{2}{|c|}{ Cechy społeczno-demograficzne } \\
\hline Wiek & $\begin{array}{l}\text { osoby poniżej 25. oraz powyżej 55. roku życia mają mniejszą świa- } \\
\text { domość finansową }\end{array}$ \\
\hline Wysokość dochodów & $\begin{array}{l}\text { wraz ze wzrostem wysokości dochodów zwiększała się wiedza fi- } \\
\text { nansowa }\end{array}$ \\
\hline Wykształcenie & $\begin{array}{l}\text { osoby z wykształceniem co najmniej średnim miały wyższą wiedzę } \\
\text { finansową }\end{array}$ \\
\hline Wykonywany zawód & $\begin{array}{l}\text { pracownicy fizyczni charakteryzowali się niższym poziomem wie- } \\
\text { dzy finansowej }\end{array}$ \\
\hline Miejsce zamieszkania & $\begin{array}{l}\text { osoby z większych miejscowości i miast cechują się wyższym pozio- } \\
\text { mem świadomości finansowej }\end{array}$ \\
\hline Status społeczny & $\begin{array}{l}\text { osoby samotne i samotnie wychowujące dzieci mają niższą wiedzę } \\
\text { finansową }\end{array}$ \\
\hline Pozostawanie bezrobotnym & osoby bezrobotne gorzej wypadały w teście wiedzy finansowej \\
\hline $\begin{array}{l}\text { Religia, rasa, } \\
\text { narodowość }\end{array}$ & $\begin{array}{l}\text { osoby z mniejszości narodowych lub religijnych zwykle posiadają } \\
\text { niższą wiedzę finansową }\end{array}$ \\
\hline \multicolumn{2}{|c|}{ Cechy psychologiczne } \\
\hline Stosunek do ryzyka & $\begin{array}{l}\text { osoby lubiące podejmować ryzykowne decyzje mają wyższą wiedzę } \\
\text { finansową }\end{array}$ \\
\hline Skłonności do oszczędzania & osoby oszczędne mają wyższą wiedzę finansową \\
\hline Reakcja na stres & $\begin{array}{l}\text { osoby uznające radzenie sobie z pieniędzmi jako stresujące mają niż- } \\
\text { szą wiedzę finansową }\end{array}$ \\
\hline $\begin{array}{l}\text { Trudności w życiu } \\
\text { w społeczeństwie }\end{array}$ & $\begin{array}{l}\text { osoby bezradne albo mające skłonność do przemocy i zachowań } \\
\text { przestępczych charakteryzują się niższą świadomością finansową }\end{array}$ \\
\hline
\end{tabular}

Źródło: opracowanie własne.

Wskazane w tablicy cechy stanowią determinanty różnicujące poziom wiedzy finansowej w społeczeństwie. Nie wyczerpują one katalogu cech osób nieposiadających wiedzy finansowej lub posiadających ją na niedostatecznym poziomie, ale pozwalają na nakreślenie pewnego obrazu osoby nieposiadającej wystarczającej wiedzy finansowej, łączącego kryteria społeczno-demograficzne i psychologiczne. Należy wskazać, że kluczowymi cechami wpływającymi na brak świadomości finansowej na pożądanym poziomie jest niski poziom wykształcenia, niski poziom dochodów, brak stałego zatrudnienia lub bezrobocie, młody lub zaawansowany wiek, zamieszkiwanie na obszarach wiejskich oraz zestaw cech psychologicznych związanych z generalnym brakiem zaradności w życiu. 
W dostępnych badaniach, które koncentrowały się na analizie związku między wiekiem a poziomem wiedzy finansowej wielokrotnie potwierdzone zostało, że:

- średnia znajomość finansów obniża się o około 1\% za każdy rok po ukończeniu 60. roku życia ${ }^{50}$;

- wraz z wiekiem obniżają się umiejętności poznawcze i częściej podejmowane były niepoprawne decyzje finansowe;

- wraz z wiekiem wzrasta zbytnia pewność siebie, która staje się istotnym czynnikiem ryzyka stania się ofiarą oszustwa finansowego ${ }^{51}$;

- wraz z wiekiem maleje umiejętność rozwiazywania problemów, która jest wymagana przy podejmowaniu decyzji finansowych ${ }^{52}$;

- wraz z obniżaniem się inteligencji skrystalizowanej ${ }^{53}$ po 55. roku życia pogarsza się jakość podejmowanych decyzji kredytowych ${ }^{54}$;

- pomimo dowodów poprawiania się umiejętności dokonywania inwestycji wraz z wiekiem, po 70. roku życia znacząco obniża się realizacja planowanych wyników ${ }^{55}$.

Wartością dodaną prezentowanych wyników badań (niestety nielicznych i niekompleksowych) jest wskazanie kluczowych obszarów, które są charakterystyczne w obszarze edukacji finansowej osób 50+. Oczywiście należy podczas wyciągania wniosków uwzględnić dużą różnorodność gospodarstw domowych kwalifikujących się do tej kategorii, począwszy od najmłodszej wiekowo grupy (55-65 lat) aktywnych zawodowo, poprzez osoby w wieku 65-70 lat, które już są na emeryturze i zdołały zgromadzić pewne środki finansowe (ewentualnie majątek trwały), a skończywszy na osobach najstarszych (czyli powyżej 70 lat), które zwykle mają relatywnie niskie dochody i jednocześnie najwyższe wydatki na zdrowie. Jednakowo prezentowane wyniki wskazują na potrzebę szerzenia informacji i wiedzy finansowej, która pozwoliłaby w lepszym zrozumieniu zagadnień finansowych niezbędnych do dywersyfikacji ryzyka, optymalizowania kosztów i zwiększenia skuteczności w oszczędzaniu na emeryturę.

${ }^{50}$ M. S. Finke, J. Howe, S. J. Huston, Old Age and the Decline in Financial Literacy, August 24, 2011, http://papers.ssrn.com/sol3/papers.cfm?abstract_id=1948627 (stan na dzień 22.07.2014), s. $10-15$.

${ }^{51}$ K. Gamble, P. Boyle, L. Yu and D. Bennett, Aging, Financial Literacy, and Fraud, Netspare Discussion Papers, 2013, s. 4-5.

52 J. J. McArdle, E. Ferrer-Caja, F. Hamagami, R. W. Woodcock, Comparative Longitudinal Structural Analyses of the Growth and Decline of Multiple Intellectual Abilities Over the Life Span, "Developmental Psychology" 2002, Vol. 38, No. 1, s. 134-135.

${ }^{53}$ Inteligencja skrystalizowana powstaje pod wpływem indywidualnych doświadczeń w określonym kontekście kulturowym jako wynik doświadczenia i uczenia się. P. Marcinek, Funkcjonowanie intelektualne w okresie starości, „Gerontologia Polska” 2007, t. 15, nr 3, s. 70.

${ }^{54}$ S. Agarwal, J. C. Driscoll, X. Gabaix, D. Laibson, The Age of Reason: Financial Decisions over the Life-Cycle with Implications for Regulation, http://dash.harvard.edu/bitstream/handle/1/4554335/Laibson_AgeofReason.pdf?sequence=2 (stan na dzień 22.07.2014), s. 12-19.

${ }_{55}$ Szerzej: G. M. Korniotis, A. Kumar, Do older investors make better investment decisions? "The Review of Economics and Statistics" 2011, 93(1), s. 244-265. 
Zidentyfikowany w większości krajów niski poziom wiedzy finansowej spowodował powstanie licznych inicjatyw dotyczących edukacji finansowej realizowanych w poszczególnych państwach. Ich syntetyczne zestawienie przedstawia tablica 44.

Tablica 44. Przegląd programów dotyczących budowania świadomości finansowej w krajach UE

\begin{tabular}{|c|c|}
\hline $\begin{array}{l}\text { Cechy charakterystyczne } \\
\text { programów }\end{array}$ & Wyszczególnienie \\
\hline \multirow{8}{*}{$\begin{array}{l}\text { Podmioty zaangażowane } \\
\text { w przekazywanie } \\
\text { wiedzy finansowej }\end{array}$} & Banki centralne \\
\hline & Organy nadzoru nad rynkiem finansowym \\
\hline & Krajowe organy władzy publicznej, władze oświatowe \\
\hline & Banki komercyjne i spółdzielcze \\
\hline & Instytucje/organizacje szkoleniowe \\
\hline & Stowarzyszenia konsumentów \\
\hline & Organizacje udzielające mikrokredytów \\
\hline & Pracownicy opieki społecznej \\
\hline \multirow{3}{*}{$\begin{array}{l}\text { Zakres merytoryczny } \\
\text { programów edukacji } \\
\text { finansowej }\end{array}$} & Korzystanie z produktów finansowych \\
\hline & $\begin{array}{l}\text { Umiejętność konstruowania budżetów, w tym zarządzania kredytami } \\
\text { i zadłużeniem }\end{array}$ \\
\hline & Problematyka oszczędzania i możliwości inwestowania środków \\
\hline \multirow{5}{*}{$\begin{array}{l}\text { Grupy docelowe } \\
\text { najczęściej obejmowane } \\
\text { programami edukacyjnymi }\end{array}$} & Dzieci i młodzież \\
\hline & Seniorzy \\
\hline & Mieszkańcy wsi i małych miejscowości \\
\hline & Kobiety \\
\hline & Osoby o niskich dochodach \\
\hline
\end{tabular}

Źródło: opracowanie na podstawie: M. Habschick, B. Seidl, J. Evers, Survey of financial literacy schemes in the EU 27, VT Markt/2006/26H - Final Report, Hamburg, November 2007, s. 24-98.

Przeprowadzone badania dotyczące poziomu wiedzy finansowej pokazują skalę problemów, jakie napotykają pod tym względem konsumenci. W ich ramach można wskazać na trzy kluczowe aspekty ${ }^{56}$ :

- dla wielu osób świat finansów jest trudny do zrozumienia: wyniki badań jednoznacznie wskazują, że brakuje im pewnych podstawowych umiejętności koniecznych do zrozumienia i dokonywania operacji finansowych. Może to mieć istotne konsekwencje dla zdolności prowadzenia negocjacji z podmiotami oferującymi odpowiednie usługi oraz uzyskania od nich najlepszej oferty;

- ludzie często przeceniają własną wiedzę na temat usług finansowych. Konsumenci zainteresują się propozycjami edukacji finansowej jedynie wówczas, gdy

${ }^{56}$ Komisja Wspólnot Europejskich, Komunikat Komisji. Edukacja finansowa, KOM(2007) 808, Bruksela 2007, s. 8. 
uświadomią sobie, że wiedza z tego zakresu może mieć dla nich znaczenie. Pierwszym krokiem jest zatem zwrócenie uwagi tych osób, które nie są świadome braków we własnej wiedzy, np. poprzez przeprowadzanie testów wiedzy finansowej;

- wiele osób nie potrafi planować przyszłości pod względem finansowym lub wybiera produkty, które nie odpowiadają ich potrzebom. Dużo większe jest więc prawdopodobieństwo, że osoby te wpadną w pułapkę zadłużenia lub będą miały inne trudności finansowe, jeśli zmieni się ich sytuacja osobista, np. w wyniku utraty bliskich, rozpadu związku lub okresów bezrobocia. Utrudnia im to również utrzymanie zadowalającego standardu życia po przejściu na emeryturę.

Pewnych trudności nastręcza ocena korzyści płynących z inicjatyw na rzecz edukacji finansowej, $\mathrm{w}$ tym $\mathrm{w}$ grupie $50+$. Wynikają one $\mathrm{z}$ braku możliwości jednoznacznego odróżnienia wpływu programów edukacji finansowej od wpływu szerszych czynników rynkowych na rozwój sektora finansowego i sytuację ekonomiczną społeczeństwa. $\mathrm{Z}$ tego względu bardzo często poszczególne programy edukacyjne podlegają ewaluacji i na podstawie odpowiedzi respondentów dotyczących ich opinii na temat pozyskanej wiedzy finansowej dokonywana jest ocena efektów prowadzenia danego programu edukacyjnego. Ponadto zmiany zachowania wywołane podniesieniem poziomu finansowego są widoczne dopiero w dłuższej perspektywie, zatem należy spodziewać się większej liczby analiz poświęconych ocenie korzyści płynących z programów edukacji finansowej dopiero w najbliższych latach.

Dotychczas przeprowadzone oceny koncentrują się zwykle na statystykach związanych z udziałem w poszczególnych programach edukacji finansowej. Stosowane są przy tym wskaźniki, takie jak: wzrost liczby uczestników, ilość zamówionych publikacji, liczba osób odwiedzających daną stronę internetową, ilość relacji prasowych, nadesłanych zapytań itp. Skutecznym narzędziem wykorzystywanym do pomiaru korzyści przez niektóre podmioty oferujące usługi w zakresie edukacji finansowej, w tym przez państwa członkowskie, są badania podstawowe. Określają one poziom wiedzy finansowej w populacji w danym momencie, pozwalają określić priorytety i ułatwiają monitorowanie osiągniętego postępu po upływie określonego czasu.

\subsection{Socjalizacja ekonomiczna pierwotna i wtórna}

Ważnym jest, że edukacja finansowa jest traktowana jako element socjalizacji ekonomicznej zarówno w wymiarze pierwotnym, jak i wtórnym. Początki badań podejmowanych przez psychologów nad problematyką wiedzy na temat zasad funkcjonowania gospodarki w kontekście uczestnictwa dzieci oraz młodzieży w życiu ekonomicznym sięgają lat pięćdziesiątych ubiegłego wieku (prowadzili 
je m.in. Strauss ${ }^{57}$, Danzinger ${ }^{58}$, Barey i Pollay ${ }^{59}$, Guest $\left.^{60}, \mathrm{NcNeal}^{61}\right)$. Rozproszone prace dotyczące funkcjonowania dzieci i osób młodych na rynku zebrał w ramach jednej problematyki Scott Ward, definiując pojęcie socjalizacji konsumenckiej ${ }^{62}$. Stanowiło ono podwaliny pod dalsze badania nad takimi zagadnieniami, jak wiedza o podstawowych elementach rynku, zachowania konsumenckie dziecka, decyzje zakupowe rodziny, konsumpcja a rozwój systemu wartości ${ }^{63}$.

Szerszym zagadnieniem od socjalizacji konsumenckiej jest socjalizacja ekonomiczna. Socjalizacja ekonomiczna pierwotna jest według badaczy pojęciem odnoszącym się do wszystkich procesów, dzięki którym dziecko zdobywa umiejętność rozumienia otaczającego je świata gospodarczego oraz uczy się działania w nim. Zgodnie z jedną z najbardziej rozpowszechnionych interpretacji tego pojęcia socjalizację ekonomiczną traktuje się jako proces obejmujący przyswajanie przez dziecko wiedzy pojęciowej, umiejętności, opinii, postaw, wartości oraz poznawczych reprezentacji różnych elementów systemu ekonomicznego ${ }^{64}$.

Badania nad socjalizacją ekonomiczną pierwotną pozwalają na zidentyfikowanie dwóch niezmiernie ważnych kwestii. Pierwszą z nich jest problematyka kształtowania się w dzieciństwie nawyków związanych z konsumpcją i planowaniem wydatków, oszczędzaniem, działaniami przedsiębiorczymi czy też ubezpieczeniowymi. Drugim zaś powodem analizowania procesów socjalizacji ekonomicznej jest planowanie przez różnorodne instytucje (szkoły, fundacje, instytucje finansowe) programów edukacji ekonomicznej. Zgodnie z wynikami badań wczesne inicjatywy edukacyjne przyczyniają się do wzrostu wiedzy oraz świadomości konsumenckiej,

${ }^{57}$ A. Strauss, The development and transformation of monetary meaning in the child, "American Sociological Review" 1952, 17, s. 275-286.

${ }^{58}$ K. Danziger, Children's earliest conceptions of economic relationships (Australia),"Journal of Social Psychology" 47, 2, 1958, s. 31-240.

${ }^{59}$ L. Barey, R. W. Pollay, The infuencing role of the child in family decision making, "Journal of Marketing Research" 1968, 5, s. 70-72.

${ }^{60}$ L. P. Guest, Brand loyalty - Twelve years later, "Journal of Applied Psychology” 1955, 39, s. 405-408.

${ }^{61}$ Szerzej: J. McNeal, Children as consumers, Austin: Bureau of Business Research, University of Texas at Austin, 1964.

${ }^{62}$ Socjalizacja konsumencka jest procesem, w którym dzieci zdobywają umiejętności, wiedzę i postawy umożliwiające im funkcjonowanie na rynku w roli konsumentów. S. Ward, Consumer socialization, "Journal of Consumer Research" 1974, Vol. 1, s. 1-14.

${ }^{63}$ E. Brombosz, Socjalizacja ekonomiczna - nowy kierunek socjalizacji, [w:] E. Mandal, R. Stefańska-Klar (red.), Wspótczesne problemy socjalizacji, Wydawnictwo Uniwersytetu Śląskiego, Katowice 1995, s. 61-78; Por. B. Frączak-Rudnicka, Dzieci w roli konsumentów-przyspieszona socjalizacja konsumencka, [w:] M. Marody (red.), Zmiana czy stagnacja? Społeczeństwo polskie po czternastu latach transformacji, Wydawnictwo Naukowe Scholar, Warszawa 2004, s. 88-99. Por. A. Jasielska, R. A. Maksymiuk, Dorośli reklamuja, dzieci kupują. Kindermarketing i psychologia, Wydawnictwo Naukowe Scholar, Warszawa 2010.

${ }^{64}$ Ch. R. Lévy, Wjaki sposób nabywamy pojęcia i wartości ekonomiczne, [w:] T. Tyszka (red.), Psychologia ekonomiczna, Gdańskie Wydawnictwo Psychologiczne, Gdańsk 2004, s. 284-285. 
dzięki czemu młodzi klienci mogą stać się bardziej odporni na perswazyjne przekazy reklamowe i dokonywać wyborów ekonomicznych zgodnie z obowiązującymi zasadami, normami społecznymi oraz własnymi przekonaniami ${ }^{65}$.

Rozkwit badań nad socjalizacją ekonomiczną miał miejsce w latach osiemdziesiątych. Badania w tym obszarze prowadził m.in. Furth ${ }^{66}$, Berti i Bombi ${ }^{67}$, Burris $^{68}$. Kontynuację tych rozważań można znaleźć w nowszych badaniach autorstwa Furnhama ${ }^{69}$, Ottoa, Schotsa, Westermana i Webleya ${ }^{70}$ oraz Nyhusa i Webleya $^{71}$. Polska historia badań dotycząca tego nurtu psychologii ekonomicznej jest znacznie krótsza. Pierwsze badania przeprowadzono w latach osiemdziesiątych i na początku 90-tych (Gasparski) ${ }^{72}$. Od tamtej pory powstały nieliczne prace dotyczące wiedzy i zachowań ekonomicznych polskich dzieci, spośród których jednym z kluczowych obszarów ze względu na poruszaną w niniejszej publikacji tematykę było pojęcie pieniądza oraz jego znaczenia w transakcjach wymiany (kupna i sprzedaży), a także inne formy posługiwania się pieniędzmi, takie jak oszczędzanie czy też korzystanie z usług banków ${ }^{73}$. Najczęściej poruszaną kwestią w ramach badań nad socjalizacją ekonomiczną są interakcje między dzieckiem (podmiotem socjalizacji) a rodzicami, systemem edukacji, instytucjami społecznymi i ekonomicznymi, środkami masowego przekazu (agentami socjalizacji).

${ }^{65}$ Szerzej: M. Goszczyńska, S. Kołodziej, A. Trzcińska, Uwikłani w świat pieniądza i konsumpcji. O socjalizacji ekonomicznej dzieci i młodzieży, Difin, Warszawa 2012.

${ }^{66}$ H. Furth, The word of grown-ups, Elsevier, New York 1980.

${ }^{67}$ E. A. Berti, A. S Bombi, The child's construction of economics, Cambridge University Press, Cambridge 1988.

${ }^{68}$ V. Burris, Stages in the development of economic concepts, "Human Relations" 1983, 36, s. $791-812$.

${ }^{69}$ A. Furnham, Economic socialization: A study of adults' perceptions and uses of allowances (pocket money) to educate children, "British Journal of Developmental Psychology" 1999, 17, s. 585-604; A. Furnham, The saving and spending habits of young people, "Journal of Economic Psychology" 1999, 20, s. 677-697; A. Furnham, Parental attitudes to pocket money/allowances for children, "Journal of Economic Psychology" 2001, 22, s. 397-422; A. Furnham, M. P. Goletto-Tankel, Understanding savings, pensions and life assurance in 16-21-year-olds, "Human Relations" 2002, 55, s. 603-628.

${ }^{70}$ A. M. C. Otto, P. A. M. Schots, J. A. J. Westerman, P. Webley, Children's use of saving strategies: An experimental approach, "Journal of Economic Psychology" 2006, 27, s. 57-72.

${ }^{71}$ E. K. Nyhus, P. Webley, The role of personality in household saving and borrowing behaviour, "European Journal of Personality" 2001, 15, s. 85-103.

72 P. Gasparski, Dziecięce finanse - kieszonkowe, prezenty, zarobki, „Bank i Kredyt” 1991, nr 2; tenże, Motywacja dzieci do udziatu w bankowych formach oszczędzania, „Bank i Kredyt” 1991, nr 3, s. 11-16; tenże, Oszczędzanie - psychologiczna charakterystyka motywów oszczędzania. Raport z badań, „Ekonomista” 1991, nr 2-3, s. 347-353; tenże, Użyteczność pieniędzy i poziom optymizmu ekonomicznego jako wyznaczniki decyzji dotyczacych oszczędzania, „Przegląd Psychologiczny" 1991, XXXIV (4), s. 657-669; tenże, Wyznaczniki indywidualnych skłonności do bankowych form oszczędzania, „Bank i Kredyt” 1993, nr 12, s. 16-21.

${ }^{73}$ M. Goszczyńska, S. Kołodziej, A. Trzcińska, Uwikłani w świat pieniądza i konsumpcji. O socjalizacji ekonomicznej dzieci i młodzieży, Difin, Warszawa 2012. 
Drugim wymiarem socjalizacji ekonomicznej jest socjalizacja wtórna, która jest efektem zmian ról, jakie osoby dorosłe odgrywają w życiu, oraz zdarzeń, jakie ich dotykają. W jej efekcie nabyte w dzieciństwie zachowania ekonomiczne stają się bardziej zindywidualizowane, a wiedza finansowa jest na bieżąco aktualizowana. Konieczność uaktualniania wiedzy finansowej wynika chociażby z wdrażania coraz to nowych produktów i usług oraz kanałów dostępu do produktów bankowych. Nie dotyczy to tylko osób w wieku 50+, ale wszystkich obywateli, także tych dla których nowoczesne technologie nie stanowią żadnej bariery.

Socjalizacja ekonomiczna wtórna jest niezmiernie ważna, gdyż wiedza finansowa zdobyta $\mathrm{w}$ dzieciństwie ulega pewnej deprecjacji wraz z upływem czasu ze względu na zmiany zachodzące $w$ otoczeniu, szczególnie w gospodarce oraz w kanałach dystrybucji i różnorodności oferowanych produktów i usług finansowych (chociażby pojawienie się bankowości internetowej). Tym samym wiedza finansowa pozyskana w procesie socjalizacji pierwotnej w gospodarce centralnie planowanej nie jest adekwatna do specyfiki funkcjonowania instytucji finansowych obecnie ${ }^{74}$.

Ewolucja wiedzy ekonomicznej i w ślad za nią idąca konieczność zdobywania nowych umiejętności i korygowania już pozyskanych jest kluczowym argumentem przemawiającym za systematycznym aktualizowaniem i pogłębianiem wiedzy finansowej przez osoby w wieku 50+. Pozwoli to zwiększyć świadomość finansową i zarządzać finansami w sposób bardziej racjonalny przy wykorzystaniu dostępnych produktów finansowych. Ze względu na fakt, że rodzina i rodzice oraz dziadkowie są bardzo ważnym czynnikiem wpływającym na procesy socjalizacji ekonomicznej dzieci, należy podkreślić fakt, że lepiej wykształcone osoby 50+ będą w stanie przekazywać swoje poprawne zachowania ekonomiczne kolejnym pokoleniom.

\subsection{Edukacja finansowa w Polsce}

\subsubsection{Problem edukacji finansowej w Polsce}

Specyfika polskiego społeczeństwa w obszarze edukacji finansowej ściśle skorelowana jest z przemianami ustroju społeczno-gospodarczego, jakie miały miejsce po 1989 r. Dopiero rozwój gospodarki rynkowej zdeterminował konieczność zwiększenia zainteresowania problemem edukacji finansowej przez rząd oraz instytucje finansowe. Drugim ważnym wydarzeniem wpływającym

74 D. Maison, Polak w świecie finansów, Wydawnictwo Naukowe PWN, Warszawa 2013, S. $184-185$. 
na kształtowanie poziomu edukacji finansowej w polskim społeczeństwie było wstąpienie Polski do Unii Europejskiej i związana z tym konieczność ratyfikowania określonych postanowień.

Pierwszym krokiem na rzecz integracji z UE było opracowanie Narodowej Strategii Integracji Społecznej (NSIS) oraz Krajowego Planu Działania na rzecz Integracji Społecznej (National Action Plan on Inclusion), które opierały się o deklarację wspólnych działań zwaną Wspólnym Memorandum o Integracji Społecznej (Joint Memorandum on Social Inclusion lub Joint Inclusion Memorandum - JIM). Celem stworzenia Narodowej Strategii Integracji Społecznej było włączanie się Polski w realizację drugiego z celów Strategii Lizbońskiej UE stawiającego na modernizację europejskiego modelu socjalnego, inwestowanie w ludzi oraz zwalczanie wykluczenia społecznego ${ }^{75}$.

Na potrzeby prac legislacyjnych wyłączenie społeczne zdefiniowane zostało w szerszym wymiarze jako brak integracji społecznej wynikający nie tylko z niskich dochodów, ale odzwierciedlający również niedostateczne zdrowie i edukację, deprywację pod względem wiedzy i komunikacji społecznej, niezdolność do cieszenia się ludzkimi i politycznymi prawami i nieobecność godności, zaufania i szacunku dla samego siebie, czyli sposób i jakość życia ${ }^{76}$. Kolejne lata zwróciły uwagę, że jednym z komponentów wspierania integracji społecznej powinna być edukacja finansowa.

Niestety nadal nie została opracowana wzorem innych państw UE Narodowa Strategia Edukacji Finansowej (NSEF), której celem byłoby określenie standardów kształcenia w obszarze edukacji finansowej. W dalszej perspektywie NSEF służyłaby wyrównywaniu szans w dostępie do wiedzy fachowej osób wykluczonych finansowo ${ }^{77}$.

Konieczność zweryfikowania poziomu świadomości finansowej polskiego społeczeństwa i jego podnoszenia wynika z kombinacji czynników społeczno-ekonomicznych:

- zmiany struktury rynku usług finansowych,

- zmian demograficznych,

- reformy systemów emerytalnych.

Wszystkie te obszary sprowadzają się do kwestii zarządzania budżetem domowym. A w dalszej kolejności świadczą o ścisłym związku między edukacją finansową a biedą i ubóstwem. Zgodnie z opracowaniami Unii Europejskiej Polska jest krajem charakteryzującym się wysokim ryzykiem ubóstwa. Świadczą o tym poniższe dane (rysunek 38).

${ }^{75}$ MIPS, Narodowa Strategia Integracji Społecznej dla Polski, Warszawa 2003.

${ }^{76}$ C. Mizejewski, Narodowa Strategia Integracji Społecznej do 2010 roku. Podsumowanie $i$ wnioski na przyszłość, Ekspertyza przygotowana w ramach projektu „EAPN Polska - razem na rzecz Europy Socjalnej”, [w:] Ubóstwo i wykluczenie społeczne w Polsce, Raport krajowy Polskiej Koalicji Social Watch i Polskiego Komitetu European Anti-Poverty Network, 2010, s. 167-168.

${ }^{77}$ EIOPA, Report on Financial Literacy and Education Initiatives by Competent Authorities, EIOPA-CCPFI-11/018, 2011, s. 12. 


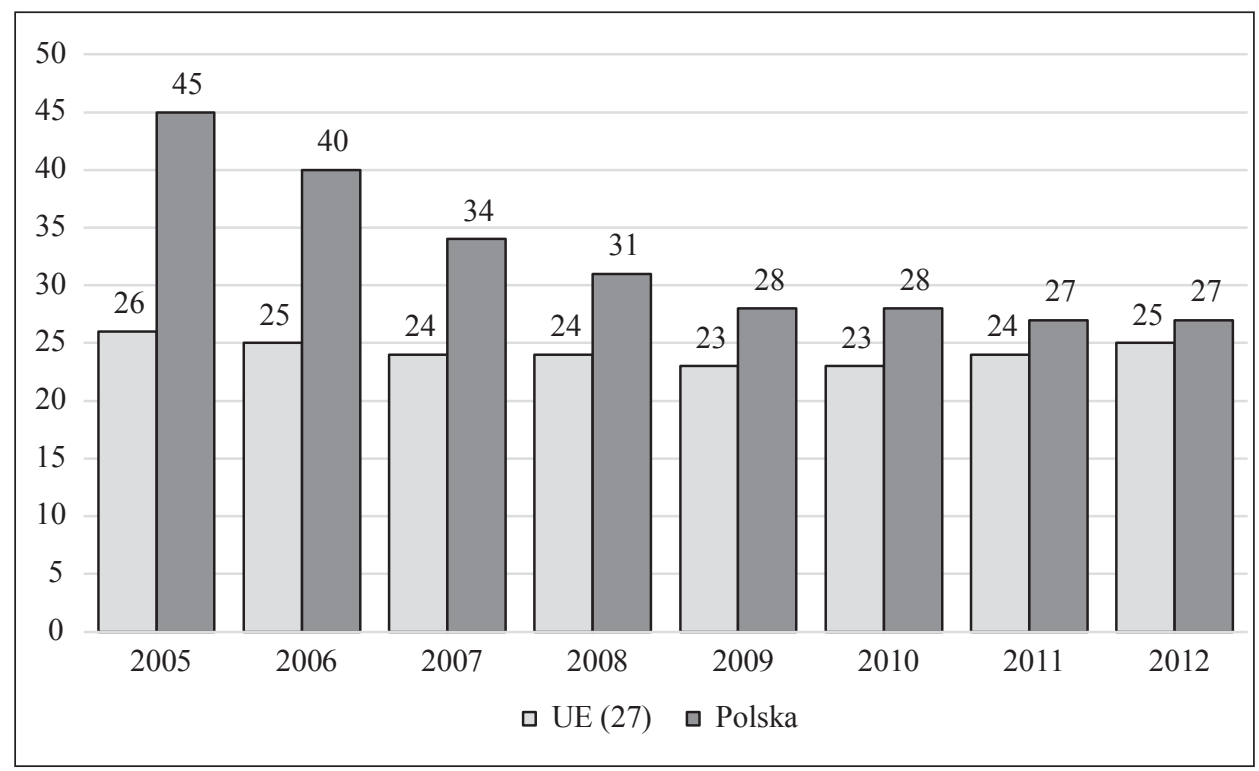

Rysunek 38. Osoby zagrożone biedą i wykluczeniem społecznym w Polsce na tle krajów UE (dla 2012 r. jest to średnia dla EU 28) (w \%)

Źródło: opracowanie własne na podstawie danych Eurostat

Jak wynika z przedstawionych danych, w roku 2012 dotkniętych ubóstwem było $24,8 \%$ populacji, podczas gdy w Polsce wskaźnik ten sięgnął aż $26,7 \%$ społeczeństwa. Biorąc pod uwagę wiek, według Eurostatu średnio 14,9\% osób w wieku od 55 lat jest zagrożonych ubóstwem lub wykluczeniem społecznym, podczas gdy w Polsce jest to $15,8 \%$.

Bieda i ubóstwo występujące w Polsce są w dużej mierze efektem wieloletnich zaniedbań w zakresie kształtowania przedsiębiorczych podstaw i wspierania rozwoju mikro, małych i średnich przedsiębiorstw. Szybki rozwój globalnych rynków finansowych, pojawianie się nowych i coraz bardziej skomplikowanych produktów finansowych oraz częste zawirowania na globalnych rynkach finansowych zmuszają do nowego spojrzenia na edukację całego społeczeństwa w tym zakresie.

O dużym znaczeniu polityki edukacji ekonomicznej świadczy silny związek pomiędzy jakością edukacji ekonomicznej a rozwojem gospodarczym. Bez świadomego ekonomicznie i finansowo społeczeństwa nie jest możliwy stabilny wzrost gospodarczy.

W strategii edukacji ekonomicznej Narodowego Banku Polskiego na lata 2010-2012 podkreślono, że „stan wiedzy i świadomości ekonomicznej Polaków jest wysoce niesatysfakcjonujący. Brakuje zarówno wiedzy o instytucjach, jak i praktycznych umiejętności korzystania z instrumentów finansowych. Istotnym 
zagrożeniem są również stereotypy, mity i błędne przekonania dotyczące zagadnień ekonomicznych. O dużym znaczeniu polityki edukacji ekonomicznej może świadczyć silny związek pomiędzy jakością edukacji ekonomicznej a rozwojem gospodarczym. Bez świadomego ekonomicznie i finansowo społeczeństwa nie jest możliwy stabilny wzrost gospodarczy. Wobec powyższego istnieje konieczność prowadzenia kompleksowych działań edukacyjnych, ukierunkowanych na przekazywanie wiedzy, jak również kształtowanie świadomości Polaków jako klientów instytucji finansowych"78.

Kompleksowe badania świadomości i dojrzałości ekonomicznej są prowadzone w Polsce systematycznie przez wiele ośrodków. Wsparciem dla tych badań są sondaże, przeprowadzane co jakiś czas przez ośrodki badania opinii publicznej, które koncentrują się na pojedynczych obszarach tematycznych, takich jak: skłonność do oszczędzania, postawy wobec wprowadzenia w Polsce euro, postawy wobec kredytów bankowych czy też przezorność ubezpieczeniowa. $\mathrm{Z}$ dostępnych wyników badań wynika, iż stan wiedzy finansowej Polaków ulega wprawdzie pewnej poprawie, lecz nadal pozostaje na niskim poziomie. Powołać można się na kilka największych badań przeprowadzanych na całej populacji.

Jednym z nich jest raport z badania ilościowego przeprowadzonego na przełomie lipca i sierpnia 2009 r. przez Pentor Research International w formie bezpośrednich wywiadów kwestionariuszowych CAPI (Computer Assisted Personal Interview). Celem głównym badania „Stan wiedzy finansowej Polaków” było zbadanie poziomu wiedzy ekonomicznej Polaków i diagnoza obszarów, w których Polakom najbardziej potrzebna jest edukacja ekonomiczna (obszary dla działań kampanii edukacyjnych). Obszary badania obejmowały:

- opis poziomu wiedzy ekonomicznej Polaków i identyfikację obszarów, w których wiedza ta jest najmniejsza - potencjalnych obszarów dla działań edukacyjnych;

- opis zwyczajów Polaków związanych z wydawaniem pieniędzy, oszczędzaniem i inwestowaniem;

- postawy związane z pieniędzmi, oszczędzaniem i inwestowaniem;

- oszacowanie poziomu zaufania wobec instytucji finansowych;

- diagnozę poziomu wiedzy ekonomicznej oraz wskazanie uwarunkowań tej wiedzy;

- identyfikację grup najbardziej potrzebujących wiedzy ekonomicznej;

- wskazanie najbardziej obiecujących dróg dotarcia z ofertą edukacyjną do odbiorcy (media, Internet czy np. szkolenia).

W przeprowadzonym badaniu wiedza ekonomiczna Polaków była mierzona na kilka sposobów jako:

- wiedza obiektywna - narzędziem służącym do jej pomiaru był test wiedzy finansowej;

${ }^{78}$ NBP, Strategia edukacji ekonomicznej Narodowego Banku Polskiego na lata 2010-2012, NBP, Departament Edukacji i Wydawnictw, Warszawa 2009, s. 6. 
- wiedza subiektywna - opierająca się na samoocenie w zakresie poziomu posiadanej wiedzy finansowej;

- wiedza relatywna - ukazująca poziom wiedzy w porównaniu do średniej wiedzy Polaków.

Wyniki badania przedstawia rysunek 39 .

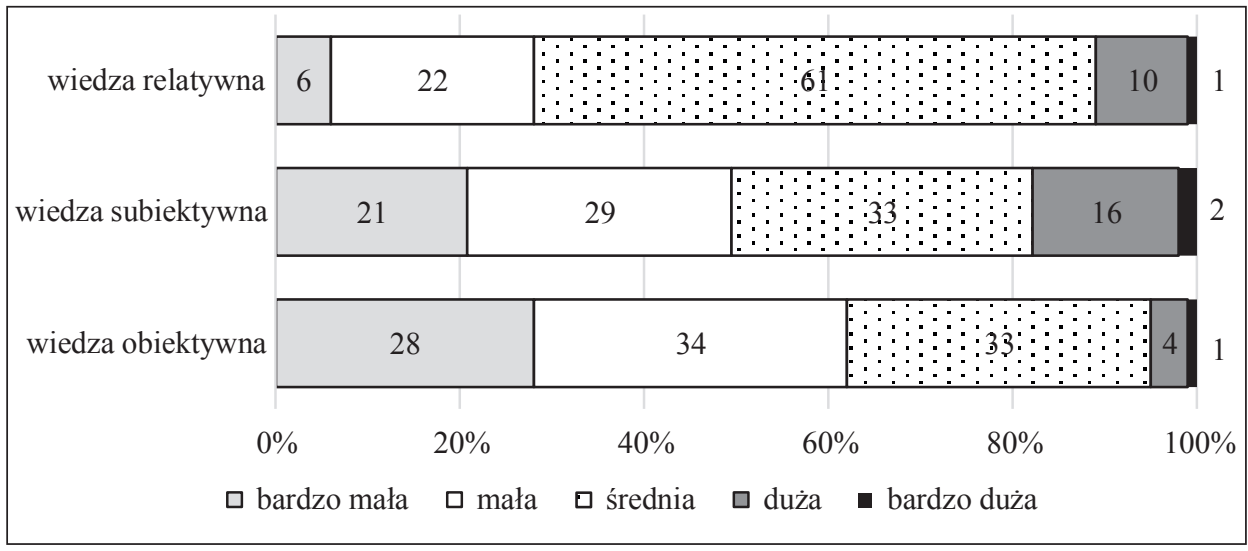

Rysunek 39. Wiedza finansowa obiektywna, subiektywna i relatywna (w \%)

Źródło: opracowanie na podstawie: Dom Badawczy Maison, Stan wiedzy finansowej Polaków, Raport Fundacji Kronenberga przy Citi Handlowy, wrzesień 2009, s. 101, 115-116

Uzyskane wyniki wskazują na słabą znajomość zagadnień finansowych w każdym z branych pod uwagę wymiarów. Zdecydowana większość Polaków (62\%) ocenia swoją wiedzę na tematy finansowe jako bardzo małą i małą, jedna trzecia jako średnią (33\%), a jedynie 5\% jako dużą i bardzo dużą. Na przeprowadzony test wiedzy ekonomicznej składający się z 20 pytań respondenci odpowiedzieli średnio na 8 pytań, czyli mniej niż połowę. Dodatkowo między posiadaną faktycznie wiedzą finansową wystąpiła dysproporcja. Blisko jedna trzecia osób oceniających swoją wiedzę ekonomiczną jako średnią lub dobrą, w wyniku przeprowadzonego testu wiedzy uplasowała się w grupie osób posiadających wiedzę poniżej przeciętnej ${ }^{79}$.

Diagnoza wiedzy subiektywnej uszczegółowiona została ze względu na takie cechy, jak płeć, wiek i dochód. Jej rezultaty prezentuje rysunek 40.

Polacy nisko oceniają stan swojej wiedzy ekonomicznej. Dwie trzecie uważa, że ma małą lub bardzo małą wiedzę na temat finansów. Ocena posiadanej wiedzy finansowej jest wyższa u mężczyzn niż u kobiet, wśród osób między 34 . a 54. rokiem życia, w grupie z dochodem powyżej 2000 PLN. Wraz z wiekiem widoczne jest obniżanie się samooceny poziomu wiedzy finansowej. Potwierdza tę tendencję rysunek 41.

${ }^{79}$ D. Maison, Polak w świecie finansów..., s. 187-188. 


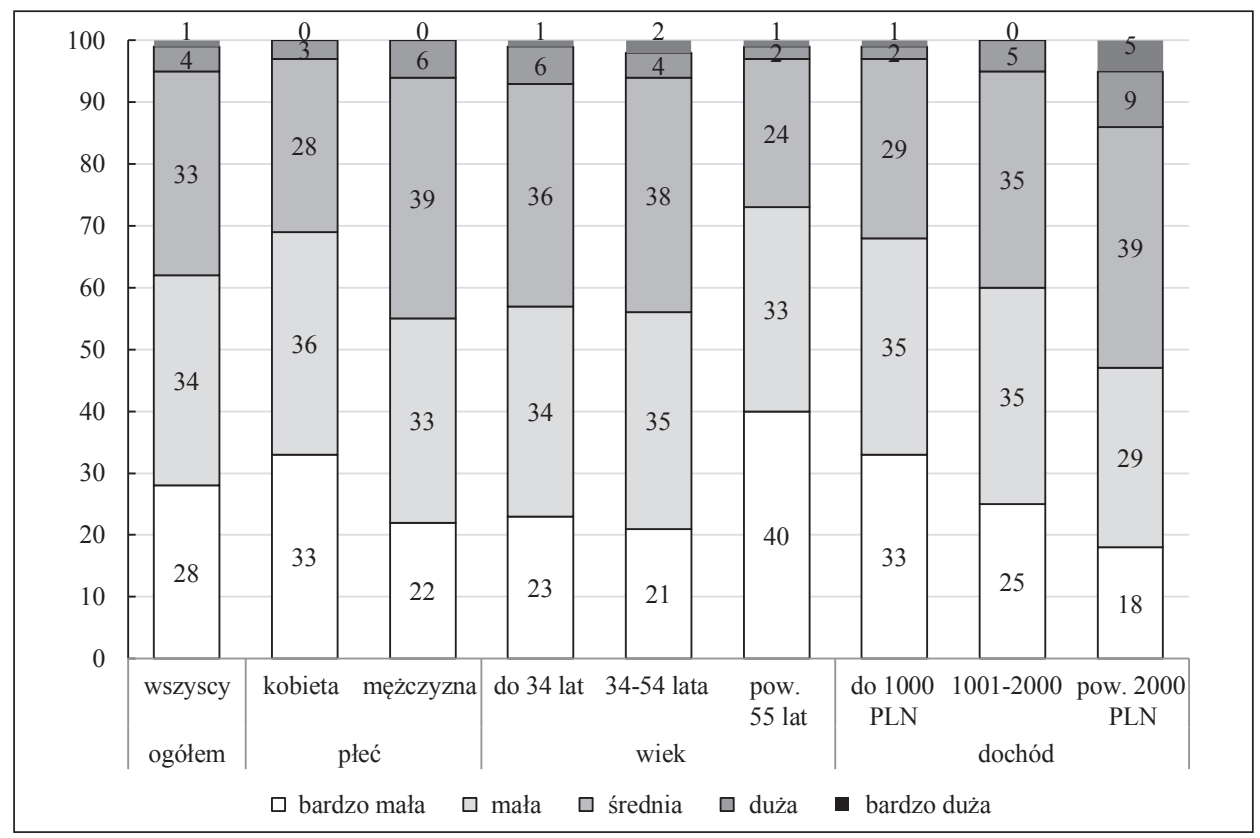

Rysunek 40. Ocena własnej wiedzy na temat zagadnień finansowych (w \%)

Źródło: Dom Badawczy Maison, Stan wiedzy finansowej Polaków, Raport Fundacji Kronenberga przy Citi Handlowy, wrzesień 2009, s. 102

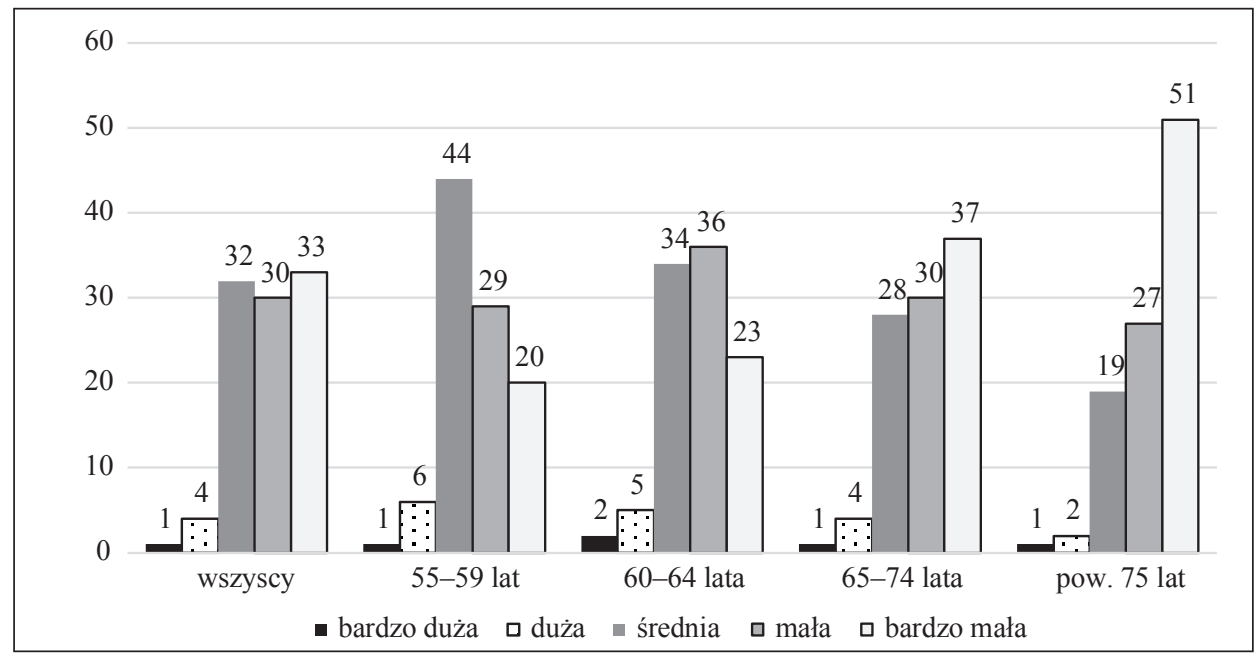

Rysunek 41. Wiedza finansowa a wiek (w \%)

Źródło: Badanie postaw Polaków powyżej 60. roku życia wobec obrotu bezgotówkowego, Dom Badawczy Maison, Raport przygotowany dla NBP, Warszawa, kwiecień 2012, s. 105 
Generalnie, w grupie osób powyżej 55. roku życia widoczna jest niska ocena posiadanej wiedzy finansowej, a dodatkowo wraz z wiekiem drastycznie zwiększała się liczba respondentów, którzy ocenili najniżej poziom swojej wiedzy. W ślad za niską samooceną posiadanej wiedzy idzie faktyczny jej niedostatek $\mathrm{w}$ grupie $55+$.

Jak wynika z przeprowadzonego na grupie osób 55+ testu wiedzy finansowej w przypadku większości pytań około połowa osób nie potrafiła określić, czy powyższe stwierdzenia są prawdziwe czy fałszywe (wybierano odpowiedź „nie wiem"). Najwięcej problemów sprawiały respondentom stwierdzenia dotyczące banku internetowego oraz porównania akcji i obligacji (56-57\% osób nie było W stanie ocenić prawdziwości tych stwierdzeń). Pytaniem, na które najwięcej osób nie potrafiło odpowiedzieć, jest na pytanie o możliwość otrzymania pomocy od pracownika banku w przypadku korzystania z dostępu do konta przez Internet. Wynik ten ma o tyle duże znaczenie, że może być jedną z barier leżących u podłoża niekorzystania z bankowości elektronicznej.

$\mathrm{Na}$ podstawie poprawności udzielonych odpowiedzi opracowano indeks wiedzy finansowej ${ }^{80}$. Biorąc pod uwagę przedziały wiekowe, wskaźnik ukształtował się następująco ${ }^{81}$ :

- wszyscy - 2,54,

- 55-59 lat $-3,32$,

- 60-64 lata $-2,95$,

- 65-74 lata $-2,25$,

- powyżej 75 roku życia - 1,61.

Generalnie wysokość indeksu nie była satysfakcjonująca w żadnym ze wskazanych przedziałów wiekowych. A jeszcze wraz z wiekiem malał udział poprawnie udzielonych odpowiedzi.

Potwierdzeniem słabej znajomości zagadnień finansowych jest powszechna niewiedza na temat parabanków. Zdaniem jednej dziesiątej parabank to bank, który łatwo i szybko udziela pożyczek, a 54\% respondentów nie potrafiło udzielić odpowiedzi na to pytanie. Co więcej, przed podpisaniem umowy dotyczącej pożyczki lub zainwestowania pieniędzy jedna piąta ankietowanych przyznała, że nie czyta zawartych w niej warunków. Te wnioski o niewiedzy Polaków, czym się zajmuje parabank, w sytuacji gdy obsługują one około 3-4 mln osób może skutkować dalszymi stratami inwestorów. Ponadto niekorzystny obraz parabanków może wpłynąć na zaufanie Polaków do samych banków, zwłaszcza że zdaniem $28 \%$ klientów banków firmy oferujące produkty podobne do lokat bankowych są jednakowo wiarygodne jak banki. Ponadto $13 \%$ inwestujących w prywatne pożyczki uważało, że są one tak samo gwarantowane jak lokata bankowa ${ }^{82}$.

${ }^{80}$ Wskaźnik ten przyjmował wartości od 0 do 7.

${ }^{81}$ Badanie postaw Polaków powyżej 60. roku życia wobec obrotu bezgotówkowego, Dom Badawczy Maison, Raport przygotowany dla NBP, Warszawa, kwiecień 2012, s. 111.

${ }^{82}$ TNS Polska, Postawy Polaków wobec oszczędzania, Raport Fundacji Kronenberga przy Citi Handlowy, wrzesień 2012, s. 17. 
Podobną niewiedzą w obszarze mechanizmów produktów bankowych wykazali się respondenci podczas ostatniego badania pt. „Postawy Polaków wobec oszczędzania”, dotyczące kosztów kredytu gotówkowego. Na pytanie: Proszę sobie wyobrazić, że zaciąga Pan(i) kredyt gotówkowy na 18 miesięcy w wysokości 1000 zł oprocentowany na 10\% w skali roku. Jaką kwotę będzie musiał Pan(i) zapłacić? Jedynie $24 \%$ respondentów udzieliła poprawnej odpowiedzi. Pozostałe wskazywały albo na nieprawidłową kwotę, albo wprost na brak wiedzy na temat sposobu policzenia kosztów kredytu ${ }^{83}$.

Wreszcie, zgodnie z wynikami raportu opisującego stan wiedzy ekonomicznej Polaków, opracowanego przez Instytut Wolności i Raiffeisen Polbank SA, stwierdzono, że wraz ze wzrostem wieku badanych spadał poziom ich wiedzy o prowizjach pobieranych przy wypłacaniu gotówki z bankomatu (powyżej 60. roku życia już tylko $46 \%$ respondentów znało czynniki wpływające na wysokość prowizji, z $65 \%$ ogółem), wzrastał zaś odsetek osób otwarcie deklarujących swoją niewiedzę w tym temacie (z $14 \%$ do $30 \%)^{84}$.

Niestety, pomimo przytoczonych wyników, opinia, że wiedza ekonomiczna jest potrzebna nie jest wcale powszechna - tylko połowa badanych w wieku powyżej 55. roku życia sądzi, że potrzebowaliby większej wiedzy na tematy finansowe, a co czwarty jest przeciwnego zdania. W grupie wiekowej 55-59 lat jedynie $8 \%$ jest zdania, że większa wiedza na tematy finansowe byłaby potrzebna, podczas gdy w grupie powyżej 75 . roku życia ten odsetek wzrósł aż do $21 \%{ }^{85}$.

Potrzebę edukacji ekonomicznej najbardziej dostrzegają osoby z wykształceniem podstawowym oraz wykształceniem wyższym. Potrzeba wiedzy w tych dwóch grupach wynika prawdopodobnie z nieco innych pobudek. Osoby z podstawowym wykształceniem prawdopodobnie często czują się niekompetentne w tym obszarze. Natomiast u osób lepiej wykształconych istnieje większa świadomość przydatności jeszcze większej i bardziej zaawansowanej wiedzy. Zainteresowanie wiedzą finansową osób 55+ przedstawia rysunek 42.

Jedynie dla $22 \%$ osób w wieku 55+ wiedza finansowa wydawała się być interesująca, podczas gdy aż połowa ma wobec niej obojętny stosunek. Dla $28 \%$ badanych wiedza finansowa okazała się być nudna bądź bardzo nudna.

Najnowszym badaniem prezentującym zachowania osób starszych jest „Senior w świecie finansów". Zostało ono przeprowadzone w 2013 r. przez instytut badawczy TNS na zlecenie Grupy KRUK, na reprezentatywnej grupie osób w wieku powyżej 65 lat. Obejmowało ono przede wszystkim diagnozę sytuacji finansowej seniorów w Polsce oraz analizę zadowolenia ze stanu swoich finansów ${ }^{86}$.

${ }^{83}$ Ibidem, październik 2013, s. 32.

${ }^{84}$ Stan wiedzy ekonomicznej Polaków, Raport Instytutu Wolności i Raiffeisen Polbank, lipiec 2014, s. 23.

${ }^{85}$ Dodatkowo, najbardziej niechętne powiększaniu swojej wiedzy finansowej są osoby, które mają tę wiedzę najmniejszą - aż $40 \%$ osób o bardzo małym zakresie wiedzy deklaruje, że jest to wiedza wystarczająca. Badanie postaw Polaków powyżej 60. roku życia..., s. 106.

${ }^{86}$ Senior $w$ świecie finansów, http://pl.kruk.eu/aktualnosci/art124,senior-w-swiecie-finansow. html (stan na dzień 27.01.2014). 


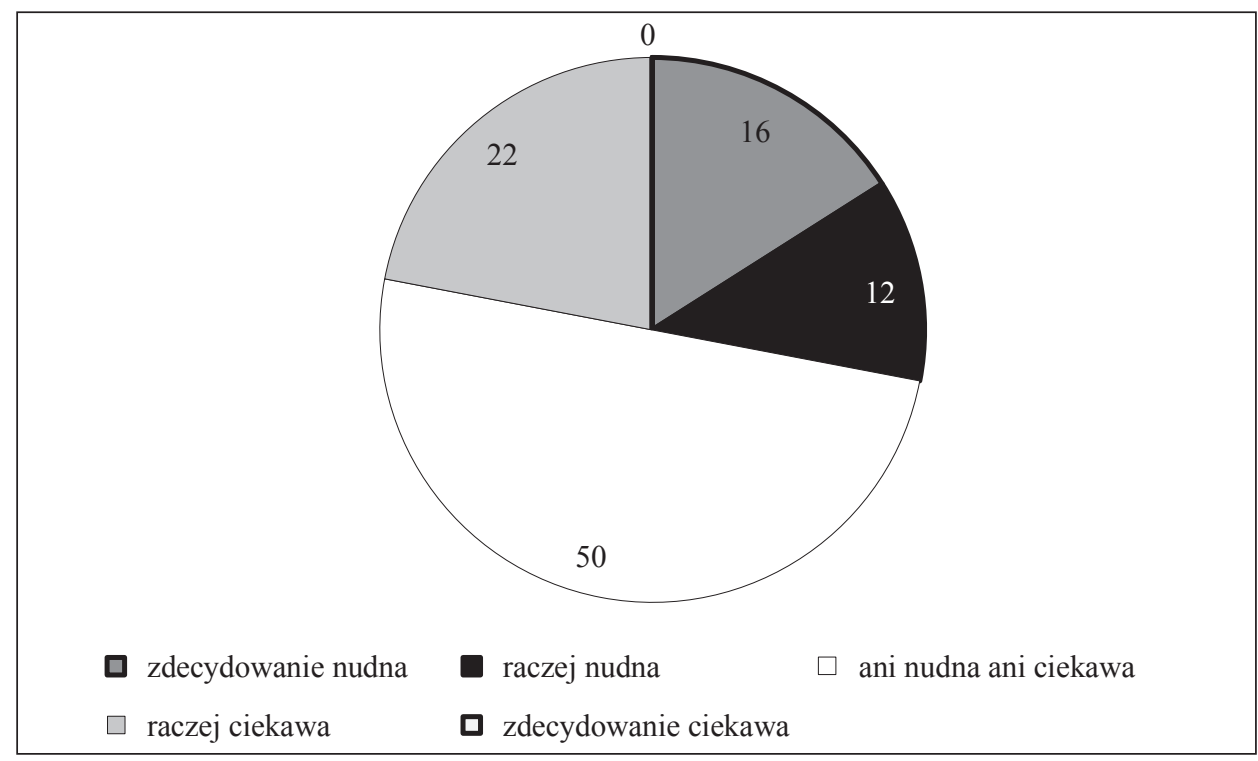

Rysunek 42. Zainteresowanie wiedzą finansową osób 55+ (w \%)

Źródło: D. Maison, Polak w świecie finansów, Wydawnictwo Naukowe PWN, Warszawa 2013, s. 192

Zwykle osoby powyżej 65. roku życia nie mają w zwyczaju prowadzenia domowego budżetu oraz bieżącego kontrolowania wydatków. Blisko połowa badanych (46\%) przyznała, że nie prowadzi jakichkolwiek zapisów oraz nie kontroluje stanu swoich pieniędzy, nie upewnia się, ile może jeszcze wydać. Coraz więcej osób (40\%) udaje się do banku w celu uregulowania swoich rachunków. Wciąż niezbyt popularną formą wśród tej grupy wiekowej jest płatność internetowa - jedynie $10 \%$ dokonuje transakcji przez Internet.

Osoby powyżej 65. roku życia zwykle korzystają z podstawowych produktów bankowych. Najczęściej przechowują swoje pieniądze na koncie w banku - postępuje już tak $62 \%$ badanych, a wśród nich $12 \%$ ma konto internetowe. Posiadanie konta jest w dużym stopniu zależne od poziomu wykształcenia (ma je $84 \%$ badanych legitymujących się wykształceniem wyższym, zaś tylko $29 \%$ z podstawowym) oraz miejsca zamieszkania (79\% pochodzących z miast 500-tysięcznych oraz $49 \%$ mieszkających na wsi). Połowa osób $65+$ posiada w swoim portfelu kartę płatniczą. Także $\mathrm{w}$ tym przypadku są to najczęściej badani z dużych miast, wykształceni i relatywnie młodsi. Inne produkty bankowe nie są zbyt popularne wśród osób $65+$ - tylko $37 \%$ posiada konto oszczędnościowe, 30\% lokatę pieniężną, $6 \%$ obligacje skarbowe lub fundusze inwestycyjne, a jedynie $4 \%$ akcje giełdowe.

Osoby powyżej 65. roku życia stosunkowo chętnie korzystają z różnych form kredytowania. $43 \%$ badanych w ciągu 5 ostatnich lat pożyczało pieniądze, $28 \%$ zaciągnęło kredyt, natomiast $31 \%$ zdecydowało się na zakup na raty. Na takie 
działania najczęściej decydowały się osoby z przedziału wiekowego 65-74 lat w celu zakupu sprzętu do domu, na remont oraz leczenie. Badanie potwierdza także, że dzieci i wnuki mogą liczyć na osoby 65+, które częściej są skłonne zaciągnąć pożyczkę na potrzeby innej osoby z rodziny (10\%) niż na własne przyjemności, np. wakacje (1\%).

Niepokojąco przedstawiają się wyniki badania dotyczącego problematyki zadłużania się. Jak wynika z przeprowadzonych badań, aż 73\% osób powyżej 65. roku życia twierdziło, że rozłożenie długów na raty jest dobrym sposobem na wyjście $\mathrm{z}$ trudnej sytuacji. Badani w większości nie unikaliby też kontaktu z firmą, która obsługiwałaby ich zadłużenie. 66\% odpowiedziało, że szybko skontaktowałoby się z wierzycielem, żeby rozwiązać ten problem. Taka postawa osób $65+$ oznacza, że większość z nich nie obawia się brania odpowiedzialności za zaciągnięte zobowiązania, mimo że często dysponują skromnymi środkami.

Jak wskazują badania, osoby 65+ niezbyt dobrze oceniają swoją wiedzę z zakresu finansów. $40 \%$ badanych przyznaje, że nie orientuje się w finansowych ofertach i jest zmuszona prosić o pomoc w ich zrozumieniu. Swobodne poruszanie się w zawiłym świecie finansów przede wszystkim zależy od wykształcenia - im wyższe, tym wiedza o nich jest większa. W kwestii pieniędzy osoby powyżej 65 . roku życia najlepiej orientują się w sprawach codziennych, które bezpośrednio ich dotyczą. Ponad połowa badanych (54\%) wiedziała, jak kontrolować swoje wydatki, aby związać koniec z końcem. W przypadku ubezpieczenia na życie, zaciągania pożyczek i kredytów oraz bankowości internetowej ich wiedza okazała się nikła. Wskazywanym głównym źródłem informacji były media - blisko $60 \%$ badanych o finansach dowiadywało się za pośrednictwem telewizji, radia czy gazet ${ }^{87}$.

Kwestie zachowania osób 50+ w świecie finansów były także przedmiotem zainteresowania organizacji nonprofit. W ramach projektu „Finanse na 50 plus” realizowanego przez Fundację na Rzecz Kobiet „Ja Kobieta” na przełomie 2011 i 2012 r. w 5 miastach Polski (Kraków, Lublin, Tczew, Poznań, Warszawa) została przeprowadzona ankieta, która pozwoliła oszacować wstępnie stan wiedzy w zakresie finansów osobistych oraz potrzeby osób z tego segmentu wiekowego. Jedna piąta badanych osób określiła swoją wiedzę na temat podstawowych usług finansowych, np. prowadzenia konta osobistego ROR, jako słabą. Ponad 40\% przyznało się do braku znajomości zasad przyznawania kredytów i pożyczek. Ponad jedna czwarta respondentów nie była usatysfakcjonowana swoim poziomem wiedzy na temat lokaty bankowej oraz prawie połowa - na temat karty kredytowej ${ }^{88}$.

Z przeprowadzonej ankiety wynikało, że niemal połowa respondentów wyraziła chęć uczestnictwa w szkoleniach dotyczących finansów osobistych. Warunkiem podstawowym przekazywanej przez ekspertów wiedzy miały być - w opinii samych zainteresowanych - jasny i klarowny język, pozbawiony żargonu ekonomicznego, którego niezrozumienie powoduje obawę przed różnego rodzaju ,ukry-

\footnotetext{
${ }^{87}$ Ibidem.

${ }^{88}$ www.finanse-na50plus.pl/o-projekcie_7.html (stan na dzień 27.01.2014).
} 
tymi” opłatami. Osoby 50+ oczekiwały również rzeczowego i przystępnego poinformowania o sposobie wyliczania odsetek i prowizji bankowych od kredytów, pożyczek i kapitału, a także analizy konkretnych ofert przy pomocy niezależnego doradcy finansowego, który wskaże wady i zalety każdej z nich. Interesujące jest również, że poza potrzebą uzyskania tak zwanych twardych narzędzi niezbędnych do przeciwdziałania wykluczeniu finansowemu osób z segmentu 50+ - takich jak wiedza, szkolenia dotyczące korzystania z Internetu - osoby te zgłaszają również potrzebę poprawy „miękkich” umiejętności, na przykład sposobów negocjowania z bankiem warunków spłaty kredytu, co sygnalizuje niskie poczucie bezpieczeństwa seniorów w kontakcie z instytucjami finansowymi.

Niski stan wiedzy finansowej poza osobami z grupy wiekowej $50+$ jest charakterystyczny dla najuboższych gospodarstw domowych ${ }^{89}$. Potwierdził się on $\mathrm{w}$ badaniu przeprowadzonym przez organizację Microfinance Centre w ramach międzynarodowego projektu „Financial Literacy for the Poor” finansowanego przez Citigroup Foundation. Celem projektu było określenie największych braków w wiedzy i umiejętnościach gospodarstw domowych o najniższych dochodach oraz zrozumienie ich postaw wobec zarządzania finansami domowymi, aby możliwe było wypracowanie zestawu narzędzi poprawiających świadomość finansową. Przeprowadzone badanie pozwoliło zidentyfikować cztery kluczowe obszary edukacyjne ${ }^{90}$ :

- długookresowe planowanie finansowe,

- systematyczne oszczędzanie i sporządzanie budżetu domowego,

- zarządzanie sytuacjami kryzysowymi i racjonalne pożyczanie,

- podstawy oferty usług finansowych.

Niewystarczający poziom wiedzy ekonomicznej jest też charakterystyczny dla osób młodych. Jak wynika z badania świadomości i dojrzałości ekonomicznej przeprowadzonego w grupie uczestników programów edukacyjnych adresowanych do uczniów ostatnich klas szkoły podstawowej i pierwszych klas gimnazjum, dojrzałość ekonomiczna uczniów jest niewielka. Najsłabiej rozumianymi kategoriami pojęć są zagadnienia makroekonomiczne, z którymi respondenci mają styczność przede wszystkim za pośrednictwem mediów. Wiedza z tego zakresu jest nieuporządkowana, pełna przekłamań i uproszczeń, bazuje na zakorzenionych w społeczeństwie mitach. Lepiej rozumiane wśród przebadanej grupy są terminy, z którymi ankietowani mają okazję zetknąć się w życiu codziennym, np. uczestnicząc $\mathrm{w}$ rozmowach prowadzonych $\mathrm{w}$ gospodarstwach domowych lub w zdarzeniach gospodarczych, z którymi dane pojęcia się wiążą. Nie zawsze

${ }^{89} \mathrm{~W}$ Polsce $12 \%$ obywateli żyje w ubóstwie pomimo posiadania pracy. Dla porównania średnia w krajach UE wynosi 15\%. H. Frazer, E. Marlier, In-work Poverty and Labour Market. Segmentation in EU, Synthesis report, Overview based on the national reports prepared by the EU Network of Independent Experts on Social Inclusion, December 2010, s. 9.

${ }_{90}$ M. Matul, K. Pawlak, J. Fałkowski, Priorytety wzmacniania edukacji finansowej wśród ubogich rodzin w Polsce, październik 2004, http://edufin.pl/images/pdf/dok4.pdf (stan na dzień 15.02.2014), s. 36-37. 
jednak lepsze rozumienie pojęcia przekłada się na umiejętność wykorzystania wiedzy w praktycznych zachowaniach, zwłaszcza gdy wymaga to syntezy umiejętności z innych dyscyplin ${ }^{91}$.

Niestety również środowiska opiniotwórcze, kształtujące świadomość społeczną, charakteryzują się stosunkowo niskim poziomem wiedzy ekonomicznej. Jak wynika $z$ danych przedstawionych w raporcie „Poglądy ekonomiczne i potrzeby szkoleniowe dziennikarzy", wiedza przedstawicieli tej grupy zawodowej nie odbiega od poziomu wiedzy reszty społeczeństwa, przez co utrudnia lub wręcz uniemożliwia przedstawienie zjawisk ekonomicznych w sposób fachowy i jednocześnie zrozumiały dla odbiorcy. W raporcie podkreślono także brak szerokiej publicznej debaty na tematy ekonomiczne, o wysokim poziomie merytorycznym ${ }^{92}$.

$\mathrm{W}$ ostatnich latach przeprowadzane były również badania w innych środowiskach osób. Warto przytoczyć chociażby badanie ukazujące świadomość finansową w trzech grupach ${ }^{93}$ :

- studentów - jako osób, które miały kontakt z zagadnieniami ekonomicznymi podczas zajęć z Podstaw przedsiębiorczości;

- środowisku medycznym - jako zawodu wymagającego uczenia się przez całe życie i generującego wyższy poziom dochodów niż przeciętny;

- środowisku informatyków - podobnie jak w przepadku środowiska medycznego wymagającego nieustannej aktualizacji posiadanej wiedzy.

$\mathrm{Na}$ podstawie zdefiniowanego wzorca przeciętnej świadomości finansowej dokonano porównania badanych grup w 5 sferach problemowych. Wyniki przedstawia tablica 45.

Tablica 45. Ocena świadomości finansowej

\begin{tabular}{|c|c|c|c|}
\hline Oceniana sfera & Studenci & Środowisko medyczne & Środowisko informatyczne \\
\hline Ubankowienie & dobrze & dobrze & dobrze \\
\hline \multirow{2}{*}{$\begin{array}{l}\text { Rozumienie działania } \\
\text { produktów finansowych }\end{array}$} & dobrze (ROR) & dobrze (ROR) & dobrze (ROR) \\
\hline & słabo & wystarczająco & wystarczająco \\
\hline $\begin{array}{l}\text { Pozyskiwanie informacji } \\
\text { na temat produktów }\end{array}$ & dobrze & wystarczająco & dobrze \\
\hline Planowanie wydatków & wystarczająco & dobrze & dobrze \\
\hline $\begin{array}{l}\text { Znajomość praw i me- } \\
\text { chanizmów ochronnych }\end{array}$ & słabo & wystarczająco & wystarczająco \\
\hline
\end{tabular}

Źródło: M. Iwanicz-Drozdowska (red.), Edukacja i świadomość finansowa. Doświadczenia i perspektywy, Oficyna Wydawnicza SGH w Warszawie, Warszawa 2011, s. 214.

${ }_{91}$ B. Majewski, Badanie świadomości i podstaw wiedzy ekonomicznej wśród uczestników programów edukacyjnych skierowanych do najmłodszych, kwiecień 2010, „e-mentor”, $\mathrm{nr} 2$ (34), s. 22-27.

92 NBP, Strategia edukacji ekonomicznej Narodowego Banku Polskiego na lata 2010-2012, Departament Edukacji i Wydawnictw, Warszawa, s. 13.

${ }_{93}$ Szerzej: M. Iwanicz-Drozdowska (red.), Edukacja i świadomość finansowa. Doświadczenia i perspektywy, Oficyna Wydawnicza SGH w Warszawie, Warszawa 2011. 
Najwyższą świadomością finansową wykazali się reprezentanci grupy informatyków, m.in. ze względu na wykorzystywanie informacji na temat produktów finansowych dostępnych w Internecie oraz porównywarek. Poza tą sferą ocena wiedzy finansowej w grupie informatyków jest zbliżona do przedstawicieli środowiska medycznego.

Od 2008 r. przeprowadzane są coroczne badania „Postawy Polaków wobec oszczędzania” na potrzeby akcji „Tydzień dla Oszczędzania”, którą organizuje Fundacja Kronenberga przy Citi Handlowy. Mają one formę sondażu przeprowadzanego na 1000-osobowej reprezentatywnej próbie mieszkańców kraju w wieku powyżej piętnastu lat w oparciu o technikę wywiadów osobistych. Ich celem jest pozyskanie informacji na temat:

- postaw Polaków związanych z oszczędzaniem i inwestowaniem,

- wykorzystywanych sposobów zarządzania pieniędzmi,

- poziomu tolerancji ryzyka przez Polaków.

Powtarzalnym wynikiem jest przekonanie większości Polaków o tym, że warto oszczędzać i równoczesny brak zachowań zmierzających w kierunku realizacji tej deklaracji. Może to świadczyć o braku znajomości mechanizmów pomnażania oszczędności i o braku umiejętności zarządzania swoimi finansami przy ograniczonych możliwościach finansowych ${ }^{94}$.

Oszczędzając, prawie połowa oszczędzających Polaków (44\%) myśli o perspektywie roku. Jedynie nieliczni wskazywali na perspektywę czasową dłuższą niż trzy lata. Tak krótka perspektywa czasowa wynika z tego, że gros ludzi kojarzy oszczędzanie z formą odkładania pieniędzy przynoszącą jedynie nieznaczne zyski. Aż $86 \%$ nie oszczędza na emeryturę poza ZUS i II filarem (OFE/Otwartym Funduszem Emerytalnym). Jedynie 7\% ankietowanych przyznało, iż inwestuje, to znaczy kupuje akcje, obligacje, fundusze inwestycyjne, dzieła sztuki, ziemię lub nieruchomości.

W kolejnych latach coraz bardziej widoczny stawał się wpływ obecnej sytuacji gospodarczej na postawy wobec oszczędzania, szczególnie podkreślany przez osoby gorzej sytuowane lub grupy narażone na ubóstwo. Polacy deklarują coraz bardziej wyraźny negatywny wpływ kryzysu finansowego na wysokość oszczędności, przed skutkami którego na ogół nie zabezpieczyli się. Osoby te relatywnie częściej pochodzą z grup społecznych narażonych na ubóstwo (osoby starsze, o niskich dochodach), stąd istnieje obawa, że obecna rzeczywistość społeczna pogłębi ich niekorzystną sytuację ${ }^{95}$.

Najczęściej wskazywanym skutkiem kryzysu jest ograniczenie możliwości zarobkowania i związany z tym spadek dochodów (24\% ogółu dorosłych). Drugim skutkiem kryzysu co do częstości wskazywania jest obniżenie wartości majątku, np. akcji, jednostek udziałowych funduszu inwestycyjnego (11\% ogółu $)^{96}$.

${ }^{94}$ Pentor, Postawy Polaków wobec oszczędzania, Raport Fundacji Kronenberga przy Citi Handlowy, 2008, s. 3.

${ }^{95}$ Ibidem, wrzesień 2009, s. 6.

${ }^{96}$ CBOS, Reakcje na kryzys gospodarczy, Warszawa, luty 2009, s. 2-3. 
Charakterystyczną postawą osób 55+ zidentyfikowaną podczas badania „Postawy Polaków wobec oszczędzania" był stosunek do zarządzania pieniędzmi polegający na przeznaczaniu wszystkich środków na bieżące wydatki, negatywnym stosunku do oszczędzania, kontrolowaniu nawet najdrobniejszych wydatków i wysokiej awersji do ryzyka.

Po 2008 r. Polacy krytyczniej oceniają również poziom własnej wiedzy o bankowości. Przed okresem spowolnienia gospodarczego poczucie zrozumienia zachodzących zjawisk oraz procesów ekonomicznych, a także deklarowana wiedza o produktach bankowych była większa niż obecnie. Dopiero spowolnienie gospodarcze uświadomiło klientom banków konsekwencje związane z korzystaniem $\mathrm{z}$ niektórych produktów finansowych. Informacje prezentowane w reklamach okazały się niewystarczające do podejmowania trafnych decyzji ekonomicznych. Brak podstawowej wiedzy z zakresu finansów potęgował poczucie zagrożenia i niepewności wśród klientów banków. Obecnie utrzymuje się głębokie przekonanie o konieczności zwiększenia wiedzy ekonomicznej społeczeństwa.

Kryzys finansowy wpłynął na postrzeganie bezpiecznych sposobów oszczędzania oraz odkładania na emeryturęę7. Osoby zamożniejsze częściej wskazywały inwestowanie w ziemię, natomiast grupy bardziej zagrożone ubóstwem (mieszkańcy wsi, osoby starsze) częściej wskazywały takie strategie, jak trzymanie gotówki w domu czy dodatkowy etat. Może to sugerować brak znajomości instrumentów oszczędzania ${ }^{98}$. Można zatem mówić o relatywnie niskim poziomie edukacji finansowej, o czym świadczy ${ }^{99}$ :

- korzystanie z instrumentów oszczędzania (rachunek rozliczeniowy czy trzymanie gotówki w domu), które nie są przystosowane do tego celu, aż ponad jedna trzecia badanych oszczędza z wykorzystaniem konta osobistego, czyli formy nieprzeznaczonej do generowania zysku, a jedynie do obracania pieniędzmi;

- nieznajomość wysokości oprocentowania rachunku rozliczeniowego przez ponad $20 \%$ respondentów.

Wyniki te wskazują na konieczność wdrażania akcji edukacji finansowej skierowanych do najuboższych grup społecznych. Pozytywnym natomiast aspektem jest rosnąca liczba respondentów wykazujących skłonność do zaufania pracownikom instytucji finansowych oraz chęć traktowania ich jako źródło informacji o sposobach oszczędzania.

Potwierdzeniem wpływu kryzysu finansowego na świadomość finansową są wyniki badania rynku consumer finance przeprowadzone przez Millward Brown SMG/KRC na zlecenie PricewaterhouseCoopers (PwC). Badani przyznają, że zmiana sytuacji gospodarczej wpłynęła na podniesienie poziomu wiedzy o rynku kredytowym. 66\% badanych zetknęło się z terminem „spirala kredytowa”. Wzrost świadomości finansowej przekłada się na wzrost akceptacji produk-

\footnotetext{
${ }^{97}$ Por. European Commission, The financial crisis and financial education, Brussels 2009.

98 Pentor, Postawy Polaków wobec oszczędzania..., październik 2011, s. 6.

${ }^{99}$ Ibidem, 2010, s. 5.
} 
tów consumer finance i zmniejsza grupę osób nastawionych skrajnie negatywnie do zaciągania zobowiązań, przyczyniając się jednocześnie do bardziej odpowiedzialnego pożyczania ${ }^{100}$.

Wyniki te świadczą także o korelacji posiadanej wiedzy ekonomicznej i korzystaniu z narzędzi finansowych ${ }^{101}$. Jak potwierdzają badania, osoby, które miały najwyższy wynik testu wiedzy finansowej korzystają ze zdecydowanie największej ilości usług finansowych, np. 79\% osób w tej grupie ma konto (w całej populacji 56\%), dostęp do konta internetowego ma $47 \%$ (w populacji $25 \%$ ), lokaty ma $20 \%$ (w populacji $10 \%)^{102}$. Jedynie 7\% Polaków regularnie oszczędza. Główną przyczyną tak niskich wyników jest przede wszystkim niewiedza i brak umiejętności z zakresu finansów osobistych. Niska świadomość korzyści związanych z oszczędzaniem wynika z kolei z niskiego poziomu świadomości ekonomicznej społeczeństwa polskiego ${ }^{103}$.

Interesującym elementem podlegającym analizie podczas badania „Stan wiedzy finansowej Polaków" była identyfikacja zależności między poziomem wiedzy finansowej a włączeniem w system finansowy. Posiadanie i korzystanie z poszczególnych instrumentów finansowych w zależności od reprezentowanego poziomu wiedzy finansowej przedstawia rysunek 43 .

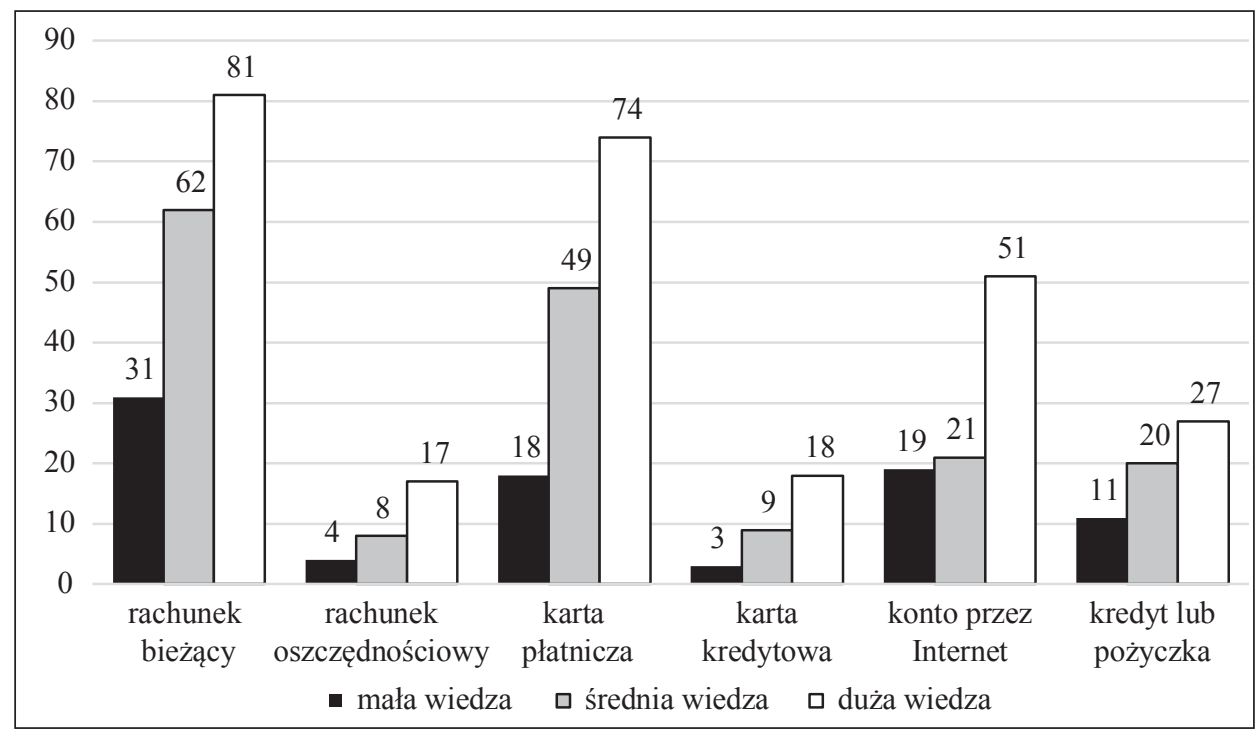

Rysunek 43. Posiadanie i korzystanie z poszczególnych instrumentów finansowych w zależności od reprezentowanego poziomu wiedzy finansowej (w \%)

Źródło: D. Maison, Polak w świecie finansów, Wydawnictwo Naukowe PWN, Warszawa 2013, s. 198

100 PwC, Czekajac na impuls, 2011, s. 13.

${ }^{101} 63 \%$ posiada rachunek bankowy, podczas gdy jedynie $36 \%$ jest posiadaczami ubezpieczenia, 25\% karty kredytowej, 18\% rachunek oszczędnościowy.

102 Pentor, Postawy Polaków wobec oszczędzania..., wrzesień 2009, s. 9.

${ }^{103}$ Ibidem, październik 2011, s. 16. 
Zgodnie z wynikami przeprowadzonych analiz, posiadana wiedza ekonomiczna istotnie wpływa na stopień włączenia w system finansowy, a w szczególności na kwestię korzystania z usług finansowych i nieco słabiej na korzystanie z ubezpieczeń ${ }^{104}$. Najsilniejszy związek został zaobserwowany w przypadku ubankowienia i wiedzy obiektywnej (korelacja $\mathrm{r}=0,47$; $\mathrm{p}<0,001$ ), słabszy w przypadku wiedzy relatywnej (korelacja $\mathrm{r}=0,36 ; \mathrm{p}<0,001$ ) i subiektywnej (korelacja $\mathrm{r}=0,31 ; \mathrm{p}<0,001)$.

Związek ten okazał się być również widoczny w grupie wiekowej powyżej 55. roku życia. Udowodniona została bowiem zależność między wiedzą finansową a posiadaniem rachunku bankowego. Spośród osób powyżej 55. roku życia, które były właścicielami kont, indeks wiedzy finansowej odpowiadający poprawnie udzielonym odpowiedziom na pytania z dziedziny finansów ukształtował się na poziomie 3,22 (w skali od 0 do 7), podczas gdy w grupie osób nieubankowionych wyniósł jedynie $1,35^{105}$.

O poziomie świadomości ekonomicznej polskiego konsumenta może też świadczyć częstotliwość, z jaką dokonuje on zmian podmiotów oferujących usługi finansowe. Okazuje się, że 90\% osób, które w ciągu ostatnich dwóch lat deklarowały korzystanie z usług banku, nie zmieniły go na inny. Z innych badań wynika, że polscy konsumenci najrzadziej zmieniają produkty finansowe i aż $59 \%$ deklaruje, że lubi korzystać z oferty jednego banku. Przyczyn nie należy bynajmniej doszukiwać się w trosce o klienta, miłej obsłudze czy skutecznych programach lojalnościowych. Klient, który nie jest świadomy różnic w usługach oferowanych przez różne instytucje, nie będzie szukał korzystniejszej oferty ${ }^{106}$.

\subsubsection{Stan świadomości finansowej w Polsce na tle krajów UE w świetle badań wtórnych}

Wyniki dotyczące poziomu świadomości finansowej polskiego społeczeństwa można porównać z wnioskami z badań realizowanych na poziomie międzynarodowym. Najbardziej reprezentatywne są wyniki badań przeprowadzanych w krajach UE.

Jednym z nich jest cykliczne badanie Grupy ING, przeprowadzane w kilkunastu krajach na całym świecie, dotyczące badania zachowania i postawy konsumentów wobec zagadnień finansowych. Poziom wiedzy finansowej Polaków okazał się być poniżej średniej dla 11 krajów, które brały udział w międzynarodowym badaniu na temat wiedzy finansowej konsumentów w Polsce i na świecie realizowanym na zlecenie ING. Osoby, które w teście osiągnęły wyższy wynik,

104 Dom Badawczy Maison, Stan wiedzy finansowej Polaków, Raport Fundacji Kronenberga przy Citi Handlowy, wrzesień 2009, s. 123.

${ }^{105}$ Badanie postaw Polaków powyżej 60. roku życia..., s. 111.

${ }^{106}$ K. Pilecka, Świadomy klient poszukiwany, „Miesięcznik Finansowy Bank” 2008, nr 2, s. 21. 
staranniej kontrolowały swoje wydatki i finanse. Polska okazała się być jedynym krajem, w którym większość osób kontroluje swoje wydatki w sposób umiarkowany. Zdecydowanie kobiety okazały się być bardziej skrupulatne w zarządzaniu finansami. Ponadto aż 96\% respondentów udzieliło odpowiedzi, iż chce, aby wiedza finansowa była przekazywana w szkołach. Jednocześnie kompetencja finansowa zwiększała się $\mathrm{z}$ wiekiem ankietowanych ${ }^{107}$.

Jednym $\mathrm{z}$ większych przedsięwzięć na skalę międzynarodową było badanie przeprowadzone we współpracy Citi Foundation, CSR Europe oraz Money Advice Service. Było ono zrealizowane w dwóch etapach. Pierwszym etapem był sondaż na Facebooku dotyczący postaw finansowych ok. 1200 osób w wieku 16-30 lat z Francji, Polski, Hiszpanii i Wielkiej Brytanii. Drugi etap dotyczył grupy wiekowej 55-64 lat, osób krótko przed emeryturą i obejmował przegląd literatury dotyczącej postaw i kompetencji finansowych, w tym raporty $\mathrm{z}$ badań oceniających poziom kompetencji finansowych społeczeństw i przegląd istniejących systemów edukacji finansowej. W tym etapie powstał ogólny zarys sytuacji w 27 krajach członkowskich UE i szczegółowe porównanie Francji, Polski, Hiszpanii i Wielkiej Brytanii.

$\mathrm{Z}$ przeprowadzonych analiz wyłonił się spójny obraz niewystarczającego poziomu kompetencji finansowych osób młodych oraz w wieku przedemerytalnym. Większość młodych ludzi jeszcze nie angażuje się aktywnie w długofalowe planowanie swojej przyszłości finansowej, często ze względu na trudną sytuację finansową, w jakiej się znajduje ${ }^{108}$. Jednoznacznie we wszystkich krajach w grupie osób starszych wskazywano na brak kompetencji finansowych stanowiący zasadniczą barierę dla długofalowego oszczędzania i planowania finansów ${ }^{109}$.

Niekorzystny obraz edukacji finansowej w Polsce potwierdziło ostatnie badanie przeprowadzone przez OECD w 14 krajach $^{110}$. Wykorzystany w badaniu kwestionariusz polecany jest przez OECD i International Network on Financial Education (INFE) jako bazowy instrument służący pomiarowi poziomu wiedzy finansowej $\mathrm{w}$ poszczególnych krajach, umożliwiający dokonanie porównania między krajami. Na potrzeby tego badania OECD i INFE opracowało definicję świadomości finansowej jako „połączenie świadomości, wiedzy, umiejętności, postawy i zachowań w podejmowaniu decyzji finansowych prowadzących do osiągnięcia indywidualnego finansowego dobrobytu"111. Konstrukcję kwestionariusza ankietowego uwzględniającą poszczególne składowe świadomości finansowej prezentuje rysunek 44 .

107 Finansowy barometr ING: Wiedza finansowa, maj 2012, s. 9-10.

108 Enterprise 2020, European youth financial attitudes 2011, CSR Europe, December 2011, s. 3-6.

109 Enterprise 2020, Financial capability for people in Europe approaching retirement, CSR Europe, December 2011, s. 92-96.

${ }^{110} \mathrm{Na}$ podstawie kwestionariusza wykorzystanego w tym badaniu przeprowadzone zostało badanie wiedzy finansowej wśród seniorów, którego wyniki zawiera rozdział IV.

111 OECD/INFE, Measuring Financial Literacy: Questionnaire and Guidance Notes for Conducting an Internationally Comparable Survey of Financial Literacy, 2011, s. 3. 


\begin{tabular}{|c|c|c|c|c|}
\hline Zachowanie & Wiedza & $\begin{array}{c}\text { Stosunek } \\
\text { (postawy } \\
\text { i zachowania) }\end{array}$ & $\begin{array}{c}\text { Inkluzja } \\
\text { finansowa }\end{array}$ & $\begin{array}{c}\text { Cechy } \\
\text { społeczno- } \\
\text {-demograficzne }\end{array}$ \\
\hline $\begin{array}{l}\text { - posiadanie } \\
\text { wolnych } \\
\text { środków } \\
\text { pieniężnych } \\
\text { - „,wiązanie } \\
\text { końca } \\
\text { z końcem” } \\
\text { - wybieranie } \\
\text { i korzystanie } \\
\text { z produktów } \\
\text { finansowych } \\
\text { - krótko- } \\
\text { i długookreso- } \\
\text { we planowanie }\end{array}$ & $\begin{array}{l}\text { - procent prosty } \\
\text { i składany } \\
\text { - inflacja - } \\
\text { - wartość } \\
\text { pieniądza } \\
\text { w czasie } \\
\text { - ryzyko i zwrot } \\
\text { - dywersyfikacja } \\
\text { ryzyka }\end{array}$ & \begin{tabular}{|c|} 
- stosunek do \\
oszczędzania \\
i wydatkowa- \\
nia pieniędzy \\
- preferencje \\
w wydatkowa- \\
niu (teraz/w \\
przyszłości) \\
- skłonność do \\
ryzyka
\end{tabular} & $\begin{array}{l}\text { - świadomość } \\
\text { produktów } \\
\text { finansowych } \\
\text { - posiadanie } \\
\text { i użytkowanie } \\
\text { produktów } \\
\text { finansowych } \\
\text { - wybór } \\
\text { produktów } \\
\text { finansowych }\end{array}$ & $\begin{array}{l}\text { - wiek } \\
\text { - płeć } \\
\text { - wykształcenie } \\
\text { - zawód } \\
\text { - dochód }\end{array}$ \\
\hline
\end{tabular}

Rysunek 44. Kluczowe elementy kwestionariusza ankietowego

Źródło: opracowanie własne na podstawie: OECD/INFE, Measuring Financial Literacy: Questionnaire and Guidance Notes for Conducting an Internationally Comparable Survey of Financial Literacy, 2011, s. 3

Pytania zadawane respondentom miały na celu zidentyfikowanie poziomu wiedzy finansowej oraz ocenę zachowań i postaw wobec takich aspektów świadomości finansowej, jak zarządzanie budżetem domowym, krótko- i długoterminowe planowanie finansowe, determinanty wyboru produktów finansowych. Zestawienie prezentujące udział procentowy prawidłowych odpowiedzi Polaków na tle obywateli pozostałych krajów przedstawia tablica 46.

W Polsce odnotowano zróżnicowany poziom wiedzy finansowej. Największa liczba respondentów znała pojęcie podziału środków $(91 \%)^{112}$, wartości pieniądza w czasie (77\%) oraz odsetek płaconych od pożyczek (85\%), najmniejsza zaś procent składany (21\%) oraz ryzyka i zwrotu $(48 \%)^{113}$. Sposób, w jaki zachowują się respondenci, ma wpływ na ich sytuację finansową. Odpowiednie zestawienie zawiera tablica 47.

112 Dzielenia kwoty pieniężnej.

113 A. Atkinson, F. Messy, Measuring Financial Literacy: Results of the OECD/International Network on Financial Education (INFE) Pilot Study, OECD Working Papers on Finance, Insurance and Private Pensions 2012, No. 15, s. 7. 


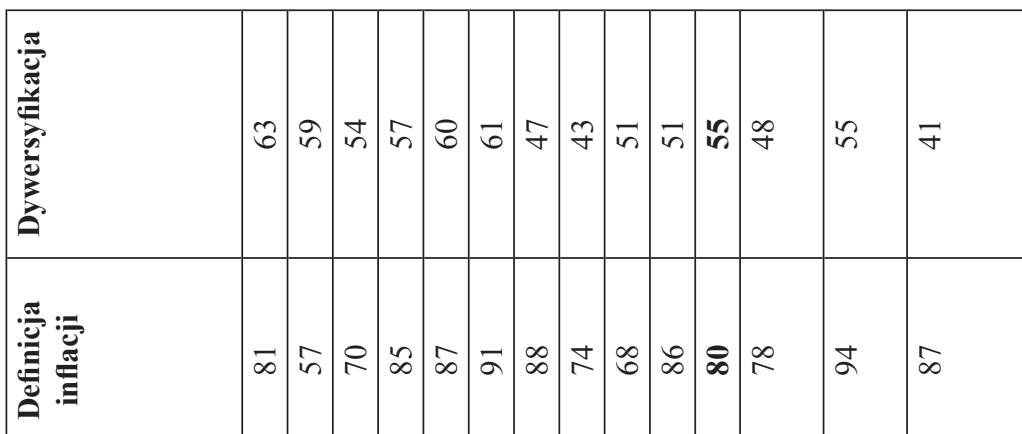

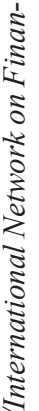

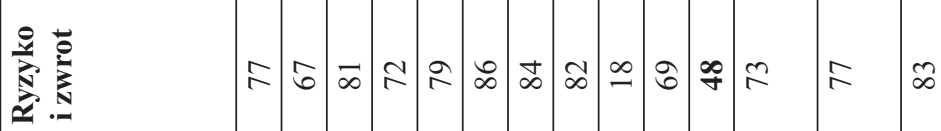

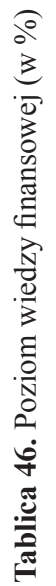

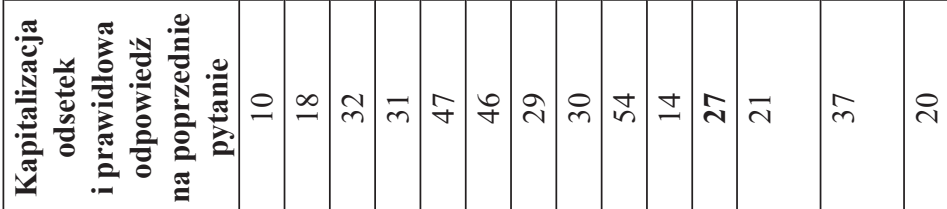

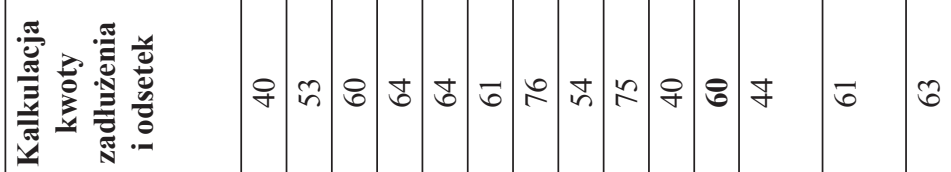

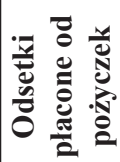

$$
\text { ப் }
$$

\begin{tabular}{|c|c|c|c|c|c|c|c|c|c|c|c|c|c|c|}
\hline 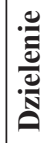 & $\infty$ & $\infty$ & $\tilde{a}$ & 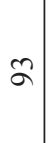 & $\infty$ & ฉ & $\tilde{a}$ & å & 5 & ஃ & $\bar{a}$ & 2 & 2 & $\infty$ \\
\hline 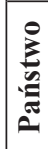 & 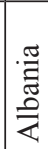 & 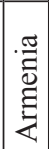 & 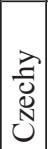 & 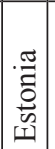 & 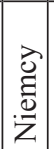 & $\begin{array}{l}\vec{D} \\
\overrightarrow{3} \\
3\end{array}$ & 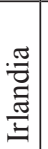 & $\mid \begin{array}{c}\frac{\pi}{2} \\
\frac{0}{\pi} \\
\sum\end{array}$ & $\begin{array}{l}. \frac{\pi}{50} \\
0 \\
3 \\
0 \\
z\end{array}$ & : & $\begin{array}{l}\frac{\pi}{4} \\
\frac{0}{0} \\
2\end{array}$ & 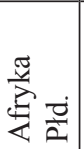 & 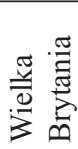 & 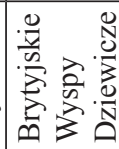 \\
\hline
\end{tabular}

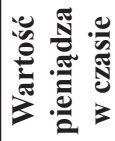

$$
\text { చ }
$$

ชิ n

○ั

ะ

o.

帘

2.

डे

¿

.

공

క

ङ

bo

.

डิ

旅

令政

$\sum$

工

ธี ฮ

:

这

$\ddot{0}$

玩

हे

ฮ

瑝

정

苋引

竞 


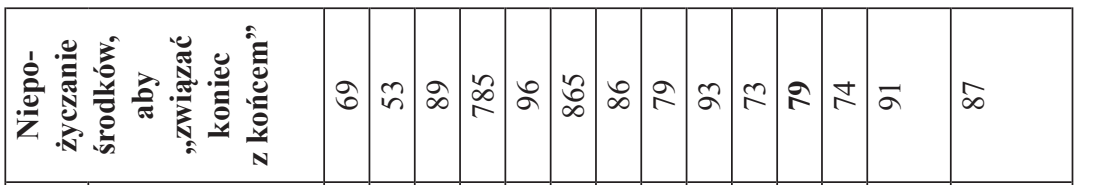

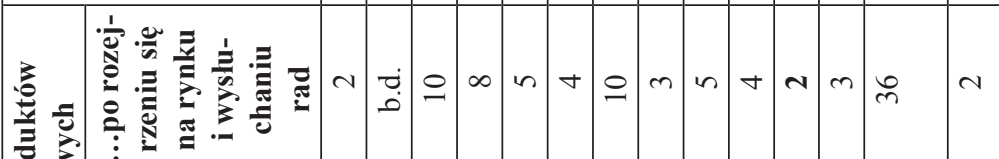

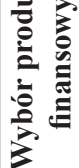

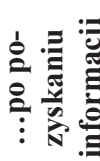

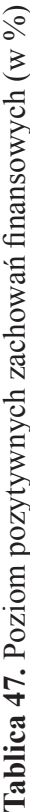

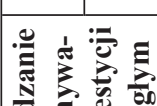

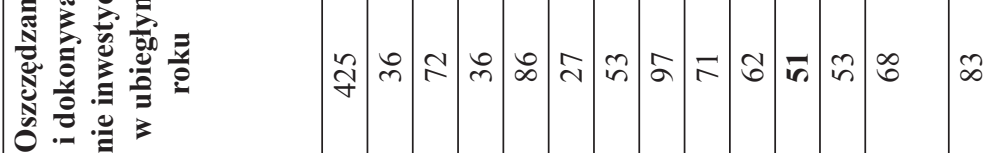

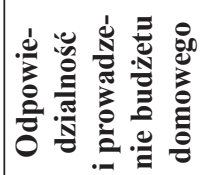

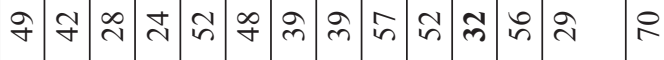

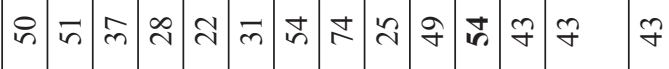

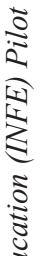

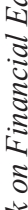

章

$\stackrel{8}{\frac{1}{3}}$

$\frac{\sqrt{2}}{2}$

\begin{tabular}{|c|c|c|c|c|c|c|c|c|c|c|c|c|c|c|}
\hline \multirow{4}{*}{ 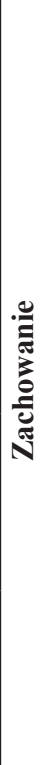 } & 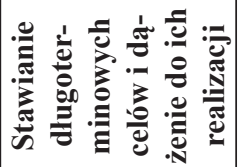 & 尺্লি & $\stackrel{\infty}{\infty}$ & అలి & $\bar{\nabla}$ & 5 & กิ & $\stackrel{\circ}{\circ}$ & t) & in & $R$ & $\begin{array}{l}8 \\
+\end{array}$ & $\hat{r}$ & $\stackrel{m}{\sim}$ \\
\hline & 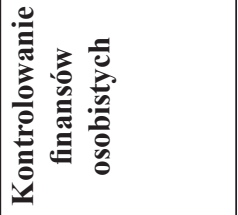 & $\nabla$ & $\bar{\infty}$ & 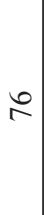 & $\stackrel{\infty}{\infty}$ & $\infty$ & $\nabla$ & $\infty$ & $\infty$ & ஓి & \begin{tabular}{c|l}
$\infty$ & $\bar{\alpha}$
\end{tabular} & $\infty$ & $6 \infty$ & $\infty$ \\
\hline & 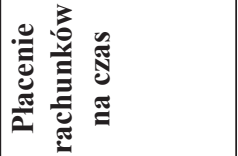 & $\approx$ & む゙ & $\infty$ & $\tilde{\infty}$ & 2 & $\infty$ & $\infty$ & (2) & 2 & $\infty$ & $\infty 5$ & $0 \infty$ & $\tilde{\infty}$ \\
\hline & 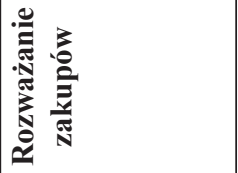 & $\infty$ & $\bar{\sigma}$ & $\cong$ & $\infty$ & $\tilde{\infty}$ & $\infty$ & $\hat{\infty}$ & 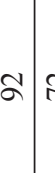 & $\mathbb{N}$ & $\bar{\sigma}$ & $R \mid \tilde{\alpha}$ & $6=$ & $\infty$ \\
\hline & 离 & 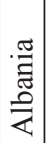 & 吾 & 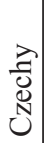 & 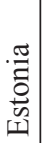 & 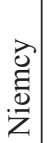 & $\begin{array}{l}\overrightarrow{2} \\
50 \\
3 \\
3\end{array}$ & 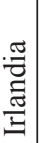 & $\frac{\frac{\pi}{N}}{\frac{0}{\pi}}$ & $\begin{array}{l}.5 \\
0 \\
0 \\
0 \\
3 \\
0 \\
z \\
z\end{array}$ & 링 & 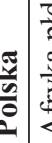 & 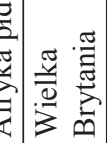 & 量 \\
\hline
\end{tabular}

年 
Widoczne jest znaczne zróżnicowanie zachowań finansowych wśród respondentów pochodzących z poszczególnych krajów. W przypadku Polski aż $81 \%$ respondentów deklarowało, że uważnie przygląda się sprawom finansowym i 78\% płaci rachunki w terminie, natomiast jedynie $2 \%$ podejmuje decyzję o produkcie finansowym po rozejrzeniu się na rynku i uzyskaniu niezależnej informacji lub rady.

Wreszcie ostatnim elementem determinującym podejmowane decyzje finansowe poza wiedzą i zachowaniem jest stosunek i preferencje w zakresie poszczególnych zachowań finansowych. Zestawienie prezentujące stosunek do długoterminowego postrzegania finansów przedstawia tablica 48 .

Tablica 48. Stosunek do długoterminowego postrzegania finansów (w \%)

\begin{tabular}{|c|c|c|c|}
\hline \multirow[b]{2}{*}{ Państwo } & \multicolumn{3}{|c|}{ Udział osób niezgadzających się z poniższymi stwierdzeniami } \\
\hline & $\begin{array}{c}\text { bardziej } \\
\text { satysfakcjonujące } \\
\text { jest wydawanie } \\
\text { niż oszczędzanie } \\
\text { w dłuższym czasie }\end{array}$ & $\begin{array}{c}\text { preferowane jest życie } \\
\text { z dnia na dzień niż } \\
\text { dbanie o przyszlość }\end{array}$ & $\begin{array}{c}\text { pieniądze są po to, } \\
\text { aby je wydawać }\end{array}$ \\
\hline Albania & 61 & 66 & 45 \\
\hline Armenia & 8 & 60 & 2 \\
\hline Czechy & 45 & 60 & 29 \\
\hline Estonia & 39 & 49 & 24 \\
\hline Niemcy & 49 & 65 & 26 \\
\hline Węgry & 56 & 68 & 33 \\
\hline Irlandia & 38 & 54 & 30 \\
\hline Malezja & 47 & 57 & 26 \\
\hline Norwegia & 57 & b.d. & b.d. \\
\hline Peru & 64 & 72 & 45 \\
\hline Polska & 19 & 45 & 12 \\
\hline Afryka Płd. & 48 & 60 & 39 \\
\hline $\begin{array}{l}\text { Wielka } \\
\text { Brytania }\end{array}$ & 35 & 50 & 29 \\
\hline $\begin{array}{l}\text { Brytyjskie } \\
\text { Wyspy } \\
\text { Dziewicze }\end{array}$ & 60 & 66 & 31 \\
\hline
\end{tabular}

Źródło: A. Atkinson, F. Messy, Measuring Financial Literacy: Results of the OECD/International Network on Financial Education (INFE) Pilot Study, OECD Working Papers on Finance, Insurance and Private Pensions 2012, No. 15, s. 9.

Niepokojącym wynikiem w przypadku Polski jest fakt, że tylko $19 \%$ respondentów nie zgodziło się ze stwierdzeniem, iż bardziej satysfakcjonujące jest wydawanie pieniędzy niż ich oszczędzanie w długim terminie. Jedynie $12 \%$ nie zgodziło się ze stwierdzeniem, że pieniądze są po to, aby je wydawać. 
Jedynym nawiązaniem do osób 55+ w badaniu stanowiła weryfikacja relacji między wiekiem a wiedzą finansową. Generalnie, zaobserwowano wzrost wiedzy finansowej wraz z wiekiem wynikający z rosnących kompetencji, jednak wskazano na dwa kluczowe czynniki:

- osoby 55+ miały trudności z nadążeniem za szybkim rozwojem rynku usług finansowych, szczególnie w ślad za wprowadzaniem nowoczesnych technologii;

- wraz z wiekiem malały funkcje poznawcze, ograniczając umiejętność absorpcji nowej i zastosowania posiadanej wiedzy finansowej.

Niski poziom edukacji finansowej powoduje, że Polacy nie korzystają ze wszystkich możliwości, jakie oferują współcześnie instytucje finansowe. Edukacja finansowa oraz zidentyfikowanie (a może nawet wykreowanie nowych) potrzeb klientów mogą być czynnikami decydującymi o dynamice dalszego rozwoju rynku usług finansowych. $\mathrm{Z}$ tego względu niezbędna jest kontynuacja działań na poziomie ogólnokrajowym mających na celu pogłębianie świadomości finansowej Polaków, w tym w szczególności grupy wiekowej 55+, i wykształcenie praktycznych umiejętności gospodarowania środkami finansowymi. W celu zapewnienia skuteczności tych działań powinny być w nie zaangażowani zarówno przedstawicie rządu, instytucji finansowych, jak i organizacji społecznych. 


\section{Rozdział IV. Świadomość finansowa gospodarstw domowych $w$ świetle badań pierwotnych}

\subsection{Tendencje demograficzne w województwie łódzkim i ich konsekwencje w dziedzinie zaspokajania potrzeb osób 50+}

Wprawdzie, odnosząc się do informacji zawartych w rozdziale trzecim, należy przyznać, że dostępne są wyniki badań prowadzonych na skalę krajową i międzynarodową dotyczące poziomu wiedzy finansowej gospodarstw domowych, jednak w niewielkim stopniu koncentrują się one na osobach w wieku 50+. Ze względu na specyfikę poruszanego w monografii problemu, jakim jest opieranie gospodarki na osobach starszych, niezbędnym stało się precyzyjne zdiagnozowanie poziomu wiedzy finansowej w tej grupie wiekowej oraz zidentyfikowanie istnienia zależności między posiadaną wiedzą finansową a zakresem korzystania $\mathrm{z}$ produktów finansowych. W tym celu przeprowadzone zostało badanie metodą indywidualnego wywiadu osobistego face to face $\mathrm{w}$ domu respondenta (technika PAPI) na reprezentatywnej próbie mieszkańców województwa łódzkiego w wieku 50+. Wybór województwa łódzkiego determinowany był faktem, iż w przypadku tego województwa najbardziej wyraźna jest tendencja starzenia się mieszkańców i generalnie depopulacji, przez co problemy demograficzne w województwie należą do największych w skali kraju i stanowią poważne zagrożenie dla jego przyszłego rozwoju.

Możliwość rozwoju miasta determinowana jest koniecznością posiadania pewnego kapitału rozwojowego. Pojęcie kapitału rozwojowego należy rozpatrywać nie tylko w wymiarze pieniężnym, ale znacznie szerzej, uwzględniając kwestie kwalifikacji ludzi (kapitał ludzki), umiejętności współdziałania (kapitał społeczny) oraz ich wiedzę i doświadczenie. Tym samym przez koncepcję kapitału rozwojowego należy rozmieć wszelkie zasoby niezbędne do rozwoju, zarówno te finansowe, rzeczowe, ludzkie oraz istniejące w sferze psychologicznej (np. kapitał wizerunku), które do rozwoju wymagają umiejętnego inwestowania przez wiele lat. 
Pomiar potencjału rozwojowego polskich miast odbywa się na podstawie metodyki opracowanej przez PwC i stosowanej do oceny sytuacji metropolii. Bazuje ona na przekonaniu, że dla harmonijnego rozwoju niezbędne jest jednoczesne posiadanie 7 kapitałów, z których każdy jest ważny dla rozwoju metropolii'

1. Kapitał Ludzki i Społeczny (KLS) określa jakość zasobów ludzkich, którymi dysponuje miasto. Jest ona weryfikowana poprzez ocenę wiedzy i kwalifikacji pracowników, analizę struktury demograficznej (miasta o starzejącej się ludności charakteryzują się mniejszą dynamiką rozwojową od miast „młodych”), badanie aktywności społecznej mieszkańców.

2. Kapitał Kultury i Wizerunku (KKW) pokazuje, w jaki sposób miasto jest postrzegane. Wykreowanie pozytywnego wizerunku pozwala łatwiej przyciągnąć do miasta inwestorów i pobudzić aktywność mieszkańców.

3. Kapitał Jakości Życia (KJZ) mówi, jakie warunki życia i pracy oferuje miasto. Kapitał ten budowany jest poprzez stan środowiska naturalnego, poziom opieki zdrowotnej, jakość instytucji edukacyjnych oraz poczucie bezpieczeństwa.

4. Kapital Techniczny i Infrastrukturalny (KTI) określa szeroko rozumianą infrastrukturę, którą posiada miasto: zasoby mieszkaniowe, drogi, środki transportu oraz zasoby handlowe, bankomaty czy szerzej infrastrukturę płatniczą i Internet.

5. Kapitał Instytucjonalno-Demokratyczny (KID) pokazuje sprawność funkcjonowania instytucji miejskich (władz i administracji) oraz obserwowaną aktywność społeczeństwa obywatelskiego.

6. Kapitał Atrakcyjności Inwestycyjnej (KAI) wskazuje na poziom atrakcyjności miasta w oczach inwestorów, zarówno zagranicznych, jak i krajowych.

7. Kapitał Źródel Finansowania (KZF) określa możliwości pozyskiwania środków pieniężnych przez miasto niezbędnych do sfinansowania rozwoju.

Harmonijny wzrost 7 kapitałów posiadanych przez miasta stanowi skuteczną drogę przyspieszenia ich rozwoju gospodarczego, a w ślad za tym wzrostu poziomu i jakości życia mieszkańców. Z punktu widzenia kształtowania świadomości finansowej i włączanie w system osób w wieku 50+ największe znaczenie odgrywa poziom kapitału ludzkiego i społecznego, czyli zespół cech określających wartość posiadanych zasobów ludzkich ${ }^{2}$. Kapitał ludzki i społeczny mierzony jest takimi kryteriami, jak:

- demografia,

- wykształcenie,

- aktywność społeczna,

- prorynkowość,

- rynek pracy.

${ }^{1}$ PwC, Raport na temat wielkich miast Polski, 2011, s. 3-4.

${ }^{2}$ Kapitał ludzki jest często utożsamiany z zasobami intelektualnymi, zaś kapitał społeczny stanowi o jakości społeczeństwa obywatelskiego. 
Przy średnim poziomie dla 11 miast (Białystok, Bydgoszcz, Katowice, Kraków, Lublin, Łódź, Poznań, Szczecin, Trójmiasto, Warszawa, Wrocław) równym 100, łączny kapitał ludzki i społeczny Łodzi oszacowany został na poziomie $87,2^{3}$. Wpływ na stosunkowo niską wartość kapitału wywarła przede wszystkim trudna sytuacja demograficzna Łodzi.

Diagnozy sytuacji społeczno-gospodarczej, statystyki GUS, raporty z badań oraz opracowania merytoryczne w zakresie demografii województwa łódzkiego jednoznacznie wskazują na tendencję starzenia się mieszkańców i występowanie zjawiska depopulacji województwa łódzkiego. Zdiagnozowane problemy demograficzne w województwie należą do najpoważniejszych w skali kraju i wymagają jak najszybszej reakcji ${ }^{4}$.

Zestawienie zmian w liczbie ludności w podziale na poszczególne przedziały wiekowe przedstawia rysunek $45^{5}$.

W całym analizowanym okresie przewiduje się nieustanny spadek liczby mieszkańców województwa łódzkiego. Do roku 2015 bezwzględne i względne rozmiary ubytku w kolejnych pięcioleciach będą niemal niezmienne w związku z przewidywanym zahamowaniem spadku urodzeń i stabilizacją ujemnego przyrostu naturalnego. $\mathrm{W}$ następnych podokresach wraz z rosnącym ubytkiem naturalnym przewiduje się wzrost rozmiarów i natężenia ubytku rzeczywistego ludności.

Do 2030 r. liczba ludności województwa zmniejszy się o 295,8 tys. osób, tj. o 11,5\%, z czego liczba ludności w wieku przedprodukcyjnym na obszarze województwa łódzkiego zmniejszy się o 168,0 tys., tj. o 34,7\% (w porównaniu do 2005 r.). Intensywny wzrost ubytków w latach 2020-2025 i 2025-2030 będzie efektem malejącej liczby urodzeń w latach 2016-2030.

Ludność w niemobilnej grupie wieku produkcyjnego zmniejszy się w latach 2005-2020 o ok. 15\%. W tym okresie będą napływać do niej generacje niżowe, urodzone w latach 60 -tych i na początku 70 -tych, natomiast w wiek poprodukcyjny wchodzić będą roczniki pierwszego powojennego wyżu urodzeń. W latach 2020-2030 w wiek niemobilny wchodzić będą generacje wyżu urodzeń z lat 1975-1985 i w rezultacie liczba ludności w niemobilnej grupie wieku produkcyjnego powiększy się o $9,9 \%$.

${ }^{3}$ Wszystkie wskaźniki, łączne i cząstkowe, zostały zdefiniowane i wyliczone w taki sposób, że wartość wyższa oznacza większą wartość kapitału, a średnia dla 11 badanych miast wynosi 100.

${ }^{4}$ Urząd Marszałkowski Województwa Łódzkiego, Plan przeciwdziałania depopulacji w województwie tódzkim. Rodzina, dzieci, praca, Łódź 2013, s. 7.

${ }^{5}$ Kryteria podziału ogółu ludności:

- ludność w wieku przedprodukcyjnym (0-17 lat);

- ludność w wieku produkcyjnym (mężczyźni 18-64 lata, kobiety 18-59 lat);

- ludność w niemobilnej grupie wieku produkcyjnego (45-64 lata mężczyźni, 45-59 lat kobiety);

- ludność w wieku poprodukcyjnym (mężczyźni 65 lat i więcej, kobiety 60 lat i więcej). 


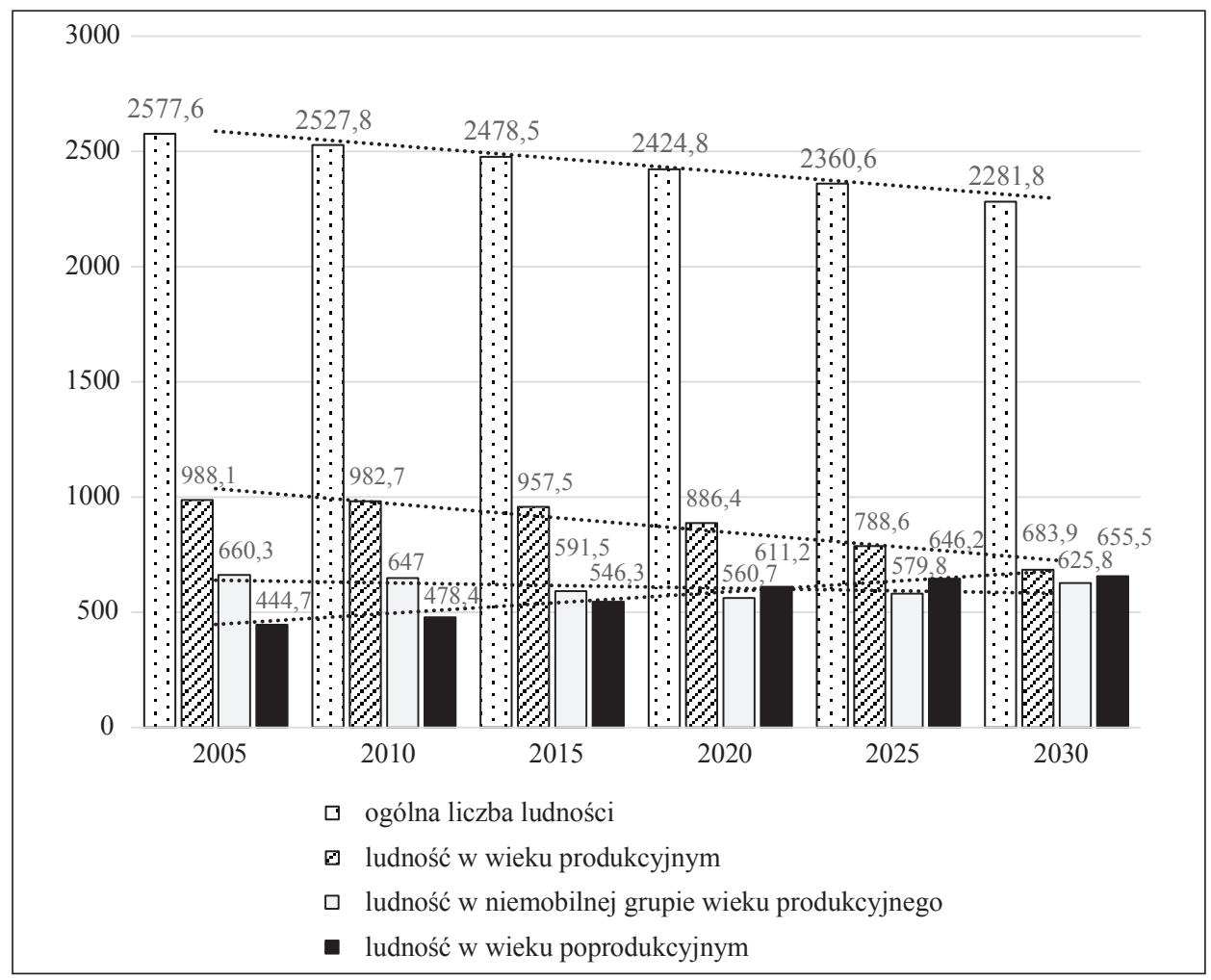

Rysunek 45. Zmiany w liczbie ludności w województwie łódzkim wraz z prognozą (w tys.) ${ }^{*}$ "Przedziały wiekowe: - wiek produkcyjny (mężczyźni 18-64 lata, kobiety 18-59 lat); - niemobilna grupa wieku produkcyjnego (45-64 lata mężczyźni, 45-59 lat kobiety); - wiek poprodukcyjny (mężczyźni 65 lat i więcej, kobiety 60 lat i więcej).

Źródło: opracowanie na podstawie danych GUS

W ciągu całego okresu 2005-2030 liczba ludności w wieku poprodukcyjnym w województwie łódzkim wzrośnie o 210,8 tys., a więc o 47,4\%. Po roku 2005 do grupy osób w wieku emerytalnym napływają generacje osób urodzonych w latach 1946-1960, a więc w okresie pierwszego powojennego wyżu urodzeń. Szczyt przyrostu przypadnie na lata 2010-2020, kiedy liczba osób w wieku emerytalnym zwiększy się o 27,8\%. Następować będzie proces szybkiego starzenia się ludności, udział osób w wieku 60+, wynoszący 5,3\% (2011r.), wzrośnie do roku 2020 do $33,3 \%{ }^{6}$. Równolegle z dynamicznie rosnącą liczbą osób w wieku poprodukcyjnym w jeszcze większym tempie wzrastać będzie w województwie łódzkim populacja osób w wieku 80 lat i więcej.

${ }^{6}$ Diagnoza strategiczna Lodzi. Synteza, Biuro Strategii, Partnerstwa i Funduszy Oddział Strategii Rozwoju Miasta Urzędu Miasta Łodzi, 2011, s. 4. 
Determinantą warunkującą depopulację województwa łódzkiego jest też dzietność kobiet. Przewiduje się w zakresie dzietności kobiet stabilizację liczby urodzeń w latach 2006-2015 i nieustanny spadek ich liczebności w trzech kolejnych pięcioleciach. W latach 2026-2030 liczba urodzeń będzie o 30\% mniejsza niż w okresie 2006-20107.

Podsumowując, w efekcie zróżnicowanych przekształceń w poszczególnych grupach wiekowych ludności wskaźnik obciążenia demograficznego ${ }^{8}$ ulegał systematycznemu pogorszeniu i w roku 2012 r. wynosił 59 (w roku 2002 jego wartość wynosiła 62). Przewiduje się natomiast wzrost wskaźnika do $74 \mathrm{w}$ roku $2030^{9}$.

Biorąc pod uwagę wartość kapitału ludzkiego posiadanego przez Łódź na tle pozostałych metropolii, należy wskazać na konieczność jego dalszego intensywnego rozwoju, w celu poprawienia sytuacji gospodarczej i społecznej miasta przede wszystkim poprzez odwrócenie niekorzystnych trendów demograficznych.

Warto także wspomnieć o kapitale jakości życia. Jednym z jego elementów jest jakość edukacji. Aktywna polityka innowacyjna i edukacyjna to jeden z głównych priorytetów działań na rzecz zrównoważonego rozwoju miast wskazywany przez dokument UE zwany „Kartą Lipskąa” ${ }^{10}$. Zgodnie z jego treścią, miasta są podstawowymi ośrodkami tworzenia i przekazywania wiedzy, a zrównoważony rozwój metropolii powinien uwzględniać dbałość o stałe podnoszenie poziomu edukacji.

Na tle pozostałych badanych miast przy średnim poziomie dla 11 miast równym 100, kapitał jakości życia w Łodzi w zakresie jakości edukacji kształtuje się na poziomie 90,0. Wnioskując na podstawie pomiaru potencjału rozwojowego polskich miast, konieczne są zatem działania zmierzające do poprawy wykształcenia ludności, w czym zawiera się także problematyka poprawienia świadomości finansowej.

\subsection{Metodyka badań w zakresie ekskluzji bankowej}

Zdiagnozowanie poziomu wiedzy finansowej mieszkańców województwa łódzkiego w wieku 50+ oraz zidentyfikowanie istnienia zależności między posiadaną wiedzą finansową a zakresem korzystania z produktów finansowych odbyło się za pomocą badania ilościowego. Badanie zostało przeprowadzone metodą

7 Urząd Statystyczny w Łodzi, Perspektywy demograficzne województwa łódzkiego do $2030 \mathrm{r}$, Łódź 2005, s. 7.

${ }^{8}$ Wskaźnik obciążenia demograficznego informuje, ile przypada osób w wieku nieprodukcyjnym na 100 osób w wieku produkcyjnym.

${ }^{9}$ Urząd Statystyczny w Łodzi, Stan i ruch naturalny ludności w województwie łódzkim, Łódź 2012, s. 10.

${ }^{10}$ Szerzej: Karta Lipska na rzecz zrównoważonego rozwoju miast europejskich, www.mir. gov.pl/rozwoj_regionalny/Polityka_regionalna/rozwoj_miast/rozwoj_miast_w_UE/Documents/ KL_PL.pdf (stan na dzień 6.01.2014). 
indywidualnego wywiadu osobistego face to face $\mathrm{w}$ domu respondenta (technika PAPI) w okresie maj-czerwiec 2013 r., na reprezentatywnej próbie 500 mieszkańców województwa łódzkiego w wieku 50+.

W celu przeprowadzenia badania zastosowano wystandaryzowaną technikę badawczą w postaci wywiadu kwestionariuszowego. Narzędziem służącym do realizacji badania był kwestionariusz wywiadu. Do przeprowadzenia badania posłużono się kwestionariuszem wywiadu, który wypełniał ankieter na podstawie odpowiedzi udzielonych przez uczestnika badania (ankietowanego). Narzędzie badawcze składało się z:

- pytań metryczkowych, takich jak: płeć, wiek, miejsce zamieszkania, dochód miesięczny netto, wykształcenie, stan cywilny;

- pytań kwestionariusza dotyczących zapotrzebowania na edukację finansową wśród mieszkańców województwa łódzkiego w wieku 50+11.

Zastosowany kwestionariusz to wysoce wystandaryzowane narzędzie badawcze, dzięki któremu uzyskane wyniki, sytuacje oraz środki badawcze można ujednolicić do postaci pewnych wzorców. Przedstawia się to w zadawaniu jednakowych pytań badanym bądź zapisywaniu uzyskanych odpowiedzi na jednolitych formularzach. Jednakże największą zaletą standaryzacji jest możliwość wszechstronnego badania zjawisk wynikających z zebranych danych. Zastosowany kwestionariusz zawierał pytania:

- jednokrotnego wyboru, zamknięte z podaną kafeterią odpowiedzi;

- jednokrotnego wyboru, półotwarte z podaną kafeterią odpowiedzi oraz kategorią otwartą;

- wielokrotnego wyboru z podaną kafeterią odpowiedzi;

- wielokrotnego wyboru z kategorią otwartą.

Próba badawcza była podzielona ze względu na trzy kluczowe kryteria:

- płeć,

- wiek,

- klasę wielkości miejscowości, w której mieszkał respondent.

Badanie odbyło się obligatoryjnie we wszystkich powiatach województwa łódzkiego (3 grodzkich i 21 ziemskich) oraz wszystkich miastach powyżej 20 tys. mieszkańców. W klasach miejscowości o mniejszej liczbie mieszkańców odpowiednia liczba miast była losowana. Losowanie miast odbyło się według schema-

${ }^{11}$ Kwestionariusz ankietowy stanowił odzwierciedlenie kwestionariusza opracowanego przez OECD i International Network on Financial Education (INFE) w celu wskazania kierunków badania wiedzy finansowej w poszczególnych krajach umożliwiających ich porównywalność pod kątem kluczowych grup społeczno-demograficznych i opracowanie krajowych strategii edukacji finansowej. A. Atkinson, F. Messy, Measuring Financial Literacy: Results of the OECD/International Network on Financial Education (INFE) Pilot Study, OECD Working Papers on Finance, Insurance and Private Pensions 2012, No. 15. Por. OECD INFE, OECD/INFE toolkit to measure financial literacy and inclusion. Guidance, core questionnaire and supplementary questions, Paris, June 2013. 
tu ze zwracaniem. Warstwy dla obszarów wiejskich wyznaczone zostały zgodnie $\mathrm{z}$ podziałem terytorialnym na powiaty. W każdym powiecie dobierane były gminy, przy czym losowanie dokonywane było według schematu ze zwracaniem.

W celu zoptymalizowania realizacji badan dokonane zostało wiązkowanie próby. Liczebność wiązki wynosiła od $\mathrm{N}=3$ do $\mathrm{N}=5$ (w zależności od klasy wielkości miejscowości). $Z$ każdego punktu startowego przeprowadzany był jeden wywiad. Ankieter z punktu startowego poruszał się według instrukcji metodą random route (ustalonej ścieżki), aż do momentu przeprowadzenia efektywnego wywiadu. Po przeprowadzeniu wywiadu ankieter udawał się na kolejny wylosowany punkt startowy i dalej analogicznie poruszał się według instrukcji metodą random route (ustalonej ścieżki), aż do momentu przeprowadzenia efektywnego wywiadu z osobą spełniającą kryteria doboru. Cykl ten był powtarzany do momentu zrealizowania odpowiedniej liczby wywiadów w wiązce.

Przeprowadzone badanie miało charakter reprezentatywny. Próba badawcza została ustalona w oparciu o dane z Rocznika Demograficznego 2012, Wydawnictwo GUS oraz Rocznika Statystycznego Województwa Łódzkiego 2012, Wydawnictwo WUS Łódź. Na ich podstawie próba została podzielona na kohorty zgodnie z poniższymi kategoriami:

a) mężczyźni i kobiety:

$\mathrm{K}-57,46 \%=287$,

$\mathrm{M}-42,54 \%=213$,

Łącznie K i M - 100\%;

b) kohorty wiekowe:

50-54 lata $-9,76 \%(\mathrm{~K}-10,25 \%, \mathrm{M}-9,5 \%)-51-48$,

$55-59$ lat $-21,18 \%(\mathrm{~K}-11,17 \%, \mathrm{M}-10,00 \%)-56-50$,

$60-64$ lata $-18,53 \%(\mathrm{~K}-10,21 \%, \mathrm{M}-8,32 \%)-51-41$,

65-69 lat $-11,51 \%(\mathrm{~K}-6,61 \%, \mathrm{M}-4,90 \%)-33-25$,

$70-74$ lata $-9,47 \%(\mathrm{~K}-5,78 \%, \mathrm{M}-3,69 \%)-29-18$,

$75-79$ lat $-8,56 \%(\mathrm{~K}-5,56 \%, \mathrm{M}-3,00 \%)-28-15$,

80 i więcej lat $-10,99 \%(\mathrm{~K}-7,87 \%, \mathrm{M}-3,12 \%)-39-16$,

Łącznie 50 i więcej lat $=100 \%$;

c) klasę wielkości miejscowości (miejsce zamieszkania - klasa wielkości miejscowości):

Łódź - 28,6\% - 143,

miasta 50-99 tys. mieszkańców $-13,0 \%-65$,

miasta 20-49 tys. mieszkańców $-13,8 \%-69$,

miasta $10-29$ tys. mieszkańców $-4,3 \%-21$,

miasta do 10 tys. mieszkańców $-4,1 \%-21$,

wsie $-36,2 \%-181$,

Łącznie miejsce zamieszkania $=100 \%$.

Rozkład w poszczególnych klasach wielkości miejscowości kształtował się następująco: 
a) W Łodzi rozkład na dzielnice:

Bałuty -42 ankiety,

Górna -33 ankiety,

Polesie -28 ankiet,

Widzew -26 ankiet,

Śódmieście - 14 ankiet;

b) Miasta liczące 50-100 tys. mieszkańców (Piotrków Trybunalski, Pabianice, Bełchatów, Tomaszów Mazowiecki, Zgierz) - w każdym z miast zrealizowanych zostało minimalnie 10, a maksymalnie 20 ankiet. Wiązka w poniższych miastach $\mathrm{N}=5$;

c) Miasta liczące 20-49 tys. mieszkańców (Skierniewice, Radomsko, Kutno, Zduńska Wola, Sieradz, Łowicz, Wieluń, Opoczno, Aleksandrów Łódzki, Ozorków) - w każdym z miast zrealizowanych zostało minimalnie 6, a maksymalnie 9 ankiet. Wiązka w powyższych miastach $\mathrm{N}=3$;

d) Miasta liczące 10-19 tys. mieszkańców (Łask, Konstantynów Łódzki, Rawa Mazowiecka, Łęczyca, Głowno, Koluszki, Brzeziny) w każdym z miast zrealizowanych zostało minimalnie 0 , a maksymalnie 6 ankiet. Wiązka w powyższych miastach $\mathrm{N}=3$;

e) Miasta liczące poniżej 10 tys. mieszkańców (Wieruszów, Żychlin, Zelów, Poddębice, Tuszyn, Pajęczno, Sulejów, Działoszyn, Krośniewice, Drzewica, Przedbórz, Stryków, Złoczew, Rzgów, Warta, Biała Rawska, Uniejów, Kamieńsk, Wolbórz, Błaszki, Szadek) - w każdym z miast zrealizowanych zostało minimalnie 0 , a maksymalnie 6 ankiet. Wiązka w powyższych miastach $\mathrm{N}=3$;

f) Wsie - w każdym z powiatów ziemskich na wsiach przeprowadzonych zostało minimum 6, a maksymalnie 12 ankiet. Wiązka na wsiach $\mathrm{N}=3$ (dodatkowo jedna wiązka $\mathrm{N}=4$ ).

Analiza uzyskanych danych została przeprowadzona z wykorzystaniem następujących statystyk ${ }^{12}$ :

- średnia (arytmetyczna) - średnia obliczona z sumy wszystkich wartości przez liczebność - wrażliwa na wartości skrajne;

- mediana - średnia, wyznaczona z liczby będącej dokładnie w połowie wszystkich wartości, niebędąca wrażliwa na wartości skrajne;

- odchylenie standardowe - szerokość rozrzucenia wartości wokół średniej. Przedział plus/minus od wartości średniej. Im większa wartość odchylenia, tym wartości są bardziej rozrzucone od wartości średniej;

- dominanta - wartość, która najczęściej występowała w liczebności;

- kwartyl (Q) - podział liczebności na cztery równe części liczące po 25\% - pierwszy kwartyl (Q1) do $25 \%$, drugi od $25 \%$ do $50 \%$ (Q2), trzeci od $50 \%$ do $75 \%$ (Q3), czwarty kwartyl (Q4) od 75\% do 100\%.

${ }_{12}$ Wszystkie wykresy i tablice powstałe w wyniku analizy danych zawierają procentowanie do ogółu ważnych przypadków. 


\subsection{Analiza struktury na podstawie przeprowadzonych badań pierwotnych}

\subsubsection{Struktura demograficzna próby}

W ramach kryteriów demograficznych próby badawczej wyróżniona została: płeć, miejsce zamieszkania i wiek, zgodnie z założeniami przyjętymi przy doborze próby badawczej. Poza tymi cechami badaną próbę można sklasyfikować, biorąc pod uwagę stan cywilny, liczbę osób w wieku równym lub poniżej 18. roku życia w gospodarstwie domowym oraz liczbę osób powyżej 18. roku życia w gospodarstwie domowym. Istotnymi elementami różnicującymi badaną populację okazały się być aspekty finansowe rozpatrywane w kontekście wysokości oraz systematyki uzyskiwanych miesięcznie dochodów netto.

Strukturę uwzględniającą stan cywilny badanej populacji przedstawia rysunek 46.

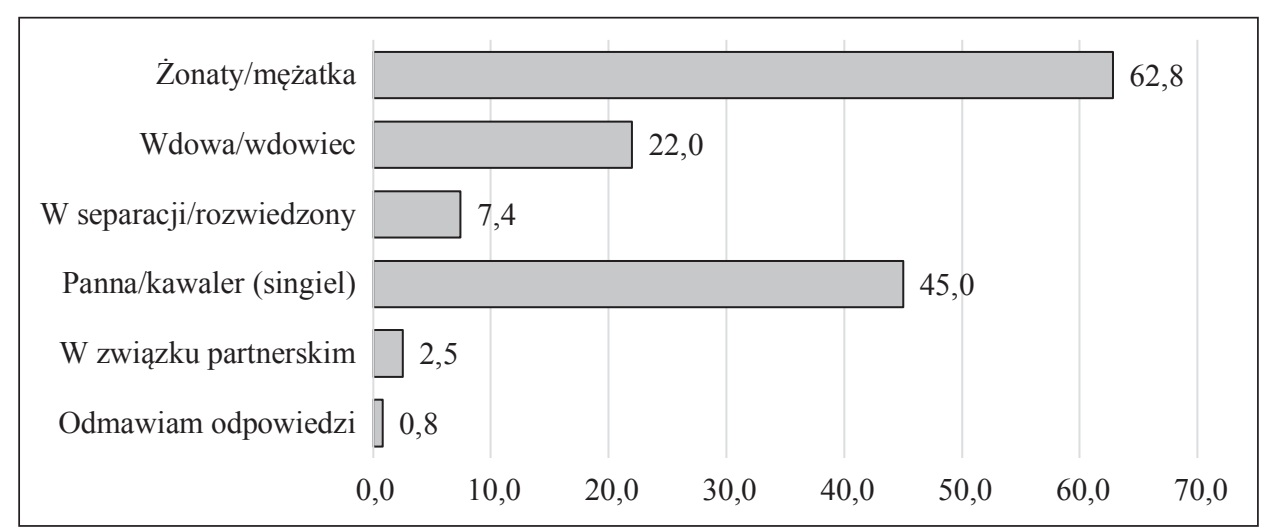

Rysunek 46. Zróżnicowanie badanej zbiorowości ze względu na stan cywilny (w \%)

Źródło: opracowanie własne na podstawie wyników badania kwestionariuszowego

Niemal $63 \%$ badanych to osoby będące w związku małżeńskim $(62,8 \%)$. Wdowy/wdowcy stanowili 22,0\% zbiorowości. Niższym odsetkiem charakteryzowały się osoby pozostające $\mathrm{w}$ separacji bądź rozwiedzione oraz pozostające w stanie panieńskim lub kawalerskim.

Interesującym aspektem różnicującym próbę badawczą była liczba osób tworzących wspólne gospodarstwo domowe. Strukturę uwzględniającą zróżnicowanie ze względu na liczbę osób badanej populacji przedstawia rysunek 47. 


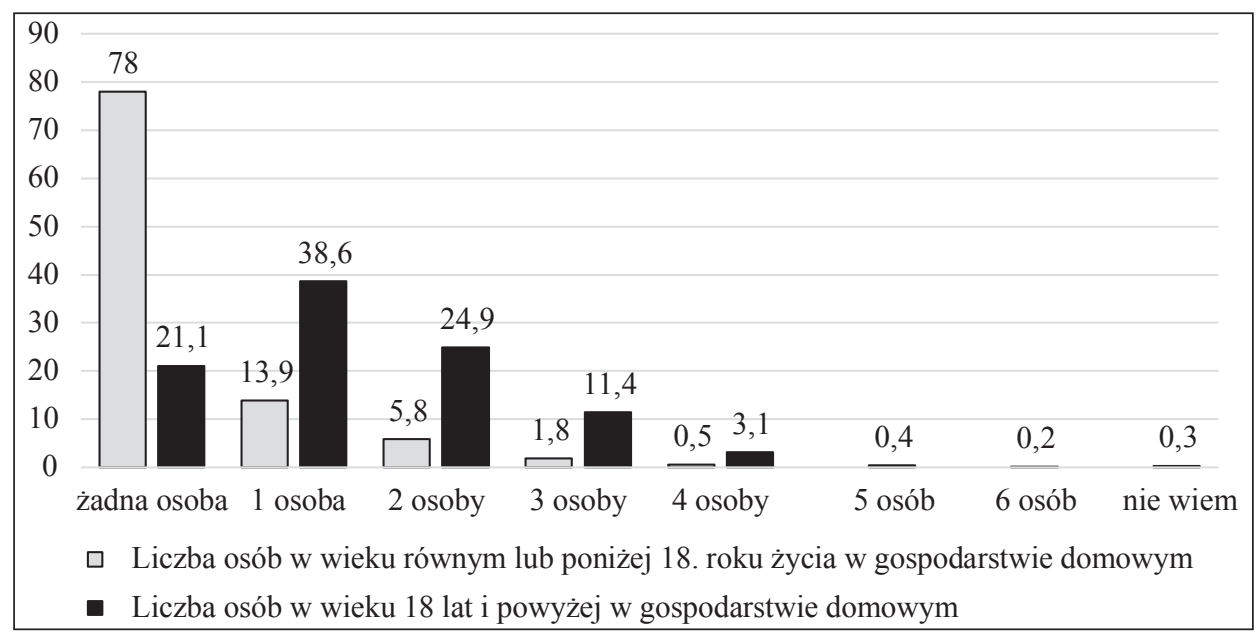

Rysunek 47. Zróżnicowanie badanej zbiorowości ze względu na liczbę osób w wieku równym lub poniżej 18. oraz powyżej 18. roku życia w gospodarstwie domowym (w \%)

Źródło: opracowanie własne na podstawie wyników badania kwestionariuszowego

Z zebranych danych wynika, że ponad 3/4 badanych nie dzieliła gospodarstwa domowego z osobą w wieku równym lub poniżej 18 . roku życia $(78,0 \%)$. Badani zostali poproszeni o wskazanie liczby osób w wieku 18 lat i więcej, które mieszkają z nimi w gospodarstwie domowym (wyłączając siebie samych). Z odpowiedzi ankietowanych wynika, że w przypadku 38,6\% zbiorowości była to jedna osoba. Co czwarty uczestnik badania przyznał, że gospodarstwo domowe zamieszkują z nim dwie osoby w tym wieku. Natomiast w przypadku $21,1 \%$ badanych w ogóle nie było takich osób w gospodarstwie domowym.

Następną cechą demograficzną różnicującą zbiorowość było wykształcenie. Biorąc je pod uwagę, badana populacja wykazała się zróżnicowaniem (rysunek 48).

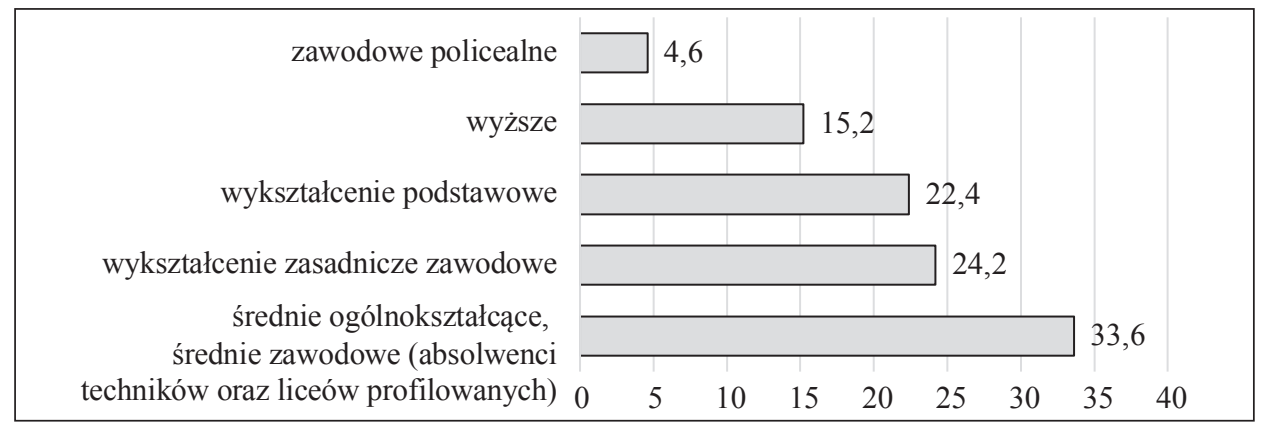

Rysunek 48. Zróżnicowanie badanej zbiorowości ze względu na wykształcenie (w \%)

Źródło: opracowanie własne na podstawie wyników badania kwestionariuszowego 
Około 1/3 badanych stanowiły osoby z wykształceniem średnim ogólnokształcącym, średnim zawodowym $(33,6 \%)$. Co czwarty respondent posiadał wykształcenie zasadnicze zawodowe $(24,2 \%)$, a co piąty - podstawowe $(22,4 \%)$.

W ślad za analizą struktury wykształcenia można dokonać weryfikacji zróżnicowania badanej zbiorowości ze względu na sytuację zawodową. Odpowiednie zestawienie przedstawia rysunek 49 .

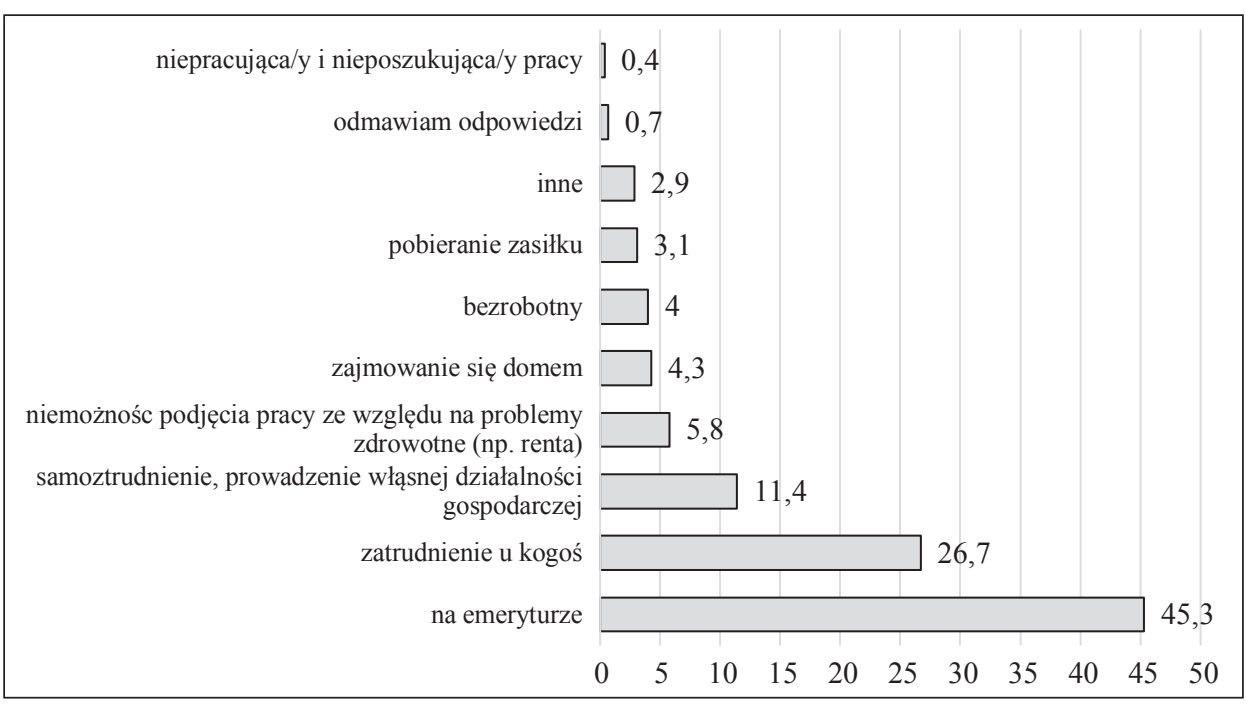

Rysunek 49. Zróżnicowanie badanej zbiorowości ze względu na sytuację zawodową (wielokrotny wybór) (w \%)

Źródło: opracowanie własne na podstawie wyników badania kwestionariuszowego

Ponad $45 \%$ badanych było na emeryturze (45,3\%). Niemal 27\% uczestników badania przyznało, że jest zatrudnione u kogoś (26,7\%). Samozatrudnionych lub prowadzących własną działalność gospodarczą było 11,4\% osób.

Taka struktura badanej populacji ze względu na sytuację zawodową znalazła odzwierciedlenie w specyfice źródeł utrzymania gospodarstwa domowego. Ich zróżnicowanie prezentuje rysunek 50 .

Zdecydowana większość uczestników badania przyznała, że posiada regularne źródło utrzymania gospodarstwa domowego $(80,6 \%)$. Posiadanie regularnego źródła utrzymania nie wiązało się jednak wprost z liczbą przepracowanych godzin ze względu na specyfikę badanej grupy (osób w wieku 50+), wśród których ponad $45 \%$ badanych było na emeryturze. Uzupełnieniem tych danych było pozyskanie informacji na temat liczby przepracowanych godzin. Dane prezentuje rysunek 51. 


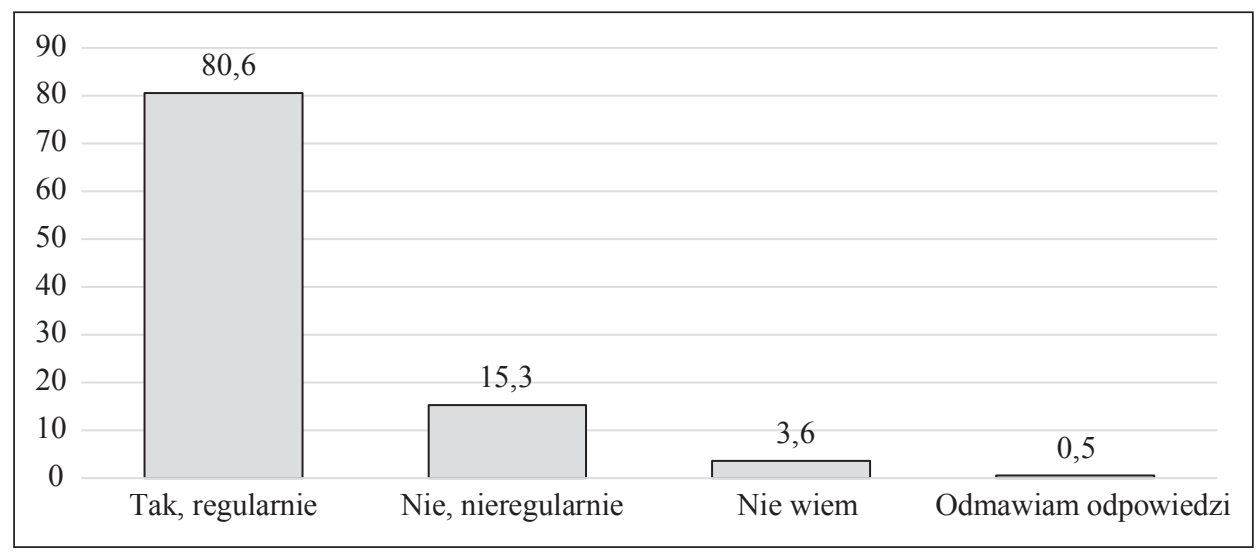

Rysunek 50. Źródła utrzymania gospodarstwa domowego (w \%)

Źródło: opracowanie własne na podstawie wyników badania kwestionariuszowego

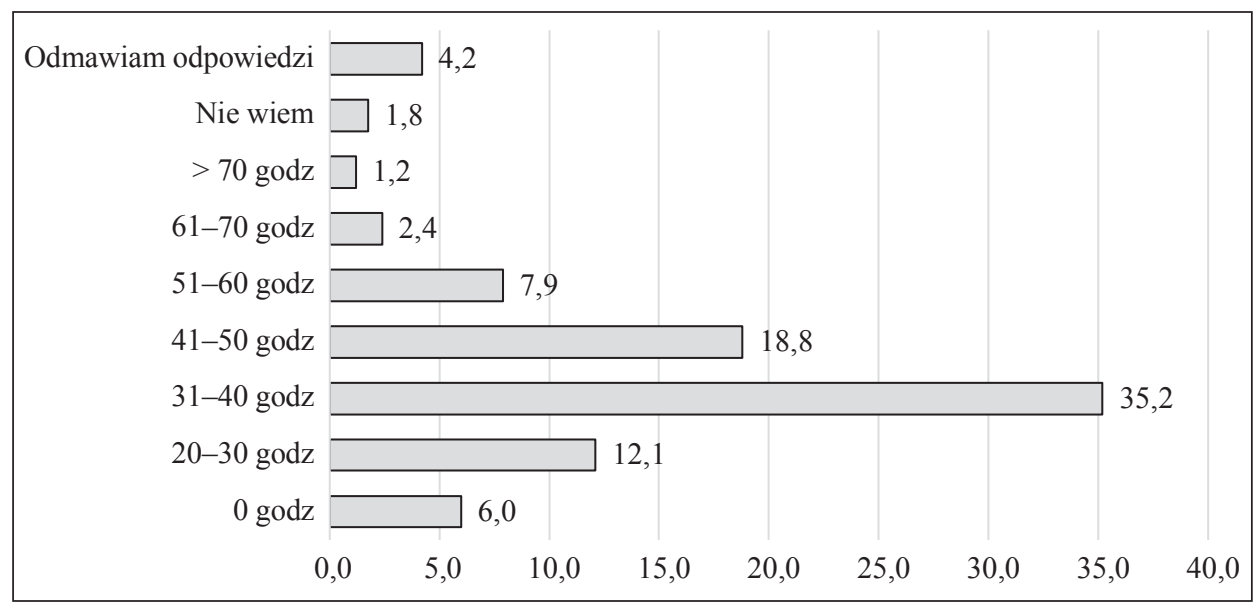

Rysunek 51. Liczba godzin przepracowanych w ciągu tygodnia poprzedzającego udział w badaniu (w \%)

Źródło: opracowanie własne na podstawie wyników badania kwestionariuszowego

Na podstawie zgromadzonych danych dotyczących ilości godzin przepracowanych w ciągu tygodnia poprzedzającego udział w badaniu stwierdzono, że 47,9\% osób przepracowało mniej niż 40 godzin. Maksymalna liczba przepracowanych godzin wynosiła 84 godziny/tydzień ${ }^{13}$.

${ }^{13}$ Był to przypadek ekstremalny. 
Istotnym aspektem różnicującym badaną zbiorowość była wysokość osiąganych dochodów netto na osobę w gospodarstwie domowym. Rysunek 52 zawiera odpowiednie zestawienie.

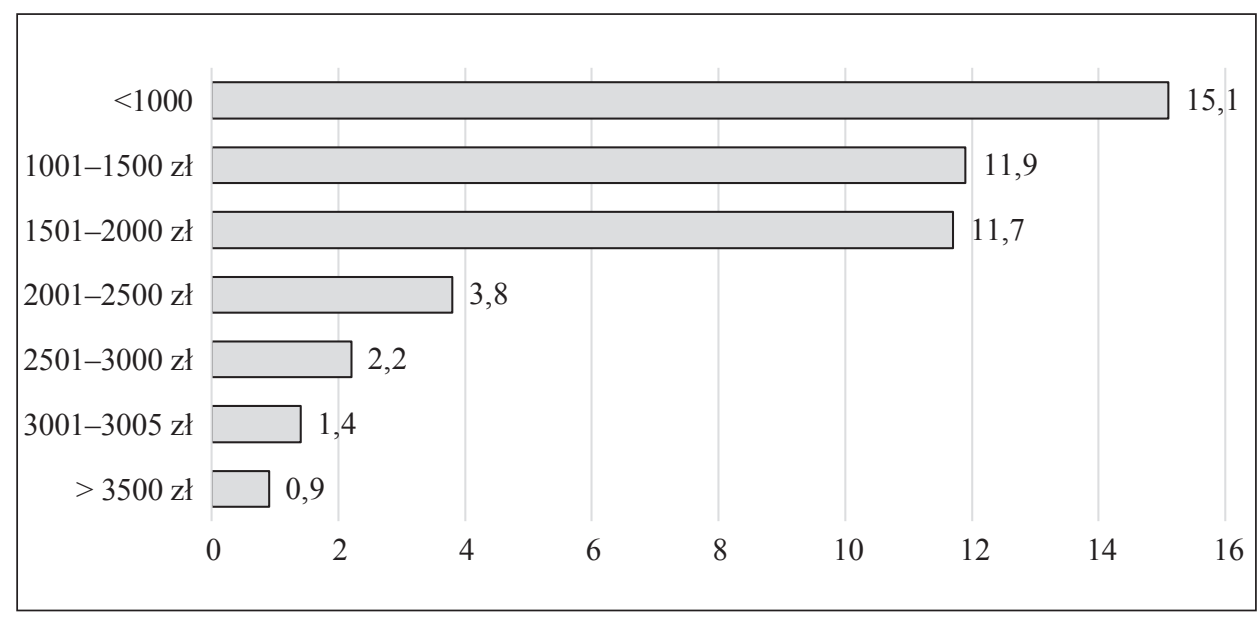

Rysunek 52. Dochody netto ogółem z okresu poprzedzającego udział w badaniu (w \%)

Źródło: opracowanie własne na podstawie wyników badania kwestionariuszowego

Dochody netto ze wszystkich źródeł z okresu ostatniego miesiąca (poprzedzającego udział w badaniu), nieprzekraczające 1000 zł posiadało $15,1 \%$ respondentów. Zbliżony udział badanych, tj. po około $12 \%$, przyznał, że posiada indywidualne dochody netto ogółem w granicach $1001-1500 \mathrm{zł}$ netto oraz 1501-2000 zł netto (odpowiednio: $11,0 \%$ oraz $11,7 \%$ ). Minimalne dochody netto ze wszystkich źródeł utrzymania to $200 \mathrm{zł}$, natomiast maksymalne $5000 \mathrm{zł}$ netto.

Zestawienie przedstawiające wysokość miesięcznych dochodów netto można uzupełnić o analizę wskazującą na przedziały miesięcznych dochodów netto na osobę w gospodarstwie domowym ${ }^{14}$. Ich zestawienie prezentuje rysunek 53 .

Miesięczne dochody netto w wysokości powyżej 1730 zł posiadało $30,8 \%$ badanych. Nieco mniejszy udział respondentów posiadał dochody w granicach 1001-1730 zł netto. Blisko 17\% ankietowanych odmówiło odpowiedzi na to pytanie $(16,6 \%)$.

Kolejnym elementem podlegającym identyfikacji w ramach przeprowadzonego badania była identyfikacja osoby odpowiedzialnej za podejmowanie bieżących decyzji finansowych w gospodarstwie domowym. Wyniki prezentuje rysunek 54 .

${ }^{14}$ Przedziały dochodów zostały wyznaczone na podstawie mediany dochodu. Pierwszy przedział dochodów stanowi poniżej 75\% mediany, drugi zawiera się w przedziale $75-125 \%$ mediany, trzeci określony został powyżej 125\% mediany. 


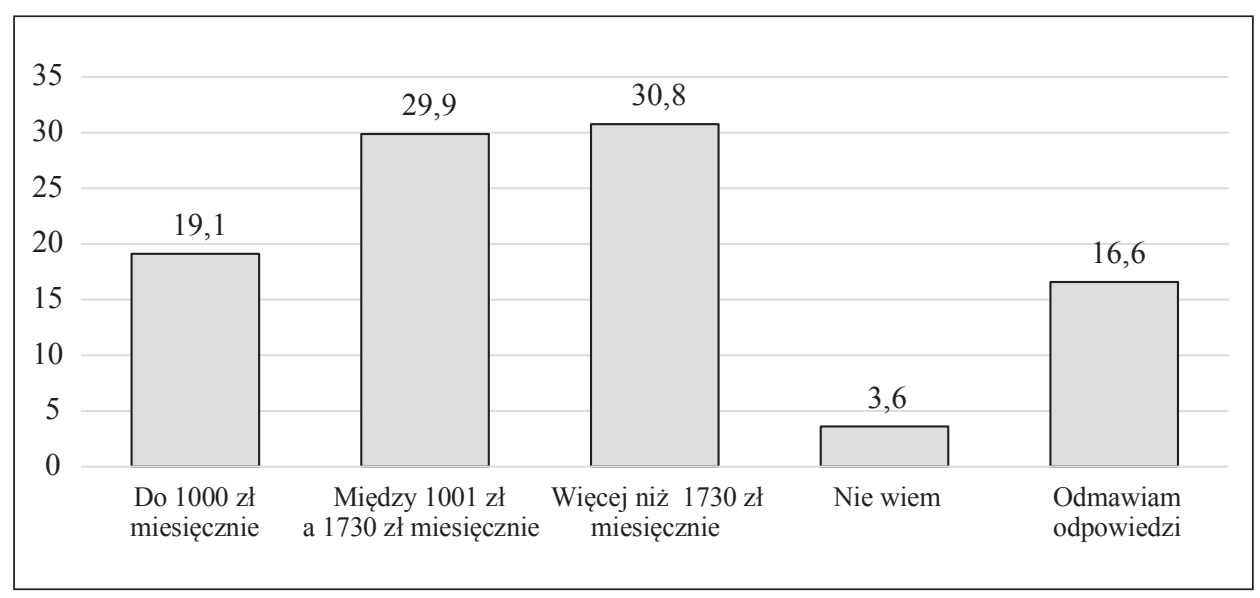

Rysunek 53. Miesięczne dochody netto - przedziały (w \%)

Źródło: opracowanie własne na podstawie wyników badania kwestionariuszowego

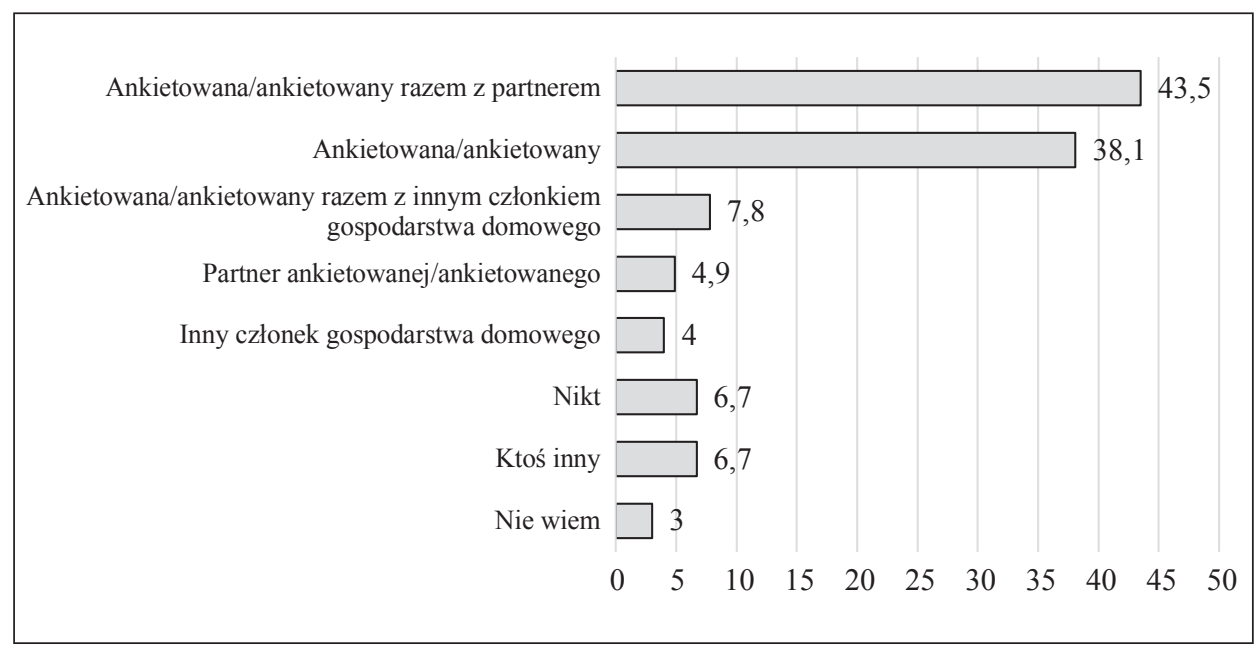

Rysunek 54. Osoba odpowiedzialna za podejmowanie bieżących decyzji finansowych (w \%)

Źródło: opracowanie własne na podstawie wyników badania kwestionariuszowego

Na podstawie zgromadzonych danych stwierdzono, że w przypadku około 44\% uczestników badania to właśnie ankietowani wraz partnerem/partnerką byli odpowiedzialni za podejmowanie decyzji finansowych $(43,5 \%)$. W przypadku 38,1\% zbiorowości jedynie ankietowani podejmowali tego rodzaju decyzje. 


\subsubsection{Stosunek do pieniędzy}

W ramach analizy zachowań konsumenckich w obszarze decyzji finansowych ważnym elementem jest identyfikacja stosunku do pieniędzy, szczególnie w zakresie determinant kształtujących ich wydatkowanie i umiejętność pozyskiwania korzyści z lokowania wolnych środków pieniężnych w produkty finansowe.

Pierwszym badanym aspektem była weryfikacja podejścia badanych do wydatkowania posiadanych środków pieniężnych. Wyniki przedstawia rysunek 55.

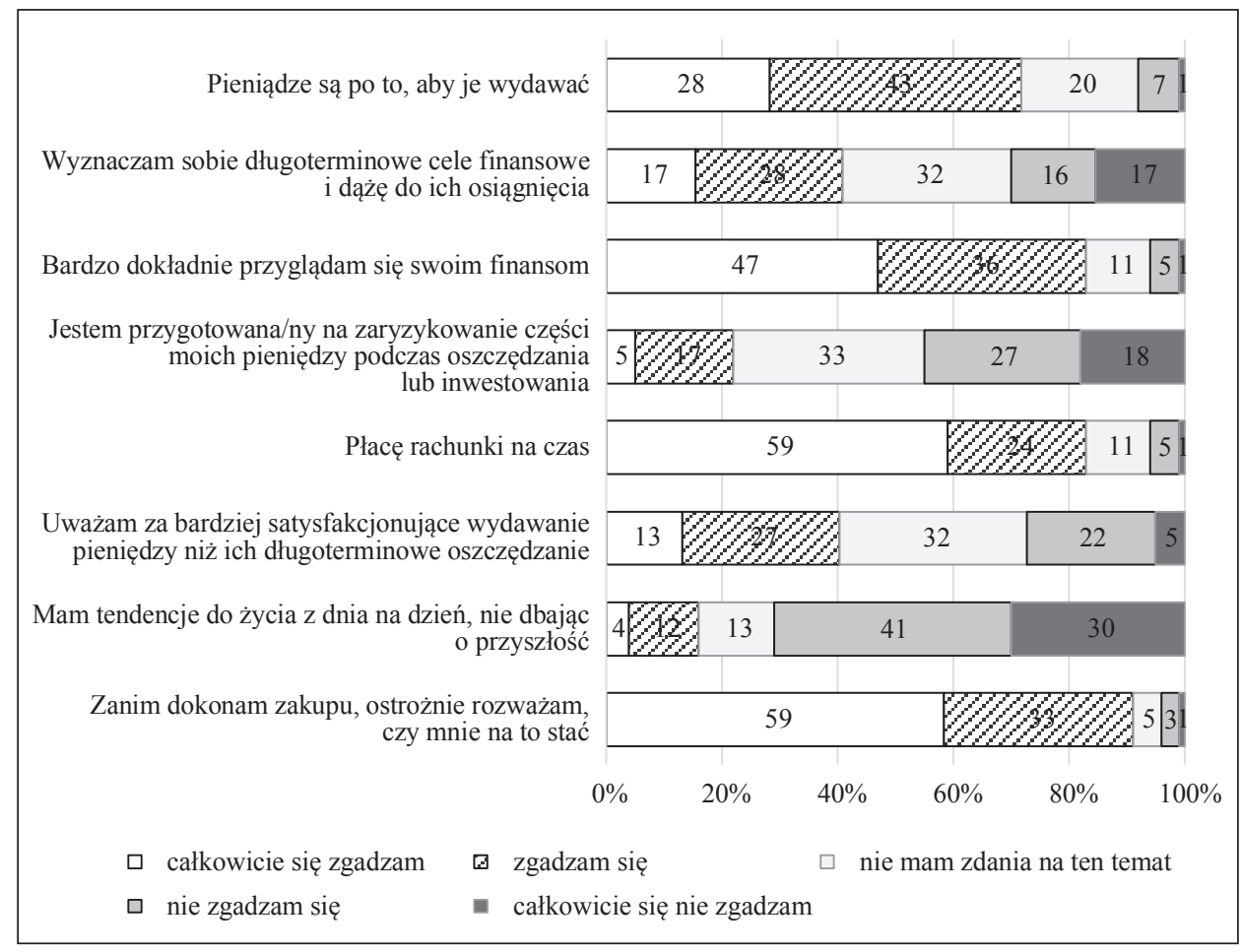

Rysunek 55. Stosunek badanych do pieniędzy - skala całkowicie się zgadzam - całkowicie się nie zgadzam (w \%)

Źródło: opracowanie własne na podstawie wyników badania kwestionariuszowego

Zdecydowana większość ankietowanych zgodziła się oraz całkowicie zgodziła się z tym, że zanim dokonała zakupu, ostrożnie rozważyła, czy może sobie pozwolić na dany wydatek (suma odsetek odpowiedzi całkowicie się zgadzam oraz zgadzam się: $92,2 \%$ ). Wprawdzie ponad 70\% uczestników badania nie zgodziła się ze sformułowaniem mówiącym o posiadaniu tendencji do życia z dnia na dzień, nie dbając o przyszłość (suma odsetek odpowiedzi nie zgadzam się oraz calkowicie się nie zgadzam: 70,4\%), to jednak odpowiedzi ankietowanych zwią- 
zane ze stwierdzeniem dotyczącym tego, czy bardziej satysfakcjonujące jest wydawanie pieniędzy czy ich długoterminowe oszczędzanie, były podzielone. Około 1/3 osób nie miała zdania w tej kwestii. Odsetek osób, które zgodziły się z tym sformułowaniem oraz były odmiennego zdania, był zbliżony.

Ponad $83 \%$ badanych przyznało, że płaci rachunki na czas (suma odsetek odpowiedzi catkowicie się zgadzam oraz zgadzam się: $83,2 \%$ ). Blisko połowa uczestników badania uznała, że nie jest przygotowana na zaryzykowanie części swoich pieniędzy podczas oszczędzania lub inwestowania (suma odsetek odpowiedzi nie zgadzam się oraz calkowicie się nie zgadzam: 45,0\%). Aczkolwiek około 1/3 osób nie miała zdania na ten temat $(33,2 \%)$. Zdecydowana większość ankietowanych zgodziła się ze sformułowaniami wskazującymi na to, że badani bardzo dokładnie przyglądają się swoim finansom oraz z tym, że pieniądze są po to, żeby je wydawać (suma odsetek odpowiedzi catkowicie się zgadzam oraz zgadzam się odpowiednio: $83,3 \%$ oraz $71,1 \%$ ). W kwestii związanej z wyznaczaniem sobie długoterminowych celów finansowych i dążeniu do ich osiągnięcia opinie były podzielone, około 1/3 osób nie miała zdania na ten temat (32,3\%).

Drugim analizowanym elementem było posiadanie wystarczającej ilości środków pieniężnych na pokrycie kosztów. Rysunek 56 przedstawia wyniki analizy.

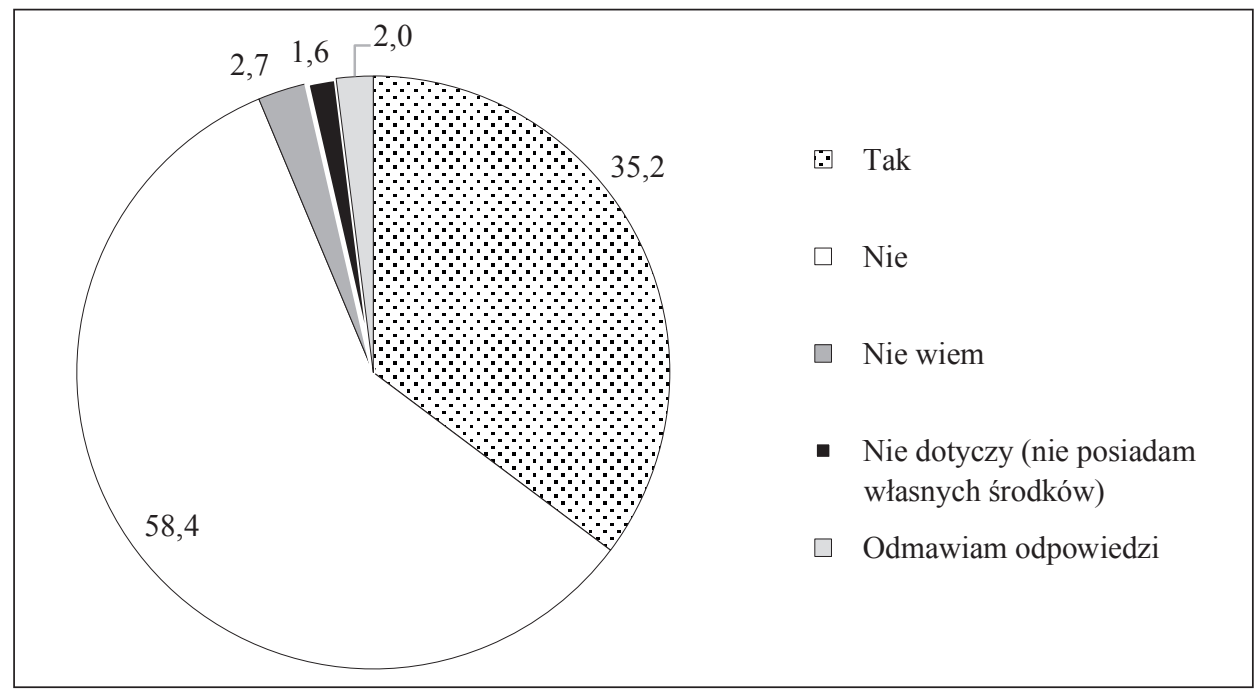

Rysunek 56. Możliwość pokrycia kosztów z posiadanych pieniędzy (w \%)

Źródło: opracowanie własne na podstawie wyników badania kwestionariuszowego

Blisko $60 \%$ respondentów przyznało, że w ciągu ostatnich 12 miesięcy poprzedzających udział w badaniu miała miejsce sytuacja, w której posiadane przez nich pieniądze nie wystarczyły na pokrycie kosztów. W konsekwencji kolejne pytanie dotyczyło sposobów radzenia sobie w sytuacji wystąpienia braku środ- 
ków na pokrycie kosztów. Grupie osób, które przyznały, że w ciągu ostatnich 12 miesięcy (od momentu udziału w badaniu) posiadane przez nich pieniądze nie wystarczyły na pokrycie kosztów, zadano pytanie o postępowanie w takiej sytuacji. Rozkład udzielonych odpowiedzi prezentuje tablica 49.

Tablica 49. Postępowanie w przypadku braku środków na pokrycie kosztów (wielokrotny wybór)

\begin{tabular}{|c|c|c|}
\hline Typ rozwiązania & Rozwiązanie & $\begin{array}{l}\text { Udzial } \\
(w \%)\end{array}$ \\
\hline \multirow[t]{3}{*}{$\begin{array}{l}\mathrm{Z} \text { istniejących } \\
\text { zasobów }\end{array}$} & $\begin{array}{l}\text { Wypłata środków z oszczędności lub przelew oszczędności } \\
\text { na rachunek bieżący }\end{array}$ & 12,4 \\
\hline & $\begin{array}{l}\text { Ograniczenie wydatkowania, wydawanie mniej, poradze- } \\
\text { nie sobie bez czegoś }\end{array}$ & 75,2 \\
\hline & Sprzedaż czegoś z posiadanego mienia & 5,6 \\
\hline Tworzenie zasobów & Nadgodziny, dodatkowe źródło zarobkowania & 21,7 \\
\hline \multirow{5}{*}{$\begin{array}{l}\text { Dostęp do kredytów } \\
\text { przy wykorzystaniu } \\
\text { istniejących kontaktów, } \\
\text { zasobów }\end{array}$} & Pożyczenie jedzenia lub pieniędzy od rodziny, znajomych & 39,8 \\
\hline & Pożyczenie od pracodawcy & 1,9 \\
\hline & Zastawienie posiadanej rzeczy w lombardzie & 2,5 \\
\hline & Zaciągnięcie pożyczki w kasie zapomogowo-pożyczkowej & 5,0 \\
\hline & $\begin{array}{l}\text { Ubieganie się o kredyt lub wypłatę z funduszu emerytalnego } \\
\text { (III filar) }\end{array}$ & 4,3 \\
\hline \multirow{2}{*}{$\begin{array}{l}\text { Zadłużenie } \\
\text { w istniejącej } \\
\text { linii kredytowej }\end{array}$} & $\begin{array}{l}\text { Wykorzystywanie zgodnie } \mathrm{z} \text { umową zadłużenia na rachunku } \\
\text { bieżącym lub linię kredytową }\end{array}$ & 13,0 \\
\hline & Wykorzystywanie karty kredytowej & 15,5 \\
\hline \multirow[t]{3}{*}{$\begin{array}{l}\text { Dostęp do nowej } \\
\text { linii kredytowej }\end{array}$} & $\begin{array}{l}\text { Wzięcie kredytu/pożyczki z instytucji finansowej (banki, in- } \\
\text { stytucje mikrofinansowe, SKOKi) }\end{array}$ & 9,3 \\
\hline & Wzięcie tzw. szybkiej pożyczki & 4,3 \\
\hline & Wzięcie kredytu/pożyczki z instytucji parabankowej & 2,5 \\
\hline \multirow[t]{2}{*}{$\begin{array}{l}\text { Zaległości płatnicze } \\
\text { /przekroczenie salda }\end{array}$} & $\begin{array}{l}\text { Używanie nieuzgodnionego z bankiem przekroczenia salda } \\
\text { na koncie (,wymuszony” debet) }\end{array}$ & 0,6 \\
\hline & $\begin{array}{l}\text { Opłacenie rachunków po terminie, pozostawienie rachunków } \\
\text { bez zapłaty }\end{array}$ & 17,4 \\
\hline \multirow[t]{3}{*}{ Inne odpowiedzi } & Inne & 2,5 \\
\hline & Nie wiem & 2,5 \\
\hline & Odmawiam odpowiedzi & 1,9 \\
\hline
\end{tabular}

Źródło: opracowanie własne na podstawie wyników badania kwestionariuszowego.

Zdecydowana większość ankietowanych w sytuacji wystąpienia braku środków na pokrycie bieżących kosztów sięga po rozwiązania pasywne. Około 3/4 tej grupy badanych przyznało, że ograniczało wydatkowanie, wydawało mniej pieniędzy, poradziło sobie bez (kupienia) czegoś $(75,2 \%)$. Blisko $40 \%$ ankietowanych, w przypadku których zabrakło środków na pokrycie kosztów, pożyczało 
jedzenie lub pieniądze od rodziny, znajomych $(39,8 \%$ ), a jedynie $21,7 \%$ osób pracowało dłużej (nadgodziny), aby uzyskać dodatkowe źródło zarobkowania. Dopiero na dalszych miejscach znalazły się rozwiązania polegające na dodatkowym zadłużeniu w istniejącej linii kredytowej w formie wykorzystania limitu kredytowego lub karty kredytowej.

Dodatkowo ankietowani zostali zapytani o wskazanie okresu możliwości pokrycia wydatków bez pożyczania pieniędzy w przypadku utraty głównego źródła dochodu. Zestawienie uzyskanych odpowiedzi przedstawia rysunek 57.

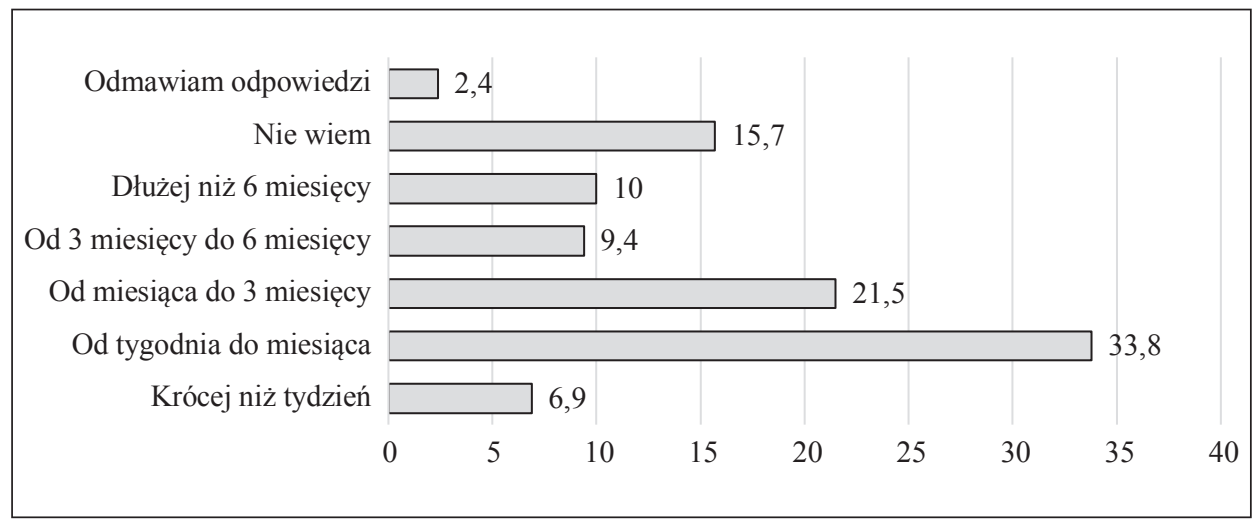

Rysunek 57. Okres możliwości pokrycia wydatków bez konieczności pożyczania pieniędzy (w \%)

Źródło: opracowanie własne na podstawie wyników badania kwestionariuszowego

Około 1/3 badanych przyznała, że w sytuacji utraty głównego źródła dochodów byłaby w stanie pokryć wydatki bez pożyczania pieniędzy przez okres stosunkowo krótki, gdyż od tygodnia do miesiąca $(33,9 \%)$. Co piąta osoba określiła ten przedział czasowy na miesiąc - 3 miesiące $(21,5 \%)$. W przypadku co dzisiątego ankietowanego czas ten wyniósłby więcej niż 6 miesięcy, natomiast krócej niż tydzień bez pożyczania obyłoby się 7,0\% uczestników badania.

Uzyskane wyniki świadczą o tym, że większość ankietowanych wprawdzie posiada oszczędności, jednak ich wartość nie byłaby w stanie pokryć długoterminowych trudności finansowych. Uzupełnieniem wcześniejszego pytania była weryfikacja sposobów lokowania wolnych środków pieniężnych przez badanych. Odpowiedzi zawiera rysunek 58.

Badani zapytani o najczęściej wybierany typ lokowania oszczędności (bez względu na to, czy jeszcze takie oszczędności posiadają) najczęściej wpłacali pieniądze na rachunek w banku (35,0\%). Blisko $15 \%$ ankietowanych przyznało, że oszczędności przechowywała w domu (14,6\%). Niespełna 40\% osób w ogóle nie lokowało pieniędzy (nie oszczędzało, nie posiadało środków, aby oszczędzać). 


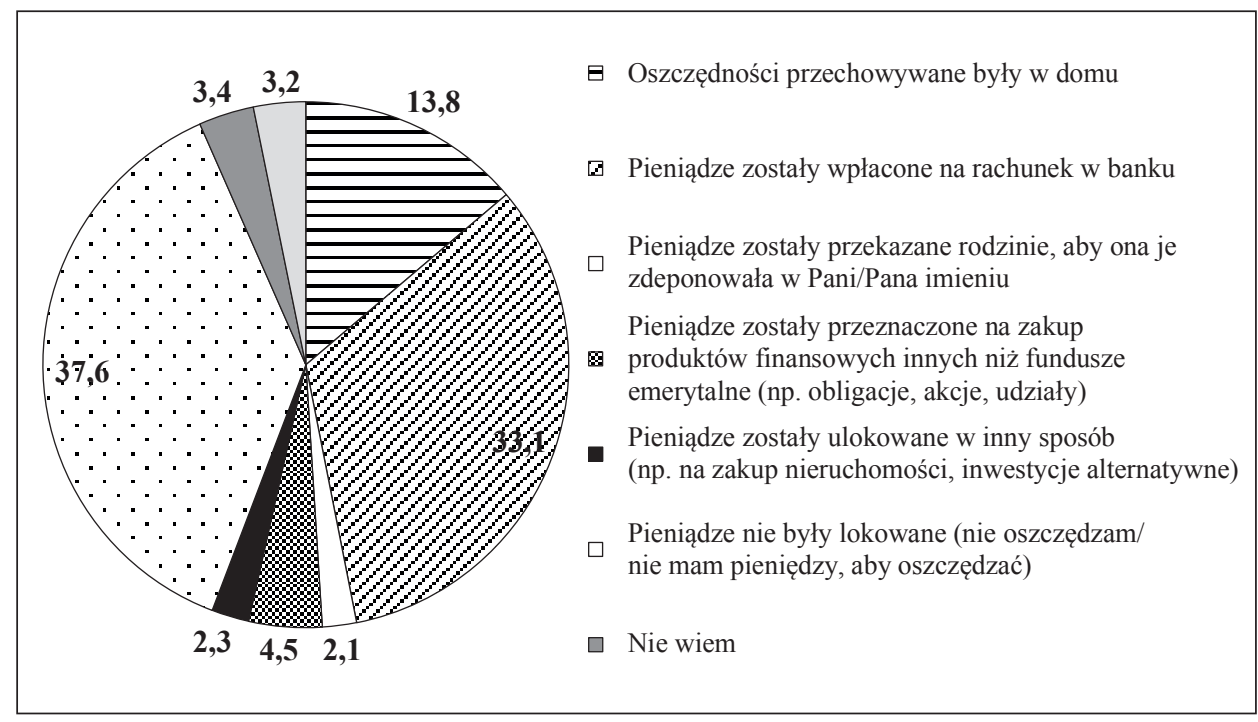

Rysunek 58. Sposoby lokowania oszczędności (w \%)

Źródło: opracowanie własne na podstawie wyników badania kwestionariuszowego

\subsubsection{Subiektywna wiedza finansowa}

Jednym z kluczowych założeń przeprowadzonego badania było zweryfikowanie wiedzy ankietowanych na temat poszczególnych produktów finansowych. Punktem wyjścia do przedstawienia wyników dotyczących poziomu wiedzy finansowej badanych jest kwestia opracowywania budżetu domowego. Można uznać, że stanowi ona pierwszy krok w kierunku świadomego i konsekwentnego zarządzania finansami. Planowanie budżetu polega na bilansowaniu dochodów i wydatków. Właściwe podzielenie posiadanego dochodu na konieczne wydatki pozwala na szacowanie możliwych oszczędności i wcześniejsze przewidywanie deficytu w domowych finansach. Zróżnicowanie badanej populacji ze względu na posiadanie budżetu prezentuje rysunek 59 .

Ponad 59\% uczestników badania przyznało, że ich gospodarstwo domowe posiada budżet $(59,2 \%)$. Blisko $1 / 3$ badanych odpowiedziała przecząco na pytanie o domowy budżet $(31,6 \%)$. Wynik ten jest zbliżony do danych ogólnopolskich. W 2013 r., zgodnie z raportem 68\% gospodarstw domowych planowało wydatki, a $79 \%$ je kontrolowało ${ }^{15}$.

15 TNS Polska, Postawy Polaków wobec oszczędzania, Raport Fundacji Kronenberga przy Citi Handlowy, październik 2013, s. 8. 


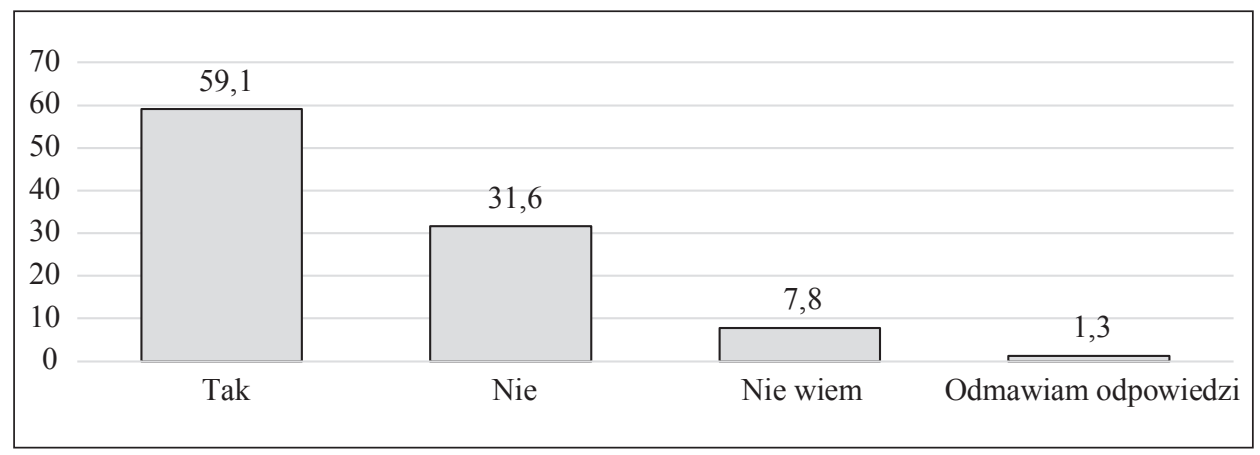

Rysunek 59. Opracowywanie budżetu w gospodarstwie domowym (w \%)

Źródło: opracowanie własne na podstawie wyników badania kwestionariuszowego

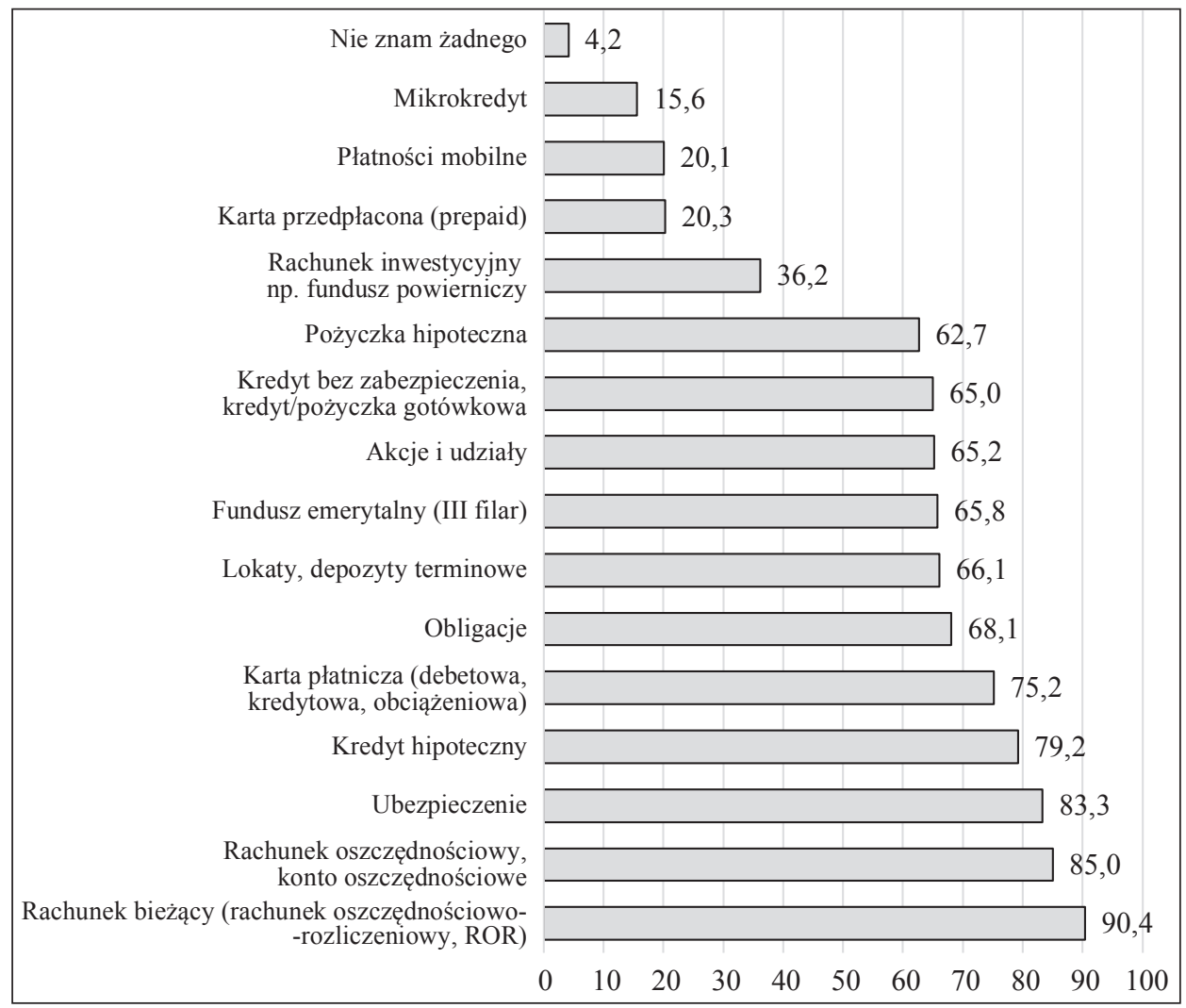

Rysunek 60. Zróżnicowanie badanej zbiorowości ze względu na znajomość produktów finansowych (wielokrotny wybór) (w \%)

Źródło: opracowanie własne na podstawie wyników badania kwestionariuszowego 
Dalszym krokiem w analizie poziomu świadomości finansowej jest weryfikacja znajomości poszczególnych produktów finansowych przez ankietowanych. Zestawienie obrazujące poziom wiedzy na temat poszczególnych produktów i usług finansowych przedstawia rysunek 60 .

W świetle odpowiedzi na pytanie: Czy Pani/Pan słyszała o następujących produktach bankowych - najbardziej znanym produktem okazały się: rachunek bieżący (oszczędnościowo-rozliczeniowy, ROR), rachunek oszczędnościowy (konto oszczędnościowe), ubezpieczenie, kredyt hipoteczny, karta płatnicza. Produkty te uzyskały ponad 3/4 wskazań badanych (odpowiednio: 90,4\%; 85,0\%; $83,3 \% ; 79,2 \% ; 75,2 \%)$. Jest to zgodne z oczekiwanymi rezultatami, gdyż produkty te stanowią podstawę typowej oferty bankowej.

Natomiast stosunkowo najmniej znanymi produktami bankowymi były: mikrokredyt (15,6\%), płatności mobilne $(20,1 \%)$ oraz karta przedpłacona $(20,3 \%)$. Wyniki te mogą być rezultatem obawy osób starszych przed nowoczesnymi technologiami oraz nowościami technologicznymi, które dotyczą płatności bezstykowych, zaś w przypadku płatności mobilnych są kluczowe.

\subsubsection{Zakres i częstotliwość korzystania z produktów bankowych}

Drugim elementem podlegającym analizie $\mathrm{w}$ ramach przeprowadzonego badania kwestionariuszowego była kwestia korzystania z produktów finansowych zarówno w aspekcie zakresu, jak i częstotliwości. Badani zostali zapytani o to, jakie posiadają aktualnie produkty finansowe - osobiście lub wspólnie. Uzyskane wyniki prezentuje rysunek 61 .

Z zebranych danych wynika, że rachunek bieżący (rachunek oszczędnościowo-rozliczeniowy, ROR) okazał się produktem finansowym, który posiadało $77,0 \%$ zbiorowości. Udział osób, które posiadały ubezpieczenie oraz kartę płatniczą oscylował wokół około 40-45\%. Takie produkty jak mikrokredyt, pożyczka hipoteczna, płatności mobilne, kredyt hipoteczny, obligacje nie uzyskały więcej niż 3\% wskazań ankietowanych.

Uzupełnienie analizy aktualnie posiadanych produktów finansowych stanowi statystyka ilości posiadanych obecnie produktów (tablica 50).

Z przeprowadzonych analiz wynika, że badani średnio oraz najczęściej (dominanta) aktualnie posiadali 2 produkty finansowe. Maksymalnie respondenci deklarowali posiadanie 9 produktów finansowych. 


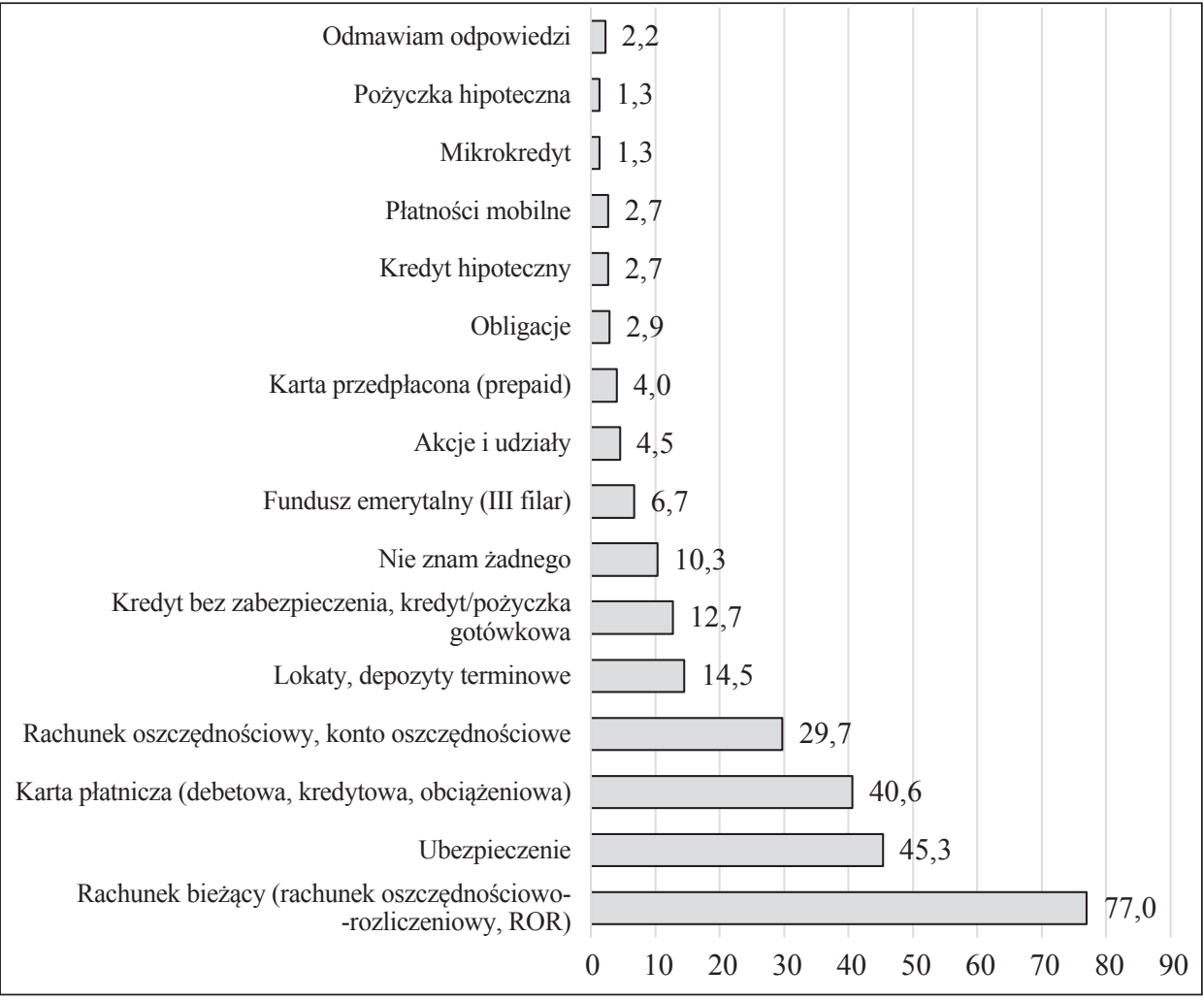

Rysunek 61. Zróżnicowanie badanej zbiorowości ze względu na aktualne posiadanie produktów finansowych (wielokrotny wybór) (w \%)

Źródło: opracowanie własne na podstawie wyników badania kwestionariuszowego

Tablica 50. Statystyka ilości posiadanych (aktualnie) produktów finansowych

\begin{tabular}{|c|c|c|}
\hline $\begin{array}{l}\text { Statystyka - ilość posiadanych } \\
\text { produktów finansowych }\end{array}$ & \multicolumn{2}{|c|}{ Wartości (liczba produktów) } \\
\hline Średnia & \multicolumn{2}{|c|}{2} \\
\hline Mediana & \multicolumn{2}{|c|}{2} \\
\hline Dominanta & \multicolumn{2}{|c|}{2} \\
\hline Odchylenie standardowe & \multicolumn{2}{|c|}{1,690} \\
\hline Minimum & \multicolumn{2}{|c|}{0} \\
\hline Maksimum & \multicolumn{2}{|c|}{9} \\
\hline \multirow[t]{3}{*}{ Kwartyle } & $25 \%$ & 1 \\
\hline & $50 \%$ & 2 \\
\hline & $75 \%$ & 3 \\
\hline
\end{tabular}

Źródło: opracowanie własne na podstawie wyników badania kwestionariuszowego. 
Analiza aktualnie posiadanych produktów finansowych została uzupełniona analizą posiadania produktów finansowych w ciągu 2 ostatnich lat. Oprócz ustalenia, który z produktów finansowych badani posiadali aktualnie (w czasie trwania badania), respondentów zapytano o posiadanie produktów finansowych w ciągu ostatnich dwóch lat (poprzedzających udział w badaniu), niezależnie od tego, czy posiadali go nadal. Zróżnicowanie badanej zbiorowości ze względu na posiadanie produktów finansowych w ciągu 2 ostatnich lat zawiera rysunek 62 .

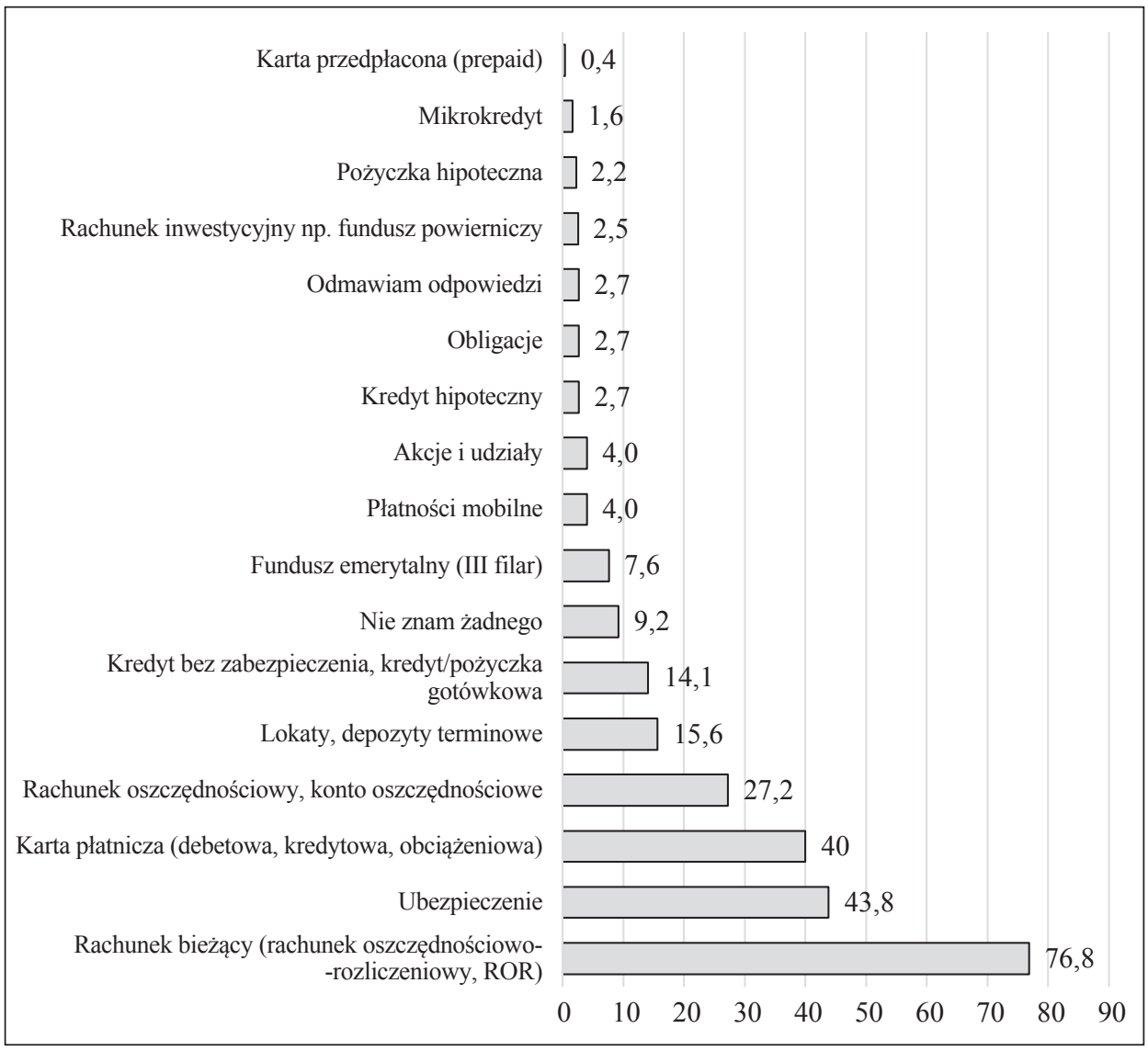

Rysunek 62. Zróżnicowanie badanej zbiorowości ze względu na posiadanie produktów finansowych w ciągu 2 ostatnich lat (wielokrotny wybór) (w \%)

Źródło: opracowanie własne na podstawie wyników badania kwestionariuszowego

Rozkład odpowiedzi uczestników badania przedstawiał się podobnie jak w poprzednim pytaniu - najwięcej wskazań ankietowanych uzyskało posiadanie rachunku bieżącego (76,8\%). Udział wskazań na ubezpieczenie oraz kartę 
płatniczą wynosił około 40-44\%. Mniej niż 3\% wskazań uczestników badania uzyskały takie produkty finansowe, jak mikrokredyt, pożyczka hipoteczna, rachunek inwestycyjny, obligacje, kredyt hipoteczny.

Badani zostali zapytani również o sposób wyboru danego produktu finansowego. Należy dodać, że pytanie to nie było zadawane osobom, które posiadały, aktualnie lub w ciągu 2 lat poprzedzających udział w badaniu, akcje i udziały, obligacje. Zestawienie przedstawiające czynniki wpływające na wybór produktów finansowych zawiera rysunek 63.

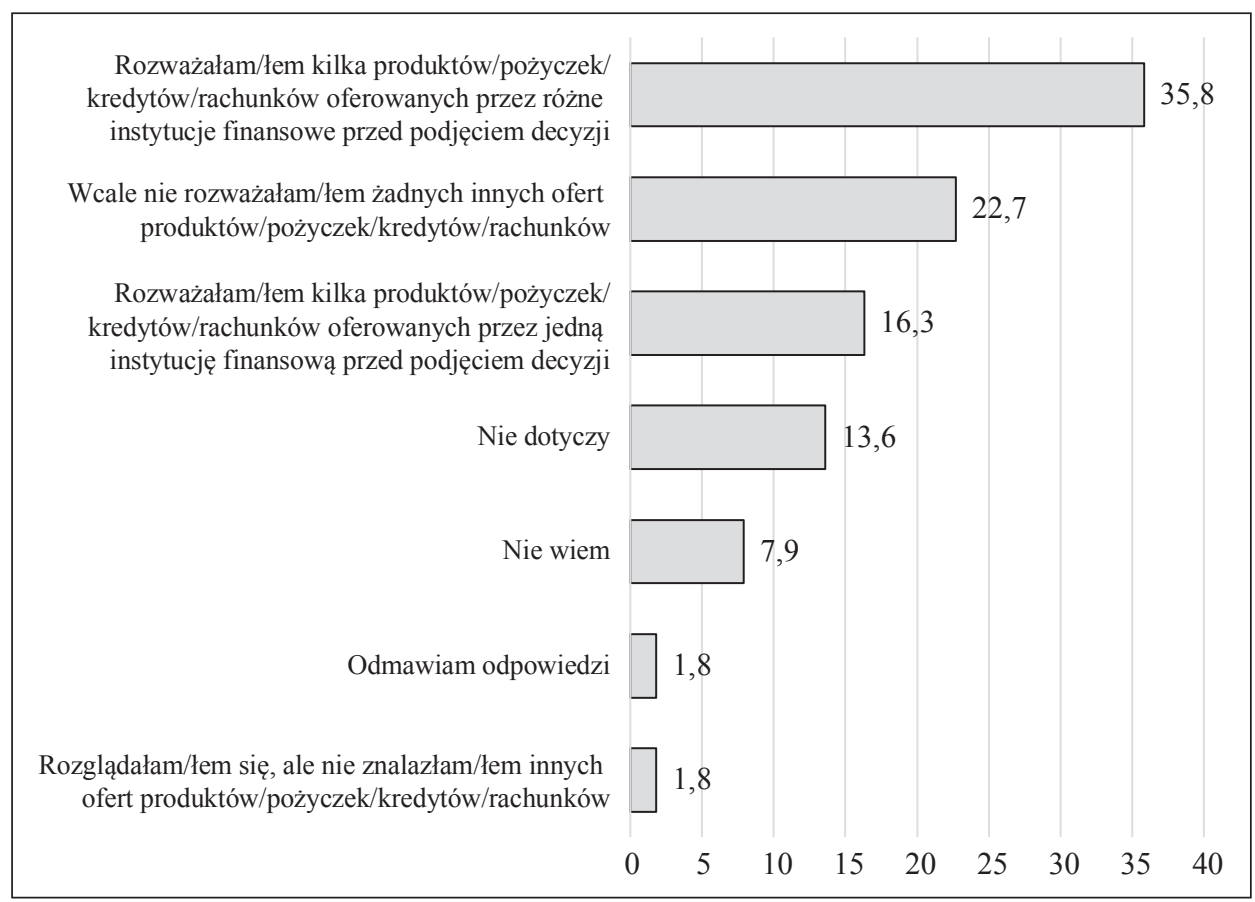

Rysunek 63. Czynniki wpływające na wybór produktów finansowych (poza obligacjami i akcjami, udziałami) (w \%)

Źródło: opracowanie własne na podstawie wyników badania kwestionariuszowego

Niemal 36\% ankietowanych przyznało, że rozważało kilka produktów finansowych oferowanych przez różne instytucje finansowe (35,8\%). Blisko $23 \%$ badanych wcale nie rozważało żadnych innych ofert produktów finansowych $(22,7 \%)$. Około $2 \%$ ankietowanych przyznało, że rozglądało się, ale nie znalazło innych ofert $(1,8 \%)$.

$\mathrm{Na}$ dalszym etapie przeprowadzono analizę między najczęściej aktualnie posiadanymi produktami finansowymi (rachunek bieżący, ubezpieczenie, karta płatnicza, rachunek oszczędnościowy) a sposobami podejmowania decyzji o ich wyborze. Ich zestawienie przedstawia rysunek 64. 


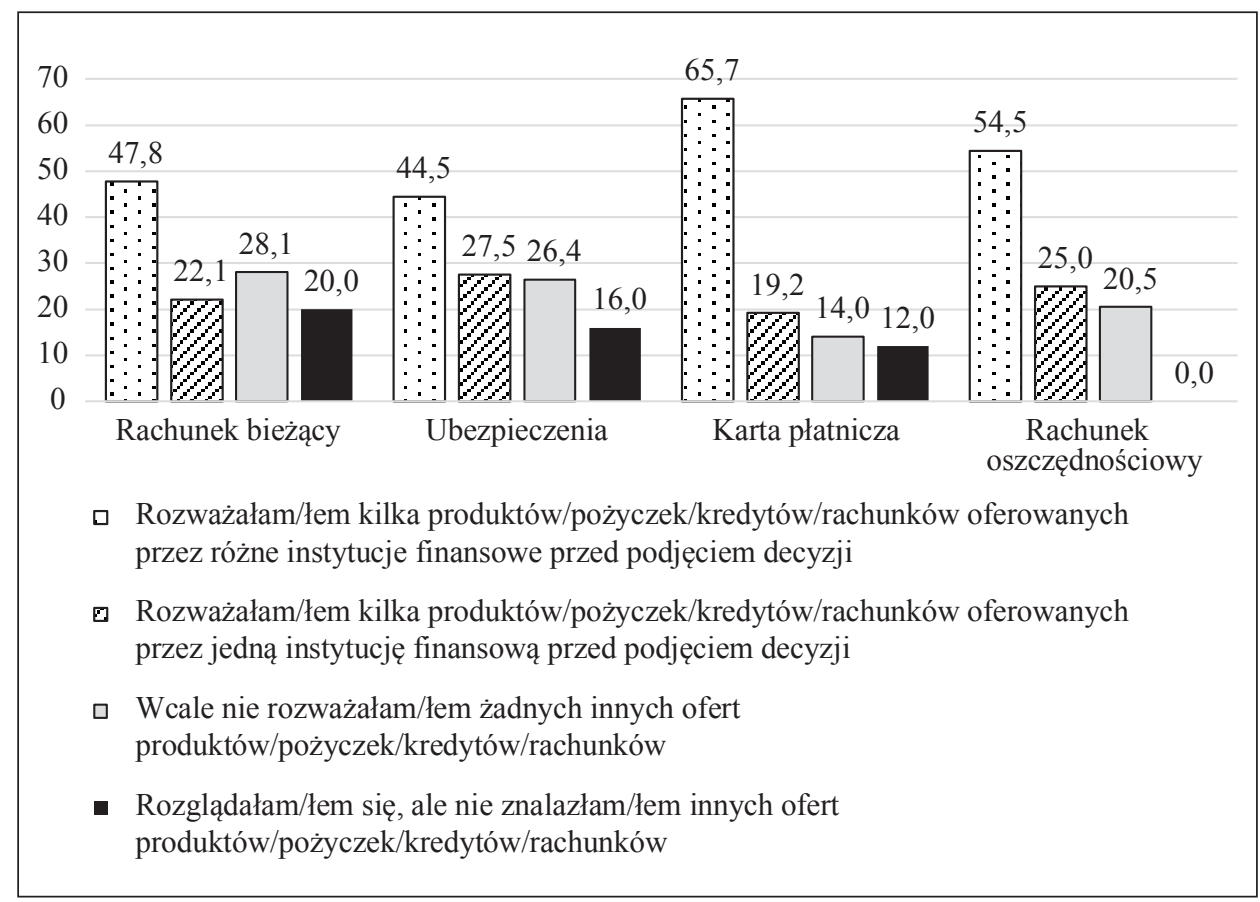

Rysunek 64. Najczęściej aktualnie posiadane produkty finansowe a sposób podejmowania decyzji o ich wyborze (w \%)

Źródło: opracowanie własne na podstawie wyników badania kwestionariuszowego

W przypadku każdego z produktów finansowych - rachunku bieżącego, ubezpieczenia, rachunku oszczędnościowego, karty płatniczej - badani przed podjęciem decyzji o wyborze najczęściej rozważali kilka produktów finansowych oferowanych przez różne instytucje finansowe. Należy dodać, że rozważania te miały największy udział $\mathrm{w}$ wyborze karty płatniczej $(65,7 \%)$. W przypadku rachunku bieżącego $28,1 \%$ osób, które aktualnie posiadały ten produkt, wcale nie rozważało żadnych innych ofert produktów, a nieco ponad $22 \%$ respondentów $\mathrm{z}$ tej grupy przed podjęciem decyzji o wyborze rachunku bieżącego, rozważało kilka produktów oferowanych przez jedną instytucję finansową $(22,1 \%)$.

Wśród badanych, którzy aktualnie byli posiadaczami ubezpieczenia, rozważania nad kilkoma produktami oferowanymi przez jedną instytucję oraz całkowity brak rozważań innych ofert produktów, miały podobny udział wskazań osób z tej zbiorowości oscylujący wokół 26-27\% (odpowiednio: 27,5\% oraz 26,4\%).

Co czwarty respondent, który aktualnie posiadał rachunek oszczędnościowy, przyznał, że przed podjęciem decyzji o wyborze rachunku rozważał kilka produktów oferowanych przez jedną instytucję finansową, a co piąty wcale nie brał pod uwagę innych produktów finansowych. 
Wśród osób, które aktualnie posiadały kartę płatniczą, co piąty badany zanim podjął decyzję o wyborze konkretnej karty, rozważał kilka produktów oferowanych przez jedną instytucję (19,2\%), a 14,0\% wcale nie rozważało innych produktów.

Podobna analiza została przeprowadzona w odniesieniu do produktów finansowych posiadanych przez badanych w ciągu ostatnich 2 lat. Na podstawie analizy między najczęściej posiadanymi produktami finansowymi w ciągu ostatnich 2 lat (rachunek bieżący, ubezpieczenie, karta płatnicza, rachunek oszczędnościowy) a czynnikami wpływającymi na ich wybór sprawdzono, w jaki sposób najczęściej była podejmowana decyzja o ich wyborze. Wyniki przedstawia rysunek 65 .

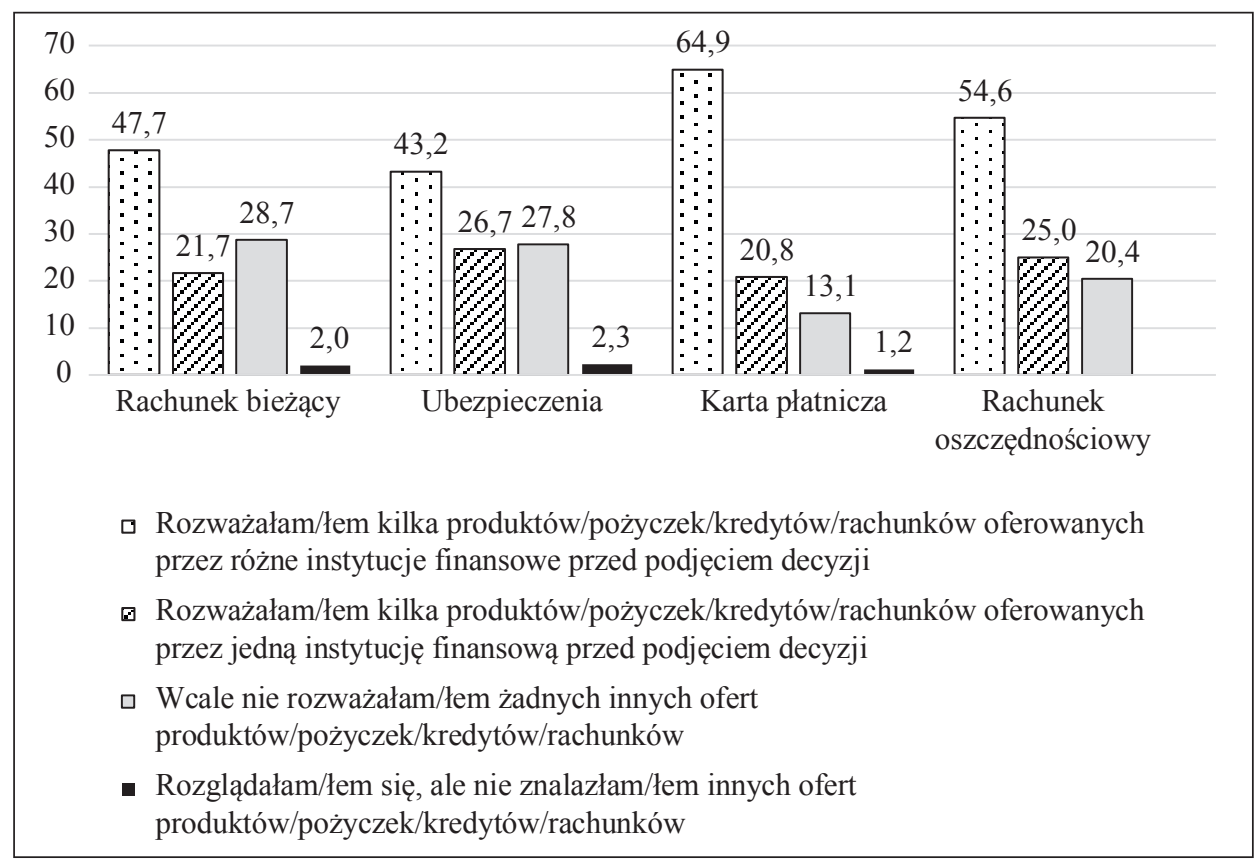

Rysunek 65. Produkty finansowe posiadane w ciągu 2 ostatnich lat a sposób podejmowania decyzji o ich wyborze (w \%)

Źródło: opracowanie własne na podstawie wyników badania kwestionariuszowego

Z przeprowadzonych analiz wynika, że w największym stopniu badani rozważali kilka produktów finansowych oferowanych przez różne firmy przed podjęciem decyzji o wyborze zarówno rachunku bieżącego, ubezpieczenia, rachunku oszczędnościowego oraz karty płatniczej. Sytuacja ta dotyczyła $64,9 \%$ osób posiadających kartę płatniczą, a ponad połowy $(54,6 \%)$ badanych, którzy w ciągu ostatnich 2 lat byli posiadaczami rachunku oszczędnościowego.

W przypadku około $27-28 \%$ osób posiadających w tym czasie rachunek bieżący oraz ubezpieczenia, wcale nie rozważano żadnych innych ofert produktów (odpowiednio: $28,6 \%$ oraz $27,8 \%$ ). Nieco mniejszy udział mieli badani, którzy przed 
wyborem rachunku bieżącego czy ubezpieczenia rozważali kilka produktów oferowanych przez jedną instytucję (odpowiednio $21,7 \%$ oraz $26,7 \%$ ). W przypadku $20,8 \%$ respondentów, którzy w ciągu ostatnich 2 lat posiadali kartę płatniczą, przed podjęciem decyzji o wyborze karty rozważano inne produkty oferowane przez jedną instytucję. Co czwarty posiadacz rachunku oszczędnościowego także rozważał kilka produktów oferowanych przez jedną instytucję, zanim ostatecznie zdecydował się na wybór rachunku, a co piąty wcale nie brał pod uwagę innych ofert.

Weryfikacji poddano źródła informacji, które wpłynęły na decyzję o wyborze danego produktu finansowego. Warto dodać, że pytanie to nie dotyczyło osób, które posiadały (aktualnie lub w ciągu 2 lat od momentu udziału w badaniu) akcje i obligacje, udziały (tablica 51).

Tablica 51. Źródła informacji wpływające na decyzję o wyborze produktów finansowych (wielokrotny wybór)

\begin{tabular}{|c|c|c|}
\hline Rodzaj źródła & Źródło informacji na temat produktów finansowych & Udzial (\%) \\
\hline \multirow{4}{*}{$\begin{array}{l}\text { Podstawowe } \\
\text { informacje } \\
\text { dotyczące } \\
\text { produktu }\end{array}$} & Informacje wysłane pocztą & 6,9 \\
\hline & Informacje pozyskane w oddziale & 44,7 \\
\hline & Informacje znalezione w Internecie & 17,5 \\
\hline & $\begin{array}{l}\text { Informacje pozyskane od pracowników } \\
\text { danej instytucji finansowej }\end{array}$ & 25,5 \\
\hline \multirow[t]{4}{*}{$\begin{array}{l}\text { Porównanie } \\
\text { ofert }\end{array}$} & $\begin{array}{l}\text { Tabele } \mathrm{z} \text { ofertami porównującymi oferty } \\
\mathrm{w} \text { czasopismach/magazynach }\end{array}$ & 3,3 \\
\hline & $\begin{array}{l}\text { Tabele } \mathrm{z} \text { ofertami porównującymi oferty znalezione } \\
\mathrm{w} \text { Internecie }\end{array}$ & 8,0 \\
\hline & Specjalistyczne czasopisma/publikacje & 2,8 \\
\hline & $\begin{array}{l}\text { Rekomendacje od niezależnych doradców } \\
\text { finansowych lub brokerów }\end{array}$ & 3,8 \\
\hline \multirow[t]{3}{*}{$\begin{array}{l}\text { Porady } \\
\text { ogólne }\end{array}$} & $\begin{array}{l}\text { Rady znajomych/przyjaciól/krewnych } \\
\text { (niepracujących w instytucjach finansowych) }\end{array}$ & 33,8 \\
\hline & $\begin{array}{l}\text { Rady znajomych/przyjaciół/krewnych } \\
\text { (pracujących w instytucjach finansowych) }\end{array}$ & 11,6 \\
\hline & Rady pracodawcy & 2,8 \\
\hline \multirow[t]{2}{*}{ Media } & Artykuły w gazetach & 10,4 \\
\hline & Programy telewizyjne/radiowe & 14,9 \\
\hline \multirow[t]{3}{*}{ Reklama } & Reklama w gazetach & 6,6 \\
\hline & Reklama w telewizji & 18,4 \\
\hline & Inny rodzaj reklamy & 4,0 \\
\hline \multirow[t]{5}{*}{ Inne } & Wlasne doświadczenie & 42,6 \\
\hline & Inne źródła & 2,1 \\
\hline & Nie wiem & 2,4 \\
\hline & Nie dotyczy & 11,6 \\
\hline & Odmawiam odpowiedzi & 2,4 \\
\hline
\end{tabular}

Źródło: opracowanie własne na podstawie wyników badania kwestionariuszowego. 
Głównym źródłem informacji wpływających na podjęcie decyzji o wyborze produktu finansowego było pozyskanie informacji w oddziale oraz własne doświadczenie (odpowiednio: 44,7\% oraz 42,6\%). Około 1/3 ankietowanych jako źródło informacji podała porady znajomych/przyjaciół/krewnych niepracujących w instytucjach finansowych. Co czwarty badany wskazał na informacje pozyskane od pracowników danej instytucji finansowej $(25,5 \%)$. Reklama w telewizji stanowiła źródło informacji dla 18,4\% zbiorowości. Reasumując, podstawowe informacje dotyczące produktu, porady ogólne, własne doświadczenie (kategoria inne) oraz reklama w największym stopniu wpłynęły na decyzję o wyborze produktów finansowych.

Pogłębionej analizie zostały poddane podstawowe produkty finansowe, pod kątem wykorzystania przy ich wyborze źródła informacji o danym produkcie. Na podstawie rezultatów analizy między aktualnie posiadanymi poszczególnymi produktami finansowymi oraz źródłami informacji o produkcie sprawdzono, jakie źródła informacji najczęściej wskazywali posiadacze poszczególnych produktów. Odpowiednie zestawienie przedstawia tablica 52.

Tablica 52. Aktualne posiadanie produktu finansowego a źródło informacji o produkcie (wielokrotny wybór - maksymalnie 5 odpowiedzi) (w \%)

\begin{tabular}{|l|c|c|c|c|}
\hline \multicolumn{1}{|c|}{ Źródło informacji } & $\begin{array}{c}\text { Rachunek } \\
\text { bieżący }\end{array}$ & Ubezpieczenia & $\begin{array}{c}\text { Rachunek } \\
\text { oszczędnościowy }\end{array}$ & $\begin{array}{c}\text { Karta } \\
\text { platnicza }\end{array}$ \\
\hline \multicolumn{1}{|c|}{ 1 } & 2 & 3 & 4 & 5 \\
\hline Informacje pozyskane w oddziale & $\mathbf{5 0 , 8}$ & $\mathbf{5 3 , 2}$ & $\mathbf{5 0}$ & $\mathbf{6 4 , 2}$ \\
\hline Wlasne doświadczenie & $\mathbf{4 8 , 0}$ & $\mathbf{5 5 , 2}$ & $\mathbf{5 3}$ & $\mathbf{6 3 , 7}$ \\
\hline $\begin{array}{l}\text { Rady znajomych/przyjaciół/ } \\
\text { krewnych (niepracujących } \\
\text { w instytucjach finansowych) }\end{array}$ & $\mathbf{3 6 , 2}$ & $\mathbf{3 6 , 3}$ & $\mathbf{3 5 , 6}$ & $\mathbf{3 4 , 6}$ \\
\hline $\begin{array}{l}\text { Informacje pozyskane } \\
\text { od pracowników danej } \\
\text { instytucji finansowej }\end{array}$ & $\mathbf{2 9 , 5}$ & $\mathbf{3 8 , 3}$ & $\mathbf{3 8 , 6}$ & $\mathbf{3 1 , 8}$ \\
\hline Informacje znalezione w Internecie & 20,4 & 22,4 & 28,8 & 25,7 \\
\hline Reklama w telewizji & 17,3 & 11,4 & 17,4 & 9,5 \\
\hline Programy telewizyjne/radiowe & 14,3 & 15,4 & 19,7 & 8,4 \\
\hline $\begin{array}{l}\text { Rady znajomych/przyjaciół/ } \\
\text { krewnych (pracujących } \\
\text { w instytucjach finansowych) }\end{array}$ & 12,5 & 13,4 & 18,2 & 14 \\
\hline Artykuły w gazetach & & & 1,2 & 13,4 \\
\hline $\begin{array}{l}\text { Tabele z ofertami porównującymi } \\
\text { oferty znalezione w Internecie }\end{array}$ & 10,0 & 11,9 & 15,2 & 13,4 \\
\hline Reklama w gazetach & 6,7 & 1,5 & 3,8 & 4,5 \\
\hline Informacje wysłane pocztą & 6,4 & 6,5 & 9,1 & 7,3 \\
\hline Nie dotyczy & 6,4 & 5 & & 1,5 \\
\hline
\end{tabular}




\begin{tabular}{|l|c|c|c|c|}
\hline \multicolumn{1}{|c|}{1} & 2 & 3 & 4 & 5 \\
\hline Inny rodzaj reklamy & 4,3 & 4 & 6,1 & 1,7 \\
\hline $\begin{array}{l}\text { Tabele z ofertami porównującymi } \\
\text { oferty w czasopismach/ } \\
\text { magazynach }\end{array}$ & 3,3 & 4 & 6,8 & 4,5 \\
\hline Rady pracodawcy & 3,3 & 1,5 & 3 & 2,8 \\
\hline $\begin{array}{l}\text { Specjalistyczne czasopisma/ } \\
\text { publikacje }\end{array}$ & 3,0 & 4,5 & 3,8 & 2,8 \\
\hline $\begin{array}{l}\text { Rekomendacje od niezależnych } \\
\text { doradców finansowych } \\
\text { lub brokerów }\end{array}$ & 3,0 & 6,5 & 6,1 & 4,5 \\
\hline Inne źródła & 1,8 & 1,5 & 0,8 & 1,7 \\
\hline Odmawiam odpowiedzi & 1,2 & 1 & 1,5 & 0 \\
\hline Nie wiem & 0,9 & 1,5 & 0,8 & 0 \\
\hline
\end{tabular}

Źródło: opracowanie własne na podstawie wyników badania kwestionariuszowego.

Decyzja o wyborze każdego z analizowanych produktów podejmowana była w oparciu o takie same źródła informacji. Należy wśród nich wskazać na:

- informacje pozyskane w oddziale,

- własne doświadczenie,

- rady znajomych/przyjaciół/krewnych (niepracujących w instytucjach finansowych),

- informacje pozyskane od pracowników danej instytucji finansowej.

Na podkreślenie zasługuje, iż praktycznie w równym stopniu decydującą rolę wywierały informacje pochodzące bezpośrednio z instytucji finansowej (zarówno z oddziału, jak i od pracownika instytucji finansowej) oraz informacje pozyskiwane na własną rękę przez badanych, bazujące na ich doświadczeniu lub poradzie osób najbliższych niezwiązanych z instytucjami finansowymi zawodowo.

W przypadku rachunku bieżącego połowa badanych przyznała, że w największym stopniu na wybór rachunku bieżącego wpłynęły informacje pozyskane w oddziale $(50,8 \%)$. Własne doświadczenie wskazało $48,0 \%$ badanych, natomiast rady znajomych/przyjaciót/krewnych - 36,2\%. Informacje pozyskane od pracowników danej instytucji finansowej stanowiły źródło informacji dla 29,5\% respondentów. Dla co piątego uczestnika badania ważne okazały się informacje znalezione w Internecie $(20,4 \%)$, a dla co dzisiątego - tabele $\mathrm{z}$ ofertami porównującymi oferty znalezione w Internecie (10,0\%). Badani mogli wskazać maksymalnie 5 odpowiedzi.

Analizie poddano także aktualne posiadanie ubezpieczenia względem źródeł informacji o produktach finansowych, dzięki czemu sprawdzono, jakie źródła w największym stopniu wpłynęły na decyzję o wyborze ubezpieczenia. W przypadku około połowy badanych źródłem informacji o ubezpieczeniach było własne doświadczenie $(55,2 \%)$ oraz informacje pozyskane w oddziale $(53,2 \%)$. Informacje pozyskane od pracowników danej instytucji finansowej stanowiły źródło 
informacji dla 38,3\% respondentów. Niewiele mniejszy udział/wpływ na podjęcie decyzji związanej z posiadaniem ubezpieczenia miały rady znajomych/przyjaciół/ krewnych $(36,3 \%)$.

W przypadku 22,4\% uczestników badania to informacje znalezione w Internecie okazały się znaczące przy wyborze ubezpieczenia. Znalezione w Internecie tabele porównawcze $\mathrm{z}$ ofertami stanowiły źródło wiedzy dla 11,9\% badanych, a niewiele mniejszy udział wskazań miała reklama w telewizji.

$\mathrm{Na}$ podstawie analizy między aktualnym posiadaniem karty płatniczej oraz źródłami informacji o produktach finansowych wykazano, jakie źródła informacji miały największy wpływ na podjęcie decyzji o wyborze karty płatniczej. W większości przypadków informacje pozyskane w oddziale oraz własne doświadczenie wpłynęły na decyzję badanych o wyborze karty płatniczej (odpowiednio: 64,2\% oraz $63,7 \%$ ). W przypadku około $1 / 3$ respondentów znaczące okazały się rady znajomych/przyjaciół/krewnych (34,6\%). Niewiele mniejszy udział/wpływ miały informacje pozyskane od pracowników danej instytucji finansowej $(31,8 \%)$. Na wybór karty płatniczej w przypadku co czwarty respondenta miały informacje znalezione w Internecie $(25,7 \%)$. Co dziesiąty uczestnik badania wskazał na reklamę w telewizji jako źródło, które miało wpływ na decyzję o wyborze karty płatniczej $(9,5 \%)$.

Poprzez analizę odpowiedzi badanych na pytanie dotyczące aktualnie posiadanych produktów finansowych względem źródła informacji o produktach finansowych zweryfikowano to, jakie źródła w największym stopniu miały wpływ na decyzję o wyborze rachunku oszczędnościowego. Ponadto, ponad połowa badanych przyznała, że na wybór rachunku oszczędnościowego miało wpływ własne doświadczenie, a blisko połowa, że były to też informacje pozyskane w oddziale (odpowiednio: $53,0 \%$ oraz $50,0 \%$ ). Informacje pozyskane od pracowników danej instytucji finansowej okazały się znaczące dla 38,6\% respondentów, a rady znajomych/przyjaciół/krewnych dla 35,6\% grupy. Dla co piątego badanego istotny wpływ na podjęcie decyzji o wyborze rachunku oszczędnościowego miały programy telewizyjne/radiowe $(19,7 \%)$, a dla co dziesiątego informacje wysłane pocztą $(9,1 \%)$.

Dodatkowej analizie została poddana grupa osób wykluczonych finansowo. Z przedstawionych powyżej statystyk wynika, że $8,9 \%$ respondentów nie posiadało żadnego produktu finansowego. Widoczne było jednak zróżnicowanie tej grupy ze względu na:

- wiek,

- miejsce zamieszkania,

- wykształcenie,

- sytuację zawodową,

- dochód netto.

Pierwszym z kryteriów branych pod uwagę był wiek. Zróżnicowanie osób nieposiadających produktów finansowych pod względem wieku przedstawia tablica 53. 
Tablica 53. Statystyka osób nieposiadających produktów finansowych pod względem wieku

\begin{tabular}{|c|c|c|}
\hline Statystyka & \multicolumn{2}{|c|}{ Wiek (liczba lat) } \\
\hline Średnia & \multicolumn{2}{|c|}{67,79} \\
\hline Mediana & \multicolumn{2}{|c|}{65} \\
\hline Dominanta & \multicolumn{2}{|c|}{82} \\
\hline Odchylenie standardowe & \multicolumn{2}{|c|}{11,632} \\
\hline Minimum & \multicolumn{2}{|c|}{53} \\
\hline Maksimum & \multicolumn{2}{|c|}{89} \\
\hline \multirow[t]{3}{*}{ Kwartyle } & $25 \%$ & 58 \\
\hline & $50 \%$ & 65 \\
\hline & $75 \%$ & 79 \\
\hline
\end{tabular}

Źródło: opracowanie własne na podstawie wyników badania kwestionariuszowego.

Średnia wieku badanych nieposiadających produktów finansowych wynosiła około 68 lat ( \pm 11,632 lat). Co ważne, wśród ankietowanych nieposiadających produktów finansowych dominowały osoby 82-letnie (dominanta). Najmłodszy respondent nieposiadający produktów finansowych miał 53 lata, a najstarszy 89 lat. Warto dodać, że dzieląc badanych na 4 grupy liczące po $25 \%$ jednostek, pierwszą grupę stanowili respondenci do 58. roku życia, kolejną - od 58 lat do 65 lat. Trzecią grupę stanowiły osoby do 79. roku życia, a ostatnią od 79 lat do 89 lat.

Drugą analizowaną determinantą w przypadku osób wykluczonych finansowo było miejsce zamieszkania. Wyniki analiz prezentuje rysunek 66.

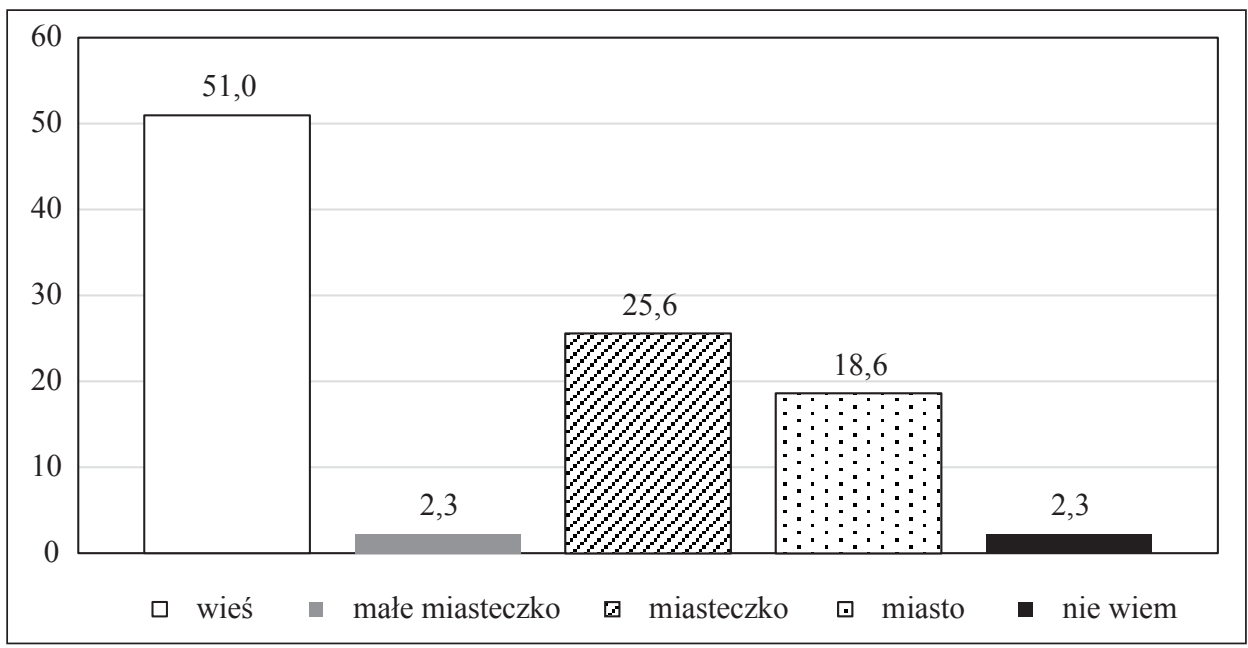

Rysunek 66. Wykluczeni finansowo a miejsce zamieszkania (w \%)

Źródło: opracowanie własne na podstawie wyników badania kwestionariuszowego 
Jak wynika ze zgromadzonych danych, ponad połowa osób nieposiadających produktów finansowych zamieszkiwała tereny wiejskie $(51,2 \%)$. Około 1/4 badanych wykluczonych finansowo mieszkała w miasteczkach liczących 15 000-100 000 mieszkańców (25,6\%). Warto zauważyć, że część respondentów nie potrafiła prawidłowo zaklasyfikować wielkości zamieszkiwanej miejscowości.

Kolejnym rozważanym kryterium w grupie osób powyżej 50. roku życia, niekorzystających z produktów finansowych było wykształcenie. Relację między wykształceniem a wykluczeniem finansowym przedstawia rysunek 67.

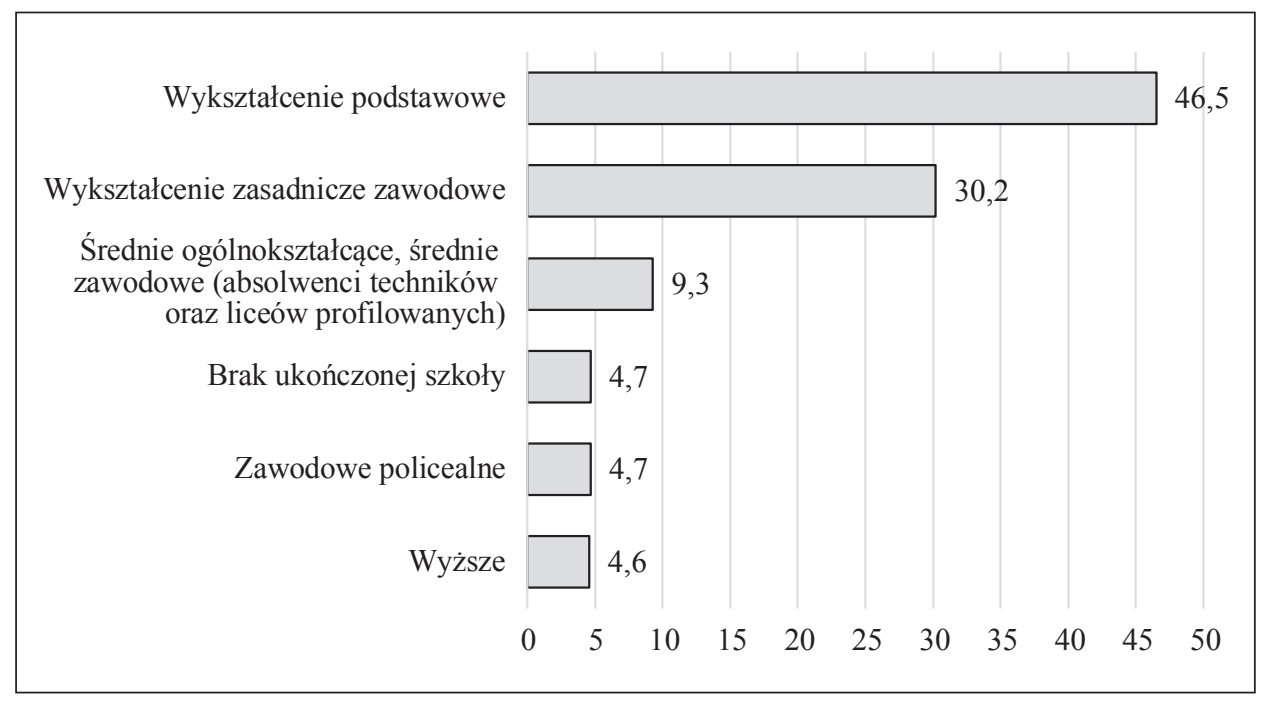

Rysunek 67. Wykluczeni finansowo a wykształcenie (w \%)

Źródlo: opracowanie własne na podstawie wyników badania kwestionariuszowego

Z przeprowadzonych analiz należy wnioskować, że badani nieposiadający produktów finansowych najczęściej posiadali wykształcenie podstawowe (46,5\%). Około $1 / 3$ respondentów stanowiły osoby $z$ wykształceniem zasadniczym zawodowym (30,2\%). Jedynie 4,6 osób z wykształceniem wyższym była wykluczona finansowo.

Czwartym czynnikiem różnicującym grupę osób wykluczonych finansowo okazała się sytuacja zawodowa. Wyniki analiz prezentuje rysunek 68 .

Najbardziej liczną grupę osób wykluczonych finansowo stanowiły osoby na emeryturze (było to aż 46,5\%). Co dziesiąty badany był bezrobotny. Ważny jest również fakt, że żaden $\mathrm{z}$ respondentów nieposiadający produktów finansowych nie prowadził własnej działalności gospodarczej.

Ostatnim z czynników determinujących wykluczenie był dochód. Odpowiednie zestawienie prezentuje rysunek 69 . 


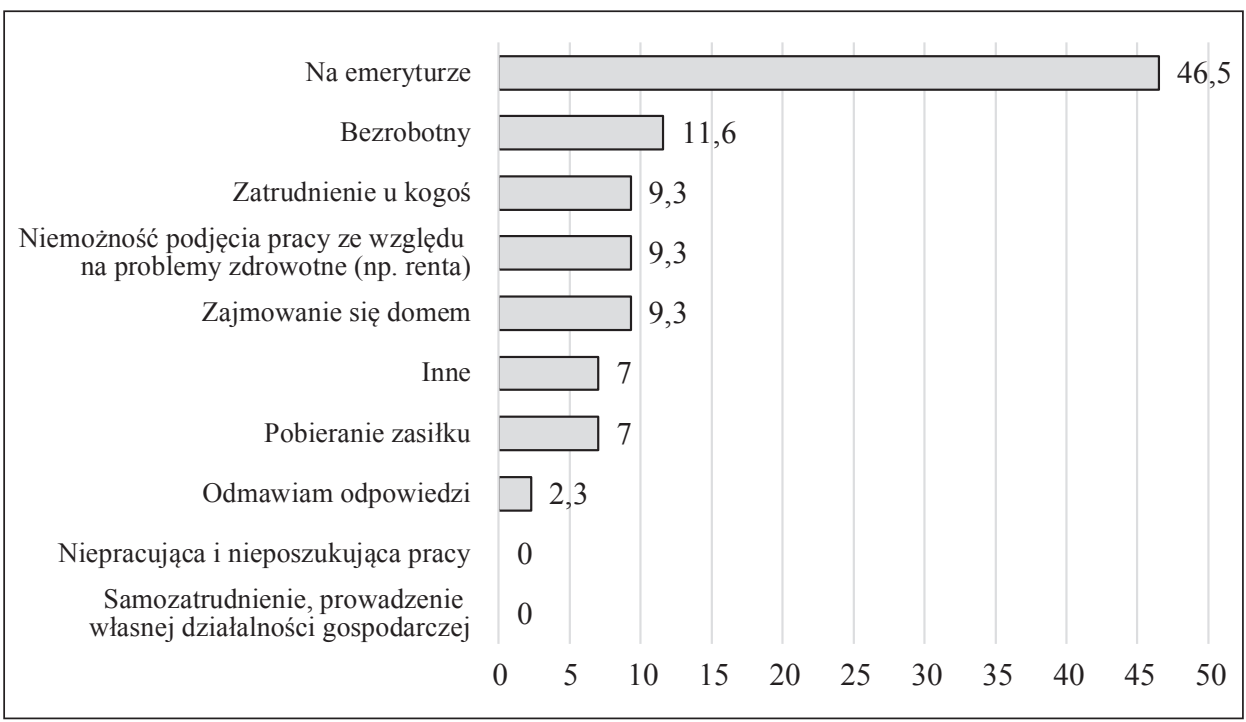

Rysunek 68. Wykluczeni finansowo a status zawodowy (w \%)

Źródło: opracowanie własne na podstawie wyników badania kwestionariuszowego

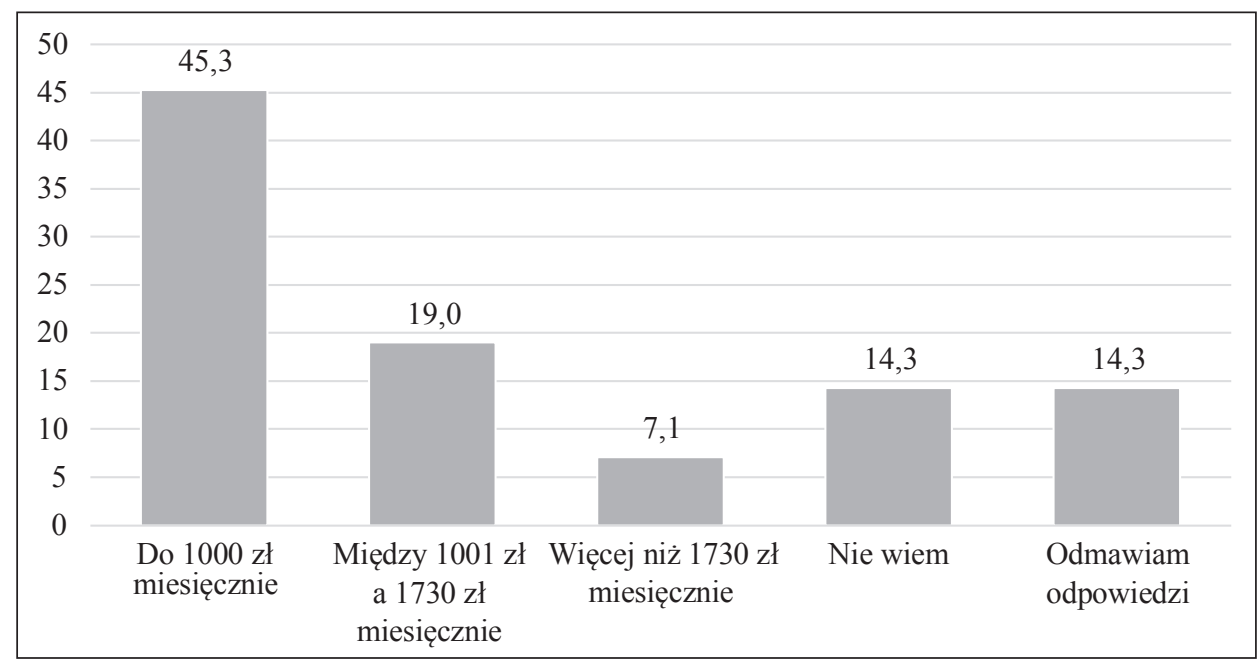

Rysunek 69. Wykluczeni finansowo a dochód netto (w \%)

Źródło: opracowanie własne na podstawie wyników badania kwestionariuszowego

Biorąc pod uwagę dochody netto osób nieposiadających produktów finansowych, większość z nich zadeklarowała dochód na poziomie poniżej 1000 zł miesięcznie $(45,3 \%)$. Blisko $1 / 5$ respondentów posiadała dochody w granicach 
1001-1730 zł netto (19,0\%). Można zauważyć, że wraz z mniejszym dochodem netto badanych liczba osób wykluczonych finansowo zmniejszała się.

Podsumowując wyniki analizy czynników wpływających na wykluczenie finansowe osób powyżej 50. roku życia, takich jak wiek, miejsce zamieszkania, wykształcenie, status zawodowy, miesięczny dochód, udało się potwierdzić prawidłowości wskazywane we wcześniejszej części monografii. Zgodnie z nimi na wykluczenie finansowe najbardziej narażone są osoby o najniższych dochodach, zamieszkujące tereny wiejskie, niewykształcone, najbardziej zaawansowane wiekowo. W przypadku respondentów z województwa łódzkiego, zgodnie z oczekiwaniami, osobami wykluczonymi finansowo okazały się być osoby, które posiadały wykształcenie podstawowe $(46,5 \%)$ i osoby z wykształceniem zasadniczym zawodowym $(30,2 \%)$, zamieszkujące tereny wiejskie $(51,2 \%)$ i niewielkie miasteczka $(25,6 \%)$, osiągające miesięczne dochody netto nieprzekraczające $1000 \mathrm{zł}(45,3 \%)$. Średnia wieku badanych wykluczonych finansowo wynosiła około 68 lat, a wśród ankietowanych nieposiadających produktów finansowych dominowały osoby 82-letnie.

\subsection{Identyfikacja zależności między poszczególnymi determinantami wykluczenia bankowego a wiedzą finansową}

\subsubsection{Wskaźnik wiedzy finansowej teoretycznej}

W przeprowadzonym badaniu określeniem ,wiedza finansowa” zdefiniowano poziom informacji posiadanych przez badanych z zakresu finansów. Obszar „wiedzy finansowej” podzielono na część praktyczną i teoretyczną, przypisując im określone wskaźniki. Wskaźnikami „wiedzy finansowej - teoretycznej” uznano zagadnienia typu ,prawda-fałsz" (5 zagadnień) i na podstawie odpowiedzi badanych było możliwe określenie poziomu wiedzy finansowej (teoretycznej).

W ramach badania poziomu wiedzy teoretycznej zadanych zostało 5 pytań:

1. Proszę odpowiedzieć czy Pani/Pana zdaniem poniższe stwierdzenia są prawdziwe czy fałszywe: „Inwestycja o wysokiej stopie zwrotu charakteryzuje się wysokim ryzykiem"16.

2. Gdyby ktoś Pani/Panu zaoferował szansę zarobienia dużych pieniędzy, czy jednocześnie postrzega to Pani/Pan jako możliwość stracenia dużej kwoty pieniędzy?

${ }^{16}$ Pytanie 1 i 2 dotyczą kwestii ryzyka, ale w pytaniu 1 użyto wprost tego pojęcia, zaś w pytaniu 2 opisano go. 
3. Czy Pani/Pana zdaniem wysoka inflacja oznacza, że koszty życia gwałtowanie wzrastają?

4. Czy Pani/Pana zdaniem zazwyczaj istnieje możliwość ograniczenia ryzyka podczas inwestowania na giełdzie poprzez zakup różnych akcji?

5. Czy Pani/Pana zdaniem istnieje wyższe prawdopodobieństwo stracenia wszystkich pieniędzy, jeśli są one przechowywane wszystkie w jednym miejscu?

Ankietowani w zróżnicowany sposób udzielali odpowiedzi na zadane pytania. Rozkład wyników odpowiedzi udzielonych na poszczególne pytania z uwzględnieniem ich prawidłowości przedstawia tablica 54.

Tablica 54. Wyniki odpowiedzi na pytania dotyczące wiedzy finansowej - część teoretyczna (w \%)

\begin{tabular}{|l|c|c|c|c|c|}
\hline Udzielona odpowiedź & Pytanie 1 & Pytanie 2 & Pytanie 3 & Pytanie 4 & Pytanie 5 \\
\hline Prawdziwa & $\mathbf{6 0 , 8}$ & $\mathbf{5 8 , 6}$ & $\mathbf{8 0}$ & $\mathbf{4 6 , 4}$ & $\mathbf{7 1 , 3}$ \\
\hline Fałszywa & 33,3 & 26,1 & 4,3 & 44,4 & 22,2 \\
\hline Nie wiem & 3,8 & 14,4 & 15 & 7,6 & 6,3 \\
\hline Odmawiam odpowiedzi & 2,1 & 0,9 & 0,7 & 1,6 & 0,2 \\
\hline
\end{tabular}

Źródło: opracowanie własne na podstawie wyników badania kwestionariuszowego.

Generalnie widoczne jest znaczne zróżnicowanie prawidłowości udzielanych odpowiedzi. Najwięcej prawidłowych odpowiedzi zostało udzielonych na pytanie nr 3 i 5, na dalszym miejscu znalazło się pytanie nr 1 i 2 (wyniki bardzo zbliżone ze względu na podobieństwo tych pytań). Zdecydowanie największe trudności sprawiło udzielnie prawidłowej odpowiedzi na pytanie 4, które wymagało znajomości pojęcia ryzyka oraz podstaw specyfiki inwestowania na giełdzie papierów wartościowych.

Prawidłowej odpowiedzi na sformułowanie dotyczące inwestycji o wysokiej stopie zwrotu udzieliło $60,8 \%$ badanych. Brakiem wiedzy na ten temat charakteryzowało się $33,3 \%$ ankietowanych. O tym, że szansa zarobienia dużych pieniędzy wiąże się z możliwością stracenia dużej kwoty, wiedziało 58,6\% badanych. Zdecydowana większość ankietowanych znała prawidłową odpowiedź na zagadnienie nr 3 dotyczące konsekwencji wysokiej inflacji. Ponad 46\% uczestników badania nie wiedziało, czy istnieje możliwość ograniczenia ryzyka podczas inwestowania na giełdzie poprzez zakup różnych akcji (46,4\%). Prawidłową odpowiedź na to zagadnienie znało 44,4\% badanych. Zdecydowana większość osób wiedziała, że wyższe prawdopodobieństwo stracenia wszystkich pieniędzy występuje w sytuacji, gdy są one przechowywane wszystkie w jednym miejscu $(71,3 \%)$.

Dalszej analizie zostało poddane zróżnicowanie prawidłowości udzielanych odpowiedzi na pytania teoretyczne $\mathrm{z}$ wiedzy finansowej w zależności od następujących kryteriów: 
- płci,

- miejsca zamieszkania,

- wieku,

- wykształcenia,

- miesięcznego dochodu netto.

Pierwszym kryterium różnicującym zbiorowość osób, które udzieliły prawidłowej odpowiedzi na 5 pytań teoretycznych była płeć. Zestawienie pogłębionej analizy przedstawia rysunek 70 .

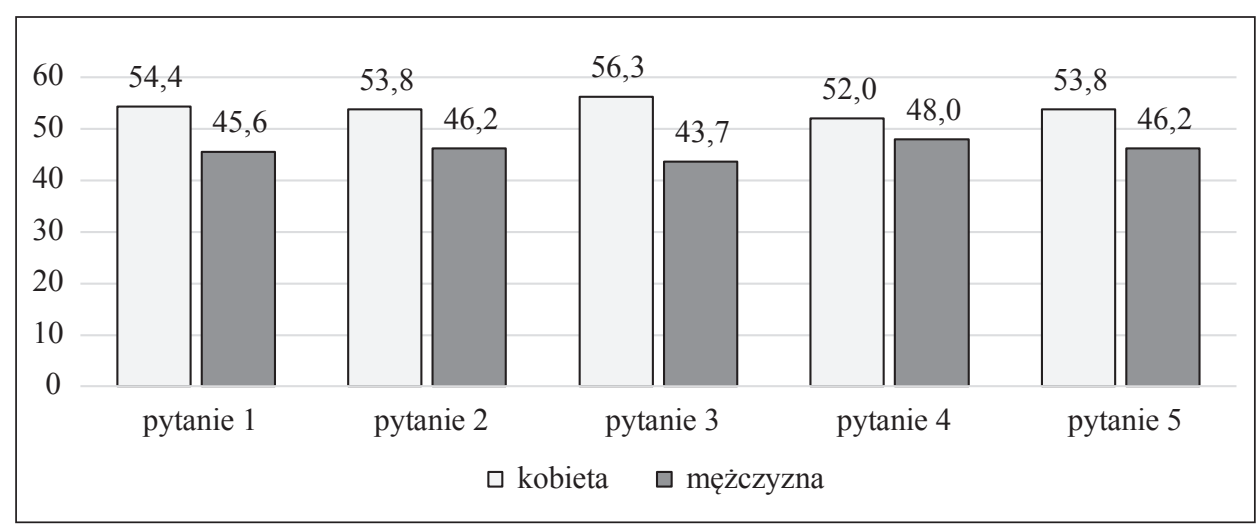

Rysunek 70. Wiedza finansowa - teoretyczna a płeć badanych (w \%)

Źródło: opracowanie własne na podstawie wyników badania kwestionariuszowego

W rezultacie przeprowadzonych analiz stwierdzono, że częściej kobiety udzielały prawidłowej odpowiedzi w przypadku każdego z zagadnień testu wiedzy finansowej teoretycznej - udział kobiet udzielających poprawnych wskazań oscylował wokół około 52-56\%.

Drugą analizowaną determinantą w przypadku prawidłowo udzielonych odpowiedzi na pytania teoretyczne z wiedzy finansowej było miejsce zamieszkania. Wyniki analiz prezentuje rysunek 71 .

Z przeprowadzonych analiz pomiędzy wskaźnikami wiedzy finansowej teoretycznej oraz miejscem zamieszkania badanych wynika, że największy udział badanych, którzy udzielili poprawnej odpowiedzi na pytania testu wiedzy teoretycznej, przypadało na mieszkańców wsi oraz większych miast (po około 30-35\%) ${ }^{17}$.

Trzecim kryterium różnicującym zbiorowość, która udzieliła prawidłowych odpowiedzi w teście wiedzy teoretycznej, był wiek. Zestawienie wyników ujmuje rysunek 72 .

${ }^{17}$ Zdarzyły się sporadyczne przypadki, że osoba nie była w stanie dopasować miejsca zamieszkania do odpowiedniej kategorii wielkości. 


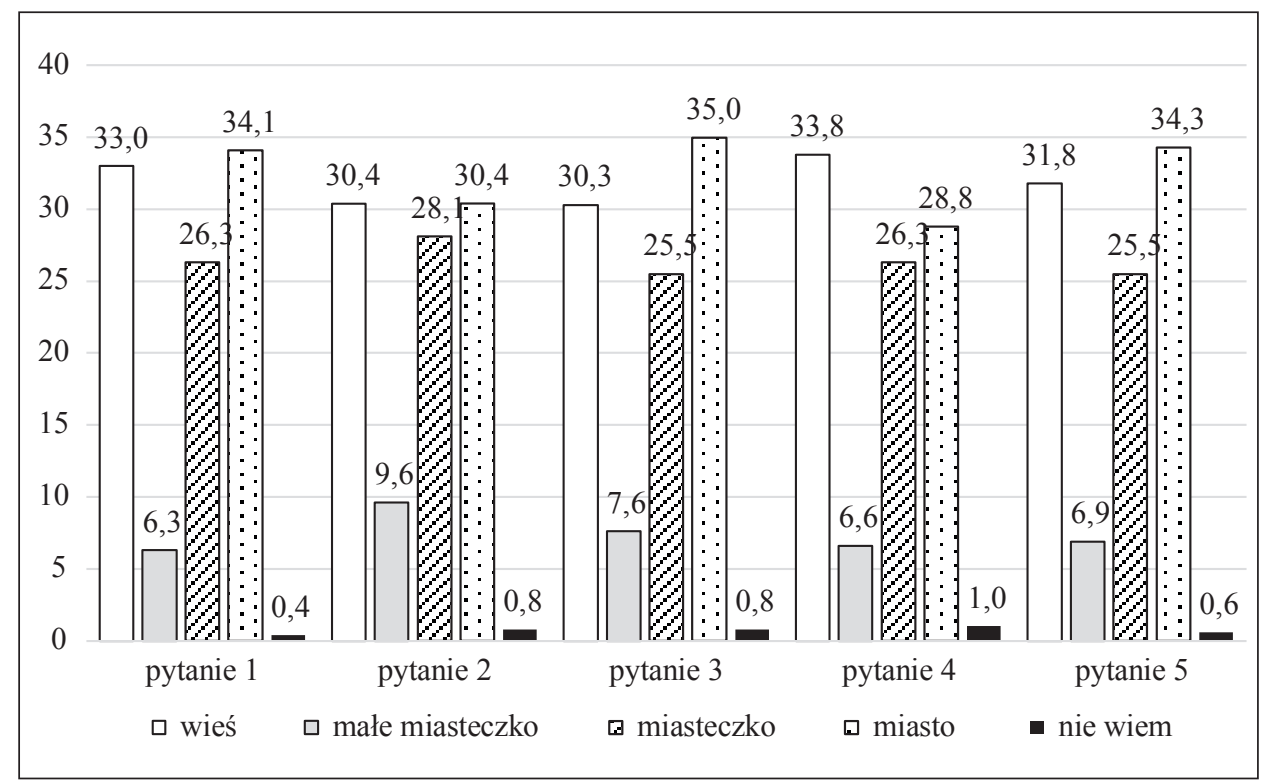

Rysunek 71. Wiedza finansowa - teoretyczna a miejsce zamieszkania badanych (w \%)

Źródło: opracowanie własne na podstawie wyników badania kwestionariuszowego

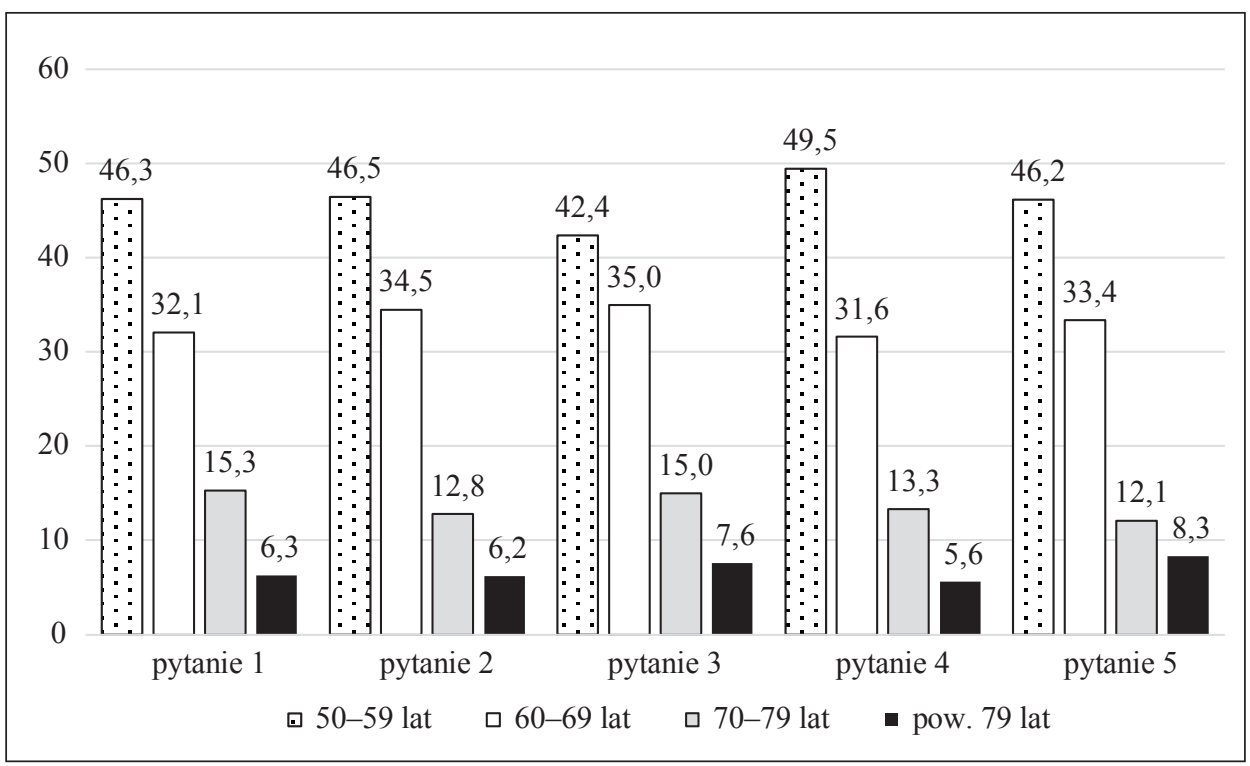

Rysunek 72. Wiedza finansowa - teoretyczna a wiek badanych (w \%)

Źródło: opracowanie własne na podstawie wyników badania kwestionariuszowego 
Analizując zróżnicowanie wiekowe badanych i ich poziom wiedzy finansowej teoretycznej, stwierdzono, że to osoby najmłodsze, tj. w wieku od 50 do 59 lat, najczęściej wskazywały poprawne odpowiedzi. Wyraźnie widoczna była tendencja, że wraz w wiekiem badanych udział poprawnych wskazań malał z poziomu ponad $40 \%$ do poniżej $9 \%$.

Trzecim kryterium służącym pogłębieniu analizy dotyczącej wskaźnika wiedzy teoretycznej było wykształcenie badanych. Rezultaty przedstawia rysunek 73 .

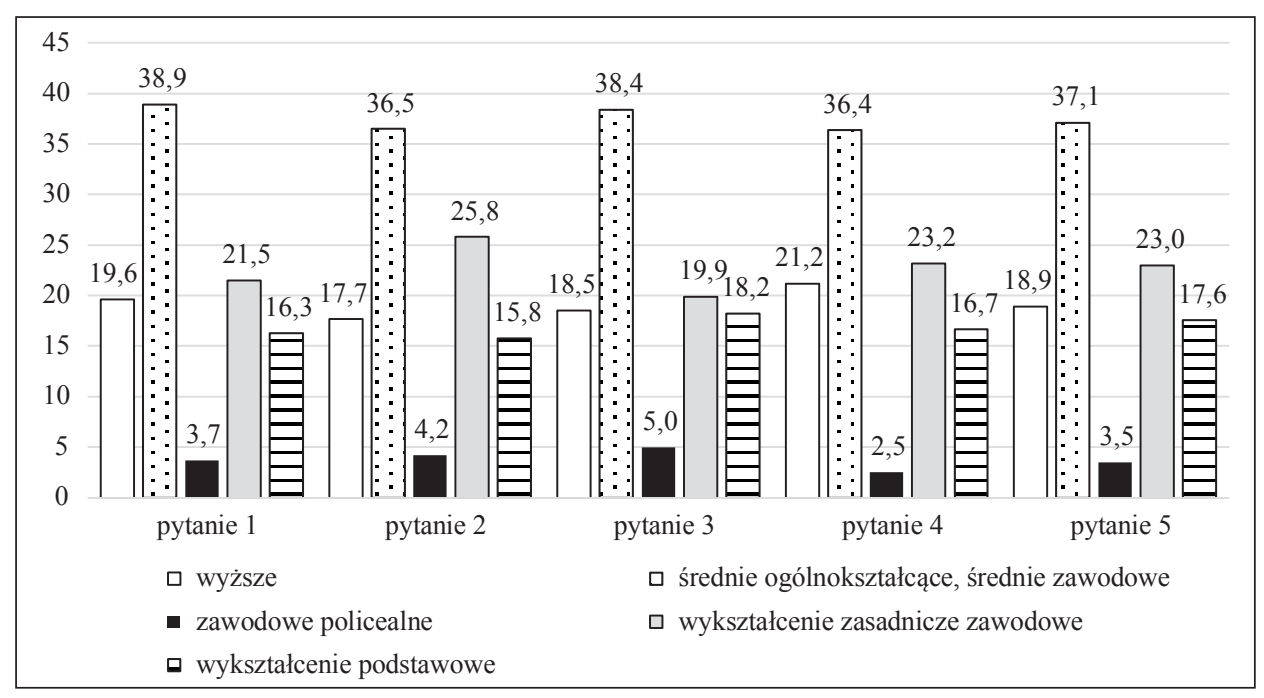

Rysunek 73. Wiedza finansowa - teoretyczna a wykształcenie badanych (w \%)

Źródło: opracowanie własne na podstawie wyników badania kwestionariuszowego

$\mathrm{Z}$ analizy między poziomem wykształcenia a poziomem wiedzy finansowej praktycznej wynika, że badani z wykształceniem średnim ogólnokształcącym, średnim zawodowym stanowili najliczniejszą grupę respondentów, którzy udzielali poprawnych wskazań na zagadnienia testu wiedzy finansowej teoretycznej. Sytuacja ta dotyczyła wszystkich pytań będących wskaźnikami testu wiedzy, a odsetki poprawnych odpowiedzi oscylowały wokół około 36-39\%.

Wreszcie, ostatnim czynnikiem różnicującym badaną zbiorowość był dochód. Rozkład prawidłowych odpowiedzi w zależności od miesięcznego dochodu netto badanych prezentuje rysunek 74 .

W przypadku wysokości uzyskiwanego miesięcznego dochodu i prawidłowości udzielanych odpowiedzi widoczny jest wyraźny związek. W przypadku każdego z pytań testu wiedzy finansowej - teoretycznej, poprawnych wskazań najczęściej udzielali badani z dochodami powyżej 1730 zł netto miesięcznie (około 33-35\%). Osoby z dochodem poniżej $1000 \mathrm{zł}$ miesięcznie najrzadziej udzielały prawidłowych odpowiedzi bez uwzględniania osób, które nie chciały lub nie umiały podać wysokości miesięcznych dochodów. 


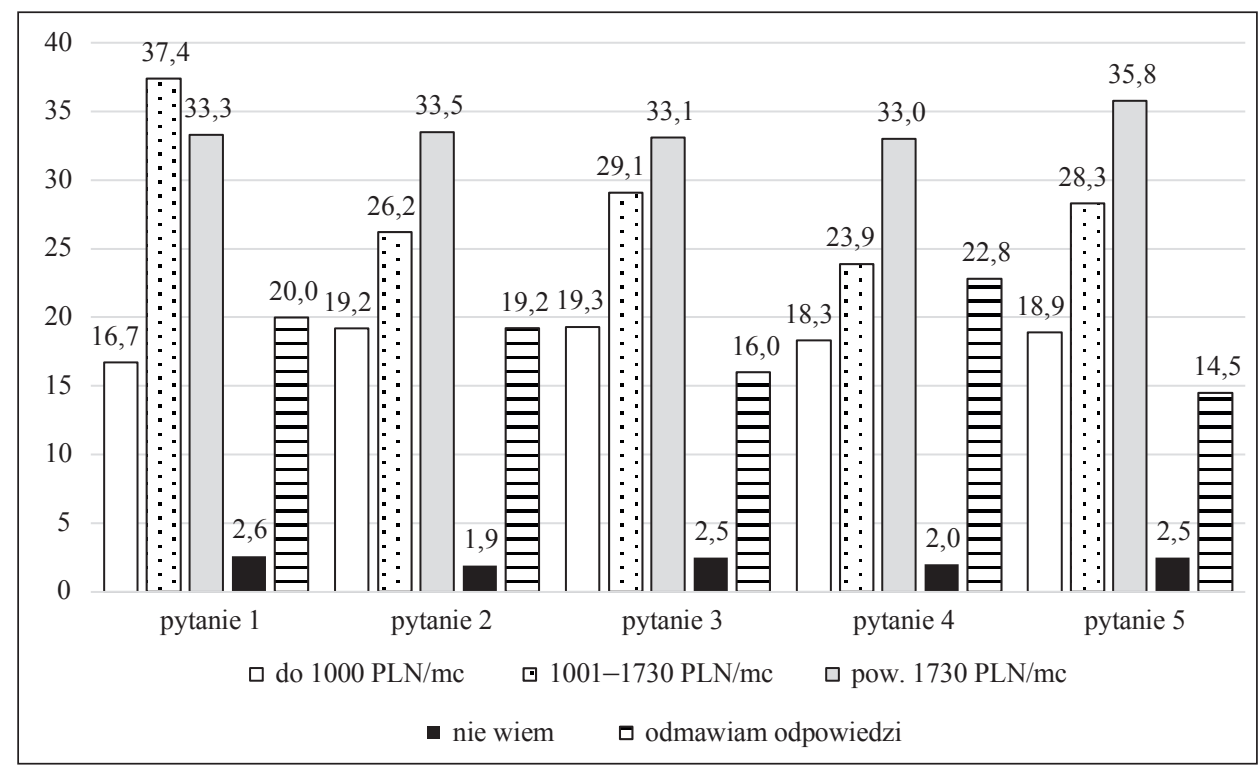

Rysunek 74. Wiedza finansowa - teoretyczna a miesięczny dochód netto badanych (w \%)

Źródło: opracowanie własne na podstawie wyników badania kwestionariuszowego

\subsubsection{Wskaźnik wiedzy finansowej praktycznej}

Drugą częścią badania obszaru „wiedzy finansowej” była część praktyczna. Wskaźnikami „wiedzy finansowej - praktycznej” uznano zadania logiczne (5 zadań) i na podstawie odpowiedzi badanych było możliwe określenie poziomu wiedzy finansowej (praktycznej).

W ramach badania poziomu wiedzy praktycznej poproszono ankietowanych o rozwiązanie 5 zadań logicznych o tematyce finansowej:

1. Proszę sobie wyobrazić, że 5 braci dostało 1000 zł. W przypadku gdyby bracia mieli podzielić się po równo, to ile każdy z braci powinien dostać pieniędzy?

2. Proszę sobie wyobrazić, że bracia będą musieli poczekać rok na swoje udziały w 1000 zł, inflacja jest na poziomie 4\%. Należy wskazać wśród wariantów odpowiedzi, jaką kwotą będą dysponowali w okresie jednego roku.

3. Pożyczyła/ł Pani/Pan przyjacielowi 25 zł, a on oddał Pani/Panu następnego dnia $25 \mathrm{zł}$. Jakie odsetki zapłacił od tej pożyczki?

4. Załóżmy, że Pani/Pan wpłaciła/ł 1000 zł na bezpłatny (bez prowizji) rachunek oszczędnościowy, z gwarantowanym oprocentowaniem $2 \%$ rocznie. Nie dokonywała Pani/Pan żadnych dalszych wpłat na ten rachunek ani wypłat. Jak dużo środków będzie na koniec pierwszego roku na rachunku? 
5. Załóżmy, że Pani/Pan wpłaciła/ 1000 zł na bezpłatny (bez prowizji) rachunek oszczędnościowy, z gwarantowanym oprocentowaniem $2 \%$ rocznie. Jaka kwota będzie na rachunku po 5 latach, jeśli nie ma za niego żadnych opłat?

Badani w zróżnicowany sposób udzielali odpowiedzi na zadane pytania. Rozkład wyników odpowiedzi udzielonych na poszczególne pytania z wiedzy finansowej praktycznej z uwzględnieniem ich prawidłowości przedstawia tablica 55.

Tablica 55. Wyniki odpowiedzi na pytania dotyczące wiedzy finansowej - część praktyczna (w \%)

\begin{tabular}{|l|c|c|c|c|c|}
\hline Udzielona odpowiedź & Zadanie 1 & Zadanie 2 & Zadanie 3 & Zadanie 4 & Zadanie 5 \\
\hline Prawdziwa & $\mathbf{9 1}$ & $\mathbf{4 6 , 4}$ & $\mathbf{8 4 , 3}$ & $\mathbf{5 5 , 1}$ & $\mathbf{3 3 , 6}$ \\
\hline Fałszywa & 2,1 & 32,1 & 2,5 & 12,9 & 38,7 \\
\hline Nie wiem & 5,6 & 18,8 & 10,3 & 29,1 & 26,1 \\
\hline Odmawiam odpowiedzi & 1,3 & 2,7 & 2,9 & 2,9 & 1,6 \\
\hline
\end{tabular}

Źródło: opracowanie własne na podstawie wyników badania kwestionariuszowego.

Najlepiej poradzili sobie ankietowani z pytaniem numer 1 dotyczącym podziału kwoty na równe części. Prawidłowej odpowiedzi na zadanie logiczne nr 1 udzieliło 91,0\% ankietowanych. Poprawnej odpowiedzi na zadanie nr 3 udzieliło $84,3 \%$ badanych. Należy jednak podkreślić, że oba zadania charakteryzowały się najniższym stopniem trudności.

Zdecydowanie gorsze rezultaty uzyskane zostały w przypadku zadania nawiązującego do wpływu inflacji na posiadane środki, gdzie jedynie $46 \%$ respondentów poprawnie rozwiązało zadanie. Prawidłowe rozwiązane zadania logicznego $\mathrm{nr} 4$ podało $55,1 \%$ badanych. Natomiast większe trudności sprawiło zadanie 5 , stanowiące kontynuację zadania 4 . Około $1 / 3$ ankietowanych udzieliła poprawnej odpowiedzi na zadanie logiczne nr 5 (33,6\%).

Uzyskane wyniki świadczą o posiadaniu przez ankietowanych niższej wiedzy finansowej praktycznej niż teoretycznej. Większa liczba ankietowanych udzielała prawidłowych odpowiedzi na pytania teoretyczne i zdecydowanie mniejsza liczba odpowiadała, że nie umie udzielić odpowiedzi.

Dalszej analizie zostało poddane zróżnicowanie prawidłowości udzielanych odpowiedzi na zadania praktyczne z wiedzy finansowej w zależności od następujących kryteriów:

- płci,

- miejsca zamieszkania,

- wieku,

- wykształcenia,

- miesięcznego dochodu netto.

Pierwszym kryterium różnicującym zbiorowość osób, które prawidłowo rozwiązały zadania $\mathrm{z}$ wiedzy finansowej praktycznej była płeć. Zestawienie pokazujące pogłębioną analizę przedstawia rysunek 75 . 


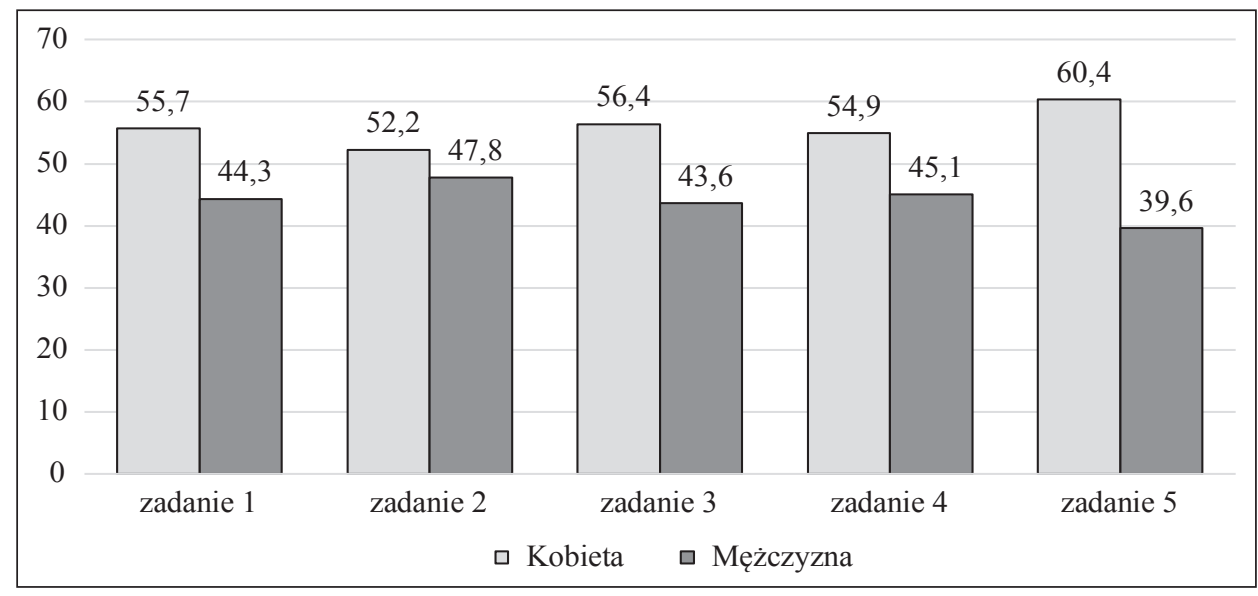

Rysunek 75. Wiedza finansowa - praktyczna a płeć badanych (w \%)

Źródło: opracowanie własne na podstawie wyników badania kwestionariuszowego

Zróżnicowanie odpowiedzi testu wiedzy praktycznej ze względu na płeć wskazywało, że to kobiety częściej udzielały poprawnych wskazań. W przypadku zadań 1-4 odsetki te oscylowały wokół około 52-56\%. W przypadku sformułowania zadania piątego udział kobiet, które prawidłowo odpowiedziały na to pytanie wynosił 60,4\%.

Drugim kryterium w przypadku badanych, którzy prawidłowo rozwiązali zadania z wiedzy finansowej praktycznej, było miejsce zamieszkania. Rezultaty uwzględniające miejsce zamieszkania prezentuje rysunek 76 .

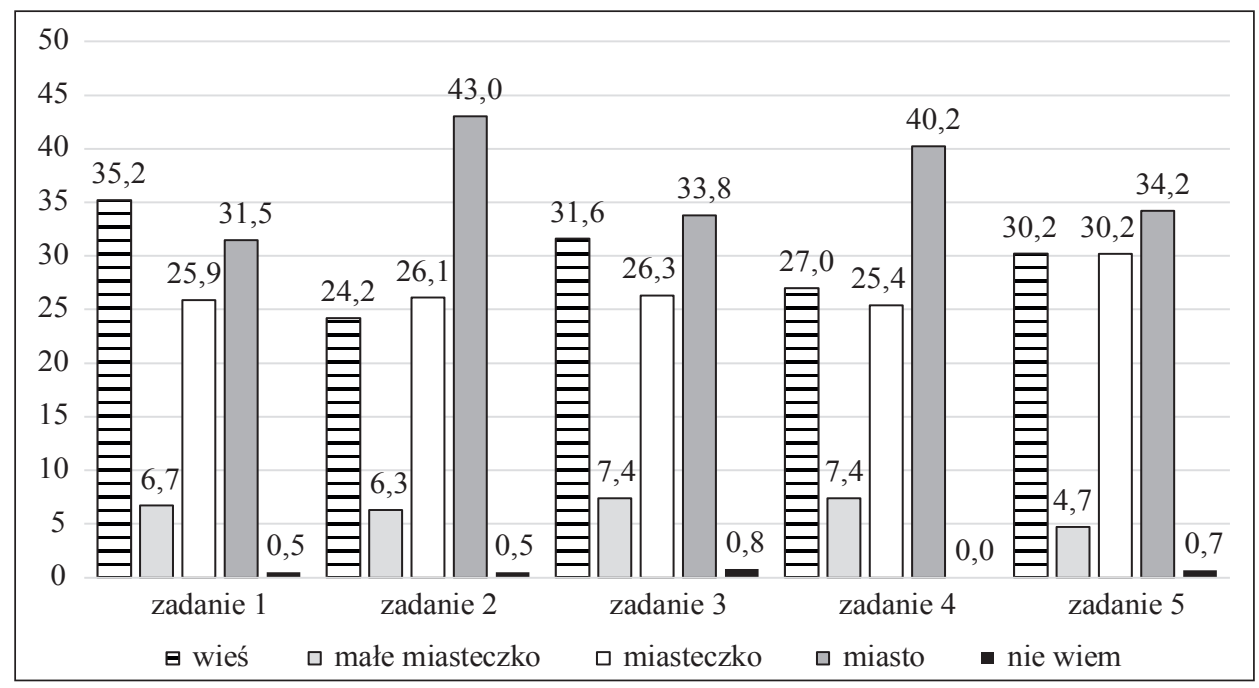

Rysunek 76. Wiedza finansowa - praktyczna a miejsce zamieszkania badanych (w \%) Źródło: opracowanie własne na podstawie wyników badania kwestionariuszowego 
Osoby zamieszkujące miasta najczęściej prawidłowo rozwiązywały zadanie $2(43,0 \%)$, zadanie $3(33,8 \%)$, zadanie $4(40,2 \%)$ oraz zadanie $5(34,2 \%)$. W przypadku zadania pierwszego to osoby zamieszkujące wsie miały największy udział wśród badanych, którzy poprawnie rozwiązali to zadanie.

Kolejnym kryterium uwzględnianym w pogłębionej analizie wiedzy finansowej praktycznej jest wiek. Rysunek 77 zawiera informacje na temat prawidłowo rozwiązanych zadań ze względu na wiek.

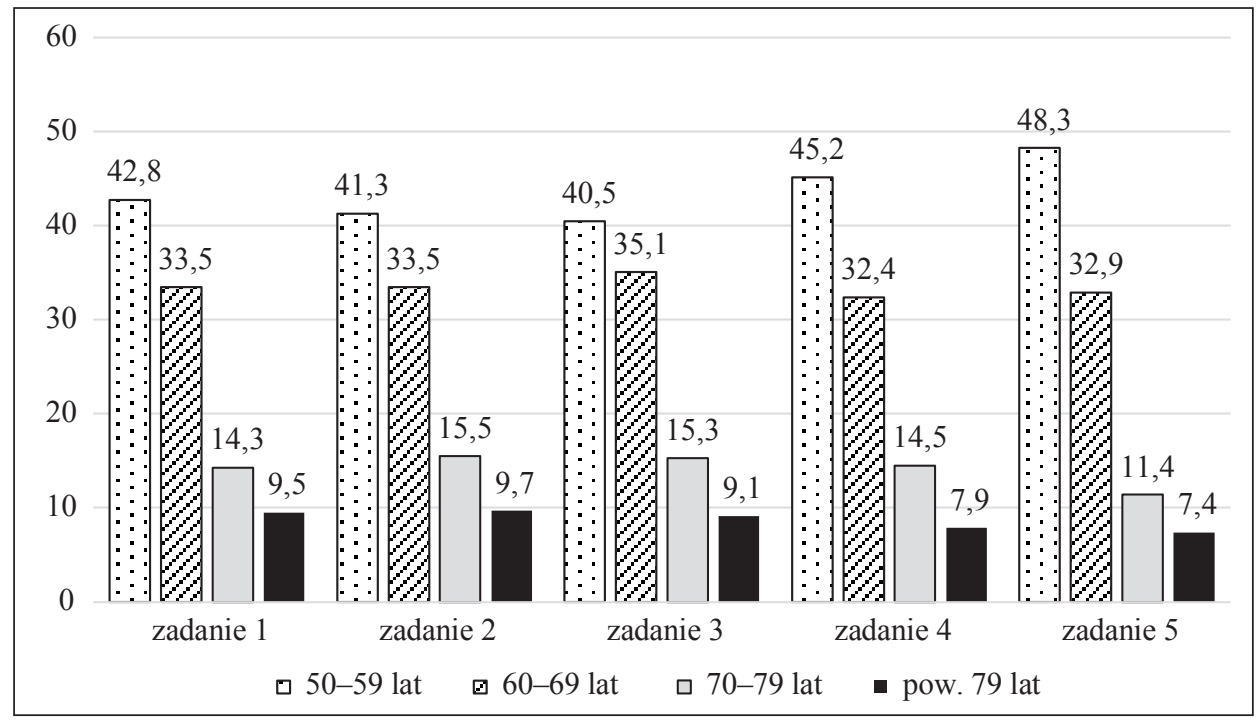

Rysunek 77. Wiedza finansowa - praktyczna a wiek badanych (w \%)

Źródło: opracowanie własne na podstawie wyników badania kwestionariuszowego

Na podstawie analizy między wiekiem a wskaźnikami wiedzy finansowej-praktycznej wykazano, że najczęściej najmłodsi uczestnicy badania, tj. osoby w wieku 50-59 lat, udzielali prawidłowej odpowiedzi na zadania testu wiedzy (odsetki wskazań około 40-48\%). Co więcej, stwierdzono, że im respondenci byli starsi, tym udział prawidłowych odpowiedzi zmniejszał się. Była to dokładnie taka sama tendencja jak w przypadku korelacji między wiekiem a wiedzą finansową teoretyczną.

Następną cechą służącą pogłębieniu analizy dotyczącej wskaźnika wiedzy praktycznej było wykształcenie badanych. Rezultaty przedstawia rysunek 78 .

Respondenci z wykształceniem średnim ogólnokształcącym, średnim zawodowym stanowili największy udział wśród osób, które znały poprawne odpowiedzi na sformułowania testu wiedzy finansowej - praktycznej. Największy odsetek badanych charakteryzujących się tym stopniem wykształcenia prawidłowo odpowiedział na zadanie $5(42,3 \%)$. W teście wiedzy finansowej teoretycznej również osoby z wykształceniem średnim ogólnokształcącym, średnim zawodowym najczęściej udzielały prawidłowych odpowiedzi. 


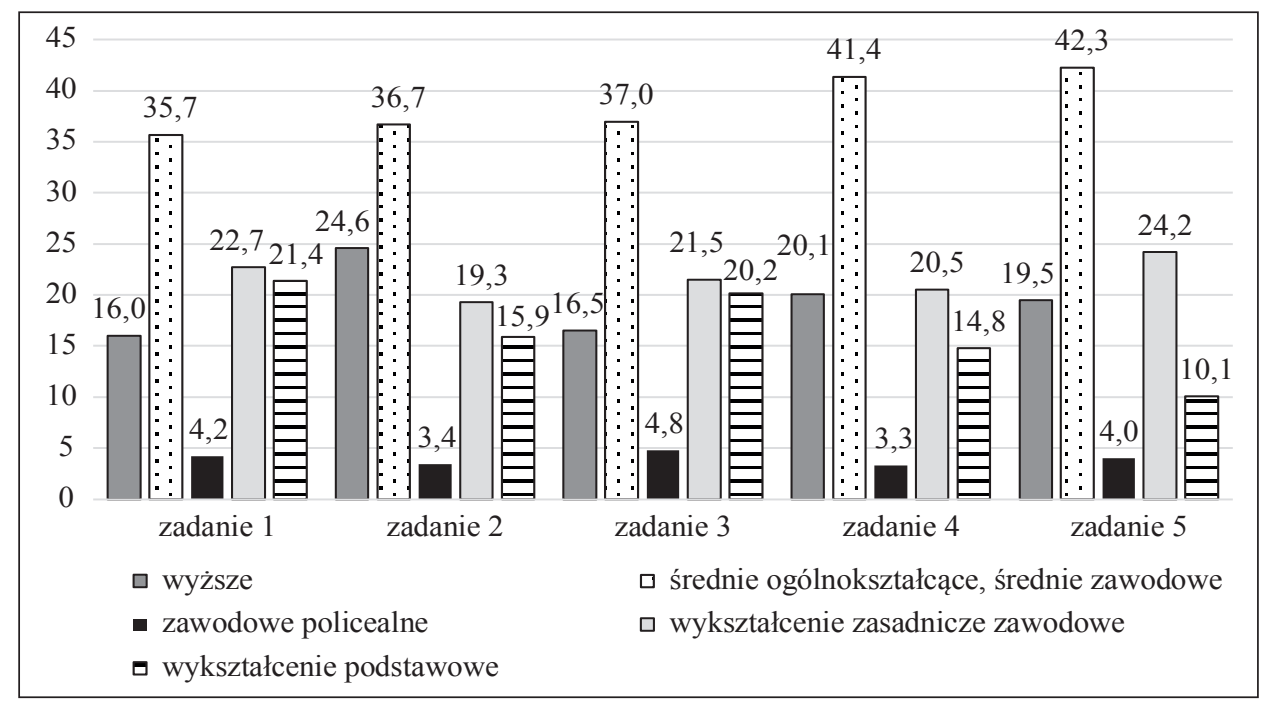

Rysunek 78. Wiedza finansowa - praktyczna a wykształcenie badanych (w \%)

Źródło: opracowanie własne na podstawie wyników badania kwestionariuszowego

Ostatnim z czynników różnicujących badaną zbiorowość, która prawidłowo rozwiązała zadania z wiedzy finansowej praktycznej, był dochód. Rozkład prawidłowych odpowiedzi w zależności od miesięcznego dochodu netto badanych prezentuje rysunek 79 .

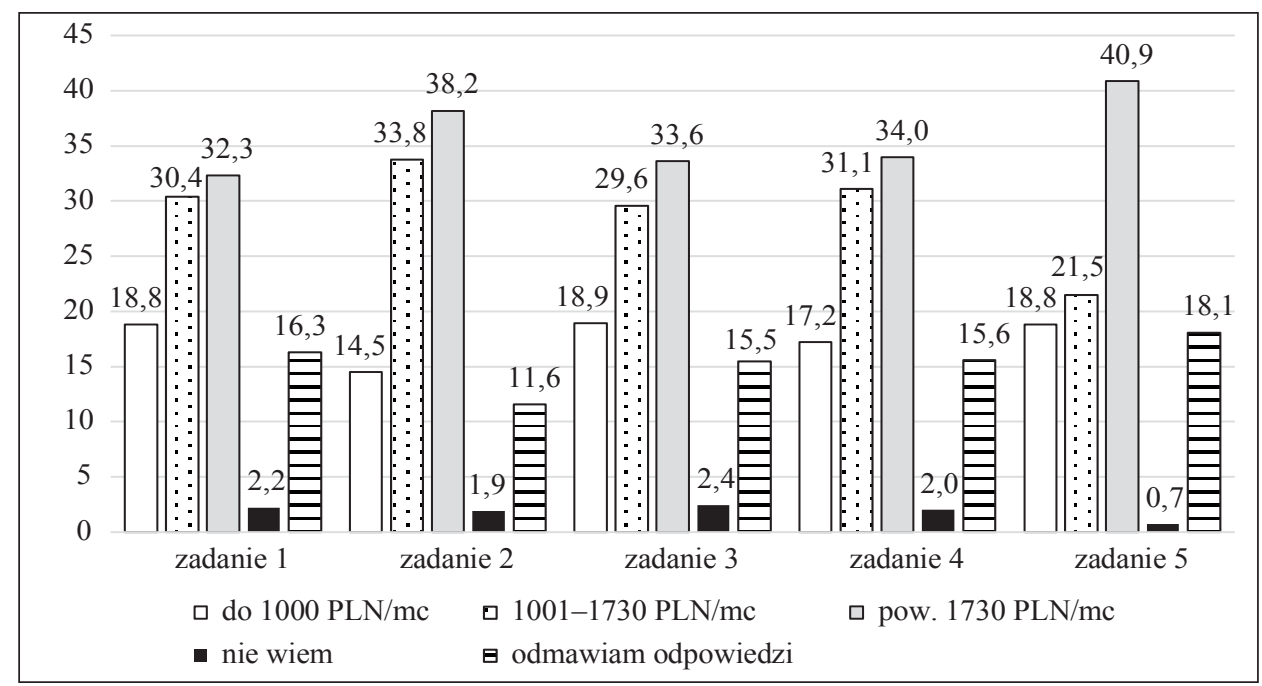

Rysunek 79. Wiedza finansowa - praktyczna a dochód badanych (w \%)

Źródło: opracowanie własne na podstawie wyników badania kwestionariuszowego 
Na podstawie analizy między miesięcznym dochodem netto badanych oraz udzielaniem poprawnych odpowiedzi na zadania testu wiedzy finansowej - praktycznej, stwierdzono, że najczęściej zadania były prawidłowo rozwiązywane przez osoby, których dochód przekraczał 1730 zł miesięcznie. Udział badanych posiadających taki dochód był wyróżniający w przypadku zadania piątego, na które poprawnie odpowiedziało $40,9 \%$ osób. Podobne rezultaty uzyskane zostały podczas analizy odpowiedzi dotyczących wiedzy finansowej teoretycznej.

\subsubsection{Aktualne posiadanie produktów finansowych}

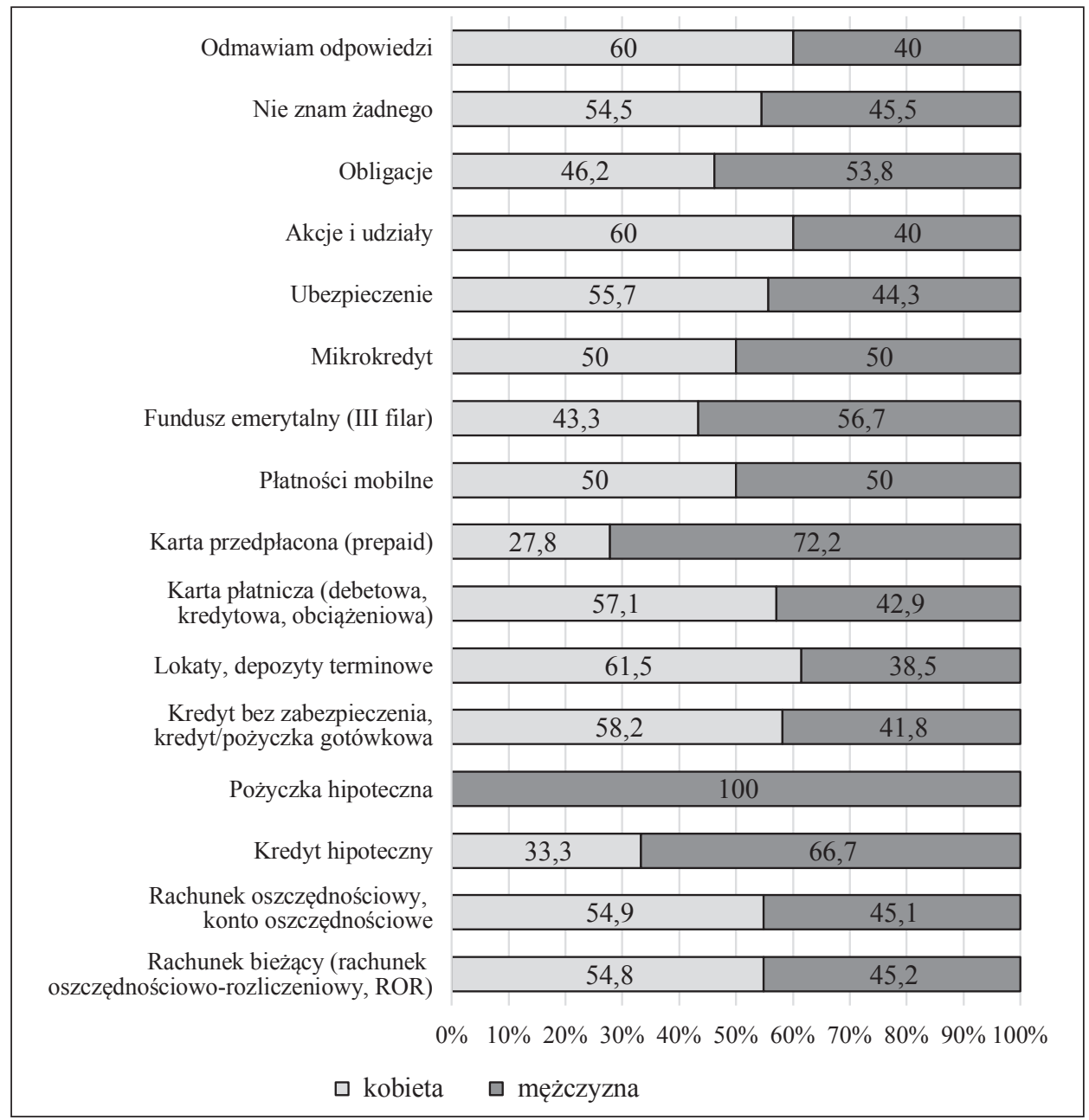

Rysunek 80. Aktualnie posiadane produkty finansowe a płeć badanych (w \%)

Źródło: opracowanie własne na podstawie wyników badania kwestionariuszowego 
Analizie poddano aktualnie posiadane przez badanych produkty finansowe oraz wybrane zmienne metryczkowe i sprawdzono, w jaki sposób prezentuje się posiadanie danego produktu finansowego na tle takich zmiennych, jak: płeć, miejsce zamieszkania, wiek, wykształcenie, miesięczny dochód netto. Wyniki zróżnicowania badanej populacji ze względu na płeć i zakres posiadanych aktualnie produktów finansowych przedstawia rysunek 80 .

Na podstawie przeprowadzonych analiz stwierdzono, że takie produkty finansowe, jak: rachunek bieżący, rachunek oszczędnościowy, kredyt bez zabezpieczenia, lokaty, depozyty terminowe, karta płatnicza, mikrokredyt oraz ubezpieczenie częściej posiadały kobiety. Żadna kobieta nie posiadała pożyczki hipotecznej. Wśród osób, które przyznały, że wykorzystują płatności mobilne oraz zaciągnęły mikrokredy $t^{18}$ połowę stanowiły kobiety. Około $3 / 4$ osób, które wskazały na posiadanie karty przedpłaconej, to mężczyźni. Obligacje, fundusz emerytalny oraz kredyt hipoteczny częściej posiadali mężczyźni. Wśród osób, które przyznały, że nie znają żadnego produktu finansowego, było więcej kobiet. Także kobiety częściej odmawiały odpowiedzi na pytanie o aktualne posiadanie produktów finansowych.

Poza uwzględnieniem wieku w identyfikacji cech osób posiadających poszczególne produkty finansowe weryfikacji podlegał także związek pomiędzy aktualnie posiadanymi produktami finansowymi i miejscem zamieszkania. Jej wyniki przedstawia tablica 56 .

Tablica 56. Aktualnie posiadane produkty finansowe - struktura wg miejsca zamieszkania badanych (w \%)

\begin{tabular}{|l|c|c|c|c|c|c|}
\hline Produkt finansowy & Wieś & $\begin{array}{c}\text { Małe } \\
\text { miasteczko }\end{array}$ & Miasteczko & Miasto & $\begin{array}{c}\text { Bardzo } \\
\text { duże } \\
\text { miasto }\end{array}$ & $\begin{array}{c}\text { Nie wiem (nie } \\
\text { znam wielkości } \\
\text { miejscowości) }\end{array}$ \\
\hline \multicolumn{1}{|c|}{1} & 2 & 3 & 4 & 5 & 6 & 7 \\
\hline $\begin{array}{l}\text { Rachunek bieżący } \\
\text { (rachunek } \\
\text { oszczędnościowo- } \\
\text {-rozliczeniowy, ROR) }\end{array}$ & 31,9 & 7,2 & 26,7 & 33,3 & 0,6 & 0,3 \\
\hline $\begin{array}{l}\text { Rachunek } \\
\text { oszczędnościowy, } \\
\text { konto } \\
\text { oszczędnościowe }\end{array}$ & 24,8 & 6,8 & 21,1 & 46,6 & 0,7 & 0,0 \\
\hline Kredyt hipoteczny & 25,0 & 0,0 & 0,0 & 66,7 & 8,3 & 0,0 \\
\hline Pożyczka hipoteczna & 33,3 & 0,0 & 16,7 & 50,0 & 0,0 & 0,0 \\
\hline $\begin{array}{l}\text { Kredyt bez } \\
\text { zabezpieczenia, kre- } \\
\text { dyt/pożyczka } \\
\text { gotówkowa }\end{array}$ & 30,9 & 9,1 & 32,7 & 25,5 & 1,8 & 0,0 \\
\hline
\end{tabular}

${ }^{18}$ Mikrokredyt rozumiany jest jako niskokwotowy kredyt. 
Tablica 56 (cd.)

\begin{tabular}{|l|c|c|c|c|c|c|}
\hline \multicolumn{1}{|c|}{1} & 2 & 3 & 4 & 5 & 6 & 7 \\
\hline $\begin{array}{l}\text { Lokaty, depozyty } \\
\text { terminowe }\end{array}$ & 20,0 & 7,6 & 26,2 & 46,2 & 0,0 & 0,0 \\
\hline $\begin{array}{l}\text { Karta płatnicza } \\
\text { (debetowa, } \\
\text { kredytowa, } \\
\text { obciążeniowa) }\end{array}$ & 26,9 & 7,1 & 29,7 & 35,7 & 0,6 & 0,0 \\
\hline $\begin{array}{l}\text { Karta przedpłacona } \\
\text { (prepaid) }\end{array}$ & 27,8 & 0,0 & 16,6 & 55,6 & 0,0 & 0,0 \\
\hline Płatności mobilne & 8,3 & 8,3 & 50,0 & 33,3 & 0,0 & 0,0 \\
\hline $\begin{array}{l}\text { Fundusz emerytalny } \\
\text { (III filar) }\end{array}$ & 30,0 & 6,7 & 10,0 & 46,7 & 6,6 & 0,0 \\
\hline Mikrokredyt & 33,3 & 0,0 & 16,7 & 50,0 & 0,0 & 0,0 \\
\hline Ubezpieczenie & 20,7 & 6,8 & 21,7 & 48,3 & 1,5 & 1,0 \\
\hline Akcje i udziały & 20,0 & 5,0 & 20,0 & 55,0 & 0,0 & 0,0 \\
\hline Obligacje & 15,4 & 0,0 & 30,8 & 53,8 & 0,0 & 0,0 \\
\hline Nie znam żadnego & 56,8 & 2,3 & 25,0 & 13,6 & 0,0 & 2,3 \\
\hline $\begin{array}{l}\text { Odmawiam } \\
\text { odpowiedzi }\end{array}$ & 40,0 & 10,0 & 50,0 & 0,0 & 0,0 & 0,0 \\
\hline
\end{tabular}

Źródło: opracowanie własne na podstawie wyników badania kwestionariuszowego.

Z analizy związku pomiędzy aktualnie posiadanymi produktami finansowymi i miejscem zamieszkania wynika, że:

- rachunek bieżący posiadało około 1/3 mieszkańców miast (33,3\%);

- połowa osób, która posiadała rachunek oszczędnościowy zamieszkiwała miasta $(46,6 \%)$;

- blisko $67 \%$ badanych aktualnie posiadających kredyt hipoteczny zamieszkiwało miasta, a $1 / 4$ wsie;

- wśród osób, które przyznały, że zaciągnęły pożyczkę hipoteczną, połowę stanowiły osoby zamieszkujące miasta, a 1/3 mieszkańcy wsi;

- kredytobiorcy bez zabezpieczenia to po około $30 \%$ mieszkańcy wsi oraz miasteczek;

- osoby, które przyznały, że posiadają lokaty, depozyty terminowe to $\mathrm{w} 46,2 \%$ mieszkańcy miast;

- mieszkańcy miast stanowili 35,7\% osób, które zadeklarowały, że posiadały kartę płatniczą;

- wśród respondentów posiadających kartę przedpłaconą ponad połowa to mieszkańcy miast $(55,6 \%)$;

- połowa osób, które deklarowały posiadanie płatności mobilnych, to badani mieszkający w miasteczkach;

- respondenci posiadający ubezpieczenie to w $48,3 \%$ mieszkańcy miast; 
- pozostałe produkty finansowe, jak: fundusz emerytalny, akcje i udziały oraz obligacje w większości posiadali mieszkańcy miast.

Najwięcej osób (56,8\%), które przyznały, że nie znają żadnego produktu finansowego zamieszkiwało wsie. Połowa badanych, którzy odmówili odpowiedzi na pytanie dotyczące aktualnego posiadania produktów finansowych zamieszkiwała miasteczka.

Trzecim analizowanym czynnikiem pogłębiającym analizę korzystania z produktów finansowych był wiek. Związek między wiekiem a faktem posiadania produktów finansowych przedstawia tablica 57.

Tablica 57. Aktualnie posiadane produkty finansowe a wiek badanych (w \%)

\begin{tabular}{|l|c|c|c|c|}
\hline \multicolumn{1}{|c|}{ Produkt finansowy } & $\mathbf{5 0 - 5 9}$ lat & $\mathbf{6 0 - 6 9}$ lat & $\mathbf{7 0 - 7 9}$ lat & Pow. 79 lat \\
\hline $\begin{array}{l}\text { Rachunek bieżący } \\
\text { (rachunek oszczędnościowo- } \\
\text {-rozliczeniowy, ROR) }\end{array}$ & 45,2 & 34,0 & 12,9 & 7,9 \\
\hline $\begin{array}{l}\text { Rachunek oszczędnościowy, } \\
\text { konto oszczędnościowe }\end{array}$ & 47,0 & 30,3 & 15,9 & 6,8 \\
\hline Kredyt hipoteczny & 75,0 & 25,0 & 0,0 & 0,0 \\
\hline Pożyczka hipoteczna & 83,3 & 16,7 & 0,0 & 0,0 \\
\hline $\begin{array}{l}\text { Kredyt bez zabezpieczenia, } \\
\text { kredyt/pożyczka gotówkowa }\end{array}$ & 40,4 & 36,8 & 14,0 & 8,8 \\
\hline Lokaty, depozyty terminowe & 54,7 & 28,1 & 12,5 & 4,7 \\
\hline $\begin{array}{l}\text { Karta płatnicza (debetowa, } \\
\text { kredytowa, obciążeniowa) }\end{array}$ & 51,1 & 32,2 & 9,4 & 7,3 \\
\hline Karta przedpłacona (prepaid) & 66,7 & 22,2 & 11,1 & 0,0 \\
\hline Płatności mobilne & 50,0 & 41,7 & 8,3 & 0,0 \\
\hline Fundusz emerytalny (III filar) & 73,3 & 13,3 & 10,0 & 3,4 \\
\hline Mikrokredyt & 66,7 & 33,3 & 0,0 & 0,0 \\
\hline Ubezpieczenie & 42,6 & 30,7 & 18,3 & 8,4 \\
\hline Akcje i udziały & 52,6 & 42,1 & 5,3 & 0,0 \\
\hline Obligacje & 46,2 & 38,5 & 15,3 & 0,0 \\
\hline Nie znam żadnego & 30,4 & 23,9 & 19,6 & 26,1 \\
\hline Odmawiam odpowiedzi & 25,0 & 25,0 & 0,0 & 50,0 \\
\hline
\end{tabular}

Źródło: opracowanie własne na podstawie wyników badania kwestionariuszowego.

W przypadku posiadania każdego z produktów finansowych, najmniejszy udział miały osoby najstarsze. Badani ci, tj. w wieku powyżej 79. roku życia, stanowili połowę respondentów, którzy odmówili odpowiedzi na pytanie o aktualnie posiadane produkty finansowe, co więcej, co czwarty badany w tym wieku przyznał, że nie zna żadnego produktu finansowego $(26,1 \%)$. Struktura wieku osób, które aktualnie posiadały dany produkt finansowy przedstawiała się następująco: 
- blisko połowa osób, które posiadały rachunek bieżący lub rachunek oszczędnościowy była w wieku 50-59 lat (odpowiednio: 45,2\%, 47,0\%);

- badani, którzy zadeklarowali posiadanie kredytu hipotecznego, to w zdecydowanej większości osoby do 59. roku życia (co jest zgodne z teorią);

- osoby, które posiadały pożyczkę hipoteczną, w $83,3 \%$ były w wieku 50-59 lat;

- nieco ponad $40 \%$ osób, które przyznały, że mają kredyt bez zabezpieczeń, nie miało więcej niż 60 lat (40,4\%). Niewiele mniejszy udział mieli badani w wieku 60-69 lat (36,8\%);

- ponad połowa osób, które posiadały lokaty, depozyty terminowe oraz kartę płatniczą było w wieku 50-59 lat (odpowiednio: 54,7\% oraz 51,1\%);

- wśród osób, które posiadały kartę przedpłaconą oraz mikrokredyt, $66,7 \%$ to badani do 59. roku życia;

- niemal $43 \%$ osób posiadających ubezpieczenie miało 50-59 lat (42,6\%), a 30,7\% - 60-69 lat;

- osoby posiadające fundusz emerytalny (III filar) to w zdecydowanej większości badani najmłodsi, tj. do 59. roku życia (73,3\%);

- około połowa respondentów deklarująca posiadanie akcji i udziałów oraz obligacji nie miała więcej niż 60 lat (odpowiednio: 52,6\% oraz 46,2\%).

Kolejną determinantą kształtującą skalę posiadania aktualnie produktów finansowych przez ankietowanych było wykształcenie. Zróżnicowanie zakresu włączenia finansowego i poziomu wykształcenia przedstawia tablica 58.

Tablica 58. Aktualnie posiadane produkty finansowe a wykształcenie badanych (w \%)

\begin{tabular}{|l|c|c|c|c|c|}
\hline Produkt finansowy & Wyższe & $\begin{array}{c}\text { Zawodowe } \\
\text { policealne }\end{array}$ & $\begin{array}{c}\text { Średnie } \\
\text { ogólnoksztal- } \\
\text { cące, średnie } \\
\text { zawodowe }\end{array}$ & $\begin{array}{c}\text { Wykształcenie } \\
\text { zasadnicze } \\
\text { zawodowe }\end{array}$ & $\begin{array}{c}\text { Wykształcenie } \\
\text { podstawowe }\end{array}$ \\
\hline \multicolumn{1}{|c|}{1} & 2 & 3 & 4 & 5 & 6 \\
\hline $\begin{array}{l}\text { Rachunek bieżący } \\
\text { (rachunek } \\
\text { oszczędnościowo- } \\
\text {-rozliczeniowy, ROR) }\end{array}$ & 18,3 & 4,9 & 38,3 & 22,3 & 16,2 \\
\hline $\begin{array}{l}\text { Rachunek } \\
\text { oszczędnościowy, } \\
\text { konto } \\
\text { oszczędnościowe }\end{array}$ & 26,3 & 4,5 & 40,6 & 18,8 & 9,8 \\
\hline Kredyt hipoteczny & 58,3 & 0,0 & 33,3 & 8,4 & 0,0 \\
\hline Pożyczka hipoteczna & 33,3 & 0,0 & 66,7 & 0,0 & 0,0 \\
\hline $\begin{array}{l}\text { Kredyt bez } \\
\text { zabezpieczenia, } \\
\text { kredyt/pożyczka } \\
\text { gotówkowa }\end{array}$ & 16,4 & 7,2 & 38,2 & 20,0 & 18,2 \\
\hline
\end{tabular}




\begin{tabular}{|l|c|c|c|c|c|}
\hline \multicolumn{1}{|c|}{1} & 2 & 3 & 4 & 5 & 6 \\
\hline $\begin{array}{l}\text { Lokaty, depozyty } \\
\text { terminowe }\end{array}$ & 33,8 & 6,2 & 44,6 & 6,2 & 9,2 \\
\hline $\begin{array}{l}\text { Karta płatnicza } \\
\text { (debetowa, } \\
\text { kredytowa, } \\
\text { obciążeniowa) }\end{array}$ & 25,3 & 3,8 & 42,3 & 19,2 & 9,4 \\
\hline $\begin{array}{l}\text { Karta przedpłacona } \\
\text { (prepaid) }\end{array}$ & 50,0 & 5,6 & 38,9 & 0,0 & 5,5 \\
\hline Płatności mobilne & 0,0 & 8,3 & 75,0 & 16,7 & 0,0 \\
\hline $\begin{array}{l}\text { Fundusz emerytalny } \\
\text { (III filar) }\end{array}$ & 50,0 & 0,0 & 43,3 & 0,0 & 6,7 \\
\hline Mikrokredyt & 16,7 & 16,7 & 33,3 & 16,7 & 16,6 \\
\hline Ubezpieczenie & 23,2 & 3,5 & 36,9 & 18,7 & 17,7 \\
\hline Akcje i udziały & 40,0 & 0,0 & 40,0 & 10,0 & 10,0 \\
\hline Obligacje & 46,2 & 0,0 & 46,2 & 7,6 & 0,0 \\
\hline Nie znam żadnego & 4,5 & 4,5 & 9,2 & 27,3 & 54,5 \\
\hline $\begin{array}{l}\text { Odmawiam } \\
\text { odpowiedzi }\end{array}$ & 0,0 & 0,0 & 10,0 & 70,0 & 20,0 \\
\hline
\end{tabular}

Źródło: opracowanie własne na podstawie wyników badania kwestionariuszowego.

Na podstawie analizy między posiadaniem danego produktu finansowego oraz wykształcenia stwierdzono ${ }^{19}$ :

- po około $40 \%$ osób posiadających rachunek bieżący oraz oszczędnościowy posiadało wykształcenie średnie ogólnokształcące, średnie zawodowe (odpowiednio: $38,3 \%$ oraz $40,6 \%$ );

- ponad $22 \%$ respondentów będących posiadaczami rachunku bieżącego miało wykształcenie zasadnicze zawodowe (22,3\%);

- co czwarty posiadacz rachunku oszczędnościowego wyróżniał się ukończeniem uczelni wyższej (26,3\%), a co czwarty posiadał wykształcenie zasadnicze zawodowe;

- ponad połowa respondentów, którzy nie znali żadnego produktu finansowego zakończyła edukację na poziomie podstawowym (54,5\%);

- osoby, które posiadały kredyt hipoteczny, to w większości osoby z wykształceniem wyższym (58,3\%), a 1/3 z nich to posiadacze wykształcenia średniego ogólnokształcącego, średniego zawodowego;

- respondenci z wykształceniem średnim ogólnokształcącym, średnim zawodowym stanowili większość wśród badanych posiadających pożyczki hipoteczne (66,7\%), a 1/10 osób z tej zbiorowości tworzyli ci z wykształceniem wyższym;

${ }^{19}$ Uzyskane wyniki są zgodne z oczekiwaniami wynikającymi z rezultatów dla próby ogólnopolskiej wskazującej, że wyższym poziomem ubankowienia charakteryzują się osoby z wyższym bądź średnim wykształceniem, np. cykliczne badanie "Stan wiedzy finansowej Polaków” lub D. Maison, Polak w świecie finansów, Warszawa 2013. 
- uczestnicy badania będący posiadaczami kredytu bez zabezpieczenia to w $38,2 \%$ osoby ze średnim, ogólnokształcącym, zawodowym wykształceniem. Co piąta osoba $\mathrm{z}$ tej grupy miała wykształcenie zasadnicze zawodowe;

- niemal $45 \%$ posiadaczy lokat, depozytów terminowych miało wykształcenie średnie ogólnokształcące, zawodowe, a 33,8\% - wyższe;

- wśród osób posiadających kartę płatniczą 42,3\% to respondenci z wykształceniem średnim ogólnokształcącym, zawodowym, a 33,8\% to osoby, które posiadały dyplom uczelni wyższej;

- posiadacze ubezpieczenia to $\mathrm{w} 1 / 3$ badani z wykształceniem średnim ogólnokształcącym, średnim zawodowym $(36,9 \%)$, a $23,2 \%$ z nich to osoby z wykształceniem wyższym;

- w przypadku posiadaczy pozostałych produktów finansowych, znaczący udział miały osoby z wykształceniem wyższym oraz średnim ogólnokształcącym, zawodowym;

- zdecydowana większość badanych, którzy odmówili odpowiedzi na pytanie dotyczące aktualnego posiadania produktu finansowego, miała wykształcenie zasadnicze zawodowe $(70,0 \%)$.

Ostatnią cechą badanej populacji w odniesieniu do posiadanych aktualnie produktów finansowych był miesięczny dochód netto. Zależność między dochodem a skalą korzystania z produktów finansowych ujmuje rysunek 81 .

Wnioski z analizy między aktualnie posiadanymi produktami finansowymi a miesięcznym dochodem netto wskazywały na wyższy poziom ubankowienia towarzyszący wyższym miesięcznym dochodom, co było zgodne z przewidywaniami popartymi wynikami badań ogólnopolskich i światowych. Szczegółowe wyniki były następujące:

- miesięczne dochody netto niemal $46 \%$ posiadaczy rachunku bieżącego wynosiły więcej niż $1730 \mathrm{zk}$;

- ponad połowa respondentów posiadających rachunek oszczędnościowy miała dochody netto przekraczające 1730 zł miesięcznie;

- więcej niż $1730 \mathrm{zł}$ netto miesięcznie dochodu posiadało $90,0 \%$ posiadaczy kredytu hipotecznego;

- ponad 1730 zł netto miesięcznie dochodu miało 80,0\% osób posiadających kredyt hipoteczny;

- kredyt bez zabezpieczeń zaciągnęło 47,6\% badanych z miesięcznym dochodem netto wynoszącym 1001-1730 zł, a o około 5 punktów procentowych mniej było tych z dochodami powyżej 1730 zł netto (42,9\%);

- większość osób z dochodami powyżej 1730 zł netto miesięcznie $(68,0 \%)$ stanowili badani posiadający aktualnie lokaty, depozyty terminowe;

- dochody miesięczne netto przekraczające $1730 \mathrm{zł}$ miała ponad połowa posiadaczy karty płatniczej $(52,6 \%)$, a dochody $37,0 \%$ osób z tej grupy wynosiły 1001-1730 zł netto miesięcznie; 


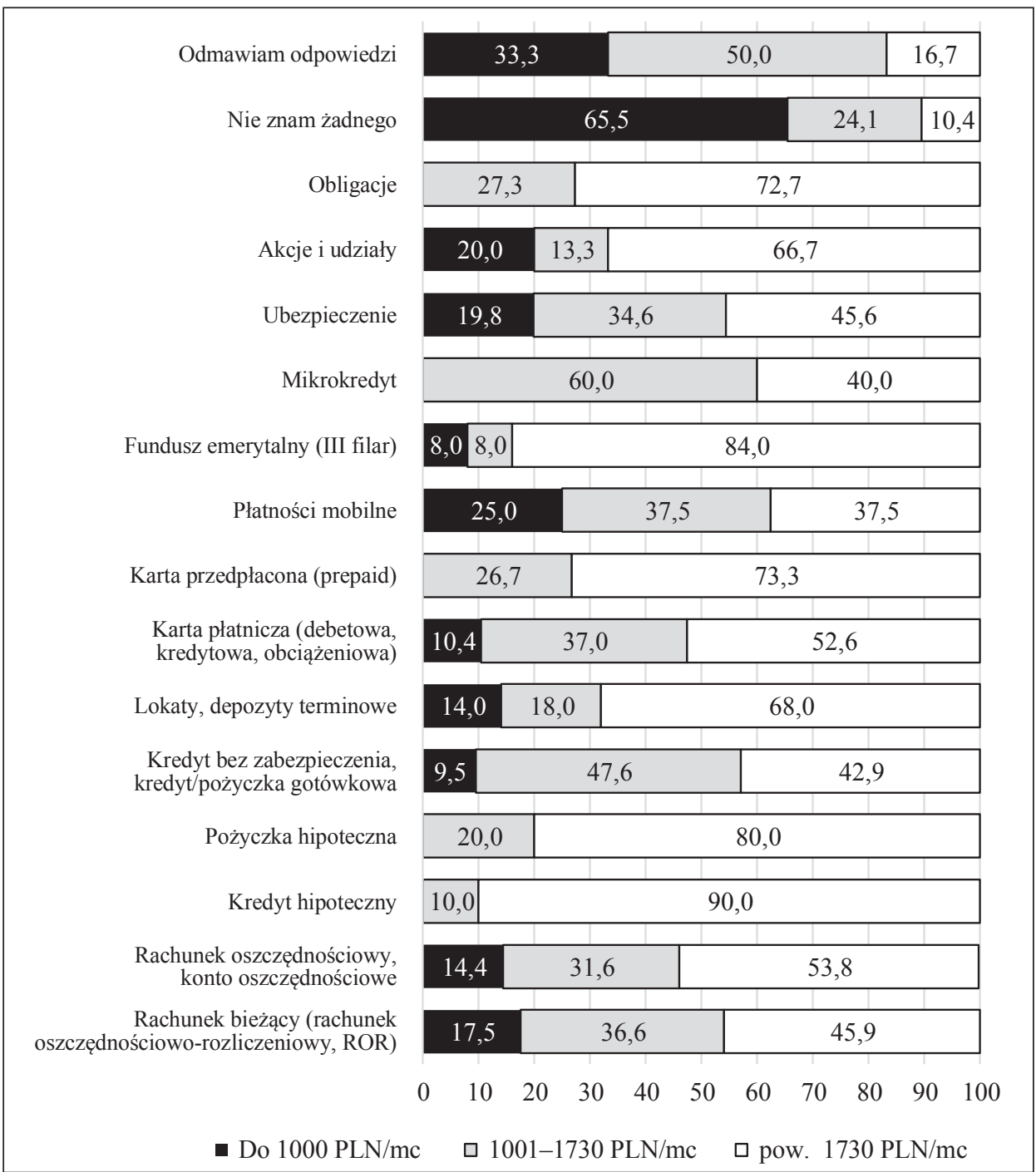

Rysunek 81. Aktualne posiadanie produktów finansowych a miesięczne dochody netto badanych (w \%)

Źródło: opracowanie własne na podstawie wyników badania kwestionariuszowego

- osoby posiadające kartę przedpłaconą, obligacje oraz fundusz emerytalny to w zdecydowanej większości badani, których miesięczne dochody netto przekraczały 1730 zł (odpowiednio: 73,3\%; 72,7\% oraz 84,0\%);

- blisko 46\% uczestników badania posiadających ubezpieczenie miało dochody powyżej 1730 zł netto, natomiast dochody $1 / 3$ z nich oscylowały między 1001-1730 zł netto miesięcznie; 
- w przypadku większości pozostałych produktów finansowych, ich posiadaczami były osoby, których miesięczny dochód netto wynosił więcej niż 1730 zł netto;

- większość badanych, którzy przyznali, że nie znali żadnego produktu finansowego, uzyskała dochód do 1000 zł netto miesięcznie;

- połowa osób, które odmówiły odpowiedzi na pytanie dotyczące aktualnie posiadanych produktów finansowych, posiadała dochody w granicach 1001-1730 zł netto miesięcznie.

Podsumowując zakres aktualnie posiadanych produktów finansowych przez badanych oraz brane pod uwagę cechy demograficzne różnicujące populację, należy przede wszystkim podkreślić potwierdzenie zależności wskazywanych wcześniej w teorii. Kobiety chętniej korzystały z klasycznych produktów bankowych, takich jak rachunek bieżący lub oszczędnościowy oraz lokaty i depozyty terminowe, podczas gdy mężczyźni dominowali w przypadku kredytów hipotecznych. Mieszkańcy miast i większych miejscowości chętniej sięgali po produkty finansowe, takie jak kredyty hipoteczne, rachunki oszczędnościowe oraz lokaty i depozyty terminowe. Nie występowała różnica w przypadku podstawowego poziomu ubankowienia identyfikowanego jako posiadanie rachunku bankowego (ROR). Największą aktywnością i zróżnicowaniem w posiadanych produktach finansowych wykazywały się osoby w wieku 50-59 lat. Wraz z wiekiem wyraźnemu zmniejszeniu ulegało posiadanie produktów finansowych. Większy udział wśród osób posiadających poszczególne produkty finansowe widoczny był w przypadku osób legitymujących się wykształceniem średnim ogólnokształcącym i średnim zawodowym. Zdecydowanie wraz ze wzrostem miesięcznych dochodów pozostających w dyspozycji badanych zwiększeniu i większemu zróżnicowaniu ulegała liczba posiadanych produktów finansowych we wszystkich ich typach.

\subsubsection{Posiadane produkty finansowe $w$ ciągu 2 ostatnich lat}

Poza analizą aktualnie posiadanych produktów finansowych przez respondentów badaniu kwestionariuszowemu poddano także kwestię posiadania produktów finansowych w ciągu 2 ostatnich lat. W tym przypadku posłużono się takimi samymi zmiennymi metryczkowymi (płeć, miejsce zamieszkania, wiek, wykształcenie, miesięczny dochód netto) jak w przypadku aktualnie posiadanych produktów finansowych. Zestawienie podsumowujące zależność między płcią a posiadaniem produktów finansowych w ciągu ostatnich 2 lat prezentuje rysunek 82 .

Na podstawie analizy zależności między płcią badanych a posiadanymi przez nich w ciągu ostatnich 2 lat produktami finansowymi stwierdzono, że udział kobiet oscylujący wokół 50-60\% dotyczył posiadania takich produktów finansowych, jak: 
rachunek bieżący, rachunek oszczędnościowy, kredyt bez zabezpieczeń, lokaty, depozyty terminowe, karta płatnicza, ubezpieczenie, akcje i udziały, obligacje. Posiadaniem pozostałych produktów charakteryzowali się w większości mężczyźni, szczególnie w przypadku karty przedpłaconej, gdzie wśród osób nią dysponujących byli tylko mężczyźni. Kobiety stanowiły 53,8\% badanych, którzy przyznali, że nie znają żadnego produktu finansowego. Niemal $67 \%$ kobiet stanowiło tych uczestników badania, którzy odmówili odpowiedzi na to pytanie $(66,7 \%)$.

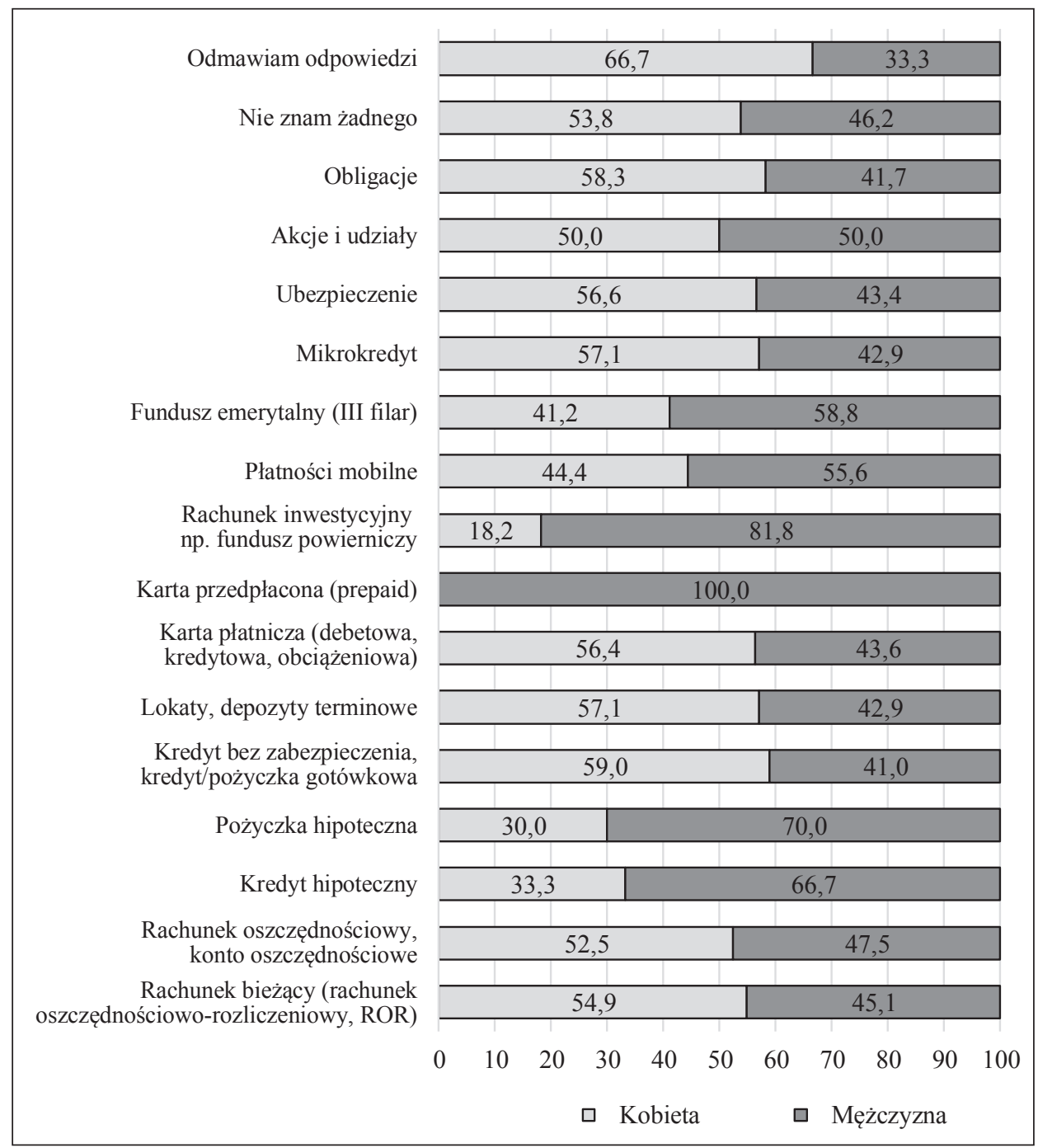

Rysunek 82. Posiadanie produktów finansowych w ciągu ostatnich 2 lat a płeć badanych (w \%)

Źródło: opracowanie własne na podstawie wyników badania kwestionariuszowego 
Drugim kryterium różnicującym osoby posiadające produkty finansowe w ciągu ostatnich 2 lat było miejsce zamieszkania. Wyniki przedstawia tablica 59.

Tablica 59. Posiadanie produktów finansowych w ciągu ostatnich 2 lat a miejsce zamieszkania badanych (w \%)

\begin{tabular}{|l|c|c|c|c|c|c|}
\hline \multicolumn{1}{|c|}{ Produkt finansowy } & Wieś & $\begin{array}{c}\text { Małe } \\
\text { miasteczko }\end{array}$ & Miasteczko & Miasto & $\begin{array}{c}\text { Bardzo } \\
\text { duże miasto }\end{array}$ & $\begin{array}{c}\text { Nie } \\
\text { wiem }\end{array}$ \\
\hline $\begin{array}{l}\text { Rachunek bieżący } \\
\text { (rachunek oszczędnościowo- } \\
\text {-rozliczeniowy, ROR) }\end{array}$ & 32,0 & 7,0 & 26,7 & 33,4 & 0,6 & 0,3 \\
\hline $\begin{array}{l}\text { Rachunek oszczędnościowy, } \\
\text { konto oszczędnościowe }\end{array}$ & 21,3 & 7,4 & 20,5 & 50,8 & 0,0 & 0,0 \\
\hline Kredyt hipoteczny & 16,7 & 0,0 & 16,7 & 58,3 & 8,3 & 0,0 \\
\hline Pożyczka hipoteczna & 40,0 & 0,0 & 20,0 & 40,0 & 0,0 & 0,0 \\
\hline $\begin{array}{l}\text { Kredyt bez zabezpieczenia, } \\
\text { kredyt/pożyczka gotówkowa }\end{array}$ & 26,2 & 8,2 & 31,1 & 31,1 & 1,6 & 1,8 \\
\hline Lokaty, depozyty terminowe & 17,1 & 7,1 & 22,9 & 52,9 & 0,0 & 0,0 \\
\hline $\begin{array}{l}\text { Karta płatnicza (debetowa, } \\
\text { kredytowa, obciążeniowa) }\end{array}$ & 26,8 & 6,1 & 29,1 & 36,9 & 1,1 & 0,0 \\
\hline $\begin{array}{l}\text { Karta przedpłacona } \\
\text { (prepaid) }\end{array}$ & 0,0 & 0,0 & 0,0 & 100,0 & 0,0 & 0,0 \\
\hline Płatności mobilne & 27,3 & 0,0 & 18,2 & 54,5 & 0,0 & 0,0 \\
\hline $\begin{array}{l}\text { Fundusz emerytalny } \\
\text { (III filar) }\end{array}$ & 27,8 & 0,0 & 50,0 & 22,2 & 0,0 & 0,0 \\
\hline Mikrokredyt & 23,5 & 5,9 & 17,6 & 47,1 & 5,9 & 0,0 \\
\hline Ubezpieczenie & 28,6 & 0,0 & 42,8 & 28,6 & 0,0 & 0,0 \\
\hline Akcje i udziały & 21,9 & 8,2 & 17,9 & 49,5 & 1,5 & 1,0 \\
\hline Obligacje & 27,8 & 0,0 & 11,1 & 61,1 & 0,0 & 0,0 \\
\hline Nie znam żadnego & 8,4 & 0,0 & 33,3 & 58,3 & 0,0 & 0,0 \\
\hline Odmawiam odpowiedzi & 56,4 & 2,6 & 28,2 & 12,8 & 0,0 & 0,0 \\
\hline
\end{tabular}

Źródło: opracowanie własne na podstawie wyników badania kwestionariuszowego.

$\mathrm{Z}$ rozkładu posiadanych przez badanych produktów finansowych w ciągu ostatnich 2 lat względem miejsca zamieszkania wynika:

- po około 1/3 osób posiadających rachunek bieżący zamieszkiwało wsie oraz miasta (odpowiednio: $32,0 \%$ oraz $33,4 \%$ );

- ponad połowa posiadaczy rachunku oszczędnościowego zamieszkiwała miasta (50,8\%), a po około $20 \%$ badanych miasteczka (odpowiednio: $21,3 \%$ oraz $20,5 \%)$;

- niemal 59\% osób będących posiadaczami kredytów hipotecznych było mieszkańcami miast (58,3\%);

- osoby posiadające pożyczkę hipoteczną to w $40 \%$ mieszkańcy miast; 
- odsetek osób, które posiadały pożyczkę hipoteczną i zamieszkiwały wsie albo miasta, wynosił po $40 \%$;

- jednakowy odsetek posiadaczy kredytów bez zabezpieczenia zamieszkiwał miasta i miasteczka - po 31,1\% zbiorowości;

- blisko 55\% posiadających rachunek inwestycyjny zamieszkiwało miasta $(54,5 \%)$;

- osoby posiadające kartę płatniczą to w $36,9 \%$ mieszkańcy miast;

- wszyscy, którzy posiadali kartę przedpłaconą, zamieszkiwali miasta;

- połowa respondentów będących posiadaczami ubezpieczenia to osoby mieszkające w miastach $(49,5 \%)$, co piąty mieszkał na wsi;

- osoby, które nie znały lub odmówiły odpowiedzi na pytanie dotyczące posiadania w ciągu ostatnich 2 lat produktu finansowego, w większości zamieszkiwały wsie (odpowiednio 56,4\% oraz 50,0\%).

Kolejnym czynnikiem służącym pogłębieniu analizy korzystania z produktów finansowych w ciągu 2 lat był wiek. Związek między tą cechą a posiadanymi w ciągu 2 lat produktami finansowymi prezentuje tablica 60 .

Tablica 60. Posiadanie produktów finansowych w ciągu ostatnich 2 lat a wiek badanych (w \%)

\begin{tabular}{|l|c|c|c|c|}
\hline \multicolumn{1}{|c|}{ Produkt finansowy } & $\mathbf{5 0 - 5 9}$ lat & $\mathbf{6 0 - 6 9}$ lat & $\mathbf{7 0 - 7 9 ~ l a t ~}$ & Pow. 79 lat \\
\hline $\begin{array}{l}\text { Rachunek bieżący } \\
\text { (rachunek oszczędnościowo- } \\
\text {-rozliczeniowy, ROR) }\end{array}$ & 45,0 & 34,4 & 12,7 & 7,9 \\
\hline $\begin{array}{l}\text { Rachunek oszczędnościowy, } \\
\text { konto oszczędnościowe }\end{array}$ & 44,3 & 32,0 & 17,2 & 6,5 \\
\hline Kredyt hipoteczny & 75,0 & 16,7 & 8,3 & 0,0 \\
\hline Pożyczka hipoteczna & 60,0 & 40,0 & 0,0 & 0,0 \\
\hline $\begin{array}{l}\text { Kredyt bez zabezpieczenia, } \\
\text { kredyt/pożyczka gotówkowa }\end{array}$ & 41,3 & 39,7 & 12,7 & 6,3 \\
\hline Lokaty, depozyty terminowe & 50,7 & 30,4 & 14,5 & 4,4 \\
\hline $\begin{array}{l}\text { Karta płatnicza (debetowa, } \\
\text { kredytowa, obciążeniowa) }\end{array}$ & 52,0 & 29,9 & 10,2 & 7,9 \\
\hline Karta przedpłacona (prepaid) & 50,0 & 0,0 & 50,0 & 0,0 \\
\hline Płatności mobilne & 81,8 & 18,2 & 0,0 & 0,0 \\
\hline Fundusz emerytalny (III filar) & 55,6 & 33,3 & 11,1 & 0,0 \\
\hline Mikrokredyt & 79,4 & 14,8 & 2,9 & 2,9 \\
\hline Ubezpieczenie & 42,9 & 42,9 & 14,2 & 0,0 \\
\hline Akcje i udziały & 42,3 & 30,4 & 19,1 & 8,2 \\
\hline Obligacje & 58,8 & 35,3 & 5,9 & 0,0 \\
\hline Nie znam żadnego & 33,3 & 41,7 & 25,0 & 0,0 \\
\hline Odmawiam odpowiedzi & 26,8 & 26,8 & 17,1 & 29,3 \\
\hline
\end{tabular}

Źródło: opracowanie własne na podstawie wyników badania kwestionariuszowego. 
Na podstawie wyników rozkładu posiadanych przez badanych produktów finansowych w ciągu ostatnich 2 lat względem wieku stwierdzono, że udział osób starszych był najniższy w przypadku każdego z produktów. Ponadto:

- wśród respondentów posiadających rachunek bieżący lub rachunek oszczędnościowy, około $45 \%$ stanowili badani do 59. roku życia (włącznie) (odpowiednio: $45,0 \%$ oraz $44,3 \%$ );

- zdecydowana większość osób, które posiadały kredyt hipoteczny, miała 50-59 lat (75,0\%);

- uczestnicy badania do 59. roku życia (włącznie) stanowili 60,0\% posiadaczy pożyczki hipotecznej;

- udział osób najmłodszych, tj. w wieku 50-59 lat, wynosił 41,3\% w grupie badanych mających kredyt bez zabezpieczenia;

- po około $50 \%$ respondentów posiadających lokaty, depozyty terminowe, kartę płatniczą, rachunek inwestycyjny miało 50-59 lat (odpowiednio: 50,7\%; $52,0 \% ; 50,0 \%)$;

- zdecydowana większość posiadaczy rachunku inwestycyjnego oraz funduszu emerytalnego miała po 50-59 lat (odpowiednio: 81,8\% oraz 79,4\%);

- wśród osób posiadających ubezpieczenie $42,9 \%$ to badani do 59 . roku życia (włącznie), a 30,4\% z nich miało 60-69 lat;

- w przypadku pozostałych produktów finansowych dominowali respondenci do 69. roku życia;

- udział osób, które przyznały, że nie znają żadnego z produktów finansowych nie był znacząco zróżnicowany ze względu na wiek;

- wśród tych, którzy odmówili odpowiedzi na pytanie dotyczące posiadania produktów finansowych w ciągu ostatnich 2 lat, $60 \%$ stanowily osoby w wieku 50-59 lat.

Następną cechą kształtującą skalę posiadania w ciągu 2 ostatnich lat produktów finansowych przez ankietowanych było wykształcenie. Zróżnicowanie zakresu włączenia finansowego w ciągu 2 lat i poziomu wykształcenia przedstawia tablica 61 .

Tablica 61. Posiadanie produktów finansowych w ciągu ostatnich 2 lat a wykształcenie badanych (w \%)

\begin{tabular}{|c|c|c|c|c|c|}
\hline Produkt finansowy & Wyższe & $\begin{array}{c}\text { Zawodowe } \\
\text { policealne }\end{array}$ & $\begin{array}{c}\text { Średnie ogól- } \\
\text { nokształcące, } \\
\text { średnie } \\
\text { zawodowe }\end{array}$ & $\begin{array}{c}\text { Wyksztalcenie } \\
\text { zasadnicze } \\
\text { zawodowe }\end{array}$ & $\begin{array}{c}\text { Wykształcenie } \\
\text { podstawowe }\end{array}$ \\
\hline 1 & 2 & 3 & 4 & 5 & 6 \\
\hline $\begin{array}{l}\text { Rachunek bieżący } \\
\text { (rachunek } \\
\text { oszczędnościowo- } \\
\text {-rozliczeniowy, ROR) }\end{array}$ & 17,4 & 5,0 & 37,5 & 22,4 & 17,7 \\
\hline
\end{tabular}




\begin{tabular}{|c|c|c|c|c|c|}
\hline 1 & 2 & 3 & 4 & 5 & 6 \\
\hline $\begin{array}{l}\text { Rachunek } \\
\text { oszczędnościowy, } \\
\text { konto } \\
\text { oszczędnościowe }\end{array}$ & 26,2 & 4,9 & 41,8 & 18,9 & 8,2 \\
\hline Kredyt hipoteczny & 66,7 & 0,0 & 25,0 & 8,3 & 0,0 \\
\hline Pożyczka hipoteczna & 30,0 & 0,0 & 40,0 & 10,0 & 20,0 \\
\hline $\begin{array}{l}\text { Kredyt } \\
\text { bez zabezpieczenia, } \\
\text { kredyt/pożyczka } \\
\text { gotówkowa }\end{array}$ & 18,0 & 8,2 & 37,7 & 21,3 & 14,8 \\
\hline $\begin{array}{l}\text { Lokaty, depozyty } \\
\text { terminowe }\end{array}$ & 34,3 & 5,7 & 47,1 & 2,9 & 10,0 \\
\hline $\begin{array}{l}\text { Karta płatnicza } \\
\text { (debetowa, } \\
\text { kredytowa, } \\
\text { obciążeniowa) }\end{array}$ & 26,8 & 2,8 & 42,5 & 19,0 & 8,9 \\
\hline $\begin{array}{l}\text { Karta przedpłacona } \\
\text { (prepaid) }\end{array}$ & 50,0 & 0,0 & 50,0 & 0,0 & 0,0 \\
\hline Płatności mobilne & 72,7 & 9,1 & 18,2 & 0,0 & 0,0 \\
\hline $\begin{array}{l}\text { Fundusz emerytalny } \\
\text { (III filar) }\end{array}$ & 11,1 & 0,0 & 72,2 & 16,7 & 0,0 \\
\hline Mikrokredyt & 41,3 & 0,0 & 52,9 & 2,9 & 2,9 \\
\hline Ubezpieczenie & 14,3 & 28,6 & 14,3 & 28,6 & 14,2 \\
\hline Akcje i udziały & 24,0 & 3,1 & 36,7 & 18,3 & 17,9 \\
\hline Obligacje & 50,0 & 0,0 & 33,3 & 5,6 & 11,1 \\
\hline Nie znam żadnego & 41,7 & 16,6 & 41,7 & 0,0 & 0,0 \\
\hline $\begin{array}{l}\text { Odmawiam } \\
\text { odpowiedzi }\end{array}$ & 7,7 & 5,1 & 10,3 & 25,6 & 51,3 \\
\hline
\end{tabular}

Źródło: opracowanie własne na podstawie wyników badania kwestionariuszowego.

Analiza rozkładu takich zmiennych jak posiadanie produktu finansowego w ciągu ostatnich 2 lat oraz wykształcenia dostarczyła następujących wniosków:

- badani posiadający rachunek bieżący to w $37,5 \%$ osoby z wykształceniem średnim ogólnokształcącym, zawodowym;

- blisko $42 \%$ posiadaczy rachunku oszczędnościowego miała wykształcenie średnie ogólnokształcące, zawodowe (41,8\%);

- większość posiadających kredyt hipoteczny to osoby z dyplomem uczelni wyższej $(66,7 \%)$;

- po około $40 \%$ tych, którzy posiadali pożyczkę hipoteczną, kredyt bez zabezpieczenia lub kartę płatniczą miało wykształcenie średnie ogólnokształcące, zawodowe (odpowiednio: 40,0\%; 37,7\%; 42,5\%); 
- wśród badanych posiadających lokaty, depozyty terminowe oraz kartę przedpłaconą, około połowa miała wykształcenie średnie ogólnokształcące, średnie zawodowe (odpowiednio: $47,1 \%$ oraz 50,0\%);

- zdecydowana większość posiadaczy rachunku inwestycyjnego miała wykształcenie wyższe $(72,7 \%)$;

- w gronie posiadaczy ubezpieczenia $36,7 \%$ miało wykształcenie średnie ogólnokształcące, zawodowe, a co czwarty z nich wykształcenie wyższe (24,0\%);

- w przypadku pozostałych produktów finansowych znaczący udział mieli posiadacze wykształcenia wyższego oraz średniego ogólnokształcącego, zawodowego;

- ponad połowa osób, które nie znały żadnego z produktów finansowych miała wykształcenie podstawowe $(51,3 \%)$;

- najczęściej odpowiedzi na pytanie dotyczące posiadania produktów finansowych w ciągu ostatnich 2 lat odmawiali badani z wykształceniem zasadniczym zawodowym $(58,3 \%)$.

Ostatnią determinantą badanej populacji w odniesieniu do posiadanych w ciągu 2 lat produktów finansowych był miesięczny dochód netto. Zależność między tą cechą a skalą korzystania z produktów finansowych ujmuje rysunek 83 .

Wnioski z analizy między posiadanymi produktami finansowymi w ciągu 2 ostatnich lat a miesięcznym dochodem netto przedstawiają się następująco:

- osoby, które w ciągu ostatnich 2 lat posiadały rachunek bieżący, to w 45,3\% badani posiadający miesięczne dochody w wysokości powyżej 1730 zł netto;

- niemal 55\% respondentów będących posiadaczami rachunku oszczędnościowego miało dochody przekraczające $1730 \mathrm{zł}$ netto miesięcznie;

- zdecydowaną większość osób, które zaciągnęły kredyt hipoteczny, stanowili badani o dochodach powyżej $1730 \mathrm{zł}$ netto miesięcznie;

- wszyscy, który posiadali kredyt hipoteczny bądź kartę przedpłaconą, mieli dochody miesięczne przekraczające $1730 \mathrm{zł}$ netto;

- udział uczestników badania posiadających dochody miesięczne w wysokości 1001-1730 zł netto wśród posiadających kredyt bez zabezpieczenia wynosił $49,0 \%$;

- zdecydowana większość posiadaczy lokat, depozytów terminowych miała dochody miesięczne przekraczające $1730 \mathrm{zł}$ netto $(72,2 \%)$;

- ponad połowa osób posiadających kartę płatniczą to badani z dochodem miesięcznym ponad $1730 \mathrm{zł}$ netto $(55,0 \%)$;

- wśród osób posiadających rachunek inwestycyjny bądź fundusz emerytalny czy akcje i udziały, zdecydowana większość posiadała zarobki powyżej 1730 zł netto miesięcznie (odpowiednio: 90,0\%; 75,9\%; 83,4\%);

- w grupie posiadaczy ubezpieczenia $43,3 \%$ stanowili respondenci z dochodem przekraczającym 1730 zł netto na miesiąc, a ci z dochodami w granicach $1001-1730$ zł-36,0\%; 
- w przypadku pozostałych produktów finansowych mniejszość stanowili ci $\mathrm{z}$ dochodami do $1000 \mathrm{zł}$ netto miesięcznie;

- wśród badanych, którzy nie znali żadnego produktu finansowego dominowali ci z miesięcznymi dochodami netto do $1000 \mathrm{zk}$;

- osoby z dochodami do 1730 zł netto na miesiąc dominowały wśród tych, którzy odmówili odpowiedzi na pytanie o posiadane produkty finansowe w ciągu 2 ostatnich lat.

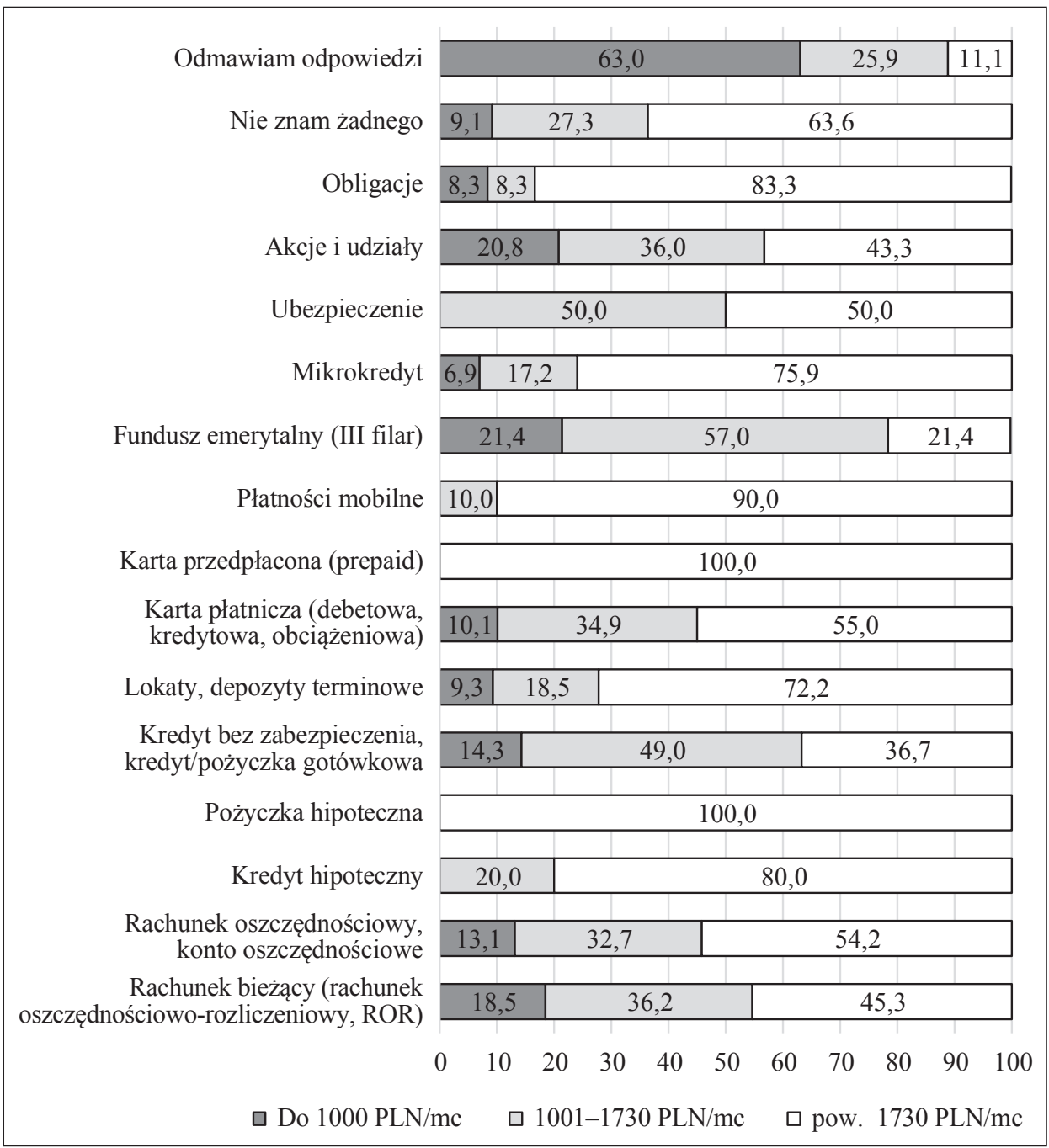

Rysunek 83. Posiadanie produktów finansowych w ciągu ostatnich 2 lat a miesięczne dochody netto badanych (w \%)

Źródło: opracowanie własne na podstawie wyników badania kwestionariuszowego 
Podsumowując zakres posiadanych w ciągu dwóch lat produktów finansowych przez respondentów oraz brane pod uwagę cechy demograficzne różnicujące populację, należy zwrócić uwagę na ich zbieżność z założeniami teoretycznymi warunkującymi włączenie w system finansowy, czy też węziej - bankowy. Wyższym włączeniem bankowym charakteryzują się osoby w niższych przedziałach wiekowych, zamieszkujące większe miejscowości i miasta. Ponadto kobiety okazały się być posiadaczkami najbardziej klasycznych produktów bankowych (rachunek bankowy, lokata, kredyt), podczas gdy mężczyźni chętniej korzystali $\mathrm{z}$ bardziej urozmaiconego wachlarza produktów.

Ponadto, znamienne okazało się uzyskanie bardzo zbliżonych wyników dla takich czynników, jak: płeć, miejsce zamieszkania, wiek, wykształcenie oraz miesięczny dochód netto w przypadku zakresu aktualnie posiadanych produktów finansowych oraz produktów, z których korzystali badani w ciągu 2 ostatnich lat. Należy zatem wnioskować, że tak krótki upływ czasu nie wpływa znacząco na zmianę nawyków dotyczących korzystania z produktów finansowych. Tym samym zwiększająca się skala ubankowienia jest efektem włączania w system bankowy innych grup wiekowych niż 50+. Stabilny poziom włączenia finansowego osób w wieku 50+ świadczy o ich przywiązaniu do zaakceptowanych wcześniej rozwiązań i o istnieniu ewidentnie barier w ich przełamywaniu.

\subsection{Wiedza finansowa teoretyczna a aktualne posiadanie produktów finansowych}

Uzupełnieniem przedstawionych wcześniej w rozdziale analiz jest identyfikacja bardzo istotnej z punktu widzenia badania poziomu wiedzy finansowej oraz problemu wykluczenia finansowego zależności pomiędzy posiadaną wiedzą teoretyczną a zakresem korzystania z produktów finansowych. Poniższe analizy przedstawiają profil badanych związany jednocześnie z posiadanymi przez nich produktami finansowymi oraz udzieleniem prawidłowych odpowiedzi na zagadnienia - wskaźniki wiedzy finansowej teoretycznej ${ }^{20}$.

Pierwsze pytanie służące identyfikacji poziomu wiedzy finansowej teoretycznej sformułowane było następująco: proszę odpowiedzieć czy Pani/Pana zdaniem poniższe stwierdzenia są prawdziwe czy fałszywe: Inwestycja o wysokiej stopie zwrotu charakteryzuje się wysokim ryzykiem. Wyniki analizy wskazującej na skalę posiadanych produktów finansowych i prawidłowość udzielonej odpowiedzi przedstawia rysunek 84 .

${ }^{20}$ Wskaźnikami „wiedzy finansowej - teoretycznej” uznano zagadnienia typu „prawda-fałsz” (5 zagadnień) i na podstawie odpowiedzi badanych było możliwe określenie poziomu wiedzy finansowej (teoretycznej). 


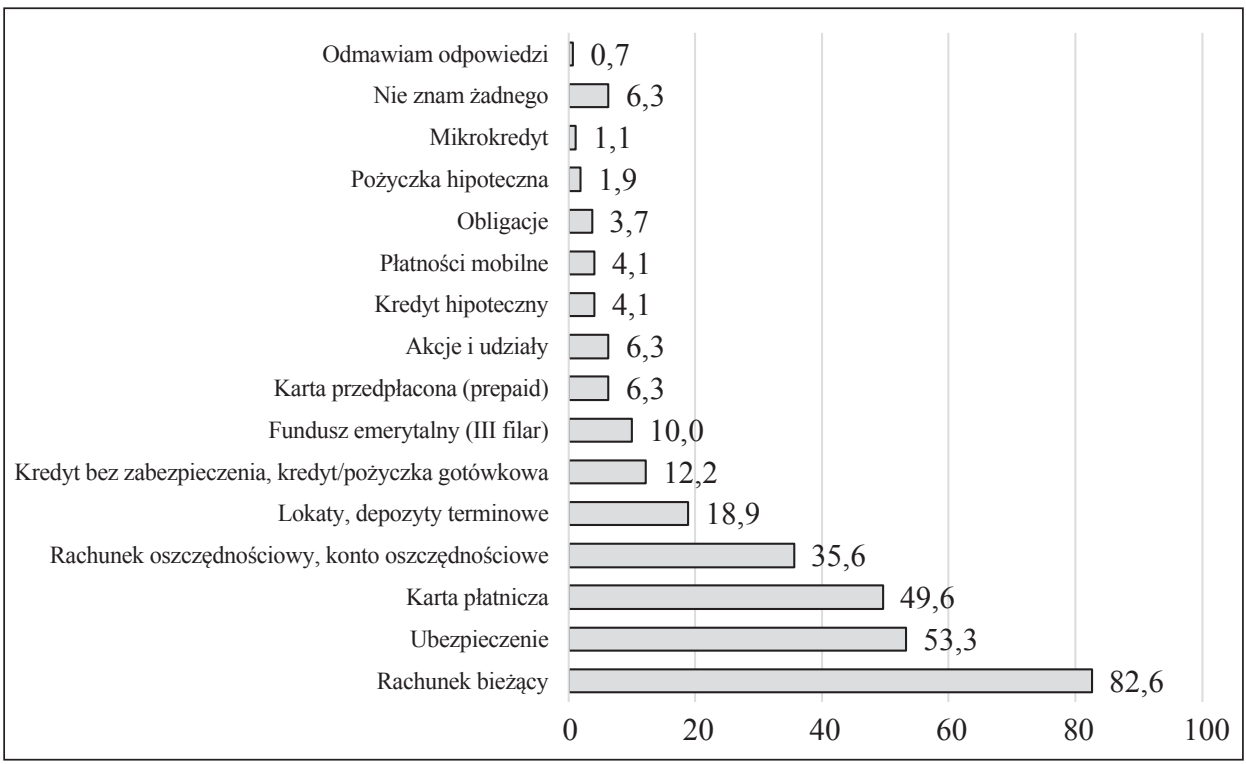

Rysunek 84. Prawidłowe odpowiedzi na pytanie 1 a aktualne posiadanie produktów finansowych (wielokrotny wybór) (w \%)

Źródło: opracowanie własne na podstawie wyników badania kwestionariuszowego

Wśród osób, które poprawnie odpowiedziały na pytanie 1, będące wskaźnikiem wiedzy finansowej - teoretycznej, zdecydowana większość posiadała rachunek bieżący $(82,6 \%)$, około połowa była posiadaczami ubezpieczenia oraz karty płatniczej (odpowiednio: $53,3 \%$ oraz 49,6\%). Niemal 36\% respondentów z tej grupy posiadało rachunek oszczędnościowy (35,6\%). Co piąta osoba, która wiedziała, że inwestycja o wysokiej stopie zwrotu charakteryzuje się wysokim ryzykiem posiadała lokatę, depozyt terminowy (18,9\%), a około 10\% - kredyt bez zabezpieczeń oraz fundusz emerytalny (odpowiednio: $12,2 \%$ oraz $10,0 \%$ ). Posiadacze pozostałych produktów finansowych stanowili mniej niż 7\% osób, które poprawnie odpowiedziały na pytanie 1 .

Drugim pytaniem weryfikującym wiedzę finansową teoretyczną było następujące zagadnienie: gdyby ktoś Pani/Panu zaoferował szansę zarobienia dużych pieniędzy czy jednocześnie postrzega to Pani/Pan jako możliwość stracenia dużej kwoty pieniędzy? Związek między poprawnie udzielonymi na niego odpowiedziami a posiadanymi produktami finansowymi przedstawia rysunek 85 .

Wśród osób, które, mając szansę zarobienia dużych pieniędzy i jednocześnie postrzegało to jako możliwość stracenia dużej kwoty pieniędzy, ponad 82\% posiadało rachunek bieżący $(82,3 \%)$. W przybliżeniu połowa respondentów posiadająca wiedzę związaną z pytaniem 2 była posiadaczami ubezpieczenia oraz karty płatniczej (odpowiednio: 49,2\% oraz 46,9\%). Osoby posiadające rachunek 
oszczędnościowy stanowiły $29,6 \%$ grupy. Posiadacze lokat, depozytów terminowych oraz kredytów bez zabezpieczeń stanowili około $15 \%$ badanych, którzy znali prawidłową odpowiedź na pytanie 2 (odpowiednio: 15,0\% oraz 13,8\%). Respondenci posiadający pozostałe produkty finansowe stanowili mniej niż $8 \%$ badanych z tej zbiorowości.

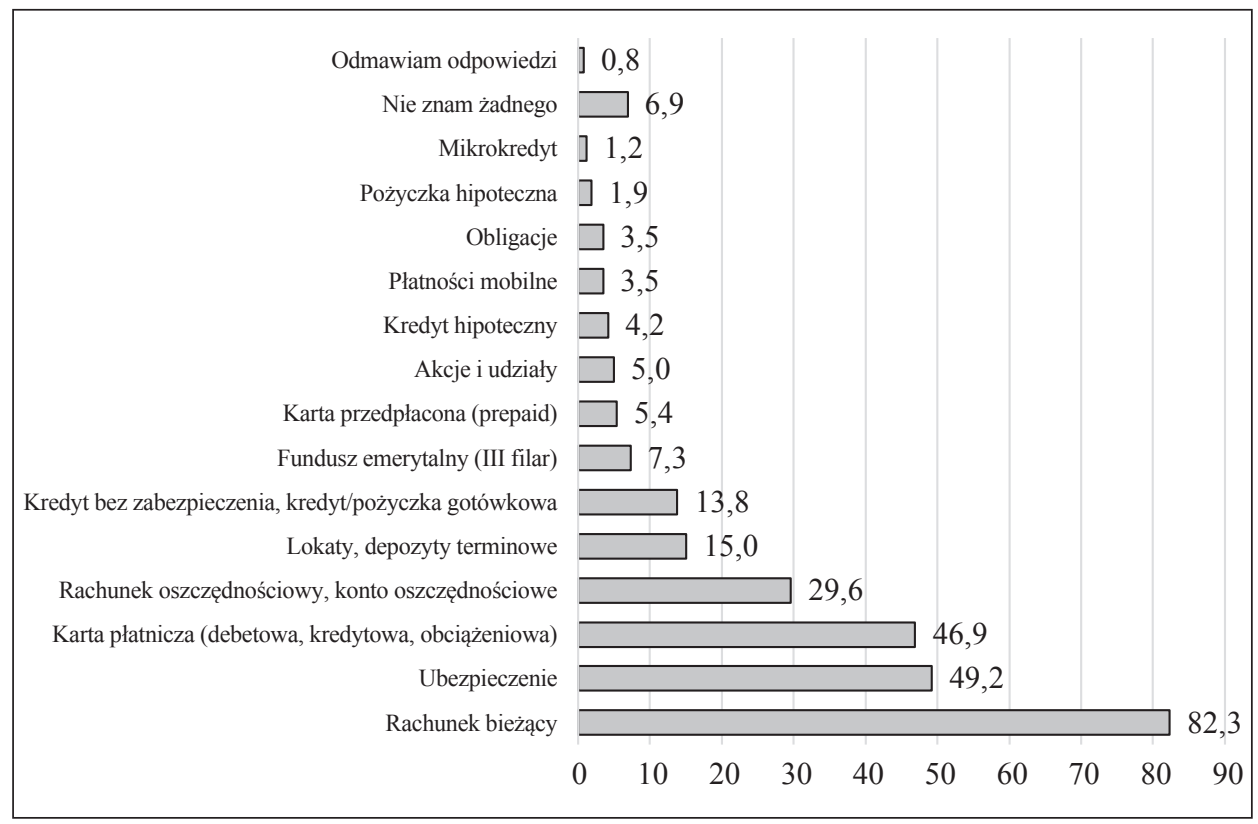

Rysunek 85. Prawidłowe odpowiedzi na pytanie $\mathrm{nr} 2$ a aktualne posiadanie produktów finansowych (wielokrotny wybór) (w \%)

Źródło: opracowanie własne na podstawie wyników badania kwestionariuszowego

Trzecie zadane ankietowanym pytanie, mające na celu zbadanie poziomu ich wiedzy finansowej brzmiało: czy Pani/Pana zdaniem wysoka inflacja oznacza, że koszty życia gwałtowanie wzrastają? Rysunek 86 prezentuje rozkład prawidłowo udzielonych odpowiedzi wraz ze skalą posiadanych produktów finansowych.

Zdecydowana większość respondentów, którzy wiedzieli, że wysoka inflacja oznacza gwałtowny wzrost kosztów życia, posiadało rachunek bieżący $(81,0 \%)$. Ponad połowa badanych $\mathrm{z}$ tej grupy była posiadaczami ubezpieczenia $(51,3 \%)$. Kartę płatniczą posiadało $44,5 \%$ osób znających prawidłową odpowiedź na pytanie 3, a rachunek oszczędnościowy około 1/3 (32,2\%). Ponad 17\% uczestników badania odznaczających się wiedzą związaną z pytaniem 3 posiadało lokaty, depozyty terminowe $(17,1 \%)$, a $13,4 \%$ - karty bez zabezpieczenia. Respondenci posiadający pozostałe produkty finansowe stanowili mniej niż $9 \%$ uczestników badania, którzy odpowiedzieli poprawnie na to zagadnienie. 


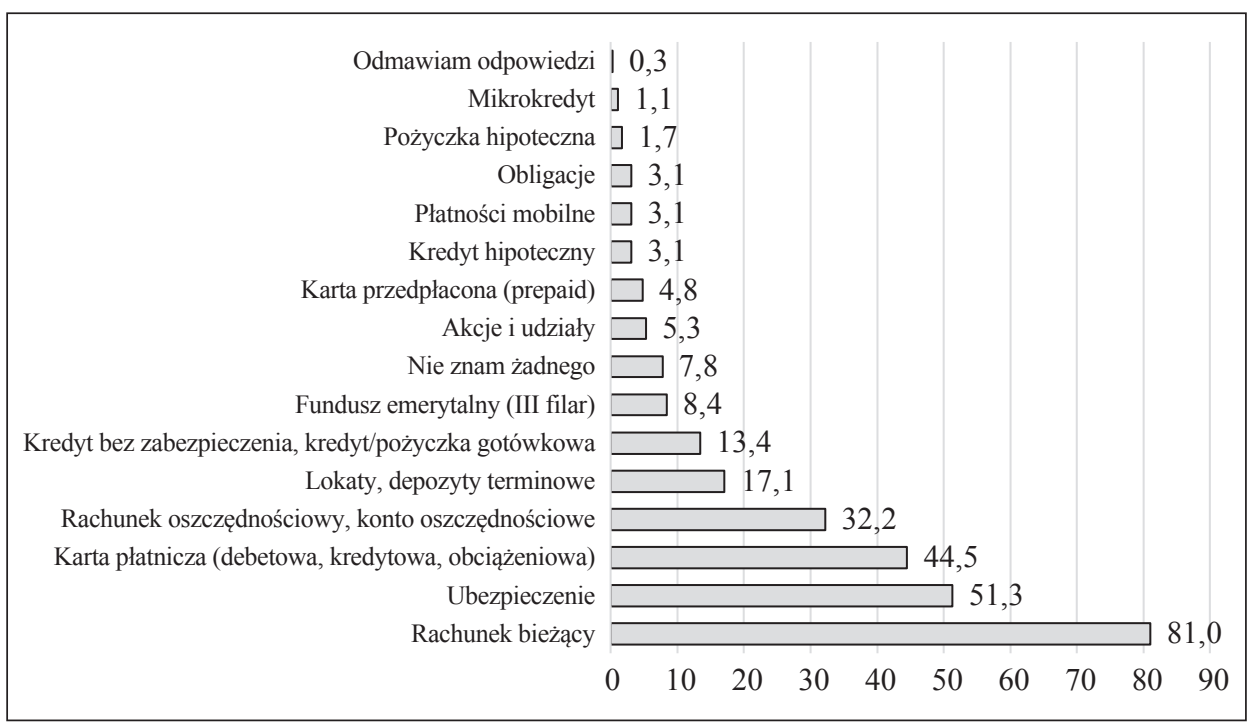

Rysunek 86. Prawidłowe odpowiedzi na pytanie nr 3 a aktualne posiadanie produktów finansowych (wielokrotny wybór) (w \%)

Źródło: opracowanie własne na podstawie wyników badania kwestionariuszowego

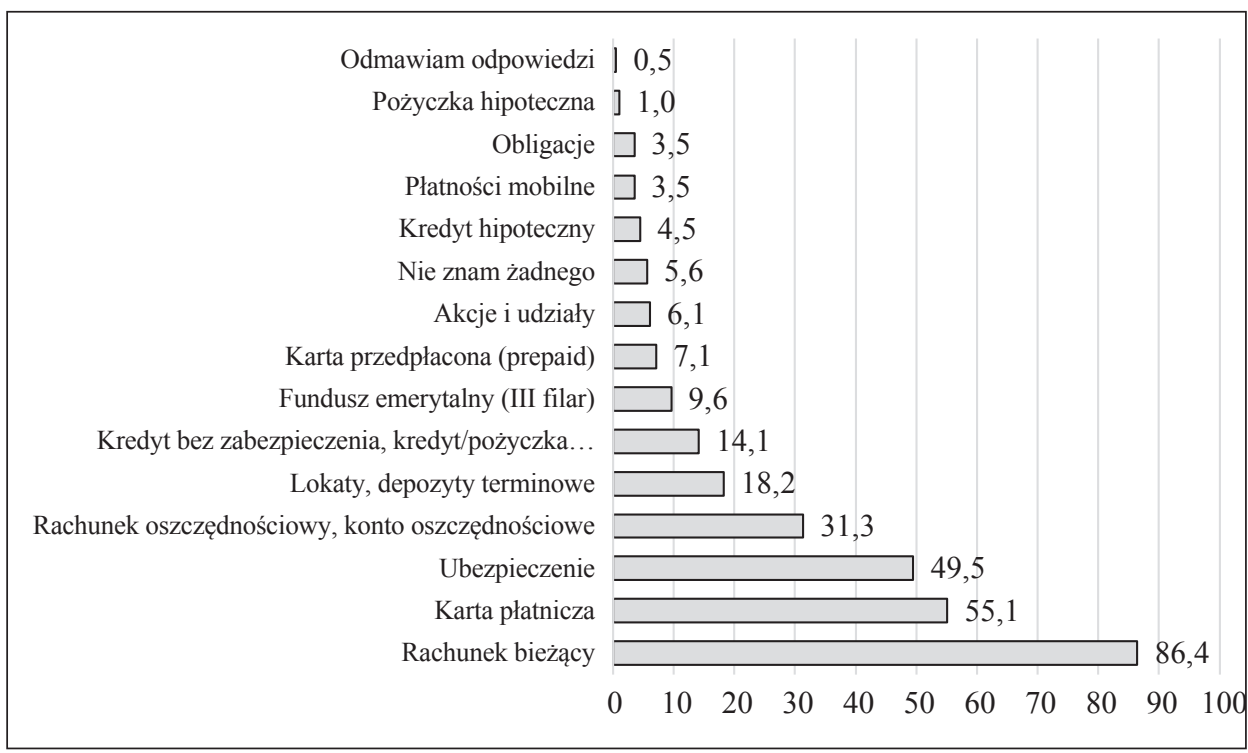

Rysunek 87. Prawidłowe odpowiedzi na pytanie $\mathrm{nr} 4$ a aktualne posiadanie produktów finansowych (wielokrotne odpowiedzi) (w \%)

Źródło: opracowanie własne na podstawie wyników badania kwestionariuszowego 
Czwarte pytanie identyfikujące poziom wiedzy finansowej w aspekcie teoretycznym odnosiło się do zagadnienia inwestowania na giełdzie papierów wartościowych i brzmiało następująco: czy Pani/Pana zdaniem zazwyczaj istnieje możliwość ograniczenia ryzyka podczas inwestowania na giełdzie poprzez zakup różnych akcji? Rysunek 87 przedstawia rozkład prawidłowych odpowiedzi w odniesieniu do rodzaju posiadanego produktu finansowego.

Wśród osób, które wiedziały, że zazwyczaj istnieje możliwość ograniczenia ryzyka podczas inwestowania na giełdzie poprzez zakup różnych akcji, 86,4\% było posiadaczami rachunku bieżącego. Kartę płatniczą posiadało 55,1\% respondentów odznaczających się tą wiedzą. Połowa badanych znających poprawną odpowiedź na pytanie 4 miało ubezpieczenie, a około $30 \%$ - rachunek oszczędnościowy $(31,3 \%)$. Uczestnicy badania, którzy znali prawidłową odpowiedź na to zagadnienie i jednocześnie byli posiadaczami lokaty, depozytu terminowego, stanowili 18,2\% grupy, natomiast ci, którzy zaciągnęli kredyt bez zabezpieczenia - 14,1\% zbiorowości. Mniej niż 10\% badanych, znających prawidłową odpowiedź na pytanie 4 stanowili posiadacze pozostałych produktów finansowych.

Ostatnie pytanie, które posłużyło opracowaniu wskaźnika wiedzy finansowej miało następującą formułę: czy Pani/Pana zdaniem istnieje wyższe prawdopodobieństwo stracenia wszystkich pieniędzy, jeśli są one przechowywane w jednym miejscu? Zależność między prawidłowo udzielonymi na to pytanie odpowiedziami a posiadanymi przez ankietowanych produktami finansowymi prezentuje rysunek 88 .

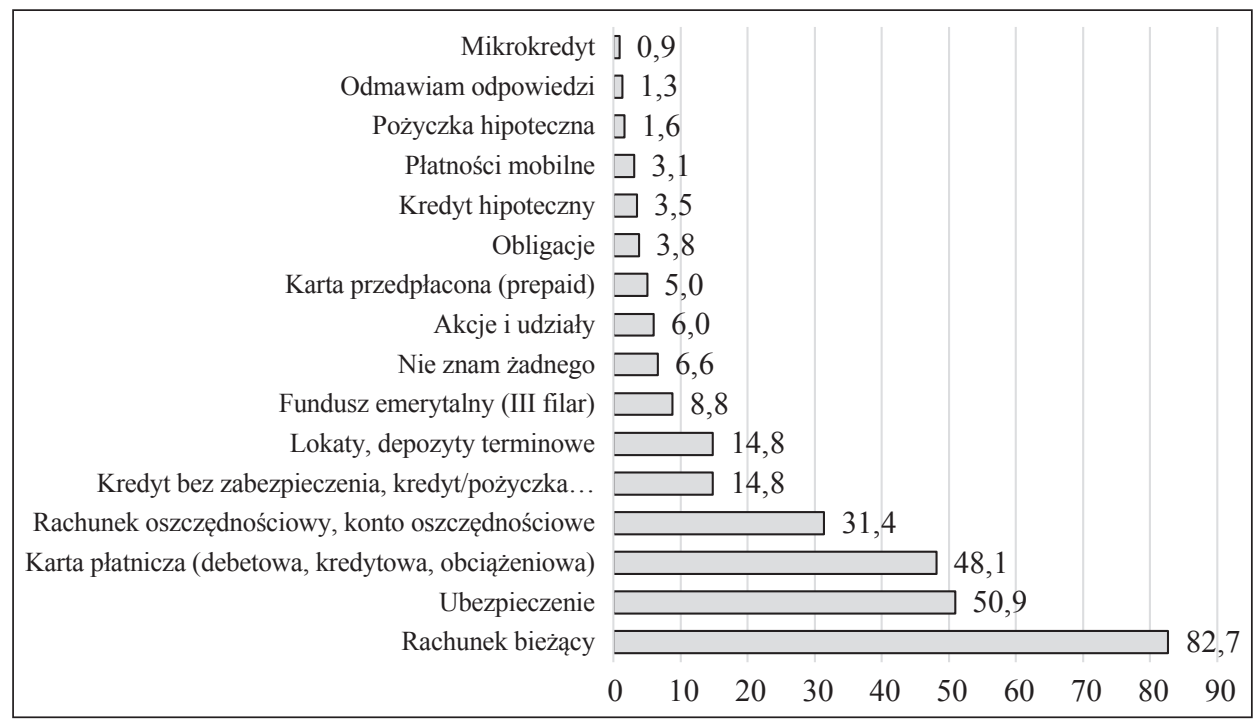

Rysunek 88. Prawidłowe odpowiedzi na pytanie nr 5 a aktualne posiadanie produktów finansowych (wielokrotne odpowiedzi) (w \%)

Źródło: opracowanie własne na podstawie wyników badania kwestionariuszowego 
Zdecydowana większość osób, których zdaniem istnieje wyższe prawdopodobieństwo stracenia wszystkich pieniędzy, jeśli są one przechowywane w jednym miejscu, posiadało rachunek bieżący $(82,7 \%)$. Blisko połowa osób z tej grupy to posiadacze ubezpieczenia $(50,9 \%)$ oraz karty płatniczej $(48,1 \%)$. Rachunek oszczędnościowy posiadało 31,4\% badanych znających prawidłową odpowiedź na to zagadnienie. Po 14,8\% respondentów, którzy wykazali się wiedzą związaną z wyższym prawdopodobieństwem stracenia wszystkich pieniędzy w przypadku przechowywania ich w jednym miejscu, posiadali kredyt bez zabezpieczenia oraz lokaty, depozyt terminowy. Badani posiadający pozostałe produkty finansowe stanowili mniej niż $9 \%$ zbiorowości.

Przedstawiona powyżej analiza związku między wiedzą finansową a korzystaniem z produktów finansowych wskazała na istnienie korelacji między posiadanym poziomem wiedzy a poziomem włączenia w system finansowy. Wśród osób, które poprawnie odpowiedziały na pytania od 1 do 5, będące wskaźnikiem wiedzy finansowej - teoretycznej, we wszystkich przypadkach zdecydowana większość posiadała rachunek bieżący (zwykle blisko 80\%), blisko połowa była posiadaczami ubezpieczenia oraz karty płatniczej, niemal $1 / 3$ respondentów z tej grupy posiadała rachunek oszczędnościowy i około $1 / 5$ badanych korzystało z lokaty lub depozytu terminowego. Na dalszych miejscach wskazywano kredyty i pozostałe produkty finansowe. Udział osób, które udzieliły prawidłowych odpowiedzi, ale nie posiadają żadnych produktów finansowych pozostawał na niskim poziomie i wahał się w zależności od pytania od $6,3 \%$ do $7,8 \%$.

\subsection{Podsumowanie}

Podsumowując wyniki badania kwestionariuszowego, należy uznać, że generalnie poziom wiedzy finansowej osób w wieku 50+ nie odbiega znacząco od wyników dla pozostałych grup wiekowych ${ }^{21}$, aczkolwiek istnieją obszary, w których dysproporcje są bardziej widoczne. Zestawienie wyników dotyczących poziomu wiedzy finansowej uzyskanych podczas realizacji badania pierwotnego, w porównaniu z wynikami badania przeprowadzonego w Polsce przez OECD prezentuje rysunek 89 .

${ }^{21}$ Wyniki badań pierwotnych dotyczących mieszkańców województwa łódzkiego w wieku osób powyżej 50. lat porównano z wynikami badań przeprowadzonych na ogólnej populacji Polaków, przeprowadzonymi według tej samej metodologii (patrz A. Atkinson, F. Messy, Measuring Financial Literacy: Results of the CD/International Network on Financial Education (INFE) Pilot Study, OECD Working Papers on Finance, Insurance and Private Pensions, No. 15, OECD Publishing, 2012). Badanie OECD zawierało poza standardowym zestawem pytań także zestaw pytań uzupełniających pozwalający na bardziej rozbudowaną analizę. Badanie przeprowadzone przez autorów pomimo mniejszej liczby pytań pozwala wnioskować na temat ważnych z punktu widzenia realizacji celu publikacji zależności. 


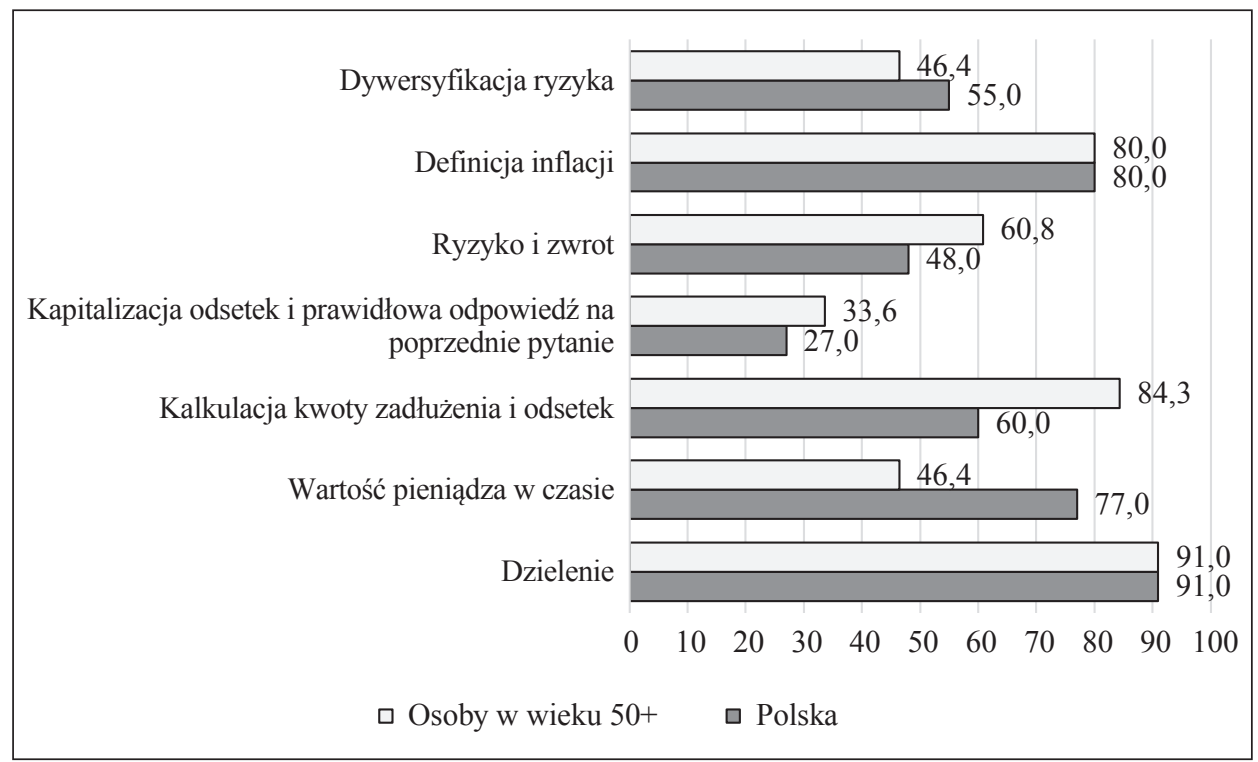

Rysunek 89. Porównanie wiedzy finansowej na podstawie badań pierwotnych i wtórnych (w \%)

Źródło: opracowanie własne na podstawie wyników badania kwestionariuszowego oraz A. Atkinson, F. Messy, Measuring Financial Literacy: Results of the CD/International Network on Financial Education (INFE) Pilot Study, OECD Working Papers on Finance, Insurance and Private Pensions, No. 15, OECD Publishing, 2012.

Pojęcie dzielenia oraz inflacji okazało się być tak samo znajome dla osób w wieku 50+ jak i dla wszystkich grup wiekowych badanych przez OECD. Pozytywnie należy ocenić świadomość finansową w kwestii zależności ryzyka i stopy zwrotu z inwestycji oraz kalkulacji kwoty zadłużenia. Uzyskane tak dobre rezultaty mogą być wynikiem obaw osób 50+ przed zadłużaniem się i ponoszeniem dodatkowego ryzyka, gdyż tak jak już wspomniano wcześniej awersja do ryzyka wzrasta wraz z wiekiem. Na niższym poziomie okazała się być wiedza z dziedziny możliwości dywersyfikowania ryzyka oraz wartości pieniądza w czasie. Te dwa obszary powinny być $\mathrm{w}$ większym stopniu brane pod uwagę w programach edukujących osoby $50+$.

Kolejnym elementem podlegającym porównaniu jest kwestia poziomu pozytywnych zachowań finansowych. Porównanie wyników uzyskanych w badaniach pierwotnych i wtórnych przedstawia rysunek 90.

Osoby w wieku 50+ okazały się być zdecydowanie bardziej rozważne podczas podejmowania decyzji na temat zakupu produktów finansowych i chętniej zasięgające opinii przed podjęciem decyzji o ich nabyciu. Respondenci w wieku 50+ przywiązywali większą wagę do płacenia rachunków na czas. Natomiast charakteryzowali się niższą odpowiedzialnością przy kontrolowaniu budżetu do- 
mowego i częściej podejmowali decyzję o zadłużaniu się w przypadku wystąpienia bieżących problemów finansowych. Traktowali to jako najbardziej popularną formę postępowania w przypadku braku środków na pokrycie kosztów, co może świadczyć o częstszym występowaniu trudności w pokryciu kosztów życia oraz problemów w pozyskaniu alternatywnych form finansowania niespodziewanych wydatków.

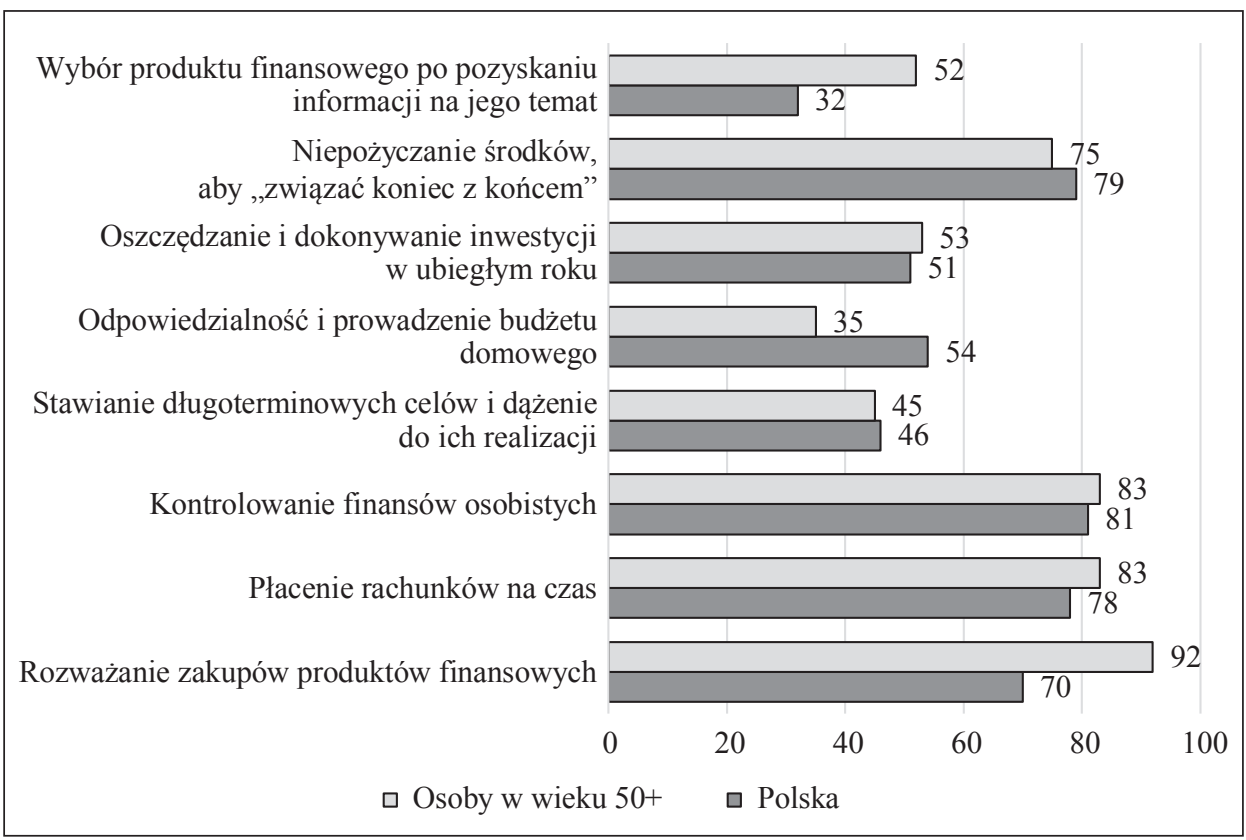

Rysunek 90. Porównanie poziomu pozytywnych zachowań finansowych na podstawie badań pierwotnych i wtórnych (w \%)

Źródło: opracowanie własne na podstawie wyników badania kwestionariuszowego orazA. Atkinson, F. Messy, Measuring Financial Literacy: Results of the CD/International Network on Financial Education (INFE) Pilot Study, OECD Working Papers on Finance, Insurance and Private Pensions,

No. 15, OECD Publishing, 2012

Ostatnim porównywanym aspektem był stosunek do długoterminowego postrzegania finansów. W tym celu analizie poddane zostały odpowiedzi na trzy poniższe zagadnienia:

- pieniądze są po to, aby je wydawać,

- preferowane jest życie z dnia na dzień niż dbanie o przyszłość,

- bardziej satysfakcjonujące jest wydawanie niż oszczędzanie w dłuższym okresie czasu.

Zestawienie wyników uzyskanych w badaniach pierwotnych na tle wyników badań wtórnych przedstawia rysunek 91 . 


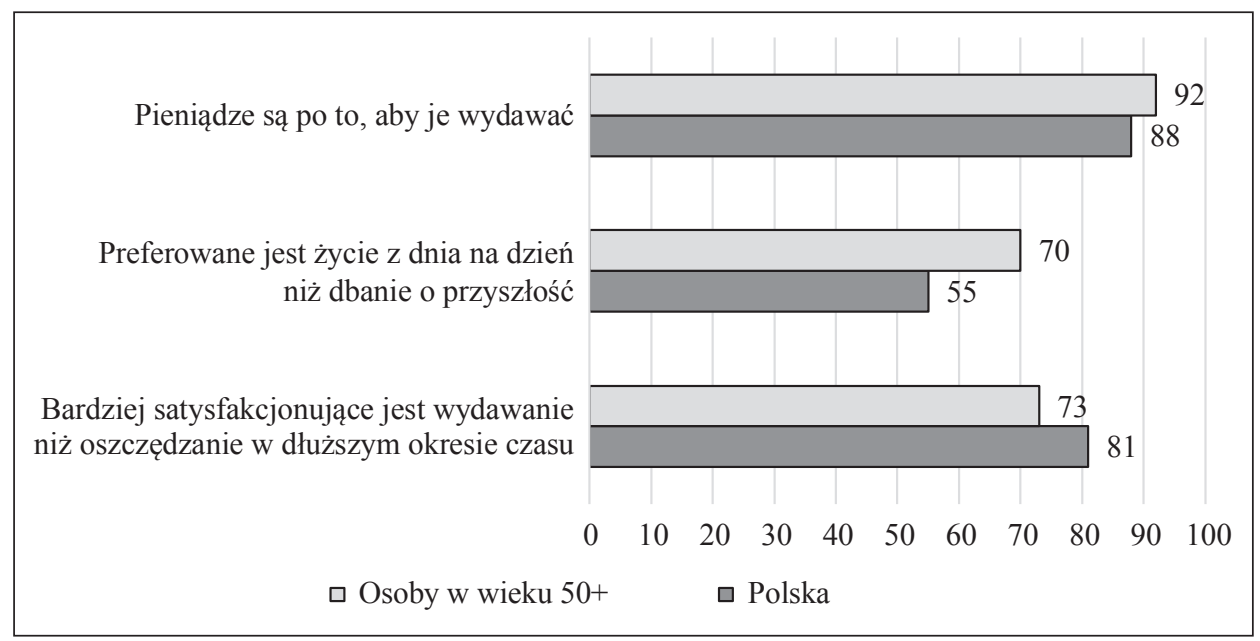

Rysunek 91. Stosunek do długoterminowego postrzegania finansów na podstawie badań pierwotnych i wtórnych (w \%)

Źródło: opracowanie własne na podstawie wyników badania kwestionariuszowego orazA. Atkinson, F. Messy, Measuring Financial Literacy: Results of the CD/International Network on Financial Education (INFE) Pilot Study, OECD Working Papers on Finance, Insurance and Private Pensions,

No. 15, OECD Publishing, 2012

Widoczne są znaczne dysproporcje między osobami w wieku 50+ a pozostałymi respondentami w długoterminowym postrzeganiu finansów. Osoby starsze w większym stopniu postrzegają pieniądze przez pryzmat ich wydawania i preferują życie z dnia na dzień. Może to być wynikiem mniejszej ilości środków pieniężnych, jakie mają do dyspozycji. Natomiast mniejszy odsetek respondentów w wieku 50+ zgodził się ze stwierdzeniem, że bardziej satysfakcjonujące jest wydawanie niż oszczędzanie w dłuższym okresie czasu.

Podsumowując, uzyskane wyniki świadczą o istnieniu pozytywnej zależności między posiadaną wiedzą a zakresem włączenia w system bankowy czy też szerzej - finansowy. W przypadku osób w wieku 50+ widoczne jest korzystanie z podstawowych (tradycyjnych) produktów bankowych i towarzyszące im większe obawy przed pozostałymi produktami finansowymi oraz niechęć do ich stosowania.

Poziom wiedzy finansowej starszych mieszkańców województwa łódzkiego wypadł w większości pytań kontrolnych dość korzystnie na tle całego społeczeństwa, natomiast gorsze rezultaty odnotowano w odniesieniu do zachowań finansowych i stosunku do długoterminowych finansów. W tych obszarach osoby starsze wykazały się niższą odpowiedzialnością przy kontrolowaniu budżetu domowego i podejmowaniem decyzji finansowych bez dokładnego rozważenia jej konsekwencji długookresowych. 
Przedstawione w ostatnim rozdziale, uzyskane podczas badania wyniki stanowić będą wytyczne dla sformułowania rekomendacji kierowanych do instytucji rządowych, samorządowych oraz przede wszystkim finansowych w aspekcie kierunków działań, jakie powinny być podejmowane w celu ograniczenia wykluczenia finansowego. 



\section{Rozdział V. Program wyrównywania szans w dostępie do wiedzy finansowej osób 50+}

\subsection{Rekomendacje dedykowane instytucjom bankowym w zakresie działań stymulujących ograniczanie zjawiska wykluczenia bankowego i podnoszenie świadomości finansowej}

\subsubsection{Przegląd i ocena działań prowadzonych przez instytucje sektora bankowego w Polsce na rzecz podnoszenia wiedzy finansowej}

Dla podniesienia poziomu wiedzy ekonomicznej społeczeństwa niezbędne jest podejmowanie na skalę masową działań edukacyjnych. Dynamiczny rozwój technologii informacyjno-komunikacyjnych oraz pojawienie się nowych mediów opartych m.in. na filozofii Web 2.0 i Web 3.0 mają istotny wpływ na cały system edukacji, w tym i na kształtowanie postaw przedsiębiorczych, i edukację ekonomiczną. Na znaczeniu zaczęły zyskiwać nowe kanały komunikacji, chociażby takie jak media społecznościowe, które umożliwiają zaangażowanie konsumentów w rozmowę na tematy finansowe za pomocą takich kanałów, jak Facebook, Twitter czy YouTube. Są one szczególnie popularne wśród osób młodych, aczkolwiek $\mathrm{z}$ roku na rok widoczny jest przyrost użytkowników w wieku 50+ wykorzystujących media społecznościowe do podtrzymywania kontaktów z członkami rodzin przebywającymi poza granicami kraju.

Rekomendowanie działań mających na celu podniesienie świadomości finansowej w grupie osób 55+ wymaga przyjrzenia się zwyczajom oraz preferowanym sposobom spędzania czasu oraz źródłom pozyskiwania wiedzy. Ze względu na wspominaną już wielokrotnie różnorodność gospodarstw domowych kwalifikujących się do tej kategorii, począwszy od najmłodszej wiekowo grupy (55-65 lat) aktywnych zawodowo, poprzez osoby w wieku 65-70 lat, które już są na emeryturze, a skończywszy na osobach powyżej 70 lat, które są najmniej aktywne 
zawodowo i społecznie, zdecydowano się skoncentrować na charakterystyce grupy wiekowej $60+^{1}$. W tym celu wykorzystano wyniki badania postaw Polaków powyżej 60. roku życia wobec obrotu bezgotówkowego.

Zgodnie z wynikami tego badania osoby $60+$ najczęściej w wolnym czasie oglądają telewizję ( $68 \%$ - często, $25 \%$ - czasami) - często programy informacyjne lub słuchają radia ( $32 \%$ - często, $33 \%$ - czasami) - zwykle popularnych, masowych stacji. Czytanie prasy cieszy się mniejszą popularnością. Wprawdzie $86 \%$ zadeklarowało sięganie po prasę przynajmniej czasami, ale często $\mathrm{w}$ ten sposób spędza czas $18 \%$ osób. Największą popularnością wśród osób $60+$ cieszy się „TeleTydzień” (regularnie czyta go 9\% respondentów), zaś wśród dzienników największą popularnością cieszy się „Fakt” (5\% regularnie, 12\% - od czasu do czasu) i „Gazeta Wyborcza” (odpowiednio: 4\%, 13\%) .

Dużo wolnego czasu osoby powyżej 60. roku życia poświęcają na czynności związane $\mathrm{z}$ domem ${ }^{3} \mathrm{tj}$.:

- gotowanie ( $40 \%$ - często, $29 \%$ - czasami),

- sprzątanie ( $34 \%$ - często, $37 \%$ - czasami),

- zajmowanie się roślinami domowymi (30\% - często, 31\% - czasami),

- opiekę nad zwierzętami ( $33 \%$ - często, 19\% - czasami).

Część osób w czasie wolnym udziela się towarzysko, głównie spędzając czas z rodziną (35\% - często, $47 \%$ - czasami) lub spotykając się z przyjaciółmi, znajomymi lub sąsiadami (18\% - często, $50 \%$ - czasami). Nieco rzadziej w czasie wolnym respondenci deklarowali opiekę nad wnukami, jeżdżenie na działkę, chodzenie na spacery, na zakupy lub czytanie książek. Zidentyfikowana została także grupa osób, która nic nie robi w czasie wolnym. 12\% osób $60+$ wskazało, że często spędza wolny czas w ten sposób, a 33\% - czasami. Popularną aktywnością w analizowanej grupie wiekowej okazało się uczęszczanie do kościoła. Udział w nabożeństwach zadeklarowało $92 \%$ respondentów, z czego największą grupę stanowili chodzący do kościoła raz w tygodniu (47\%). Na tle deklarowanych form spędzania wolnego czasu chodzenie do kościoła wydaje się być pewnym standardem $\mathrm{w}$ grupie osób $60+$, a tym samym może warto rozważyć wprowadzenie po mszy dodatkowych zajęć dla osób chętnych o tematyce finansowej, nawet przez pracowników banków lub specjalnie w tym celu prze-

${ }^{1}$ Do oceny aktualnego stanu społeczno-demograficznego, a także określenia jego perspektyw rozwojowych w ramach opracowań GUS opracowany został podział ludności według ekonomicznych grup wieku oparty na przesłankach społeczno-ekonomicznych, w ramach którego wyodrębnia się zwykle trzy grupy:

- wiek przedprodukcyjny (0-17 lat),

- wiek produkcyjny (18-59 lat kobiety, 18-64 lata mężczyźni),

- wiek poprodukcyjny (60 lat i więcej kobiety, 65 lat i więcej mężczyźni).

${ }^{2}$ Badanie postaw Polaków powyżej 60. roku życia wobec obrotu bezgotówkowego, Raport przygotowany dla NBP, Dom Badawczy Maison, Warszawa, kwiecień 2012, s. 10-13.

${ }^{3}$ Ibidem, s. 11. 
szkolonych pracowników kancelarii. Wydawać może się to kontrowersyjne, lecz biorąc pod uwagę charakterystykę osób powyżej 60. roku życia może okazać się skuteczne.

Zamiłowanie do oglądania telewizji i generalnie spędzania czasu w domu znajduje swoje odzwierciedlenie we wskazywanych jako najbardziej powszechne kanały pozyskiwania wiedzy finansowej. Zestawienie popularności poszczególnych źródeł czerpania wiedzy ekonomicznej przedstawia rysunek 92.

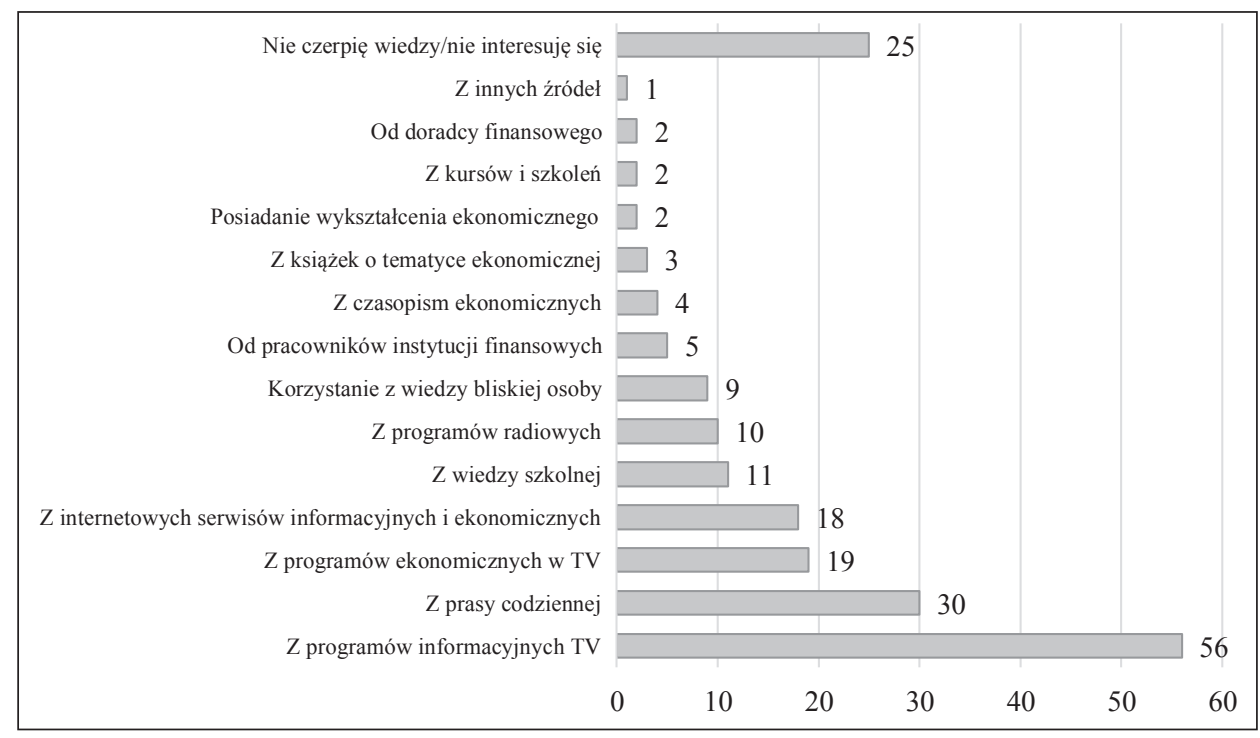

Rysunek 92. Źródła pozyskiwania wiedzy finansowej (w \%)

Źródło: Dom Badawczy Maison, Stan wiedzy finansowej Polaków, raport Fundacji Kronenberga przy Citi Handlowy, wrzesień 2009, s. 110

Najpopularniejszymi źródłami pozyskiwania wiedzy ekonomicznej okazały się programy telewizyjne oraz prasa codzienna i Internet ${ }^{4}$. Może to oczywiście wynikać z największej powszechności i przystępności tego kanału. Podobne rezultaty uzyskano w badaniu przeprowadzonym w 2012 r., kiedy to spośród obywateli 11 krajów (Austria, Belgia, Francja, Niemcy, Włochy, Luksemburg, Holandia, Polska, Hiszpania, Turcja, Wielka Brytania) największa liczba respondentów z Polski (ok. 55\%) odpowiedziała, że czerpie wiedzę na temat finansów z Internetu, prasy, telewizji lub radia 5 .

${ }^{4}$ Podobne wyniki uzyskane zostały w wyniku badania społeczeństwa w Australii, gdzie Internet został wskazany jako najważniejsze źródło pozyskiwania informacji finansowych obok książek o tematyce finansowej, artykułów w czasopismach, telewizji i radio oraz kontaktu osobistego z pracownikiem instytucji finansowej. ANZ, ANZ survey of adult financial literacy in Australia (The Social Research Centre), Melbourne 2011, s. 113.

${ }^{5}$ Finansowy barometr ING: Wiedza finansowa, maj 2012, s. 5. 
Podobne wyniki uzyskane zostały $\mathrm{w}$ trakcie badania jakościowego przeprowadzanego na osobach 55+, dotyczącego wykluczenia finansowego, gdzie jednym z elementów były źródła wiedzy finansowej. W ramach wywiadów grupowych osoby starsze były pytane o ich źródła informacji, skojarzenia i doświadczenia z pięcioma kategoriami produktów: kredyty i pożyczki, konta bankowe, ubezpieczenia, lokaty, zakupy ratalne. Rozmówcy wskazali trzy główne sposoby zdobywania informacji o usługach finansowych. Pierwszym i sygnalnym była reklama, która informowała o samym produkcie finansowym, drugim - pracownik instytucji finansowej, najczęściej banku, w którym osoba starsza ma konto, trzecim - znajomi i bliscy 6 .

Warto dokonać skontrastowania źródeł pozyskiwania wiedzy z preferowanymi kanałami pozyskiwania informacji finansowych (rysunek 93).

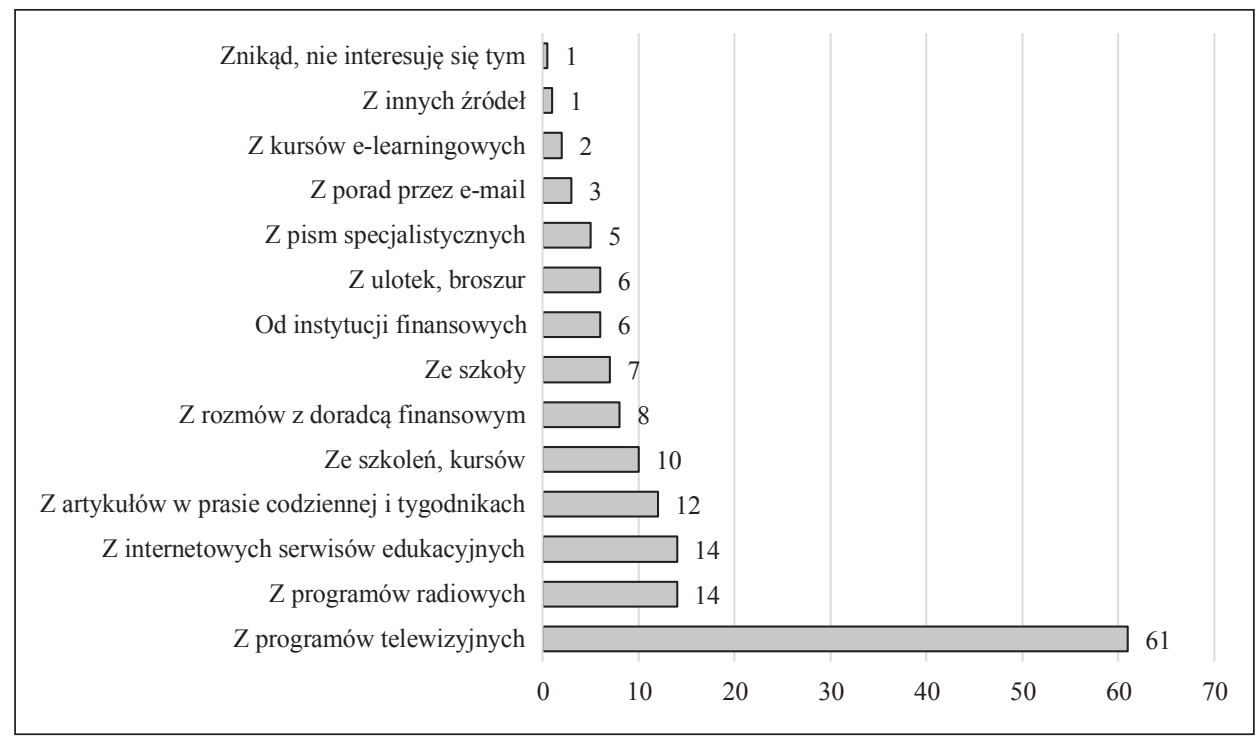

Rysunek 93. Pożądane źródła wiedzy finansowej (w \%)

Źródlo: jak przy rys. 92

Telewizja okazała się być po raz kolejny medium, z którego Polacy najchętniej chcieliby czerpać wiedzę finansową. Wynika to chociażby z dostępności tego medium i popularności (szczególnie wśród osób 55+). Na drugim miejscu znalazły się programy radiowe i internetowe serwisy edukacyjne. Oczekiwania wobec różnych źródeł wiedzy zależały również od wieku. Rola Internetu jako źródła wiedzy malała wraz z wiekiem respondentów na poczet tradycyjnych kanałów

${ }^{6}$ P. Kubicki, Osoby starsze na rynku ustug finansowych, s. 54-55, www.academia. edu/4087765/Osoby_starsze_na_rynku_uslug_finansowych (stan na dzień 02.02.2014). 
- telewizji i radia ${ }^{7}$. Tym samym, chociaż niezbędne jest szerzenie wiedzy finansowej wszystkimi dostępnymi kanałami, nie można pomijać tradycyjnej formy, jaką są programy TV, które okazują się być ważne w grupie wiekowej 55+.

Potwierdzeniem preferencji w zakresie stacjonarnego spędzania wolnego czasu są wyniki badania dotyczące aktywności podejmowanych przez osoby w wieku $60+$. Okazuje się, że aż 85\% seniorów nie jest zaangażowanych w żadną działalność - co, biorąc pod uwagę założenia koncepcji silver economy i aktywny udział w życiu społecznym i gospodarczym osób w wieku powyżej 55 lat, jest niezmiernie niepokojące. Jedynie $10 \%$ respondentów podejmowało jedną aktywność, a 3\% dwie różne aktywności. Największa liczba osób wskazała jako swoją aktywność działanie w kole parafialnym (6\%) lub udział w spotkaniach klubu seniora (4\%). Jeszcze mniej, bo $3 \%$ respondentów wykazywało aktywność w kołach zainteresowań, domach kultury lub kołach wiejskich, a 2\% uczęszczało na zajęcia Uniwersytetu Trzeciego Wieku, wspomagało organizacje charytatywne lub udzielało się w chórze, grupie teatralnej8.

Wprawdzie osoby powyżej 60. roku życia średnio oceniają stan swojego zdrowia, ale warto podkreślić, że równocześnie większość osób deklaruje, że ich stan zdrowia pozwala im funkcjonować w pełni samodzielnie lub przy niewielkiej jedynie pomocy innych (69\%). Tym samym wykazywany brak aktywności społecznych jest $\mathrm{w}$ większym stopniu wynikiem braku chęci niż możliwości determinowanych stanem zdrowia.

Zidentyfikowana niska aktywność społeczna skorelowana jest z niską aktywnością zawodową $\mathrm{w}$ grupie osób 55+. Polska należy do krajów, które w najniższym stopniu wykorzystują na rynku pracy potencjał osób dojrzałych. Ich wcześniejsza dezaktywizacja prowadzi do utraty istotnych zasobów kapitału ludzkiego, które zgromadzili, oznacza także konieczność ukierunkowania środków publicznych na ich wsparcie dochodowe. Wcześniejsza dezaktywizacja to także problem społeczny - wiele osób po przejściu na emeryturę traci swoje więzi społeczne, często związane ze środowiskiem pracy, co rodzi ryzyko poczucia osamotnienia, depresji oraz wykluczenia społecznego.

Biorąc pod uwagę wszystkie państwa członkowskie UE, współczynnik aktywności ekonomicznej ${ }^{9}$ w Polsce w IV kwartale 2012 r. dla ludności ogółem w Polsce (56,0\%) był niższy w porównaniu z całą Unią Europejską (EU 27) o 1,8

${ }^{7}$ Zbliżone wyniki uzyskane zostały w badaniu przeprowadzonym w październiku 2007 r. na zlecenie Providenta przez IPSOS. Badanie przeprowadzone zostało na grupie 1000 respondentów w celu zweryfikowania poziomu wiedzy Polaków na temat planowania, oszczędzania i zarządzania osobistymi finansami. 39\% badanych deklarowało chęć pogłębienia wiedzy na temat domowego budżetu poprzez czytanie artykułów w prasie, $21 \%$ wskazało na Internet, a 13\% na specjalistyczne poradniki. IPSOS, Oszczędzanie i zwyczaje finansowe, badanie dla Provident Polska, Warszawa, październik 2007, s. 3.

${ }^{8}$ Badanie postaw Polaków powyżej 60. roku życia..., s. 12.

9 Współczynnik aktywności zawodowej określa udział ludności aktywnej zawodowo wśród ludności danej kategorii. Informacje o aktywności ekonomicznej osób powyżej 50. roku życia zostały opracowane na podstawie uogólnionych wyników reprezentacyjnego „Badania aktywności ekonomicznej ludności” (BAEL). Badanie Aktywności Ekonomicznej Ludności prowadzone jest w Polsce kwartalnie od maja 1992 r. zgodnie z zaleceniami Eurostat. 
punktu procentowego, a dla osób w wieku powyżej 50. roku życia wyniósł w Polsce $34,1 \%$. W województwie łódzkim najniższym poziomem aktywności zawodowej charakteryzowały się osoby w wieku powyżej 55. roku życia, dla których współczynnik ten wyniósł $25,6 \%(22,7 \% \text { rok wcześniej })^{10}$.

Przy współczynniku aktywności zawodowej widoczne są też dysproporcje ze względu na płeć. Mężczyźni (zarówno w Polsce, jak i w krajach EU) charakteryzują się większą aktywnością zawodową na rynku pracy niż kobiety. Dla osób powyżej 50. roku życia w krajach EU 27 współczynnik wyniósł 43,2\% dla mężczyzn i 29,7\% dla kobiet, z kolei w Polsce odpowiednio 43,6\% i 26,7\%.

Wskaźnik zatrudnienia dla ogółu ludności w Polsce w IV kwartale 2012 r. wyniósł $50,4 \%$, przy czym dla mężczyzn był wyższy niż u kobiet i wyniósł odpowiednio: 58,4 \% i 43,0\%. Dla osób powyżej 50. roku życia wskaźnik ten wyniósł: dla ogółu - 31,7\%, dla mężczyzn - 40,5\% i dla kobiet - 24,8\%. W całej Unii Europejskiej dla ogółu ludności wskaźnik ten wyniósł 51,7 \%, a wśród osób powyżej 50. roku życia - 33,3\%. Wskaźnik zatrudnienia mężczyzn był zdecydowanie wyższy w porównaniu do kobiet - o 12,3 punktu procentowego zarówno dla ogółu, jak i w przypadku osób powyżej 50. roku życia ${ }^{11}$.

Uzupełnieniem profilu osób w wieku powyżej 60. roku życia jest ich podejście do nowoczesnych technologii. Szczególne miejsce wśród czynników wykluczających osoby $\mathrm{z}$ analizowanej grupy wiekowej z aktywnego uczestniczenia w życiu społecznym jest wykluczenie związane z dostępem i umiejętnością posługiwania się nowoczesnymi narzędziami informacyjnymi (np. komputer, Internet). Okazuje się, że osoby powyżej 60 . roku życia nie są dobrze obeznane z nowoczesną technologią. Zaledwie $16 \%$ korzysta z komputera, ale co znamienne niemal wszyscy, którzy umieją obsłużyć komputer używają także Internetu.

Zazwyczaj osoby 60+ wykorzystują podstawowe możliwości Internetu, a zatem $86 \%$ spośród korzystających z Internetu przegląda strony www, a 66\% korzysta z poczty internetowej. Wiele osób dzięki Internetowi podtrzymuje i rozwija swoje relacje społeczne, często ze względu na wyjazdy zagraniczne dzieci oraz wnuków ${ }^{12}$ i tak:

- 30\% korzysta z portali społecznościowych;

- 24\% korzysta z komunikatorów internetowych;

- $6 \%$ korzysta z telefonu przez Internet;

$-18 \%$ robi zakupy lub licytuje na aukcjach.

Pozytywnym aspektem jest korzystanie przez część respondentów z bankowości elektronicznej. 45\% spośród korzystających z Internetu obsługuje konto przez Internet.

${ }^{10}$ GUS, Aktywność ekonomiczna ludności w województwie łódzkim, marzec 2014, s. 5.

${ }^{11}$ GUS, Osoby powyżej 50. roku życia na rynku pracy w 2012 r., Warszawa-Bydgoszcz 2014, s. 34.

${ }_{12}$ Badanie postaw Polaków powyżej 60. roku życia..., s. 14. 
W znacznej mierze wykluczenie cyfrowe jest skutkiem faktu, że przez wiele lat jedynym źródłem wiedzy na temat użytkowania nowoczesnych technologii byli młodsi członkowie rodziny, którzy nie zawsze dysponowali czasem, cierpliwością i zdolnościami, aby przekazać swoim rodzicom lub dziadkom podstawy obsługi komputera i Internetu. Na chwilę obecną sytuacja ta ulega stopniowo zmianie. Już od kilku lat, za sprawą rosnącego zainteresowania sprawami i potrzebami osób 55+ wśród instytucji i organizacji odpowiedzialnych za politykę społeczną państwa, osoby te stały się głównymi adresatami akcji i kampanii społecznych, które mają na celu walkę z wykluczeniem cyfrowym.

Zilustrowany powyżej niekorzystny wizerunek Polaków w wieku 50+ niestety $\mathrm{w}$ znacznym stopniu potwierdza stereotypowe myślenie o osobach z tej grupy wiekowej jako o osobach, które z racji wieku są mniej aktywne, z racji ustania pracy zawodowej mają mniej kontaktów z innymi ludźmi, preferują pozostawanie w domu i oglądanie telewizji, względnie czytanie prasy. Rzadko decydują się na udział w życiu społecznym, jeśli już to zwykle jest to pójście do kościoła lub na spotkanie w kole parafialnym. Również nowoczesne technologie okazują się nie być sprzymierzeńcami w bardziej aktywnej partycypacji zgodnej w koncepcją silver economy. Oczywiście nie można uogólniać i należy pamiętać o grupie aktywnych osób w wieku 55+ czy nawet aktywnych emerytów, którzy łamią opisane konwenanse, jednak trzeba mieć świadomość, jak wiele należy jednak zrobić, ale odwrócić proporcję aktywnych i nieaktywnych osób 55+.

Idąc tym tropem, Polska wskazywana jest jako jeden z najbardziej aktywnych krajów Europy wschodniej pod względem inicjatyw mających na celu podniesienie świadomości finansowej obywateli ${ }^{13}$. Już w 2005 r. na tle krajów należących do UE największą liczbę programów edukacyjnych zidentyfikowano w Wielkiej Brytanii (32\%), Niemczech (22\%) i Austrii (10\%). Polska okazała się być najbardziej aktywnym krajem z bloku Europy wschodniej (6\%). Najmniej inicjatyw służących podniesieniu poziomu wiedzy finansowej odnotowano na Litwie, w Luksemburgu, w Słowenii i Rumunii ${ }^{14}$. Szacuje się, że w 2010 r. aż 70 instytucji i organizacji było zaangażowanych w proces edukacji finansowej w Polsce i za ich pośrednictwem realizowano ponad 100 ogólnopolskich programów edukacji ekonomicznej.

Pierwszoplanowa rola w kreowaniu świadomości finansowej przypada NBP. Oczywiście podkreślić należy, że powinna ona być realizowana we współpracy zarówno sektora publicznego, jak i prywatnego poprzez instytucje rządowe i samorządowe, organizacje środowiskowe i konsumenckie oraz instytucje infrastruktury rynku finansowego. W edukacji finansowej niezbędna jest bowiem koordynacja tych działań, wyznaczenie celów, standardów edukacyjnych, zachęcenie organizacji

${ }_{13} \mathrm{http}: / /$ ec.europa.eu/internal_market/finservices-retail/docs/capability/report_survey_ en.pdf, s. 18 (stan na dzień 12.08.2012).

${ }^{14}$ M. Habschick, B. Seidl, J. Evers, D. Klose, Y. Parsian, Survey of financial literacy schemes in the EU 27, VT Markt/2006/26H - Final Report, Hamburg, November 2007, s. 18. 
pozarządowych do udziału w programie podnoszenia świadomości finansowej Polaków poprzez częściowe wsparcie ze środków publicznych.

Edukacja ekonomiczna, w tym edukacja osób 55+ jest ważną częścią działalności Narodowego Banku Polskiego. NBP rozwija działalność edukacyjną od 2002 r., między innymi korzystając z doświadczeń banków centralnych w innych krajach - Stanach Zjednoczonych, Wielkiej Brytanii czy w Niemczech. Działania te skupiają się m.in. na takich tematach, jak pieniądz, funkcjonowanie banku centralnego i rynków pieniężnych, przedsiębiorczość, rynek pracy, a także finanse - zarówno publiczne, jak i prywatne ${ }^{15}$.

Biorąc pod uwagę zweryfikowany poziom wiedzy ekonomicznej polskiego społeczeństwa, działania edukacyjne podejmowane przez Narodowy Bank Polski powinny mieć charakter kompleksowy i kierowany do różnorodnych grup docelowych. Działania NBP są adresowane do uczniów gimnazjów i szkół ponadgimnazjalnych, do studentów, do osób w wieku 50+, a także do osób, które z racji pełnionej funkcji lub wykonywanego zawodu przekazują wiedzę innym, np. nauczycieli, wykładowców, dziennikarzy, księży. Duża część programów edukacyjnych kierowana jest do całego społeczeństwa, ponieważ ważnym celem działań edukacyjnych banku jest powszechna edukacja ekonomiczna społeczeństwa.

Wśród różnych narzędzi edukacyjnych używanych przez NBP w działaniach edukacyjnych nie zabrakło „edutainmentu” ", realizowanego we współpracy ze środkami masowego przekazu. Generalnie należy wskazać na trzy podstawowe formy prowadzenia polityki edukacyjnej, do których należą ${ }^{17}$ :

- działania edukacyjne NBP polegające na opracowywaniu oraz realizacji specjalistycznych programów edukacyjnych przez jednostki organizacyjne NBP oraz wspieranie realizacji działań edukacyjnych prowadzonych przez inne instytucje;

- ogłaszanie konkursów z zakresu edukacji ekonomicznej;

- udzielanie wsparcia finansowego dla studentów, doktorantów i habilitantów poprzez programy stypendialne Prezesa NBP.

W odniesieniu do osób 50+ NBP zaangażowany był w kilka inicjatyw zmierzających do podniesienia ich wiedzy finansowej. Pierwszą z inicjatyw, o których należy wspomnieć jest cykliczna akcja „O finansach w bibliotece” realizowana przez Fundację Rozwoju Społeczeństwa Informacyjnego, a finansowa ze środków NBP. Celem projektu jest ${ }^{18}$ :

${ }^{15}$ Na potrzebę aktywnego zaangażowania NBP w kreowanie świadomości finansowej zwrócona została uwaga w Planie działalności Narodowego Banku Polskiego na lata 2007-2009. NBP, Plan działalności Narodowego Banku Polskiego na lata 2007-2009, Warszawa, styczeń 2007 r., s. 8. Wyrazem uwzględnienia problematyki edukacji finansowej w działaniach NBP było opracowanie Strategii edukacji ekonomicznej Narodowego Banku Polskiego na lata 2010-2012 stanowiącej uszczegółowienie Strategii zarzadzania NBP na lata 2009-2012. NBP, Strategia edukacji ekonomicznej Narodowego Banku Polskiego na lata 2010-2012, Departament Edukacji i Wydawnictw, Warszawa 2009, s. 16.

${ }^{16}$ Eduitment należy rozumieć jako edukację rozrywkową, czyli edukowanie poprzez zabawę.

${ }_{17}$ NBP, Strategia edukacji ekonomicznej..., s. 9.

${ }^{18} \mathrm{http}: / /$ www.biblioteki.org/pl/o_finansach/o_projekcie (stan na dzień 27.08.2014). 
- zwiększenie u osób 50+ mieszkających na terenach wiejskich i w małych miastach umiejętności korzystania z usług finansowych, w tym bankowości elektronicznej ${ }^{19}$;

- wzmocnienie zdolności bibliotekarzy z bibliotek publicznych do zwiększania umiejętności korzystania z usług finansowych wśród osób starszych, mieszkających na terenach wiejskich i w małych miastach.

Projekt realizowany jest dwuetapowo, najpierw odbywają się szkolenia dla pracowników bibliotek uczące ich przekazywania podstawowej wiedzy dotyczącej oszczędzania, inwestowania, ubezpieczeń, a następnie odbywają się spotkania w bibliotekach z osobami 50+, podczas których poza przekazywaniem wiedzy finansowej prowadzone są zajęcia uczące korzystania z komputera i Internetu pod kątem możliwości korzystania $\mathrm{z}$ bankowości internetowej.

Wybór bibliotek jako miejsc odbywania spotkań i szkoleń determinowany był doświadczeniem, jakie mają biblioteki w przekazywaniu wiedzy i rozwijaniu kompetencji, w tym cyfrowych kompetencji osób 50+, oraz faktem, iż są one instytucjami darzonymi zaufaniem, postrzeganymi jako miejsca bezpieczne, nieprowadzące działalności o charakterze komercyjnym. Ponadto, grupa zawodowa bibliotekarzy cieszy się zaufaniem społecznym, łatwo nawiązuje kontakt z osobami $50+$. W ramach projektu realizowanych jest 5 zagadnień finansowych. Ich zakres przedstawia Tablica 62 .

Tablica 62. Zakres projektu „O finansach w bibliotece”

\begin{tabular}{|c|c|}
\hline Obszar & Zagadnienia szczegółowe \\
\hline 1 & 2 \\
\hline \multirow{4}{*}{$\begin{array}{l}\text { Jak racjonalnie } \\
\text { gospodarować } \\
\text { domowym } \\
\text { budżetem? }\end{array}$} & Zasady tworzenia budżetu domowego \\
\hline & Racjonalne planowanie wydatków \\
\hline & $\begin{array}{l}\text { Oszczędności w budżecie domowym, m.in. minimalizacja wydatków stałych, } \\
\text { tanie zakupy }\end{array}$ \\
\hline & Jak bezpiecznie oszczędzać? \\
\hline \multirow{8}{*}{$\begin{array}{l}\text { Bank przez } \\
\text { Internet } \\
\text { - jak założyć } \\
\text { e-konto i robić } \\
\text { przelewy } \\
\text { przez Internet? }\end{array}$} & $\begin{array}{l}\text { Podstawowe usługi bankowe (konto osobiste, lokaty, rachunki oszczędnościo- } \\
\text { we, kredyty, karty płatnicze i kredytowe) }\end{array}$ \\
\hline & $\begin{array}{l}\text { Korzyści dla klientów banków związane z usługami (bezpieczeństwo środków, } \\
\text { gwarancje bankowe, możliwość pomnażania środków - oprocentowanie itp.) }\end{array}$ \\
\hline & $\begin{array}{l}\text { Co powinien wiedzieć klient banku (rodzaje opłat pobieranych przez banki } \\
\text { (np. prowizja, opłaty za usługi), umowa klienta z bankiem, prawa konsumen- } \\
\text { ta) }\end{array}$ \\
\hline & Wybór konta bankowego \\
\hline & Zakładanie konta i e-konta \\
\hline & Obsługa e-konta - jakie są korzyści z bankowości internetowej \\
\hline & Jak robić przelewy \\
\hline & Koszty usług bankowych - jak je sprawdzać? \\
\hline
\end{tabular}

${ }_{19}$ Projekt dedykowany jest osobom dorosłym w wieku 50+, którzy w bibliotekach publicznych (placówki gminne i ich filie) pozyskują wiedzę na temat finansów. 
Tablica 62 (cd.)

\begin{tabular}{|c|c|}
\hline 1 & 2 \\
\hline \multirow{8}{*}{$\begin{array}{l}\text { Kredyty, lokaty } \\
\text { i karty } \\
\text { - jak wybrać } \\
\text { najkorzystniejszą } \\
\text { ofertę bankową? }\end{array}$} & Jak wybrać najkorzystniejszą lokatę (obliczyć oprocentowanie lokat) \\
\hline & Kredyt a pożyczka - podobieństwa i różnice \\
\hline & Rodzaje kredytów \\
\hline & $\begin{array}{l}\text { Co powinien wiedzieć kredytobiorca - zawieranie umowy kredytowej, koszt } \\
\text { kredytu }\end{array}$ \\
\hline & Ocena różnych ofert kredytowych \\
\hline & $\begin{array}{l}\text { Rodzaje kart płatniczych, czym się różnią i do czego służą? Zasady bezpiecz- } \\
\text { nego korzystania z kart }\end{array}$ \\
\hline & Jak korzystać z bankomatu \\
\hline & $\begin{array}{l}\text { Ryzyko popadnięcia w spiralę zadłużenia - zagrożenia związane z usługami } \\
\text { instytucji finansowych niebędących bankami (pożyczki, kredyty) }\end{array}$ \\
\hline \multirow{2}{*}{$\begin{array}{l}\text { Jak wybrać polisę } \\
\text { ubezpieczeniową? }\end{array}$} & Na co zwracać uwagę przy wyborze polisy \\
\hline & $\begin{array}{l}\text { Gdzie i jak można porównać ceny polis } \\
\text { Prawa klienta banku i firmy ubezpieczeniowej - jak z nich korzystać }\end{array}$ \\
\hline \multirow{5}{*}{$\begin{array}{l}\text { Bank centralny } \\
\text { a inne banki } \\
\text { - czy stopy } \\
\text { procentowe } \\
\text { mają wpływ } \\
\text { na nasz } \\
\text { budżet domowy? }\end{array}$} & Banki komercyjne a bank centralny \\
\hline & Gdzie można śledzić działalność NBP \\
\hline & $\begin{array}{l}\text { Co to są stopy procentowe NBP i jak wpływają na oprocentowanie lokat i kre- } \\
\text { dytów }\end{array}$ \\
\hline & Jak porównywać cenę walut i najkorzystniej wymieniać złotego \\
\hline & Korzyści i obawy związane $\mathrm{z}$ wejściem do strefy euro \\
\hline
\end{tabular}

Źródło: http://www.biblioteki.org/pl/o_finansach/o_projekcie/dzialania (stan na dzień 27.08.2014).

Omawiane podczas spotkań w bibliotece tematy realizowane są podczas pięciu trzygodzinnych spotkań. Każda z grup tematów poświęcona jest innym zagadnieniom związanym z bezpiecznym, świadomym korzystaniem z usług finansowych. Odnoszą się one do praktycznych, codziennych problemów, które zostały wybrane na podstawie wyników badań fokusowych przeprowadzonych na grupie wiekowej 50+.

Drugim ważnym projektem edukacyjnym kierowanym do grupy wiekowej powyżej 50. roku życia jest inicjatywa „Nowoczesne i bezpieczne finanse seniora" realizowana przez Ogólnopolską Federację Stowarzyszeń UTW, a finansowana ze środków $\mathrm{NBP}^{20}$. Głównym celem projektu jest podniesienie poziomu wiedzy i praktycznych umiejętności osób 50+ w zakresie bezpiecznego korzystania $\mathrm{z}$ różnorodnych produktów finansowych oferowanych przez banki i inne podmioty z uwzględnieniem podnoszenia kompetencji osób $50+$ w obszarze korzystania z nowoczesnych technologii informatycznych niezbędnych do efektywnego zarządzania finansami osobistymi. Cele szczegółowe przedsięwzięcia obejmują natomiast ${ }^{21}$ :

${ }^{20}$ Edukacja ekonomiczna seniorów, NBP, Krynica 5 września 2013 r., www.forumtrzeciegowieku. pl/index.php?...edukacja-ekonomiczna-seniorow, s. 8 (stan na dzień 27.07.2014).

${ }^{21} \mathrm{http} / / /$ www.federacjautw.pl/fds/index.php?option=com_content\&view=article\&id=1\&Itemid=2 (stan na dzień 27.07.2014). 
- podniesienie ogólnego poziomu wiedzy uczestników projektu dotyczącej bezpiecznego korzystania z podstawowych produktów finansowych oferowanych przez banki i inne podmioty ze szczególnym uwzględnieniem kredytów, pożyczek oraz inwestycji;

- wykształcenie podstawowych umiejętności związanych z wykorzystaniem komputera do sprawniejszego zarządzania finansami domowymi ze szczególnym uwzględnieniem korzystania z elektronicznych usług bankowych;

- kształtowanie wśród uczestników projektu podstawowych umiejętności niezbędnych do racjonalnego zarządzania finansami osobistymi;

- kształtowanie wśród uczestników projektu pożądanych postaw pro bankowych.

W ramach projektu realizowane są cykle wykładów i warsztatów dla członków UTW „Bezpieczne finanse seniora”. Podczas spotkań poruszane są następujące kwestie:

- kredyty, pożyczki, inwestycje (m.in. ich istota, prawa i obowiązki stron umowy, zasady bezpiecznego korzystania z tych produktów, ryzyko związane $z$ inwestowaniem pieniędzy $i$ zasady jego szacowania);

- tzw. parabanki (m.in. istota, różnice w porównaniu do banków, zagrożenia związane z korzystaniem z oferty parabanków, na co należy zwrócić szczególną uwagę, zaciągając zobowiązania/powierzając pieniądze takiemu podmiotowi);

- instytucje nadzorcze i regulacyjne rynku finansowego - Narodowy Bank Polski, Komisja Nadzoru Finansowego, Bankowy Fundusz Gwarancyjny, Urząd Ochrony Konkurencji i Konsumentów.

Poza wskazanymi wyżej wykładami realizowane są też warsztaty „Nowoczesne finanse seniora". W ich ramach omawiane są zagadnienia dotyczące ${ }^{22}$ :

- bankowości internetowej i bezpiecznego korzystania z niej - wspomagane pracą na symulatorze banku elektronicznego, pozwalającą przećwiczyć założenie i obsługę konta internetowego;

- planowania budżetu domowego z wykorzystaniem komputera;

- pułapek w ramach umów finansowych (kredytów, pożyczek i inwestycji).

Ponadto powstał punkt informacyjno-doradczy dla osób 50+, w którym udzielane są informacje i porady prawne dotyczące m.in. tego, na co należy zwrócić szczególną uwagę przy zaciąganiu kredytów, pożyczek i innych zobowiązań, jak interpretować kluczowe zapisy umów pożyczkowych lub związanych z inwestowaniem oszczędności, jak postępować w przypadku grożącej nam niewypłacalności, jak negocjować $\mathrm{z}$ bankiem, np. w sprawie przełożenia spłaty rat zadłużenia itp. Ostatnim elementem projektu jest newsletter "Niezbędnik finansowy seniora” poświęcony szeroko rozumianym zagadnieniom ekonomicznym i finansowym w wymiarze przydatnym osobom $50+23$.

${ }^{22}$ Projekt Nowoczesne finanse seniora, http://zutw.hekko.pl/news.php?readmore=10 (stan na dzień 27.07.2014).

${ }^{23}$ W 2013 r. zorganizowano też i przeprowadzono panel dyskusyjny poświęcony edukacji ekonomicznej seniorów na Forum III Wieku 2013 - podczas Konferencji Towarzyszącej Forum Ekonomicznemu w Krynicy Zdroju. 
NBP, biorąc pod uwagę preferowany sposób spędzania wolnego czasu osób $50+$ zaangażował się też w edukowanie poprzez najpopularniejszy w Polsce w tej grupie wiekowej dziennik „Fakt”. Zamieszczony w nim został cykl dodatków zatytułowanych „Senior w świecie finansów”24. Projekt był realizowany przez Wydawnictwo Ringer Axel Springer Polska. Projekt polegał na ukazywaniu się w każdą środę od 4 lipca do 5 września 2012 r., razem z gazetą codzienną „Fakt”, specjalnych dodatków edukacyjnych skierowanych do osób 50+. Dzięki publikowanym materiałom osoby powyżej 50 . roku życia miały szansę poznać zalety posiadania karty płatniczej, dowiedzieć się, jak działają bankomaty oraz na co należy uważać, zaciągając kredyt. Ważny temat poruszany w ramach cyklu stanowiły kwestie podwyższenia świadczeń emerytalnych, ich waloryzacji i możliwości pracy na emeryturze. Opisane zostały także propozycje banków dla osób $50+{ }^{25}$.

Poza docieraniem do osób 50+ przez dziennik „Fakt”, NBP uwzględnił w swojej strategii edukowania tej grupy wiekowej aktywność religijną i umieścił w tygodniku katolickim „Gość Niedzielny” cykl 8 dodatków „Finanse Seniora”. Został on następnie ujęty w jednej broszurze zatytułowanej „Finanse dla seniora" obejmującej takie zagadnienia, jak dokonać wyboru odpowiedniego rachunku bankowego i innych produktów bankowych, jak korzystać z karty płatniczej i bankomatu, jak kontrolować swoje wydatki opłacane kartą, jakie korzyści niesie oszczędzanie i wreszcie w jaki sposób bezpiecznie korzystać z bankowości elektronicznej ${ }^{26}$.

Broszura ta publikowana jest $\mathrm{w}$ wersji elektronicznej w ramach następnego projektu, w który zaangażowany jest NBP, dedykowanemu do wszystkich grup wiekowych, a mianowicie Akademii „Dostępne Finanse”"27. Celem tej inicjatywy jest podniesienie wiedzy polskiego społeczeństwa na temat usług finansowych i obrotu bezgotówkowego, zwiększenie zaufania konsumentów do pieniądza bezgotówkowego, a w dłuższej perspektywie zmiana postaw społeczeństwa polskiego wobec obrotu bezgotówkowego.

Akademia jest projektem realizowanym w 16 oddziałach okręgowych NBP we współpracy z Departamentem Systemu Płatniczego oraz Departamentem Komunikacji i Promocji i Departamentem Edukacji i Wydawnictw NBP. Zadaniem oddziałów NBP jest dotarcie i nawiązanie współpracy z ambasadorami obrotu bezgotówkowego - osobami będącymi liderami w społecznościach lokalnych,

${ }^{24}$ Szerzej: http://www.fakt.pl/tag/senior-w-swiecie-finansow,artykuly,1 (stan na dzień 27.07.2014).

${ }^{25}$ Szerzej o projekcie: www.nbportal.pl/pl/edukacja/projekty-zakonczone/projekty_2012/senior_w_swiecie_finansow (stan na dzień 5.02.2014).

${ }^{26}$ Finanse dla seniora, Akademia Dostępne Finanse, NBP, http://www.nbp.pl/adf/adf_edu_finanse_dla_seniora.pdf (stan na dzień 27.07.2014).

${ }^{27}$ Poza broszurą dla osób 50+ opracowane zostały broszury: „ABC Finansów Osobistych”, „Bankowy zawrót głowy”, ulotka „Karty płatnicze - co warto o nich wiedzieć”. 
którzy swoją wiedzą, autorytetem i zaangażowaniem będą w bezpośredni sposób promować idee projektu i wiedzę nt. obrotu bezgotówkowego w środowiskach w regionie. Spodziewane rezultaty projektu to ${ }^{28}$ :

- podniesienie wiedzy na temat obrotu bezgotówkowego,

- pozytywne postrzeganie przez społeczeństwo obrotu bezgotówkowego,

- aktywizacja osób niekorzystających lub w minimalny sposób korzystających z bezgotówkowych instrumentów płatniczych,

- zmiana postaw osób w korzystaniu z bezgotówkowych instrumentów,

- promocja wizerunku NBP jako instytucji zaangażowanej w rozwój nowoczesnego społeczeństwa, ograniczenie wykluczenia finansowego,

- wzrost wskaźnika ubankowienia w Polsce.

Omówione powyżej inicjatywy zmierzające do podniesienia świadomości finansowej w grupie osób powyżej 50. roku życia, w które zaangażowany był NBP, wskazują na uwzględnienie w tych działaniach preferencji tej grupy wiekowej dotyczącej sposobu spędzania wolnego czasu. Działalności edukacyjne prowadzone były i są nadal przez najbardziej popularne wśród osób 50+ kanały informacyjne. Ponadto, biorąc pod uwagę zakres omawianych zagadnień finansowych, widoczna jest koncentracja na dziedzinach, które sprawiają największe trudności osobom $50+$ i wskazywane były przez nich samych jako bariery utrudniające włączenie w system bankowy. $Z$ tego względu we wszystkich projektach kładziony jest nacisk na nauczanie korzystania $\mathrm{z}$ podstawowych produktów bankowych, w tym oferowanych drogą elektroniczną, oraz na kwestie bezpiecznego korzystania z produktów i usług bankowych.

Przykładem kolejnej inicjatywy dofinansowanej ze środków NBP jest projekt „Finanse na 50plus” realizowany przez Fundację na Rzecz Kobiet JA KOBIETA, w okresie od 15 grudnia 2011 do 15 czerwca 2012 r. Głównym celem projektu było przeciwdziałanie wykluczeniu finansowemu osób w wieku $50+$ poprzez zaoferowanie uczestnikom zdobycia praktycznych życiowych umiejętności, które są przydatne $\mathrm{w}$ ich codziennym życiu, a także pokazanie osobom $50+$, jakie ułatwienia daje Internet i nowoczesne technologie w odniesieniu do tematyki finansów osobistych ${ }^{29}$.

W ramach projektu odbyły się konsultacje z ekspertami dotyczące potrzeb osób 50+ w zakresie finansowym, omówione zostały tematy i problemy dotyczące tego zagadnienia. W pięciu miastach w Polsce (Warszawa, Kraków, Tczew, Lublin, Poznań) zorganizowane zostały seminaria o tematyce finansowej, podczas których każdemu uczestnikowi wręczana była „Teczka edukacyjna" zawierająca przystępne omówienie wybranych zagadnień z dziedziny finansów.

${ }_{28}$ Podsumowanie dotychczasowych wyników realizacji projektu Akademia „Dostęne Finanse”, Departament Systemu Płatniczego, Warszawa 2014, s. 5.

${ }^{29}$ Szerzej o projekcie: www.finanse-na50plus.pl/o-projekcie_7.html (stan na dzień 5.02.2014). 
Poza projektami bezpośrednio dedykowanymi osobom 50+, NBP zaangażowany był w szereg inicjatyw o charakterze bardziej uniwersalnym. Wśród nich można wymienić:

- serial Pogromczynie mitów, wyprodukowany przez Telewizję Polską SA, w ramach którego każdy z odcinków dotyczył innego zagadnienia ze świata gospodarki: banku centralnego (NBP), emisji pieniądza i fałszerstw, inflacji, nadzoru bankowego, euro, budżetu państwa, bezrobocia, roli państwa w gospodarce, kredytów i lokat;

- teleturniej Złoty dla zuchwałych emitowany na antenie TVN, w którym widzowie mogli sprawdzić swoją wiedzę z sześciu obszarów tematycznych: bezrobocie i rynek pracy, wolny rynek i przedsiębiorczość, polityka pieniężna, finanse publiczne, oszczędzanie i inwestowanie oraz prywatyzacja. Ta akcja edukacyjna wspomagana była cyklem artykułów edukacyjnych w prasie i audycji radiowych oraz serwisem internetowym.

- słuchowisko Motel w pót drogi, w którym bohaterowie programu muszą pokonywać wiele przeszkód związanych z podjęciem własnej działalności i od podstaw poznawać zasady funkcjonowania systemu bankowego.

- cykl 266 miniwywiadów z gwiazdami TVN-u poświęconych sprawom oszczędzania i wydawania pieniędzy. Celem akcji „Polaków portfel własny” było przekazanie kilkunastu zasad racjonalnego gospodarowania własnymi finansami, oszczędzania, inwestowania czy też planowania wydatków osobistych ${ }^{30}$.

Stałym elementem edukacyjnym jest Portal Edukacji Ekonomicznej NBP (www.NBPortal.pl). W zasobach portalu znajdują się nie tylko opracowania i analizy poświęcone szerokiej tematyce ekonomicznej, ale również różnego rodzaju quizy, gry decyzyjne i strategiczne, zabawy, krzyżówki oraz biblioteka filmów animowanych. Nowoczesne, multimedialne i interaktywne narzędzia edukacyjne pozwalają szybciej poznać tajniki finansów, przedsiębiorczości i bardziej świadomie uczestniczyć w naszym życiu gospodarczym. Ostatnim elementem edukacyjnym podejmowanym przez NBP jest cykliczne organizowanie Dni Otwartych w Centrali i Oddziałach Okręgowych NBP. Ich celem jest pokazanie, czym zajmuje się bank centralny ${ }^{31}$.

W celu wspierania działań promujących rozwój nauk ekonomicznych i edukacji ekonomicznej prowadzonej przez NBP powołana została Fundacja Narodowego Banku Polskiego ${ }^{32}$. Statutowym celem Fundacji NBP jest wspieranie dzia-

${ }^{30}$ M. Polak, Edutainment $w$ ksztaltowaniu postaw przedsiębiorczych i edukacji ekonomicznych, [w:] P. Wachowiak, M. Dąbrowski, B. Majewski (red.), Ksztaltowanie postaw przedsiębiorczych a edukacja ekonomiczna, Fundacja Promocji i Akredytacji Kierunków Ekonomicznych, Warszawa 2007, s. 263-264.

${ }^{31}$ Portal edukacji ekonomicznej, www.nbportal.pl/pl/np (stan na dzień 03.09.2012).

${ }^{32}$ Fundacja Narodowego Banku Polskiego została ustanowiona aktem notarialnym w dniu 10 sierpnia 2009 r. w Warszawie na czas nieokreślony, z siedzibą w mieście stołecznym Warszawa. Działa na mocy przepisów z dnia 6 kwietnia 1984 r. o fundacjach (Dz. U. z 1991 r., nr 46, poz. 203 z późn. zm.) oraz postanowień Statutu Fundacji NBP. 
łań promujących rozwój nauk ekonomicznych i edukacji ekonomicznej. Fundacja NBP realizuje ten cel zarówno poprzez własne projekty, jak i poprzez udzielanie wsparcia inicjatywom innych instytucji, stowarzyszeń i osób ${ }^{33}$.

Poza NBP, instytucją sektora bankowego zaangażowaną w proces kształtowania świadomości finansowej jest Związek Banków Polskich (ZBP). Publikuje on na swojej stronie internetowej liczne poradniki na temat korzystania z produktów bankowych, w tym na temat dziedziczenia środków z rachunku bankowego oraz zachowania bezpieczeństwa podczas dokonywania transakcji płatniczych. Cenną inicjatywą jest realizacja w porozumieniu z policją kampanii edukacyjnej skierowanej do osób 50+ mającej na celu uchronienie przed popularnymi $\mathrm{w}$ tej grupie wiekowej wyłudzeniami ${ }^{34}$.

Instytucją zaangażowaną w budowanie świadomości finansowej jest Komisja Nadzoru Finansowego (KNF). Wartą odnotowania jest kampania informacyjna „Sprawdź, komu powierzasz”. Kampania zachęca do weryfikacji podmiotów rynku finansowego w rejestrach dostępnych na stronach internetowych KNF oraz sprawdzenie, czy powierzone im środki podlegają publicznemu systemowi gwarantowania. Istotnym źródłem informacji jest również lista ostrzeżeń publicznych, na której umieszczone są podmioty prowadzące działalność bez odpowiedniej licencji KNF. Jej celem jest zwiększenie zaufania do sektora finansowego i bezpieczeństwa transakcji finansowych ${ }^{35}$.

Wiele inicjatyw mających na celu podniesienie wiedzy finansowej wśród osób 50+ realizowanych jest we współpracy instytucji sektora bankowego i pozabankowego. Przykładem takich działań jest konkurs „Bank dostępny,” w organizację którego włączył się NBP, ZBP i Stowarzyszenie „Otwarte Drzwi”. Konkurs miał na celu zwrócenie uwagi na problem dostępności banków i ich usług dla osób niepełnosprawnych i starszych. W ramach konkursu dokonana została ocena stopnia dostępności banków uwzględniająca procedurę obsługi oraz kwestię usuwania barier architektonicznych i technicznych, na podstawie opinii zebranych od osób niepełnosprawnych i starszych ${ }^{36}$.

W edukację osób 50+ włączają się także pojedyncze banki. Najbardziej aktywny w tym obszarze jest Bank Pekao SA oraz Konsorcjum Banku Pocztowego SA i Poczty Polskiej SA W ramach licznych akcji promocyjno-edukacyjnych zachęcają one świadczeniobiorców ZUS do korzystania z rachunków bankowych. Bank Pocztowy SA w strategii rozwoju na lata 2014-2017 deklaruje, że jest aktualnie bankiem kojarzonym z obsługą seniorów i chce takim bankiem pozostać.

${ }^{33}$ Szerzej: www.fundacjanbp.pl (stan na dzień 12.08.2012).

${ }^{34}$ Poradnik. Jak nie paść ofiarq oszustwa metoda ,,Na wnuczka”, http://zbp.pl/public/ repozytorium/dla_konsumentow/poradnik_zbp/knw_informator_zbp.pdf (stan na dzień 28.07.2014).

${ }^{35} \mathrm{KNF}$, Kampania informacyjna ,Sprawdź komu powierzasz”, http://www.knf.gov.pl/ sprawdz_komu_powierzasz.html (stan na dzień 12.10.2014).

${ }^{36}$ Konkurs „Bank Dostępny” rozstrzygnięty, http://www.bankier.pl/wiadomosc/Konkurs -Bank-Dostepny-rozstrzygniety-1373611.html (stan na dzień 27.07.2014). 
Identyfikuje tę grupę jako emerytów i rencistów w wieku powyżej 66 lat, z wykształceniem średnim, zamieszkującą w miejscowościach o różnorodnej wielkości. Wskazuje, że główne potrzeby tej grupy wiekowej to szeroka dostępność placówek, relacyjność, stabilność i bezpieczeństwo oraz zrozumiałość informacji $\mathrm{i}$ instrukcji i że jest $\mathrm{w}$ stanie tym oczekiwaniom sprostać ${ }^{37}$. Banki oferują też szkolenia z bankowości elektronicznej, zarządzania budżetem domowym, dokonywania zakupów przez Internet oraz prelekcje na temat bezpieczeństwa finansów dla osób powyżej 50. roku życia ${ }^{38}$.

W ramach podejmowanych działań mających na celu poprawę świadomości finansowej w polskim społeczeństwie można zauważyć koncentrację poza osobami w wieku 50+ na osobach młodych ${ }^{39}$, najuboższych gospodarstwach domowych oraz mieszkańcach wsi. W przypadku najuboższych gospodarstw domowych edukacja finansowa jest szczególnie ważna, ponieważ buduje zdolność do kontrolowania i lepszego zarządzania ograniczonymi finansami osobistymi. Celem edukacji finansowej jest dostarczenie ludziom o niskich dochodach wiedzy oraz kompetencji związanych z zarządzaniem własnymi, nawet niewielkimi pieniędzmi, poprzez oszczędzanie, racjonalizację wydatków i przewidywanie. Może ona służyć jako narzędzie przeciwdziałające popadnięciu w ubóstwo lub ułatwiające wyjście z ubóstwa ${ }^{40}$, szczególnie że Polska jest państwem o wysokim ryzyku wystąpienia ubóstwa.

Przykładami najbardziej popularnych inicjatyw są ${ }^{41}$ :

- działania podejmowane przez Fundację Kronenberga przy Banku Citi Handlowy wraz z NBP i Fundacją Młodzieżowej Przedsiębiorczości o nazwie „Moje finanse" dedykowane uczniom szkół ponadgimnazjalnych. Program realizowany jest od 2010 r. w 5 modułach ${ }^{42}$;

- inicjatywy podejmowane w partnerstwie firm i instytucji sektora bankowego ${ }^{43}$ pod hasłem „Bankowcy dla edukacji finansowej młodzieży, BAKCYL”.

${ }^{37}$ Grupa seniorów stanowi 17\% wszystkich klientów Banku Pocztowego SA. Aktywizacja, rentowność, edukacja. Strategia rozwoju Banku Pocztowego S.A. w latach 2014-2017, Bank Pocztowy SA, media.pocztowy.pl/file/.../a3/strategia-bankupocztowego-11-06.pdf (stan na dzień 28.07.2014).

${ }^{38}$ Np. Bank Pekao SA w Kielcach, Bank Spółdzielczy w Limanowej.

${ }^{39}$ W. Kołodziejczyk, M. Polak, Jak będzie zmieniać się edukacja. Wyzwania dla polskiej szkoty i ucznia, Instytut Obywatelski, Warszawa 2011, s. 68.

${ }^{40}$ M. Polak, Edukacja finansowa i przedsiębiorczość sposobem na biedę, ,e-mentor”, nr 3 (25), czerwiec 2008, s. 17-18.

${ }^{41}$ Zestawienie inicjatyw edukacyjnych dedykowanych osobom młodym dostępne jest na stronie: http://zbp.pl/public/repozytorium/dla_konsumentow/edukacja/mapa-2012-lista.pdf (stan na dzień 27.07.2014).

42 J. Bogdaniowicz, T. Borkowski, Banki uczniom, „Gazeta Bankowa” 2007, nr 47, s. 52-53. Por. E. Rokicka, Raport z pogłębionych badań ewaluacyjnych przeprowadzonych w szkołach ponadgimnazjalnych realizujacych program Moje finanse, Warszawa 2006, s. 65.

${ }^{43}$ W realizację projektu zaangażował się Narodowy Bank Polski, Związek Banków Polskich oraz banki komercyjne i spółdzielcze: Bank Pekao SA, BGK, BGŻ SA, BOŚ SA, BRE Bank SA, BS Płońsk, BS Pruszków, Citi Handlowy, PBS Ciechanów, Raiffeisen Bank SA, Warszawski Bank Spółdzielczy. 
Celem projektu jest przygotowanie osób młodych, które coraz wcześniej i częściej mają dostęp do różnego rodzaju usług finansowych i tym samym wiedza finansowa jest im potrzebna do podejmowania świadomych decyzji finansowych ${ }^{44}$.

- projekt partnerski dofinansowywany ze środków NBP z zakresu edukacji ekonomicznej „Zaplanuj swoją przyszłość”, dedykowany mieszkańcom wsi i miejscowości do 20000 mieszkańców. Jego celem było uświadomienie potrzeby edukacji ekonomicznej i finansowej, przekazanie im niezbędnej wiedzy w celu efektywnego gospodarowania własnymi środkami, umiejętnego rozpoznawania dostępnych na rynku usług finansowych i korzystania z nich poprzez cykle warsztatów trenerskich i szkoleń dotyczących edukacji finansowej, działania informacyjno-edukacyjne oraz kampanię społeczną i medialną ${ }^{45}$.

Cenną praktyką instytucji finansowych podejmowaną na rzecz szerzenia edukacji ekonomicznej jest prowadzenie serwisów edukacyjnych. Przykładem takich praktyk jest serwis Zafinansowani.pl ${ }^{46}$ prowadzony przez ING Bank Śląski SA, serwis bankomaniapkobp.p ${ }^{47}$ prowadzony przez PKO BP SA czy też blogi o tematyce finansowej prowadzone przez kilkanaście banków (najbardziej popularne blogi posiada: mBank SA, T-mobile usługi bankowe dostarczane przez Alior Sync, PKO BP SA). Na stronach internetowych zamieszczane są artykuły i ikonografiki opracowywane przez ekspertów finansowych banku oraz zewnętrznych specjalistów, zawierające porady na temat rozsądnego zarządzania finansami.

Dodatkowo należy wskazać na działania edukacyjne podejmowane przez sektor ubezpieczeń (Polska Izba Ubezpieczeń - ABC ubezpieczeń; PZU SA - różnorodne akcje prewencyjne), a także sektor inwestycyjny (Giełda Papierów Wartościowych i Fundacja Edukacji Rynku Kapitałowego oferujące różnorodne programy edukacyjne $)^{48}$.

Podsumowując, przedsięwzięcia edukacji ekonomicznej i finansowej skierowane do osób 50+ cechowały się dużą różnorodnością. Prowadzone były przy wykorzystaniu najbardziej popularnych kanałów informacyjnych i przy zastosowaniu nowoczesnych środków i metod. Udział w projektach był bezpłatny, a zatem kwestie finansowe nie stanowiły dodatkowej bariery dla uczestników. Pozytywnie należy też ocenić zakres merytoryczny omawianych zagadnień finansowych obejmujący najważniejsze tematy z punktu widzenia osób 50+. Pewną niedoskonałością realizowanych inicjatyw może być ich sygnalność oraz brak

${ }^{44}$ Szerzej o projekcie: www.bakcyl.wib.org.pl (stan na dzień 5.02.2014).

${ }^{45}$ B. Gontarek, A. Kolbusz, K. Stachańska, A. Kosidło, Zaplanuj swoja przyszłość. Poradnik dla uczestników szkoleń z zakresu edukacji finansowej, Fundacja Wspomagania Wsi, Warszawa 2009 , s. 5.

46 www.zafinansowani.pl (stan na dzień 5.02.2014).

47 www.bankomania.pkobp.pl (stan na dzień 27.07.2014).

${ }^{48}$ M. Iwanicz-Drozdowska, A. Matuszyk, A. K. Nowak, R. Kitala, Produkty finansowe i edukacja finansowa w Polsce na tle wybranych krajów wysoko rozwiniętych. Raport z badań, Warszawa 2009, s. 158. 
koordynacji poszczególnych projektów. Należy podkreślić aktywność NBP oraz innych instytucji sektora bankowego i niewielkie zaangażowanie agend rządowych jako partnerów tych inicjatyw.

\subsubsection{Przykłady dobrych praktyk podejmowanych przez banki za granicą}

W przypadku wielu sektorów bankowych na świecie widoczny jest wyraźny podział podmiotów zaangażowanych w proces inkluzji bankowej na instytucje, których działalność w tej sferze ogranicza się jedynie do reklamowania produktów i usług dedykowanych dla osób 50+ (niekiedy są one jedynie symboliczną modyfikacją standardowej oferty) oraz organizacje podejmujące inicjatywy skutkujące wzrostem świadomości finansowej wskazanej grupy klientów. Jedne i drugie przedsięwzięcia mogą okazać się skuteczne i w efekcie przyczynić się do włączenia bankowego. Należy przy tym zauważyć, że w pierwszym przypadku determinantą rozpoczęcia współpracy przez klientów z grupy $50+\mathrm{z}$ bankiem są bardzo często drobne zmiany w ofercie, widoczne w tabeli opłat i prowizji, powodujące wzrost atrakcyjności określonych rozwiązań, w drugim zaś niejednokrotnie potrzeba poszerzenia wiedzy z zakresu finansów. Coraz częściej zmianom w zakresie produktów i usług bankowych towarzyszą przedsięwzięcia mające podnieść przeciętny poziom wiedzy finansowej klientów, co wskazuje na zmiany w strategii wielu banków skutkujące zmianą podejścia do klientów z grupy 50+.

Interesującym przykładem inicjatyw podejmowanych przez banki jest projekt realizowany przez DBS Bank (Singapur). Inicjatywa zapoczątkowana w 2009 r. zakłada współpracę wskazanej instytucji finansowej z Radą ds. Trzeciego Wieku, tj. organizacją promującą aktywne starzenie się w Singapurze. Celem opisywanego partnerstwa $\mathrm{z}$ jednej strony jest tworzenie produktów i usług bankowych przy wykorzystaniu wiedzy i doświadczeń obu jednostek, z drugiej zaś przygotowanie grupy klientów 50+ na funkcjonowanie w ramach obecnie obserwowanego otoczenia sektora bankowego.

Drugi cel współpracy DBS Banku z Radą ds. Trzeciego Wieku jest możliwy do osiągnięcia poprzez realizację rozmaitych projektów, do których należy m.in. „Active Neighbours Programme”. Wspomniane przedsięwzięcie polega na rekrutowaniu klientów z grupy 50+ do pomocy innym obywatelom Singapuru (również należącym do wskazanej grupy wiekowej) m.in. przy dokonywaniu operacji bankowych w placówkach banku oraz korzystaniu z bankomatów. Osoby 50+ wspierające innych klientów banku DBS są również obecne na warsztatach i szkoleniach - niejednokrotnie dzielą się one swoimi doświadczeniami i wiedzą, dzięki czemu wiedza merytoryczna jest przekazywana w bardziej przystępny sposób ${ }^{49}$.

\footnotetext{
${ }^{49}$ http://www.agelessonline.net/524/the-posb-experience/ (stan na dzień 01.08.2014).
} 
Oprócz inicjatywy „Active Neighbours Programme” klienci DBS Banku mogą korzystać z wielu zniżek, programów partnerskich oraz przywilejów wynikających z faktu posiadania określonych produktów i usług bankowych ${ }^{50}$.

Kolejnym przykładem banku angażującego się w proces włączenia bankowego osób 50+ jest Citizens Bank (Stany Zjednoczone), prowadzący działania polegające na edukacji finansowej swoich klientów. Projekt będący częścią bardziej złożonego przedsięwzięcia (1 z 5 obszarów wspierania klientów), oparty jest na idei pomocy obywatelskiej, sprowadzającej się do nauczania klientów z grupy 50+ zarządzania budżetem domowym przez osoby należące do tej samej grupy wiekowej, wyselekcjonowane spośród klientów banku.

Inną formą wsparcia analizowanej grupy wiekowej jest przekazywanie darowizn na odbudowę oraz remonty domów oraz mieszkań osób 50+ zapewniające im niezależność w kolejnych latach życia ${ }^{51}$.

Niezwykle interesującą i zarazem pożyteczną inicjatywę podjął Bank of the West (Stany Zjednoczone), który skoncentrował swoje działania wokół ochrony klientów z grupy 50+ przed różnego rodzaju oszustwami i nadużyciami finansowymi, na które są oni narażeni. W związku z rosnącym ryzykiem wykorzystywania osób 50+ przez grupy przestępcze do prowadzenia nielegalnych operacji i transakcji, wspomniana instytucja finansowa prowadzi akcje informacyjną poprzez wszystkie dostępne kanały komunikacji z klientami, wskazując na możliwości ochrony przed tego typu działaniami. Kampanii tej towarzyszy umieszczanie przykładowych filmów w Internecie (kanał YouTube), których celem jest uwrażliwienie społeczeństwa na zagrożenia dla nich samych oraz ich bliskich (rodziny, sąsiadów) należących do grupy klientów $50+52$.

Przykładem instytucji finansowej zaangażowanej w inkluzję bankową jest również Bank of American Fork (Stany Zjednoczone). Włączenie bankowe osób $50+$ jest $\mathrm{w}$ przypadku tej organizacji realizowane $\mathrm{w}$ wyniku prowadzonej akcji informacyjnej dla klientów banku o możliwych oszustwach oraz nadużyciach finansowych. Bank of American Fork, informując o głównych zagrożeniach płynących z braku przestrzegania odpowiednich procedur, wskazuje jednocześnie na prawidłowy sposób korzystania z produktów i usług bankowych.

Oprócz troski o bezpieczeństwo finansów klientów z grupy 50+, wspomniana instytucja stworzyła poradnik pt.: Navigating Your Rights: The Utah Legal Guide for Those 55 and Over. Oprócz porad o charakterze stricte finansowym znaleźć tam można wiele praktycznych informacji o sposobach rozwiązywania

\footnotetext{
${ }^{50} \mathrm{http}: / / w w w . d b s . c o m / c o m m u n i t y /$ posbinitiatives/default.aspx (stan na dzień 01.08.2014).

${ }^{51} \mathrm{http}: / /$ www.citizensbank.com/about-us/news/citizens/2013/12_11_13_first_ward.aspx (stan na dzień 01.08.2014).

${ }^{52} \mathrm{https} / / / \mathrm{www} \cdot$ bankofthewest.com/about-us/press-center/press-releases/details/201305-13-elder-abuse. html (stan na dzień 01.08.2014).
} 
problemów osób z grupy wiekowej, do której adresowana jest ta pozycja książkowa. Poradnik dostępny jest w formacie pdf za darmo, przez co treści w nim zawarte wydają się być łatwo dostępne ${ }^{53}$.

Pozostałymi inicjatywami Bank of American Fork wartymi odnotowania są również organizacja oraz współorganizacja lokalnych wydarzeń przeznaczonych dla osób 50+, a także wspieranie obchodów Światowego Dnia Praw Osób Starszych, organizowanego przez Organizację Narodów Zjednoczonych ${ }^{54}$.

Interesującym przedsięwzięciem jest także projekt Barclays Bank (Wielka Brytania), którego realizacja zakłada szkolenie grupy 3500 pracowników w zakresie udzielania pomocy klientom 50+ przy korzystaniu z bankowości elektronicznej oraz portali społecznościowych. Osoby te są ponadto odpowiedzialne za organizację oraz prowadzenie warsztatów dla wskazanej grupy wiekowej, przy czym mają one charakter otwarty, co oznacza, że każda osoba (bez względu na to, czy jest klientem banku czy nie) może wziąć w nich udział. Działania te są elementem strategii banku skoncentrowanej wokół klienta, który bez względu na wiek może być równoprawnym użytkownikiem serwisów transakcyjnych bankowości elektronicznej ${ }^{55}$.

Poza wskazaną aktywnością, Barclays Bank współrealizuje rozmaite projekty, których beneficjentami są osoby 50+, m.in. z organizacją Age UK, supermarketami Asda oraz domami opieki społecznej ${ }^{56}$.

Przykładem instytucji finansowej udzielającej wsparcia osobom 50+ jest także Danske Bank (Dania) organizujący cykliczne szkolenia „Step-by-step”. Celem przedsięwzięcia jest przekazanie elementarnej wiedzy z zakresu korzystania $\mathrm{z}$ nowoczesnych technologii $\mathrm{w}$ taki sposób, aby przedstawiciele analizowanej grupy wiekowej bez przeszkód i obaw przystosowali się do użytkowania Internetu.

Oprócz organizacji szkoleń oraz przekazywania elementarnej wiedzy z zakresu korzystania z sieci www, inicjatywa Danske Bank wspiera również swoich klientów z grupy 50+ w zakresie korzystania z bankowości elektronicznej. Osoby te mogą rejestrować się na bezpłatne warsztaty, dzięki którym poznają sposób funkcjonowania serwisu transakcyjnego banku, jego funkcjonalność oraz możliwości, jakie daje korzystanie z banku w trybie online ${ }^{57}$.

53 J. Gunther, Navigating Your Rights: The Utah Legal Guide for Those 55 and Over, Utah Department of Human Services, Salt Lake City 2011; http://legalguide55.utah.gov/pdf/navigating complete_web.pdf (stan na dzień 01.08.2014).

${ }^{54} \mathrm{http} / /$ www.americanownews.com/story/25820353/bank-of-american-fork-encourages-age -friendly-banking-to-combat-elder-financial-abuse (stan na dzień 01.08.2014).

${ }_{55} \mathrm{http} / /$ www.telegraph.co.uk/sponsored/finance/your-bank/10890358/tablet-training-for-seniors.html (stan na dzień 13.08.2014).

${ }^{56} \mathrm{http} / / /$ app.gdruk.com/html/BarclaysdigitalEagles_261.html (stan na dzień 13.08.2014).

${ }^{57} \mathrm{https}$ ://www.danskebank.com/en-uk/CSR/business/accessibility/Pages/Step-by-step-meetings.aspx (stan na dzień 13.08.2014). 
Przykładem wspierania inicjatyw na rzecz osób 50+ jest także działalność grupy UniCredit, która poprzez swoją fundację realizuje oraz współrealizuje liczne projekty (w 2014 r. było to ponad 200 inicjatyw przedsięwziętych w różnych krajach). Konsekwencją aktywnego zaangażowania w projekty na rzecz wskazanej grupy wiekowej jest organizacja konkursu Social Innovation in Ageing, którego celem jest promowanie oraz wspieranie zdrowego oraz aktywnego starzenia się $e^{58}$.

Inicjatywa ta zakłada wybór najlepszych i najbardziej innowacyjnych projektów realizowanych lub współrealizowanych przez Fundację UniCredit. Zakres tematyczny inicjatyw jest niezwykle szeroki - od wspierania domów opieki społecznej po mentoring z zakresu korzystania z Internetu, bankowości elektronicznej oraz przedsiębiorczości ${ }^{59}$. Biorąc pod uwagę skalę zaangażowania UniCredit, międzynarodowy charakter oraz szeroki zakres tematyczny przedsięwzięć, należy zauważyć, że jest to jeden z najbardziej kompleksowych programów wspierających osoby $50+$.

Godna odnotowania jest również inicjatywa Walls Fargo, który wspieranie osób 50+ opiera na zindywidualizowanym podejściu do problemów poszczególnych klientów w zakresie opieki zdrowotnej, prawnej oraz rozwiązań finansowych. Współpraca z klientami należącymi do wskazanej grupy wiekowej zaczyna się od oceny ich sytuacji, a następnie sprowadza się do przedstawienia proponowanych rozwiązań m.in. w zakresie opieki zdrowotnej, opieki personalnej, ubezpieczeń, zarządzania majątkiem czy też ustanawiania pełnomocnictw. Klient sam decyduje o tym, która z propozycji jest najlepiej dopasowana do jego potrzeb i tym samym osobiście określa, jaką współpracą jest zainteresowany ${ }^{60}$.

Należy zauważyć, że oprócz analizowanych przedsięwzięć istnieje szereg innych inicjatyw na rzecz zwiększania aktywności finansowej osób starszych w wybranych krajach (tablica 63).

Jak można zauważyć, projektów na rzecz zwiększania aktywności finansowej osób starszych jest wiele i są uzależnione od wielu czynników, m.in. poziomu ubankowienia seniorów oraz poziomu świadomości finansowej. W krajach, w których osoby powyżej 50. roku życia korzystają z produktów finansowych, a wiedza i świadomość finansowa są wysokie, działania ograniczają się zwykle do edukacji (szkolenia, materiały informacyjne). Co istotne, inicjatywy na rzecz walki z wykluczeniem finansowym seniorów są podejmowane zarówno przez instytucje publiczne, jak i prywatne, przy czym działania te są najskuteczniejsze wtedy, gdy interwencje podejmowane są w różnych obszarach i przy wykorzystaniu różnych instrumentów.

${ }^{58} \mathrm{https}$ ://www.unicreditfoundation.org/en/pressmedia/news/social-innovation-in-ageing0. html (stan na dzień 13.08.2014).

${ }^{59} \mathrm{https} / / /$ www.unicreditfoundation.org/en/pressmedia/news/social-innovation-in-ageing.html (stan na dzień 13.08.2014).

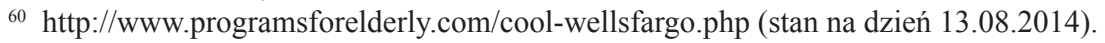




\begin{tabular}{|c|c|c|c|c|c|c|c|c|c|}
\hline & $m$ & 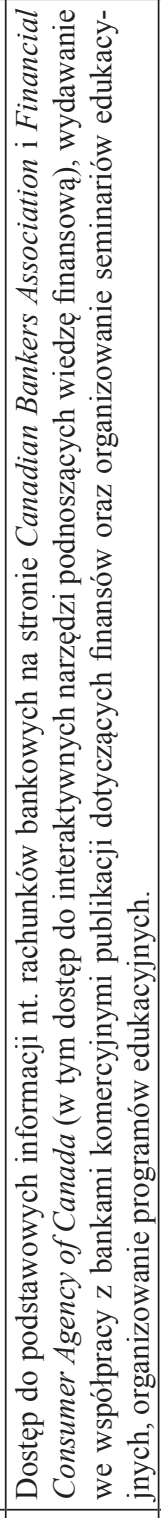 & 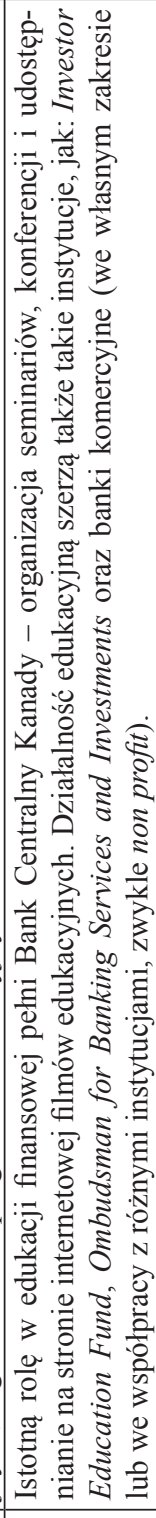 & 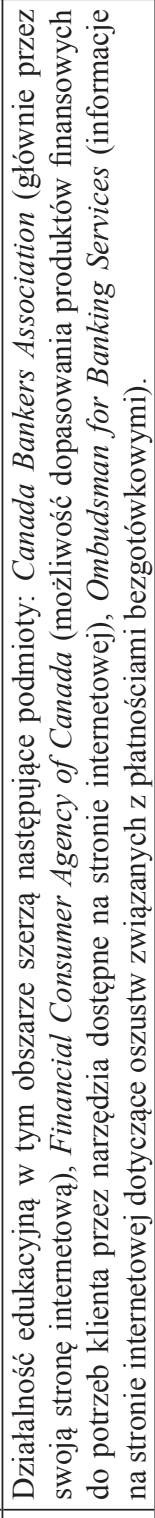 & 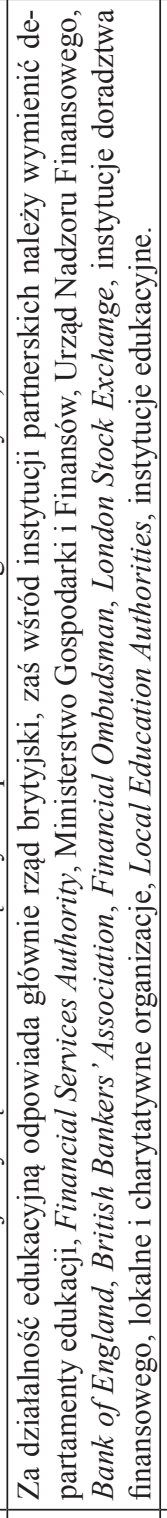 & 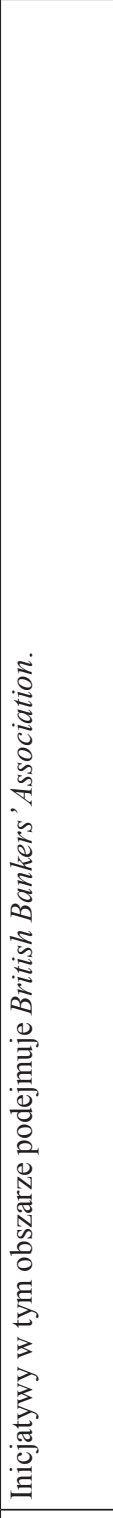 & 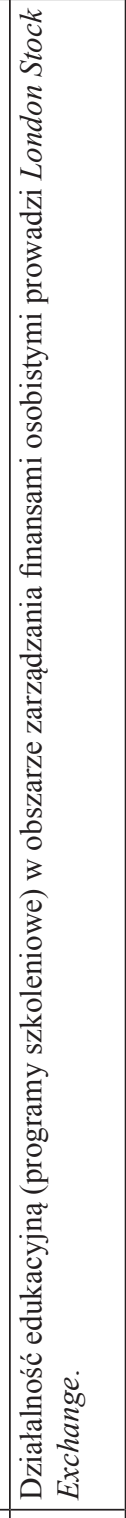 & 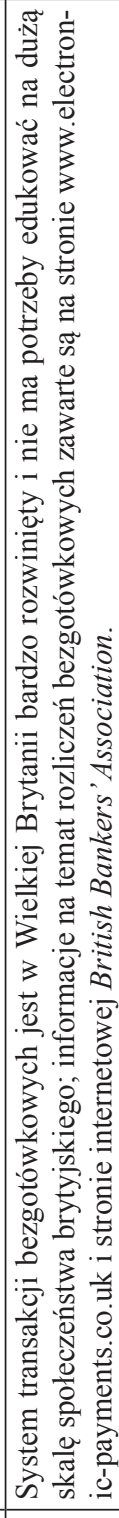 & 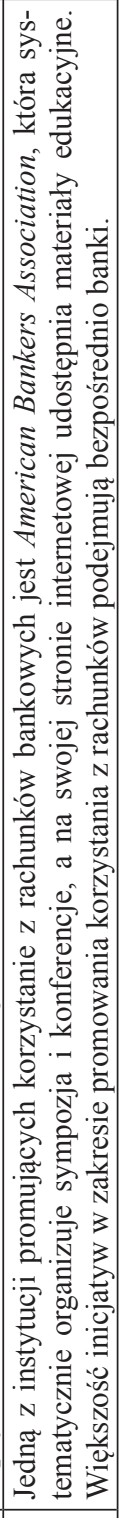 \\
\hline 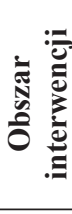 & $\sim$ & 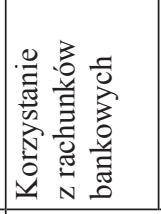 & 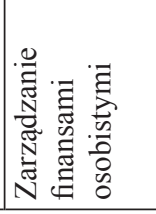 & 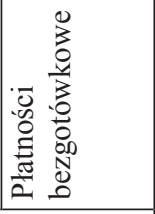 & 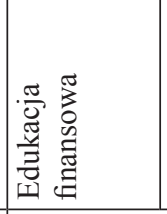 & 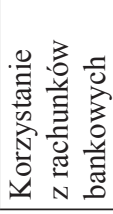 & 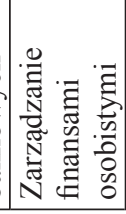 & 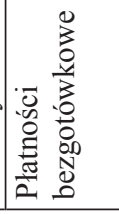 & 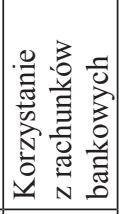 \\
\hline ב & -7 & 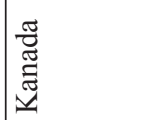 & & & 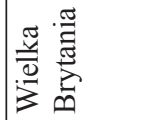 & & & & $\triangleright$ \\
\hline
\end{tabular}




\begin{tabular}{|c|c|c|c|c|c|c|c|c|c|}
\hline 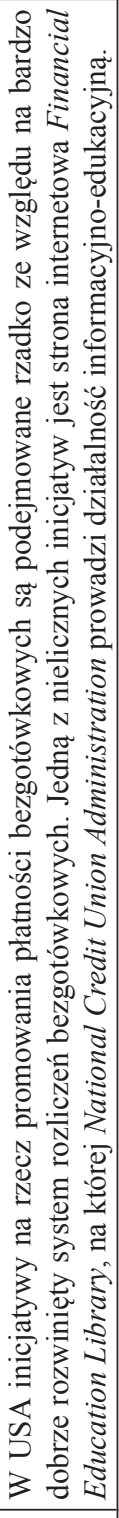 & 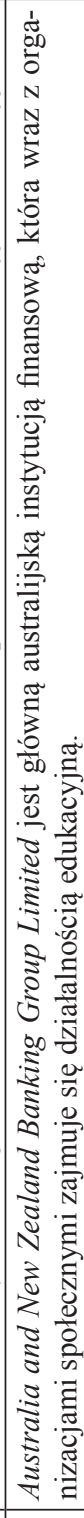 & 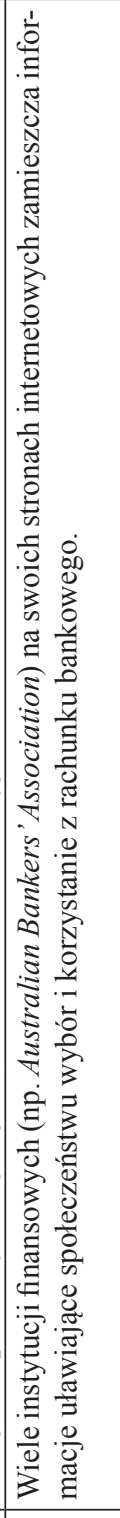 & 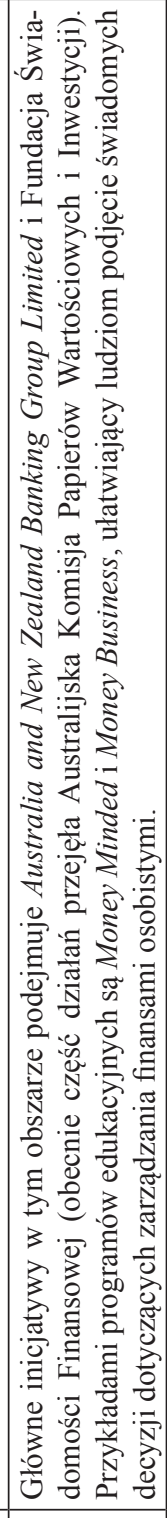 & 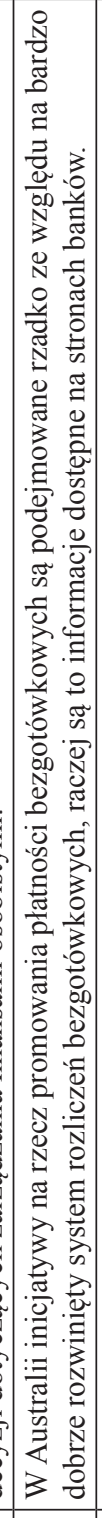 & 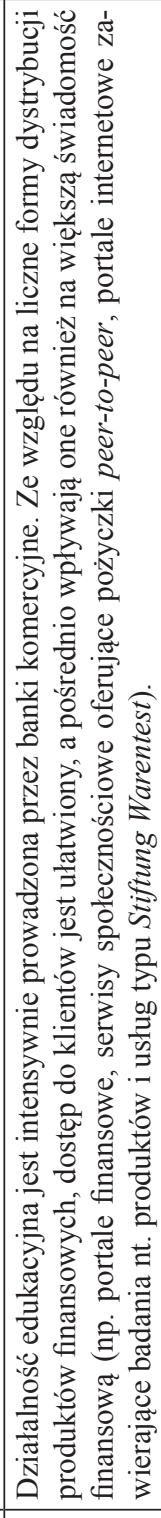 & 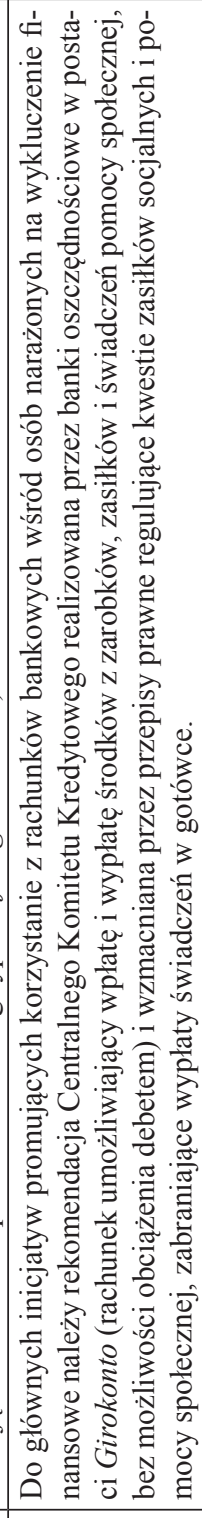 & 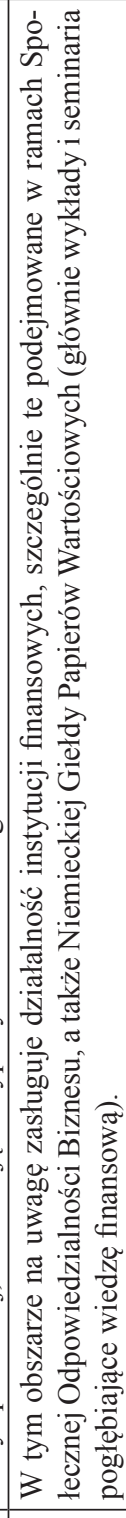 & 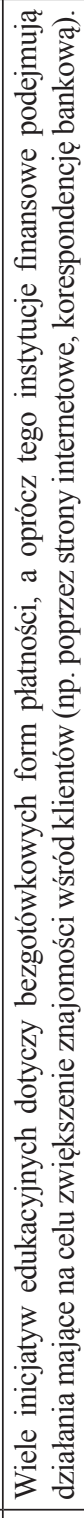 & 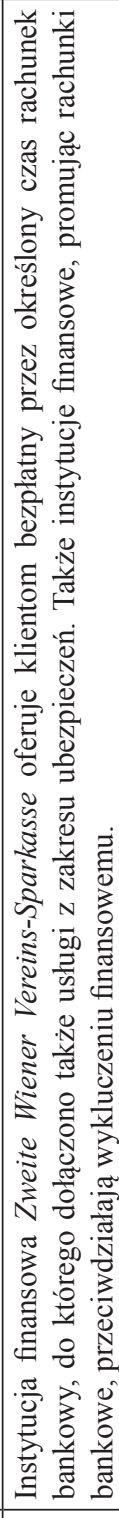 \\
\hline $\begin{array}{ll}0 & 0 \\
0 & 0 \\
0 & 0 \\
0 & 0 \\
0 & 0 \\
0 & 0 \\
0 & 0\end{array}$ & 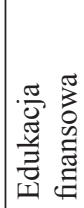 & 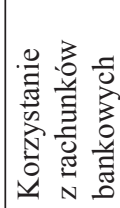 & 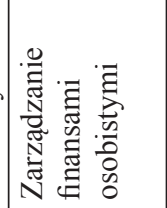 & 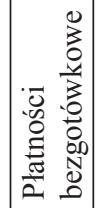 & 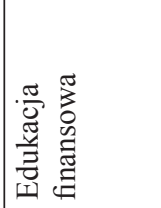 & 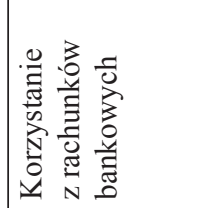 & 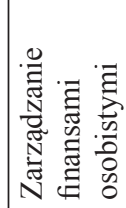 & 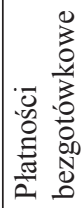 & 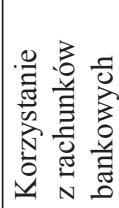 \\
\hline & & & & & \multicolumn{4}{|l|}{ 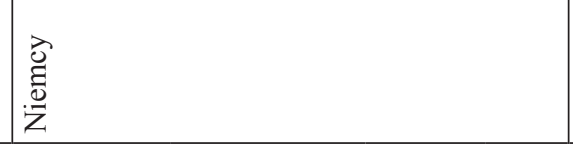 } & \\
\hline
\end{tabular}




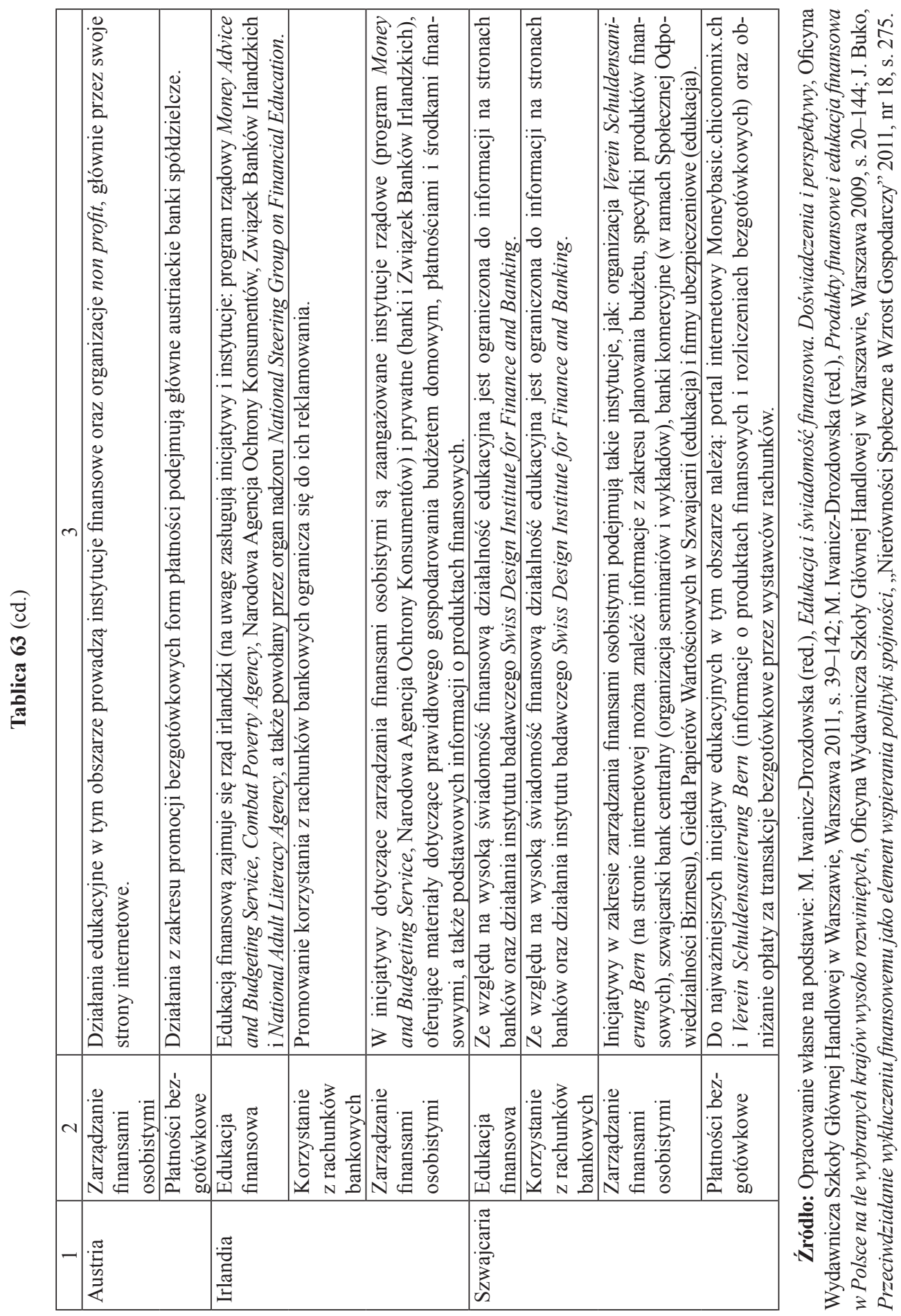


Wychodząc naprzeciw problemowi wykluczenia finansowego osób starszych, banki podejmują różne działania edukacyjne, mające na celu podnoszenie wiedzy i świadomości finansowej. Przykładem może być Harris Bank, który oferuje swoim klientom doradztwo w zakresie zarządzania aktywami, dysponowania budżetem domowym, oszczędzania, unikania długów oraz planowania środków na emeryturę. Jednakże działalność edukacyjna nie musi mieć formy tradycyjnego doradztwa, niektóre instytucje (np. Asset Builders of America) oferują swoim klientom prezentacje multimedialne, tłumaczące krok po kroku, jak zarządzać swoim domowym budżetem ${ }^{61}$.

Podnoszenie wiedzy i świadomości finansowej seniorów może przybierać formę tradycyjnych szkoleń lub seminariów (praktykowaną m.in. przez M \& I Marshall \& Ilsley Bank ${ }^{62}$ ). Uczestnicy spotkań oprócz bezpośredniego pozyskania wiedzy otrzymują materiały, do których w każdej chwili mogą wrócić i powtórzyć wybrane informacje. Zaletą tej metody jest także nawiązywanie bezpośredniego kontaktu z klientami oraz budowanie relacji pomiędzy uczestnikami spotkań.

Jedną z najprostszych, lecz najskuteczniejszych metod zwiększania wiedzy i świadomości finansowej osób starszych są audycje radiowe i telewizyjne. Emisja takich komunikatów w czasie godzin emisyjnych, w których nadawane są programy chętnie oglądane i słuchane przez seniorów, pozwoli na łatwe dotarcie do odbiorcy na szerszą skalę. Takie rozwiązanie przyniosło pozytywne efekty wśród latynoskich imigrantów w Stanach Zjednoczonych, do których kierowano komunikaty o charakterze edukacyjnym w czasie emisji oglądanych przez nich telenowel ${ }^{63}$.

Podobną inicjatywę zaproponowała VISA (Visa Financial Literacy Roadshow), oferując osobom zagrożonym wykluczeniem bankowym 35-minutowe występy objazdowe grup industrialnych teatrów. Przedstawienia dotyczyły tematyki zarządzania budżetem, kart debetowych oraz bezpieczeństwa środków zapewnionych dzięki zabezpieczeniom systemu bankowego ${ }^{64}$. Inicjatywa ta charakteryzuje się ciekawą i przystępną formą, która mogłaby zapewnić dotarcie do osób obawiających się zawiłości procedur bankowych.

Obie przedstawione wyżej inicjatywy należą do nurtu edukacji rozrywkowej, zapewniającej przekazanie informacji edukacyjnej w ciekawej i przystępnej

${ }^{61}$ BMO Financial Group, What we owe, Corporate Social Responsibility Report, BMO 2013, s. 10.

${ }^{62}$ A. Askari, Banks and Financial Education. Integrating Practice, Products, and Partnerships, http://www.frbsf.org/community-development/files/askari_ammar.pdf (stan na dzień 14.04.2014).

${ }^{63}$ J. Spader, J. Ratcliffe, J. Montoya, P. Skillern, The Bold and the Bankable: How the Nuestro Barrio Telenovela Reaches Latino Immigrants with Financial Education, "Journal of Consumer Affairs" 2009 (March 1), no 43 (1), s. 56-79.

${ }^{64}$ VISA, Case Study: Financial Literacy Education in Sub-Saharan Africa, VISA, November 2009, http://corporate.visa.com/media-center/media-kits/fifa.shtml (stan na dzień 14.04.2014). 
formie. Innym przykładem mogą być ulotki i broszury opisujące zarządzanie domowym budżetem oraz korzystanie $\mathrm{z}$ usług finansowych $\mathrm{w}$ formie rysunkowej lub komiksowej, przygotowywane przez Bank Światowy ${ }^{65}$.

Alternatywną formę walki z wykluczeniem bankowym osób starszych zaproponował Postbank. Inicjatywa miała formę jednodniowych warsztatów dotyczących korzystania z usług finansowych, zarządzania ryzykiem, oszczędzania i kredytowania ${ }^{66}$. Pewne próby $\mathrm{w}$ tym obszarze były podejmowane w Polsce, a ze względu na pozytywne efekty tych działań instytucje finansowe powinny w większym zakresie organizować warsztaty podnoszące wiedzę i świadomość finansową seniorów.

Instytucje finansowe odgrywają znaczną rolę w edukacji finansowej społeczeństwa, a co ważniejsze, skuteczność tych działań jest dodatkowo podnoszona poprzez współpracę z innymi organizacjami (rządem, organizacjami non profit, przedsiębiorstwami). Przykładem może być austriacka instytucja finansowa Zweite Wiener Vereins-Sparkasse, która oferuje klientom bezpłatny przez określony czas rachunek bankowy, do którego dołączono także usługi z zakresu ubezpieczeń - takie rozwiązanie pozwoliłoby zwiększyć stopień korzystania z rachunków przez seniorów. Podobną inicjatywę wykazała BBVA Compass, która we współpracy z instytucją non profit oferuje klientom indywidualnym konto prowadzone na preferencyjnych warunkach, które umożliwia poznanie tego instrumentu finansowego (Individual Development Accounts). Innym przykładem działań tej instytucji jest uproszczenie procedur dla osób predestynowanych do wykluczenia finansowego ${ }^{67}$.

Należy zauważyć, że inicjatywy zwiększające aktywność finansową osób powyżej 50. roku życia są różne, natomiast każde podjęte działanie należy ocenić pozytywnie ze względu na ich wpływ na włączenie finansowe seniorów.

\subsubsection{Rekomendacje rozwiązań na rzecz osób w wieku $50+$ na podstawie przykładów dobrych praktyk}

Zmiany demograficzne oraz transformacje systemów emerytalnych wymagają wzięcia większej odpowiedzialności za planowanie swojej emerytury, co z kolei otwiera większe możliwości w segmencie oszczędnościowym i nowych produktów finansowych. Niezbędne jest wykształcenie świadomości finansowej tak, aby podejmowane decyzje były korzystne w dłuższej perspektywie czasowej.

${ }^{65} \mathrm{http} / / /$ wbi.worldbank.org/wbi/content/africa-regional-dialogue-financial-literacy-and-capability (stan na dzień 14.04.2014).

${ }^{66}$ Szerzej: D. Colin, M. Eltringham, The Postbank Financial Literacy Project: Final Report, Financial Education Fund, January 2011.

${ }^{67}$ BBVA Compass, Corporate Responsibility 2012. Annual Report, BBVA Compass, 2012 , s. 16 . 
Wystąpienie kryzysu finansowego było czynnikiem stymulującym zainteresowanie społeczeństwa zagadnieniami ekonomicznymi. Przełożyło się ono nie tylko na zwiększenie liczby programów o tematyce finansowej o charakterze edukacyjnym, ale przede wszystkim na wzmożone zainteresowanie samych gospodarstw domowych podniesieniem swojej wiedzy finansowej. Świadomość korzyści płynących z posiadania wyższej wiedzy finansowej jest ważnym motywatorem $\mathrm{w}$ jej pozyskiwaniu.

$\mathrm{Na}$ świecie edukacja finansowa prowadzona jest wielowątkowo. Każdy z krajów wypracował określone rozwiązania, aby poprawić świadomość finansową i trudno jest wyodrębnić jeden wspólny model. Często podkreślane jest, że na edukację finansową powinny zostać przekazywane wyższe kwoty, gdyż koszty i skutki wykluczenia finansowego często przekraczają koszty edukacji. Najczęściej inicjatywy podnoszące wiedzę finansową koncentrują się na czterech obszarach $^{68}$ :

- inicjatywy promujące korzystanie z konta bankowego,

- inicjatywy uczące, jak zarządzać finansami osobistymi,

- inicjatywy umożliwiające rozwiazywanie problemów osób nadmiernie zadłużonych,

- inicjatywy promujące płatności bezgotówkowe.

W Polsce inicjatywy dedykowane osobom $50+$ powinny również zawierać co najmniej te cztery obszary, gdyż są one kluczowe dla kształtowania świadomości finansowej. Dokonany w raporcie Produkty finansowe $i$ edukacja finansowa w Polsce na tle wybranych krajów wysoko rozwiniętych przegląd zakresu edukacji finansowej w Polsce i w wybranych krajach wysoko rozwiniętych (Australia, Austria, Niemcy, Kanada, USA, Wielka Brytania, Irlandia i Szwajcaria) pozwolił na wskazanie dystansu dzielącego Polskę od analizowanych państw. Spośród analizowanych krajów wysoko ocenione zostały rozwiązania brytyjskie ze względu na duże zaangażowanie rządu zarówno w edukację, jak i w rozwiazywanie problemów osób nadmiernie zadłużonych. Negatywnie ocenione zostały rozwiązania w USA. Natomiast inicjatywy realizowane w Niemczech i Austrii wskazywały na największe podobieństwa.

Wydaje się, że problem edukacji finansowej został lepiej rozwiązany w niektórych krajach, w których wdrożono narodowe strategie edukacji i to za ich pośrednictwem wyznaczono standardy kształcenia w obszarze edukacji finansowej, przypisując jednocześnie poszczególnym instytucjom konkretne zadania w zakresie kształtowania świadomości finansowej społeczeństwa. Polska należy do krajów, które nadal takiej strategii niestety nie wypracowały, skutkiem czego, jakkolwiek podejmowane są liczne działania mające na celu podniesienie świadomości finansowej, jednak brakuje im kompleksowości i cykliczności.

${ }^{68}$ Przegląd inicjatyw promujących edukację finansową dokonany został w: M. Iwanicz-Drozdowska, A. Matuszyk, A. K. Nowak, R. Kitala, Produkty finansowe i edukacja finansowa w Polsce na tle wybranych krajów wysoko rozwiniętych. Raport z badań, Warszawa 2009. 
Zidentyfikowane w pierwszym rozdziale, pogłębiające się zmiany demograficzne, a co za tym idzie dalsze zmiany w strukturze gospodarstw domowych, w tym przewidywany wzrost udziału gospodarstw jednoosobowych, będący kontynuacją zmian zapoczątkowanych w poprzednim dziesięcioleciu (starzenia się ludności oraz zmiany stylu życia), może sugerować potrzebę opracowania nowej oferty bankowej. Zmiany w strukturze społeczno-demograficznej mogą okazać się na tyle silne, że wymuszą zaktualizowanie kształtu obecnych produktów lub powstanie całkiem nowych usług, elastycznie dopasowujących się do indywidualnych potrzeb potencjalnych klientów ${ }^{69}$. Wskazane zmiany demograficzne będą skutkować zmianami w popycie na poszczególne produkty finansowe i będą stanowić wyzwanie dla banków. W ślad za zmieniającą się liczbą mieszkańców kraju i strukturą wiekową społeczeństwa, zmieni się bowiem popyt na usługi bankowe i ulegnie zmianie zachowanie klientów wobec banków. Syntetyczne zestawienie przewidywanego wpływu zmian społeczno-demograficznych na poszczególne segmenty rynku usług finansowych ilustruje tablica 64 .

Tablica 64. Przewidywany wpływ zmian społeczno-demograficznych na poszczególne segmenty rynku usług finansowych

\begin{tabular}{|l|l|l|l|}
\hline \multicolumn{1}{|c|}{ Obszar } & \multicolumn{1}{|c|}{$\begin{array}{c}\text { Perspektywa } \\
\text { krótkoterminowa }\end{array}$} & \multicolumn{1}{c|}{$\begin{array}{c}\text { Perspektywa } \\
\text { średnioterminowa }\end{array}$} & \multicolumn{1}{c|}{$\begin{array}{c}\text { Perspektywa } \\
\text { długoterminowa }\end{array}$} \\
\hline 1 & 2 & \multicolumn{1}{c|}{3} & \multicolumn{1}{c|}{4} \\
\hline $\begin{array}{l}\text { Oszczędności } \\
\text { gospodarstw } \\
\text { domowych }\end{array}$ & $\begin{array}{l}\text { Struktura } \\
\text { oszczędności } \\
\text { kształtowana } \\
\text { przez bieżącą sytuację }\end{array}$ & $\begin{array}{l}\text { Wzrost oszczędności } \\
\text { na skutek skumulowa- } \\
\text { nia środków na starość; } \\
\text { kierowanie się w stronę } \\
\text { bardziej bezpiecznych } \\
\text { aktywów }\end{array}$ & $\begin{array}{l}\text { Stopniowy spadek } \\
\text { oszczędności } \\
\text { (ich wydatkowanie) } \\
\text { w celu utrzymania } \\
\text { poziomu życia }\end{array}$ \\
\hline $\begin{array}{l}\text { Bankowość } \\
\text { (działalność } \\
\text { kredytowa) }\end{array}$ & $\begin{array}{l}\text { Wzrost } \\
\text { zainteresowania } \\
\text { kredytami } \\
\text { konsumpcyjnymi } \\
\text { i mieszkaniowymi } \\
\text { w celu podniesienia } \\
\text { standardu życia }\end{array}$ & $\begin{array}{l}\text { Stopniowy spadek } \\
\text { kredytów konsumpcyj- } \\
\text { nych i mieszkaniowych }\end{array}$ & $\begin{array}{l}\text { Spadek kredytów miesz- } \\
\text { kaniowych; } \\
\text { zainteresowanie } \\
\text { odwróconą hipoteką } \\
\text { ze strony } \\
\text { jednoosobowych } \\
\text { gospodarstw domowych }\end{array}$ \\
\hline Ubezpieczenia & $\begin{array}{l}\text { Wzrost } \\
\text { zainteresowania } \\
\text { ubezpieczeniami } \\
\text { na życie } \\
\text { i zdrowotnymi }\end{array}$ & $\begin{array}{l}\text { Wzrost zainteresowania } \\
\text { polisami long term care } \\
\text { i assisstance (polisy } \\
\text { opiekuńcze) }\end{array}$ & $\begin{array}{l}\text { Pogorszenie wyników } \\
\text { finansowych zakładów } \\
\text { ubezpieczeń i koniecz- } \\
\text { ność podniesienia } \\
\text { składek; konieczność } \\
\text { zabezpieczenia ryzyka } \\
\text { długowieczności }\end{array}$ \\
\hline
\end{tabular}

${ }^{69}$ M. Iwanicz-Drozdowska (red.), Polski rynek finansowy wobec zmian społeczno-demograficznych, Instytut Badań nad Gospodarką Rynkową, Gdańsk, lipiec 2009, s. 10. 


\begin{tabular}{|c|c|c|c|}
\hline 1 & 2 & 3 & 4 \\
\hline $\begin{array}{l}\text { Rynek } \\
\text { kapitałowy }\end{array}$ & $\begin{array}{l}\text { Wzrost liczby } \\
\text { indywidualnych } \\
\text { inwestorów giełdowych }\end{array}$ & $\begin{array}{l}\text { Spadek liczby } \\
\text { inwestorów } \\
\text { indywidualnych } \\
\text { i wzrost znaczenia } \\
\text { firm inwestycyjnych; } \\
\text { przesunięcie } \\
\text { zainteresowań } \\
\text { z akcji na bezpieczne } \\
\text { papiery dłużne }\end{array}$ & $\begin{array}{l}\text { Stopniowa wyprzedaż } \\
\text { aktywów }\end{array}$ \\
\hline
\end{tabular}

Źródło: M. Iwanicz-Drozdowska (red.), Polski rynek finansowy wobec zmian społeczno-demograficznych, Instytut Badań nad Gospodarką Rynkową, Gdańsk, lipiec 2009, s. 164.

Zgodnie ze wskazanym w tablicy zestawieniem, w kolejnych latach czekają sektor bankowy (a nawet szerzej - finansowy) poważne zmiany w popycie na poszczególne typy produktów w trzech perspektywach czasowych. Przewiduje się, że w najbliższej perspektywie czasowej zmiany demograficzne nie powinny wywierać negatywnego wpływu na funkcjonowanie instytucji finansowych. Powinny one wywołać wzrost popytu na różne usługi finansowe, głównie dzięki poprawie zamożności społeczeństwa ${ }^{70}$.

W średniookresowej perspektywie trendy demograficzne powinny wywrzeć bardziej widoczny wpływ na instytucje finansowe, głównie w obszarze zaciągania kredytów i lokowania oszczędności. Oczekuje się, że nastąpi stopniowy spadek zapotrzebowania na kredyty przy jednoczesnym wzroście zainteresowania produktami oszczędnościowymi. Będzie to wywołane zaspokojeniem potrzeb mieszkaniowych oraz znacznej części potrzeb konsumpcyjnych przez pokolenie wyżu demograficznego z początku lat 80-tych, przy oczekiwanym wzroście dochodów tej dużej grupy osób umożliwiającym gromadzenie oszczędności ${ }^{71}$.

Wydaje się, że czynnikiem stymulującym procesy gromadzenia oszczędności mogą być coraz bardziej widoczne obawy społeczeństwa przed wysokością przyszłych emerytur, co może być efektem prowadzonej wielokanałowo kampanii informacyjnej przez rząd, w tym zmianami w $\mathrm{OFE}^{72}$. Ze względu na silną korelację wieku i preferencji w zakresie wyboru form oszczędzania (wraz z wiekiem

${ }^{70}$ Przy założeniu braku poważnych kryzysów oraz drastycznych niekorzystnych zmian w sytuacji rynkowej i koniunkturze gospodarczej.

${ }^{71}$ M. Iwanicz-Drozdowska (red.), Polski rynek finansowy wobec zmian społeczno-demograficznych, Instytut Badań nad Gospodarką Rynkową, Gdańsk, lipiec 2009, s. 46.

${ }^{72}$ Niestety na razie w ślad za narastającym przekonaniem, że emerytura będzie niższa od obecnego uposażenia niewielu Polaków odkłada na emeryturę. Szerzej: TNS Polska, Postawy Polaków wobec oszczędzania, raport Fundacji Kronenberga przy Citi Handlowy, październik 2013. Nadal popularną formą oszczędzania w Polsce jest przechowywanie środków w gotówce. Por. H. Stix, Why Do People Save in Cash? Distrust, Memories of Banking Crises, Weak Institutions and Dollarization, Oesterreichische Nationalbank, January 2012. 
wzrasta awersja do ryzyka) w strukturze aktywów finansowych gospodarstw domowych dominować będą bezpieczne formy lokowania, takie jak depozyty bankowe, polisy na życie oraz obligacje.

Najbardziej negatywny wpływ zmian społeczno-demograficznych na funkcjonowanie instytucji finansowych jest oczekiwany w najdłuższej perspektywie czasowej. W tym okresie najsilniej będą już działać efekty zmian demograficznych powodujących wydłużanie się przeciętnego wieku jak i zmian społecznych związanych z ewolucją modelu rodziny. Obniżenie popytu na usługi bankowe będzie rezultatem silnego wzrostu wskaźnika obciążenia demograficznego osobami starszymi (elderly dependency ratio), co znajdzie odzwierciedlenie w spadku stopy oszczędzania i dalszym zmniejszeniu zainteresowania produktami kredytowymi.

Powinno to stanowić wskazówkę dla banków dotyczącą opracowania oferty uwzględniającej przewidywane zmiany w popycie. Powinna ona zostać opracowana i wdrożona jak najszybciej, tak aby możliwie maksymalnie złagodzić te niekorzystne tendencje. Propozycję pakietu usług bankowych dedykowaną 50+ zawiera tablica 65 .

Tablica 65. Rekomendowany pakiet usług bankowych

\begin{tabular}{|c|c|c|}
\hline $\begin{array}{l}\text { Produkt } \\
\text { bankowy }\end{array}$ & $\begin{array}{c}\text { Grupa osób } \\
\text { aktywnych zawodowo }\end{array}$ & $\begin{array}{c}\text { Grupa osób } \\
\text { biernych zawodowo }\end{array}$ \\
\hline 1 & \multicolumn{2}{|r|}{2} \\
\hline $\begin{array}{l}\text { Rachunek } \\
\text { bankowy }\end{array}$ & \multicolumn{2}{|c|}{$\begin{array}{l}\text { - darmowy } \\
\text { - z darmową kartą płatniczą, umożliwiającą podjęcie środków w bankomatach bez } \\
\text { opłat } \\
\text { - z dostępem elektronicznym }\end{array}$} \\
\hline & $\begin{array}{l}\text { - z pakietem darmowych przelewów } \\
\text { (optymalna ich liczba - 20) }\end{array}$ & $\begin{array}{l}\text { - z pakietem darmowych przelewów } \\
\text { (wystarczy 10) }\end{array}$ \\
\hline & $\begin{array}{l}\text { - z dostępem przez urządzenie mobilne } \\
\text { (tablet, telefon) }\end{array}$ & $\begin{array}{l}\text { - } \mathrm{z} \text { dostępem przez telewizor (o ile tele- } \\
\text { wizor ma takie możliwości technicz- } \\
\text { ne), telefon stacjonarny }\end{array}$ \\
\hline & $\begin{array}{l}\text { - z darmową opcją rachunku oszczęd- } \\
\text { nościowego }\end{array}$ & $\begin{array}{l}\text { - z opcją przyniesienia środków do domu } \\
\text { przez pracowników banku/listonoszy } \\
\text { - na wzór Banku Pocztowego SA-dar- } \\
\text { mowo przy jednorazowej wypłacie }\end{array}$ \\
\hline & $\begin{array}{l}\text { - z darmową opcją bankowości inwe- } \\
\text { stycyjnej }\end{array}$ & $\begin{array}{l}\text { - wyznaczenie konkretnego pracownika } \\
\text { banku na opiekuna danego klienta }\end{array}$ \\
\hline & $\begin{array}{l}\text { - z darmową opcją zbierania punktów } \\
\text { rabatowych za wykonane transakcje } \\
\text { kartą płatniczą }\end{array}$ & $\begin{array}{l}\text { - z dodatkową premią za regularne } \\
\text { wpływy w postaci emerytury }\end{array}$ \\
\hline & & $\begin{array}{l}\text { - karta płatnicza z wyświetlaniem kwoty } \\
\text { pozostałej na rachunku bankowym }\end{array}$ \\
\hline
\end{tabular}




\begin{tabular}{|c|c|c|}
\hline \multirow[t]{2}{*}{$\begin{array}{l}\text { Produkty } \\
\text { pożyczkowo- } \\
\text {-kredytowe }\end{array}$} & \multicolumn{2}{|c|}{$\begin{array}{l}\text { - maksymalna przejrzystość i czytelność oferty kredytowej, brak dodatkowych } \\
\text { zapisów w formie małej czcionki bądź gwiazdek, ze wskazaniem wszystkich } \\
\text { warunków, pełnego kosztu oraz informacją na temat postępowania w przypadku } \\
\text { niespłacania pożyczki/kredytu zgodnie z harmonogramem } \\
\text { - pożyczki i kredyty konsumpcyjne - przyznawane w uproszczony sposób, } \\
\text { ale z uwzględnieniem oceny zdolności kredytowej } \\
\text { - kredyty hipoteczne - ze względu na wydłużenie wieku emerytalnego oficjalne } \\
\text { wydłużenie wieku najstarszego kredytobiorcy do 80. roku życia } \\
\text { - pomimo jednego negatywnego wpisu w BIK SA możliwość wnioskowania o kre- } \\
\text { dyt i jego uzyskania po pozytywnej weryfikacji w banku pod warunkiem spełnie- } \\
\text { nia wymogów dotyczących zdolności kredytowej }\end{array}$} \\
\hline & & $\begin{array}{l}\text { - odwrócona hipoteka - oferowana na } \\
\text { głównym rynku finansowym uwzględ- } \\
\text { niająca faktyczną wartość nierucho- } \\
\text { mości i przewidywany okres życia } \\
\text { kredytobiorcy }\end{array}$ \\
\hline \multirow[t]{2}{*}{$\begin{array}{l}\text { Produkty } \\
\text { oszczędno- } \\
\text { ściowe }\end{array}$} & \multicolumn{2}{|c|}{$\begin{array}{l}\text { - maksymalna przejrzystość i czytelność oferty oszczędnościowej, brak dodatko- } \\
\text { wych zapisów w formie małej czcionki bądź gwiazdek, ze wskazaniem wszyst- } \\
\text { kich warunków, opłat, wymaganych miesięcznych wpłat, z symulacjami pokazu- } \\
\text { jącymi przyszłą wartość gromadzonych środków } \\
\text { - z możliwością wypłaty środków przed zapisanym w umowie terminem w realnej } \\
\text { wysokości, niepomniejszonej o dodatkowe opłaty/kary }\end{array}$} \\
\hline & & $\begin{array}{l}\text { - produkt niegenerujący żadnych trudności } \\
\text { podczas dziedziczenia przez osoby wska- } \\
\text { zane przez osobę, która produkt oszczęd- } \\
\text { nościowy założyła }\end{array}$ \\
\hline \multirow[t]{3}{*}{$\begin{array}{l}\text { Produkty } \\
\text { dodatkowe }\end{array}$} & $\begin{array}{l}\text { Produkty typu asystent domowy, poma- } \\
\text { gający skontaktować z elektrykiem, hy- } \\
\text { draulikiem, mechanikiem samochodo- } \\
\text { wym lub innym potrzebnym specjalistą }\end{array}$ & $\begin{array}{l}\text { - Produkty typu asystent domowy, po- } \\
\text { magający skontaktować się z elektry- } \\
\text { kiem, hydraulikiem lub innym potrzeb- } \\
\text { nym specjalistą }\end{array}$ \\
\hline & & $\begin{array}{l}\text { - Produkty typu asystent medyczny, dbają- } \\
\text { cy o zapisywanie do lekarza pierwszego } \\
\text { kontaktu oraz do specjalisty (publiczny } \\
\text { i prywatny system opieki zdrowotnej), } \\
\text { dbający o przedłużenie recept }\end{array}$ \\
\hline & $\begin{array}{l}\text { Produkty typu concierge łączące funkcje } \\
\text { informacyjno-organizacyjne oferowane } \\
\text { do każdego typu rachunku, a nie tylko } \\
\text { private banking - ewentualnie z ograni- } \\
\text { czeniem do pewnej grupy usług }\end{array}$ & \\
\hline
\end{tabular}

Źródło: opracowanie własne.

W tablicy dokonano podziału na dwie grupy: osoby aktywne i nieaktywne zawodowo. Podział ten niesie za sobą więcej konsekwencji niż rozgraniczenie bazujące tylko na przedziale wiekowym. Osoby aktywne zawodowo obejmują zarówno osoby pracujące, jak i osoby bezrobotne poszukujące pracy i zainteresowane jej podjęciem, zaś osoby nieaktywne zawodowo są to osoby niewykazujące 
chęci do zatrudnienia mimo posiadania zdolności do podjęcia pracy, osoby w wieku emerytalnym lub takie, które są w wieku produkcyjnym, ale uzyskały uprawnienia rentowe i nie zamierzają powrócić na rynek pracy ${ }^{73}$.

Segment klientów aktywnych zawodowo obejmuje głównie osoby ze średnim wynagrodzeniem (zwykle ich dochód jest o $25 \%$ wyższy niż emerytów), które mają wysokie wymagania zarówno w stosunku do cen produktów bankowych, jak i jakości obsługi. Dla tej grupy osób ważny jest wizerunek banku, z którym są związani. W drugiej zaś grupie znajdują się przede wszystkim emeryci, których oczekiwania skupiają się na cenie produktu oraz na bliskości oddziału banku od miejsca zamieszkania. Osoby te cechują niższe wymagania co do jakości obsługi przy jednoczesnym wysokim stopniu deklarowanej lojalności ${ }^{74}$. Tym samym ważne jest podążanie przez banki za potrzebami klientów na różnych etapach jego życia i śledzenie procesów zmian w preferencjach tak, aby znalazło to działanie odzwierciedlenie w satysfakcji i lojalności klientów.

Podstawowym elementem oferty bankowej dla obu grup jest rachunek bankowy. W przypadku zarówno aktywnych, jak i biernych zawodowo nie powinien on dodatkowo obciążać budżetu domowego, powinien być darmowy, z darmową kartą umożliwiającą dokonywanie wypłat ze wszystkich bankomatów bezpłatnie oraz z dostępem przez Internet. Różnicującą cechą może być liczba darmowych przelewów, ograniczona do $10 \mathrm{w}$ przypadku osób biernych zawodowo. W przypadku aktywnych zawodowo rachunek bankowy powinien być jak najbardziej rozbudowany pod kątem możliwości zakładania produktów oszczędnościowych i monitorowania ich wysokości. W przypadku osób biernych zawodowo, większy nacisk powinien być położony na pomoc $\mathrm{w}$ dostępie do rachunku bankowego i dokonywanie za jego pomocą przelewów. Wygodnym byłoby przyjęcie rozwiązania z private banking, polegającego na przypisaniu do konkretnego rachunku bankowego doradcy, który mógłby zawsze służyć pomocą klientowi. Udogodnieniem dla osób nieaktywnych zawodowo, które najczęściej obawiają się dokonywania transakcji płatniczych kartą ze względu na trudności w kontrolowaniu wydatków, byłaby karta płatnicza z wyświetlaczem wskazująca kwotę pozostałą na rachunku bankowym.

Obok rachunku bankowego, w podstawowej ofercie dedykowanej osobom 50+ powinny znaleźć się produkty pożyczkowo-kredytowe dopasowane do indywidulanych potrzeb. Najważniejszą i wspólną ich cechą musi być maksymalna przejrzystość i czytelność oferty kredytowej, brak dodatkowych zapisów w formie małej czcionki bądź gwiazdek, ze wskazaniem wszystkich warunków, pełnego kosztu oraz informacją na temat postępowania w przypadku niespłacania pożyczki/kredytu zgodnie z harmonogramem. Ważna z punktu widzenia bez-

${ }^{73}$ Definicja przyjęta w opracowaniach GUS.

${ }^{74}$ Deloitte, Segmentacja homogenicznych potrzeb. W jaki sposób potrzeby klientów powinny budować segmentację?, maj 2012, s. 5. 
pieczeństwa kredytobiorcy jest możliwość skorzystania z produktów pożyczkowo-kredytowych na głównym rynku bankowym zamiast za pośrednictwem parabanków (czy też instytucji shadow banking). $\mathrm{Z}$ tego względu i dodatkowo biorąc pod uwagę wydłużenie wieku emerytalnego wygodnym rozwiązaniem byłoby oficjalne wydłużenie przez banki wieku najstarszego kredytobiorcy do 80 . roku życia. Bardziej kontrowersyjnym rozwiązaniem mogłoby być oferowanie osobom z negatywną historią kredytową szansy na ponowne zadłużenie w banku pod warunkiem spełnienia oczywiście bardziej rygorystycznych wymogów co do zdolności kredytowej.

Produktem specjalnie dedykowanym osobom biernym zawodowo może być odwrócona hipoteka. Aktualnie nadal trwają prace nad poszczególnymi artykułami rządowego projektu ustawy o odwróconym kredycie hipotecznym. Jej ostateczne zapisy powinny gwarantować kredytobiorcom godziwą miesięczną płatność wyliczoną na podstawie faktycznej wartości nieruchomości i przewidywanego okresu życia kredytobiorcy. Odwrócona hipoteka byłaby oczywiście produktem bankowym, a zatem musiałby on generować pewien zysk dla banku, ale jego wysokość powinna być współmierna do ponoszonego ryzyka oraz aktualnej i przewidywanej koniunktury na rynku nieruchomości.

Wreszcie, ważnym elementem oferty bankowej dedykowanej osobom 50+ są produkty o charakterze oszczędnościowym. Ze względu na zmiany w systemie emerytalnym oferta bankowa musi zawierać produkt oszczędnościowy, który zakupiony odpowiednio wcześnie, pozwoliłby przez kolejne lata wypracować nadwyżkę finansową przeznaczoną do wypłaty po przejściu na emeryturę. Jak pokazało doświadczenie funduszy inwestycyjnych i emerytalnych, nie powinien ten produkt być obarczony nadmiernym ryzykiem związanym z inwestowaniem w ryzykowne instrumenty finansowe, a jednocześnie muszą swoją konstrukcją zapewnić akceptowalny poziom zwrotu przy zakładanej inflacji i sile nabywczej pieniądza ${ }^{75}$. Produkt ten powinien być przejrzyście skonstruowany, tak aby samodzielnie móc wyliczyć zaoszczędzoną kwotę w zależności od odkładanych środków w kilku wariantach uwzględniających nie tylko wysokość dokonywanych wpłat, ale także zmiany w sytuacji gospodarczej.

Poza atrakcyjną z punktu widzenia osoby $50+$ ofertą bankową konieczne są szersze działania realizowane przez instytucje sektora bankowego zmierzające do zwiększenia włączenia w sektor bankowy tej grupy wiekowej i podniesienia jej kompetencji w dziedzinie finansów. Rekomendowane są zatem inicjatywy mające na celu usprawnienie decyzji finansowych podejmowanych przez osoby $50+$. Można je pogrupować na działania w zakresie usprawnień technicznych oraz w obszarze edukacji finansowej. Ich zestawienie prezentuje tablica 66 .

${ }^{75}$ Część polskiego społeczeństwa nadal pamięta o efektach oszczędzania w gospodarce centralnie planowanej, co rodzi obawy przed ponownym podjęciem próby oszczędzania. 
Tablica 66. Rekomendacje w zakresie usprawnienia decyzji finansowych podejmowanych przez osoby $50+$

\begin{tabular}{|c|c|}
\hline Typ działania & Rekomendowane aktywności \\
\hline 1 & 2 \\
\hline \multicolumn{2}{|c|}{ Działania w zakresie usprawnień technicznych } \\
\hline \multirow[t]{7}{*}{ W placówce banku } & zwiększenie przejrzystości zawieranych umów \\
\hline & udogodnienia architektoniczne przy wejściu do placówki \\
\hline & możliwość pożyczenia okularów \\
\hline & wydrukowanie oferty czcionką ułatwiającą czytanie \\
\hline & zapewnienie siedzących miejsc w poczekalni banku \\
\hline & $\begin{array}{l}\text { dedykowanie specjalnego okienka do obsługi osób powyżej } 60 \text {. } \\
\text { roku życia }\end{array}$ \\
\hline & $\begin{array}{l}\text { zapewnienie spokojnego miejsca, w którym można zapoznać się } \\
\text { z ofertą bankową }\end{array}$ \\
\hline \multirow{4}{*}{$\begin{array}{l}\text { Podczas korzystania } \\
\text { z bankowości elektronicznej }\end{array}$} & przejrzystość strony internetowej banku \\
\hline & łatwość dokonywania transakcji poprzez serwis transakcyjny \\
\hline & opisy ułatwiające poruszanie się po serwisie \\
\hline & $\begin{array}{l}\text { wyposażenie osób starszych w przystępnie napisany przewodnik } \\
\text { po serwisie }\end{array}$ \\
\hline \multicolumn{2}{|c|}{ Działania w obszarze edukacji finansowej } \\
\hline \multirow{8}{*}{$\begin{array}{l}\text { Prowadzenie edukacji } \\
\text { finansowej przez instytucje } \\
\text { sektora finansowego } \\
\text { za pośrednictwem } \\
\text { zróżnicowanych form } \\
\text { przekazu }\end{array}$} & media: prasa, TV, radio, Internet \\
\hline & w kościołach, klubach parafialnych \\
\hline & w miejscach pracy \\
\hline & poprzez pocztę tradycyjną \\
\hline & w klubach seniora \\
\hline & na Uniwersytetach Trzeciego Wieku \\
\hline & w przychodniach, szpitalach, sklepach, parkach \\
\hline & w placówkach opieki społecznej \\
\hline $\begin{array}{l}\text { Zakres tematyczny } \\
\text { warsztatów, wykładów, } \\
\text { spotkań edukacyjnych }\end{array}$ & $\begin{array}{l}\text { Najważniejsze zagadnienia dla osób } 55+\text { z obszaru bankowości: } \\
\text { - korzyści z posiadania rachunku i innych produktów, } \\
\text { - bezpieczeństwo usług bankowych, w tym płatności, } \\
\text { - koszty płatności banki vs poczta, } \\
\text { - różnice między bankami i parabankami oraz instytucjami, } \\
\text { - w których można zrealizować płatność, } \\
\text { - działanie bankomatu, karty płatniczej (w tym zbliżeniowej), } \\
\text { - korzystanie z bankowości elektronicznej, } \\
\text { - wady i zalety odwróconej hipoteki, } \\
\text { - problematyka równoważenia budżetu domowego, } \\
\text { - informacje na temat pułapek w ofertach finansowych, } \\
\text { - zasady porównywania ofert }\end{array}$ \\
\hline $\begin{array}{l}\text { Organizowanie bezpłatnych } \\
\text { kursów i szkoleń podnoszą- } \\
\text { cych wiedzę finansową }\end{array}$ & $\begin{array}{l}\text { Część spotkań mogłaby odbywać się w placówkach banków } \\
\text { w celu zaznajomienia osób 50+ z oddziałami. Organizacja tzw. } \\
\text { „Drzwi otwartych” }\end{array}$ \\
\hline
\end{tabular}




\begin{tabular}{|l|l|}
\hline \multicolumn{1}{|c|}{1} & \multicolumn{1}{|c|}{2} \\
\hline $\begin{array}{l}\text { Budowanie zaufania } \\
\text { do instytucji finansowych }\end{array}$ & $\begin{array}{l}\text { Wskazywanie na różnice w korzystaniu z usług głównego rynku } \\
\text { finansowego oraz z usług parabanków }\end{array}$ \\
\cline { 2 - 2 } & Kładzenie nacisku na rolę BFG w gwarantowaniu depozytów \\
\cline { 2 - 2 } & $\begin{array}{l}\text { Wskazywanie na znaczenie KNF w licencjonowaniu działalności } \\
\text { banków, a szczególnie w limitowaniu działalności parabanków }\end{array}$ \\
\cline { 2 - 2 } & $\begin{array}{l}\text { Zwracanie uwagi na działania NBP podejmowane w celu zapew- } \\
\text { nienia stabilności sektora finansowego }\end{array}$ \\
\cline { 2 - 2 } & Zapoznanie z funkcją Bankowego Arbitrażu Konsumenckiego \\
\hline
\end{tabular}

Źródło: opracowanie własne.

Wskazane wyżej działania mające na celu usprawnienie podejmowania decyzji finansowych przez osoby w wieku 50+ zostały podzielone na dwie części: o charakterze technicznym i edukacyjnym. Bowiem bariery w dostępie do usług bankowych w znacznej mierze wynikają z braku fizycznej możliwości skorzystania $\mathrm{z}$ oferty bankowej albo z braku umiejętności.

Poważną przeszkodą stojącą na drodze inkluzji bankowej jest obawa osób 50+ przed skomplikowanymi zapisami w umowach (obarczonymi często gwiazdkami) zawieranych z bankami i wręcz brak zrozumienia większości zapisów. Wprowadzenie uregulowań $\mathrm{w}$ obszarze informacyjnym ma na celu zwiększenie przejrzystości zawieranych umów, zmniejszenie ryzyka związanego z ukrytymi kosztami i opłatami. Są one niezmiernie cenne w przypadku osób powyżej 50. roku życia, które często padają ofiarą wyłudzeń i zdecydowanie częściej korzystają z kredytu konsumenckiego niż np. hipotecznego i mają trudności z samodzielnym wyliczeniem całkowitego kosztu zaciągniętego zobowiązania. Regulacje te powinny także wpłynąć na zmniejszenie nadmiernego zadłużania gospodarstw domowych wynikające $\mathrm{z}$ nieznajomości całkowitych kosztów obsługi zadłużenia. Zapewnienie przejrzystości umów wraz z informacjami o pełnych kosztach oraz ryzyku towarzyszącym skorzystaniu z danego produktu lub usługi bankowej pozwala na bardziej świadome podejmowanie decyzji finansowych i przekłada się na wzrost zaufania do sektora bankowego, a w dalszej perspektywie na chęć pełnego włączenia się w system bankowy. NBP opracował nawet prosty kodeks korzystania z usług bankowych, który poleca postępowanie zgodne z 4 zasadami ${ }^{76}$ :

- sprawdzenie wiarygodności danego podmiotu,

- policzenie całkowitego kosztu pożyczki,

- dokładne przeczytanie umowy,

- niepodpisywanie umowy, jeśli się jej nie rozumie ${ }^{77}$.

${ }^{76}$ Edukacja ekonomiczna seniorów, NBP, Krynica 5 września 2013 r., www.forumtrzeciegowieku. pl/index.php?...edukacja-ekonomiczna-seniorow, s. 5 (stan na dzień 28.08.2014).

${ }^{77}$ Uzupełnieniem przejrzystych umów powinno być zapewnienie miejsca w banku umożliwiającego zapoznanie się z zapisami i przemyślenie decyzji o zawarciu konkretnej umowy. 
W przypadku osób 50+ duże znaczenie mają udogodnienia techniczne, które mogłyby przełożyć się na zwiększenie ich ubankowienia. Mają one wymiar czysto praktyczny i dla osób młodych mogą wydawać się zupełnie zbędne, jednak biorąc pod uwagę stan zdrowia seniorów są istotne. Przede wszystkim największą barierą w poruszaniu się po domu lub poza domem są utrudnienia architektoniczne, które zyskują na znaczeniu wraz z wiekiem. Z tego względu lokalizacja i możliwość wejścia do placówki banku powinny uwzględniać możliwości osób powyżej 50. roku życia. Podobnie ważnym aspektem jest wyposażenie placówek sprzyjające oczekiwaniu na obsługę (zapewnienie poczekalni) i wykorzystywane do realizacji transakcji (wypożyczenie okularów, wydrukowanie dokumentów większą czcionką). Ze względu na dynamicznie zwiększającą się liczbę osób w podeszłym wieku dobrym rozwiązaniem mogłoby być wydzielenie okienka dedykowanego specjalnie do obsługi osób powyżej 60. roku życia.

Dla osób 50+, które decydują się na korzystanie z bankowości elektronicznej powinny zostać przewidziane specjalne nakładki na strony transakcyjne ułatwiające poruszanie się po serwisie i skorzystanie z podstawowych usług, takich jak sprawdzenie salda rachunku i dokonanie przelewu. Aktualnie banki przywiązują dużą uwagę do personalizacji bankowości elektronicznej i systematycznie poszerzają wachlarz usług dostępnych online (poza typowymi usługami bankowymi jak zakładanie lokat, dokonywanie różnego rodzaju płatności, monitorowanie spłat rat kredytów zwykle rachunki bankowe są wyposażane w funkcje dokonujące analiz wpływów i wydatków realizowanych przy wykorzystaniu konta osobistego), co jest bardzo wygodne dla osób młodszych, ale okazuje się być zbyt skomplikowane dla starszych grup wiekowych.

Działania z drugiego obszaru, jakim jest edukacja finansowa, powinny kontynuować rozpoczęte już trendy. Powinny być prowadzone poprzez preferowane przez osoby $\mathrm{w}$ wieku 50 + kanały informacyjne (telewizja - programy informacyjne ogólnopolskie; prasa - dziennik „Fakt”, tygodnik katolicki; radio - stacje masowe, katolickie). Wprawdzie zidentyfikowano, że wraz z wiekiem maleje aktywność społeczna, jednak nie powinny być zaniedbywane także miejsca potencjalnych spotkań, takie jak przychodnie, sklepy, parki i kościół.

Poza miejscem prowadzenia działań edukacyjnych niezmiernie ważny jest zakres tematyczny warsztatów, wykładów, spotkań edukacyjnych. Powinien on być dopasowany do potrzeb i oczekiwań konkretnej grupy wiekowej. Wskazane w tablicy obszary działań edukacyjnych zostały opracowane na podstawie literatury przedmiotu, a w szczególności badań prowadzonych na zlecenie NBP. Obejmują one zagadnienia $\mathrm{z}$ różnych poziomów trudności, dedykowane zarówno osobom dotychczas wykluczonym z sektora bankowego oraz tym, które są już wprawdzie użytkownikami produktów i usług bankowych, ale chciałyby pozyskać informacje na temat dokonywania porównywania i wyboru ofert bankowych, określania kosztów towarzyszących konkretnym produktom i usługom lub mają konkretne obawy związane z przejściem do wyższego poziomu ubankowienia, czyli bankowości elektronicznej i płatności elektronicznych. 
Uzupełnieniem rekomendacji $\mathrm{w}$ zakresie usprawnienia procesu podejmowania decyzji finansowych przez osoby 50+ stanowić powinno zintensyfikowanie przekazu kierowanego do tej grupy wiekowej pobudzającego zaufanie do sektora bankowego, które jest niskie w tej grupie wiekowej. Budowaniu zaufania może posłużyć edukacja na temat roli jaką pełnią poszczególne instytucje funkcjonujące w ramach sieci bezpieczeństwa, czyli NBP, BFG, KNF.

Na pewno koniecznym jest wzmożona edukacja na temat bezpieczeństwa lokowanych środków w banku. Ustawowo powinny zostać wskazane środki przekazu odpowiedzialne za informowanie klientów o gwarancji deponowanych przez nich środków. W społeczeństwie widoczny jest brak wiedzy, na temat roli, jaką pełni BFG w gwarantowaniu depozytów ${ }^{78}$, który przełożył się m.in. na skalę działania parabanku Amber Gold i liczbę dokonanych przez niego oszustw na szkodę jego klientów. W konsekwencji doprowadził on do utraty zaufania także do banków działających na mocy ustawy Prawo bankowe, gdyż społeczeństwo nie zawsze jest do końca świadome różnic w działaniu parabanków i banków, a co więcej nie zawsze wie z usług, jakiego rodzaju instytucji korzysta.

Z kwestią bezpieczeństwa wiąże się także działalność licencyjna prowadzona przez KNF. Należy edukować osoby w wieku 50+ na temat chociażby konieczności sprawdzenia w razie jakichkolwiek wątpliwości obecności danej instytucji na publikowanej przez KNF liście ostrzeżeń publicznych ${ }^{79}$.

Kryzys finansowy trwający w ostatnich latach znacząco przełożył się na utratę zaufania do sektora bankowego. Przekonanie osób w wieku 50+ do włączenia w sektor bankowy wymaga edukowania w zakresie roli, jaką pełni NBP w zapewnieniu bezpieczeństwa i stabilności polskiego sektora bankowego. Jak potwierdziły cytowane wcześniej badania, wiele osób obawiało się upadłości banku i wolało przechowywać pieniądze w gotówce i niewiele osób powyżej 50. roku życia było w stanie zinterpretować rolę, jaką pełni NBP jako pożyczkodawca ostatniej instancji.

Ostatnim z zagadnień służących budowaniu zaufania do sektora bankowego poprzez edukację jest zapoznanie osób 50+ z instytucją Bankowego Arbitrażu Konsumenckiego działającego przy ZBP ${ }^{80}$. Został on powołany w celu rozstrzygania sporów pomiędzy klientami banków a bankami w zakresie roszczeń pieniężnych z tytułu niewykonania lub nienależytego wykonania przez bank czynności bankowych lub innych czynności na rzecz konsumenta ${ }^{81}$. Postępowanie to jest możliwe po wyczerpaniu postępowania reklamacyjnego

${ }^{78}$ Ramy prawe działania BFG ustala ustawa z dnia 14 grudnia 1994 r. o Bankowym Funduszu Gwarancyjnym, tekst jednolity: Dz. U. z 2009 r., nr 84, poz. 711 ze zm.

${ }^{79}$ Lista ostrzeżeń publicznych Komisji Nadzoru Finansowego, http://www.knf.gov.pl/o_nas/ ostrzezenia_publiczne/lista_ostrzezenia.html (stan na dzień 28.07.2014).

${ }^{80}$ Szerzej: http://zbp.pl/dla-konsumentow/arbiter-bankowy/dzialalnosc (stan na dzień 28.07.2014).

${ }^{81}$ Bankowy Arbiter Konsumencki rozstrzyga w przypadku roszczeń, w których wartość roszczeń nie przekracza 8000 zł. 
w banku i polega na złożeniu wniosku i dokonaniu wpłaty w wysokości 50 zł. Cechą charakterystyczną tego postępowania jest ochrona konsumenta polegająca na tym, że w przypadku pozytywnego rozstrzygnięcia na rzecz klienta, bank nie ma już żadnej możliwości odwołania się od decyzji Arbitra. Natomiast $\mathrm{w}$ przypadku niekorzystnego rozstrzygnięcia, klient banku ma prawo do dwuinstancyjnego postępowania sadowego. Przewagą arbitrażu nad postępowaniem sądowym jest uwzględnianie w postępowaniu kwestii, czy bank nie naruszył zasad etycznych określonych w Zasadach Dobrej Praktyki Bankowej, czyli możliwe jest opieranie roszczenia na zasadach współżycia społecznego i etycznego postępowania.

Doświadczenia innych krajów pokazują, że społeczeństwo wykazuje większe zainteresowanie i zaufanie do programów realizowanych pod patronatem instytucji państwowych. W Polsce corocznie realizowanych jest szereg inicjatyw zmierzających do poprawienia świadomości finansowej, z których pewna część jest kierowana do osób 50+. Jednak cennym byłoby przede wszystkim zapewnienie cykliczności działań edukacyjnych realizowanych przez instytucje sektora finansowego, w tym szczególnie banki, gdyż to one są jednym z głównych beneficjentów włączenia bankowego większej liczby obywateli. Cennym uzupełnieniem inicjatyw edukacyjnych prowadzonych przez instytucje sektora finansowego, szczególnie przez NBP, ale także ZBP oraz banki komercyjne i spółdzielcze, byłaby ich realizacja we współpracy z agendami rządowymi i samorządowymi. Pozwoliłoby to podejmowane inicjatywy lepiej usystematyzować i zsynchronizować, co niestety wydaje się być trudne do zrealizowania bez uchwalonej narodowej strategii edukacji finansowej.

\subsection{Rekomendacje dla podmiotów działających na rzecz osób 50+ na poziomie lokalnym w obszarze kształtowania świadomości finansowej}

\subsubsection{Przegląd doświadczeń zagranicznych $w$ obszarze edukacji i włączenia w sektor bankowy osób 50+}

Inicjatywy umożliwiające włączenie w sektor bankowy osób 50+ mogą przybierać różne formy, przy czym najczęściej występującym sposobem dokonania inkluzji bankowej są działania o charakterze edukacyjnym. Przedsięwzięcia te mają różnorodny zasięg (częściej lokalny, rzadziej krajowy), co jest uzależnione głównie środkami finansowymi, jakimi dysponuje organizacja angażująca się w tego typu działania oraz skala jej działalności. Zarówno pośród mniejszych, 
jak i większych projektów, których celem jest włączenie ich uczestników (osób 50+) w sektor bankowy, znaleźć można bardziej skuteczne i w efekcie zasługujące na implementację przez podmioty w innych krajach.

Interesującym przykładem organizacji pozarządowej angażującej się w pomoc osobom 50+ jest Age UK. Instytucja ta poprzez organizowane inicjatywy oferuje różnorodne usługi oraz wsparcie udzielane zarówno na szczeblu krajowym, jak i lokalnym. Działalność wspomnianej organizacji nie ogranicza się tylko i wyłącznie do terytorium Wielkiej Brytanii - jej wolontariusze prowadzą aktywną działalność w ponad 40 rozwijających się krajach ${ }^{82}$.

Age $U K$ udziela pomocy osobom $50+$ poprzez ich inspirowanie, wspieranie oraz włączanie w rozmaite inicjatywy, co jest możliwe m.in. poprzez ${ }^{83}$ :

- organizowanie kampanii społecznych mających na celu wzrost świadomości społeczeństwa oraz instytucji na temat problemów osób 50+ oraz ich potrzeb;

- oferowanie produktów dedykowanych dla osób 50+ oraz dostosowanych do ich potrzeb (w tym produktów bankowych o charakterze oszczędnościowym i kredytowym);

- organizowanie szkoleń, którymi objętych jest rocznie około 10000 osób, mających na celu np. wskazanie sposobów poszukiwania zatrudnienia przez osoby $50+$ oraz implementację innowacyjnych technik uczenia się przez wskazaną grupę społeczeństwa;

- prowadzenie badań w celu poszukiwania sposobów na ułatwienie codziennego życia osobom 50+;

- prowadzenie działalności doradczo-informacyjnej, którą umożliwia bezpłatna infolinia oraz biuletyny informacyjne.

Obszary tematyczne udzielonego wsparcia koncentrują się wokół różnorodnych zagadnień, do których należą finanse, zdrowie, podróże, opieka oraz zatrudnienie ${ }^{84}$. W ramach bloku tematycznego poświęconego zagadnieniom z zakresu finansów osoby należące do grupy $50+$ mogą poszerzyć swoją wiedzę m.in. na temat ${ }^{85}$ :

- świadczeń emerytalnych,

- podatków,

- zadłużania i oszczędzania,

- kwestii prawnych,

- porad dla konsumentów.

Dzięki zaangażowaniu w inicjatywy przedsięwzięte przez Age UK osoby 50+ mogą pozyskać, oprócz bogatej wiedzy merytorycznej, umiejętności praktyczne, które w efekcie umożliwią im podejmowanie bardziej świadomych i racjonalnych decyzji inwestycyjnych, a także pozwolą na spłatę zobowiązań ${ }^{86}$.

${ }^{82} \mathrm{http}: / /$ www.ageuk.org.uk/about-us/age-international/ (stan na dzień 04.08.2014).

${ }^{83} \mathrm{http}: / /$ www.ageuk.org.uk/about-us/what-we-do/ (stan na dzień 04.08.2014).

${ }^{84} \mathrm{http}: / /$ www.ageuk.org.uk/ (stan na dzień 04.08.2014).

${ }^{85} \mathrm{http}: / /$ www.ageuk.org.uk/money-matters/ (stan na dzień 04.08.2014).

${ }^{86} \mathrm{http}: / /$ www.ageuk.org.uk/money-matters/money-management/ (stan na dzień 04.08.2014). 
Kolejną instytucją włączającą osoby $50+$ w sektor finansowy jest Center for Financial Inclusion. Podmiot ten jest instytucją non profit działającą na rzecz szerzenia idei włączenia finansowego wszystkich grup narażonych na wykluczenie na całym świecie, w tym także osób powyżej 50. roku życia. Co istotne, działania tej organizacji mają charakter wielopłaszczyznowy, ponieważ podejmowane są w następujących obszarach ${ }^{87}$ :

- Podnoszenie świadomości finansowej klientów poprzez kontrolę i monitoring wdrażania przez instytucje finansowe Zasad Ochrony Konsumenta, zapewniających mu przejrzystość oferty, wiarygodność oraz najwyższą jakość obsługi (instytucje, które spełniają takie standardy, otrzymują specjalne certyfikaty). Center for Financial Inclusion jest organizacją działającą niezależnie od organów nadzoru finansowego, ale poprzez uwzględnienie w swoich audytach finansowych perspektywy klienta (a zwłaszcza nieposiadającego wiedzy i świadomości finansowej) możliwe jest wykrycie obszarów działania instytucji finansowych, które, choć zgodnie z prawem, mogą przyczyniać się do zwiększania zjawiska wykluczenia finansowego, jak choćby zawiłość procedur.

- Wspieranie działań rządowych w walce z wykluczeniem finansowym oraz działań związanych z zarządzaniem ryzykiem - dzielenie się doświadczeniami poszczególnych krajów oraz wzajemne uczenie się, tworzenie zespołów roboczych z najlepszych ekspertów w tej dziedzinie, wymieniających się wiedzą na temat podejmowanych działań oraz specyfiki poszczególnych krajów, z których pochodzą, tworzenie systemu zarządzania ryzykiem związanym z walką z ekskluzją finansową, podejmowanie wspólnych inicjatyw, mających na celu poszukiwanie prywatnych inwestorów finansowych.

- Opracowywanie dla poszczególnych krajów programów walki z wykluczeniem finansowym, tworzenie praktycznych narzędzi ułatwiających włączenie w system finansowy, opracowywanie dokumentów i publikacji na temat poszczególnych produktów finansowych i ochrony konsumenta.

Innym przykładem organizacji angażującej się $\mathrm{w}$ inkluzję finansową jest działające od 1990 r. The Centre for Housing and Support. Działania instytucji koncentrują się na podnoszeniu świadomości finansowej osób 50+, co jest możliwe dzięki organizacji konferencji, warsztatów, kursów (tradycyjnych oraz przy wykorzystaniu Internetu) oraz publikowaniu różnorodnych poradników zawierających zbiór dobrych praktyk ${ }^{88}$.

Ciekawym rozwiązaniem są kursy e-learningowe, zwłaszcza w kontekście osób, które z różnych powodów cechują się ograniczoną mobilnością, przez co nie mogą uczestniczyć w standardowych szkoleniach. Spośród wielu modułów znaleźć można również kurs poświęcony zagadnieniom finansowym. Koncentruje się on wokół podstawowych zagadnień związanych m.in. z rachunkami banko-

\footnotetext{
${ }^{87} \mathrm{http} / / /$ www.centerforfinancialinclusion.org/programs-a-projects/pwd (stan na dzień 1.08.2014).

${ }^{88} \mathrm{http}: / /$ www.chs.ac.uk/index.php?page=_About_Us\&id=2020 (stan na dzień 04.08.2014).
} 
wymi, sposobami oszczędzania oraz źródłami pozyskiwania środków, przy czym przekazywana wiedza ma charakter bardziej praktyczny, dzięki czemu osoba, która ukończy kurs powinna rozumieć rolę, jaką odgrywa domowy budżet, identyfikować potencjalne korzyści z oszczędzania oraz rozróżniać rozliczne źródła pozyskiwania środków, a także, co szczególnie istotne, mieć świadomość kosztu ich pozyskania ${ }^{89}$.

Niewątpliwą zaletą kursu e-learningowego jest możliwość jego ukończenia w dowolnym miejscu i czasie oraz powrót do wybranych zagadnień, które wcześniej były niezrozumiałe.

Ciekawą inicjatywą jest również Money Smart for Older Adults (MSOA). Są to prowadzone przez instruktora szkolenia opracowane wspólnie przez Federal Deposit Insurance Corporation i Consumer Financial Protection Bureau. Moduł ten ma na celu zwiększenie świadomości wśród osób starszych i ich opiekunów poprzez udostępnienie informacji, w jaki sposób zapobiec eksploatacji finansowej, a także zachęcenie do wcześniejszego planowania i świadomego podejmowania decyzji finansowych. Szkolenie miało postać spotkania z zainteresowanymi stronami i wykład, czym jest wyzysk finansowy i dlaczego osoby starsze są narażone na jego ryzyko. Co istotne, inicjatywa ta zakłada także uczestnictwo banków na zasadzie partnerstwa (na przykład pracownicy banku mogą dostarczyć informacji umożliwiających walkę $\mathrm{z}$ wykluczeniem finansowym na podstawie własnej współpracy z dostawcami usług telekomunikacyjnych lub starszymi osobami). Program obejmuje siedem obszarów tematycznych ${ }^{90}$ :

- wspólne typy finansowej eksploatacji starszych,

- oszustwa względem seniorów,

- kradzież tożsamości,

- medyczna kradzież tożsamości,

- oszustwa czyhające na posiadaczy domów,

- planowanie nieoczekiwanych zdarzeń życiowych,

- finansowe przygotowanie na klęski żywiołowe.

Przykładem wsparcia udzielanego osobom 50+ może być również pomoc oferowana przez Citizens Advice Oxfordshire (CAOx), organizację funkcjonującą na obszarze ośmiu hrabstw. Wspomniana instytucja angażuje się głównie w działalność o charakterze doradczo-informacyjnym, przy czym zakres udzielanego wsparcia jest bardzo szeroki. Citizens Advice Oxfordshire (CAOx) realizuje różnorodne projekty, które łączy jeden cel - ułatwianie życia mieszkańcom hrabstw biorących udział w przedsięwzięciu.

Podobnie jest w przypadku inkluzji finansowej - działania opisywanej instytucji skupiają się na doradztwie w zakresie maksymalizowania dochodów mieszkańców objętych wsparciem. Inkluzja finansowa jest w tym przypadku

${ }^{89} \mathrm{http}: / /$ www.chs.ac.uk/index.php?page=_Our_Courses\&id=2312 (stan na dzień 04.08.2014).

${ }^{90} \mathrm{http}: / /$ www.fdic.gov/consumers/consumer/moneysmart/olderadult.html (stan na dzień 01.08.2014). 
nierozerwalnie powiązana z inkluzją społeczną - Citizens Advice Oxfordshire, podnosząc umiejętności mieszkańców w zakresie zarządzania budżetem domowym, próbuje zachęcać osoby $50+$ do uczestnictwa w wydarzeniach lokalnych ${ }^{91}$.

W kontekście włączenia w sektor bankowy osób 50+ należy również wspomnieć o działaniach podejmowanych przez National Council on Aging. Jest to instytucja non profit reprezentująca osoby starsze i organizacje społeczne, które je obsługują. Jej celem jest poprawa zdrowia i gospodarczego bezpieczeństwa $10 \mathrm{mln}$ osób starszych do roku 2020. Organizacja współpracuje z partnerami lokalnymi i krajowymi w celu dostarczenia osobom starszym narzędzi i informacji, jak zachować zdrowie i bezpieczeństwo, a także podejmuje liczne programy i działania na rzecz poprawy warunków życia wszystkich seniorów, zwłaszcza najsłabszych. Do jednych z nich należy Savvy Saving Seniors, opracowany we współpracy z fundacją charytatywną Bank of America. Program ma formę zestawu narzędzi (filmy video dostępne w sieci oraz informacje $\mathrm{w}$ formie prezentacji lub publikacji elektronicznej, za opłatą możliwość zamówienia także w wersji papierowej) informujących seniorów o tym, jak zarządzać budżetem, jak uniknąć oszustw, jak ubiegać się o świadczenia i zarządzać przedpłaconymi kartami debetowymi ${ }^{92}$.

Przykładem instytucji zaangażowanej w proces włączenia bankowego osób 50+ jest także Fundacja Citi, organizująca Światowe Forum Wiedzy Finansowej. Oprócz wymiany wiedzy w trakcie wydarzenia są także testowane innowacyjne narzędzia i produkty, które zachęcają do zarządzania budżetem, zarządzania i zmniejszenia zadłużenia, długoterminowego planowania finansowego i innych pozytywnych zachowań finansowych. W trakcie Forum w 2013 r. były podejmowane następujące zagadnienia ${ }^{93}$ :

- prezentacja innowacyjnych technologii i produktów, które zwiększają zdolność finansową grup o niskich dochodach, w tym m.in. osób starszych;

- zapoznanie z metodami pomiaru wpływu programów edukacji finansowej na zjawisko wykluczenia finansowego.

Kolejną inicjatywą przyczyniającą się do inkluzji bankowej osób 50+ jest program SCREEN. Jest to inicjatywa realizowana przez Institute for Financial Literacy (instytucja non profit, zapewniająca skuteczną edukację finansową dla Amerykanów, w tym dla osób powyżej 50. roku życia) w ramach partnerstwa z AssetPlatform.org (organizacja oferuje przyjazne dla użytkownika produkty, usługi i szkolenia). Program szkoleniowy mający na celu zwiększanie wiedzy i świadomości finansowej swoich klientów został opracowany dla pracowników instytucji finansowych. Dwuczęściowy program SCREEN (Senior Citizen \& Re-

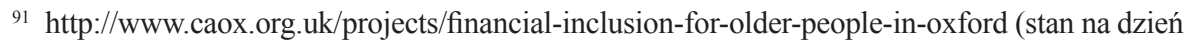
04.08.2014).

${ }^{92} \mathrm{http} / / / \mathrm{www} \cdot \mathrm{ncoa}$.org/enhance-economic-security/economic-security-Initiative/savvy-saving-seniors/ (stan na dzień 01.08.2014).

${ }_{93} \mathrm{https}: / /$ www.etouches.com/ehome/fined2013/ (stan na dzień 01.08.2014). 
tiree Empowerment Education Network) certyfikuje doradców w ramach programu Certified Educator in Personal Finance i uwierzytelnia uczestników tego programu po to, aby spełnić specyficzne potrzeby finansowe osób starszych ${ }^{94}$.

Organizacją, której działalność zasługuje na uwagę jest także Canadian $\mathrm{Na}$ tional Initiative for the Care of Elderly (NICE). Wspomniana organizacja skierowała do starszych kobiet (powyżej 55. roku życia) program „Older Women and Financial Literacy: Briding the Income Group". W ramach tej inicjatywy uczestnicy nabywali wiedzę na temat produktów finansowych, a także poznawali narzędzia ułatwiające zarządzanie domowym budżetem, zapobieganie sytuacjom o znamionach finansowego wyzysku, zarządzanie zadłużeniem, regularne oszczędzanie oraz wybór usług kredytowych i oszczędnościowych najbardziej odpowiadających ich potrzebom ${ }^{95}$.

Warto również wspomnieć o wspólnym przedsięwzięciu Citi i National Institute on Consumer Education. Instytucje te zorganizowały w $2011 \mathrm{r}$. w Japonii program dla kobiet w starszym i średnim wieku, mający na celu pomoc w nauczeniu się zarządzania budżetem, regularnego oszczędzania oraz wyboru odpowiednich instrumentów finansowych w obszarze kredytowym i oszczędnościowym ${ }^{96}$.

\subsubsection{Zidentyfikowanie rozwiązań na rzecz osób w wieku 50+ jako przykładów dobrych praktyk}

Rozwój rynków finansowych, w tym również sektora bankowego, oraz oferty produktowej dedykowanej dla klientów indywidualnych sprawia, że świadome korzystanie z produktów i usług bankowych wymaga coraz większej wiedzy merytorycznej osób fizycznych. W relatywnie trudniejszej sytuacji wydają się być osoby starsze, które często, obawiając się zmian i innowacji, ograniczają się do korzystania wyłącznie z podstawowej oferty bankowej, a z czasem wzrasta ryzyko ich wykluczania finansowego. W związku z tym, na uwagę zasługują inicjatywy podejmowane przez różne podmioty gospodarcze, instytucje oraz organizacje, których celem jest podnoszenie poziomu wiedzy o finansach u osób starszych, a co za tym idzie ich włączenie finansowe. Działania, które mają na celu zapobieganie wykluczeniu finansowemu osób starszych oraz ich inkluzji na poziomie lokalnym, podejmowane są przede wszystkim przez organizacje non profit. W większości obejmują one inicjatywy edukacyjne, które mają na celu wykształcenie wśród społeczeństwa świadomości finansowej w zakresie szans i zagrożeń niesionych przez poszczególne instrumenty finansowe. $\mathrm{Z}$ punktu widzenia

${ }^{94} \mathrm{https}$ ://financiallit.org/institute-for-financial-literacy-launches-financial-education-program -designed-for-senior-citizens/ (stan na dzień 01.08.2014).

${ }_{95} \mathrm{http}: / /$ www.nicenet.ca/de.aspx?id=274 (stan na dzień 01.08.2014).

${ }^{96} \mathrm{http}: / /$ www.citigroup.jp/english/press_release/2011/20110623 en.pdf (stan na dzień 01.08.2014). 
przeprowadzonego przeglądu działań organizacji lokalnych na rzecz zwiększania aktywności finansowej osób starszych są Uniwersytety Trzeciego Wieku' ${ }^{97}$. Ich znaczenie dla osób powyżej 50. roku życia należy rozpatrywać nie tylko w kontekście włączania społecznego, ale także finansowego, gdyż zapewniają swoim uczestnikom możliwość zdobycia wiedzy finansowej oraz zapoznania się z zasadami działania rynku finansowego.

Przykładami kolejnych przedsięwzięć ukierunkowanych na włączenie finansowe osób starszych są inicjatywy podejmowane przez Stowarzyszenie Krzewienia Edukacji Finansowej. Wśród działań prowadzonych przez wspomnianą organizację wyróżnić można m.in. następujące aktywności:

- „Organizacja czasu wolnego Gdynia 55+” - Żyj Finansowo! Abc Praw Konsumenta" - projekt realizowany w 2009 r., którego celem było zwiększenie świadomości prawnej konsumentów, w tym wzrost znajomości procedury egzekwowania praw im należnych ${ }^{98}$.

- „Krajowa Sieć Ośrodków Doradztwa Finansowego i Konsumenckiego" - inicjatywa sfinansowana ze środków programu „Granty dla konsumenckich organizacji pozarządowych" (TransitionFacility, 2004). Celem przedsięwzięcia było „Zwiększenie dostępności konsumentów do usług specjalistycznej pomocy i doradztwa w zakresie nadmiernego zadłużenia", natomiast w efekcie podjętych działań utworzono 5 nowych Ośrodków Doradztwa Finansowego i Konsumenckiego, w tym również w Łodzi ${ }^{99}$. Należy podkreślić, że wsparcie zainicjowane w ramach opisywanej inicjatywy jest wciąż oferowane i sprowadza się do nieodpłatnej oraz poufnej pomocy w zakresie poradnictwa, głównie z zakresu finansów i prawa. Warunkiem skorzystania z oferowanego wsparcia jest wypełnienie i przesłanie formularza ankiety informacyjnej, dostępnego na stronie internetowej Stowarzyszenia ${ }^{100}$.

- Audycje radiowe, programy telewizyjne i video, w tym również udział w tworzeniu poradników w postaci krótkich filmów umieszczanych w serwisie YouTube - zawartość merytoryczna omawiana w ramach wskazanych działań obejmuje m.in.: obszar związany $\mathrm{z}$ bankowością elektroniczną, $\mathrm{w}$ tym analizę korzyści z posiadania rachunku bankowego (internetowego), korzystanie z bankomatów itd.

Należy podkreślić, że działania podejmowane przez Stowarzyszenie Krzewienia Edukacji Finansowej w obszarze inkluzji finansowej przyczyniają się do reintegracji społecznej, która jest jednym z głównych wyzwań wspomnianej organizacji.

${ }^{97}$ www.utw.pl/ (stan na dzień 23.01.2014).

${ }_{98}$ www.skef.pl/projekty/twoje-osobiste-finanse/warsztaty-konsumenckie-gdynia-55/ (stan na dzień 05.02.2014).

${ }^{99}$ www.skef.pl/projekty/twoje-osobiste-finanse/krajowa-siec-odfik/ (stan na dzień 05.02.2014).

${ }^{100}$ www.skef.pl/pogotowie-dla-zadluzonych/osrodki-doradztwa-finansowego-i-konsumenckiego/\#warszawa (stan na dzień 05.02.2014). 
Zwiększanie poziomu wiedzy finansowej osób starszych możliwe było również dzięki realizacji projektu smartSENIOR. Inicjatorami przedsięwzięcia był Ośrodek Pomocy Społecznej Dzielnicy Ursynów m.st. Warszawy oraz Fundacja na Rzecz Kobiet JA KOBIETA, natomiast jednostką współfinansującą działania - Ministerstwo Pracy i Polityki Społecznej ${ }^{101}$. Projekt był realizowany w okresie od 1 listopada 2012 r. do 30 czerwca 2013 r. i wsparcie udzielone $\mathrm{w}$ jego ramach polegało m.in. na prowadzeniu indywidualnych oraz grupowych zajęć z zakresu bankowości i oszczędzania (finansów domowych i planów emerytalnych) ${ }^{102}$, zwłaszcza przy wykorzystaniu innowacyjnych technologii i urządzeń, w tym komputerów, tabletów i smartfonów ${ }^{103}$.

Należy przy tym wskazać, że nie są to jedyne inicjatywy edukacyjne podejmowane na rzecz zwiększania aktywności finansowej osób starszych. Przykładowe działania edukacyjne:

- poradniki online (informacje o produktach finansowych i zasadach ich działania oraz płatnościach bezgotówkowych w postaci filmów multimedialnych dostępnych do obejrzenia w Internecie - oferowane m.in. przez Stowarzyszenie Krzewienia Edukacji Finansowej $\left.{ }^{104}\right)$;

- poradnie dla seniorów (oferujące m.in. poradnictwo w zakresie zarządzania finansami osobistymi, np. Centrum Inicjatyw Senioralnych ${ }^{105}$ );

- broszury i poradniki dostępne w wersji elektronicznej (informacje o produktach finansowych i zasadach ich działania oraz płatnościach bezgotówkowych $\mathrm{w}$ postaci publikacji dostępnych $\mathrm{w}$ Internecie - znajdują się na stronach m.in. Stowarzyszenia Krzewienia Edukacji Finansowej ${ }^{106}$ );

- szkolenia, doradztwo i seminaria dla seniorów (np. inicjatywa Zarządu Miejskiego Polskiego Komitetu Pomocy Społecznej w Tczewie przy współpracy z Forum Inicjatyw Społecznych MOPS w Tczewie w ramach inicjatywy fundacji „Ja kobieta” - „Finanse na 50plus”107, projekt realizowany na zlecenie Polskiej Agencji Rozwoju Przedsiębiorczości „Aktywny emeryt”"108);

- tworzenie sieci networkingowych organizacji pozarządowych działających na rzecz osób starszych (np. inicjatywa „Śniadanie u Kolpinga” organizowane przez Centrum NGO KOLPING ${ }^{109}$ ).

${ }^{101}$ www.ops-ursynow.civ.pl/index.php/aktualnosci/91-ruszyl-projekt-smartsenior (stan na dzień 05.02.2014).

102 www.ngo.pl/x/882343 (stan na dzień 05.02.2014).

${ }_{103}$ www.ops-ursynow.civ.pl/index.php/proj/ze-srodkow-efs/projekty-zrealizowane/projekt-smartsenior (stan na dzień 05.02.2014).

104 www.skef.pl/ (stan na dzień 23.01.2014).

$105 \mathrm{http} / / /$ centrumis.pl/poradnia.html (stan na dzień 23.01.2014).

106 www.skef.pl/ (stan na dzień 23.01.2014).

$107 \mathrm{http} / / / \mathrm{mops} . t c z e w . p 1 /$ fis/aktualnosci/wykluczenie-finansowe-os-b-starszych (stan na dzień 23.01.2014).

108 www.finanse-na50plus.pl/materialy/start-rekrutacji-w-ramach-projektu-\&bdquoaktywny -emeryt\&rdquo 2,119.html (stan na dzień 23.01.2014).

${ }^{109}$ www.mojabochnia.pl/?p=98900 (stan na dzień 23.01.2014). 
Warto wymienić jeszcze dwa kierunki zwiększania aktywności osób starszych w zakresie korzystania z rachunków bankowych - sugerowany przez Ministerstwo Finansów tani Internet jako sposób walki z wykluczeniem informatycznym i finansowym ${ }^{110}$ oraz już funkcjonujące portale finansowe, na których seniorzy mogą porównać poszczególne produkty finansowe i wybrać najkorzystniejszy dla nich ${ }^{111}$.

Na uwagę zasługują również działania podejmowane przez Centrum Inicjatyw Senioralnych koncentrujące się wokół udzielania informacji z zakresu zarządzania finansami osobistymi i pojęć ekonomicznych. Inicjatywa ta w efekcie ma przełożyć się na wzrost wiedzy oraz świadomości finansowej osób starszych, które w przyszłości ułatwią rozwiązywanie nawet bardziej złożonych problemów finansowych ${ }^{112}$.

Ciekawą i innowacyjną inicjatywą jest „Śniadanie dla NGO u Kolpinga” organizowane przez Centrum NGO KOLPING dla przedstawicieli małopolskich organizacji pozarządowych pod hasłem „Edukacja seniorów - między teorią a praktyką". Uczestnicy prezentowali swoje organizacje, a następnie odbył się warsztat moderowany z zakresu różnych form współpracy organizacji pozarządowych oraz dyskusja na temat przeszkód w podejmowaniu współpracy ${ }^{113}$. Inicjatywa ma szczególne znaczenie dla zwiększania aktywności finansowej seniorów ze względu na możliwość wymiany najlepszych praktyk oraz wzajemne wspieranie się w działalności na rzecz osób powyżej 50. roku życia.

Jak można zauważyć, działania podejmowane na poziomie lokalnym są ograniczone głównie do pozyskiwania wiedzy finansowej w czasie konferencji i warsztatów, a także informowania o produktach finansowych, tylko nieliczne (jak sieć networkingowa Centrum NGO KOLPING czy „Aktywny Emeryt”) mają charakter bardziej aktywny, zaś ich efektywność jest większa ze względu na aspekt włączenia społecznego seniorów.

\subsubsection{Rekomendacje rozwiązań na rzecz osób w wieku 50+ na podstawie przykładów dobrych praktyk}

Podsumowując dotychczasowe rozważania, można przedstawić rekomendacje, których wdrożenie w życie pozwoli na kształtowanie świadomości finansowej osób powyżej 50. roku życia na poziomie lokalnym.

${ }_{110}$ www.obserwatorfinansowy.pl/nbp/tani-internet-zmniejszy-wykluczenie-finansowe/ (stan na dzień 23.01.2014).

111 Przykładowa strona: http://najlepszeporownanie.pl/ (stan na dzień 23.01.2014).

$112 \mathrm{http}: / /$ centrumis.pl/poradnia.html (stan na dzień 05.02.2014).

113 www.mojabochnia.pl/?p=98900 (stan na dzień 05.02.2014). 
Tablica 67. Rekomendacje w zakresie kształtowania świadomości finansowej osób powyżej 50. roku życia na poziomie lokalnym

\begin{tabular}{|c|c|}
\hline Typ działania & Rekomendowane aktywności \\
\hline \multicolumn{2}{|c|}{ Dzialania o charakterze organizacyjnym } \\
\hline \multirow[t]{2}{*}{$\begin{array}{l}\text { W obszarze } \\
\text { instytucjonalnym }\end{array}$} & $\begin{array}{l}\text { Tworzenie i wspieranie instytucji lokalnych zaangażowanych we włączanie } \\
\text { finansowe osób starszych. }\end{array}$ \\
\hline & $\begin{array}{l}\text { Opracowanie strategii edukacji osób starszych oraz monitorowanie efektów } \\
\text { edukacji finansowej. }\end{array}$ \\
\hline \multirow[t]{2}{*}{$\begin{array}{l}\text { W obszarze } \\
\text { funkcjonalnym }\end{array}$} & $\begin{array}{l}\text { Usuwanie barier uniemożliwiającym seniorom uczestnictwo w życiu spo- } \\
\text { łeczno-finansowym (np. barier fizycznych uniemożliwiających im wyjście } \\
\text { z domu i dotarcie do określonej instytucji). }\end{array}$ \\
\hline & $\begin{array}{l}\text { Upowszechnianie wolontariatu jako instytucji skutecznej w walce z wyklu- } \\
\text { czeniem finansowym i społecznym osób powyżej 50. roku życia. }\end{array}$ \\
\hline $\begin{array}{l}\text { W obszarze } \\
\text { technicznym }\end{array}$ & $\begin{array}{l}\text { Tworzenie poradni dla seniorów, ułatwiające stały dostęp do porad finanso- } \\
\text { wych }\end{array}$ \\
\hline \multirow[t]{2}{*}{$\begin{array}{l}\text { W obszarze } \\
\text { informacyjnym }\end{array}$} & $\begin{array}{l}\text { Planowanie lokalnych kampanii informacyjnych w zakresie włączania finan- } \\
\text { sowego osób starszych i powołania w tym celu określonych instytucji. }\end{array}$ \\
\hline & Upowszechnienie przykładów dobrych praktyk. \\
\hline $\begin{array}{l}\text { W obszarze } \\
\text { finansowym }\end{array}$ & $\begin{array}{l}\text { Dostarczenie wsparcia finansowego na włączanie finansowe osób starszych } \\
\text { przez instytucje rządowe, samorządowe, lokalne i instytucje prywatne. }\end{array}$ \\
\hline \multicolumn{2}{|c|}{ Dzialania w obszarze edukacji finansowej } \\
\hline \multirow{4}{*}{$\begin{array}{l}\text { Prowadzenie } \\
\text { edukacji finansowej } \\
\text { za pośrednictwem } \\
\text { zróżnicowanych } \\
\text { form przekazu }\end{array}$} & $\begin{array}{l}\text { Udostępnianie materiałów edukacyjnych, m.in. przy wykorzystaniu lokalnej } \\
\text { prasy, telewizji i radia. }\end{array}$ \\
\hline & Udostępnianie w Internecie przez władze lokalne poradników online. \\
\hline & $\begin{array}{l}\text { Organizowanie programów edukacyjnych, m.in. w klubach seniora, } \\
\text { w Związkach Emerytów, Rencistów i Inwalidów, w placówkach opieki spo- } \\
\text { łecznej i na Uniwersytetach Trzeciego Wieku. }\end{array}$ \\
\hline & $\begin{array}{l}\text { Stworzenie linii telefonicznej, gdzie mogą dzwonić osoby starsze po porady } \\
\text { finansowe. }\end{array}$ \\
\hline $\begin{array}{l}\text { Organizowanie } \\
\text { bezpłatnych } \\
\text { kursów i szkoleń } \\
\text { podnoszących } \\
\text { wiedzę finansową }\end{array}$ & $\begin{array}{l}\text { Organizowane dla seniorów szkolenia powinny dotyczyć wiedzy na temat } \\
\text { produktów i usług finansowych oraz sposobów korzystania z nich, uaktual- } \\
\text { niania posiadanej już wiedzy, nabywania nowych umiejętności (np. pozna- } \\
\text { wanie kolejnych czynności bankowych), poznawanie aktualnych przepisów } \\
\text { bankowych, rozwijanie umiejętności osobowych. }\end{array}$ \\
\hline \multirow[t]{3}{*}{$\begin{array}{l}\text { Organizowanie } \\
\text { sieci współpracy }\end{array}$} & $\begin{array}{l}\text { Zwiększanie wiedzy i świadomości finansowej w ramach integracji we- } \\
\text { wnątrzpokoleniowej (seniorzy pomagają sobie wzajemnie). }\end{array}$ \\
\hline & $\begin{array}{l}\text { Zwiększanie wiedzy i świadomości finansowej w ramach integracji między- } \\
\text { pokoleniowej (seniorzy uzyskują wsparcie od młodszych pokoleń). }\end{array}$ \\
\hline & $\begin{array}{l}\text { Tworzenie sieci networkingowych, umożliwiających seniorom współpracę } \\
\text { z wykorzystaniem Internetu. }\end{array}$ \\
\hline
\end{tabular}

Źródło: opracowanie własne.

Działania w zakresie edukacji finansowej i ograniczania wykluczenia powinny być podejmowane przez następujące grupy podmiotów: 
- Rząd - najistotniejszym zadaniem rządu jest opracowanie Narodowej Strategii Edukacji, określającej obowiązki różnych podmiotów w zakresie walki z wykluczeniem finansowym, ponadto powinien mierzyć poziom zdolności finansowej, finansować badania naukowe nad skutecznymi metodami walki z wykluczeniem finansowym i wspierać tworzenie standardów. Rząd pełni także ważną rolę w dostarczaniu informacji w zakresie zdolności finansowej, zwłaszcza w celu zapewnienia, że klienci rozumieją swoje prawa i są one przestrzegane przez instytucje działające na rynku finansowym.

- Instytucje świadczące usługi finansowe - doradcy powinni być świadomi trudności pojawiających się u osób starszych przy korzystaniu z usług finansowych, w związku z czym powinni dostarczać jak najszerszej informacji w celu zapewnienia wiedzy i bezpieczeństwa.

- Instytucje non profit - grupy zaangażowane w edukację i ograniczanie wykluczenia finansowego seniorów w ramach licznych inicjatyw, m.in. szkoleń, warsztatów, spotkań z ekspertami itp.

- Grupy seniorów w ramach pomocy wzajemnej i dzielenia się wiedzą i doświadczeniami, np. w trakcie spotkań w klubach seniora, w Związkach Emerytów, Rencistów i Inwalidów, na Uniwersytetach Trzeciego Wieku itp., a także przy wykorzystaniu Internetu.

- Osoby należące do młodszych pokoleń - grupa ta jest zaznajomiona z usługami bankowymi oraz narzędziami komunikacyjno-informatycznymi, dlatego też mogłaby być skutecznym przewodnikiem dla seniorów.

- Instytucje zaangażowane w ochronę konsumenta - przykładem może być Urząd Ochrony Konkurencji i Konsumenta, do którego seniorzy mogą zwrócić się o pomoc w sytuacji naruszenia ich praw.

- Instytucje niefinansowe związane z finansami seniorów - warto zwrócić uwagę m.in. na rolę Zakładu Ubezpieczeń Społecznych, czyli podmiotu zaangażowanego w dystrybucję rent i emerytur - w ramach akcji Emerytura na koncie bankowym ZUS zachęcał świadczeniobiorców do korzystania z bezgotówkowej formy pobierania emerytury lub renty.

- Inne grupy - np. media, instytucje społeczne itp., są również istotnym elementem walki z wykluczeniem finansowym osób powyżej 50. roku życia. Mogą one dostarczać ogólnych informacji (np. sposoby zarządzania budżetem domowym, prawa klientów), których dostarczaniem instytucje finansowe nie zawsze są zainteresowane. Przykładem działań niekwalifikujących się do inicjatyw żadnej z wymienionych wcześniej grup są partnerstwa między organizacjami non profit i dostawcami usług finansowych, co jest uznawane za jeden z efektywniejszych sposobów zastosowania skutecznych technik edukacji finansowej.

Podejmowane na szczeblu lokalnym inicjatywy są szczególnie cenne dla osób starszych ze względu na relatywną łatwość dostępu do realizowanych inicjatyw oraz duże prawdopodobieństwo dotarcia do odbiorcy informacji o organizowanym zdarzeniu. Jak wspomniano we wcześniejszej części książki, osoby powyżej 
50. roku życia, szczególnie ci nieaktywni zawodowo, spędzają czas w środowisku lokalnym, m.in. w kościele, klubie rolnika, na Uniwersytetach Trzeciego Wieku, w klubach seniora itp., w związku z czym szerzenie edukacji finansowej powinno być ściśle związane $z$ tymi miejscami (łatwiejszy dostęp do seniorów, a także usunięcie bariery związanej z przebywaniem przez osoby starsze w nieznanym środowisku). Należy przy tym wskazać, że osoby te, ze względu na ograniczenie dostępu do technologii komunikacyjno-informatycznych wynikających z bierności zawodowej, wymagają nie tylko dostarczenia informacji o produktach finansowych, ale także zaznajomienia z technologią umożliwiającą korzystanie z nich. Dotarcie do osób aktywnych zawodowo jest zadaniem stosunkowo trudniejszym ze względu na ich zwykle ograniczony czas, jednak w tym wypadku pomocne byłyby osoby należące do młodszych pokoleń, media, instytucje non profit lub akcje organizowane przez różne instytucje związane z ich finansami (np. Zakład Ubezpieczeń Społecznych), które mogłyby przekazać określone informacje.

Pomimo że instytucje lokalne są skoncentrowane głównie na zwiększaniu aktywności społecznej osób powyżej 50. roku życia, ukierunkowanie działań także na aktywność finansową byłoby niezwykle ważne w walce $\mathrm{z}$ wykluczeniem finansowym osób starszych. 



\section{Zakończenie}

Edukacja finansowa i przeciwdziałanie wykluczeniu finansowemu są dziś bardzo ważnymi obszarami polityki społecznej. Zagadnienia te są szczególnie ważne w odniesieniu do segmentu starszych konsumentów. Charakter i tempo przemian gospodarczych, społecznych i technologicznych powodują, że te osoby są szczególnie narażone na zjawisko wykluczenia finansowego, które wiąże się z wykluczeniem społecznym.

Wobec rosnącego średniego wieku oraz przewidywanego przeciętnego okresu życia obywateli i zwiększającego się odsetka seniorów w populacji, ,srebrna gospodarka" staje się koncepcją, która zyskuje popularność i winna być w centrum uwagi zarówno instytucji publicznych (organizacji rządowych i samorządowych oraz gremiów międzynarodowych), jak i podmiotów prywatnych.

Obecnie obserwujemy wiele inicjatyw na rzecz podnoszenia wiedzy finansowej, prowadzonych przez sektor organizacji rządowych i pozarządowych, jak i same instytucje finansowe. W pracy opisano szereg działań, których podejmowanie ma na celu zapobieganie wykluczeniu finansowemu osób starszych oraz ich inkluzji bankowej.

Banki na ogół koncentrują swą uwagę na klientach młodych, rozwojowych. Rozważania przeprowadzone $\mathrm{w}$ niniejszej pracy prowadzą do konstatacji, że instytucje te powinny uwzględnić w swych strategiach marketingowych także „srebrną gospodarkę”. Większość instytucji finansowych ignoruje potrzeby osób starszych lub nie przykłada wystarczającej troski do uwzględnienia specyficznych oczekiwań tego segmentu w konstrukcji oferty.

Jednym $z$ celów monografii było przeprowadzenie analizy dostępności i atrakcyjności ofert polskich banków dedykowanych seniorom. Badaniem objęto oferty siedmiu instytucji, które uwzględniały produkty dla tej grupy celowej chociaż w jednej z trzech wymienionych kategorii (rachunki bankowe, lokaty terminowe, kredyty). Analizę atrakcyjności ofert przeprowadzono, uwzględniając kryteria:

- w przypadku RORów: dostępność, cena, dodatkowe usługi,

- w przypadku depozytów terminowych: dostępność, cena, elastyczność,

- w przypadku kredytów: dostępność, cena, wygoda oraz uproszczone procedury. 
Podstawowym wnioskiem z przeprowadzonej analizy jest niewystarczająca oferta banków dla osób powyżej 50. roku życia. Przeprowadzone analizy potwierdziły relatywnie słabą dostępność na polskim rynku produktów adresowanych specyficznie do seniorów. Polskie banki z reguły nie dostrzegają jeszcze konieczności tworzenia oddzielnej oferty dla starszych klientów. Co więcej, niektóre banki stosują ograniczenia wiekowe w dostępie do produktów i usług bankowych, co przyczynia się do wykluczenia finansowego w tym segmencie.

Na początku 2014 r. zaledwie siedem banków wychodziło naprzeciw specyficznym potrzebom osób starszych ${ }^{1}$. Należy przy tym dodać, że te banki także nie mają kompleksowej oferty dla klientów 50+. Spośród analizowanych ofert, uwzględniając wymienione kryteria, najlepiej zostały ocenione produkty: Getin Noble Banku SA, Banku Zachodniego WBK SA oraz Banku Pocztowego SA.

Drugim celem empirycznym niniejszej monografii było zdiagnozowanie poziomu wiedzy finansowej mieszkańców województwa łódzkiego w wieku 50+ oraz zidentyfikowanie istnienia zależności między posiadaną wiedzą finansową a zakresem korzystania z produktów finansowych.

$\mathrm{Na}$ podstawie badań kwestionariuszowych ${ }^{2}$ przeprowadzonych w połowie 2013 r. ustalono, że osoby z analizowanego segmentu korzystają z podstawowych (tradycyjnych) produktów bankowych, a przy tym mają większe obawy przed pozostałymi produktami finansowymi i przejawiają niechęć do korzystania z nich. Dość szerokie (acz nie powszechne) jest posiadanie rachunku oszczędnościowo-rozliczeniowego (deklarowało go ponad 3/4 respondentów), mniej niż połowa osób korzysta z ubezpieczeń (45\%) i kart płatniczych (40\%). Relatywnie niewielka część respondentów lokowała w bankach oszczędności - niespełna $30 \%$ ankietowanych deklarowało posiadanie rachunku oszczędnościowego, a 15\% - lokaty terminowej. Co piąty badany był zadłużony, przy czym najczęściej dotyczyło to kredytu bez zabezpieczenia/pożyczki gotówkowej (poniżej 15\%), dość rzadko kredytu lub pożyczki hipotecznej (5\%), a najrzadziej - mikrokredytu (poniżej $2 \%$ ). Nieco ponad połowa respondentów deklarowała, że przed podjęciem decyzji rozważała oferty innych instytucji, a niespełna $1 / 4$ ankietowanych przyznała, że nie analizowała innych ofert. Głównym czynnikiem wpływającym na podjęcie decyzji o wyborze produktu finansowego było pozyskanie informacji w oddziale oraz własne doświadczenie (w obu przypadkach powyżej 40\% wskazań). Jedy-

${ }^{1}$ Pekao SA, Bank Pocztowy SA, Bank Zachodni WBK SA, PKO Bank Polski SA, Deutsche Bank SA, Getin Noble Bank SA, Bank Gospodarki Żywnościowej SA.

2 Kwestionariusz ankietowy stanowił odzwierciedlenie kwestionariusza opracowanego przez OECD i International Network on Financial Education (INFE) w celu wskazania kierunków badania wiedzy finansowej w poszczególnych krajach umożliwiających ich porównywalność pod kątem kluczowych grup społeczno-demograficznych i opracowanie krajowych strategii edukacji finansowej. A. Atkinson, F. Messy, Measuring Financial Literacy: Results of the OECD/International Network on Financial Education (INFE) Pilot Study, OECD Working Papers on Finance, Insurance and Private Pensions, No. 15, 2012. Por. OECD INFE, OECD/INFE toolkit to measure financial literacy and inclusion. Guidance, core questionnaire and supplementary questions, Paris, June 2013. 
nie co czwarty badany wskazał na informacje pozyskane od pracowników danej instytucji finansowej; ważnym źródłem informacji są w tej grupie klientów opinie znajomych/przyjaciół/krewnych niepracujących w instytucjach finansowych (33\% odpowiedzi).

Wiedza finansowa respondentów była bardzo zróżnicowana. Dość dobrze rozumiano konsekwencje występowania inflacji, a relatywnie słabo wypadały odpowiedzi na pytania dotyczące zrozumienia ryzyka związanego z inwestycjami. Warto zauważyć, że lepszą wiedzę teoretyczną miały kobiety. Jak należało się spodziewać, poziom wiedzy finansowej maleje wraz z wiekiem respondentów; lepszą wiedzę mają osoby o wyższych dochodach. Wyniki w odniesieniu do wiedzy praktycznej były znacznie gorsze niż w przypadku wiedzy teoretycznej. Oznacza to, że znaczna część osób, która rozumie zagadnienia teoretyczne, nie potrafi tej wiedzy wykorzystać w praktyce. Ogółem zatem kompetencje finansowe są na niesatysfakcjonującym poziomie.

Połącznie wyników badania dotyczących wiedzy finansowej oraz korzystania z produktów finansowych pozwoliło na stwierdzenie istnienia pozytywnej zależności między posiadaną wiedzą a zakresem włączenia w system finansowy (w tym zwłaszcza bankowy). Spośród osób, które poprawnie odpowiedziały na pytania będące wskaźnikiem teoretycznej wiedzy finansowej zdecydowana większość (zwykle blisko 80\%) posiadała rachunek oszczędnościowo-rozliczeniowy, około połowa była posiadaczami ubezpieczenia oraz karty płatniczej, niemal 1/3 respondentów $\mathrm{z}$ tej grupy posiadała rachunek oszczędnościowy i około $1 / 5$ badanych korzystała z lokaty terminowej. Były to zatem odsetki wyższe niż dla ogółu badanych. Udział osób, które udzieliły prawidłowych odpowiedzi, ale nie posiadają żadnych produktów finansowych, pozostawał na niskim poziomie.

Poziom wiedzy finansowej seniorów z województwa łódzkiego wypadł w większości objętych badaniem zagadnień dość korzystnie na tle całego społeczeństwa ${ }^{3}$, natomiast gorsze rezultaty odnotowano w odniesieniu do zachowań finansowych i stosunku do długoterminowych aspektów gospodarowania finansami. W tych obszarach osoby starsze wykazały się niższą odpowiedzialnością przy kontrolowaniu budżetu domowego i podejmowaniem decyzji finansowych bez dokładnego rozważenia jej konsekwencji długookresowych.

W literaturze przedmiotu podkreśla się, że niska wiedza finansowa oraz brak informacji wpływają negatywnie na możliwości w zakresie oszczędzania i zapewnienia bezpiecznego, wygodnego życia na emeryturze, a brak znajomości podstawowych zagadnień finansowych może być powiązany z brakiem planowania

${ }^{3}$ Porównania dokonano z wynikami badania ogólnopolskiego, bez wyodrębnionych grup wiekowych. Nie są dostępne badania, które umożliwiłyby ocenienie mieszkańców województwa łódzkiego ogółem na tle Polaków ogółem oraz seniorów z województwa łódzkiego na tle polskich seniorów ogółem. Jakkolwiek nie ma przesłanek do stwierdzenia, by występowały istotne różnice między mieszkańcami województwa łódzkiego a ogółem mieszkańców Polski, to jednak należy mieć świadomość ograniczeń związanych z tym wnioskowaniem. 
na okres emerytury i niską majętnością. Programy edukacji finansowej mogą wesprzeć zachowania oszczędnościowe i poprawić jakość podejmowanych decyzji finansowych ${ }^{4}$.

Prezentowane w monografii wyniki przeprowadzonych badań pierwotnych są kolejnym potwierdzeniem znaczenia edukacji finansowej. Wzmacnianie kompetencji finansowych konsumentów jest niezbędne dla ograniczania ekskluzji bankowej, a w konsekwencji winno także przyczynić się do ograniczenia skali wykluczenia społecznego. Niezbędne jest przy tym prowadzenie takich działań, które przyczynią się nie tylko do zwiększenia wiedzy seniorów, ale także ich umiejętności praktycznych w zakresie finansów, a także do kreowania odpowiedzialnych postaw i zachowań w tym obszarze.

W ostatnim rozdziale przedstawiono przegląd działań prowadzonych przez banki oraz organizacje rządowe i pozarządowe, mających na celu zwiększanie świadomości finansowej Polaków, wskazano także dobre praktyki z innych państw. Na tej podstawie sformułowano rekomendacje pod adresem tych instytucji, które mogą przyczynić się do lepszego dostępu seniorów do wiedzy finansowej i zwiększenia ich umiejętności w zakresie zarządzania finansami osobistymi.

Pożądanym jest, by banki prowadziły działalność edukacyjną w zakresie finansów, której beneficjentami byliby zarówno ich klienci, jak i szersza społeczność. Doświadczenia wskazują, że zwłaszcza w przypadku osób nieubankowionych, najbardziej efektywna jest współpraca banków z organizacjami społecznymi ${ }^{5}$.

Podstawowym celem edukowania w zakresie finansów jest:

- przekazanie wiedzy i umiejętności w zakresie zarządzania finansami osobistymi (w tym planowania wpływów i wydatków), oceny, wyboru i efektywnego korzystania z usług bankowych,

- zwiększenie odpowiedzialności klientów w podejmowaniu decyzji finansowych (dotyczy to między innymi zwiększania skłonności do oszczędzania, umiejętności oceny ryzyka oraz odpowiedzialnego zadłużania się).

Dostęp do podstawowych usług finansowych jest dziś niezbędnym warunkiem pełnego uczestnictwa w życiu gospodarczym i społecznym nowoczesnego społeczeństwa, a fakt, że wiele osób nie może korzystać z usług banków powoduje pogłębianie się nierówności społecznych ${ }^{6}$. Konsumenci, którzy nie rozumieją zasad ekonomii i nie potrafią odpowiedzialnie zarządzać finansami osobisty-

${ }^{4}$ A. Lusardi, Household Saving Behavior: The Role of Financial Literacy, Information, and Financial Education Programs, NBER Working Paper No. 13824, February 2008.

${ }^{5}$ Dove Consulting, Banks' Efforts to Serve the Unbanked and Underbanked. Final report for The Federal Deposit Insurance Corporation, www.fdic.gov/unbankedsurveys/unbankedstudy/ FDICBankSurvey_Chapter1.pdf (stan na dzień 10.09.2012).

${ }^{6}$ Komisja Europejska, Dokument roboczy stużb Komisji. Streszczenie oceny skutków, towarzyszacy dokumentowi: Zalecenie Komisji w sprawie dostępu do zwyktego rachunku płatniczego, Bruksela, 2011, http://ec.europa.eu/internal_market/finservices-retail/docs/inclusion/sec_2011_907_ pl.pdf (stan na dzień 10.09.2012). 
mi, nieumiejętnie, a czasem beztrosko korzystają z produktów bankowych - nie potrafią ocenić ryzyka, jakie wiąże się z kontraktami finansowymi i dokonują nieefektywnych wyborów. Niebezpieczne jest zarówno nadmiernie optymistyczne lokowanie przez nich środków w instrumenty obarczone wysokim ryzykiem, jak i nierozważne zaciąganie kredytów (bez wnikliwej analizy możliwości sprostania w przyszłości obowiązkom ich spłaty wraz z odsetkami) ${ }^{7}$.

Banki powinny zatem zmodyfikować swoje strategie marketingowe i uwzględnić w nich specyficzne potrzeby starszych klientów. Należy mieć przy tym świadomość, że kryterium wiekowe nie może być wyłącznym kryterium segmentacji także i w tej grupie klientów i potencjalnych klientów (choć - jak dowiodły także prezentowane w pracy wyniki badań empirycznych - wiele różnic jest dostrzegalnych właśnie wśród podgrup wiekowych osób 50+). Bez wątpienia należy uwzględnić także inne kryteria demograficzne i społeczno-ekonomiczne (w tym płeć, status rodzinny i zawodowy, wykształcenie, poziom dochodów i wielkość majątku). Segmentacja musi jednak uwzględnić także aspekty psychograficzne i behawioralne. Osoby w wieku powyżej 50 lat są bowiem grupą bardzo zróżnicowaną - są tu zarówno osoby aktywne zawodowo i społecznie, jak i osoby na emeryturze. $Z$ uwagi na zachodzące przemiany społeczne, kulturowe, technologiczne, można też wyodrębnić grupę seniorów będących osobami nowoczesnymi, lepiej przygotowanymi do życia i radzenia sobie ze sferą ekonomiczną oraz seniorów tradycyjnych, w większym stopniu narażonych na ekskluzję finansową.

W niniejszej monografii zaakcentowano, że analiza potrzeb i oczekiwań różnych grup seniorów winna być podstawą dla skonstruowania oferty bankowej dostosowanej do specyfiki tych osób. W szczególności banki powinny zapewnić „srebrnej gospodarce":

- podstawowy rachunek bankowy (ROR) zapewniający możliwość wykonywania kluczowych operacji: polecenia przelewu, transakcji płatniczych przy użyciu karty płatniczej, polecenia zapłaty;

- atrakcyjne formy lokowania oszczędności i inwestowania, uwzględniające dostosowane do potrzeb seniorów horyzonty czasowe produktów i profil ryzyka adekwatny do możliwości klientów;

- dostępność kredytów umożliwiających spełnienie potrzeb finansowych, przy uwzględnieniu wymogów odpowiedzialnego kredytowania i zabezpieczeniu przed nadmiernym zadłużeniem się klientów;

- dodatkowe usługi umożliwiające osiąganie przez seniorów dodatkowych korzyści z relacji z bankami (m.in. ubezpieczenia, usługi concierge, dostęp do opieki zdrowotnej, kultury i rozrywki, zniżki na określone produkty);

- dostęp do przejrzystych, zrozumiałych, pełnych informacji na temat swej oferty oraz profesjonalne doradztwo w wyborze i korzystaniu z produktów finansowych;

${ }^{7}$ M. Marcinkowska, Kapitat relacyjny banku, t. 2: Relacje banku z kluczowymi interesariuszami, Wydawnictwo Uniwersytetu Lódzkiego, Łódź 2013, s. 298. 
- edukację i pomoc w korzystaniu z nowoczesnych kanałów dystrybucji (bankomaty, bankowość internetowa, bankowość mobilna).

W obliczu trendów demograficznych inkluzja osób nieubankowionych, w tym w szczególności seniorów, jest współcześnie jednym z największych wyzwań stojących przed instytucjami finansowymi. Przemiany ekonomiczno-społeczne i technologiczne sprawiają, że problematyka ta będzie wkrótce codziennością sektora finansowego. Można się spodziewać, że te banki, które lepiej będą potrafiły sprostać tym wyzwaniom, będą w stanie odnieść korzyści nie tylko wizerunkowe, ale także wymierne, rynkowe. 


\section{Bibliografia}

Ageing and solidarity between generations. A statistical portrait of the European Union 2012, Eurostat, Luksemburg 2011.

Agarwal S., Driscoll J. C., Gabaix X., Laibson D., The Age of Reason: Financial Decisions over the Life-Cycle with Implications for Regulation, http://dash.harvard.edu/bitstream/handle/1/4554335/Laibson_AgeofReason.pdf? sequence $=2$

Aizcorbe A., Kennickell A., Moore K. B., Recent changes in U.S. family finances: evidence from the 1998 and 2001 Survey of Consumer Finances, "Federal Reserve Bulletin", January 2003.

Aktywizacja, rentowność, edukacja. Strategia rozwoju Banku Pocztowego S.A. w latach 2014-2017, Bank Pocztowy SA, media.pocztowy.p1/file/.../a3/strategia-bankupocztowego-11-06.pdf.

Aktywność społeczna w organizacjach obywatelskich, CBOS, Warszawa 2012.

Alessie R., Hochguertel S., van Soest A., Household portfolios in the Netherlands, [w:] L. Guiso, M. Haliassos, T. Jappelli (red.), Household Portfolios, MA: MIT Press, Cambridge 2002.

Anderloni L., Access to Bank Account and Payment Services, [w:] L. Anderloni, M. D. Braga, E. M. Carluccio (red.), New Frontiers in Banking Services. Emerging Needs and Tailored Products for Untapped Markets, Springer - Verlag, Berlin-Heidelberg 2007, http://books.google. $\mathrm{pl} /$ books? $\mathrm{id}=\mathrm{UCH} 1 \mathrm{yc} 3 \mathrm{p} 314 \mathrm{C} \& \mathrm{pg}=\mathrm{PA} 28 \& \mathrm{lpg}=\mathrm{PA} 28 \& \mathrm{dq}=$ Anderloni,+socially+disadvanta ge\&source $=$ bl\&ots $=$ pwfwxMNq60\&sig $=$ V_I2V0QWNO367QgnFX145_mQ_fI\&hl=pl\&

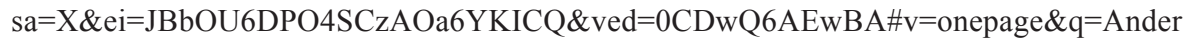
loni $\% 2 \mathrm{C} \% 20$ socially $\% 20$ disadvantage $\& \mathrm{f}=$ false

Ando A., Modigliani F., The "Life Cycle" Hypothesis of Saving: Aggregate Implications and Tests, "The American Economic Review" 1963, Vol. 53, No. 1, Part 1, s. 55-84.

Andrews G., Clark M. J., The International Year of Older Persons: Putting Aging and Research Onto the Political Agenda, [w:] D. L. Infeld, Disciplinary Approaches to Aging: Sociology of aging, Taylor \& Francis, New York 2002.

Anioła P., Gołaś Z., Zastosowanie wielowymiarowych metod statystycznych $w$ typologii strategii oszczędnościowych gospodarstw domowych w Polsce, „Materiały i Studia”, Zeszyt nr 282, Warszawa 2012.

ANZ, Adult financial literacy in Australia, Full Report of the results from the 2011, ANZ Survey, December 2011.

Askari A., Banks and Financial Education. Integrating Practice, Products, and Partnerships, http:// www.frbsf.org/community-development/files/askari_ammar.pdf.

Atkinson A. B., Marlier E., Income and living conditions in Europe, Eurostat, European Union, 2010.

Atkinson A., Messy F., Measuring Financial Literacy: Results of the OECD/International Network on Financial Education (INFE) Pilot Study, OECD Working Papers on Finance, Insurance and Private Pensions 2012, No. 15. 
Australian Securities and Investments Commission, National financial literacy strategy, March 2011.

Badanie postaw Polaków powyżej 60. roku życia wobec obrotu bezgotówkowego, Raport przygotowany dla NBP, Dom Badawczy Maison, Warszawa, kwiecień 2012.

Barey L., Pollay R. W., The infuencing role of the child in family decision making, "Journal of Marketing Research" 1968, 5.

Barr M., Banking the poor, "Yale Journal on Regulation" 2004, Vol. 21.

Batra J. C., Rights for the Aged, [w:] P. H. Parekh (red.), Human Rights Year Book 2010, Universal Law Publishing, New Delhi 2010.

BBVA Compass, Corporate Responsibility 2012. Annual Report, BBVA Compass, 2012.

Beckmann E., Hake M., Urvova J., Determinants of Households' Savings in Central, Eastern and Southeastern Europe, "Focus on European Economic Integration", Q3/13, s. 8-29.

Benedikter R., Social Banking and Social Finance. Answers to the Economic Crisis, Springer, New York 2011.

Bernheim B. D., Garrett D. M., Maki D. M., Education and Saving: The Long-term Effects of High School Financial Curriculum Mandates, "Journal of Public Economics” 2001, Vol. 80, Issue 3.

Bernheim B. D., Financial illiteracy, education, and retirement saving, [w:] O. Mitchell, S. Schieber (red.), Living with Defined Contribution Pensions, University of Pennsylvania Press, Philadelphia, PA, 1998.

Berti E. A., Bombi A. S., The child's construction of economics, Cambridge University Press, Cambridge 1988.

Białowąs S., Zachowania oszczędnościowe w polskich gospodarstwach domowych. Postawy, determinanty, model, Wydawnictwo Uniwersytetu Ekonomicznego w Poznaniu, Poznań 2013.

BIG InfoMonitor, Ogólnopolski raport o klientach wysokiego i podwyższonego ryzyka w obrocie gospodarczym, Polskie regiony, styczeń 2014.

Błędowski P., Iwanicz-Drozdowska M., Financial Services Provision and Prevention of Financial Exclusion in Poland, Fininc, Warsaw, September 2007.

BMO Financial Group, What we owe, Corporate Social Responsibility Report, BMO 2013.

Bogdaniowicz J., Borkowski T., Banki uczniom, „Gazeta Bankowa” 2007, nr 47.

Broda-Wysocki P., Wykluczenie i inkluzja społeczna. Paradygmaty i próby definicji, IPISS, Warszawa 2012.

Brombosz E., Socjalizacja ekonomiczna - nowy kierunek socjalizacji, [w:] E. Mandal, R. Stefańska-Klar (red.), Współczesne problemy socjalizacji, Wydawnictwo Uniwersytetu Śląskiego, Katowice 1995, s. 61-78.

Buko J., Przeciwdziałanie wykluczeniu finansowemu jako element wspierania polityki spójności, „Nierówności Społeczne a Wzrost Gospodarczy”2011, nr 18.

Burris V., Stages in the development of economic concepts, "Human Relations" 1983, 36.

Byrne N., McCarthy O., Ward M., Meeting the Credit Needs of Low-Income Groups: Credit Unions -V-Moneylenders, Working paper 05/05, Dublin: Combat Poverty Agency, 2005.

Bywalec C., Ekonomika i finanse gospodarstw domowych, Wydawnictwo Naukowe PWN, Warszawa 2009.

Campbell J., Household Finance, "Journal of Finance" 2006, Vol. 61, No. 4.

Carbo S., Gardener E. P., Molyneux P., Financial Exclusion, Palgrave MacMillan, London 2005.

CBOS, Reakcje na kryzys gospodarczy, Warszawa, luty 2009.

CFA, College student consumer knowledge: The results of a nationwide test, Washington 1993.

CFA, High school student consumer knowledge: A nationwide test, Washington 1991.

CFA, U.S. consumer knowledge: The results of a nationwide test, Washington 1990.

Citi Foundation, CSR Europe, Enterprise 2020, Money Advice Service, Financial Capability for Europe's Youth and Pre-retirees. Improving the Provision of Financial Education and Advice, July 2012, www.csreurope.org/financial-capability-background-and-further-information\#.U2 $\mathrm{pLjFd} 9 \mathrm{mPV}$ 
Christelis D., Jappelli T., Padula M., Cognitive abilities and portfolio choice, "European Economic Review" 2007, Vol. 54, Issue 1.

Colin D., Eltringham M., The Postbank Financial Literacy Project: Final Report, Financial Education Fund, January 2011.

Comptroller of the Currency, Administrator of National Banks, Fair Lending. Comptroller's Handbook, January 2010.

Corr C., Financial Exclusion in Ireland: An exploratory study and policy review, Dublin: Combat Poverty Agency, 2006.

Czapiński J., Panek T. (red.), Diagnoza społeczna 2013, Rada Monitoringu Społecznego, Warszawa 2013.

Czarnik S., Turek K., Aktywność zawodowa Polaków. Praca zawodowa, wykształcenie, kompetencje, Polska Agencja Rozwoju Przedsiębiorczości, Warszawa 2012.

Czechowska I. D., Ograniczenia $w$ dostępie do ustug bankowych $60+w$ perspektywie zrównoważonych finansów, „Zeszyty Prac Naukowych Uniwersytetu Ekonomicznego we Wrocławiu” 2013, nr 311.

Czechowska I. D., Rachunki osobiste dla klientów 60+, „Prace Naukowe Uniwersytetu Ekonomicznego we Wrocławiu" 2013, nr 306.

Danziger K., Children's earliest conceptions of economic relationships (Australia), "Journal of Social Psychology" 47.

de Clerk F., Ethical banking, [w:] V. Vandemeulebrouke, K. Beck, K. Käufer, Networking Social Finance, Brussels 2010, www.social-banking.org/fileadmin/isb/Artikel_und_Studien/Networking_Social_Finance_Beck_Kaeufer_Vandemeulebrouke.pdf.

Decyzja Parlamentu Europejskiego i Rady nr 940/2011/UE z dnia 14 września 2011 r. w sprawie Europejskiego Roku Aktywności Osób Starszych i Solidarności Międzypokoleniowej (2012), Dziennik Urzędowy Unii Europejskiej (23.9.2011), L246.

Decyzja Rady z dnia 6 października 2006 r. w sprawie strategicznych wytycznych Wspólnoty dla spójności wraz z załącznikiem - Strategiczne wytyczne Wspólnoty dla spójności gospodarczej, społecznej i terytorialnej na lata 2007-2013, (2006/702/WE), Bruksela 2006, s. 12; www.mir.gov.pl/aktualnosci/fundusze_europejskie_2007_2013/documents/f8d206ed005b4d a38290a5117005a7c0sww20072013_p14.pdf (stan na dzień 18.01.2014).

Deloitte, Segmentacja homogenicznych potrzeb. W jaki sposób potrzeby klientów powinny budować segmentację? Maj 2012.

Demograficzna przyszłość Europy - przeksztatcić wyzwania w nowe możliwości, COM(2006) 571 wersja ostateczna, Komisja Wspólnot Europejskich, Bruksela 2006, http://eur-lex.europa.eu/ LexUriServ/LexUriServ.do?uri=COM:2006:0571:FIN:PL:PDF (stan na dzień 18.01.2014).

Diagnoza strategiczna Łodzi. Synteza, Biuro Strategii, Partnerstwa i Funduszy Oddział Strategii Rozwoju Miasta Urzędu Miasta Łodzi, 2011.

Dom Badawczy Maison, Stan wiedzy finansowej Polaków, Raport Fundacji Kronenberga przy Citi Handlowy, wrzesień 2009.

Dove Consulting, Banks' Efforts to Serve the Unbanked and Underbanked. Final report for The Federal Deposit Insurance Corporation, www.fdic.gov/unbankedsurveys/unbankedstudy/ FDICBankSurvey_Chapter1.pdf.

Dutkiewicz M., Sobiesiak-Penszko P., Starość w trzecim sektorze - aktywnie czy opiekuńczo?, „Trzeci Sektor” 2011, nr 25.

Edukacja ekonomiczna seniorów, NBP, Krynica 5 września 2013 r., www.forumtrzeciegowieku. pl/ index.php?...edukacja-ekonomiczna-seniorow

EIOPA, Report on Financial Literacy and Education Initiatives by Competent Authorities, EIOPA -CCPFI-11/018, 2011.

Enterprise 2020, European youth financial attitudes 2011, CSR Europe, December 2011. 
EPFSF, Briefing Financial Education and Financial Capability, European Parliamentary Financial Services, 14 March 2008.

Eurofinas AISBL, Eurofinas response to the European Commission's consultation on European households'over-indebtedness, February 2013.

European charter (reviesed), European Treaty Series - No. 163, 3.V.1996, rozdział 30, Strasbourg.

European Commision, Social Protection and Social Inclusion in Europe - Key facts and figures, Brussels, 16 October 2008.

European Commission Internal Market and Services DG, Review of the Initiatives of the European Commission in the Area of Financial Education, Staff Working Document of the Internal Market and Services DG, Brussels, March 2011, http://ec.europa.eu/internal_market/finservi ces-retail/docs/capability/evaluation_financial_education_en.pdf.

European Commission, Consumers' views on switching service providers. Analytical Report, Flash Eurobarometer 243 - The Gallup Organization, January 2009.

European Commission, Eurobarometer survey on poverty and social exclusion, Brussels 2009.

European Commission, Financial Education, Communication from the Commission, COM/2007/0808, 2007.

European Commission, Financial Services Provision and Prevention of Financial Exclusion, VC/2006/0183, March 2008.

European Commission, Financial Services Provision and Prevention of Financial Exclusion Study, Brussels 2008.

European Commission, National Strategies for Financial Education. Report, Brussels 2008.

European Commission, Report on indicators in the field of poverty and social exclusion, 2001.

European Commission, Special Eurobarometer 279 - Poverty and exclusion, 2009.

European Commission, Special Eurobarometer 373, Retail financial services, 2012.

European Commission, Special Eurobarometer 273, European Social Reality, 2007.

European Commission, The financial crisis and financial education. Report, Brussels 2009.

European Commission, Towards a common operational definition of over-indebtedness, February 2007.

European Commission Internal Market and Services DG, Public consultation on Responsible Lending and Borrowing in the EU, Brussels, June 2009,.

European Parliamentary Financial Services, Briefing paper compendium on financial services issue 2008-2009, 2009.

European Year For Combating Poverty and Social Exclusion, http://ec.europa.eu/employment_social/ 2010againstpoverty/?langid $=\mathrm{pl}$

Europejskie badanie dochodów $i$ warunków życia (EU-SILC) w 2012 r., 23.12.2013, www.stat.gov. $\mathrm{pl} / \mathrm{cps} / \mathrm{rde} / \mathrm{xbcr} / \mathrm{gus} / \mathrm{WZ}$ badanie_dochodow_warunkow_zycia_EU-SILC2012.pdf.

Eurostat, Combating poverty and social exclusion, A statistical portrait of the European Union, 2010, http://epp.eurostat.ec.europa.eu/cache/ITY_OFFPUB/KS-EP-09-001/EN/KS-EP-09001-EN.PDF.

Eurostat, Participation rate in education and training (last 4 weeks) by sex and age, http://appsso. eurostat.ec.europa.eu/nui/submitViewTableAction.do;jsessionid=9ea7d07e30d6ea8a172d36 824b218af0e848ec863fbe.e34MbxeSahmMa40LbNiMbxaNa38Pe0

Executive Order 13530, President's Advisory Council on Financial Capability, 29 January 2010.

Fatuła D., Zachowania polskich gospodarstw domowych na rynku finansowym, Wydawnictwo Uniwersytetu Ekonomicznego w Krakowie, Kraków 2010.

FEBEA, What really differentiates ethical banks from traditional banks?, April 2012, www.ethical bankingeurope.com/sites/default/files/Definition\%20Ethical\%20Bank.pdf.

FDIC, National Survey of Unbanked and Underbanked Households, December 2009. 
Federal Reserve Bank of Kansas City, A Study of the Unbanked \& Underbanked Consumer in the Tenth Federal Reserve District, May 2010, www.kansascityfed.org/publicat/research/ community/Unbanked.Report.pdf.

Finke M. S., Howe J., Huston S. J., Old Age and the Decline in Financial Literacy, August 24, 2011, http://papers.ssrn.com/sol3/papers.cfm?abstract_id=1948627

Financial Inclusion Taskforce, Access to Financial Services by those on the Margins of Banking. Final Report, November 2006.

Financial Services Authority, In or Out? A Literature and Research Review, "Consumer Research", July 2000, No. 3 .

Finanse dla seniora, Akademia Dostępne Finanse, NBP, http://www.nbp.pl/adf/adf_edu_finanse_ dla_seniora.pdf.

Finansowy barometr ING: Wiedza finansowa, maj 2012.

Frączak-Rudnicka B., Dzieci w roli konsumentów - przyspieszona socjalizacja konsumencka, [w:] M. Marody (red.), Zmiana czy stagnacja? Społeczeństwo polskie po czternastu latach transformacji, Wydawnictwo Naukowe Scholar, Warszawa 2004, s. 88-99.

Frazer H., Marlier E., In-work Poverty and Labour Market. Segmentation in EU, Synthesis report, Overview based on the national reports prepared by the EU Network of Independent Experts on Social Inclusion, December 2010.

Frieske K. W., hasło: marginalność społeczna, [w:] Encyklopedia socjologii, t. 2, Oficyna Naukowa, Warszawa 1999.

Fundacja Kronenberga, Badanie dotyczace programu edukacyjnego Moje finanse 2009, Raport Fundacji Kronenberga przy Citi Handlowy, Poznań, 8 kwietnia 2009.

Furnham A., Economic socialization: A study of adults' perceptions and uses of allowances (pocket money) to educate children, "British Journal of Developmental Psychology" 1999, 17.

Furnham A., Goletto-Tankel M. P., Understanding savings, pensions and life assurance in 16-21-year -olds, "Human Relations" 2002, 55.

Furnham A., Parental attitudes to pocket money/allowances for children, "Journal of Economic Psychology" 2001, 22.

Furnham A., The saving and spending habits of young people, "Journal of Economic Psychology" 1999, 20.

Furth H., The word of grown-ups, Elsevier, New York 1980.

Gamble K., Boyle P., Yu L., Bennett D., Aging, Financial Literacy, and Fraud, Netspare Discussion Papers, 2013.

Gasparski P., Dziecięce finanse - kieszonkowe, prezenty, zarobki, „Bank i Kredyt” 1991, nr 2.

Gasparski P., Motywacja dzieci do udziału w bankowych formach oszczędzania, „Bank i Kredyt” 1991, nr 3.

Gasparski P., Oszczędzanie - psychologiczna charakterystyka motywów oszczędzania. Raport z badań, „Ekonomista” 1991, nr 2-3.

Gasparski P., Użyteczność pieniędzy i poziom optymizmu ekonomicznego jako wyznaczniki decyzji dotyczacych oszczędzania, „Przegląd Psychologiczny” 1991, XXXIV (4).

Gasparski P., Wyznaczniki indywidualnych skłonności do bankowych form oszczędzania, „Bank i Kredyt" 1993, nr 12.

Geach N., The Digital Devine, Financial Exclusion and Mobile Phone Technology: Two Problems, One Solution?, "Journal of International Trade Law and Policy" 2007, Vol. 6, Issue 1, s. 21-29.

Gerardi K., Goette L., Meier S., Financial Literacy and Subprime Mortgage Delinquency: Evidence from a Survey Matched to Administrative Data, Federal Reserve Bank of Atlanta Working Paper Series No. 2010 -10, 2010.

Gloukoviezoff G., The Caisse d'Epargne and housholds' financial exclusion: Which actions should be taken and what are the prospects?, Access to Finance Conference, World Savings Banks Institute - The World Bank, Bruxelles 2004, http://www.spanish.microfinancegateway.org/files/21774_exclusion.pdf. 
Glukoviezoff G., Understanding and combating financial exclusion and over indebtedness in Ireland: a European perspective. What could Ireland learn from Belgium, France and the United Kingdom?, Studies in Public Policy, October 2011.

Golinowska S., ,, Srebrna gospodarka” i miejsce w niej sektora zdrowotnego. Koncepcja i regionalne przykłady zastosowania, „Zdrowie Publiczne i Zarządzanie” 2011, t. IX, nr 1.

Goszczyńska M., Kołodziej S., Trzcińska A., Uwikłani w świat pieniadza i konsumpcji. O socjalizacji ekonomicznej dzieci i młodzieży, Difin, Warszawa 2012.

Grifoni A., Messy F. A., Current Status of National Strategies for Financial Education. A comparative analysis and relevant practices, OECD Working Papers on Finance, Insurance and Private Pensions No. 16, OECD Publishing, 2012.

Grotowska-Leder J. (red.), Ekskluzja i inkluzja społeczna. Diagnoza-uwarunkowania-kierunki działań, Wydawnictwo Edukacyjne Akapit, Toruń 2005.

Guest L. P., Brand loyalty - Twelve years later, "Journal of Applied Psychology" 1955, 39.

GUS, Aktywność ekonomiczna ludności w województwie łódzkim, Marzec 2014.

GUS, Budżety gospodarstw domowych w 2012 r., Warszawa 2013.

GUS, Dochody $i$ warunki życia ludności Polski (raport z badania EU-SILC 2012), Warszawa 2014, http://stat.gov.pl/obszary-tematyczne/warunki-zycia/dochody-wydatki-i-warunki-zycia-ludnosci/dochody-i-warunki-zycia-ludnosci-polski-raport-z-badania-eu-silc-2012,6,5.html

GUS, Osoby powyżej 50 roku życia na rynku pracy w 2012 r., Warszawa-Bydgoszcz 2014.

Habschick M., Seidl B., Evers J., Survey of financial literacy schemes in the EU 27, VT Markt/ 2006/26H - Final Report, Hamburg, November 2007.

Hamerla D., Kacuga K., Raport ewaluacyjny programu edukacji finansowej realizowanego przez Fundacje Wspomagania Wsi w latach 2008-2011, Warszawa 2011.

Harasim J. (red.), Oszczędzanie $i$ inwestowanie w teorii i praktyce, Polskie Towarzystwo Ekonomiczne Oddział w Katowicach, Katowice 2010.

Hilgert M. A., Hogarth J. M., Household Financial Management: The Connection between Knowledge and Behavior, Federal Reserve Bulletin, July 2003.

HM Treasury, Promoting financial inclusion, December 2004.

Hogarth J. M., Financial Education and Economic Development, Paper prepared for Improving Financial Literacy International Conference hosted by the Russian G8 Presidency in Cooperation with the OECD, 29-30 November 2006, s. 4, www.oecd.org/finance/financialeducation/37742200.pdf.

Hoskins I., Focusing on opportunities: Active ageing, [w:] United Nations. Economic Commission for Europe, A Society for All Ages, United Nations Publications, Geneva 2008.

IPSOS, Oszczędzanie i zwyczaje finansowe, badanie dla Provident Polska, Warszawa, październik 2007.

Iwanicz-Drozdowska M. (red.), Produkty finansowe i edukacja finansowa w Polsce na tle wybranych krajów wysoko rozwiniętych, Oficyna Wydawnicza Szkoły Głównej Handlowej w Warszawie, Warszawa 2009.

Iwanicz-Drozdowska M. (red.), Edukacja i świadomość finansowa. Doświadczenia i perspektywy, Oficyna Wydawnicza Szkoły Głównej Handlowej w Warszawie, Warszawa 2011.

Iwanicz-Drozdowska M., Działania na rzecz poprawy poziomu edukacji finansowej w Unii Europejskiej podczas globalnego kryzysu finansowego, ,Zarządzanie i Finanse, Journal of Management and Finance" 2013, nr 2/1.

Iwanicz-Drozdowska M. (red.), Polski rynek finansowy wobec zmian społeczno-demograficznych, Instytut Badań nad Gospodarką Rynkową, Gdańsk, lipiec 2009.

Iwanicz-Drozdowska M., Wykluczenie finansowe - poważny problem społeczny, „Management and Business Administration. Central Europe" 2008, Vol. 16, No. 1.

Iwanicz-Drozdowska M., Matuszyk A., Nowak A. K., Kitala R., Produkty finansowe i edukacja finansowa $w$ Polsce na tle wybranych krajów wysoko rozwiniętych. Raport z badań, Warszawa 2009. 
Iwanicz-Drozdowska M., Nowak A. K., Lewandowski A., Preferencje polskich gospodarstw domowych $w$ zakresie korzystania $z$ ustug finansowych. Wyniki badania ankietowego, „Bank i Kredyt", październik 2008.

Jajuga K., Bank a gospodarstwo domowe-znaczenie edukacji i doradztwa, [w:] S. Flejterski, A. Gospodarowicz (red.), Banki w spolecznej gospodarce rynkowej w świetle doświadczeń z kryzysu i stanu rozwoju rynku finansowego, Związek Banków Polskich, Warszawa 2014, s. 245-253.

Jasielska A., Maksymiuk R. A., Dorośli reklamuja, dzieci kupują, Kindermarketing i psychologia, Warszawa Wydawnictwo Naukowe Scholar, Warszawa 2010.

Jones P., Barnes T., Would You Credit It?: People Telling Stories About Credit, The Co-operative Bank in association with Liverpool JMU and Citizen Advice Bureau, 2005.

Kaczmar K., Kompetencje finansowe Polaków w gospodarce rynkowej, 7 marca 2013, „Infos”, $\mathrm{nr} 5(142)$.

Karta Lipska na rzecz zrównoważonego rozwoju miast europejskich, www.mir.gov.pl/rozwoj_regionalny/Polityka_regionalna/rozwoj_miast/rozwoj_miast_w_UE/Documents/KL_PL.pdf.

Kempson E., Whyley C., Caskey J., Sharon Collard S., In or Out? Financial Exclusion: a literature and research review, FSA, UK, 2000.

Kempson E., Whyley C., Kept Out or Opted Out? Understanding and Combating Financial Exclusion, Bristol: Policy Press, 1999, http://www.pfrc.bris.ac.uk/Reports/Kept_out_opted_out. pdf.

Keynes J. M., Ogólna teoria zatrudnienia, procentu i pieniądza, Wydawnictwo Naukowe PWN, Warszawa 2003.

KNF, Kampania informacyjna „Sprawdź komu powierzasz”, http://www.knf.gov.pl/sprawdz komu powierzasz.html

Kołodziejczyk W., Polak M., Jak będzie zmieniać się edukacja. Wyzwania dla polskiej szkoty i ucznia, Instytut Obywatelski, Warszawa 2011.

Komisja Europejska, Dokument roboczy stużb Komisji. Streszczenie oceny skutków, towarzyszacy dokumentowi: Zalecenie Komisji w sprawie dostępu do zwykłego rachunku płatniczego, Bruksela 2011, http://ec.europa.eu/internal_market/finservices-retail/docs/inclusion/sec_2011_907_ pl.pdf.

Komisja Europejska, Działania w ramach Strategicznego planu realizacji Europejskiego partnerstwa na rzecz innowacji sprzyjajacej aktywnemu starzeniu się $w$ dobrym zdrowiu, COM(2012) 83 final, Bruksela 2012, http://eur-lex.europa.eu/LexUriServ/LexUriServ.do?uri=COM:2012: 0083:FIN:PL:PDF

Komisja Europejska, Europa 2020. Strategia na rzecz inteligentnego i zrównoważonego rozwoju sprzyjajacego właczeniu Społecznemu, Bruksela 2010

Komisja Wspólnot Europejskich, Biała księa. Polityka $w$ dziedzinie ustug finansowych na lata 2005-2010, Bruksela 2005.

Komisja Wspólnot Europejskich, Decyzja Komisji z dnia 30 kwietnia 2008 r. powolująca grupe ekspertów w dziedzinie edukacji finansowej, 2008/365/WE

Komisja Wspólnot Europejskich, Komunikat Komisji dla Parlamentu Europejskiego, Rady Europejskiego Komitetu Ekonomiczno-Społecznego i Komitetów Regionów, Jednolity rynek Europy XXI wieku, Bruksela 2007.

Komisja Wspólnot Europejskich, Komunikat Komisji. Edukacja finansowa, KOM(2007) 808, Bruksela 2007.

Komisja Wspólnot Europejskich, Zielona księga w sprawie detalicznych ustug finansowych na jednolitym rynku, Bruksela 2007.

Konkurs „Bank Dostępny” rozstrzygnięty, http://www.bankier.pl/wiadomosc/Konkurs-Bank-Dostepny-rozstrzygniety-1373611.html

Konkluzje Rady ECOFIN z dnia 8 maja 2007, 9171/07 (Presse 97).

Kontek K., Bariery rozwoju polskiego systemu funduszy emerytalnych, „Studia Ekonomiczne” 2010, nr 3. 
Korniotis G. M., Kumar A., Do older investors make better investment decisions?, "The Review of Economics and Statistics" 2011, 93(1).

Kotowska I. E. (red.), Diagnoza społeczna 2013. Rynek pracy i wykluczenie społeczne w kontekście percepcji Polaków, Ministerstwo Pracy i Polityki Społecznej, Centrum Rozwoju Zasobów Ludzkich, Warszawa 2014.

Kowalak T., hasło: marginalizacja społeczna, [w:] B. Rysz-Kowalczyk (red.), Leksykon polityki spolecznej, ASPRA-JR, Warszawa 2001.

Koźliński T., Zwyczaje płatnicze Polaków, NBP, Departament Systemu Płatniczego, Warszawa, maj 2013.

Krasucka M., Maciejasz-Świątkiewicz M., Pieczonka J., Poskart R., Produkty i ustugi finansowe dla gospodarstw domowych w Polsce, Wydawnictwo Uniwersytetu Opolskiego, Opole 2011.

Kubicki P., Osoby starsze na rynku ustug finansowych, www.academia.edu/4087765/Osoby starsze na_rynku_uslug finansowych

Kuchciak I., Nǟmierne zadlużanie się gospodarstw domowych - przyczyna i skutek wykluczenia finansowego, „Bezpieczny Bank” 2013, nr 2-3, s. 51-52.

Kuchciak I., Odwrócona hipoteka jako odpowiedź sektora bankowego na trendy demograficzne, „Annales UMCS” 2010, Sectio H, t. XLIV, z. 2., s. 297-310.

Kuchciak I., Problematyka nadmiernego zadlużania w kontekście wykluczenia finansowego, „Prace Naukowe Uniwersytetu Ekonomicznego we Wrocławiu" 2013, nr 306.

Laboul A., National strategies for financial education, COLUMBIA-OECD-WORLD BANK, Conference on Financial Education Cartagena, 31 October 2012.

Leeladhar V., Taking Banking Services to the Common Man - Financial Inclusion, "Reserve Bank of India Bulletin", January 2006.

Lévy Ch. R., W jaki sposób nabywamy pojęcia i wartości ekonomiczne, [w:] T. Tyszka (red.), Psychologia ekonomiczna, Gdańskie Wydawnictwo Psychologiczne, Gdańsk 2004.

Leyshon A., Thrift N., Geographies of financial exclusion: financial abandonment in Britain and the United States, Transactions of the Institute of British Geographers, "New Series", vol. 20, No. 3, 1995, http://www.jstor.org/discover/10.2307/622654?uid=3739256\&uid=2\&uid=4 $\& \operatorname{sid}=21104514833753$

Lilico A., Household Indebtness in the EU, European Parliament, 2010.

Lindqvist A., A note on determinants of household saving behavior, "Journal of Economic Psychology" 1981, Vol. 1, Issue 1.

Lista ostrzeżeń publicznych Komisji Nadzoru Finansowego, http://www.knf.gov.pl/o nas/ostrzezenia publiczne/lista ostrzezenia.html

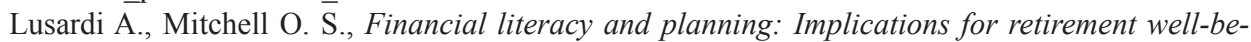
ing, 2006, www.mrrc.isr.umich.edu/publications/conference/pdf/Lusardi-Mitchell\%20UM05-09A0805C.pdf.

Lusardi A., Household Saving Behavior: The Role of Financial Literacy, Information, and Financial Education Programs, NBER Working Paper No. 13824, February 2008.

Lusardi A., Preparing for Retirement: The Importance of Planning Costs, National Tax Association Proceedings 2002.

Lusardi A., Tufano P., Debt Literacy, Financial Experience and Overindebtedness, Working Paper NBER, 2008.

Maciejasz-Świątkiewicz M., Wykluczenie finansowe i narzędzia jego ograniczania, Wydawnictwo Uniwersytetu Opolskiego, Opole 2013.

Maison D., Analiza barier dotyczacych korzystania z rachunku bankowego, NBP, Warszawa, wrzesień 2010 .

Maison D., Polak w świecie finansów, Wydawnictwo Naukowe PWN, Warszawa 2013.

Majewski B., Badanie świadomości i podstaw wiedzy ekonomicznej wśród uczestników programów edukacyjnych skierowanych do najmłodszych, kwiecień 2010, ,e-mentor”, $\operatorname{nr} 2$ (34). 
Marcinkowska M., Kapitat relacyjny banku, t. 2: Relacje banku z kluczowymi interesariuszami, Wydawnictwo Uniwersytetu Łódzkiego, Łódź 2013.

Marcinkowska M., Pożyczki P2P-zagrożenie dla banków?, [w:] L. Dziawgo, Współczesne finanse. Stan i perspektywy rozwoju bankowości, Wydawnictwo Naukowe UMK, Torun 2008.

Marcinkowska M., Społecznościowe parabanki - czyli o tym jak Internet eliminuje pośredników finansowych, [w:] E. Ostrowska, J. Ossowski (red.), Rynki finansowe. Mikrofinanse, Biblioteka Kwartalnika Naukowego „Pieniądze i Więź”, Sopot 2009.

Mastropietro E., Rapid Appraisal Method of Social Exclusion and Poverty (RAMSEP Project): Handbook, European Commission, lipiec 2000.

Matul M., Pawlak K., Fałkowski J., Priorytety wzmacniania edukacji finansowej wśród ubogich rodzin $w$ Polsce, październik 2004, http://edufin.pl/images/pdf/dok4.pdf.

McArdle J. J., Ferrer-Caja E., Hamagami F., Woodcock R. W., Comparative Longitudinal Structural Analyses of the Growth and Decline of Multiple Intellectual Abilities Over the Life Span, "Developmental Psychology" 2002, Vol. 38, No. 1.

McNeal J., Children as consumers, Bureau of Business Research, University of Texas at Austin, Austin 1964.

Międzynarodowy Plan Działania w sprawie starzenia się, Organizacja Narodów Zjednoczonych, Nowy Jork 1983, www.un.org/es/globalissues/ageing/docs/vipaa.pdf (stan na dzień 18.01.2014).

Ministerstwo Polityki Społecznej, Strategia Polityki Społecznej na lata 2007-2013, Warszawa 2005, www.mpips.gov.pl/userfiles/File/nowe/strategiaps.pdf (stan na dzień 19.01.2013).

Ministerstwo Pracy i Polityki Społecznej, Krajowy Plan Działania na rzecz Europejskiego Roku Aktywności Osób Starszych i Solidarności Międzypokoleniowej 2012 w Polsce, Warszawa 2012.

Ministerstwo Rozwoju Regionalnego, Strategia Rozwoju Kraju 2007-2015, Warszawa 2006, www. mir.gov.pl/rozwoj_regionalny/Polityka_rozwoju/SRK/Documents/SRK_2007_2015.pdf (stan na dzień 19.01.2014).

Ministerstwo Rozwoju Regionalnego, Strategia Rozwoju Kraju, listopad 2006.

MIPS, Narodowa Strategia Integracji Społecznej dla Polski, Warszawa 2003.

Mizejewski C., Narodowa Strategia Integracji Społecznej do 2010 roku. Podsumowanie i wnioski na przyszłość, Ekspertyza przygotowana w ramach projektu „EAPN Polska - razem na rzecz Europy Socjalnej”, [w:] Ubóstwo i wykluczenie społeczne w Polsce, Raport krajowy Polskiej Koalicji Social Watch i Polskiego Komitetu European Anti-Poverty Network, 2010.

Moore D., Survey of Financial Literacy in Washington State: Knowledge, Behavior, Attitudes, and Experiences, Pullman, Washington: Washington State University Socialand Economic Sciences Research Center, Technical Report, 2003.

Morgan L. A., Kunkel S. R., Aging, Society, and the Life Course, Fourth Edition, Springer Publishing Company, New York 2011.

Narodowa Strategia Integracji Społecznej dla Polski, www.funduszestrukturalne.gov.pl/informator/ npr2/ dokumenty\%20strategiczne/Narodowa\%20Strategia\%20Integracji\%20Spolecznej.pdf.

Narodowy Plan Rozwoju 2007-2013, www.funduszestrukturalne.gov.pl/informator/npr2/npr.htm

National Foundation for Credit Counseling, Financial Literacy Survey Exposes Significant Gaps In Grasp Of Personal Finance Skills, April 2012, www.nfcc.org/newsroom/newsreleases/SIGNIFICANT_GAPS.cfm

NBP, Finanse dla seniora, Warszawa 2012.

NBP, Plan działalności Narodowego Banku Polskiego na lata 2007-2009, Warszawa, styczeń 2007.

NBP, Strategia edukacji ekonomicznej Narodowego Banku Polskiego na lata 2010-2012, NBP, Departament Edukacji i Wydawnictw, Warszawa 2009.

Nyhus E. K., Webley P., The role of personality in household saving and borrowing behaviour, "European Journal of Personality" 2001, 15.

Obi T., Auffret J.-P., Iwasaki N., Aging Society and ICT: Global Silver Innovation, IOS Press, Amsterdam 2013. 
OECD INFE, OECD/INFE toolkit to measure financial literacy and inclusion. Guidance, core questionnaire and supplementary questions, Paris, June 2013.

OECD, Good Practices for Enhanced Risk Awareness and Education on Insurance issues, 2008.

OECD, Good Practices for Financial Education relating to Private Pensions, 2008.

OECD, Good Practices on Financial Education and Awareness relating to Credit, 2009.

OECD, Guidelines for Financial Education in Schools, 2012.

OECD, Improving Financial Literacy. Analysis of Issues and Policies, OECD Publishing, Paris 2005.

OECD, Recommendation on Principles and Good Practices for Financial Education and Awareness, Recommendation of the Council, July 2005.

OECD/INFE, High-level Principles on the Evaluation of Financial Education Programmes and dedicated Guides on Evaluation, June 2011.

OECD/INFE, Measuring Financial Literacy: Questionnaire and Guidance Notes for Conducting an Internationally Comparable Survey of Financial Literacy, 2011.

Opinia Europejskiego Komitetu Ekonomiczno-Społecznego w sprawie: Kredyty a wykluczenie spoteczne w spoleczeństwie dobrobytu, 2008/C 44/19, Dz. Urz. UE C44/74.

Otto A. M. C., Schots P. A. M., Westerman J. A. J., Webley P., Children's use of saving strategies: An experimental approach, "Journal of Economic Psychology" 2006, 27.

Panigyrakis G. G., Theodoridis P. K., Veloutsou C. A., All customers are not treated equally: Financial exclusion in isolated Greek islands, "Journal of Financial Services Marketing" 2002, No 7.

Penczar M. (red.), Rola edukacji finansowej w ograniczaniu wykluczenia finansowego, Instytut Badań nad Gospodarką Finansową, Gdańsk 2014.

Pentor, Postawy Polaków wobec oszczędzania, Raport Fundacji Kronenberga przy Citi Handlowy, 2008.

Pentor, Postawy Polaków wobec oszczędzania, Raport Fundacji Kronenberga przy Citi Handlowy, 2010.

Pentor, Postawy Polaków wobec oszczędzania, Raport Fundacji Kronenberga przy Citi Handlowy, październik 2011.

Perry V. G., Morris M. D., Who Is in control? The Role of Self-Perception, Knowledge, and Income in Explaining Consumer Financial Behavior, "Journal of Consumer Affairs" 2005, Vol. 39, No. 2.

Pilecka K., Świadomy klient poszukiwany, „Miesięcznik Finansowy Bank” 2008, nr 2.

Podsumowanie dotychczasowych wyników realizacji projektu Akademia „Dostępne Finanse” Departament Systemu Płatniczego, Warszawa 2014.

Polak M., Edukacja finansowa i przedsiębiorczość sposobem na biedę, „e-mentor”, czerwiec 2008, nr 3 (25).

Polak M., Edutainment $w$ ksztaltowaniu postaw przedsiębiorczych i edukacji ekonomicznych, [w:] P. Wachowiak, M. Dąbrowski, B. Majewski (red.), Fundacja Promocji i Akredytacji Kierunków Ekonomicznych, Warszawa 2007.

Poradnik. Jak nie paść ofiara oszustwa metoda ,Na wnuczka”, http://zbp.pl/public/ repozytorium/ dla_konsumentow/poradnik_zbp/knw_informator_zbp.pdf.

Portal e⿳亠口冋kacji ekonomicznej, www.nbportal.pl/pl/np

Presidency conclusion, Main Conclusions of the Lisbon Summit by the Portuguese Presidency of the EU, Lisbon, 2000.

Program Operacyjny Fundusz Inicjatyw Obywatelskich na lata 2009-2013, Fundusz Inicjatyw Obywatelskich, Warszawa 2008.

Program Solidarność pokoleń. Działania dla zwiększenia aktywności zawodowej osób w wie$k u$ 50+, Warszawa, październik 2013 r., www.mpips.gov.pl/download/gfx/.../Program50_ 30.10.2013ost1.pdf.

Projekt Nowoczesne finanse seniora, http://zutw.hekko.pl/news.php?readmore=10 
Promowanie solidarności między pokoleniami, Komisji Wspólnot Europejskich, KOM(2007) 244 wersja ostateczna, Bruksela 2007.

Przewłocka J., Ukryty potencjat? Sektor pozarzadowy w starzejacej się Polsce, [w:] M. Racław (red.), Publiczna troska, prywatna opieka, Instytut Spraw Publicznych, Warszawa 2011.

PwC, Czekając na impuls, 2011.

PwC, Raport e-commerce 2011. Aktualne wyzwania dla handlu detalicznego, czyli jak skutecznie wprowadzić elektroniczny kanat sprzedaży w tradycyjnym sklepie?, listopad 2011.

PwC, Raport na temat wielkich miast Polski, 2011.

Question of the elderly and the aged, Rezolucja Organizacji Narodów Zjednoczonych, A/ RES/3137(XXVIII), www.un.org/en/ga/search/view_doc.asp?symbol=A/RES/3137\%28 XX VIII\%29\&Lang=E\&Area=RESOLUTION (stan na dzień: 18.01.2014).

Rao D. B., Programme of Action of the World Summit for Social Development, Discovery Publishing House, New Delhi 1998.

Raport o sytuacji systemu SKOK w I kwartale 2014 r., Departament Bankowości Spółdzielczej i Spółdzielczych Kas Oszczędnościowo-Kredytowych, Warszawa, czerwiec 2014.

Regan S., Paxton W., Beyond bank accounts: full financial inclusion, Citizens Advice Bureau/IPPR, 2003.

Rezolucja Parlamentu Europejskiego w sprawie polityki w dziedzinie ustug finansowych, P6_TA -PROV(2007)0338/A6-0248/2007.

Rokicka E., Raport z pogłębionych badań ewaluacyjnych przeprowadzonych w szkołach ponadgimnazjalnych realizujacych program Moje finanse, Warszawa 2006.

Rooij M., Lusardi A., Alessie R., Financial Literacy and Stock Market Participation, NBER Working Paper 13565, 2007.

Rudnicka M., Surdej A., Gospodarka senioralna. Nowy sektor gospodarki narodowej w Polsce, Centrum im. Adama Smitha, Warszawa 2013.

Rytelewska G., Kłopocka A., Wpływ czynników demograficznych na poziom i strukturę oszczędności gospodarstw domowych w Polsce, „Bank i Kredyt” 2010, 41 (1), s. 57-80.

Rzadowy Program na rzecz Aktywności Spolecznej Osób Starszych na lata 2014-2020, Ministerstwo Pracy i Polityki Społecznej, Warszawa 2013.

Rzadowy Program na rzecz Aktywności Społecznej Osób Starszych na lata 2012-2013, Załącznik do uchwały nr 137 Rady Ministrów z dnia 24 sierpnia 2012 r., Warszawa 2012, www. mpips.gov.pl/gfx/mpips/userfiles/_public/1_NOWA\%20STRONA/Aktualnosci/seniorzy/ Rzadowy\%20Program\%20ASOS_2012-2013.pdf (stan na dzień 19.01.2014 r.). oraz Rządowy Program na rzecz Aktywności Społecznej Osób Starszych na lata 2014-2020, projekt z dnia 29 sierpnia 2013 r., Warszawa 2013 r., www.mpips.gov.pl/download/gfx/mpips/pl/de faultopisy/8266/1/1/ASOS $\% 202014-2020 \% 20$ projekt $\% 20$ z $\% 20$ dnia $\% 2029 \% 20$ sierpnia $\% 20$ 2013\%20r.pdf (stan na dzień 29.01.2014 r.)

Sarma M., Index of Financial Inclusion, Indian Council for Research on International Economic Relations, Working Paper 2008, No. 215.

Schneider F., Shadow Economies and Corruption All Over the World: New Estimates for 145 Countries, "Economics", July 2007, 9.

Sinclair S. P., Financial Exclusion: an introductory survey, Heriot Watt University Centre for Research into Socially Inclusive Services (CRSIS), Edinburgh 2001.

Stownik języka polskiego, t. 2, PWN, Warszawa 1992.

Smyczek S., Modele zachowań konsumentów na rynku ustug finansowych, Wydawnictwo Akademii Ekonomicznej w Katowicach, Katowice 2007.

Sobiesiak P., Aktywni 60+? Wolontariat osób starszych w Polsce, ISP, „Analizy i Opinie” 2011, nr 117.

Solarz J. K., Nowi wykluczeni. Ryzyko finansowe codzienności, Społeczna Akademia Nauk, ŁódźWarszawa 2012. 
Solarz M., The importance of shadow banking sector entities for population affected by credit exclusion, "Copernican Journal of Finance \& Accounting" 2013, Vol. 2, Issue 2.

Spader J., Ratcliffe J., Montoya J., Skillern P., The Bold and the Bankable: How the Nuestro Barrio Telenovela Reaches Latino Immigrants with Financial Education, "Journal of Consumer Affairs" 2009 (March 1), No. 43 (1).

Sprostanie wyzwaniom zwiazanym ze skutkami starzenia się społeczeństwa w UE (Sprawozdanie na temat starzenia się spoleczeństwa, 2009), KOM(2009) 180 wersja ostateczna, Komisja Wspólnot Europejskich, Bruksela 2009, http://eur-lex.europa.eu/LexUriServ/LexUriServ. do?uri=COM:2009:0180:FIN:PL:PDF (stan na dzień 18.01.2014).

Stamp S., A policy framework for addressing over-indebtedness, Combat Poverty Agency, Dublin: 2009.

Stan wiedzy ekonomicznej Polaków, Raport Instytutu Wolności i Raiffeisen Polbank, lipiec 2014.

Stango V., Zinman J., Debit. Debit or Credit: How People Choose to Pay, Research Monograph, Filene Institute, 2008.

Stix H., Why Do People Save in Cash? Distrust, Memories of Banking Crises, Weak Institutions and Dollarization, Oesterreichische Nationalbank, January 2012.

Strategia na rzecz inteligentnego i zrównoważonego rozwoju sprzyjającego włączeniu społecznemu (Europa 2020), KOM(2010) 2020 wersja ostateczna, Komisja Wspólnot Europejskich, Bruksela 2010, http://ec.europa.eu/eu2020/pdf/1_PL_ACT_part1_v1.pdf (stan na dzień 18.01.2014).

Strategia Wspierania Rozwoju Spoleczeństwa Obywatelskiego na lata 2009-2015, Załącznik do uchwały nr 240/2008 Rady Ministrów z dnia 4 listopada 2008 r., www.mpips.gov.pl/userfi les/ File/pozytek/SWRSO\%202009-2015.pdf (stan na dzień 19.01.2014).

Strauss A., The development and transformation of monetary meaning in the child, "American Sociological Review" 1952, 17.

Szarfenberg R., Marginalizacja i wykluczenie społeczne - panorama językowo-teoretyczna, s. 10, $\mathrm{http}: / /$ rszarf.ips.uw.edu.pl/pdf/miws_panorama.pdf.

Szarfenberg R., Ubóstwo i wykluczenie społeczne w Polsce pomiar, wyjaśnianie, strategie przeciwdziatania, www.feswar.org.pl/fes2009/pdf_doc/debaty6.pdf.

Szarfenberg R., Żołędowski C., Thesiss M. (red.), Ubóstwo i wykluczenie społeczne, perspektywa poznawcza, Dom Wydawniczy Elipsa, Warszawa 2010.

Szpringer W., Kredyt konsumencki i upadtość konsumencka na rynku ustug finansowych UE, Dom Wydawniczy ABC, Warszawa 2005.

Szukalski P. (red.), Przygotowanie do starości. Polacy wobec starzenia się, Instytut Spraw Publicznych, Warszawa 2009.

Świecka B. (red.), Bankructwa gospodarstw domowych. Perspektywa ekonomiczna i spoleczna, Difin, Warszawa 2008.

Świecka B., Niewyplacalność gospodarstw domowych. Przyczyny - skutki-przeciwdziałanie, Difin, Warszawa 2009.

Taking Financial Literacy to the Next Level: Important Challenges and Promising Solutions, OECD -US Treasury International Conference on Financial Education, Washington, DC, USA, May 7-8, 2008.

Tang F., Choi E., Morrow-Howell N., Organizational Support and Volunteering Benefits for Older Adults, „The Gerontologist” 2010, Vol. 50, No. 5.

TNS OBOP, Planowanie budżetów domowych oraz podejmowanie ważnych decyzji finansowych, TNS OBOP dla portalu domowe finanse, Warszawa 2006.

TNS Polska, Postawy Polaków wobec oszczędzania, Raport Fundacji Kronenberga przy Citi Handlowy, wrzesień 2012.

TNS Polska, Postawy Polaków wobec oszczędzania, Raport Fundacji Kronenberga przy Citi Handlowy, październik 2013. 
TNS Qual+, Ubóstwo i wykluczenie starszych obywateli UE. Sprawozdanie zbiorcze - styczeń $2011 r$., Eurobarometr 2011.

Towards a Europe for All Ages - Promoting Prosperity and Intergenerational Solidarity, COM (1999) 221 final, Commission of the European Communities, Brussels 1999.

Tyszka T. (red.), Psychologia ekonomiczna, Gdańskie Towarzystwo Ekonomiczne, Gdańsk 2004.

Uchwała Nr 148/2013 Komisji Nadzoru Finansowego dnia 18 czerwca 2013 r. w sprawie wydania Rekomendacji S dotyczącej dobrych praktyk w zakresie zarządzania ekspozycjami kredytowymi zabezpieczonymi hipotecznie, Dz. Urz. KNF, nr 15, poz. 23.

Uchwała Nr 59/2013 Komisji Nadzoru Finansowego z dnia 26 lutego 2013 r. w sprawie wydania Rekomendacji $\mathrm{T}$ dotyczącej dobrych praktyk w zakresie zarządzania ryzykiem detalicznych ekspozycji kredytowych, Dz. Urz. KNF, nr 2, poz. 11.

Urząd Marszałkowski Województwa Łódzkiego, Plan przeciwdziałania depopulacji w województwie tódzkim. Rodzina, dzieci, praca, Łódź 2013.

Urząd Statystyczny w Łodzi, Stan i ruch naturalny ludności w województwie łódzkim, Łódź, 2012.

Urząd Statystyczny w Łodzi, Perspektywy demograficzne województwa łódzkiego do 2030 r., Łódź 2005.

Ustawa z dnia 14 grudnia 1994 r. o Bankowym Funduszu Gwarancyjnym, tekst jednolity, Dz. U. z 2009, nr 84, poz. 711 ze zm.

Ustawa z dnia 28 lutego 2003 r. Prawo upadłościowe i naprawcze, Dz. U. 2003, nr 60 poz. 535 ze zm.

Ustawa z dnia 23 października 2014 r. o odwróconym kredycie hipotecznym, Dz. U. 2014, poz 1585.

Weber O., Remer S. (red.), Social Banks and the Future of Sustainable Finance, Routledge, London-New York 2011.

Wniosek Dyrektywa Parlamentu Europejskiego i Rady w sprawie porównywalności opłat za prowadzenie rachunku płatniczego, przenoszenia rachunku płatniczego oraz dostępu do podstawowego rachunku płatniczego, COM/2013/0266 final - 2013/0139 (COD), Bruksela, 8.05.2013.

VISA, Case Study: Financial Literacy Education in Sub-Saharan Africa, VISA, November 2009, http://corporate.visa.com/media-center/media-kits/fifa.shtml

Vos R., Ocampo J. A., Cortez A. L. (red.), Ageing and Development, United Nations Publications, New York 2008.

Ward S., Consumer socialization, "Journal of Consumer Research” 1974, Vol. 1, s. 1-14.

Wójcik E., Konkurencja na rynku oszczędności w Polsce, CeDeWu, Warszawa 2014.

Yoong, J., Financial Illiteracy and Stock Market Participation, Mimeo, Stanford University, 2007.

Yorke D. A., The Definition of Market Segments for Banking Services, "European Journal of Marketing" 1982, Vol. 16, Issue 3, s. 14-22.

Zaidi A. i in., Active Ageing Index 2012. Concept, Methodology and Final Results, European Centre Vienna, Vienna 2013.

Zalecenie parlamentu Europejskiego i Rady z dnia 18 grudnia 2006 r. w sprawie kompetencji kluczowych w procesie uczenia się przez całe życie, 2006/962/WE.

Zaleska M. (red.), Współczesna bankowość, Difin, Warszawa 2007.

Zgliczyński W., Aktywność społeczna osób starszych w Polsce w ramach wolontariatu i uniwersytetów trzeciego wieku, „Studia BAS” 2012, nr 2 (30).

Zielona Księga „,Wobec zmian demograficznych: nowa solidarność między pokoleniami”, COM (2005) 94 końcowy, Komisja Wspólnot Europejskich, Bruksela 2005.

Ziemba M., Świeszczak K., Marcinkowska M., Wykluczenie finansowe osób 50+ w kontekście dostęności oferty bankowej, „Finanse” 2014, nr 1(7).

Związek Banków Polskich, Kodeks Etyki Bankowej (Zasady dobrej praktyki bankowej), Warszawa, kwiecień 2013. 


\section{Strony internetowe:}

http://akademiajunior.pl

http://www.federacjautw.pl/fds/index.php?option=com_content\&view=article\&id=1\&Itemid=2

http://wolontariat.org.pl/

http://zbp.pl/dla-konsumentow/arbiter-bankowy/dzialalnosc

http://zbp.pl/public/repozytorium/dla_konsumentow/edukacja/mapa-2012-lista.pdf

www.ageuk.org.uk/

www.ageuk.org.uk/about-us/age-international/

www.ageuk.org.uk/about-us/what-we-do/

www.ageuk.org.uk/money-matters/

www.ageuk.org.uk/money-matters/money-management/

www.app.gdruk.com/html/BarclaysdigitalEagles_261.html

www.bakcyl.wib.org.pl

www.bankomania.pkobp.pl

www.biblioteki.org/pl/o_finansach/o_projekcie/dzialania

www.biblioteki.org/pl/o_finansach_w_bibliotece_2_edycja

www.bs.ostrowiec.pl/konto-dla-seniorow

www.bsolesnica.pl/page/57/pol-konto-senior.html

www.bsdobrzen.pl/index.php?c=texts\&text $=156 \&$ itemid $=12$

www.caox.org.uk/projects/financial-inclusion-for-older-people-in-oxford www.centrumis.pl/miejsce-przyjazne-seniorom $3 . \mathrm{html}$

www.centrumis.pl/poradnia.html

www.centrumis.pl/poznanski-wolontariat-o-projekcie.html

www.centrumis.pl/rekrutacja-do-piatej-edycji-targow-aktywni-501.html

www.chs.ac.uk/index.php?page $=$ _About_Us\&id $=2020$

www.chs.ac.uk/index.php?page $=$ _Our_Courses\&id $=2312$

www.citibank.pl/poland/kronenberg/polish/11430.htm

www.cnmv.es/DocPortal/Publicaciones/PlanEducacion/PlanEducacion_een

www.danskebank.com/en-uk/CSR/business/accessibility/Pages/Step-by-step-meetings.aspx

www.ec.europa.eu/social/main.jsp?catId=1062\&langId=en

www.europa.eu/ey2012/ey2012 main.jsp?langId=pl\&catId=971

www.fakt.pl/tag/senior-w-swiecie-finansow, artykuly, 1

www.finanse-na50plus.pl/

www.finanse-na50plus.pl/materialy/patronat-honorowy_2,40.html

www.finanse-na50plus.pl/materialy/start-rekrutacji-w-ramach-projektu-\&bdquoaktywny-emeryt\&rdquo 2,119.html

www.finanse-na50plus.pl/o-projekcie_7.html

www.finanse-na50plus.pl/teczka-edukacyjna_7,0.html?strona=1

www.fsa.gov.uk/pubs/other/fincap_delivering.pdf.

www.fundacjanbp.pl

www.isp.org.pl/aktualnosci,1,1287.html

www.junior.org.pl

www.kobieta50plus.pl/klub-50-plus_1,0.html

www.media.netpr.pl/generic/release/215932/bank-pocztowy-promuje-finanse-wsrod-seniorow

www.mf.gov.si/fileadmin/mf.gov.si/pageuploads/sporocila/oecd/NPFI_EN.pdf.

www.mfcr.cz/cps/rde/xbcr/mfcr/EN_CZECH_NATIONAL_STRATEGY_FOR_FINANCIAL_ EDUCATION_2010.pdf.

www.mfw4a.org/fileadmin/data_storage/documents/other-internal-documents/Ghana_gyabaah.pdf. www.mojabochnia.pl/?p=98900 
www.mops.czestochowa.um.gov.pl/category/projekty-i-programy/aktywizowanie-spolecznosci-lokalnej/

www.mops.czestochowa.um.gov.pl/formy-pomocy/pomoc-osobom-starszym-i-niepelnosprawnym/ kawiarenka-dla-seniora/

www.mops.tczew.pl/fis/aktualnosci/wykluczenie-finansowe-os-b-starszych

www.mymoney.gov/sites/default/files/downloads/NationalStrategyBook_12310.pdf.

www.najlepszeporownanie.pl/

www.nbp.pl/edukacja/dodatki_edukacyjne/Fakt_swsf/5.pdf.

www.nbp.pl/edukacja/dodatki_edukacyjne/Fakt_swsf/8.pdf.

www.nbp.pl/edukacja/dodatki_edukacyjne/gosc_niedzielny/Finanse_seniora_odc.1.pdf.

www.nbp.pl/edukacja/dodatki_edukacyjne/gosc_niedzielny/Finanse_seniora_odc.2.pdf.

www.nbp.pl/edukacja/dodatki_edukacyjne/gosc_niedzielny/Finanse_seniora_odc.3.pdf.

www.nbp.pl/edukacja/dodatki_edukacyjne/gosc_niedzielny/Finanse_seniora_odc.4.pdf.

www.nbp.pl/edukacja/dodatki_edukacyjne/gosc_niedzielny/Finanse_seniora_odc.5.pdf.

www.nbp.pl/edukacja/dodatki_edukacyjne/gosc_niedzielny/Finanse_seniora_odc.6.pdf.

www.nbp.pl/edukacja/dodatki_edukacyjne/gosc_niedzielny/Finanse_seniora_odc.7.pdf.

www.nbp.pl/edukacja/dodatki_edukacyjne/gosc_niedzielny/Finanse_seniora_odc.8.pdf.

www.nbp.pl/home.aspx?f=/adf/adf.html

www.nbp.pl/home.aspx?f=/edukacja/dodatki_edukacyjne/przeglad.html

www.nbportal.pl/pl/edukacja/projekty-zakonczone/projekty_2005/bank-dostepny-2005

www.nbportal.pl/pl/edukacja/projekty-zakonczone/projekty_2012/senior_w_swiecie_finansow

www.ngo.pl/x/882343

www.obserwatorfinansowy.pl/nbp/tani-internet-zmniejszy-wykluczenie-finansowe/

www.oecd.org/finance/financialeducation/44919982.pdf.

www.ops-ursynow.civ.pl/index.php/aktualnosci/91-ruszyl-projekt-smartsenior

www.ops-ursynow.civ.pl/index.php/proj/ze-srodkow-efs/projekty-zrealizowane/projekt-smartsenior

www.pensionsboard.ie/en/News_Press/Improving_Financial_Capability_a_multistakeholder_ap

proach.pdf.

www.powislanski.pl/oferta/ror-senior.html

www.programsforelderly.com/cool-wellsfargo.php

www.silvereconomy-europe.org/network/sigs/finances/background_en.htm

www.skef.pl/

www.skef.pl/pogotowie-dla-zadluzonych/osrodki-doradztwa-finansowego-i-konsumenckie go/\#warszawa

www.skef.pl/projekty/twoje-osobiste-finanse/krajowa-siec-odfik/

www.skef.pl/projekty/twoje-osobiste-finanse/warsztaty-konsumenckie-gdynia-55

www.telegraph.co.uk/sponsored/finance/your-bank/10890358/tablet-training-for-seniors.html

www.unicreditfoundation.org/en/pressmedia/news/social-innovation-in-ageing.html

www.unicreditfoundation.org/en/pressmedia/news/social-innovation-in-ageing $0 . h t m l$

www.utw.pl/

www.utw.pl/index.php?id=10

www.vidaedinheiro.gov.br/Enef/Default.aspx, financialliteracy.org.nz/national-strategy

www.wbi.worldbank.org/wbi/content/africa-regional-dialogue-financial-literacy-and-capability

www.wijzeringeldzaken.nl/

www.zafinansowani.pl

www.zbp.pl/dla-konsumentow/edukacja-ekonomiczna

www.zbp.pl/public/repozytorium/dla_konsumentow/poradnik_zbp/24rady.pdf.

www.zbp.pl/public/repozytorium/dla_konsumentow/poradnik_zbp/knw_informator_zbp.pdf.

www.zbp.pl/public/repozytorium/dla_konsumentow/poradnik_zbp/kredyty_internet.pdf.

www.zutw.hekko.pl/news.php?readmore $=10$ 



\section{Spis rysunków}

Rysunek 1. Prognoza udziału procentowego obywateli Polski w populacji Unii Europejskiej w latach 2015-2060 (w \%)

Rysunek 2. Porównanie wartości mediany wieku w 27 krajach UE w 1992 r. i 2012 r.

Rysunek 3. Porównanie wartości wskaźnika przeciętnego trwania życia nowo narodzonego człowieka w Unii Europejskiej dla 2003 r. i 2011 r.

Rysunek 4. Prognozowany udział procentowy społeczeństwa powyżej 50. roku życia w populacji ogółem Unii Europejskiej oraz państw członkowskich w wybranych latach $(2020,2040,2060)(w \%)$

Rysunek 5. Prognozowany udział procentowy społeczeństwa powyżej 80. roku życia w populacji ogółem Unii Europejskiej oraz państw członkowskich w latach 2020, 2040, 2060 (w \%)

Rysunek 6. Współczynnik obciążenia ekonomicznego osobami powyżej 65. roku życia w Unii Europejskiej i państwach członkowskich w latach 2020, 2040, 2060 (w \%)

Rysunek 7. Indeks aktywnego starzenia dla państw członkowskich Unii Europejskiej

Rysunek 8. Wskaźniki wykluczenia społecznego w Polsce w latach 2005-2012 (w \%)

Rysunek 9. Wskaźnik wykluczenia społecznego ogółem w Polsce na tle UE w latach 2005-2012 (w \%)

Rysunek 10. Wskaźniki wykluczenia społecznego emerytów (w \%)

Rysunek 11. Status osoby marginalnie ubankowionej lub w pełni ubankowionej w za.................... od dochodu (w \%)

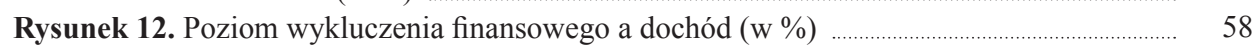

Rysunek 13. Odsetek osób posiadających rachunek w banku w poszczególnych grupach wiekowych (w \%)

Rysunek 14. Poziomy zaawansowania bezgotówkowego w poszczególnych grupach wiekowych (w \%)

Rysunek 15. Porównanie zakresu korzystania z produktów finansowych w krajach UE wśród osób 55+ (w \%)

Rysunek 16. Porównanie zakresu nabywanych produktów finansowych w krajach UE wśród osób 55+ w ciągu ostatnich 5 lat (w \%)

Rysunek 17. Powody nieposiadania rachunku w banku w poszczególnych grupach wiekowych (w \%)

Rysunek 18. Zmiany skali zadłużenia gospodarstw domowych (w \%)

Rysunek 19. Kwota zaległych płatności w województwie łódzkim na tle łącznej kwoty zaległych płatności (w mld zł)

Rysunek 20. Średnie zadłużenie w województwie łódzkim na tle łącznej kwoty zaległych płatności (w zł) 
Rysunek 21. Współzależności między wykluczeniem a nadmiernym zadłużeniem

Rysunek 22. Hierarchia zachowań finansowych i ich motywy .......................................................... 93

Rysunek 23. Motywy oszczędzania a wiek ……........................................................................... 94

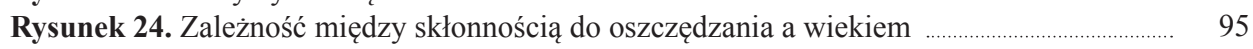

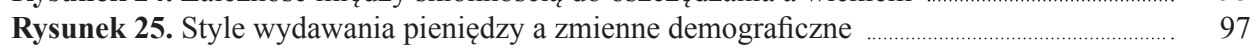

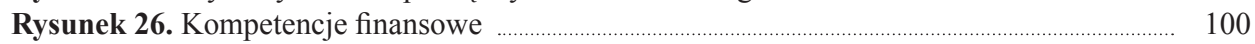

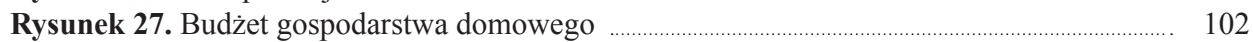

Rysunek 28. Schemat przepływów gotówkowych w gospodarstwie domowym ……………..... 103

Rysunek 29. Fazy życia i potrzeby finansowe (korzystanie z produktów bankowych) ............. 105

Rysunek 30. Gospodarstwa domowe aktywnie uczestniczące w rynku finansowym według wieku głowy gospodarstwa domowego oraz typu aktywności w 2013 r. (w \%)

106

Rysunek 31. Struktura form oszczędzania w gospodarstwach domowych według wieku w 2013 r. (w \%)

Rysunek 32. Struktura celów oszczędzania w gospodarstwach domowych według wieku w 2013 r. (w \%)

Rysunek 33. Struktura zobowiązań gospodarstw domowych według celu zobowiązań i wieku głowy gospodarstwa w 2013 r. (w \%)

Rysunek 34. Struktura zobowiązań gospodarstw domowych ze względu na źródło pochodzenia zobowiązania, według wieku (w 2013 r.) (w \%)

Rysunek 35. Ocena ofert banków w zakresie rachunków bankowych, lokat i kredytów gotówkowych

Rysunek 36. Łączna ocena oferty banków w zakresie rachunków bankowych, lokat i kredytów gotówkowych

Rysunek 37. Ryzyka wynikające z braku wiedzy finansowej

Rysunek 38. Osoby zagrożone biedą i wykluczeniem społecznym w Polsce na tle krajów UE (dla 2012 r. jest to średnia dla EU 28) (w\%)

Rysunek 39. Wiedza finansowa obiektywna, subiektywna i relatywna (w \%) .......................... 179

Rysunek 40. Ocena własnej wiedzy na temat zagadnień finansowych (w \%) .............................. 180

Rysunek 41. Wiedza finansowa a wiek (w \%) ........................................................................................... 180

Rysunek 42. Zainteresowanie wiedzą finansową osób 55+ (w \%) ……………..................... 183

Rysunek 43. Posiadanie i korzystanie z poszczególnych instrumentów finansowych w zależności od reprezentowanego poziomu wiedzy finansowej (w \%) ......................... 189

Rysunek 44. Kluczowe elementy kwestionariusza ankietowego ..................................................... 192

Rysunek 45. Zmiany w liczbie ludności w województwie łódzkim wraz z prognozą (w tys.) 200

Rysunek 46. Zróżnicowanie badanej zbiorowości ze względu na stan cywilny (w \%) .............. 205

Rysunek 47. Zróżnicowanie badanej zbiorowości ze względu na liczbę osób w wieku równym lub poniżej 18. oraz powyżej 18. roku życia w gospodarstwie domowym (w \%)

Rysunek 48. Zróżnicowanie badanej zbiorowości ze względu na wykształcenie (w \%) .......... 206

Rysunek 49. Zróżnicowanie badanej zbiorowości ze względu na sytuację zawodową (wielokrotny wybór) (w \%)

Rysunek 50. Źródła utrzymania gospodarstwa domowego (w \%)

Rysunek 51. Liczba godzin przepracowanych w ciągu tygodnia poprzedzającego udział w badaniu (w \%)

.

Rysunek 52. Dochody netto ogółem z okresu poprzedzającego udział w badaniu (w \%) ......... 209

Rysunek 53. Miesięczne dochody netto - przedziały (w \%) .

Rysunek 54. Osoba odpowiedzialna za podejmowanie bieżących decyzji finansowych (w \%) 210

Rysunek 55. Stosunek badanych do pieniędzy - skala catkowicie się zgadzam - catkowicie się nie zgadzam (w \%)

Rysunek 56. Możliwość pokrycia kosztów z posiadanych pieniędzy (w \%) .................................. 212

Rysunek 57. Okres możliwości pokrycia wydatków bez konieczności pożyczania pieniędzy (w \%) 214 
Rysunek 58. Sposoby lokowania oszczędności (w \%)

Rysunek 59. Opracowywanie budżetu w gospodarstwie domowym (w \%)

Rysunek 60. Zróżnicowanie badanej zbiorowości ze względu na znajomość produktów finansowych (wielokrotny wybór) (w \%)

Rysunek 61. Zróżnicowanie badanej zbiorowości ze względu na aktualne posiadanie produktów finansowych (wielokrotny wybór) (w \%)

Rysunek 62. Zróżnicowanie badanej zbiorowości ze względu na posiadanie produktów finansowych w ciągu 2 ostatnich lat (wielokrotny wybór) (w \%)

Rysunek 63. Czynniki wpływające na wybór produktów finansowych (poza obligacjami i akcjami, udziałami) (w \%)

Rysunek 64. Najczęściej aktualnie posiadane produkty finansowe a sposób podejmowania decyzji o ich wyborze (w \%)

Rysunek 65. Produkty finansowe posiadane w ciągu 2 ostatnich lat a sposób podejmowania decyzji o ich wyborze (w \%)

Rysunek 66. Wykluczeni finansowo a miejsce zamieszkania (w \%)

Rysunek 67. Wykluczeni finansowo a wykształcenie (w \%)

Rysunek 68. Wykluczeni finansowo a status zawodowy (w \%)

Rysunek 69. Wykluczeni finansowo a dochód netto (w \%)

Rysunek 70. Wiedza finansowa - teoretyczna a płeć badanych (w \%)

Rysunek 71. Wiedza finansowa - teoretyczna a miejsce zamieszkania badanych (w \%) ............

Rysunek 72. Wiedza finansowa - teoretyczna a wiek badanych (w \%)

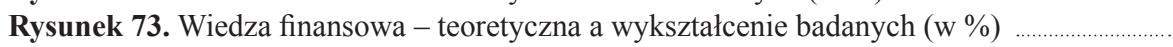

Rysunek 74. Wiedza finansowa - teoretyczna a miesięczny dochód netto badanych (w \%)

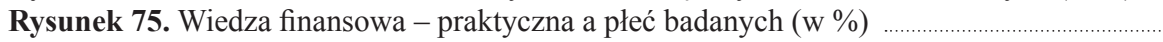

praktyczna a plec badanych (w \%)

Rysunek 76. Wiedza finansowa - praktyczna a miejsce zamieszkania badanych (w \%) .............. 237

Rysunek 77. Wiedza finansowa - praktyczna a wiek badanych (w \%) ................................... 238

Rysunek 78. Wiedza finansowa - praktyczna a wykształcenie badanych (w \%) ............................ 239

Rysunek 79. Wiedza finansowa - praktyczna a dochód badanych (w \%) ...................................... 239

Rysunek 80. Aktualnie posiadane produkty finansowe a płeć badanych (w \%) .......................... 240

Rysunek 81. Aktualne posiadanie produktów finansowych a miesięczne dochody netto badanych (w \%)

Rysunek 82. Posiadanie produktów finansowych w ciągu ostatnich 2 lat a płeć badanych (w \%)

Rysunek 83. Posiadanie produktów finansowych w ciągu ostatnich 2 lat a miesięczne docho-

dy netto badanych (w \%) .................................................................................... wych (wielokrotny wybór) (w \%)

Rysunek 85. Prawidłowe odpowiedzi na pytanie $\mathrm{nr} 2$ a aktualne posiadanie produktów finan-
sowych (wielokrotny wybór) (w \%) sowych (wielokrotny wybór) (w \%)

Rysunek 86. Prawidłowe odpowiedzi na pytanie nr 3 a aktualne posiadanie produktów finansowych (wielokrotny wybór) (w \%)

Rysunek 87. Prawidłowe odpowiedzi na pytanie $\mathrm{nr} 4$ a aktualne posiadanie produktów finansowych (wielokrotne odpowiedzi) (w \%)

Rysunek 88. Prawidłowe odpowiedzi na pytanie $\mathrm{nr} 5$ a aktualne posiadanie produktów finansowych (wielokrotne odpowiedzi) (w \%)

Rysunek 89. Porównanie wiedzy finansowej na podstawie badań pierwotnych i wtórnych (w \%)

Rysunek 90. Porównanie poziomu pozytywnych zachowań finansowych na podstawie badań pierwotnych i wtórnych (w \%)

Rysunek 91. Stosunek do długoterminowego postrzegania finansów na podstawie badań pierwotnych i wtórnych (w \%)

Rysunek 92. Źródła pozyskiwania wiedzy finansowej (w \%) _................................................. 269

Rysunek 93. Pożądane źródła wiedzy finansowej (w \%) 



\section{Spis tablic}

Tablica 1. Filary oraz przypisane im obszary działań priorytetowych i konkretne działania realizowane w ramach „Europejskiego partnerstwa na rzecz innowacji sprzyjającej aktywnemu starzeniu się w dobrym zdrowiu"

Tablica 2. Koncepcje wykluczenia społecznego

Tablica 3. Determinanty ubóstwa w Diagnozie Społecznej …….................................................. 37

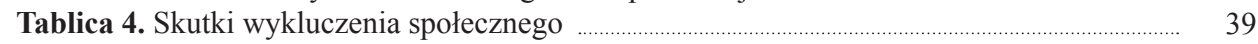

Tablica 5. Wykluczenie społeczne a życie poniżej progu ubóstwa _.................................. 45

Tablica 6. Główne przyczyny wykluczenia finansowego w wybranych krajach UE* _.............. 59

Tablica 7. Cechy predestynujące do wykluczenia finansowego i społecznego …….................... 70

Tablica 8. Skutki o charakterze indywidualnym i makroekonomicznym wykluczenia finansowego i społecznego

Tablica 9. Cechy predestynujące oraz determinanty wykluczenia i nadmiernego zadłużenia 78

Tablica 10. Kierunki interwencji na rzecz zwiększania aktywności społecznej osób starszych $\quad 87$

Tablica 11. Determinanty zachowań ekonomicznych gospodarstw domowych _...................... 91

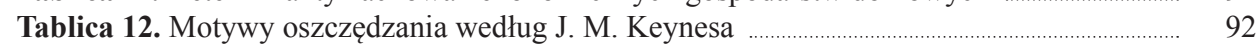

Tablica 13. Zachowania finansowe - podział ze względu na racjonalność podejmowanych decyzji

Tablica 14. Nadzieje i obawy finansowe konsumentów

Tablica 15. Różnice między tradycyjnymi i nowoczesnymi seniorami

Tablica 16. Oferta rachunków bankowych dedykowanych dla seniorów z punktu widzenia kryterium: dostępność

Tablica 17. Oferta rachunków oszczędnościowo-rozliczeniowych dedykowanych dla seniorów z punktu widzenia kryterium: cena

Tablica 18. Oferta rachunków oszczędnościowo-rozliczeniowych dedykowanych dla seniorów z punktu widzenia kryterium: dodatkowe usługi

Tablica 19. Ocena punktowa ofert rachunków oszczędnościowo-rozliczeniow........................... nych dla seniorów z punktu widzenia kryterium: dostępność

Tablica 20. Ocena punktowa ofert rachunków oszczędnościowo-rozliczeniowych dedykowanych dla seniorów z punktu widzenia kryterium: cena

Tablica 21. Ocena punktowa ofert rachunków oszczędnościowo-rozliczeniowych dedykowanych dla seniorów z punktu widzenia kryterium: dodatkowe usługi

Tablica 22. Ocena ofert rachunków oszczędnościowo-rozliczeniowych dedykowanych dla seniorów .

Tablica 23. Oferta lokat bankowych dedykowanych dla seniorów z punktu widzenia kryterium: dostępność

Tablica 24. Oferta lokat bankowych dedykowanych dla seniorów z punktu widzenia kryterium: cena 
Tablica 25. Oferta lokat bankowych dedykowanych dla seniorów z punktu widzenia kryterium: elastyczność warunków

Tablica 26. Ocena punktowa ofert lokat bankowych dedykowanych dla seniorów z punktu widzenia kryterium: dostępność

Tablica 27. Ocena punktowa ofert lokat bankowych dedykowanych dla seniorów z punktu widzenia kryterium: cena

Tablica 28. Ocena punktowa ofert lokat bankowych dedykowanych dla seniorów z punktu widzenia kryterium: elastyczność warunków

Tablica 29. Ocena ofert lokat bankowych dedykowanych dla seniorów

Tablica 30. Oferta kredytów dedykowanych dla seniorów z punktu widzenia kryterium: dostępność

Tablica 31. Oferta kredytów dedykowanych dla seniorów z punktu widzenia kryterium: cena

Tablica 32. Oferta kredytów dedykowanych dla seniorów z punktu widzenia kryterium: wygoda oraz uproszczone procedury

Tablica 33. Ocena punktowa ofert kredytów dedykowanych dla seniorów z punktu widzenia kryterium: dostępność

Tablica 34. Ocena punktowa ofert kredytów dedykowanych dla seniorów z punktu widzenia kryterium: cena

Tablica 35. Ocena punktowa ofert kredytów dedykowanych dla seniorów z punktu widzenia kryterium: wygoda oraz uproszczone procedury

Tablica 36. Ocena ofert kredytów dedykowanych dla seniorów

Tablica 37. Ocena oferty banków w zakresie rachunków bankowych, lokat i kredytów ............ 142

Tablica 38. Główne determinanty edukacji finansowej $\ldots$

Tablica 39. Dobre praktyki w zakresie edukacji finansowej .............................................................. 153

Tablica 40. Przegląd kluczowych celów narodowych strategii edukacji finansowej …............... 160

Tablica 41. Korzyści o charakterze indywidualnym i makroekonomicznym podnoszenia

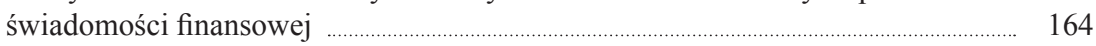

Tablica 42. Specyfika badań dotyczących poziomu świadomości finansowej …................... 167

Tablica 43. Determinanty różnicujące poziom wiedzy finansowej w społeczeństwie ……........ 169

Tablica 44. Przegląd programów dotyczących budowania świadomości finansowej w krajach UE 171

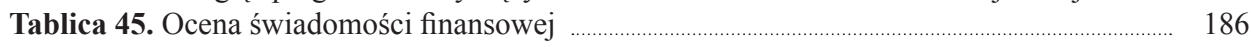

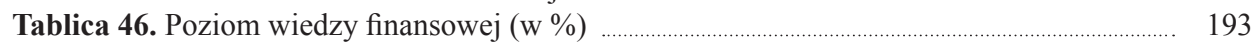

Tablica 47. Poziom pozytywnych zachowań finansowych (w \%) ................................................... 194

Tablica 48. Stosunek do długoterminowego postrzegania finansów (w \%) ......................... 195

Tablica 49. Postępowanie w przypadku braku środków na pokrycie kosztów (wielokrotny wybór) 213

Tablica 50. Statystyka ilości posiadanych (aktualnie) produktów finansowych ………….......... 218

Tablica 51. Źródła informacji wpływające na decyzję o wyborze produktów finansowych (wielokrotny wybór)

Tablica 52. Aktualne posiadanie produktu finansowego a źródło informacji o produkcie (wielokrotny wybór - maksymalnie 5 odpowiedzi) (w \%)

Tablica 53. Statystyka osób nieposiadających produktów finansowych pod względem wieku

Tablica 54. Wyniki odpowiedzi na pytania dotyczące wiedzy finansowej - część teoretyczna $(\mathrm{w} \%)$

Tablica 55. Wyniki odpowiedzi na pytania dotyczące wiedzy finansowej - część praktyczna (w \%)

Tablica 56. Aktualnie posiadane produkty finansowe - struktura wg miejsca zamieszkania badanych (w \%)

Tablica 57. Aktualnie posiadane produkty finansowe a wiek badanych (w \%) ........................ 243

Tablica 58. Aktualnie posiadane produkty finansowe a wykształcenie badanych (w \%) .......... 244 
Tablica 59. Posiadanie produktów finansowych w ciągu ostatnich 2 lat a miejsce zamieszkania badanych (w \%)

Tablica 60. Posiadanie produktów finansowych w ciągu ostatnich 2 lat a wiek badanych (w \%) 251

Tablica 61. Posiadanie produktów finansowych w ciągu ostatnich 2 lat a wykształcenie badanych (w \%)

Tablica 62. Zakres projektu „O finansach w bibliotece”

Tablica 63. Przykłady kierunków inicjatyw na rzecz zwiększania aktywności finansowej osób starszych w wybranych krajach

Tablica 64. Przewidywany wpływ zmian społeczno-demograficznych na poszczególne segmenty rynku usług finansowych

Tablica 65. Rekomendowany pakiet usług bankowych

Tablica 66. Rekomendacje w zakresie usprawnienia decyzji finansowych podejmowanych przez osoby $50+$

Tablica 67. Rekomendacje w zakresie kształtowania świadomości finansowej osób powyżej 50. roku życia na poziomie lokalnym 



\section{O autorach}

Dr Iwa Kuchciak - adiunkt w Katedrze Bankowości na Wydziale Ekonomiczno-Socjologicznym Uniwersytetu Łódzkiego. Jej zainteresowania badawcze koncentrują się wokół tendencji i uwarunkowań rozwoju bankowości elektronicznej, a w szczególności problematyki inkluzji bankowej i edukacji finansowej. Bierze ona udział w projektach badawczych realizowanych na zlecenie instytucji finansowych. Jest autorką ponad 50 publikacji naukowych, uczestnikiem kilkudziesięciu konferencji naukowych. W 2013 r. została laureatką konkursu o Nagrodę Naukową Fundacji UŁ za szczególne osiągnięcia naukowe.

Dr Marika Świeszczak - adiunkt w Katedrze Bankowości na Wydziale Ekonomiczno-Socjologicznym Uniwersytetu Łódzkiego. Jej zainteresowania naukowe koncentrują się wokół problemów edukacji finansowej, etyki w bankowości, etycznego marketingu i potencjału innowacyjnego. Jest autorką oraz współautorką wielu artykułów naukowych i popularnonaukowych, a także prelegentką na krajowych oraz zagranicznych konferencjach naukowych.

Dr Krzysztof Świeszczak - adiunkt w Katedrze Bankowości na Wydziale Ekonomiczno-Socjologicznym Uniwersytetu Łódzkiego. Jego zainteresowania naukowe koncentrują się wokół problemów edukacji finansowej, inkubacji przedsiębiorczości, etyki w bankowości, relacji na linii doradca - klient oraz standardów etycznych $\mathrm{w}$ instytucjach finansowych. Jest autorem oraz współautorem wielu artykułów naukowych i popularnonaukowych, a także prelegentem na krajowych oraz zagranicznych konferencjach naukowych. Jest laureatem pierwszej w Polsce edycji światowego konkursu „Etyka w Finansach - Nagroda Robina Cosgrove”, organizowanego przez Komisję Etyki Bankowej przy Związku Banków Polskich.

Prof. dr hab. Monika Marcinkowska - kierownik Katedry Bankowości na Wydziale Ekonomiczno-Socjologicznym UŁ. Jej zainteresowania badawcze koncentrują się na problematyce funkcjonowania banków, w tym w szczególności kreowania ich wartości dla interesariuszy. Jest autorką dziewięciu monografii oraz autorką lub współautorką wielu artykułów naukowych i popularnonaukowych. 